ROSANA DE LIMA SOARES

\title{
Mídias e Estigmas Sociais SutilezA E Grosseria da EXCLUSÃo
}

São Paulo

Agosto de 2015 


\section{ROSANA DE LIMA SOARES}

\section{Mídias E ESTIGMAS SociaIS SuTILEZA E Grosseria dA EXCLUSÃo}

Tese apresentada como requisito parcial para concurso de Livre Docência junto ao Departamento de Jornalismo e Editoração da Escola de Comunicações e Artes da Universidade de São Paulo

São Paulo

Agosto de 2015 
SUMÁRIO

I. Introdução

1. Fundamentos teóricos 12

2. Procedimentos metodológicos 23

3. Discursos midiáticos e estigmas sociais 28

II. Articulações Narrativas nas Mídias

4. Estigmas em jornais e revistas: primeiras leituras

4.1. Corpus da pesquisa em mídia impressa (jornais e revistas) 35

4.2. Primeiras páginas e capas: redundâncias e ressonâncias 37

4.2.1. Jornais diários 37

4.2.2. Revistas semanais 53

5. Estigmas em telejornais diários: primeiras chamadas $\quad 62$

5.1. Corpus da pesquisa em mídia audiovisual (telejornais) 62

5.2. Primeiras chamadas: redundâncias e ressonâncias $\quad 64$

5.2.1. Telejornais diários 65

$\begin{array}{lr}\text { 6. Estigmas em filmes: primeiras imagens } & 81\end{array}$

6.1. Filmes em longa-metragem (ficcionais e/ou documentais) 85

6.2. Estigmas sociais em filmes brasileiros $\quad 100$

III. Articulações Discursivas nas Mídias 131

$\begin{array}{ll}\text { 7. Narrativas audiovisuais: entre consolidação e transgressão } & 131\end{array}$

7.1. Referencialidade e ficcionalidade em filmes brasileiros 132

7.2. Convergências e hibridismos em narrativas audiovisuais $\quad 150$

$\begin{array}{ll}\text { 7.2.1. Vestígios de discursos na televisão e no cinema } & 158\end{array}$

$\begin{array}{ll}\text { 7.2.2. Regimes de visibilidade e políticas da representação } & 170\end{array}$

8. Novos realismos no cinema e na televisão 201

8.1. Representações da (in)visibilidade em discursos audiovisuais 214

8.2. Factualidade e ficcionalidade em programas televisivos 231

$\begin{array}{ll}\text { 8.2.1. Narrativas audiovisuais: o caso brasileiro } & 234\end{array}$

8.2.2. Narrativas audiovisuais: a televisão inglesa 246

IV. À Guisa de Conclusão 256

9. Para além dos estigmas: crítica de mídia e práticas culturais 257

10. Crítica audiovisual: visibilidades e invisibilidades encenadas 265

$\begin{array}{lr}\text { V. Bibliografia } & \mathbf{2 7 7}\end{array}$ 


\section{Mídias E EsTigmas Sociais \\ Sutileza E Grosseria da EXCLUSÃo}

Resumo: O tema desta pesquisa articula dois campos aparentemente distantes: os discursos midiáticos, em seus vários recobrimentos (jornais impressos, telejornais, revistas, internet, vídeo, televisão, filmes ficcionais e documentários) e os estigmas sociais, em suas interfaces com a psicanálise, a antropologia, a sociologia, a filosofia, as ciências da linguagem, a comunicação. Trata-se, portanto, de uma pesquisa que tem como objeto de estudo um aspecto específico presente nas mídias: a tematização e figurativização dos estigmas sociais, especialmente enquanto lugares de reforço e/ou transposição. Entre seus objetivos, o trabalho pretende apresentar como se opera, nas mídias, a construção de estigmas sociais e suas configurações predominantes, a partir da análise das narrativas nelas engendradas. O mapeamento de produtos jornalísticos impressos (jornais e revistas) e produções audiovisuais (telejornais, filmes e documentários) foi objeto da pesquisa, desdobrando-se agora nos resultados apresentados. Entre as hipóteses, buscamos demonstrar que o estabelecimento das fronteiras entre fato e relato tem ocupado, há algum tempo, o campo de estudos das mídias em seus formatos verbais, visuais e audiovisuais. Na pesquisa, propomos pensar esta questão a partir de um deslocamento: buscar, nas práticas midiáticas, as fronteiras entre o que chamamos de "referencialidade" e aquilo que, por outro lado, coloca-se como "ficcionalidade" no interior desses discursos, contribuindo para a reflexão sobre a cultura contemporânea. Em torno dessa questão, três outras se colocam: a crescente presença de narrativas de caráter realista nas mídias, manifestada especialmente pela estética construída em torno dos chamados novos realismos, ficcionalizando seus relatos; as transformações nas políticas da representação e nos regimes de visibilidade a eles associados, especialmente em relação a sujeitos não hegemônicos; e a urgência em se estabelecer, frente a esses desafios, uma perspectiva crítica nas análises dos discursos midiáticos.

Palavras-chaves: mídias; estigmas; discurso; narrativa; jornalismo; cinema; televisão. 


\section{Mídias e Estigmas Sociais: Sutileza e Grosseria da ExClusão}

\section{INTRODUÇ̃̃̃o}

A pesquisa intitulada "Mídias e estigmas sociais: sutileza e grosseria da exclusão" tem como objetivo articular os discursos midiáticos e os estigmas sociais presentes em jornais, revistas, televisão e cinema a partir de um deslocamento: apontar, nesses discursos, as fronteiras entre o que chamamos de "referencialidade" e aquilo que, por outro lado, coloca-se como "ficcionalidade" no interior de suas narrativas, contribuindo para a reflexão sobre a cultura contemporânea.

A partir desse percurso, antecipamos as metas atingidas em duas direções: em termos conceituais, um conjunto ampliado de autores foi explorado, possibilitando uma maneira menos estática de pensar a articulação mídias e estigmas sociais. Em lugar de apenas apontarmos as oscilações entre reforço ou transformação de estigmas, deparamonos com intrincadas relações entre eles, agregando à pesquisa categorias operatórias não excludentes. Em relação à amostragem, para além da separação entre narrativas referenciais e narrativas ficcionais compreendemos as limitações de tal classificação e o crescente borramento de fronteiras entre esses gêneros, tendência que pode ser percebida na amostragem final. Constituída por objetos que se articulam entre essas práticas, nela inserimos tanto discursos impressos como audiovisuais (televisivos e cinematográficos), percebendo que também esta divisão, antes mais rígida, atualmente se modifica em termos estéticos, políticos e éticos, reordenando suas fronteiras.

A pesquisa foi desenvolvida em etapas que envolveram: organização teóricometodológica (pesquisa bibliográfica; sistematização conceitual; amostragem); coleta, descrição e análise dos dados de mídia impressa (jornais e revistas), coleta, descrição e análise dos dados de mídia audiovisual (televisão e cinema), com adequação dos critérios metodológicos; sistematização dos resultados por etapas da pesquisa; descrição e análise intercalada dos dados segundo parâmetros interpretativos previamente definidos; compatibilização final, com a identificação de recorrências, variações significativas, dados originais; apresentação e publicação de artigos ${ }^{1}$.

\footnotetext{
${ }^{1}$ Ao longo dos anos, participamos de encontros e congressos nos quais foram debatidos e sistematizados os primeiros resultados da pesquisa. Além disso, publicamos em versões preliminares, parciais ou estendidas, alguns dos textos desenvolvidos, que foram reescritos e reordenados (tanto em termos de conteúdo como de formato) para compor o presente trabalho, que se torna, assim, original na composição ora apresentada e na indicação do amadurecimento e da representatividade de nossa trajetória.
} 
Os resultados do trabalho incorporam e adensam aqueles anteriormente encontrados e, além disso, tornam-se presentes nas orientações de alunos de iniciação científica, mestrado, doutorado e pós-doutorado, além de repercutirem na proposição de novas disciplinas em nível de graduação e pós-graduação. Além disso, destacamos nossa recente participação em um seminário sobre a temática do "popular" nas mídias (no qual apresentamos estudo sobre reality shows) e em um colóquio sobre crítica da imagem midiática (no qual tratamos de séries televisivas), em parceria com pesquisadores da USP e de outras universidades brasileiras, contribuições que incorporam e ampliam resultados e possibilidades abertos com a pesquisa. Em termos internacionais, estabelecemos contato com pesquisadores ingleses do King's College London - universidade na qual realizamos estágio de pós-doutorado (bolsista Fapesp) e do departamento de Media Studies da Birmingham City University.

De modo mais específico, a partir da articulação entre mídias e estigmas sociais, aprofundamos aspectos relacionados às redundâncias e ressonâncias encontradas nas mídias, especialmente em discursos audiovisuais. Ou seja: para além da hipótese inicial - apoiada na assunção de que as mídias, em suas variadas manifestações, operam como lugar de reforço dos estigmas -, chegamos a outra possibilidade - a de nelas demonstrar a transposição de estigmas sociais. Apontar nos discursos midiáticos os espaços de manutenção ou transformação dos estigmas é tarefa que nos propusemos desenvolver e que se mostrou mais complexa do que havíamos vislumbrado, sobretudo no que diz respeito à dissolução de uma postura dicotômica ao abordar tal temática, desafiada que foi pelos aportes teóricos utilizados.

Em termos de análise geral dos resultados, um tema específico tem se sobressaído cada vez mais nas pesquisas em comunicação, apoiado, sobretudo, pelos estudos culturais ou pós-coloniais e pela psicanálise: as complexas relações envolvendo a dinâmica social do convívio entre cada um e os outros, os conflitos daí decorrentes (inseparáveis da própria sociedade em que estão inseridos) e, de modo mais intenso, as possibilidades de construção da representação do outro. As chamadas "figuras de alteridade" (Prado, 2008) presentes nos discursos midiáticos sinalizam, de maneira privilegiada, pontos de confluência e de articulação de estigmas. É sempre em relação a um outro, diferente de nós (e supostamente inferiorizado na dinâmica social), que os estigmas apontam suas especificidades, respondendo a uma questão que acompanha, insistentemente, os discursos midiáticos: como, afinal, (re)presentar o "outro" de modo equilibrado e, sobretudo, ético? Como estabelecer políticas para apresentá-lo? 
É interessante confirmar que, em relação aos estigmas sociais podemos acompanhar alguns temas recorrentes - como se uma dinâmica regular (repetição e diferença) acompanhasse tais narrativas. Entre eles, questões agrárias e/ou urbanas, questões de gênero, questões étnicas, o mundo islâmico, a causa indígena, o tráfico de drogas e, sobretudo nas mídias audiovisuais, temas relacionadas à violência, imigração, pobreza e exclusão social, retratando em suas imagens sujeitos em situação de risco ou vulnerabilidade. Ainda que tenhamos estabelecido alguns conceitos a fim de guiar a análise dos temas correlatos aos estigmas presentes nas mídias audiovisuais (para diferenciá-los de preconceitos e estereótipos), é também a partir de parâmetros anteriores que ensaiamos tais definições. Ou seja: um percurso dedutivo e indutivo se coloca, pois partimos de uma teoria para encontrar a demonstração de seus postulados, ao mesmo tempo em que olhamos objetos empíricos para deles extrair uma teoria.

A questão da aids, motivadora original da temática dos estigmas sociais já na pesquisa de mestrado (1997), é tema sempre provável quando tratamos de estigmas sociais. Recentemente, entretanto, notamos haver um enfraquecimento de sua presença nas mídias em geral. Ainda que a aids permaneça como questão social relevante e estigmatizante, seu discurso articula-se a partir de um outro lugar: não mais o campo social (envolvendo as discussões ou problematizações em torno de preconceitos, direitos, exclusões), mas o campo médico-científico (corroborado pela ciência e suas incansáveis produções).

É no tratamento clínico, nas novas combinações de medicamentos e na responsabilidade de cada um em assumir tal posição - como sujeito imbuído de alcançar sua cura, tanto social como clínica - que a aids encontra seu lugar nas mídias hoje. É também nesse novo lugar que vemos delinear-se outro contorno para a questão dos estigmas e ela associados. Ainda que o corpo (o sexo, o sangue, a morte) mantenhase como ponto nodal desse traçado, seu discurso não mais se articula em torno de grupos sociais (e suas marcas aparentes) mas de indivíduos (e suas marcas invisíveis). É um corpo sobretudo imaginário - e não simplesmente biológico, como prevê a medicina - que vemos ser reafirmado no deslocamento discursivo percebido nas mídias. Nesse sentido, tal abordagem encontra-se com o tema específico desta pesquisa, qual seja, o estabelecimento de políticas da representação e a demarcação de lugares de visibilidade e invisibilidade social. 
Ao aproximarmo-nos, portanto, dos discursos das mídias não é de forma apenas teórica que o fazemos, posto que já possuímos, a priori, uma figuração de possíveis estigmas sociais; do mesmo modo, os referenciais teóricos nos auxiliam na distinção entre temas aparentemente correlatos a esse campo e outros que estabelecem fronteiras com outras questões. No caso do jornalismo, ao considerá-lo como uma narrativa - ou seja, ao falar dos estigmas sociais presentes nos discursos jornalísticos - estamos, ao mesmo tempo, tecendo a narrativa desses estigmas como escrita nos jornais. Se tomarmos como pressuposto que o jornalismo constitui-se, juntamente com outras mídias, como lugar de mediação e construção do espaço público, podemos afirmar que as notícias veiculadas nos jornais cumprem também uma função pedagógica.

Essa função possui, por um lado, um caráter informativo e, por outro, um aspecto normatizador, estabelecendo as fronteiras entre aquilo que é considerado normal ou desviante em uma determinada cultura. Partindo, portanto, das definições de jornalismo como fato de língua, da notícia como forma cultural e dos discursos jornalísticos como dotados de uma estrutura sobretudo narrativa, buscamos apontar em uma amostragem das primeiras páginas de diários brasileiros, das capas de revistas semanais, das chamadas de abertura dos telejornais e, posteriormente, de filmes brasileiros ficcionais ou documentais - algumas das configurações de estigmas sociais presentes nas mídias. Desse modo, acreditamos ter investigado, no caso do jornalismo, ao mesmo tempo os critérios de seleção de suas notícias ${ }^{2}$ (verbais ou visuais) e seus possíveis efeitos de sentido em relação à reafirmação ou questionamento de estigmas socialmente cristalizados e (re)produzidos nas mídias. Pudemos ainda apontar, sob diversas abordagens, os efeitos de sentido presentes em filmes documentais ou ficcionais, e a grande presença da tematização de estigmas sociais em suas narrativas.

Por processos contínuos de aproximação aos jornais, revistas, telejornais e filmes, efetuamos inúmeras leituras (descritivas e analíticas) até chegar às considerações aqui ensaiadas sobre este conjunto ao mesmo tempo heterogêneo e homogêneo. Ainda assim, surpreende-nos, ao final do processo, constatar a riqueza do material selecionado - mesmo após suas reduções quantitativas - e observar que os textos e imagens apresentados poderiam ser explorados ainda mais, em formas variadas. Os conteúdos e expressões neles implicados não se esgotam nos limites da pesquisa, mas transbordam suas fronteiras e possibilitam muitas outras análises e sínteses.

\footnotetext{
${ }^{2}$ Para aprofundar a questão dos critérios de noticiabilidade e valores-notícia, ver Cristina Ponte, Leituras das notícias. Contributos para uma análise do discurso jornalístico (Lisboa: Horizonte, 2004).
} 
Finalmente, detivemo-nos no estudo dos discursos audiovisuais representados por programas televisivos e filmes cinematográficos. A abrangência dessa amostragem, motivada especialmente pelo aumento da produção nacional dos últimos anos, obrigounos e escolher, dentre os diversos títulos, aqueles a partir dos quais aprofundar as análises em relação aos estigmas sociais neles presentes, tomando-os sob dois eixos principais: a divisão tradicional entre discursos ditos "ficcionais" ou "documentais", e uma outra, de cunho metodológico, entre aqueles de "consolidação" ou de "transposição" de estigmas.

A partir dos resultados encontrados, percebemos a necessidade de aprofundar aspectos relacionados a programas televisivos (especialmente reportagens e reality shows e, eventualmente, telenovelas e séries) e documentários (especialmente aqueles caracterizados por hibridismos estilísticos, estéticos, narrativos), notadamente naquilo que tais formatos (ou gêneros) nos propõem enquanto narrativas audiovisuais voltadas aos acontecimentos (événements), compondo o que hoje, mais amplamente, podemos denominar de reality $t v$, ou "telerrealidade" $"$.

É em perspectiva crítica que tal desafio se coloca, entrelaçando quatro aspectos: a inserção das investigações no campo da crítica de mídias - pensada não de modo prescritivo, mas analítico; o reconhecimento da importância de uma cultura audiovisual contemporânea (especialmente no cinema e na televisão) que perpassa todos os discursos midiáticos; a premência de se compreender de que forma os chamados novos realismos se instauram nesses discursos, articulando outros modos de construção da representação e novos regimes de visibilidade; e, finalmente, a prevalência da temática dos estigmas sociais como eixo articulador dessas narrativas, tanto em termos de conteúdo, como em seus aspectos estéticos, políticos e éticos.

A tematização dos estigmas se faz de forma cotidiana nas mídias. Desde os casos de fácil identificação, como a maior parte dos programas televisivos de auditório (ainda que com suas especificidades, citamos a um só tempo programas antigos e recentes, tais como "Programa do Ratinho", "Hora da verdade", "É show", "Programa Silvio Santos", "Domingão do Faustão", "Noite afora", "Hebe”, "Super pop", “A noite

\footnotetext{
${ }^{3}$ Traduzida para a português a partir de sua forma francesa (téléréalité) e espanhola (telerrealidad), por vezes confundida com o gênero televisivo de reality shows mas que, para alguns autores (com os quais compartilhamos essa noção), estende-se a outros formatos televisivos que, independente de serem documentais ou ficcionais, têm como elemento constitutivo um certo modo de relação e apreensão da realidade factual e do mundo vivido (Jost, 2004; 2007; 2011).
} 
é uma criança", entre outros ${ }^{4}$ ), passando pela crescente presença de reality shows de competição ("No limite", "Casa dos artistas", "Big Brother Brasil", "Acorrentados", "Ilha da sedução", "Jogo duro") e sua propagação em realities de talentos ou transformação, até os programas tidos como jornalísticos (telejornais, programas de entrevistas, programas de debates, programas semanais de reportagens), as mídias estão repletas de exemplos de estigmas sociais. A pesquisa volta-se, portanto, para os modos de construção da representação de estigmas sociais em narrativas contemporâneas a partir dos processos de identificação e de partilha do sensível nelas evocadas.

Destacamos desde já que não nos interessa tanto o conteúdo desses discursos (entendendo discurso em sentido amplo, tanto verbal quanto visual e audiovisual), mas, sobretudo, a forma como estão articulados seus elementos enunciativos e os possíveis desdobramentos a partir desta articulação. A hipótese que gostaríamos de contemplar diz respeito a tal ordenação: os discursos midiáticos, afinal, operam na construção de estigmas sociais? Nesses discursos, podemos perceber reforço ou, ao contrário, transposição de estigmas? As práticas midiáticas (discursos) velam ou re-velam (e de que forma) os estigmas sociais? De que modo os estigmas estão presentes ou ausentes nos discursos midiáticos (quais suas falas e seus silêncios)? Essas as principais perguntas que buscamos responder, analisando as mídias para delas extrair um panorama dos estigmas sociais em suas configurações discursivas.

Apresentamos, num primeiro momento, os chamados discursos jornalísticos em formato impresso e televisivo, dadas as características que revestem este fazer: os critérios de atualidade, veracidade, credibilidade, factualidade, entre outros, tornam mais ambígua (e por isso, acreditamos, mais instigante) a relação entre mídias e estigmas sociais no jornalismo do que em outros formatos mais próximos do entretenimento. Em um segundo momento, estendemos a pesquisa a programas televisivos (integrando, assim, a análise de discursos audiovisuais) para, finalmente, chegarmos à produção cinematográfica, analisando tais discursos visando problematizar as fronteiras entre formas referenciais e formas ficcionais. De maneira análoga, entre as muitas possibilidades de amostragem comportadas por esse último recorte, buscamos em programas de televisão e filmes para cinema voltados à temática dos estigmas sociais o corpus específico da pesquisa.

\footnotetext{
4 A disciplina "Ciências da linguagem: mídias e mitologia do escandaloso" (CJE-ECA), ministrada em 2002 pela profa. dra. Jeanne Marie Machado de Freitas e pela psicanalista Nilvana Nanni de Castelli tratou desses programas de forma original ao relacioná-los com as origens e formas do escândalo como apresentado em seus modos tradicionais de representação.
} 
Nesse aspecto, analisamos mais detidamente os discursos audiovisuais contemporâneos de caráter referencial - jornalismo e documentário - a fim de estabelecer um estudo contrastivo entre eles, apontando seus pontos de contato e suas especificidades. Como forma de demonstrar tais aproximações e afastamentos, foram escolhidos programas jornalísticos produzidos para televisão (incluindo telejornais tradicionais) e filmes documentários produzidos para cinema (excluindo documentários televisivos). Tal escolha reflete nosso interesse renovado no tema dos estigmas sociais mas, sobretudo, a possibilidade de, partindo desse recorte, estabelecer um critério ao mesmo tempo restritivo (no sentido de possibilitar a escolha dos programas e filmes) e abrangente (já que a questão dos estigmas está relacionada aos discursos referenciais). Para refletir sobre essas zonas limítrofes, os chamados "discursos referenciais" (ou realistas, na acepção de Barthes $^{5}$ ) foram pensados, sobretudo, à luz da filosofia da linguagem, dos estudos linguísticos, da antropologia e da história. Por analogia ao contundente debate realizado nesses campos do conhecimento, como veremos adiante, chegamos aos discursos realistas para deles extrair seu caráter de construtos.

É no jornalismo e no cinema, em forma de reportagens televisivas e filmes documentários, portanto, que encontramos o locus privilegiado de nossas inquietações, buscando aproximá-los sob a perspectiva de que, em ambos os casos, trata-se de discursos fundados sobre a referencialidade mas, ainda assim, evocando a ficcionalidade própria da literatura. Assumimos, nesse momento, a perspectiva de que o jornalismo televisivo se revela, atualmente - ao menos se considerado em seus princípios ordenadores tradicionais -, como lugar de resistência à perspectiva ora apresentada de que a realidade se faz de rastros de discursos. O cinema, seja em filmes de ficção ou de não-ficção, apresenta-se como mais permeável às ideias aqui entrelaçadas. Daí a importância de buscarmos as possibilidades de demonstrar as hipóteses acima, estabelecendo como ponto de chegada da pesquisa a apresentação das formas de narrar (ficcionais) presentes nessas formas discursivas (referenciais). A realidade seria, portanto, imaginária, ou seja, um vestígio do real ao qual não temos acesso.

\footnotetext{
${ }^{5}$ O termo "referencialidade" refere-se a um modo de articulação discursiva e de construção de sentidos empreendida a partir de elementos da realidade factual e/ou histórica, e não de elementos imaginativos ou fabulares. Autores como Roland Barthes ("O efeito de real"; "O discurso da história", 1988), Émile Benveniste ("O aparelho formal da enunciação", 1989b) e Hayden White ("As ficções da representação factual”, 1994), entre outros oferecem aportes nos quais situar essa problemática.
} 
Do real, na acepção que lhe é dada pela psicanálise, teríamos apenas seus vestígios, ou seja, os discursos que o colocam na rede simbólica de uma determinada cultura. Se o real é impossível (e nesse sentido, não existe como realidade), os vestígios do real seriam formados pelos vestígios de discursos. Nas zonas limítrofes entre reportagens jornalísticas e filmes documentários, como veremos, buscamos apreender os modos de construção de sua enunciação a partir de enunciados articulados em torno dos estigmas. Nesse sentido, algumas hipóteses vêm se somar àquelas já apresentadas, buscando especificidades em relação ao objeto da pesquisa e seus objetivos.

Entre esses objetivos, com relação aos discursos audiovisuais, buscamos problematizar o fazer jornalístico e as produções cinematográficas, assumindo que no campo da reportagem televisiva, ao contrário do cinema documentário, há mais repetições do que questionamentos. Ao fazê-lo, ensaiamos um diálogo com o fazer cinematográfico para neles apontar matrizes presentes também nas reportagens televisivas, visando encontrar outros modos de aproximação aos discursos referenciais que se pretendem legitimadores de realidades cotidianas.

\section{Fundamentos teóricos}

Em nossa pesquisa, ao falarmos de mídias e estigmas sociais partimos de alguns postulados. O primeiro diz respeito à dinâmica dos processos de identificação; o segundo diz respeito aos discursos referenciais a partir da assunção de seu estatuto enquanto construção discursiva na linguagem, lembrando o caráter arqueológico dessa criação; o terceiro diz respeito à definição de discurso sob três aspectos: a) a linguagem é constituinte do humano; b) o mundo histórico é instaurado pela linguagem; c) o discurso é um vínculo que se desenvolve na linguagem.

Em termos conceituais, os estudos de linguagem, discurso e narrativa, pensados em relação às práticas midiáticas - campo para o qual temos nos voltado em pesquisas, cursos, publicações e eventos -, são contemplados por meio da análise de reportagens e documentários que abordam a temática dos estigmas sociais. Os "regimes de visibilidade" e as "políticas da representação" neles presentes (incluindo a demarcação dos limites entre o mesmo e o outro), problematizando a suposta objetividade jornalística e a factualidade documental em discursos denominados referenciais, são conceitos centrais na articulação do trabalho, além dos hibridismos e das interseções entre referencialidade e ficcionalidade, fronteiras nas quais situamos o debate. 
Para tratar do tema, partimos de algumas definições sobre os estigmas sociais. De forma geral, podemos definir o estigma como uma marca visível, um sinal que desperta nos outros, ao mesmo tempo, um sentimento de atração e repulsa. A eles são atribuídos valores, hierarquizando-os em termos de aceitação ou rejeição, variando de acordo com diferentes épocas históricas, características culturais ou sociais. Dessa forma, podemos dizer que os estigmas operam, simultaneamente, como fatores de inclusão e de exclusão, de estabelecimento de igualdades e de desigualdades; ao fazê-lo, constituem-se como a própria gênese dos grupos sociais.

Tal fato faz com que seja inevitável, impossível mesmo, estabelecer relações entre grupos sem que, simultaneamente, sejam estabelecidas relações de inclusão/exclusão. O que não quer dizer que os estigmas sejam invariáveis (embora invariantes enquanto estrutura), tampouco que devamos nos acomodar a eles. Os estigmas sociais se colocam entre indivíduos considerados em relação a um grupo (o grupo de seus semelhantes, o grupo de seus diferentes), ou mesmo entre grupos distintos. Vem de um lugar outro - dos outros - a atribuição de algo a alguém, destinando a este alguém uma determinada posição, um determinado papel social. Ao ser incluído em um lugar definido, o indivíduo é excluído de outros por meio das marcas que carrega ou daquelas a ele atribuídas, inserindo-se no conjunto das chamadas minorias visíveis, ou seja, das "identidades culturais subjugadas" ou submetidas a posições de "não reconhecimento social" (Fraser, 1992).

Ainda que os discursos midiáticos tenham como ênfase que as diferenças sejam recíprocas e simetricamente respeitadas, diversos dispositivos de marginalização social perduram em sociedades multiculturais e estratificadas, nas quais grupos sociais apresentam-se com poderes distribuídos de modo desigual e estilos culturais valorizados de maneiras diversas (Young, 1990; Fraser, 2000; Elias e Scotson, 2000). Desse modo, Fraser sugere a "reavaliação positiva de identidades desrespeitadas e de produtos culturais de grupos excluídos" como forma de desconstruir o imaginário que a sociedade cultiva acerca desses grupos (Fraser, 1992), interferindo, de modo crítico, nas políticas da representação e na construção de visibilidades e invisibilidades sociais.

Em casos específicos, a exibição da marca estigmatizável pode até mesmo constituir-se como desejada: para os que possuem tatuagens no corpo, o processo de inclusão/exclusão é espontaneamente realizado - a tatuagem é uma marca que a própria pessoa se inflige para se incluir em um determinado grupo (marca de pertença), distinguindo-se dos demais (os que não a possuem). Seu caráter perturbador exemplifica 
com clareza a relação ambígua - de atração e repulsa - presente nos estigmas. Ao contrário de cicatrizes involuntárias - resultado de acidentes ou ferimentos, que apontam para eventos vividos no passado -, a tatuagem estabelece uma marca (uma memória) onde antes não havia nada. Mais do que lembrar um passado, as tatuagens instalam-se como marcas para singularizar um tempo em que nada de fato aconteceu, a não ser a própria inscrição (já que as marcas gravadas não foram involuntárias, como no caso de uma cicatriz, mas deliberadas pelo sujeito).

De forma semelhante, a marca de espada no rosto dos cavaleiros medievais era, sobretudo, um sinal de orgulho para mostrar que a pessoa havia lutado por algo, combatido em nome de uma causa (ou daquilo que a causava). A cicatriz da espada remetia a um passado de lutas; a tatuagem parece apontar para um presente que não se quer esquecer, a promessa de um tempo que começa a ser contado não por aquilo a que remetia, mas por aquilo que começará a acontecer - um futuro, de certo modo, antecipado no presente. Para a psicanálise, os estigmas remetem às marcas primordiais inscritas no sujeito pelo Outro, referência primeira na constituição de sua singularidade. Lacan (1990) relaciona o campo do sujeito e o campo do outro ao tratar do tema da pulsão, abrindo caminho para pensarmos os estigmas como marcas que vêm de um outro lugar:

\footnotetext{
A libido é o órgão essencial para se compreender a natureza da pulsão. Esse órgão é irreal. Irreal não é de modo algum imaginário. $O$ irreal se define por se articular ao real de um modo que nos escapa, e é justamente o que exige que sua representação seja mítica, como a fazemos. Mas, por ser irreal, isso não impede um órgão de se encarnar. Eu lhes dou já sua materialização. Uma das formas mais antigas de encarnar, no corpo, esse órgão irreal, é a tatuagem, a escarificação. O entalhe tem muito bem a função de ser para o Outro, de lá situar o sujeito, marcando seu lugar no campo das relações do grupo, entre cada um e todos os outros. E, ao mesmo tempo, ela tem, de maneira evidente, uma função erótica, de que todos aqueles que abordaram sua realidade se aperceberam (Lacan, 1990: 195).
}

Desde pequeno, o humano constitui sua identidade por meio de identificação e de oposição, uma mistura de gozo e horror, reconhecimento e exclusão, introjeção e projeção, prazer e desprazer, numa dinâmica que, nas palavras de Freud (1974), remete ao par "ideal do eu" (narcísico) / "eu ideal” (ideais culturais). De acordo com a psicanálise, o inconsciente seria a absoluta igualdade na desigualdade de todos, a igualdade das singularidades e não da homogeneização. $O$ estigma, portanto, não é qualquer marca, mas aquilo que distingue, diferencia, isola; e nem todo estigma traduzse em estereótipos ou preconceitos (ter olhos azuis, por exemplo, marca de distinção no Brasil, não gera, em princípio, nenhum desconforto). 
A separação, entretanto, nem sempre é negativa: se uma sociedade conseguisse eliminar todos os seus estigmas - todas as marcas de divisão -, talvez criasse ainda mais exclusões, pois ao tratar como "iguais os diferentes" corremos o risco de não equalizar as relações - o que só pode ser feito se, ao contrário, tratarmos os diferentes como diferentes, os que mais necessitam de atenção com maiores cuidados.

Em termos sociais, tudo aquilo que funciona como sinal de diferença é passível de transformar-se em estigma. No processo por se diferenciar dos outros (e, ao fazê-lo, aproximar-se de seus semelhantes), o humano passa a apontar as pequenas diferenças que se mostram visíveis: a cor da pele, o formato dos olhos, as roupas, o cabelo, os gestos, a fala, entre outras coisas. As diferenças são imaginárias, apontando para a repetição de uma mesma estrutura, ainda que recoberta por diferenças. Por isso arriscamos afirmar que, talvez, o multiculturalismo não se coloque exatamente como a não-estigmatização ao afirmar o "direito à igualdade"; diríamos, de outra forma, que o que deve ser afirmado é o "direito à igualdade apesar de nossas diferenças", e não a tentativa de tornar iguais os desiguais. A dinâmica dos estigmas recoloca a discussão sobre dominantes e dominados, hegemonias e subalternidades: não haveria, de um lado, os estabelecidos, e de outro, os excluídos, como se eles fossem blocos homogêneos ou autônomos. O conceito de estigmas intercambia papéis, apontando processos de hierarquizações tanto no centro como na periferia dos sistemas, movimentos que podem ser percebidos nas mídias.

Dentro de cada um dos diversos grupos sociais há brechas e passagens, para além de seus dualismos. Desde Gramsci (1999) sabemos que um mundo dividido apenas em dois grupos previamente conceituados não dá conta da complexidade atual, em que os lugares são reapropriados e os sentidos ressignificados; daí um problema crucial para as ciências humanas, relativo à dificuldade de se classificar, por exemplo, os indivíduos em classes sociais compactas. $\mathrm{O}$ conceito de estigma, nesse sentido, não se limita à oposição enunciada por Elias (2000) entre "estabelecidos e estigmatizados" (embora ela seja determinante), mas intercambia papéis, apontando para processos de hegemonias e hierarquizações dentro de cada um dos grupos sociais.

Alguns exemplos recorrentes nas mídias podem ilustrar tal troca de lugares: no início dos anos 2000, dois jogadores de futebol, Marcelinho Carioca (ex-jogador do Corinthians) e Kaká (ex-jogador do São Paulo), foram, cada um a seu modo, estigmatizados. O primeiro por ser considerado dissimulado, briguento e encrenqueiro; o segundo, por pertencer a um grupo que não costuma estar presente nos campos de 
futebol: é branco, de classe média, estudioso, elegante, sintetizando de forma ideal o jogo entre atração e repulsa que acreditamos permear os estigmas sociais. Outros exemplos temáticos de estigmas nas mídias podem ser apontados: as camisetas de futebol das torcidas organizadas; os piercings usados pelos jovens; a estrela do PT como emblema de sua criação; as ações do MST e suas reivindicações; os papéis destinados aos latinos nos filmes americanos; as referências, em telenovelas da Rede Globo, ao uso de drogas (O clone, 2001), à síndrome de Down (Páginas da vida, 2007) e à deficiência física (Viver a vida, 2009), à esquizofrenia e suas consequências sociais (Caminho das Índias, 2009), aos preconceitos de classe (Fina estampa, 2011; Avenida Brasil, 2012); os movimentos "antiglobalização", em que o prefixo anti já marca a posição a partir do qual a resistência se articula.

É curioso lembrar que os nomes próprios carregam, também eles, estigmas como o caso do menino sequestrado "Pedrinho", encontrado 17 anos depois como "Oswaldo", história presente no noticiário midiático e, posteriormente, tema da novela Senhora do destino (2004), da Rede Globo; ou as conotações curiosas em relação ao filho do empresário Eike Batista, chamado Thor, quando se envolveu em acidente automobilístico (em 2011), que resultou na morte de um ciclista, fartamente difundido pelas mídias e que resultou, alguns anos depois, na absolvição do culpado. Outro exemplo interessante em relação aos estigmas dos nomes pode ser retirado, uma vez mais, do futebol. O clube esportivo Palmeiras, comumente conhecido como "porco", adotou como apelido o nome depreciativo que lhe foi dado pela torcida adversária. $\mathrm{O}$ estigma, negativo, deixou de sê-lo quando os próprios palmeirenses adotaram este símbolo e passaram a se autodenominar "porcos".

O cinema também traz exemplos para pensarmos os estigmas. É o caso de diversos filmes do diretor norte-americano Tim Burton que, em muitos momentos, conta sua história pelo olhar dos outsiders (vilões, mendigos, deserdados), articulando suas narrativas em torno deles - lembremos, por exemplo, Edward mãos de tesoura (Edward scissorhands, 1990), misto de monstro e humano; Batman (Batman, 1992), em que a narrativa é contada a partir da perspectiva do antagonista Pinguim; o vilão sobrenatural de A lenda do cavaleiro sem cabeça (Sleepy hollow, 1999); e a refilmagem de $O$ planeta dos macacos (Planet of the apes, 2001), em que símios e humanos intercambiam lugares. Outro diretor norte-americano, David Lynch, move-se com desenvoltura no terreno pantanoso dos estigmas, despertando estranhamentos a cada filme - desde Veludo azul (Blue velvet, 1986) e História real (The Straight story, 1999), 
até Cidade dos sonhos (Mulholland Drive, 2001). Além deles, Clint Eastwood nos apresenta, em seus inúmeros filmes, uma linhagem de personagens desajustados ou incomodados com as regras vigentes, entre eles Cowboys do espaço (Space cowboys, 2000), Gran Torino (Gran Torino, 2008) e Invictus (Invictus, 2009). No registro da comédia, as figurações presentes nos filmes de Woody Allen desafiam, de modo provocador, padrões considerados normativos, como vemos em Poderosa Afrodite (Mighty Afrodite, 1995), Melinda e Melinda (Melinda and Melinda, 2004), Tudo pode dar certo (Whatever works, 2009), Meia-noite em Paris (Midnight in Paris, 2011) ou, mais recentemente, O homem irracional (Irrational man, 2015).

De modo emblemático, o filme Gattaca - A experiência genética (Gattaca, 1997), uma ficção científica que trata de formas de controle e exclusão no futuro potencializadas como vigilância e dominação no filme de Steven Spielberg, Minority report - A nova lei (Minority report, 2002) - apresenta nossas marcas únicas e invisíveis (código DNA, impressões digitais) como modos de discriminar e isolar uns dos outros. Tais marcas funcionam como estigmas, pois são sinais que levam ao isolamento e à diferenciação. Nesse filme, os três personagens masculinos apresentam entre si claras relações de atração e repulsa, apontando para a complexidade dos estigmas. Tal complexidade pode ser percebida também no filme Stigmata (Stigmata, 1999), no qual a marca que aparece no indivíduo ao mesmo tempo o faz ser percebido como destacado dos demais e lhe impinge sofrimento (na recusa a sua condição).

Ainda no cinema de ficção, o filme Os outros (The others, 2001) é ilustrativo das relações de pertença e não pertença: ao intercambiar os papéis entre vivos e mortos - habitantes e intrusos -, aponta para a relatividade de tais classificações, invertendo suas posições. Em outro registro, as fotos de Sebastião Salgado, trabalho que se coloca nas fronteiras entre arte e fotojornalismo, também apontam para os estigmas sociais. Nos rostos sofridos estampados nas páginas de seus livros (ou nas sofisticadas reproduções presentes em salas de jantar), vemos tanta miséria e tanta beleza que nos sentimos perturbados. A força das imagens fotográficas de Salgado - e seu impacto não apenas para o público, mas para o olhar do próprio fotógrafo que as testemunha - foi captada pelas lentes de Juliano Salgado, seu filho, e do cineasta alemão Wim Wenders, que editou as imagens e depoimentos no documentário $O$ sal da terra (The salt of the earth, 2014), indicado ao Oscar de melhor documentário em 2015 e ganhador de vários prêmios, a exemplo de documentário anterior de Wenders sobre músicos tradicionais cubanos (Buena Vista Social Club, 1999). 
No campo do jornalismo, jornais diários como o extinto Notícias Populares (1963-2001) e telejornais como Aqui Agora (1991-1997; 2007-2008) especializaram-se - ao menos em períodos mais recentes -, em articular suas notícias em torno dos estigmas sociais, voltando-se para um segmento específico de público, supostamente das classes populares, sob o slogan "Nada mais que a verdade" (no caso do $N P$ ) ou "Um jornal vibrante, uma arma do povo, que mostra na TV a vida como ela é!” (Aqui Agora). Aliados ao tom humorístico, os estigmas estampados nas páginas do NP captavam a atenção de seus leitores, bem como as manchetes apelativas de seu congênere televisivo. O que nos leva a perguntar: o que há, afinal, nos estigmas, que nos faz ser por eles capturados? Muitos programas televisivos utilizam-se dessa fórmula para cativar sua audiência, transmutando em imagens as marcas dos estigmas sociais.

O que une os exemplos é que os estigmas, de certa maneira, apontam para uma estrutura subjacente às sociedades humanas - a de excluir e incluir pelo estabelecimento de semelhanças e diferenças - e também para um de seus maiores desafios enquanto coletividade: saber lidar com as singularidades e incompletudes, as lacunas e ausências, que a atravessam. Ao demarcar os limites entre estabelecidos e outsiders, os estigmas revelam as representações sociais de um determinado grupo, supostamente dominante, apontando para seus recobrimentos históricos e culturais.

Um breve trajeto ao redor da palavra estigma pode auxiliar no estabelecimento de uma demarcação para a escolha do termo, ampliando a conceituação apresentada. Outras palavras podem ser a ela associadas, tais como estereótipo, preconceito, discriminação, exclusão, minorias, dominação, problematizando as definições nelas pressupostas. Muitas vezes tomados como sinônimos, o esforço por diferenciar esses conceitos torna mais complexa a temática e, ao mesmo tempo, funciona como um dos parâmetros para a identificação dos estigmas sociais presentes nos discursos midiáticos.

Em sua definição original, o estigma é uma cicatriz, uma marca visível (como os estigmas da varíola ou as chagas de Cristo), podendo caracterizar-se tanto quanto um sinal infamante ou vergonhoso, como um sinal natural do corpo; nos dois casos, as marcas assinalam uma distinção, isolando e, ao mesmo tempo, reunindo e identificando os possuidores desse mesmo atributo. Em sua origem religiosa, sua presença atesta não apenas a santidade, mas também o pertencimento a um grupo especial. Esta escolha, longe de ser um privilégio, carrega em si obrigações e desafios.

Apresentamos a seguir as distinções dos termos para, em seguida, relacioná-los. 
1. Estigma: "cicatriz, marca, sinal". Do latim stígma, derivado do grego stígma.

Estigma: a) cicatriz, marca, sinal (os estigmas da varíola); b) sinal infamante, ferrete; c) sinal natural no corpo; d) as marcas das cinco chagas de Cristo (os estigmas de são Francisco); e) fig. aquilo que marca, que assinala: os estigmas da arte; f) fig. marca infamante, vergonhosa; labéu; g) morfol. Veg. Porção terminal do gineceu, destinada a recolher o pólen, e sobre a qual ele germina. Pode ser punctiforme, capitado ou ramoso; h) zool. órgão da respiração dos insetos. (Aurélio)

2. Estereótipo: a) forma compacta obtida pelo processo estereotípico; b) estereotipia, clichê; c) lugarcomum, chavão. (Aurélio)

Estereotipia: a) processo pelo qual se duplica uma composição tipográfica, transformando-a em forma compacta, por meio da moldagem de uma matriz; b) repetição de gestos amaneirados, permanência em posições estranhas, que constituem um dos sintomas não essenciais da esquizofrenia.

3. Preconceito: "conceito ou opinião formados antecipadamente, sem maior ponderação ou conhecimento dos fatos” (pré-concebido, pré-conhecido). Do latim praeconceptu. (Etimológico)

Preconceito: a) conceito ou opinião formados antecipadamente, sem maior ponderação ou conhecimento dos fatos; b) julgamento ou opinião formada sem se levar em conta o fato que os conteste; prejuízo; c) p. ext. superstição, crendice; prejuízo; d) p. ext. suspeita, intolerância, ódio irracional ou aversão a outras raças, credos, religiões etc. (o preconceito racial é indigno do ser humano). (Aurélio)

4. Discriminação: "linha divisória, discernimento". Do latim discriminatione (Etimológico)

Discriminação: a) ato ou efeito de discriminar; b) faculdade de distinguir ou diferenciar ou discernir; c) separação, especificação, apartação, segregação (discriminação racial); eletron. eliminação de todos os sinais que entram num circuito, exceto aqueles que têm determinada característica de fase, frequência ou amplitude. (Aurélio)

5. Excluir: "ser incompatível, afastar, recusar". Do latim excludere. (Etimológico)

Excluir: a) ser incompatível com; b) afastar, desviar, eliminar; c) pôr de lado, abandonar, recusar; d) não admitir; omitir; e) pôr fora; expulsar; f) privar, despojar; g) pôr-se ou lançar-se fora; isentar-se; privar-se. (Aurélio)

Exclusão: a) ato de excluir; exceção; b) ato pelo qual alguém é privado ou excluído de determinadas funções; exclusiva. (Aurélio)

6. Minoria: "menos: em quantidade ou intensidade menor". Do latim minus. Havia em latim minus caput, "privado de seus direitos civis"; dessa expressão latina é que provavelmente se formou minuscapare (menosprezo, descrédito, menosprezar, menosprezado, minoritário).

Minoria: do latim minore (menor); a) inferioridade numérica; b) a parte menos numerosa duma corporação deliberativa, e que sustenta idéias contrárias às do maior número; c) menoridade.

7. Dominar: "ter autoridade ou poder sobre"; "conter, reprimir"; "ser ou estar sobranceiro". Do latim dominare. (Etimológico)

Dominar: a) ter autoridade ou poder sobre; b) exercer influência ou domínio sobre; c) conter, reprimir (instintos); d) elevar-se acima de; e) preponderar, predominar; f) estender-se por; ocupar; tomar; g) exercer domínio; ter grande influência; h) prevalecer, predominar; i) conter-se, moderar-se. (Aurélio)

* Definições a partir de Dicionário Aurélio da Língua Portuguesa e Dicionário Etimológico Nova Fronteira.

$\mathrm{Na}$ esteira dessas diferenciações surgem os estereótipos, "forma compacta obtida pelo processo estereotípico", uma espécie de clichê (gravação, reprodução) que se torna um lugar-comum, um chavão utilizado sem que nos perguntemos sobre suas significações. Os discursos midiáticos, em geral, e os discursos jornalísticos, em particular, encontram-se repletos dessas expressões, que não carecem de explicação. No caso de estereótipos, ao identificar certas posturas ou comportamentos automaticamente enquadramos as pessoas que os possuem em categorias previamente definidas.

Em relação aos estigmas, diríamos que os estereótipos funcionam como reforço e manutenção de um sistema já instaurado, diferenciando grupos determinados. Através dos estereótipos, encaixamos as pessoas em uma forma pronta. No caso dos estigmas, trata-se de algo que o estigmatizado evoca em relação ao Outro, uma marca que ele possui e que, de alguma maneira, faz com que o outro o estigmatize. Podemos dizer que o conjunto dessas marcas sustenta o estereótipo e o preconceito. Ainda que com cautela, 
afirmamos que para alguém ser estigmatizado deve, de alguma forma, reconhecer-se no lugar ao qual está sendo destinado, ver-se nele, estigmatizar-se. Nesse sentido, o estigma não passa apenas pela relação entre dominantes/dominados, mas por um reconhecimento desse lugar comum, num duplo jogo entre coerção/coesão.

Os preconceitos, diferentemente dos estigmas, operam como julgamentos a priori realizados sobre um grupo ou um indivíduo, de caráter sempre excludente. Podemos dizer que os estigmas, mais abrangentes, encontram-se na base dos preconceitos; estes, por sua vez, depois de instituídos socialmente e internalizados individualmente, passam a existir independentemente dos estigmas que os possam ter originado. Definidos como "conceito ou opinião formados antecipadamente, sem maior ponderação ou conhecimento dos fatos; julgamento ou opinião formada sem se levar em conta o fato que os conteste; superstição, crendice; suspeita, intolerância", os preconceitos podem gerar ódio irracional ou aversão a outras raças, credos, religiões, como notamos frequentemente em diversas relações sociais.

Outro aspecto a ser ressaltado diz respeito a uma característica fundamental em relação aos estigmas sociais: para que operem em relação a um grupo ou indivíduo, é necessário que o estigmatizado (além de ser reconhecido e reconhecer-se no estigma) esteja em um lugar no qual, supostamente, não deveria estar, um lugar ao qual não pertence. É necessário, portanto, que o sujeito esteja des-locado, ou seja: é como se alguém que não devesse estar ali estivesse lá, por isso o incômodo e a estigmatização.

A partir dessas operações discursivas - estigmas, estereótipos, preconceitos chegamos aos atos cotidianos de discriminação, que isolam e segregam aqueles que carregam as marcas (os estigmas) de sua condição, excluindo-os, afastando-os, desviando-os, tornando-os incompatíveis, abandonando-os, privando-os, despojando-os e, no limite, eliminando-os de fato do convívio social. Das relações de discriminação, exclusão e dominação constituem-se as minorias, ou seja, aqueles que, menos numerosos, sustentam ideias contrárias às do maior número. No caso do Brasil, é interessante notar que o estabelecimento de minorias se faz em termos de posições de poder tradicionalmente instituídas, como em relação aos negros e às mulheres, ainda que estes representem, de fato, maiores numéricas. Mesmo que não representem o menor número de pessoas, as relações de dominação que os submetem são mantidas por uma suposta maioria detentora de mais poder. 
Esse contraponto amplia a definição de minoria, recuperando um sentido presente na expressão latina minus caput, ou seja, alguém privado de seus direitos civis. Como lemos (ver dicionário Aurélio), “dessa expressão latina é que provavelmente se formou minuscapare (menosprezo, descrédito, menosprezar, menosprezado, minoritário)", apontando para o descaso com as chamadas "minorias" que vemos se manifestar em tantos momentos. A dominação de um grupo sobre outro indica, portanto, poder, influência, domínio, repressão, ocupação, alcance, prevalência. $O$ jogo entre essas palavras se faz de forma dinâmica e não hierárquica, ainda que possamos estabelecer uma ordem lógica - dos estigmas à dominação, passando pelos estereótipos, pelos preconceitos, pela discriminação e pela exclusão das minorias.

Exemplo vivo dessas relações encontramos nos conflitos antigos e recentes, fartamente relatados nas mídias, ocorridos no Oriente Médio (especialmente entre palestinos e israelenses), ou nas recorrentes declarações de guerra àqueles países (vindas especialmente do governo norte-americano), considerando todas as nuanças que os envolvem: religião, política, economia, sem que com isso se apaguem as relações de dominação construídas sobre fortes e visíveis estigmas. Atualmente, ecos de tal segregação se fazem ouvir nas notícias sobre a morte de centenas de imigrantes em travessia rumo à Europa e nas medidas sectárias pensadas para impedi-los de entrar naqueles países. A partir dessas observações podemos pensar os estigmas como um campo equívoco, difuso, multifacetado e fluido; os estereótipos e preconceitos, ao contrário, constituem um campo unívoco, concêntrico, unilateral, compacto.

Entre os dois polos, sabemos, há toda uma escala de matizes e variações, especialmente se pensamos nas mídias: não é de maneira pura ou isolada que encontramos essas características, mas a distinção tem, nesse momento, caráter operacional. Como exemplo, podemos citar o caso do clássico personagem de história em quadrinhos, "Meia Oito" (criado por Angeli), caricatura de um suposto militante político de esquerda: ser militante (em determinado período e para certos grupos sociais) é um estigma que, ao se transformar em desenho, agrega estereótipos, características exageradas e traços generalizados. Assim, o estigma pode ser pensado como uma estrutura vazada na qual vêm se encaixar os diferentes estereótipos, estes se caracterizando como uma forma cristalizada e pré-determinada de instauração de preconceitos. Em geral, os estigmas trazem em sua base, sustentando-os, uma grande narrativa, ou um grande tema, repetido ao longo da história, apresentando uma certa invariância (tais como questões geracionais, sexo, violência, política, religião, cultura). 
Esse grande tema parece modificar-se pouco ao longo do tempo; o que muda são as pequenas narrativas que o recobrem em sua superfície. Alguns exemplos desses grandes temas podem ser retirados das mídias: morte (aborto, doenças, drogas, suicídio); sexo (homossexualidade, prostituição, pornografia, pedofilia); gerações (crianças, adolescentes, jovens, idosos); religião (evangélicos, pentecostais, seitas, esoterismo); violência (presídios, crime organizado, sequestros, crimes hediondos); classe social (pobres, elites, moradores de rua, trabalhadores); raça (negros, japoneses, brancos, indígenas); saúde (obesidade, anorexia, bulimia, dietas); política (corrupção, esquerda, direita, partidos políticos). Entretanto, para verificar essa dimensão temporal estendida (invariâncias e variações) teríamos que observar a questão em diferentes períodos históricos, o que escapa ao alcance do que propomos.

Em síntese, a relação entre os estigmas e as demais expressões a eles correlatas não pode ser pensada de forma isolada; mas podemos estabelecer uma espécie de anterioridade lógica para delimitar nosso campo: na base dos estereótipos, preconceitos e exclusões há um estigma que os sustenta. Podemos ainda dizer que, nas três palavras acima referidas, um sujeito tenta encaixar o outro em um modelo pronto (deformando-o, se for preciso), a partir de suas representações sociais; nos estigmas, o outro evoca em mim o desejo de estigmatizá-lo, desejo este que vem de um Outro lugar (nesse sentido, o estigma é uma marca; mesmo que não seja visível há algo no sujeito que delimita esse campo, na relação estabelecida entre eu $\leftarrow \rightarrow$ outro, atravessada por um terceiro).

Se pudermos realizar, hipoteticamente, uma aproximação aos dois eixos de funcionamento da linguagem, diríamos que estereótipos, preconceitos e exclusões relacionam-se, sobretudo, à imagem, ao conteúdo, à figuração - e, portanto, ao imaginário. Os estigmas, por sua vez, relacionam-se à forma, à origem, à estrutura - ao simbólico. O primeiro grupo de conceitos encontra-se, portanto, no eixo vertical da linguagem - o do significado (paradigma, sincronia, metáfora) - e o segundo conceito encontra-se no eixo horizontal - o do significante (sintagma, diacronia, metonímia).

Por estarem relacionados à imagem, os estereótipos, preconceitos e exclusões podem ser modificados, podemos intercambiá-los, preencher esse imaginário de diferentes formas (posso, por exemplo, enquadrar-me - e aos outros - como punk, patricinha, roqueiro etc.); e também por essa razão, em alguns casos, é possível ao indivíduo ocupar outro lugar social em relação a esses conceitos (mudando sua aparência ou características pessoais). Mas se estereótipos, preconceitos e exclusões permanecem, permanecem também os estigmas. 
Essa afirmação, polêmica, leva-nos a outra característica singular dos estigmas em relação às palavras a eles correlatas: a partir deles é possível reorganizar o próprio campo entre estabelecidos e estigmatizados. Uma importante dinâmica entre "formações discursivas" (Foucault, 1996) e "discursos circulantes" (Charaudeau, 2006) é notada nesse movimento, como se os estigmas só pudessem ser transformados quando vigorarem novas formações discursivas; os estereótipos e preconceitos, ao contrário, são passiveis de mudanças sempre que seja possível interferir nos discursos circulantes ${ }^{6}$.

Os estigmas, portanto, não são em si negativos ou positivos (embora alguns autores, como Goffman (1978), discordem dessa afirmação, associando ao estigma a construção de uma "identidade deteriorada"), ainda que pareçam sempre mais prejudiciais - justamente por estarem na base de estereótipos e preconceitos. Os estigmas incluem e excluem, são dinâmicos e intercambiáveis (multifacetados), e não unilaterais, como ocorre nas cristalizações presentes em estereótipos e preconceitos, determinados por modelos prévios (embora originalmente tenha havido um fundamento concreto, anterior a eles, na dinâmica social). Tais observações iniciais permitem-nos situar mais apropriadamente o campo dos estigmas sociais.

\section{Procedimentos metodológicos}

A fim de indicar as etapas desenvolvidas na pesquisa, apresentamos seu protocolo metodológico e formas de análise dos resultados. As indagações sobre as possibilidades de identificar os estigmas sociais nas mídias e os modos como se configuram servirão de guia neste momento.

Em um momento inicial, analisamos jornais impressos e revistas semanais, tratando do jornalismo em seu formato convencional. Posteriormente, filmes de ficção e de não-ficção foram analisados, para finalmente, tratar dos pontos de aproximação e distanciamento entre jornalismo e documentário, que se colocam por meio de uma amostragem formada por programas televisivos de caráter jornalístico e filmes documentários exibidos em salas de cinema.

\footnotetext{
${ }^{6}$ De acordo com Gomes, "um discurso circulante é o que atualiza uma formação discursiva, tornando-a materialidade. Esta se manifesta tanto em um só discurso quanto nos vários que se cruzam e se apoiam nela, em determinado tempo e lugar. Esta se manifesta num entendimento de mundo ao qual nos adequamos e que comporta uma verdade segundo a qual seremos levados a agir" (Gomes, 2012: 14).
} 
Em relação à televisão, tratamos também de programas além dos telejornais tradicionais; e, no caso de documentários, realizamos um amplo levantamento da produção recente do cinema brasileiro e apontamos filmes específicos para aprofundamento das análises e demonstração das hipóteses. Como vimos, os critérios de seleção de programas e filmes se fazem a partir de uma temática central: os estigmas sociais. Justificamos essa escolha a partir de apontamentos que nos levaram à constatação de que os eixos articuladores de estigmas (e suas derivações) constituem espaço privilegiado para análise dos discursos midiáticos contemporâneos, entre eles os discursos audiovisuais.

De modo geral, notamos que, anteriormente, havia maior quantidade de discursos midiáticos articulados em torno de estigmas sociais, geralmente produzindo efeitos de reforço a eles; em um momento posterior, assuntos polêmicos passaram a ser tratados de forma positivada, agregando em torno deles novos valores; recentemente, constatamos que alguns temas desapareceram das páginas dos jornais, como se a simples omissão de certos assuntos pudesse apagar sua eficácia, ainda que a ausência possa explicitar exclusões. O que tal deslocamento sinaliza? Ele representa, de algum modo, avanços em termos de posicionamentos sociais, mudanças nos discursos circulantes com diminuição de estereótipos e preconceitos? Ou trata-se apenas de uma ausência silenciada? Se há uma ausência, por quais mecanismos ela se torna presente, ou seja, quais construções discursivas articulam os estigmas nas mídias?

Essas são algumas das perguntas que buscamos responder a partir da análise dos discursos midiáticos e da conceituação dos estigmas sociais. Para que a hipótese sobre a articulação mídias e estigmas sociais (qualquer que seja o verbo que a conjugue: reforço, construção, criação, revelação, denúncia) seja demonstrada, é preciso apontar exemplos concretos. As mídias (especialmente em seus discursos referenciais) estão de fato intrinsecamente ligadas aos estigmas sociais? Mesmo que não haja, abertamente, a presença de estigmas nas mídias, estariam eles interditos (entre os ditos) em seus discursos? O esforço empreendido se propõe à exploração dessas hipóteses, demonstrando-as ou reelaborando-as por meio de casos específicos.

Através de uma análise crítica das mídias, pode-se fazer os estigmas - velados ou revelados - emergirem, embora não se trate de buscar um significado oculto em suas aparições; ao contrário, trata-se de ver o que está no texto, ou seja, os efeitos de sentido 
provocados pelos "discursos manifestos", já que, neste campo analítico, o dito está nas linhas (na materialidade de suas produções) e não nas entrelinhas. A hipótese de que os discursos midiáticos parecem tratar indiretamente dos estigmas tem respaldo em seu aparente apagamento nas mídias, ou no seu confinamento em veículos ou programas específicos. A observação de diferentes mídias nos permitirá confrontar tal posição.

Após debater teoricamente a questão dos estigmas sociais e algumas de suas relações com as mídias, empreendemos o movimento inverso: olhar as mídias para refletir - a partir de suas narrativas - sobre os estigmas sociais nelas presentes. Acreditamos ser esta a única maneira de não nos perdermos em discussões descoladas da produção midiática contemporânea, voltando-nos à materialidade concreta de suas produções para delas extrair novas possibilidades teóricas. O objetivo, nesse momento, é construir uma ponte efetiva entre teoria e prática, refletindo sobre as mídias a partir das questões suscitadas pelos textos teóricos e, de outro lado, examinado as práticas midiáticas. A leitura regular de jornais e revistas, o acompanhamento de telejornais e programas televisivos, além das produções cinematográficas, contribuirão para a demonstração das hipóteses. Modestamente, esperamos contribuir para a reflexão nessa área multidisciplinar que é a comunicação em suas injunções com as ciências humanas.

Para identificar aquilo que é posto em circulação nos discursos midiáticos, a saber, a presença/ausência de estigmas, e de que modo isso se manifesta, é preciso atentar, concretamente, ao que está sendo veiculado em textos e imagens nas mídias, ler os textos e imagens, ver o que estão nos dizendo. Assim, esperamos demonstrar as considerações teóricas acima esboçadas a partir dos discursos midiáticos analisados no trabalho. Por suas características polêmicas, os estigmas não podem ser desvinculados das práticas discursivas em que são construídos. Um de seus paradoxos é também sua singularidade: por oposição (e, consequentemente, também por posição), os estigmas têm a capacidade de, ao mesmo tempo em que separam (dividem, catalogam, categorizam), unir em novas combinações esses desiguais - os estigmatizados.

A análise que realizamos objetiva, portanto, mostrar recorrências presentes nas mídias e realizar uma síntese das principais características dos estigmas sociais nelas desenhados.

\footnotetext{
${ }^{7} \mathrm{Na}$ definição de Foucault, "todo discurso manifesto reside secretamente em um já dito; mas esse já dito não é simplesmente uma frase já pronunciada, um texto já escrito, mas um 'jamais dito', um discurso sem corpo, uma voz tão silenciosa quanto um sopro, uma escrita que não passa do vazio de seu próprio traço" (Foucault, 2008: 91). Ou seja, aquilo que se torna formulado no discurso já se encontrava articulado em algo que o precede, que continua presente mas que ele recobre e quer calar.
} 
Na base dessa reflexão, encontra-se uma preocupação fundamental: refletir sobre as mídias para torná-las mais próximas de um empreendimento questionante e transformador, assumindo uma postura crítica em relação a elas não para destituí-las ou eliminá-las, mas visando colocá-las em crise para vislumbrar possibilidades de atuação. É importante estabelecer uma distinção entre estigmas fundantes - ou originários, se pudermos criar esta expressão - e os estigmas sociais que efetivamente aparecem nas mídias - atentando para as formas específicas com que são construídos. Como vimos, os grupos sociais se organizam (se unem e se distinguem) por meio de estigmas.

Entretanto, suas manifestações e hierarquizações não são previamente dadas, mas apontam para processos de seleção e combinação permanentes. Além dos exemplos citados, uma rápida passagem pelos jornais permite a identificação de temas que, em princípio, remetem aos estigmas sociais. Entre eles, podemos apontar os discursos em torno da legalização do aborto, o temor que recobre a adoção, a dificuldade de ser um ex-detento, o isolamento causado pela dependência química, o preconceito contra as classes populares (incluindo suas crianças), o deboche em relação às pessoas religiosas, a incompreensão em relação aos transtornos mentais, as imagens associadas aos políticos, as caracterizações de certos grupos (sem-terra, ativistas, homossexuais etc.).

Ainda em relação às mídias, podemos apontar, preliminarmente, que alguns veículos, como as revistas femininas (Claudia, Nova, Marie Claire e inúmeras outras) e, mais recentemente, as revistas masculinas ( $G$ Magazine, Men's Health, $Q G$, para citar publicações bastante heterogêneas) tratam os estigmas de forma mais aberta (a exemplo dos programas televisivos já mencionados) e, por isso, tornam-se mais provocativas (como se todos soubéssemos que os estigmas fazem parte da sociedade, mas não quiséssemos ter de encará-los). Outros veículos, como os jornais diários (entre eles, Folha de S. Paulo, Estado de S. Paulo, O Globo), não evocam de forma direta os estigmas, apenas em situações limítrofes (como no caso de crimes hediondos, assassinatos e ações envolvendo atores sociais em conflito).

Ainda assim, não ousamos responder se é de fato positivo ou negativo que não percebamos abertamente situações limiares nesses discursos, encobrindo na superfície estigmas que permanecem - não apenas nas mídias, mas na própria sociedade - como tabus. Haveria também reforço dos estigmas nessa estrutura "politicamente correta" dos grandes jornais, revistas e programas televisivos? Seriam os estigmas velados mais ou menos prejudiciais e difíceis de serem neutralizados do que os explícitos? 
Buscamos responder tais questionamentos a partir dos procedimentos metodológicos apresentados a seguir, pontos de partida para as análises e adaptados ao longo da pesquisa, de acordo com os diferentes objetos tratados.

Seleção da amostragem e do corpus: jornais, revistas, programas televisivos e produções cinematográficas, definindo sua quantidade, variedade, representatividade e abrangência. No caso de jornais e revistas, a escolha se faz de modo cronológico, implicando ainda definições como número de matérias, editorias, textos considerados; no caso de mídias audiovisuais (televisão e cinema), trata-se de definir o conjunto de programas/filmes analisados de modo não aleatório.

Leitura geral das matérias/programas/filmes: O processo de descrição e análise é dividido em duas partes: primeiras e segundas leituras. As primeiras leituras, mais abrangentes e descritivas, estabelecem uma visão geral da amostragem e subdividem os textos (verbais e/ou visuais) em grandes categorias. Nas segundas leituras, cada um dos textos é analisado de acordo com uma metodologia extraída das ciências da linguagem, destacando o que neles aparece como redundância ou como ressonância (Lacan, 1998) ou, nas palavras de Deleuze (1988), suas repetições e diferenças, e quais as narrativas tecidas nas mídias em torno dos estigmas.

Classificação temática inicial: Em uma leitura preliminar, os textos (verbais e/ou visuais) analisados são divididos por temas, a partir de seus enunciados e daquilo que é considerado seu principal enfoque, distribuindo-os em grandes categorias. Esses temas são escolhidos a partir de observações realizadas durante as leituras, apontando recorrências entre eles e uma primeira caracterização dos estigmas nas mídias.

Primeiras leituras: a) Descrição geral dos textos e/ou imagens selecionados, enumerando suas principais características. b) Montagem de quadros gerais de trabalho para cada texto (verbal e/ou visual) selecionado, relacionado ao tema dos estigmas, a partir de suas especificidades. c) Descrição individual ou agrupada dos textos (verbais e/ou visuais) selecionados a partir de aspectos relevantes para cada mídia analisada, considerando os modos específicos de sua manifestação expressiva.

Segundas leituras: Antes da enumeração das etapas desenvolvidas nas segundas leituras, vale ressaltar que os textos (verbais e/ou visuais) foram reproduzidos na íntegra (no caso de jornais e revistas), não apenas para obter um material facilmente manuseável quanto a seu conteúdo, mas também para realizar a leitura dos mesmos (no caso de telejornais, fizemos sua decupagem; no caso do cinema, foram isoladas as sequências mais relevantes). As segundas leituras envolvem as seguintes etapas: 
a) Elaboração de um comentário individual sobre cada texto (verbal e/ou visual), lendo-o ou assistindo-o em relação aos outros como se constituíssem uma só narrativa, e não fragmentos de diversos textos diferentes. Essa leitura contínua permite estabelecer relações entre aspectos muitas vezes isolados por um largo intervalo de tempo, apontando para aquilo que mais se distingue em cada texto.

b) A partir das leituras, estabelecimento de questões norteadoras das análises.

c) Construção de "quadros figurativos da enunciação" (entendida não como o texto do enunciado, mas como o ato mesmo de produzi-lo), utilizando recursos específicos para destacar determinados elementos a fim de examinar os procedimentos discursivos e defini-los no quadro formal de sua realização (Benveniste, 1989b):

- pessoa (eu/tu), espaço (aqui/lá) e tempo (agora/então) da narrativa enquanto categorias intradiscursivas; tais categorias apontam para as relações estabelecidas entre o enunciador e a enunciação; podem ainda produzir efeitos de aproximação ou distanciamento do enunciatário com relação à enunciação, nas formas do "eu-aqui-agora" e do "ele-lá-então";

- referências a outros discursos, formadores de realidades discursivas;

- protagonistas/atores da narrativa e lugares a eles atribuídos;

- reordenação temática dos textos, a partir de temas mais específicos.

d) Enumeração de aspectos gerais encontrados para cada uma das categorias utilizadas na montagem dos quadros, tratando os textos/imagens em conjunto e não isoladamente. Nessa reordenação, pode-se apontar o que se repete e o que é singular.

e) Após a articulação geral, é feito outro ordenamento temático, reorganizando os temas inicialmente apontados em grupos, buscando encadeamentos entre as imagens.

f) Finalmente, são reordenados os elementos levantados nas análises, estabelecendo conexões que apontem as recorrências dos discursos midiáticos em relação aos estigmas sociais e que servirão de suporte às análises. As categorias referentes aos textos verbais foram adaptadas, contemplando a especificidade das mídias audiovisuais.

\section{Discursos midiáticos e estigmas sociais}

Após apresentar as distinções acima, é dos discursos midiáticos que partimos para pensar suas tematizações, percorrendo as trajetórias narrativas a fim de configurar com mais precisão o campo dos estigmas. Algumas questões guiarão a escuta das mídias e suas reverberações, vozes e polifonias. 
Se for correto afirmar que os discursos midiáticos articulam-se (em grande parte) em torno de estigmas sociais, resta-nos perguntar por que tal questão nos interpela, por que tal suspeita nos incomoda, por que consideramos ser esta uma pergunta relevante. Nossa resposta inicial vai ao encontro, uma vez mais, dos estereótipos, preconceitos e exclusões: tal questão nos interroga por buscarmos alternativas para as mídias, para que não se pautem apenas pela dominação ou discriminação. Entretanto, surge outra questão: quais as possibilidades abertas por esta trilha? De que modo os discursos midiáticos podem ser diferentemente articulados? De que modo as mídias podem contribuir para o desvendamento das relações estigmatizadas e estigmatizadoras que constituem a sociedade, e para sua transformação? Outras interrogações se colocam:

1) Por que na relação "discursos midiáticos e estigmas sociais" há uma espécie de julgamento previamente negativo induzindo à percepção de que as mídias constroem ou reforçam estigmas? Qual o verbo que reúne esses dois campos - mídias e estigmas?

2) Em caso de uma resposta afirmativa quanto ao "reforço" provocado pelas mídias em relação aos estigmas (sem que estejamos pensando em ações deliberadas), tal relação poderia ser estabelecida em outras bases? E ainda: será que as mídias se movem apenas de forma dual - como reforço ou como recusa dos estigmas sociais?

Esta investigação busca, dessa forma, estabelecer uma discussão conceitual sobre os estigmas sociais e uma demonstração de sua aplicabilidade nas mídias. Tal proposta exige de nós um posicionamento ativo, uma dose de utopia para acreditar que essas abordagens podem ser diferentes e melhores. É essa a aposta que fazemos ao nos propormos a refletir sobre os estigmas sociais presentes nos discursos midiáticos.

Dois pontos devem ser ressaltados: em primeiro lugar, apesar do relativismo da questão, nem tudo nas mídias (ou na sociedade) são estigmas e nem todos os estigmas se articulam da mesma maneira ou têm o mesmo peso nos diferentes grupos. Reconhecê-los já é um desafio, que dirá então tentar transformar essa relação social. Nesta pesquisa, o caminho para o estabelecimento dessa distinção e dessa intervenção é a linguagem - por meio da enunciação e não só pelos enunciados, distinguindo o dizer e o dito (Ducrot, 1987).

Em segundo lugar, sabemos ser possível identificar a construção de estigmas nos discursos midiáticos (e dizer simplesmente que os estigmas estão neles presentes não é o bastante), como vimos nos exemplos acima. Esses discursos estigmáticos (e, por que não, enigmáticos?) criam efeitos de sentido que amplificam os mecanismos de diferenciação e oposição que estão na base da organização social (não esqueçamos que 
são dos estigmas que nascem os estereótipos e preconceitos). Assim, ainda que os estigmas existam intrinsecamente na sociedade, não podemos nos acomodar a eles, especialmente se considerarmos que os discursos midiáticos propõem modos de ver e conhecer o mundo. Mas o fato de serem "representações", como no caso de filmes, "não os impede de ter efeitos reais sobre o mundo. (...) Como assinala Stuart Hall, reconhecer a inevitabilidade da representação não significa que "não há nada em jogo"” (Shohat e Stam, 2006: 262). Ao contrário, embates discursivos são travados na "luta por representação".

Essa é uma das justificativas de nosso esforço: buscar caminhos e possibilidades de resistência a uma ordem que insiste em se instaurar, por meio das brechas deixadas nos discursos, já que não podemos negligenciar a questão ética presente quando falamos de mídias e estigmas sociais. Lembramos que os estigmas nascem dos mecanismos de controle que hierarquizam pessoas e grupos a partir de critérios sobre o que seja normal ou desviante, estabelecendo distinções e, portanto, exclusões e inclusões. Como método de escuta, acreditamos, a partir de Bakhtin, que a observação das vozes e discursos presentes nas mídias pode oferecer uma alternativa ao estudo dos estigmas: "Se a palavra 'imagem' remete à questão do realismo mimético, 'voz' invoca um realismo de delegação e interlocução, uma fala situada entre o 'quem fala' e o "para quem se fala"” (Shohat e Stam, 2006: 310), permitindo-nos comparar um discurso com outros que circulam socialmente, em perspectiva dialógica e polifônica, fazendo com que a voz de grupos minoritários e sem direito à representação possam ser de fato ouvidos.

O filme Gattaca traz uma interessante reflexão a partir da imagem de um pianista de doze dedos, indagando-nos se tal diferença se constitui como estigma ou como perfeição. O pianista nasceu com um "defeito" e o superou, tornando-se um grande músico (porque o concerto apresentado por ele só poderia ser tocado por alguém com doze dedos), ou sua mãe pediu ao geneticista "quero um filho de doze dedos para que ele seja capaz de tocar este concerto?". Questões que apontam para a ambiguidade do tema e, portanto, sua urgência. Sabemos, com Foucault (1988a; 1988b), que a relação entre o que é normal e o que é desviante é relativa e móvel, histórica e cultural, articulando-se no trânsito dos discursos instituídos; e é justamente por isso que acreditamos que os estigmas não deveriam servir como balizas para as mídias. Baseados em aparências e inconsistências (ou incompletudes), os estigmas mostram-se como falácias no sentido de determinar as relações sociais. 
Dizer que os estigmas são relativos, que são como um caleidoscópio que muda conforme o lugar do observador, não equivale a declarar seu relativismo absoluto, tampouco decretar o fim do caráter desigual por eles imposto. Apontar, portanto, as várias facetas envolvendo a questão dos estigmas é justamente buscar refletir sobre os mecanismos de seu funcionamento, perceber sua permanente manifestação para interferir em determinados padrões de exclusão e, sobretudo, buscar suas recorrências.

Como vimos, os estigmas têm em sua raiz a contradição; é sempre em relação a um padrão estabelecido que algo ou alguém pode ser estigmatizado (por comparação, portanto). É a respeito desse padrão - a possibilidade de modificá-lo e o questionamento sobre a própria necessidade de sua existência - que buscamos refletir. As saídas não são simples e encontram-se repletas de paradoxos. Mas ao tratar de fenômenos sociais complexos - como o dos estigmas - não há como ser diferente. A circularidade do caminho, entretanto, não pode nos desviar de perceber aquele que é o grande achado do filme Gattaca: que no limite, afinal, todos somos passíveis de sermos estigmatizados, dependendo do lugar a partir do qual sejamos olhados.

Nosso tema, portanto, apresenta-se como fluido e aberto. O conceito de estigma revela-se ao mesmo tempo compreensível e inapreensível. Evoca a ambiguidade e a dubiedade, mas de forma positivada. É, assim, um conceito equívoco. Atentemos para essa palavra, para seu duplo sentido: não estamos remetendo à ideia de equívoco como erro, de forma pejorativa; ela surge como contraposta à palavra unívoco e, assim, dotada de positividade (embora pudéssemos também atribuir um sentido positivo ao engano).

Para a apreensão do conceito, lançamos mão de diversas teorias: a psicanálise, a antropologia, a filosofia, a linguagem, a comunicação. Mas é preciso lembrar algo importante: ainda que fosse possível uma definição única de estigma, por não estarmos tratando deste termo abstratamente teríamos que olhar as práticas midiáticas em busca de uma conceituação - ler e ouvir as mídias para delas extrair os estigmas -, refletindo sobre o que há em comum na diversidade dos temas abordados. Teoria e prática devem ser construídas em conjunto, em um traçado feito de bifurcações. Ao falar de estigmas sociais, portanto, não é de qualquer definição que partimos, mas de uma concepção determinada, que orienta a pesquisa e a análise dos discursos midiáticos. Para entender a questão dos estigmas temos de aceitar alguns pressupostos. O primeiro diz respeito à relação eu/outro como apresentada no binômio identificação-projeção. O segundo diz respeito à concepção do jornalismo a partir de uma problematização dos termos verdade-realidade e de seu estatuto como construção discursiva na linguagem. 
Alguns autores são chamados a ampliar nosso quadro teórico, por meio de textos clássicos ou contemporâneos, nos campos da psicanálise, da sociologia, da história, da antropologia e da filosofia. Um percurso teórico se vislumbra, estabelecendo, na psicanálise, diálogos com os conceitos de Sigmund Freud e Jacques Lacan, em contraponto com interlocutores atuais, como os psicanalistas Clara Cruglak, em um trabalho sobre a identificação, Jurandir Freire Costa, ao tratar do narcisismo, Alain Didier-Weill, em sua obra sobre as injunções do superego, e Maria Rita Kehl, em texto sobre as relações entre identificações e identidades.

Lembramos, ainda uma vez, que a diferenciação eu/outro se encontra na base dos estigmas sociais, afirmação que pode ser sustentada a partir de autores citados. Nas relações do "eu ideal" e do "ideal do eu" vislumbramos uma relação de amor e ódio, já enunciada por Sigmund Freud em seus estudos sobre o inconsciente; de modo diferenciado, Claude Lévi-Strauss também aborda essa questão em seus ensaios sobre a função simbólica, ao buscar responder o que une e desune as sociedades.

O "eu ideal" freudiano caracteriza-se como um momento de identificação narcísica: "O outro é tão igual a mim que posso amar nele a mim mesmo" (e, portanto, quer as mesmas coisas que eu). $\mathrm{O}$ "ideal do eu", caracterizado como os ideais culturais oferecidos por uma sociedade (valores, mitos, ídolos), contrapõe-se a ele: "O outro é tão maior do que eu que gostaria de ser como ele" (e, portanto, tem o que eu não tenho e gostaria de ter). Essas relações engendram ao mesmo tempo amor e ódio: se o outro é tão parecido comigo, vai concorrer comigo pelas mesmas coisas (afeto, trabalho, posição, lazer, atenção, amor); se o outro é tão maior do que eu, tem o que eu não tenho e talvez nunca consiga ter. Acreditamos que na dinâmica dual da identificação encontrase uma das chaves para pensar sobre os estigmas, acrescentando que no estabelecimento de sua conceituação recorremos a outros textos clássicos ou contemporâneos.

Dessa forma, notamos que as relações eu/outro são atravessadas por um terceiro termo (o Outro) referente ao campo do simbólico, campo a partir do qual são constituídas as identidades primeiras. Ou seja: ao tratarmos dos estigmas, não nos referimos - ingenuamente - à dualidade pressuposta no binômio eu/outro, mas a uma tríade não linear que pressupõe, nas relações humanas, um terceiro lugar - comum aos dois outros, mas de forma assimétrica - a partir do qual o campo das relações sociais é demarcado. Para além do(s) outro(s) - espelho a partir do qual constituímos nossas identificações - esse terceiro lugar - denominado, a partir de Jacques Lacan, "o campo do Outro" - é determinante para a constituição das imagens que temos de nós mesmos. 
De outro lugar, mas em estreita relação com os autores acima apontados, auxiliam na delimitação do campo teórico as obras Estigma, de Erving Goffman, e Os estabelecidos e os outsiders, de Norbert Elias - sem desconsiderar os trabalhos clássicos de Michel Foucault, por um lado, e Georges Canguilhem, por outro, sobre o normal e o desviante. Da história, Peter Burke, Hayden White, Georges Duby, Guy Lardreau, Pierre Nora e Jacques Le Goff são convocados para articular nossas reflexões.

Além desses, incluímos autores identificados com o pós-estruturalismo e os estudos pós-coloniais. Pensadores como Jacques Derrida, Gilles Deleuze, Clifford Geertz, Gayatri Spivak, Homi Bhabha, entre outros, em suas diferentes áreas de atuação, possibilitam que os referenciais teóricos da pesquisa sejam expandidos para além de fronteiras temáticas. No campo da filosofia, os textos de Jean-François Lyotard se destacam. Por realizarem a ponte entre reflexão filosófica e tecnologias, são fundamentais para a configuração das mídias enquanto objeto teórico. Além disso, ao estabelecer as fronteiras entre o "saber narrativo" e o "saber científico", Lyotard possibilita uma instigante reflexão sobre a contemporaneidade.

A bibliografia indicada, além daquela efetivamente incorporada ao texto, serve de guia à realização da pesquisa. Entre os autores que abordam questões relativas à contemporaneidade de modo atual e polêmico, destacamos Slavoj Zizek, Bruno Latour, Alain Badiou e Giorgio Agamben, pensadores que estabelecem diferentes pontos de vista para tratar de questões relacionadas à formação de identidades e diferenças. No campo do cinema documentário, traremos autores de referência, como Jean-Louis Comolli, Michel Marie, Dudley Andrew, David Bordwell, Christian Metz, Bill Nichols, Michael Renov, Robert Stam, além de obras recentes publicadas no Brasil.

$\mathrm{Na}$ tentativa de relacionar os estigmas com os discursos midiáticos, autores de outras áreas são chamados a compor o quadro teórico. No campo específico dos estigmas, a ensaísta Susan Sontag, em dois trabalhos nos quais trata da doença como metáfora (câncer e aids), auxilia na delimitação do conceito nas mídias. Utilizamos ainda as contribuições da teoria literária, em Edward Said, e dos estudos culturais, na obra de Stuart Hall, como referenciais importantes para pensarmos as relações entre cada um e cada um dos outros - as relações com o radicalmente diferente em sua estranha familiaridade - e os embates envolvidos em torno dos estigmas sociais. 
Quanto à literatura da área de comunicação e de linguagem, selecionamos textos de linguística, semiótica e análise do discurso, buscando deles extrair as principais noções e conceitos. Autores como Roland Barthes, Émile Benveniste, Roman Jakobson, Ferdinand de Saussure, Julia Kristeva e Umberto Eco serão chamados, entre outros, a compor este quadro referencial.

Dos textos específicos da área de jornalismo, destacam-se os livros de Herbert Gans e Michael Schudson. Esses dois autores propõem uma discussão original e atualizada sobre a natureza do fazer jornalístico e, porque não, de sua própria essência, fugindo ao estilo dos "manuais de jornalismo" que querem apenas transmitir regras de como fazer sem refletir sobre tal fazer. Gans afirma que a tarefa primordial dos jornalistas não se restringe apenas a "informar o público"; o objetivo primeiro das notícias é derivado do papel dos jornalistas como "gerenciadores da arena simbólica" da sociedade. Dessa forma, encontra eco nas análises de Schudson, que define a informação como uma "forma cultural" chamada notícia.

Os conceitos serão dinamicamente incorporados ao longo das descrições e análises relatadas. Esperamos, ao final desse percurso, ter construído de modo produtivo não apenas um panorama de algumas das possíveis articulações entre mídias e estigmas sociais mas, sobretudo, ter contribuído para a melhor compreensão dos processos narrativos e discursivos presentes nas práticas midiáticas e em seus contratos comunicacionais (Charaudeau, 2006), determinantes das relações sociais e por elas determinados.

O panorama acima apresentado não esgota as possibilidades analíticas e reflexivas de nossa empreitada, mas oferece um quadro geral no qual situar a pesquisa e um mapa das articulações conceituais e diálogos pretendidos, tanto em termos teóricos, quanto metodológicos. A esses autores e possibilidades, outros se somarão em cada momento do trabalho, tanto por meio de novos estudos e leituras realizados, quanto por meio dos próprios caminhos e demandas apontados pelos objetos analisados, ampliando assim o escopo de pensadores, ideias e conceitos. Os autores diretamente incorporados à pesquisa, bem como aqueles indiretamente utilizados, estão referenciados na bibliografia geral, ao final do texto. 


\section{ArticulaÇões Narrativas nas Mídias}

\section{Estigmas em jornais e revistas: primeiras leituras}

Apresentamos a seguir os principais resultados da pesquisa no que se refere à mídia impressa (jornais e revistas) e mídia audiovisual (televisão e filmes). Para o desenvolvimento das análises em jornais diários e revistas semanais, organizamos uma amostragem do corpus, descrita abaixo, e a seguir apresentamos a amostragem dos

telejornais. É importante destacar, na pesquisa, o desenvolvimento cronológico: os jornais e revistas impressos foram coletados no ano de 2004; os telejornais foram coletados no ano de 2005; e os filmes no ano de 2006. A amostragem de filmes, central no trabalho, foi realizada entre 2002 e 2014, com destaque para os anos de 2007 a 2011.

\subsection{Corpus da pesquisa em mídia impressa (jornais e revistas)}

A pesquisa de mídia impressa engloba quatro jornais diários (Folha de S. Paulo, O Estado de S. Paulo, Jornal do Brasil e $O$ Globo) e quatro revistas semanais (Veja, IstoÉ, Época, Carta Capital). Os jornais e revistas foram selecionados, principalmente, devido a critérios de abrangência (distribuição nacional), alcance temático (cobertura nacional), tiragem (número de exemplares vendidos) e representatividade (credibilidade e reconhecimento junto à sociedade). Como o material totalizado seria muito extenso para os alcances da pesquisa, constituímos uma amostragem representativa do mesmo para desenvolvimento das análises. Optamos por estudar as primeiras páginas dos jornais impressos e as matérias de capa das revistas semanais. De modo análogo, analisamos as chamadas de telejornais e aspectos específicos dos filmes selecionados (ficcionais ou documentais) correlatos aos estigmas sociais.

No caso do jornalismo impresso, a amostra foi elaborada a partir de modelo proposto pelos ingleses James Curran e Jean Staton. Na pesquisa que realizaram sobre mídias, publicada no livro Power without responsibility (1988), os autores utilizaram jornais diferenciando-os de acordo com a periodicidade: dos jornais diários, selecionaram edições publicadas de segunda-feira a sábado e, dos semanários, aos domingos. O modelo por eles proposto foi por nós adaptado: para cada um dos jornais, dividiu-se o ano em seis bimestres (janeiro-fevereiro; março-abril; maio-junho; julhoagosto; setembro-outubro; novembro-dezembro), sendo que a pesquisa inclui o primeiro 
mês de cada bimestre (seis semanas ao ano por jornal). Para cada um dos meses (janeiro, março, maio, julho, setembro, novembro) foi escolhida uma semana, da primeira à quarta, alternadamente.

Em relação às revistas, procedemos de maneira semelhante: para cada uma delas, dividiu-se o ano em quatro trimestres (janeiro-março; abril-junho; julhosetembro; outubro-dezembro), sendo que a pesquisa inclui o primeiro mês de cada trimestre (quatro edições ao ano por revista). Para cada um desses meses (janeiro, abril, julho, outubro) foi escolhida uma edição semanal, da primeira à quarta, alternadamente (perfazendo um total de quatro edições por revista, distribuídas ao longo do ano). Optamos por trabalhar com menos exemplares das revistas devido à maior heterogeneidade de seus elementos verbais e visuais, e à maior abrangência de suas matérias. As tabelas referentes a jornais e revistas são apresentadas a seguir.

\begin{tabular}{|c|c|c|c|c|c|c|c|}
\hline \multicolumn{8}{|c|}{ TABELA I - JORNAIS DIÁRIOS (2004) } \\
\hline \multicolumn{2}{|c|}{ Folha de S. Paulo } & \multicolumn{2}{|c|}{ O Estado de S. Paulo } & \multicolumn{2}{|c|}{ Jornal do Brasil } & \multicolumn{2}{|c|}{ O Globo } \\
\hline Mês & Semana & Mês & Semana & Mês & Semana & Mês & Semana \\
\hline Janeiro & $1^{\mathrm{a}}$ & Janeiro & $1^{\mathrm{a}}$ & Janeiro & $1^{a}$ & Janeiro & $1^{\mathrm{a}}$ \\
\hline Março & $2^{\mathrm{a}}$ & Março & $2^{\mathrm{a}}$. & Março & $2^{\mathrm{a}}$. & Março & $2^{\mathrm{a}}$ \\
\hline Maio & $3^{\mathrm{a}}$ & Maio & $3^{a}$ & Maio & $3^{a}$ & Maio & $3^{\mathrm{a}}$ \\
\hline Julho & $4^{a}$. & Julho & $4^{a}$. & Julho & $4^{a}$. & Julho & $4^{\mathrm{a}}$. \\
\hline Setembro & $1^{a}$. & Setembro & $1^{a}$. & Setembro & $1^{a}$. & Setembro & $1^{\mathrm{a}}$. \\
\hline Novembro & $2^{a}$. & Novembro & $2^{a}$. & Novembro & $2^{\mathrm{a}}$ & Novembro & $2^{a}$. \\
\hline
\end{tabular}

TABELA II - REVISTAS SEMANAIS (2004)

\begin{tabular}{|l|l|l|l|l|l|l|l|}
\hline \multicolumn{2}{|c|}{ Veja } & \multicolumn{2}{c|}{ Istó́ } & \multicolumn{2}{c|}{ Época } & \multicolumn{2}{c|}{ Carta Capital } \\
\hline \multicolumn{1}{|c|}{ Mês } & \multicolumn{1}{c|}{ Semana } & \multicolumn{1}{c|}{ Mês } & \multicolumn{1}{c|}{ Semana } & \multicolumn{1}{c|}{ Mês } & \multicolumn{1}{c|}{ Semana } & Mês & \multicolumn{1}{c|}{ Semana } \\
\hline Janeiro & $1^{\mathrm{a}}$. & Janeiro & $1^{\mathrm{a}}$. & Janeiro & $1^{\mathrm{a}}$. & Janeiro & $1^{\mathrm{a}}$. \\
\hline Abril & $2^{\mathrm{a}}$. & Abril & $2^{\mathrm{a}}$. & Abril & $2^{\mathrm{a}}$. & Abril & $2^{\mathrm{a}}$. \\
\hline Julho & $3^{\mathrm{a}}$. & Julho & $3^{\mathrm{a}}$. & Julho & $3^{\mathrm{a}}$. & Julho & $3^{\mathrm{a}}$. \\
\hline Outubro & $4^{\mathrm{a}}$. & Outubro & $4^{\mathrm{a}}$. & Outubro & $4^{\mathrm{a}}$. & Outubro & $4^{\mathrm{a}}$. \\
\hline
\end{tabular}

Num segundo momento, estabelecemos outra classificação entre os jornais e as revistas, detendo-nos em dois jornais diários ( $O$ Estado de $S$. Paulo e $O$ Globo) e duas revistas semanais (Veja e Carta Capital), e selecionando entre suas edições aquelas mais relevantes de acordo com os referenciais teóricos norteadores do trabalho. Notemos que as possibilidades descritivas e analíticas do corpus ultrapassam os alcances da pesquisa. Tal constatação deixa entreaberto o caminho de retorno a esse material a partir de outras indagações, apresentando-nos um aspecto desafiador não apenas em relação aos estigmas, mas também às múltiplas interpretações teóricas e metodológicas de abordagem das mídias. 


\subsection{Primeiras páginas e capas: redundâncias e ressonâncias}

Em nossas análises, optamos por selecionar primeiras páginas de jornais diários e capas de revista, privilegiando as narrativas sobre estigmas sociais nelas presentes. A escolha de primeiras páginas e capas como objeto de análise se justifica na medida em que elas demarcam um complexo processo de seleção e combinação de elementos distintos apresentados de forma hierárquica e, portanto, apontam para o lugar de fala dos jornais e revistas em sua tentativa de estabelecer laços sociais.

Se o jornalismo organiza o espaço público, suas primeiras páginas e capas organizam seu espaço interno, estabelecendo nesse processo novas molduras para os eventos relatados e novos modos de dar a ver, aos leitores, a realidade. Apresentamos as tabelas e leituras da amostra, transcrevendo dia-a-dia as chamadas de capa dos jornais e as matérias de capa das revistas relacionadas aos estigmas sociais.

\subsubsection{Jornais diários}

A amostragem inclui as primeiras páginas de quatro grandes diários (Folha de $S$. Paulo, O Estado de S. Paulo, O Globo, Jornal do Brasil), compondo seis semanas por jornal, perfazendo 42 primeiras páginas por periódico e 168 primeiras páginas no total (ver tabela). Note-se que para cada semana selecionada na amostragem foram coletadas as primeiras páginas de todos os jornais, produzindo um material homogêneo do ponto de vista cronológico a fim de possibilitar confluências e divergências entre as matérias neles presentes. Como o material se mostrou bastante extenso, apresentamos um quadro geral das notícias presentes nas primeiras páginas dos quatro diários (para cada uma das semanas selecionadas) para, num segundo momento, focalizar aspectos encontrados em um grupo de notícias escolhidas por sua recorrência temática em torno dos estigmas sociais nos jornais $O$ Estado de $S$. Paulo e $O$ Globo.

Como dissemos anteriormente, apenas as manchetes relacionadas aos estigmas sociais foram consideradas. Destacamos a seguir as principais chamadas de capa relacionadas aos estigmas sociais. As notícias foram transcritas em ordem decrescente segundo sua disposição (a partir do alto da página do jornal, e da esquerda para a direita) e também respeitando os destaques de cada uma na página. Notemos que, à época da coleta, os jornais impressos ainda ocupavam espaço principal junto aos leitores, posição que foi paulatinamente sendo substituída pelo jornalismo online. 


\begin{tabular}{|c|c|c|c|c|}
\hline \multicolumn{5}{|c|}{$\begin{array}{c}\text { TABELA III } \\
\text { ESTIGMAS SOCIAIS - PRIMEIRAS PÁGINAS (JORNAIS) } \\
01-07 / 01 / 2007\end{array}$} \\
\hline Data & Folha de S. Paulo & O Estado de S. Paulo & O Globo & Jornal do Brasil \\
\hline $\begin{array}{l}01 / 01 \\
\text { Quinta }\end{array}$ & $\begin{array}{l}1 . \quad \text { "Menor participa } \\
\text { de } 1 \% \text { dos homicídios" } \\
\text { (chamada principal) } \\
2 . \quad \text { "Índios de RO } \\
\text { garimpam diamantes } \\
\text { ilegalmente" (com foto) } \\
3 . \quad \text { "Audiência de } \\
\text { do cinema nacional cresce } \\
200 \% \text { " (Ilustrada) } \\
4 . \quad \text { "Ataque mata } 5 \\
\text { em Réveillon em Bagdá" }\end{array}$ & $\begin{array}{l}1 . \quad \text { "Polícia italiana } \\
\text { prende mais } 7 \text { no caso } \\
\text { Parmalat" "A partir de hoje, } \\
2 . \\
\text { Estatuto do Idoso é lei" } \\
3 . \quad \text { "Golan: Israel } \\
\text { quer mais assentamentos" } \\
4 . \quad \text { "Explosão mata } 5 \\
\text { em Bagdá em festa de } \\
\text { réveillon" }\end{array}$ & $\begin{array}{l}1 . \quad \text { "Ano-novo no } \\
\text { Iraque começa com bomba" }\end{array}$ & $\begin{array}{l}1 . \quad \text { "Israelenses e } \\
\text { palestinos se entendem } \\
\text { na música" (Caderno B) } \\
2 . \quad \text { "Brasilianista } \\
\text { defende cotas em } \\
\text { universidade" } \\
3 . \quad \text { "Crianças e } \\
\text { idosa escapam com vida } \\
\text { dos escombros" }\end{array}$ \\
\hline $\begin{array}{l}02 / 01 \\
\text { Sexta }\end{array}$ & $\begin{array}{l}5 . \quad \text { "Polícia tira } \\
\text { digital e foto de turistas } \\
\text { americanos" } \\
6 . \quad \text { "Gestão de Lula } \\
\text { é amadora, diz Aécio" }\end{array}$ & $\begin{array}{l}5 . \quad \text { "Bolsa-Família já } \\
\text { beneficia um terço dos } \\
\text { pobres" } \quad \text { "EUA suspendem } \\
6 . \\
\text { sanções e Irã vê 'passo } \\
\text { positivo"” }\end{array}$ & $\begin{array}{l}2 . \quad \text { "Governo mapeia } \\
\text { o crime e quer acabar com } \\
\text { os bondes no Rio" } \\
3 . \quad \text { "Americanos } \\
\text { deixam digitais em São } \\
\text { Paulo" }\end{array}$ & $\begin{array}{l}\text { 4. "Americanos } \\
\text { são fichados ao chegar a } \\
\text { SP" } \quad \text { "EUA: planos } \\
5 . \quad \text { para ocupar Golfo em } \\
\text { 1973" (Arquivos Abertos) }\end{array}$ \\
\hline $\begin{array}{l}03 / 01 \\
\text { Sábado }\end{array}$ & $\begin{array}{l}7 . \quad \text { "Saúde pede } \\
\text { tempo para cumprir o } \\
\text { Estatuto do Idoso" } \\
\text { (chamada principal) } \\
8 . \quad \text { "São Paulo usa } \\
\text { só } 13,4 \% \text { de verba para } \\
\text { assentamento" } \\
9 . \quad \text { "Aposentadorias } \\
\text { batem recorde na } \\
\text { Unicamp" "País pode } \\
10 . \\
\text { acabar com fichamento de } \\
\text { americanos" }\end{array}$ & $\begin{array}{l}7 . \quad \text { "Coréia do Norte } \\
\text { aceita inspeção estrangeira" } \\
8 . \quad \text { "Embaixadora } \\
\text { estranha identificação de } \\
\text { americano" } \\
9 . \\
\text { da OAB: rigor contra jovens" }\end{array}$ & $\begin{array}{l}4 . \quad \text { "PF já ficha } \\
\text { americanos em todo o país" } \\
5 . \quad \text { "Novo estatuto } \\
\text { do idoso punirá agressor } \\
\text { em GO" }\end{array}$ & $\begin{array}{l}6 . \\
\text { hoje a fichar americanos" } \\
\text { (chamada principal) } \\
7 . \quad \text { "Chuvas } \\
\text { deixam } 300 \text { desabrigados } \\
\text { no Estado" }\end{array}$ \\
\hline $\begin{array}{l}\text { 04/01 } \\
\text { Domingo }\end{array}$ & $\begin{array}{l}11 . \quad \text { "Tráfico usa } \\
\text { verba federal do Nordeste" } \\
\text { (box com foto) } \\
12 . \quad \text { "China muda ao } \\
\text { fortalecer a diplomacia" } \\
13 . \quad \text { "Favelização } \\
\text { cresce nas cidades de } \\
\text { médio porte" }\end{array}$ & $\begin{array}{l}10 . \quad \text { "Anaconda se } \\
\text { volta agora contra a polícia } \\
\text { paulista" }\end{array}$ & $\begin{array}{l}6 . \quad \text { "Um Rio de } \\
\text { contrastes - Estado perde } \\
\text { duas posições no ranking } \\
\text { do IDH" (box com foto) } \\
7 . \text { "Polêmica em } \\
\text { festival de hip-hop } \\
\text { brasileiro" "Camelôs têm a } \\
8 . \\
\text { proteção de policiais" }\end{array}$ & $\begin{array}{l}8 . \quad \text { "Jovens do Rio } \\
\text { bebem cada vez mais" } \\
\text { (chamada principal) } \\
9 . \quad \text { "Arrastão de } \\
\text { inocentes" (Erro da } \\
\text { Polícia) "Futilidades e } \\
10 . \quad \text { preconceitos emperram a } \\
\text { Câmara" } \\
\end{array}$ \\
\hline $\begin{array}{l}\text { 05/01 } \\
\text { Segunda }\end{array}$ & $\begin{array}{l}14 . \quad \text { "Líderes } \\
\text { afegãos aprovam nova } \\
\text { constituição" } \\
15 . \quad \text { "Rebeliões } \\
\text { matam } 7 \text { presos em } \\
\text { Manaus" (Cotidiano) }\end{array}$ & $\begin{array}{l}11 . \quad \text { "Estados Unidos } \\
\text { começam hoje a fichar } \\
\text { brasileiros" } \\
12 . \quad \text { "Afeganistão } \\
\text { aprova nova Constituição" } \\
13 . \quad \text { "Assalto acaba } \\
\text { com } 3 \text { mortes no centro de } \\
\text { SP" } \\
14 . \quad \text { "Da Cidade de } \\
\text { Deus para Hollywood" }\end{array}$ & $\begin{array}{l}9 . \\
\text { aviação britânica em alerta" } \\
10 . \\
\text { queimado põe em xeque o } \\
\text { Zona Sul Legal" }\end{array}$ & $\begin{array}{l}11 . \quad \text { "Jovens } \\
\text { apedrejam idoso até a } \\
\text { morte" (chamada } \\
\text { principal) } \\
12 . \quad \text { "Britânicos } \\
\text { matam prisioneiro a } \\
\text { pontapés" }\end{array}$ \\
\hline $\begin{array}{l}\text { 06/01 } \\
\text { Terça }\end{array}$ & $\begin{array}{l}16 . \quad \text { "Ministro quer } \\
\text { deduzir do IR salário pago } \\
\text { a domésticas" } \\
17 . \quad \text { "Para Casa } \\
\text { Branca, Fidel e Chávez } \\
\text { agem contra EUA" } \\
18 . \quad \text { "Cartas-bomba } \\
\text { visam Parlamento Europeu" }\end{array}$ & $\begin{array}{l}15 . \\
\text { a gente não esquece" } \\
16 . \\
\text { europeus recebem carta- } \\
\text { bomba" } \\
17 . \quad \text { "Lavrador é } \\
\text { acusado pela morte da } \\
\text { mãe" }\end{array}$ & $\begin{array}{l}11 . \quad \text { "Americanos } \\
\text { esperam até } 8 \text { horas no } \\
\text { aeroporto para entrar no } \\
\text { Rio" (box com fotos e } \\
\text { textos) "Novo Estatuto } \\
12 . \\
\text { do Idoso faz sua 1ª. prisão" }\end{array}$ & $\begin{array}{l}13 . \quad \text { "Americanos } \\
\text { esperam } 9 \text { horas na fila" } \\
14 . \quad \text { "Morre Idalina, } \\
73 \text {, outra vítima de maus- } \\
\text { tratos" } \\
15 . \quad \text { "Mudam } \\
\text { delegacias de combate a } \\
\text { homicídios" }\end{array}$ \\
\hline $\begin{array}{l}\text { 07/01 } \\
\text { Quarta }\end{array}$ & $\begin{array}{l}19 . \quad \text { "Iraque prorroga } \\
\text { estado de sítio por mais } 30 \\
\text { dias" } \\
20 . \\
\text { no Alvorada são retiradas } \\
\text { de blogs" "Fotos de férias } \\
21 . \quad \text { "Palestina volta } \\
\text { atrás e fala em diálogo } \\
\text { com Israel" } \\
22 . \quad \text { "Mandela } \\
\text { anuncia que seu filho } \\
\text { morreu de aids" }\end{array}$ & $\begin{array}{l}18 . \quad \text { "EUA se queixam } \\
\text { de identificação: é um } \\
\text { castigo" "Atentado com } \\
19 . \text { bicicleta mata } 15 \text { no } \\
\text { Afeganistão" } \\
20 . \text { "Sobram vagas } \\
\text { nos cursos para formar } \\
\text { professor" }\end{array}$ & $\begin{array}{l}13 . \quad \text { "Fazendeiros e } \\
\text { índios isolam Roraima" } \\
14 . \quad \text { "Campanha } \\
\text { condenará xixi nas ruas" } \\
15 . \quad \text { "EUA vão } \\
\text { classificar estrangeiros" } \\
16 . \quad \text { "O hip-hop está } \\
\text { em pé de guerra" (Segundo } \\
\text { Caderno) }\end{array}$ & $\begin{array}{l}16 . \quad \text { "EUA se } \\
\text { queixam de fichamento" } \\
17 . \\
\text { oito crianças no } \\
\text { Afeganistão" } \\
18 . \text { "Guerra de } \\
\text { facções foi a razão do } \\
\text { ataque" "Jovens } \\
19 . \\
\text { descrevem assassinato } \\
\text { de idoso" "Zona Sul } \\
20 . \\
\text { voltará a sediar bailes funk" } \\
21 . \\
\text { lotam albergues no Rio" }\end{array}$ \\
\hline
\end{tabular}




\begin{tabular}{|c|c|c|c|c|}
\hline \multicolumn{5}{|c|}{$\begin{array}{c}\text { TABELA IV } \\
\text { ESTIGMAS SOCIAIS - PRIMEIRAS PÁGINAS (JORNAIS) } \\
08-14 / 03 / 2007\end{array}$} \\
\hline Data & Folha de S. Paulo & O Estado de S. Paulo & O Globo & Jornal do Brasil \\
\hline $\begin{array}{l}08 / 03 \\
\text { Segunda }\end{array}$ & $\begin{array}{l}\text { 1. "Cresce } \\
\text { preocupação com } \\
\text { desemprego" (chamada } \\
\text { principal) } \\
2 . \quad \text { "Especial enfoca } \\
\text { mulher e carro" (box) } \\
\text { 3. "Israel ataca } \\
\text { campos de refugiados; } 14 \\
\text { morrem" }\end{array}$ & $\begin{array}{l}1 . \quad \text { "Cidades do PT } \\
\text { recebem mais Bolsa- } \\
\text { Família" } \\
2 . \quad \text { "Só EUA têm } \\
\text { mais chefes mulheres que } \\
\text { o Brasil" "Do Islã } \\
3 . \quad \begin{array}{l}\text { feminino ao "Sex and the } \\
\text { city"” }\end{array}\end{array}$ & $\begin{array}{l}1 . \\
\text { fuzil da polícia" }\end{array}$ & $\begin{array}{l}1 . \\
\text { Israel mata } 14 \text { e fere } 93 \\
\text { em Gaza" } \\
2 . \quad \text { "Preso grupo de } \\
\text { favelados por saque a } \\
\text { ônibus" "Mulheres } \\
3 . \quad \begin{array}{l}\text { atraem empresas de } \\
\text { seguro" }\end{array}\end{array}$ \\
\hline $\begin{array}{l}\text { 09/03 } \\
\text { Terça }\end{array}$ & $\begin{array}{l}4 . \quad \text { "Mulheres } \\
\text { protestam por terra e } \\
\text { empregos" "Sob crítica de } \\
5 . \quad \text { "Siitas, Iraque aprova nova } \\
\text { Constituição" } \\
6 . \quad \text { "Preso bando } \\
\text { que falsificava leite em pó } \\
\text { no NE" "Chuvas matam } \\
7 . \\
4 \text { e desalojam } 60 \text { mil no } \\
\text { Ceará" }\end{array}$ & $\begin{array}{l}4 . \quad \text { "Iraque tem } \\
\text { nova Constituição, sob } \\
\text { críticas de xiitas" } \\
5 . \quad \text { "Brasil é o } 1^{\circ} \text {. a } \\
\text { assumir que tem trabalho } \\
\text { escravo" }\end{array}$ & $\begin{array}{l}2 . \quad \text { "Polícia retoma } \\
\text { operação em } 64 \text { favelas" } \\
\text { (com foto) "Afastado chefe } \\
3 . \quad \text { "Iraque: xiitas } \\
\text { de segurança de Bangu I" } \\
4 . \quad \text { recuam e assinam a } \\
\text { constituição" }\end{array}$ & $\begin{array}{l}4 . \quad \text { "Médicos são } \\
\text { ameaçados para atender } \\
\text { traficantes" } \\
5 . \quad \text { "Avião de } \\
\text { mercenários é detido no } \\
\text { Zimbábue" }\end{array}$ \\
\hline $\begin{array}{l}\text { 10/03 } \\
\text { Quarta }\end{array}$ & $\begin{array}{l}8 . \quad \text { "Acordo com } \\
\text { FMI evita calote argentino" } \\
\text { (chamada principal) } \\
9 . \quad \text { "Dívida com } \\
\text { INSS leva presidente da } \\
\text { Vasp à prisão" } \\
10 . \quad \text { "Obesidade já é } \\
\text { quase tão letal quanto o } \\
\text { fumo" } \\
11 . \quad \text { "Chávez espera } \\
\text { apoio do Brasil contra os } \\
\text { EUA" }\end{array}$ & $\begin{array}{l}6 . \\
\text { restrição a filme de Gibson } \\
\text { no país" } \\
7 . \\
\text { por balas perdidas no RJ" }\end{array}$ & $\begin{array}{l}5 . \quad \text { "Fuzileiros } \\
\text { desviam armas para o } \\
\text { tráfico e são presos" (box) }\end{array}$ & $\begin{array}{l}6 . \quad \text { "Mortes e } \\
\text { revolta na Favela Beira- } \\
\text { Mar" (com foto) } \\
7 . \quad \text { "Agente de } \\
\text { Bangu } 4 \text { desaparecido há } \\
37 \text { dias" } \\
8 . \quad \text { "Tráfico de } \\
\text { corpos põe universidade } \\
\text { sob suspeita" }\end{array}$ \\
\hline $\begin{array}{l}11 / 03 \\
\text { Quinta }\end{array}$ & $\begin{array}{l}12 . \quad \text { "PM é acusada } \\
\text { de agressões em bairro de } \\
\text { SP" }\end{array}$ & $\begin{array}{l}8 . \\
\text { ecologicamente correto" } \\
\text { (com foto) "Lucro } \\
9 . \\
\text { humanos: anistia cobra } \\
\text { Lula" }\end{array}$ & $\begin{array}{l}6 . \\
\text { matou pastor e estudante" } \\
\text { (box com foto) }\end{array}$ & $\begin{array}{l}9 . \quad \text { "Cresce número } \\
\text { de mortos em confrontos } \\
\text { com a polícia" (chamada } \\
\text { principal) "Rio recebe R\$ } \\
10 . \quad 61 \text { mil para vitimas de } \\
\text { enchentes" }\end{array}$ \\
\hline $\begin{array}{l}12 / 03 \\
\text { Sexta }\end{array}$ & $\begin{array}{l}13 . \quad \text { "Terror mata } \\
\text { mais de } 190 \text { em Madri" } \\
\text { (chamada principal com } \\
\text { foto e retrancas) } \\
14 . \quad \text { "11 de Setembro } \\
\text { espanhol tem horror e } \\
\text { solidariedade" }\end{array}$ & $\begin{array}{l}10 . \quad \text { "O massacre de } \\
\text { Madri - Al-Qaeda ou ETA: } \\
\text { terror matou } 192 \text { pessoas" } \\
\text { (chamada principal com } \\
\text { fotos mais textos de capa) }\end{array}$ & $\begin{array}{l}7 . \text { "Dia da infâmia } \\
\text { na Europa" (box com fotos } \\
\text { e texto) }\end{array}$ & $\begin{array}{l}11 . \quad \text { "Terror golpeia } \\
\text { Madri - } 192 \text { mortos e mais } \\
\text { de } 1.400 \text { feridos" } \\
\text { (chamada principal com } \\
\text { foto) }\end{array}$ \\
\hline $\begin{array}{l}13 / 03 \\
\text { Sábado }\end{array}$ & $\begin{array}{l}15 . \quad \text { "8 milhões } \\
\text { marcham contra o terror" } \\
\text { (chamada principal com } \\
\text { foto e retrancas) } \\
16 . \text { "Verba contra } \\
\text { trabalho infantil atrasa } 2 \\
\text { meses" }\end{array}$ & $\begin{array}{l}11 . \quad \text { "Onze milhões } \\
\text { de espanhóis nas ruas } \\
\text { contra o terror" (chamada } \\
\text { principal com foto) } \\
12 . \quad \text { "Ainda principal } \\
\text { suspeito do governo, ETA } \\
\text { nega autoria" }\end{array}$ & $\begin{array}{l}8 . \\
\text { contra o terror" (box com } \\
\text { foto e textos) }\end{array}$ & $\begin{array}{l}12 . \quad \text { "Espanhóis } \\
\text { desafiam o terror" } \\
\text { (chamada principal com } \\
\text { foto) "Polícia fará } \\
13 . \quad \text { ronda em hospitais } \\
\text { particulares" }\end{array}$ \\
\hline $\begin{array}{l}\text { 14/03 } \\
\text { Domingo }\end{array}$ & $\begin{array}{l}17 . \quad \text { "Prisões e fita } \\
\text { apontam para Al Qaeda" } \\
\text { (chamada principal com } \\
\text { foto e retrancas) } \\
18 . \quad \text { "Gasto com } \\
\text { avião de Lula consome } \\
75 \% \text { do investido" }\end{array}$ & $\begin{array}{l}13 . \quad \text { "Prisão de } \\
\text { suspeitos na Espanha } \\
\text { aponta para terror islâmico" } \\
\text { (chamada principal) } \\
14 . \quad \text { "Espalhar } \\
\text { riqueza pelo país: grande } \\
\text { desafio da İ́ndia" } \\
15 . \quad \text { "Três mortos em } \\
\text { dois ataques no Iraque" }\end{array}$ & $\begin{array}{l}9 . \quad \text { "Prisões em } \\
\text { Madri ampliam suspeitas } \\
\text { contra al-Qaeda" (box com } \\
\text { foto e texto) } \\
10 . \quad \text { "EUA culpam } \\
\text { carboidratos por maioria de } \\
\text { obesos" (Jornal da Família) }\end{array}$ & $\begin{array}{l}14 . \quad \text { "Europa } \\
\text { reavalia unidade pós- } \\
\text { ataque" "Luta pelo } \\
15 . \\
\text { poder no tráfico esfacela } \\
\text { facções" }\end{array}$ \\
\hline
\end{tabular}




\begin{tabular}{|c|c|c|c|c|}
\hline \multicolumn{5}{|c|}{$\begin{array}{c}\text { TABELA V } \\
\text { ESTIGMAS SOCIAIS - PRIMEIRAS PÁGINAS (JORNAIS) } \\
15-21 / 05 / 2007\end{array}$} \\
\hline Data & Folha de S. Paulo & O Estado de S. Paulo & O Globo & Jornal do Brasil \\
\hline $\begin{array}{l}15 / 05 \\
\text { Sábado }\end{array}$ & $\begin{array}{l}1 . \quad \text { "Lula anula a } \\
\text { expulsão; 'NYT' nega ter se } \\
\text { retratado" "Vaticano rejeita } \\
2 . \quad \text { casamento com } \\
\text { muçulmanos" }\end{array}$ & $\begin{array}{l}1 . \quad \text { "Governo cria } \\
\text { 'retratação' e devolve visto } \\
\text { para jornalista" } \\
2 . \quad \text { "Americanos } \\
\text { soltam } 315 \text { presos no Iraque" } \\
3 . \quad \text { "Vaticano: } \\
\text { católico não deve casar } \\
\text { com muçulmano" } \\
4 . \quad \text { "IBGE definirá } \\
\text { cota nas universidades" }\end{array}$ & $\begin{array}{l}1 . \\
\text { 'NYT' diz que não há } \\
\text { desculpa" }\end{array}$ & $\begin{array}{l}\text { 1. "Jornalista se } \\
\text { retrata e Lula cancela ato } \\
\text { de expulsão" (chamada } \\
\text { principal) } \\
2 . \quad \text { "Atuação do } \\
\text { Exército no Rio não sai do } \\
\text { papel" "Fidelidade a } \\
\text { 3. } \\
\text { Fidel Castro" (foto- } \\
\text { legenda) }\end{array}$ \\
\hline $\begin{array}{l}16 / 05 \\
\text { Domingo }\end{array}$ & $\begin{array}{l}3 . \quad \text { "Haiti será treino } \\
\text { para Rio, diz Exército" } \\
4 . \quad \text { "Polícia prende } \\
\text { acusado de furto de livros } \\
\text { raros" }\end{array}$ & $\begin{array}{l}5 . \quad \text { "Rumsfeld } \\
\text { aprovou tortura no Iraque, } \\
\text { afirma revista" } \\
6 . \quad \text { "Alunos são } \\
\text { suspeitos de roubo de } \\
\text { livros raros" }\end{array}$ & $\begin{array}{l}2 . \\
\text { Rocinhas até } 2010 " \\
3 . \quad \text { "Por que os } \\
\text { homens ficam mais e mais } \\
\text { zen" (Jornal da Família) } \\
4 . \quad \text { "Livro, show e } \\
\text { filme exaltam o subúrbio" } \\
\text { (Segundo Caderno) } \\
5 . \quad \text { "Cidades } \\
\text { fluminenses em que há } \\
\text { emprego" (Boa Chance) } \\
6 . \quad \text { "Chávez tenta } \\
\text { expulsar jornalistas" }\end{array}$ & $\begin{array}{l}\text { 4. "Sucessão em } \\
\text { Cuba expõe cisão no clã } \\
\text { dos Castro" } \\
5 . \quad \text { "Carioca dribla } \\
\text { a lei para se proteger" }\end{array}$ \\
\hline $\begin{array}{l}17 / 05 \\
\text { Segunda }\end{array}$ & $\begin{array}{l}5 . \quad \text { "Bloqueador não } \\
\text { evita uso de celulares em } \\
\text { prisões" } \\
6 . \quad \text { "Israel planeja } \\
\text { demolir casas de palestinos" } \\
7 . \quad \text { "Pagode volta a } \\
\text { atrair público jovem" }\end{array}$ & $\begin{array}{l}7 . \quad \text { "Israel ataca sede } \\
\text { da Fatah com mísseis" } \\
8 . \quad \text { "Governo fecha } \\
\text { acordo de cotas para } \\
\text { carentes" "Acusado por } 20 \\
9 . \quad \text { seqüestros é preso em SP" }\end{array}$ & $\begin{array}{l}7 . \quad \text { "Ladrões de } \\
\text { livros rasgam obras raras" } \\
8 . \quad \text { "Iraque faz } \\
\text { popularidade de Bush e } \\
\text { Blair cair" }\end{array}$ & $\begin{array}{l}6 . \quad \text { "Papa santifica } \\
\text { mulher casada" }\end{array}$ \\
\hline $\begin{array}{l}\text { 18/05 } \\
\text { Terça }\end{array}$ & $\begin{array}{l}8 . \\
\text { presidente do Conselho } \\
\text { Iraquiano" (chamada } \\
\text { principal) "CPI indiciará } \\
9 . \\
100 \text { por abusos contra } \\
\text { menor" "Imigrante nos } \\
10 . \\
\text { EUA envia ao Brasil US\$ } \\
5,2 \text { bi" }\end{array}$ & $\begin{array}{l}10 . \quad \text { "Atentado mata } \\
\text { líder do governo iraquiano" } \\
\text { (chamada principal) } \\
11 . \quad \text { "Objetivo do } \\
\text { MST é fazer marketing, } \\
\text { afirma Ermírio" } \\
12 . \quad \text { "Brasil se une a } \\
7 \text { países em bloco de } \\
\text { combate à aids" } \\
13 . \quad \text { "Fogo em prisão } \\
\text { mata } 104 \text { em Honduras" }\end{array}$ & $\begin{array}{l}9 . \\
\text { mantêm } 20 \text { reféns em } \\
\text { prédio do Alto Leblon" (com } \\
\text { foto) }\end{array}$ & $\begin{array}{l}7 . \quad \text { "Atentado mata } \\
\text { o presidente do conselho } \\
\text { de governo" (Iraque) } \\
8 . \\
\text { Leblon e índice de assalto } \\
\text { a residências não cai" } \\
9 . \quad \text { "ONU defende } \\
\text { uso de transgênicos } \\
\text { contra a fome" } \\
10 . \quad \text { "Índios matam } \\
\text { animais para exportar } \\
\text { artesanato" }\end{array}$ \\
\hline $\begin{array}{l}19 / 05 \\
\text { Quarta }\end{array}$ & $\begin{array}{l}11 . \quad \text { "Brasil tem } 26 \\
\text { milhões de pessoas sem } \\
\text { dentes" } \\
12 . \quad \text { "Famintos e } \\
\text { rebeldes vivem juntos no } \\
\text { Haiti, afirma militar" } \\
13 . \quad \text { "EUA sofrem } \\
\text { pressão para dar } \\
\text { autonomia aos iraquianos" } \\
14 . \quad \text { "19 palestinos } \\
\text { são mortos em ação de } \\
\text { Israel em Gaza" } \\
15 . \quad \text { "Prédio de luxo } \\
\text { em SP sofre arrastão" }\end{array}$ & $\begin{array}{l}14 . \quad \text { "'O MST é uma } \\
\text { ameaça', diz setor de } \\
\text { celulose" } \\
15 . \quad \text { "Olimpíada } \\
2012 \text { : segurança tira Rio } \\
\text { da disputa" } \\
16 . \quad \text { "Bando assalta } \\
\text { prédio durante } 4 \text { horas em } \\
\text { SP" } \\
17 . \quad \text { "Ofensiva } \\
\text { israelense em Gaza: } 20 \\
\text { mortos" }\end{array}$ & $\begin{array}{l}10 . \quad \text { "Ladrão devolve } \\
\text { pelo correio obras } \\
\text { roubadas" }\end{array}$ & $\begin{array}{l}11 . \quad \text { "Falhas em } \\
\text { segurança, transporte e } \\
\text { hotéis acabam com } \\
\text { chances do Rio" (chamada } \\
\text { principal) "Impunidade } \\
12 . \quad \text { "Sonia Gandhi } \\
\text { marca exploração infantil" } \\
13 . \quad \text { desiste do poder" } \\
14 . \quad \text { "Câmeras } \\
\text { agora vigiam kombis e } \\
\text { vans piratas" }\end{array}$ \\
\hline $\begin{array}{l}20 / 05 \\
\text { Quinta }\end{array}$ & $\begin{array}{l}16 . \quad \text { "Família brasileira } \\
\text { estoura orçamento" (box) } \\
17 . \quad \text { "Israel mata } 10 \\
\text { palestinos durante } \\
\text { manifestação" } \\
18 . \quad \text { "Iraquianos } \\
\text { acusam EUA de matar } 40 \text { em } \\
\text { festa" } \\
19 . \\
\text { a partir de hoje correção do } \\
\text { FGTS" }\end{array}$ & $\begin{array}{l}18 . \\
\text { passeata em Gaza e deixa } \\
\text { dez mortos" } \\
19 . \quad \text { "EUA matam } \\
\text { mais de } 40 \text { em festa no } \\
\text { Iraque" }\end{array}$ & $\begin{array}{l}11 . \quad \text { "IBGE: } 85 \% \text { das } \\
\text { famílias no vermelho" (box) } \\
12 . \quad \text { "Zona Sul tem } \\
\text { mais uma casa invadida" } \\
13 . \quad \text { "Iraque: soldado } \\
\text { é condenado por tortura" } \\
14 . \quad \text { "Israel ataca } \\
\text { passeata com mísseis" } \\
\text { (com foto) }\end{array}$ & $\begin{array}{l}15 . \quad \text { "Sobra mês no } \\
\text { fim do salário de } 150 \\
\text { milhões de brasileiros" } \\
\text { (chamada principal) } \\
16 . \quad \text { "Mulheres são } \\
\text { vítimas de tráfico humano" } \\
17 . \text { "Americano } \\
\text { condenado por tortura" }\end{array}$ \\
\hline $\begin{array}{l}21 / 05 \\
\text { Sexta }\end{array}$ & $\begin{array}{l}20 . \quad \text { "ONGs pedem a } \\
\text { Lula que fale de liberdade } \\
\text { na ida à China" } \\
21 . \quad \text { "Camelôs de SP } \\
\text { atiram ovos sobre Marta" } \\
22 \text {. "Criticado, Israel } \\
\text { mantém ação e mata mais 8" }\end{array}$ & $\begin{array}{l}20 . \quad \text { "Dois recordes: } \\
\text { novas vagas e desemprego" } \\
21 . \quad \text { "Israel mata } 8 \\
\text { em Gaza. EUA pedem fim } \\
\text { da ofensiva" }\end{array}$ & $\begin{array}{ll}15 . & \text { "Retratos da } \\
\text { barbárie" (box com foto) }\end{array}$ & $\begin{array}{l}18 . \quad \text { "Os EUA perdem } \\
\text { forte aliado no Iraque" } \\
19 . \quad \text { "Polícia fecha o } \\
\text { cerco sobre fraudadores" } \\
20 . \quad \text { "Ambulantes } \\
\text { jogam ovos em Marta } \\
\text { Suplicy (Agressão)" }\end{array}$ \\
\hline
\end{tabular}




\begin{tabular}{|c|c|c|c|c|}
\hline \multicolumn{5}{|c|}{$\begin{array}{c}\text { TABELA VI } \\
\text { ESTIGMAS SOCIAIS - PRIMEIRAS PÁGINAS (JORNAIS) } \\
22-28 / 07 / 2007\end{array}$} \\
\hline Data & Folha de S. Paulo & O Estado de S. Paulo & O Globo & Jornal do Brasil \\
\hline $\begin{array}{l}22 / 07 \\
\text { Quinta }\end{array}$ & $\begin{array}{l}1 . \\
\text { chances de barrar terror, } \\
\text { diz Congresso" } \\
2 . \quad \text { "Perueiro } \\
\text { desiste de boicote ao } \\
\text { bilhete único" }\end{array}$ & $\begin{array}{l}1 . \quad \text { "Seis } \\
\text { estrangeiros viram reféns } \\
\text { de rebeldes iraquianos" } \\
2 . \quad \text { "De volta ao } \\
\text { Centro. Para morar" }\end{array}$ & $\begin{array}{l}1 . \quad \text { "Meta de } \\
\text { recolhimento de armas } \\
\text { deve dobrar" (box) } \\
2 . \quad \text { "EUA tiveram } \\
\text { dez chances de evitar o } \\
11 / 9 "\end{array}$ & $\begin{array}{l}\text { 1. "Polícia apura } \\
\text { distribuição de vale- } \\
\text { transporte pelo tráfico" } \\
2 . \\
\text { dez chances de evitar os } \\
\text { atentados" }\end{array}$ \\
\hline $\begin{array}{l}23 / 07 \\
\text { Sexta }\end{array}$ & $\begin{array}{l}3 . \quad \text { "Desemprego } \\
\text { cai, renda sobe e } \\
\text { empresários estão mais } \\
\text { confiantes" } \\
4 . \quad \text { "Para } \\
\text { Congresso, é provável } \\
\text { novo ataque aos EUA" }\end{array}$ & $\begin{array}{l}. \\
\text { cai pelo } 2^{\circ} \text {. mês e renda } \\
\text { sobe" } \\
4 . \\
\text { matam } 25 \text { em combate ao } \\
\text { Iraque" "Tropas do EUA } \\
5 . \\
\text { infratores fogem da } \\
\text { Febem" }\end{array}$ & $\begin{array}{l}3 . \quad \text { "Emprego exibe } \\
\text { sinais de recuperação pelo } \\
2^{\circ} \text {. mês" (box) } \\
4 . \quad \text { "11/9: comissão } \\
\text { alerta para novos ataques" } \\
5 . \quad \text { "PMs acusados } \\
\text { de seqüestrar e matar" }\end{array}$ & $\begin{array}{l}\text { 3. "Relatório alerta } \\
\text { para ameaça da Al } \\
\text { Qaeda" "PMs suspeitos } \\
4 . \\
\text { de seqüestro e } \\
\text { assassinato" }\end{array}$ \\
\hline $\begin{array}{l}24 / 07 \\
\text { Sábado }\end{array}$ & $\begin{array}{l}5 . \quad \text { "MPs definem } \\
\text { acordo com aposentados e } \\
\text { redução do IR" } \\
6 . \\
\text { seqüestra diplomata do } \\
\text { Egito no Iraque" } \\
7 . \text { "Hospital testa } \\
\text { nova terapia anticâncer" } \\
\text { (Ciência) }\end{array}$ & $\begin{array}{l}6 . \quad \text { "Grupo } \\
\text { iraquiano faz novo refém: } \\
\text { um diplomata egípcio" } \\
7 . \quad \text { "Pacote garante } \\
\text { aposentarias e desconto } \\
\text { no IR" } \\
8 . \quad \text { "SP faz } \\
\text { apreensão recorde de } \\
\text { cocaína" }\end{array}$ & $\begin{array}{l}6 . \quad \text { "Arsenal em } \\
\text { casa: uma só família } \\
\text { entrega } 1.300 \text { armas à PF" } \\
\text { (box com foto) } \\
7 . \quad \text { "Pitgirls" (foto- } \\
\text { legenda) }\end{array}$ & $\begin{array}{l}\text { Edição não disponível } \\
\text { para consulta }\end{array}$ \\
\hline $\begin{array}{l}25 / 07 \\
\text { Domingo }\end{array}$ & $\begin{array}{l}8 . \\
\text { de rua está na escola" } \\
\text { (Cotidiano) } \\
9 . \\
\text { em mundo feito para 'gente } \\
\text { grande"” (Revista) }\end{array}$ & $\begin{array}{l}9 . \\
\text { agrária no ar': é a rádio dos } \\
\text { sem-terra" "'Árabes, judeus } \\
10 . \quad \text { e seus casos de amor" }\end{array}$ & $\begin{array}{l}\text { 8. "PMs sob } \\
\text { investigação este ano já } \\
\text { são } 10 \text { mil" (box) }\end{array}$ & $\begin{array}{l}\text { Edição não disponível } \\
\text { para consulta }\end{array}$ \\
\hline $\begin{array}{l}26 / 07 \\
\text { Segunda }\end{array}$ & $\begin{array}{l}10 . \quad \text { "Cigarro é pior } \\
\text { para a pele que o sol, diz } \\
\text { estudo" } \\
11 . \quad \text { "Destinos se } \\
\text { adaptam para mercado } \\
\text { GLS" (Turismo) }\end{array}$ & $\begin{array}{l}11 . \\
\text { São Tomé e Príncipe e faz } \\
\text { doação ao país" }\end{array}$ & $\begin{array}{l}9 . \\
\text { escravidão mais } 2.300 \\
\text { trabalhadores" (box em } \\
\text { destaque) } \\
10 . \\
\text { amigo ao brincar de roleta- } \\
\text { russa" }\end{array}$ & $\begin{array}{l}\text { Edição não disponível } \\
\text { para consulta }\end{array}$ \\
\hline $\begin{array}{l}27 / 07 \\
\text { Terça }\end{array}$ & $\begin{array}{l}12 . \\
\text { Grande SP cai pelo } 2^{\circ} \text {. mês } \\
\text { seguido" (chamada } \\
\text { principal) "PF prende } \\
13 . \\
\text { suspeitos de matar fiscais } \\
\text { do trabalho" } \\
14 . \quad \text { "Favela } \\
\text { comemora sucesso de } \\
\text { Adriano" (box Esporte) } \\
15 . \quad \text { "Saddam lê e } \\
\text { escreve poesias na prisão" } \\
\text { (Mundo) }\end{array}$ & $\begin{array}{l}12 . \quad \text { "Iraquianos } \\
\text { soltam refém por ser "um } \\
\text { homem religioso"” } \\
13 . \quad \text { "Com bilhete } \\
\text { único, cai assalto a ônibus" } \\
14 . \quad \text { "PF prende } \\
\text { suspeitos de matar fiscais" }\end{array}$ & $\begin{array}{l}11 . \quad \text { "Crimes de PMs } \\
\text { começam a derrubar } \\
\text { comandantes" (box em } \\
\text { destaque) "Ausência de cor } \\
12 . \quad \text { põe cadastro de pobres em } \\
\text { xeque" }\end{array}$ & $\begin{array}{l}\text { Edição não disponível } \\
\text { para consulta }\end{array}$ \\
\hline $\begin{array}{l}28 / 07 \\
\text { Quarta }\end{array}$ & $\begin{array}{l}16 . \quad \text { "Fiscais foram } \\
\text { mortos por R\$ } 50 \text { mil em } \\
\text { Minas, diz PF" } \\
17 . \quad \text { "Mais } 2 \\
\text { brasileiros morrem nos } \\
\text { EUA" (Mundo) }\end{array}$ & $\begin{array}{l}\text { Nenhuma ocorrência foi } \\
\text { verificada }\end{array}$ & $\begin{array}{l}13 . \quad \text { "Fazendeiro é } \\
\text { acusado de chacina em } \\
\text { Unaí" } \\
14 . \quad \text { "PMs acusados } \\
\text { agora de matar } 3 \text { jovens" } \\
15 . \quad \text { "Cadastro de } \\
\text { pobres será aperfeiçoado" }\end{array}$ & $\begin{array}{l}5 . \quad \text { "Protesto de } \\
\text { vans pára o Centro da } \\
\text { cidade" } \\
6 . \quad \text { "Assassinato de } \\
\text { jovem especialista comove } \\
\text { internautas" (Cidade) }\end{array}$ \\
\hline
\end{tabular}




\begin{tabular}{|c|c|c|c|c|}
\hline \multicolumn{5}{|c|}{$\begin{array}{c}\text { TABELA VII } \\
\text { ESTIGMAS SOCIAIS - PRIMEIRAS PÁGINAS (JORNAIS) } \\
01-07 / 09 / 2007\end{array}$} \\
\hline Data & Folha de S. Paulo & O Estado de S. Paulo & O Globo & Jornal do Brasil \\
\hline $\begin{array}{l}01 / 09 \\
\text { Quarta }\end{array}$ & $\begin{array}{l}1 . \quad \text { "Duplo atentado } \\
\text { mata } 16 \text { e fere } 100 \text { em } \\
\text { Israel" (box) } \\
2 . \quad \text { "Assassinados } \\
\text { no Iraque } 12 \text { seqüestrados" } \\
\text { (box) } \\
3 . \quad \text { "Explosão na } \\
\text { Rússia deixa ao menos } 10 \\
\text { mortos" (box) }\end{array}$ & $\begin{array}{l}1 . \\
\text { dois ônibus matam } 18 \text { em } \\
\text { lsrael" } \\
2 . \\
\text { em Moscou: } 10 \text { mortos e } \\
51 \text { feridos" } \\
3 . \\
\text { nepalenses no Iraque" }\end{array}$ & $\begin{array}{l}1 . \\
\text { Israel e na Rússia" }\end{array}$ & $\begin{array}{l}\text { 1. "ONGs se } \\
\text { distanciam do governo } \\
\text { Lula" } \\
2 . \quad \text { "Procurado na } \\
\text { Itália, mafioso agia no Rio" } \\
\text { 3. "Presidente } \\
\text { agora perdoa dívida de } \\
\text { Moçambique" } \\
\text { 4. "Tráfico volta a } \\
\text { agir em favela de } \\
\text { Laranjeiras" }\end{array}$ \\
\hline $\begin{array}{l}\text { 02/09 } \\
\text { Quinta }\end{array}$ & $\begin{array}{l}4 . \quad \text { "Dos candidatos, } \\
30 \% \text { não têm o ensino } \\
\text { básico" "Justiça manda } \\
5 . \\
\text { rastrear celular de área de } \\
\text { chacina" }\end{array}$ & $\begin{array}{l}\text { 4. "País sediará } \\
\text { centro mundial para } \\
\text { controle da aids" }\end{array}$ & $\begin{array}{l}2 . \quad \text { "Terror faz } \\
\text { crianças reféns na Rússia" } \\
\text { (box com foto) } \\
3 . \quad \text { "Assaltantes } \\
\text { tinham mapa de trilhas" }\end{array}$ & $\begin{array}{l}5 . \quad \text { "Delegação } \\
\text { brasileira bate recorde na } \\
\text { paraolimpíada" } \\
6 . \\
\text { assume o tráficco no } \\
\text { Vidigal" }\end{array}$ \\
\hline $\begin{array}{l}\text { 03/09 } \\
\text { Sexta }\end{array}$ & $\begin{array}{l}6 . \quad \text { "Outro morador } \\
\text { de rua é morto em SP" } \\
7 . \quad \text { "Bush repete } \\
\text { fala contra o terror no fim } \\
\text { de convenção" }\end{array}$ & $\begin{array}{l}5 . \\
\text { libertam } 26 \text { mulheres e } \\
\text { bebês" } \\
6 . \\
\text { esperam liberdade e turcos } \\
\text { morrem no Iraque" } \\
7 . \quad \text { "Obesidade, mal } \\
\text { de } 10 \% \text { dos brasileiros, vai } \\
\text { ser atacada" } \\
8 . \quad \text { "Outro mendigo } \\
\text { é assassinado no centro" }\end{array}$ & $\begin{array}{l}4 . \quad \text { "Seqüestradores } \\
\text { liberam } 26 \text { em escola na } \\
\text { Rússia" } \\
5 . \\
\text { rebeldes em cidade do } \\
\text { Haiti" }\end{array}$ & $\begin{array}{l}7 . \quad \text { "Libertados } 32 \\
\text { dos } 300 \text { reféns em escola } \\
\text { russa" } \\
8 . \\
\text { falham no teste auditivo de } \\
\text { bebês" "Evangélicos } \\
9 . \\
\text { movimentam mercado } \\
\text { milionário" "Toque de } \\
10 . \quad \text { recolher" (Vidigal) } \\
\text { recto }\end{array}$ \\
\hline $\begin{array}{l}\text { 04/09 } \\
\text { Sábado }\end{array}$ & $\begin{array}{l}8 . \\
\text { acusado de ameaçar sem- } \\
\text { teto" }\end{array}$ & $\begin{array}{l}\text { 9. "Russos } \\
\text { atribuem ação a Al-Qaeda" } \\
\text { (box) }\end{array}$ & $\begin{array}{l}6 . \quad \text { "Barbárie - } \\
\text { Confronto entre tropas } \\
\text { russas e terroristas em } \\
\text { escola deixa mais de } 200 \\
\text { mortos e } 700 \text { feridos, a } \\
\text { maioria crianças" (chamada } \\
\text { principal com fotos e texto) } \\
7 . \\
\text { guerra por morros da Zona } \\
\text { Sul" }\end{array}$ & $\begin{array}{l}11 . \quad \text { "Briga de } \\
\text { traficantes aterroriza zona } \\
\text { sul" } \\
12 . \\
\text { criminosa impõe regras a } \\
\text { políticos" } \\
13 . \quad \text { "Polícia } \\
\text { suspeita de assassinato } \\
\text { de Amaury" }\end{array}$ \\
\hline $\begin{array}{l}05 / 09 \\
\text { Domingo }\end{array}$ & $\begin{array}{l}9 . \quad \text { "Mulheres } \\
\text { planejam casamento sem } \\
\text { noivo" } 10 . \quad \text { "Árabe lamenta } \\
10 . \quad \text { ações islâmicas" }\end{array}$ & $\begin{array}{l}10 . \quad \text { "Agronegócio } \\
\text { leva fartura ao antigo ramal } \\
\text { da fome" }\end{array}$ & $\begin{array}{l}8 . \quad \text { "Mortos na } \\
\text { Rússia são mais de } 350, \\
\text { sendo } 156 \text { crianças" } \\
\text { (chamada principal com } \\
\text { foto e texto) }\end{array}$ & $\begin{array}{l}14 . \quad \text { "Equador } \\
\text { aquece a linha da miséria" } \\
15 . \quad \text { "Guerra do } \\
\text { tráfico ecoa na internet e } \\
\text { nas urnas" } \\
16 . \quad \text { "Terror faz } 325 \\
\text { vítimas, } 156 \text { são crianças" }\end{array}$ \\
\hline $\begin{array}{l}\text { 06/09 } \\
\text { Segunda }\end{array}$ & $\begin{array}{l}11 . \quad \text { "Noiva compra } \\
\text { as alianças" } \\
12 . \quad \text { "MEC paga, mas } \\
\text { não controla alfabetização" } \\
13 . \quad \text { "Estudo analisa } \\
\text { repulsa contra } \\
\text { desabrigados" }\end{array}$ & $\begin{array}{l}11 . \\
\text { e depois nega prisão do nº } \\
2 \text { de Sadam" } \\
12 . \\
\text { preso por atirar em } \\
\text { mendigos" }\end{array}$ & $\begin{array}{l}9 . \quad \text { "Mortos em } \\
\text { seqüestro em escola russa } \\
\text { podem passar de 400" (com } \\
\text { foto) }\end{array}$ & $\begin{array}{l}17 . \quad \text { "Favela, vetada } \\
\text { na campanha que só fala } \\
\text { aos pobres" } \\
18 . \quad \text { "Rússia enterra } \\
\text { as vítimas e caça } \\
\text { terroristas" "Incra retoma } \\
19 . \quad \text { terras griladas em Brasília" } \\
\text { tera }\end{array}$ \\
\hline $\begin{array}{l}\text { 07/09 } \\
\text { Terça }\end{array}$ & $\begin{array}{l}14 . \quad \text { "Universidade } \\
\text { pública cria menos vagas } \\
\text { noturnas" }\end{array}$ & $\begin{array}{l}13 . \quad \text { "Governo da } \\
\text { Rússia admite que mentiu" } \\
14 . \quad \text { "País fez } \\
\text { avanços sociais, mas não } \\
\text { distribuiu renda" }\end{array}$ & $\begin{array}{l}10 . \quad \text { "Dor e revolta" } \\
\text { (foto-legenda) } \\
11 . \quad \text { "Governo não } \\
\text { tem controle de dados do } \\
\text { Bolsa-Escola" } \\
12 \text {.Corte de } \\
\text { candidatos com ficha } \\
\text { criminal divide ministros do } \\
\text { TSE" (box) }\end{array}$ & $\begin{array}{l}20 . \quad \text { "Rússia } \\
\text { censura o terror" } \\
21 . \quad \text { "Polícia apura } \\
\text { excesso em ação contra } \\
\text { fumante" "Ronaldinho, } \\
22 . \\
\text { noivo da vez, é o retrato } \\
\text { da seleção" "Atletas } \\
23 . \quad \text { paraolímpicos visitam o } \\
\text { Planalto" }\end{array}$ \\
\hline
\end{tabular}




\begin{tabular}{|c|c|c|c|c|}
\hline \multicolumn{5}{|c|}{$\begin{array}{c}\text { TABELA VIII } \\
\text { ESTIGMAS SOCIAIS - PRIMEIRAS PÁGINAS (JORNAIS) } \\
08-14 / 11 / 2007\end{array}$} \\
\hline Data & Folha de S. Paulo & O Estado de S. Paulo & O Globo & Jornal do Brasil \\
\hline $\begin{array}{l}08 / 11 \\
\text { Segunda }\end{array}$ & $\begin{array}{l}1 . \quad \text { "Iraque decreta } \\
\text { estado de emergência" } \\
2 . \\
\text { aumento de violência pós- } \\
\text { Arafat" } \quad \text { "Costa do } \\
3 . \quad \text { Marfim tem onda de } \\
\text { violência" (Mundo) }\end{array}$ & $\begin{array}{l}\text { 1. "Decretada lei } \\
\text { marcial no Iraque" } \\
2 . \\
\text { Robinho é seqüe de } \\
\text { Rürada" }\end{array}$ & $\begin{array}{l}1 . \\
\text { aborto deixa Supremo sob } \\
\text { forte pressão" (box) } \\
2 . \quad \text { "Chuvas deixam } \\
260 \text { desalojados" } \\
3 . \quad \text { "Iraque decreta } \\
\text { lei marcial por } 60 \text { dias" } \\
4 . \quad \text { "Mãe de Robinho } \\
\text { é seqüestrada em SP" }\end{array}$ & $\begin{array}{l}1 . \quad \text { "Mãe do } \\
\text { jogador Robinho é } \\
\text { seqüestrada" } \\
2 . \quad \text { "Cariocas são } \\
\text { vitimas fáceis de extorsão } \\
\text { pelo telefone" }\end{array}$ \\
\hline $\begin{array}{l}\text { 09/11 } \\
\text { Terça }\end{array}$ & $\begin{array}{l}4 . \\
\text { ofensiva no Iraque" } \\
5 . \quad \text { "Mulher de } \\
\text { Arafat gera crise entre } \\
\text { palestinos" } \\
6 . \\
\text { máfia dos comão contra } \\
\text { leva } 42 \text { à prisão" }\end{array}$ & $\begin{array}{l}3 . \quad \text { "Fuzileiros já } \\
\text { combatem nas ruas de } \\
\text { Faluja" } \quad \text { "Dirigentes } \\
4 . \quad \text { palestinos desafiam veto e } \\
\text { vão a Arafat" } \\
5 . \quad \text { "Projeto que } \\
\text { acelera adoção é } \\
\text { contestado" }\end{array}$ & $\begin{array}{l}5 . \\
\text { Rodoviária "Protegícia a Máfia } \\
\text { da Gasolina no Rio" } \\
\text { (chamada principal em box } \\
\text { com foto e texto) } \\
6 . \quad \text { "Brasil é } 72^{\circ} \text {. no } \\
\text { ranking de educação" } \\
7 . \\
\text { denuncia complô de } \\
\text { palestinos" }\end{array}$ & $\begin{array}{l}3 . \\
\text { Faluja define os rumos do } \\
\text { Iraque" }\end{array}$ \\
\hline $\begin{array}{l}\text { 10/11 } \\
\text { Quarta }\end{array}$ & $\begin{array}{l}7 . \quad \text { "Presidente da } \\
\text { China pedirá apoio ao } \\
\text { Brasil para comércio" } \\
\text { 8. "Nova droga } \\
\text { ajuda a evitar 'efeito } \\
\text { sanfona' em dieta" }\end{array}$ & $\begin{array}{l}6 . \quad \text { "Americanos } \\
\text { chegam ao centro de } \\
\text { Faluja" "MST lança } \\
7 . \\
\text { operação "novembro } \\
\text { vermelho"” "China passa a } \\
8 . \quad \text { importar carne bovina do } \\
\text { Brasil" }\end{array}$ & $\begin{array}{l}8 . \quad \text { "Mortes } \\
\text { causadas por homicídios } \\
\text { dobram" (box) } \\
9 . \\
\text { Macapá, do PT, é preso por } \\
\text { desvio" } \\
10 . \quad \text { "Iraque: tropas } \\
\text { avançam no centro de } \\
\text { Faluja" }\end{array}$ & $\begin{array}{l}4 . \quad \text { "Política } \\
\text { apreende nova droga no } \\
\text { sul" (País) "Aliados: morto } \\
5 . \quad \text { de Arafat é iminente" } \\
6 . \quad \text { "Prefeito de } \\
\text { Macapá é preso por } \\
\text { fraude" "Confirmação } \\
7 . \quad \text { de doping aproxima Brasil } \\
\text { do ouro" (Hipismo) }\end{array}$ \\
\hline $\begin{array}{l}11 / 11 \\
\text { Quinta }\end{array}$ & $\begin{array}{l}9 . \\
\text { Arafat será no Cairo, dizem } \\
\text { palestinos" }\end{array}$ & $\begin{array}{l}9 . \\
\text { captura primos do premier } \\
\text { iraquiano" } \\
10 . \\
\text { vermelho em SP" (foto) } \\
11 . \quad \text { "Sucessão de } \\
\text { Arafat está nas mãos de } \\
\text { Israel" }\end{array}$ & $\begin{array}{l}11 . \quad \text { "Rio tem queda } \\
\text { em mortes por arma" } \\
12 . \quad \text { "Bush diz que } \\
\text { sem Arafat paz é possível" } \\
13 . \quad \text { "Iraque: EUA não } \\
\text { capturam guerrilheiros" } \\
\text { 14. "Ditadura } \\
\text { torturou } 35 \text { mil no Chile" }\end{array}$ & $\begin{array}{l}8 . \\
\text { vetados no adeus a } \\
\text { Arafat" }\end{array}$ \\
\hline $\begin{array}{l}12 / 11 \\
\text { Sexta }\end{array}$ & $\begin{array}{l}10 . \quad \text { "Morre Arafat, } \\
\text { ícone palestino" (chamada } \\
\text { principal com foto e } \\
\text { retrancas) "Sharon diz } \\
11 . \quad \text { esperar virada 'histórica' no } \\
\text { Oriente Médio" } \\
12 . \quad \text { "Fato dá nova } \\
\text { oportunidade a } \\
\text { negociação, afirma Bush" } \\
13 . \quad 600 \text { rebeldes já } \\
\text { morreram em Fallujah, } \\
\text { assumem EUA" } \\
14 . \\
\text { de Lula, } 2,5 \text { milhões de } \\
\text { pessoas deixam a classe } \\
\text { média" }\end{array}$ & $\begin{array}{l}12 . \quad \text { "Sucessor de } \\
\text { Arafat pode ser eleito em } \\
60 \text { dias" (chamada } \\
\text { principal com foto e } \\
\text { retrancas) "Fechada a 19. } \\
13 . \quad \text { desocupação do novembro } \\
\text { vermelho" "Rebeldes } \\
14 . \\
\text { atacam QG americano em } \\
\text { Faluja" "Juiz manda } \\
15 . \\
\text { abrir arquivos da repressão } \\
\text { política" }\end{array}$ & $\begin{array}{l}15 . \quad \text { "Morte de Arafat } \\
\text { mergulha o Oriente Médio } \\
\text { na incerteza" (chamada } \\
\text { principal em box com fotos } \\
\text { e textos) }\end{array}$ & $\begin{array}{l}9 . \quad \text { "Morte de } \\
\text { Arafat move xadrez } \\
\text { político do Orienta Médio" } \\
\text { (chamada principal com } \\
\text { foto e texto) } \\
10 . \quad \text { "Cresce índice } \\
\text { de assaltos em ônibus e a } \\
\text { pedestres" }\end{array}$ \\
\hline $\begin{array}{l}\text { 13/11 } \\
\text { Sábado }\end{array}$ & $\begin{array}{l}15 . \quad \text { "Brasil dá à } \\
\text { China status de economia } \\
\text { de mercado" } \\
16 . \quad \text { "Bush defende } \\
\text { Estado palestino" } \\
17 . \text { "Câncer de } \\
\text { mama deixará de matar, } \\
\text { diz especialista" }\end{array}$ & $\begin{array}{l}16 . \quad \text { "Brasil cede à } \\
\text { China em troca de mais } \\
\text { exportação" } \\
17 . \quad \text { "Bush: Estado } \\
\text { palestino até } 2009 " \\
18 . \quad \text { "Rebeldes de } \\
\text { Faluja se reagrupam em } \\
\text { outras cidades" }\end{array}$ & $\begin{array}{l}16 . \quad \text { "Comoção e } \\
\text { tumulto no adeus a Arafat" } \\
\text { (box com foto e texto) } \\
17 . \quad \text { "Brasil: China } \\
\text { tem economia de mercado" } \\
\text { (com foto) }\end{array}$ & $\begin{array}{l}\text { Edição não disponível } \\
\text { para consulta }\end{array}$ \\
\hline $\begin{array}{l}\text { 14/11 } \\
\text { Domingo }\end{array}$ & $\begin{array}{l}18 . \quad \text { "Cresce homicídio } \\
\text { de meninos em SP" } \\
\text { (chamada principal) } \\
19 . \quad \text { "Palestinos } \\
\text { podem ter presidente } \\
\text { provisório" "General diz que } \\
20 . \quad \text { "Guivo militar guarda } \\
\text { arqua } \\
\text { delações da esquerda" } \\
21 . \quad \text { "Acessório sexual } \\
\text { ativa preconceitos" (Revista) }\end{array}$ & $\begin{array}{l}19 . \quad \text { "Porção lésbica } \\
\text { da novela das 9" (TV \& } \\
\text { Lazer) "Turista } \\
20 . \\
\text { japonesa é esfaqueada no } \\
\text { Rio" "Iraque anuncia } \\
21 . \quad \text { libertação de Faluja" }\end{array}$ & $\begin{array}{l}18 . \quad \text { "Governo quer } \\
\text { criar espaços para } \\
\text { dependentes de drogas" (box) } \\
19 . \quad \text { "Os } 50 \text { negros } \\
\text { mais influentes do Brasil" } \\
\text { (Revista) "Após Arafat, } \\
20 . \quad \text { eleições são a chave para a } \\
\text { paz" }\end{array}$ & $\begin{array}{l}\text { Edição não disponível } \\
\text { para consulta }\end{array}$ \\
\hline
\end{tabular}


Lembramos, ainda, que toda forma de classificação pressupõe critérios objetivos e subjetivos, tanto do material analisado como dos procedimentos de análise. Para a escolha das chamadas de capa destacadas, procuramos nos basear em conceitos apontados anteriormente e nas definições estabelecidas para delimitar os estigmas sociais em suas relações com as mídias. Se observarmos as chamadas selecionadas, veremos que os conceitos definidores dos estigmas sociais podem ser identificados; mais do que estereótipos e preconceitos, temos a recorrência de temas relacionados à própria organização da sociedade. Além disso, é importante ressaltar que algumas dessas notícias não pressupõem uma aproximação negativa aos temas abordados, mas podemos notar uma predominância de aspectos negativos, relacionando os estigmas sociais a estereótipos e preconceitos.

Observando as tabelas, notamos que o tema dos estigmas sociais se faz presente, sobretudo, nas notícias secundárias das primeiras páginas, compondo, além das pequenas narrativas, uma grande narrativa que recorta os espaços de inclusão/exclusão de atores sociais específicos. Nos casos em que ocupa as manchetes principais, isso ocorre em temas de largo alcance, como atentados ocorridos em países da Europa, ou questões relativas aos conflitos no Oriente Médio (entre elas, destaca-se a morte de Arafat). É interessante notar, portanto, o caráter internacional dessas manchetes e a importância que as questões envolvendo o terrorismo - seja para combatê-lo ou reportálo - têm ocupado nas primeiras páginas. A questão envolvendo a identificação de cidadãos norte-americanos nos aeroportos brasileiros também ocupou com frequência as chamadas de capa daquela época.

Em relação aos estigmas sociais, na Folha de S. Paulo as principais manchetes nas semanas estudadas foram: 1) Janeiro: "Menor participa de 1\% dos homicídios"; "Saúde pede tempo para cumprir o Estatuto do Idoso"; "Tráfico usa verba federal do Nordeste"; "Líderes afegãos aprovam nova constituição"; "Ataque mata 5 em Réveillon em Bagdá”. 2) Março: "Cresce preocupação com desemprego"; "Mulheres protestam por terra e empregos"; "Sob crítica de xiitas, Iraque aprova nova Constituição"; "Terror mata mais de 190 em Madri"; "11 de Setembro espanhol tem horror e solidariedade"; "8 milhões marcham contra o terror". 3) Maio: "Vaticano rejeita casamento com muçulmanos"; "Haiti será treino para Rio, diz Exército"; "Bomba mata presidente do Conselho Iraquiano"; "Brasil tem 26 milhões de pessoas sem dentes"; "ONGs pedem a Lula que fale de liberdade na ida à China". 4) Julho: "EUA tiveram 10 chances de barrar terror, diz Congresso"; "Desemprego cai, renda sobe e empresários estão mais 
confiantes"; "No Rio, menino de rua está na escola"; "Saddam lê e escreve poesias na prisão". 5) Setembro: "Duplo atentado mata 16 e fere 100 em Israel”; “Assassinados no Iraque 12 seqüestrados"; "Explosão na Rússia deixa ao menos 10 mortos"; "Outro morador de rua é morto". 6) Novembro: "Iraque decreta estado de emergência"; "Israel teme aumento de violência pós-Arafat"; "Funeral de Arafat será no Cairo, dizem palestinos"; "Morre Arafat, ícone palestino"; "Brasil dá à China status de economia de mercado"; "Cresce homicídio de meninos em SP".

As chamadas destacadas apontam para uma variedade de assuntos e para o caráter nacional que a Folha (ainda hoje) pretende dar a seu noticiário, distribuindo-as em várias editorias (Mundo, Brasil, Cotidiano, Esportes, Economia, Política). Além disso, notamos a presença da busca por neutralidade e imparcialidade defendida pelo jornal, tornando os textos um discurso em terceira pessoa que se afasta não apenas do lugar da enunciação, mas também de seu interlocutor ou leitor pressuposto, características que se mantêm até o presente.

O jornal $O$ Estado de $S$. Paulo trouxe nas semanas assinaladas as seguintes manchetes principais: 1) Janeiro: "A partir de hoje, Estatuto do Idoso é lei”; "Golan: Israel quer mais assentamentos"; "Explosão mata 5 em Bagdá em festa de réveillon"; "Bolsa-Família já beneficia um terço dos pobres"; "EUA se queixam de identificação: é um castigo"; "Atentado com bicicleta mata 15 no Afeganistão". 2) Março: "Cidades do PT recebem mais Bolsa-Família"; "Só EUA têm mais chefes mulheres que o Brasil"; "Iraque tem nova Constituição, sob críticas de xiitas"; "Brasil é o $1^{\circ}$. a assumir que tem trabalho escravo"; "O massacre de Madri - Al-Qaeda ou ETA: terror matou 192 pessoas"; "Onze milhões de espanhóis nas ruas contra o terror"; Prisão de suspeitos na Espanha aponta para terror islâmico. 3) Maio: "Bando assalta prédio durante 4 horas em SP"; "Vaticano: católico não deve casar com muçulmano"; "IBGE definirá cota nas universidades"; “Atentado mata líder do governo iraquiano"; "Objetivo do MST é fazer marketing, afirma Ermírio"; "Ofensiva israelense em Gaza: 20 mortos". 4) Julho: "Seis estrangeiros viram reféns de rebeldes iraquianos"; "Tropas do EUA matam $25 \mathrm{em}$ combate ao Iraque"; "A cada dia, três infratores fogem da Febem"; "Reforma agrária no ar': é a rádio dos sem-terra"; "Iraquianos soltam refém por ser 'um homem religioso"”. 5) Setembro: "Bombas em dois ônibus matam 18 em Israel”; "Terrorista ataca em Moscou: 10 mortos e 51 feridos"; "País sediará centro mundial para controle da aids"; "Terroristas libertam 26 mulheres e bebês"; "Russos atribuem ação a AlQaeda"; "Iraque anuncia e depois nega prisão do no. 2 de Sadam". 6) Novembro: 
"Decretada lei marcial no Iraque"; "Mãe de Robinho é seqüestrada"; "Fuzileiros já combatem nas ruas de Faluja"; "MST lança operação "novembro vermelho"”; "Sucessor de Arafat pode ser eleito em 60 dias"; "Porção lésbica da novela das 9".

Destacamos, do conjunto de chamadas de capa de $O$ Estado, uma recorrência em matérias sobre o MST (sempre de forma depreciativa), e um grande número de temas relacionados aos estigmas sociais em contextos internacionais, e não no Brasil. Para as matérias nacionais, os assuntos - ainda que complexos - chegam a ser prosaicos, como novela, futebol, desemprego e crimes considerados corriqueiros, além da predominância de temas econômicos em detrimento de temáticas sociais.

O diário carioca $O$ Globo trouxe em suas primeiras páginas, nas semanas indicadas, as seguintes manchetes: 1) Janeiro: "Ano-novo no Iraque começa com bomba"; "Governo mapeia o crime e quer acabar com os bondes no Rio"; "Americanos deixam digitais em São Paulo"; "Polêmica em festival de hip-hop brasileiro"; "Camelôs têm a proteção de policiais"; "Novo Estatuto do Idoso faz sua $1^{\text {a }}$. prisão"; "Campanha condenará xixi nas ruas". 2) Março: "Traficante usava fuzil da polícia"; "Polícia retoma operação em 64 favelas"; "Afastado chefe de segurança de Bangu I"; "Iraque: xiitas recuam e assinam a constituição"; "Onze milhões contra o terror". 3) Maio: "Rio terá 4 novas Rocinhas até 2010"; "Cidades fluminenses em que há emprego"; "Ladrões mantêm 20 reféns em prédio do Alto Leblon"; "IBGE: 85\% das famílias no vermelho"; "Retratos da barbárie". 4) Julho: "EUA tiveram dez chances de evitar o 11/9"; "PMs acusados de seqüestrar e matar"; "PMs sob investigação este ano já são 10 mil"; "Ministério tira da escravidão mais 2.300 trabalhadores"; "Crimes de PMs começam a derrubar comandantes"; "Ausência de cor põe cadastro de pobres em xeque"; "PMs acusados agora de matar 3 jovens". 5) Setembro: "Terror mata em Israel e na Rússia" "Assaltantes tinham mapa de trilhas"; "Brasil enfrenta rebeldes em cidade do Haiti"; "Barbárie - Confronto entre tropas russas e terroristas em escola deixa mais de 200 mortos e 700 feridos, a maioria crianças"; "Tráfico prepara guerra por morros da Zona Sul"; "Mortos em seqüestro em escola russa podem passar de 400"; "Debate sobre aborto deixa Supremo sob forte pressão"; "Iraque decreta lei marcial por 60 dias". 6) Novembro: "Polícia Rodoviária protegia a Máfia da Gasolina no Rio"; "Mortes causadas por homicídios dobram"; "Rio tem queda em mortes por arma"; "Morte de Arafat mergulha o Oriente Médio na incerteza"; "Governo quer criar espaços para dependentes de drogas". 
Notamos em $O$ Globo um número maior de notícias locais (referentes ao Rio de Janeiro) e um número menor de matérias relacionadas aos estigmas sociais de modo geral, pois a primeira página deste jornal, além de trazer menos assuntos em destaque, muitas vezes assemelha-se a uma capa de revista semanal ou de variedades. Apesar disso, notamos um número maior de matérias a respeito de tráfico de drogas ou conflitos envolvendo policiais, sobretudo as que implicam em quebra da lei ou do que é esperado em relação a suas ações (recentemente, desde 2012, as ações das unidades pacificadoras em comunidades do Rio de Janeiro têm sido largamente noticiadas). Em alguns casos, há temas mais locais tratados apenas nesse jornal, como questões relativas à conservação e melhorias na cidade, referências a grupos sociais específicos, como idosos ou negros, e também matérias relativas à cultura, como as que tratam do movimento hip-hop. Apesar de aparentemente representarem um menor número, devido ao fato de termos menos chamadas de capa em $O$ Globo, os temas abordados mostramse variados e relacionados aos estigmas sociais, ainda que não de forma direta. Talvez isso ocorra justamente por tratarem questões normalmente consideradas periféricas ao jornalismo tradicional, no caso, mais populares e próximas do cidadão comum - o que torna as manchetes, de certa forma, originais, dificultando a seleção das mais relevantes justamente por apresentá-las de modo não hierarquizado.

Finalmente, o Jornal do Brasil (que em 2011 passou a ter apenas versão online) destacou nas manchetes as seguintes notícias: 1) Janeiro: "Brasilianista defende cotas em universidade"; "Americanos são fichados ao chegar a SP"; "Jovens do Rio bebem cada vez mais"; "Arrastão de inocentes"; "Jovens apedrejam idoso até a morte"; "Britânicos matam prisioneiro a pontapés"; "Zona Sul voltará a sediar bailes funk". 2) Março: "Ataque de Israel mata 14 e fere 93 em Gaza"; "Preso grupo de favelados por saque a ônibus"; "Mulheres atraem empresas de seguro"; "Médicos são ameaçados para atender traficantes"; “Avião de mercenários é detido no Zimbábue”; “Agente de Bangu 4 desaparecido há 37 dias"; "Cresce número de mortos em confrontos com a polícia"; "Terror golpeia Madri - 192 mortos e mais de 1.400 feridos"; "Espanhóis desafiam o terror" ; "Luta pelo poder no tráfico esfacela facções". 3) Maio: "Jornalista se retrata e Lula cancela ato de expulsão"; "Atuação do Exército no Rio não sai do papel"; "Sucessão em Cuba expõe cisão no clã dos Castro"; "Papa santifica mulher casada"; "Atentado mata o presidente do conselho de governo"; "Bando age no Leblon e índice de assalto a residências não cai"; "Impunidade marca exploração infantil". 4) Julho: "Polícia apura distribuição de vale-transporte pelo tráfico"; "EUA tiveram dez chances 
de evitar os atentados"; "PMs suspeitos de seqüestro e assassinato"; "Protesto de vans pára o Centro da cidade"; "Assassinato de jovem especialista comove internautas". 5) Setembro: "ONGs se distanciam do governo Lula"; "Procurado na Itália, mafioso agia no Rio"; "Presidente agora perdoa dívida de Moçambique"; "Tráfico volta a agir em favela de Laranjeiras"; "Delegação brasileira bate recorde na paraolimpíada"; "Facção assume o tráfico no Vidigal"; "Estados falham no teste auditivo de bebês"; "Evangélicos movimentam mercado milionário"; "Briga de traficantes aterroriza zona sul"; "Facção criminosa impõe regras a políticos"; "Favela, vetada na campanha que só fala aos pobres"; "Atletas paraolímpicos visitam o Planalto". 6) Novembro: "Mãe do jogador Robinho é sequestrada"; "Cariocas são vitimas fáceis de extorsão pelo telefone"; "Batalha em Faluja define os rumos do Iraque"; "Palestinos vetados no adeus a Arafat"; "Cresce índice de assaltos em ônibus e a pedestres".

No Jornal do Brasil, as notícias locais (relacionadas ao Rio de Janeiro) convivem lado a lado com as notícias internacionais, como no caso dos atentados terroristas em Madri e das ações do tráfico na capital fluminense. Notamos o grande número de chamadas de capa relacionadas aos estigmas e sua variedade, cobrindo temas de caráter mais abrangente (como na editoria Internacional), e outros mais localizados na cidade do Rio de Janeiro (como aqueles relativos ao tráfico e à ação da polícia). Diferentemente de outros jornais, o Jornal do Brasil traz algumas matérias de caráter positivado em torno dos estigmas sociais, como as paraolimpíadas e as descobertas médico-científicas sobre doenças (notemos o número de destaques em setembro).

O mês de setembro pode ser considerado singular não apenas em relação ao Jornal do Brasil (mês em que este apresentou o maior número de manchetes sobre estigmas em um único dia), pois a semana selecionada para análise inclui um importante feriado nacional: o dia da independência do Brasil, o que nos levou a supor que haveria certa homogeneidade nas notícias encontradas (ao menos nas manchetes principais). Ainda assim, fomos surpreendidos por um evento de caráter global que ocupou as manchetes dos grandes jornais: um atentado ocorrido em uma escola russa.

A pequena discrepância entre nossa aposta e o que encontramos nas primeiras páginas, entretanto, atesta uma vez mais a estrutura narrativa das notícias: uma narrativa - heroica e humana - com características nitidamente definidas (composição de heróis; atuação de seus aliados e oponentes; estabelecimento de conflitos; aparecimento de um dano; busca pela restauração do equilíbrio, por ruptura ou conciliações; reconhecimento 
final positivo ou negativo), por sua pregnância, foi sobreposta a uma narrativa fundadora (unificação em torno da "pátria").

Em relação a setembro, é interessante notar as especificidades de cada um dos jornais: enquanto a Folha de S. Paulo concentrou-se nos atentados na Rússia (quatro notícias) e em questões nacionais (três notícias), o jornal O Estado de S. Paulo trouxe cinco notícias sobre temas nacionais (salários, fraudes, produtividade) a apenas duas notícias sobre os atentados. O jornal $O$ Globo apresentou sete chamadas de capa sobre os atentados na Rússia, três matérias sobre problemas políticos e econômicos brasileiros e duas chamadas sobre questões relacionadas à cidade do Rio de Janeiro. O Jornal do Brasil, por sua vez, trouxe apenas uma manchete sobre os atentados na Rússia; as outras seis notícias versavam sobre temas nacionais, com uma curiosidade: quatro delas estavam relacionadas ao consumo de bens.

Outros temas recorrentes em setembro foram notícias sobre o jogo de futebol da seleção brasileira, o noivado do jogador Ronaldo com a modelo Daniela Cicarelli, as eleições presidenciais nos Estados Unidos, as eleições municipais no Brasil, o final das Olimpíadas. Notemos que, de modo geral, todas as capas estudadas trouxeram fotoslegendas como recurso para destacar ou os atentados na Rússia, ou questões macronacionais quando estes não foram enfocados nas manchetes principais do jornal.

Em relação aos dois jornais que destacamos na pesquisa, O Estado de S. Paulo e O Globo (e ao fazê-lo, não estamos de forma alguma desconsiderando a importância dos outros diários, mas optamos por estabelecer contrastes entre jornais de características mais regionais), o que mais nos chamou a atenção foi o fato de $O$ Estado tratar, predominantemente, assuntos de política e economia nacionais, reservando aos estigmas sociais um espaço mais relacionado a questões internacionais.

Nesse jornal, portanto, os estigmas aparecem de maneira mais indireta - quase invisíveis, imperceptíveis - como se os conflitos sociais pudessem ser aplacados pela aparente sobriedade do jornal. Se, por um lado, $O$ Estado valoriza a cobertura internacional, por outro trata o país com um certo distanciamento, como se nossos problemas se restringissem à esfera pública e político-econômica. Um fato diferenciado é a ausência de hierarquia - ao menos de forma muita marcada - entre as matérias de capa: ao contrário do outro jornal paulista constante dessa amostragem (Folha de $S$. Paulo), que estabelece distinções formais e visuais quanto à importância das matérias, há em $O$ Estado um grande número de chamadas de igual tamanho e com destaque semelhante, características que se mantêm até o momento. 
O diário carioca $O$ Globo, por sua vez, apresenta um traço incomum: suas primeiras páginas exibem um grande número de fotos, ilustrações e charges políticas. De modo geral, as capas de $O$ Globo são menos fechadas, mais arejadas devido ao menor volume de elementos textuais. Além disso, há também uma menor quantidade de assuntos destacados nas primeiras páginas, com temas mais restritos e ocupando maior espaço na capa do jornal. Notamos ainda um número maior de fotos, além das ilustrações (desenhos, infográficos etc.), dotando as capas de um aspecto mais leve, leveza que se exprime não apenas em termos visuais, mas também expressivos. Os conteúdos das chamadas de capa são, também eles, mais arejados do que nos outros jornais. Isso não quer dizer - como notamos ao destacar as manchetes relacionadas aos estigmas - que os problemas nacionais e internacionais não estejam ali presentes.

Ainda que compareçam nas capas, por estarem recobertos de elementos visuais e, além disso, colocarem-se ao lado de temas mais prosaicos, traduzem aspectos muitas vezes não contemplados nos jornais. Frequentemente temos em destaque, na parte nobre da primeira página (dobra superior, título em seis colunas), manchetes sobre esportes mescladas com um pouco de política e economia, e um grande número de notícias locais tratadas de modo coloquial (como se referir à "zona sul" na capa sem escrever que se trata da zona sul da cidade do Rio de Janeiro). Há ainda a presença marcante de mais humor (como nas charges) e mais celebridades nas primeiras páginas de $O$ Globo (a exemplo de sua presença na cidade), construindo uma narrativa muitas vezes pautada por aquilo que, em jornalismo, pode ser chamado, a partir de Barthes, de faits divers (variedades, fatos incomuns) $^{8}$. O Globo se difere dos demais, ainda, por trazer nas capas mais chamadas para textos de articulistas e uma proposta editorial próxima àquela das revistas de variedades. Geralmente há um grande espaço dedicado à chamada principal (acompanhada de box, texto, imagem), o que torna simples identificá-la.

É importante ressaltar que, nos jornais, os temas tratados foram recobertos por elementos narrativos, caracterizando os discursos neles engendrados: por meio das manchetes, acompanhamos histórias de dramas humanos (de perto e de longe), o desempenho de personagens específicos (anônimos ou famosos), a superação ou o surgimento de problemas nacionais (especialmente ligados ao governo federal), as

\footnotetext{
${ }^{8}$ Em Barthes, temos a seguinte definição para o fait divers (ou notícia geral): "É uma informação total, ou mais exatamente, imanente; ele contém em si todo seu saber: não é preciso conhecer nada do mundo para consumir um fait divers; ele não remete formalmente a nada além dele próprio; evidentemente, seu conteúdo não é estranho ao mundo" (Barthes, 1988: 59). Desse modo, teria como função "preservar no seio da sociedade contemporânea a ambiguidade do racional e do irracional, do inteligível e do insondável" (Barthes, 1988: 67).
} 
variedades de cada região (praia, bienal, futebol, entre outros). Cada uma dessas notícias realiza, nos seus relatos, processos de construção e demarcação de temáticas comuns a todos nós, leitores, que acompanhamos dia-a-dia seus episódios e desdobramentos. De modo geral, observamos que as narrativas se constroem em torno de alguns elementos recorrentes: violência urbana (máfia, tráfico, moradores de rua, favelas, assassinato); terrorismo (atentados, Israel, Iraque, Rússia, árabes); questões sociais (vagas noturnas em escolas, alfabetização, ongs); pobreza (favelas, países africanos, distribuição de renda); doença/saúde (aids, audição, fumo, obesidade); religião (evangélicos, papa).

No jornal Folha de S. Paulo, em termos numéricos assinalamos 22 matérias em janeiro; 18 em março; 15 em maio; 15 em julho; 14 em setembro; e 21 em novembro, totalizando 105 chamadas sobre estigmas sociais. Em O Estado de S. Paulo, temos 20 matérias em janeiro; 15 em março; 20 em maio; 6 em julho; 14 em setembro; e 21 em novembro, totalizando 96 chamadas de capa. Em $O$ Globo, temos 16 matérias em janeiro; 10 em março; 22 em maio; 17 em julho; 12 em setembro; e 20 em novembro, totalizando 97 chamadas. No Jornal do Brasil, temos 21 matérias em janeiro; 15 em março; 21 em maio; 14 em julho; 23 em setembro; e 10 em novembro, totalizando 104 chamadas de capa. Tal distribuição quantitativa é mostrada abaixo:

\begin{tabular}{|l|c|c|c|c|}
\hline \multicolumn{5}{|c|}{ TABELA IX- ESTIGMAS SOCIAIS } \\
\hline Jornal/Mês & Folha de S. Paulo & Estado de S. Paulo & O Globo & Jornal do Brasil \\
\hline Janeiro & 22 & 20 & 16 & 21 \\
\hline Março & 18 & 15 & 10 & 15 \\
\hline Maio & 15 & 20 & 22 & 21 \\
\hline Julho & 15 & 6 & 17 & 14 \\
\hline Setembro & 14 & 14 & 12 & 23 \\
\hline Novembro & 21 & 21 & 20 & 10 \\
\hline TOTAL & $\mathbf{1 0 5}$ & $\mathbf{9 6}$ & $\mathbf{9 7}$ & $\mathbf{1 0 4}$ \\
\hline
\end{tabular}

A maior concentração de notícias no Jornal do Brasil em um dia isolado (num total de 23 , no mês de setembro) será retomada a seguir, ao tratarmos de algumas das características de cada jornal, destacando este caso específico de setembro por conter a maior ocorrência em um mesmo dia da amostragem. Para além de recorrências, a cada dia pequenas variações são notadas nas capas do Jornal do Brasil - reforçando o caráter narrativo das notícias e recortando, entre os estigmas sociais, aqueles sobre os quais devemos focar nossa atenção como leitores-cidadãos. Um caso marcante é o dia $1^{\mathrm{o}}$. de setembro, em que o Jornal do Brasil não trouxe nenhuma chamada (tampouco a manchete principal) sobre os atentados na Rússia ou o terrorismo islâmico, temas exaustivamente narrados nos outros dois jornais. 
Nesse sentido, vale notar que o jornal carioca tem como sua grande narrativa em torno dos estigmas um diferencial em relação aos jornais paulistanos e a seu congênere carioca: de forma bastante explícita, são os estigmas da violência, da pobreza, do tráfico e das favelas, entrelaçados nas notícias, que se repetem com clareza, o que poderia explicar o maior número de notícias selecionadas neste jornal. O Jornal do Brasil foi o único que tratou com algum destaque a cobertura das paraolimpíadas (como vimos anteriormente), tema paradigmático se tomarmos a questão dos estigmas em seus aspectos favoráveis de inclusão e negação de preconceitos e estereótipos.

Em O Estado de S. Paulo, nesta primeira semana de setembro predominam as notícias sobre os atentados e o terrorismo internacional, além de temas de interesse nacional; na Folha de S. Paulo não há um tema predominante, ainda que os atentados na Rússia e o terrorismo representem quase a metade das chamadas selecionadas. Curiosamente, a Folha é o único jornal que possui, entre as notícias selecionadas, duas chamadas sobre um tema supostamente mais leve, ainda que com conotação pejorativa em relação às mulheres (daí sua caracterização como estigma). Trata-se do assunto casamento - em um dia, a capa anuncia reportagem com mulheres que têm tudo organizado para casar, menos o noivo; e no dia seguinte, a notícia é que Daniela Cicarelli, noiva do jogador Ronaldo, foi quem comprou as alianças do casal. Chama a atenção, no Jornal do Brasil, uma chamada sobre o mesmo assunto: em uma matéria sobre a seleção brasileira de futebol, Ronaldo é chamado de "noivo da vez".

As notícias destacadas tematizam os estigmas e nos revelam narrativas que apontam para os campos de interdição/normatização social. Ainda que com diferentes recobrimentos, notamos o caráter interacional dos estigmas, ressaltando nos sujeitos as marcas (desejáveis ou indesejáveis) que carregam, incluindo/excluindo não apenas "nós" e "eles", mas também unindo-nos e separando-nos dentro de um mesmo grupo e estabelecendo consensos e dissensos entre os diversos grupos sociais. Observamos nas manchetes dos jornais um diagnóstico da sociedade e, mais do que isso, um retrato do fazer jornalístico em suas funções: crítica, vigilância, denúncia, educação, reforço, manutenção, transformação, entre outras. O material excede os limites das análises, pois se mostrou amplo não apenas em termos quantitativos - já que selecionamos seis semanas de cada jornal, totalizando 24 semanas no ano - mas também qualitativos pois não imaginávamos que um tema considerado periférico (os estigmas sociais) pudesse trazer tantas ocorrências, além de grande diversidade em sua abordagem. 


\subsubsection{Revistas semanais}

Para as revistas semanais, selecionamos suas capas durante o ano de 2004. A exemplo das primeiras páginas dos jornais diários, tomamos como pressuposto o fato de as matérias principais, trazidas em destaque nas capas das revistas, apontarem para aspectos de sua articulação discursiva.

A amostragem inclui as matérias de capa de quatro revistas (notadamente as de maior circulação e de caráter nacional no momento da coleta), a saber: Veja, IstoÉ, Época e Carta Capital. Notemos que esses periódicos possuem caráter informacional associado à abordagem de varias editorias - política, economia, cultura, artes, entretenimento, comportamento -, possibilitando que, em suas matérias de capa, seja preservado ao mesmo tempo seu caráter jornalístico e sua variedade temática, sinalizando uma abordagem generalizante em termos de assuntos e reportagens. Ainda hoje, com o declínio do jornalismo impresso, fechamento de diversas revistas, demissões de profissionais e, em certos casos, descrédito em relação à isenção e ao valor informacional da cobertura, as revistas ainda se constituem como importantes fontes de notícias para os leitores.

Foram selecionadas aleatoriamente quatro semanas por ano para cada revista, incidindo nos meses de janeiro, abril, julho e outubro, totalizando 16 edições do ano de 2004. Note-se que para cada mês/semana selecionados na amostragem foram coletadas as capas das revistas, produzindo um material homogêneo do ponto de vista cronológico a fim de possibilitar possíveis confluências e divergências entre eles. Como o material se mostrou mais extenso do que imaginado, apresentamos um quadro geral das matérias de capa das quatro revistas (para cada semana selecionada) para, num segundo momento, focalizar aspectos encontrados em matérias escolhidas por sua especificidade temática em torno dos estigmas sociais em Veja e Carta Capital.

Uma vez mais, se observarmos as chamadas veremos que conceitos definidores dos estigmas podem ser identificados. Além disso, é importante ressaltar que em relação às revistas semanais, algumas dessas matérias não pressupõem uma aproximação negativa aos temas abordados, mas há de maneira clara um caráter performativo em seus textos, aproximando o jornalismo de aspectos determinadores do comportamento social, de normas de conduta, e modos de ser e viver dos sujeitos. Apresentamos as tabelas da amostragem, transcrevendo as chamadas de capa das revistas. 


\begin{tabular}{|c|c|c|c|}
\hline \multicolumn{4}{|c|}{ TABELA X - REVISTA VEJA (2004) } \\
\hline Data/Edição & Capa & Chamada & Descrição \\
\hline $\begin{array}{l}\text { 07/01/2004 } \\
\text { Edição } 1835\end{array}$ & Beleza para todos & $\begin{array}{l}\text { O antes e depois de } \\
\text { Bárbara Reiter, } 36 \text { anos, } \\
\text { gaúcha, que é um } \\
\text { exemplo da nova ordem } \\
\text { estética: silicone, lipo e } \\
\text { Botox em doze } \\
\text { prestações }\end{array}$ & $\begin{array}{l}\text { Capa em fundo azul (tom mais forte no } \\
\text { alto, em degradê),com letras em } \\
\text { branco. A figura de uma moça jovem e } \\
\text { bonita, em plano médio, ocupa o lado } \\
\text { direito da página. A moça sorri } \\
\text { serenamente e segura uma foto dela } \\
\text { própria, na altura do queixo, em que } \\
\text { aparece apenas seu rosto antes das } \\
\text { cirurgias plásticas realizadas. O } \\
\text { contraste entre a beleza dos traços } \\
\text { atuais e a foto antiga, meio desfocada, } \\
\text { é evidente. }\end{array}$ \\
\hline $\begin{array}{l}\text { 14/04/2004 } \\
\text { Edição } 1849\end{array}$ & $\begin{array}{l}\text { Os segredos da vida } \\
\text { de Ayrton Senna }\end{array}$ & $\begin{array}{l}\text { Uma nova biografia do } \\
\text { grande herói do esporte } \\
\text { brasileiro esclarece os } \\
\text { mistérios de sua vida } \\
\text { amorosa e disseca sua } \\
\text { genialidade }\end{array}$ & $\begin{array}{l}\text { Na capa predominam tons de azul } \\
\text { escuro e marrom. O semblante tenso } \\
\text { de Ayrton Senna aparece em primeiro } \\
\text { plano. O nome da revista, em vermelho, } \\
\text { destaca-se na altura da cabeça, na aba } \\
\text { do boné usado pelo piloto. A imagem } \\
\text { de Senna ocupa o lado direito da } \\
\text { página e ele não olha para a frente, } \\
\text { mas encontra-se de lado, com o olhar } \\
\text { um pouco baixo, como se olhasse para } \\
\text { o horizonte ou buscasse alguma } \\
\text { resposta. }\end{array}$ \\
\hline $\begin{array}{l}\text { 21/07/2004 } \\
\text { Edição } 1863\end{array}$ & $\begin{array}{l}10 \text { regras básicas } \\
\text { para entender e } \\
\text { ajudar os filhos }\end{array}$ & $\begin{array}{l}\text { Uma síntese de cinco } \\
\text { décadas de estudos de } \\
\text { comportamento mostra } \\
\text { que educar com sucesso } \\
\text { é muito mais simples do } \\
\text { que se imagina }\end{array}$ & $\begin{array}{l}\text { A capa se apresenta eufórica, como se } \\
\text { atestasse o que relata em sua } \\
\text { chamada. A figura de uma adolescente } \\
\text { mascando chiclete ocupa toda a } \\
\text { página. Em cores vibrantes (o nome da } \\
\text { revista aparece em pink e o fundo é } \\
\text { verde abacate), a menina nos olha com } \\
\text { um ar desafiador enquanto sustenta } \\
\text { uma bola de chiclete no ar; o número } \\
\text { dez aparece dentro desta bola, rosada, } \\
\text { e não é identificado à primeira vista (o } \\
\text { que não modifica o sentido da } \\
\text { chamada). A adolescente aparece em } \\
\text { close, ocupando o lado esquerdo da } \\
\text { página, com o rosto levemente } \\
\text { inclinado. }\end{array}$ \\
\hline $\begin{array}{l}\text { 27/10/2004 } \\
\text { Edição } 1877\end{array}$ & O enigma da Vinci & $\begin{array}{l}\text { Descobertas recentes } \\
\text { decifram os mistérios da } \\
\text { vida do homem mais } \\
\text { inteligente que já existiu }\end{array}$ & $\begin{array}{l}\text { Única capa que não traz nenhuma foto, } \\
\text { e sim uma reprodução do quadro da } \\
\text { Mona Lisa. O tom escuro da tela } \\
\text { contrasta com a moldura dourado da } \\
\text { página. O nome da revista aparece em } \\
\text { vinho e o nome da Vinci em amarelo, } \\
\text { destacado do restante do texto. O } \\
\text { enigma se configura na chamada: em } \\
\text { forma de quebra-cabeça, a figura da } \\
\text { Mona Lisa tem uma peça a menos - o } \\
\text { sorriso - que falta na tela e salta em } \\
\text { primeiro plano na capa, como se fosse } \\
\text { a resposta para os mistérios da vida de } \\
\text { Leonardo da Vinci. }\end{array}$ \\
\hline
\end{tabular}




\begin{tabular}{|c|c|c|c|}
\hline \multicolumn{4}{|c|}{ TABELA XI - REVISTA ISTOÉ (2004) } \\
\hline Data/Edição & Capa & Chamada & Descrição \\
\hline $\begin{array}{l}\text { 07/01/2004 } \\
\text { Edição } 1787\end{array}$ & $\begin{array}{l}\text { O ano da torcida (de } \\
\text { novo!!!) }\end{array}$ & $\begin{array}{l}\text { Depois do aperto para } \\
\text { arrumar a casa em } 2003 \text {, } \\
\text { Lula está confiante no } \\
\text { salto econômico e já faz } \\
\text { planos para a reforma } \\
\text { política }\end{array}$ & $\begin{array}{l}\text { Capa bastante colorida para os padrões } \\
\text { usuais em revistas, com fundo verde e } \\
\text { amarelo que evoca as cores do país e } \\
\text { combina com o tom esverdeado do } \\
\text { terno e a faixa presidencial usados por } \\
\text { Lula. Não se trata de foto, mas de um } \\
\text { desenho que reproduz a figura do } \\
\text { presidente em um estádio de futebol } \\
\text { (no canto inferior esquerdo), segurando } \\
\text { uma bola, e ladeado pela torcida que } \\
\text { ocupa as arquibancadas. Nas faixas } \\
\text { carregadas pela torcida lê "emprego", } \\
\text { "crescimento", "perspectiva 2004". O } \\
\text { texto da chamada está escrito em } \\
\text { preto, com exceção da expressão "de } \\
\text { novo", em branco, seguida de três } \\
\text { pontos de exclamação. O nome da } \\
\text { revista aparece em vermelho, e a figura } \\
\text { de um goleiro não-identificado aparece } \\
\text { em segundo plano. }\end{array}$ \\
\hline $\begin{array}{l}\text { 14/04/2004 } \\
\text { Edição } 1801\end{array}$ & Soberania ameaçada & $\begin{array}{l}\text { * Por que o governo sofre } \\
\text { pressões internacionais } \\
\text { para revelar a inovadora } \\
\text { tecnologia brasileira de } \\
\text { enriquecimento de urânio } \\
\text { *Amazônia se transforma } \\
\text { em paraíso de ONGs } \\
\text { européias e americanas } \\
\text { *A polêmica demarcação } \\
\text { da Raposa Serra do Sol, } \\
\text { reserva indígena na } \\
\text { fronteira com a Guiana e } \\
\text { a Venezuela }\end{array}$ & $\begin{array}{l}\text { Na capa predomina o tom de vermelho } \\
\text { vivo. A figura do mapa do Brasil ocupa } \\
\text { toda a capa, em amarelo, mesma cor } \\
\text { da chamada. O país é representado } \\
\text { neste desenho como um queijo } \\
\text { esburacado em que alguns ratos } \\
\text { circulam por suas cavidades. O tema é } \\
\text { atemporal e a capa traz um grande } \\
\text { número de chamadas. Chama a } \\
\text { atenção o fato do mapa do Brasil } \\
\text { recobrir o logotipo da revista, na cor } \\
\text { branca. }\end{array}$ \\
\hline $\begin{array}{l}\text { 21/07/2004 } \\
\text { Edição } 1815\end{array}$ & $\begin{array}{l}\text { Dieta para manter a } \\
\text { linha no inverno }\end{array}$ & $\begin{array}{l}{ }^{*} \text { Como evitar as } \\
\text { armadilhas dessa época } \\
\text { do ano } \\
{ }^{*} \text { Os truques para cortar } \\
\text { calorias sem comprometer } \\
\text { os prazeres da mesa } \\
{ }^{*} \text { Estratégias para não } \\
\text { abandonar os exercícios }\end{array}$ & $\begin{array}{l}\text { A capa apresenta fundo branco, com } \\
\text { pequenos pontos cor da pele em sua } \\
\text { superfície. O que vemos em primeiro } \\
\text { plano, ocupando o lado direito da } \\
\text { página, é a figura de um corpo humano, } \\
\text { sem cabeça e sem braços, pendurado } \\
\text { em um cabide de roupas. O cabide de } \\
\text { madeira está pendurado em um ferro } \\
\text { preso ao logotipo da revista, também } \\
\text { em branco e apenas com contorno } \\
\text { preto. O corpo no cabide representa um } \\
\text { pele que pode ser vestida - tem fundo } \\
\text { preto, etiqueta na parte interna e um } \\
\text { zíper que começa na altura do pescoço. } \\
\text { O corpo está de biquíni preto, sendo } \\
\text { magro, bem modelado, bronzeado. }\end{array}$ \\
\hline $\begin{array}{l}\text { 27/10/2004 } \\
\text { Edição } 1829\end{array}$ & Pedofilia & $\begin{array}{l}\text { * O Brasil ocupa um } \\
\text { vergonhoso quarto lugar } \\
\text { no ranking mundial da } \\
\text { pornografia infantil } \\
{ }^{\star} \text { Como evitar que seu } \\
\text { filho seja assediado na } \\
\text { internet }\end{array}$ & $\begin{array}{l}\text { Capa desenhada em fundo branco, } \\
\text { com o logotipo da revista em preto e a } \\
\text { palavra "pedofilia" em vermelho. A } \\
\text { figura de uma boneca de pano, sem } \\
\text { rosto, jaz na capa, como se tivesse sido } \\
\text { displicentemente atirada. Não há } \\
\text { identificação direta do sexo da criança } \\
\text { representada, mas pelo cabelo em lã } \\
\text { marrom e laços azuis parece ser de } \\
\text { uma menina. A não ser pelo uso de } \\
\text { uma calcinha, a boneca está nua, mas } \\
\text { não traz nenhum outro traço físico. }\end{array}$ \\
\hline
\end{tabular}




\begin{tabular}{|c|c|c|c|}
\hline \multicolumn{4}{|c|}{ TABELA XII - REVISTA ÉPOCA (2004) } \\
\hline Data/Edição & Capa & Chamada & Descrição \\
\hline $\begin{array}{l}\text { 05/01/2004 } \\
\text { Edição } 294\end{array}$ & $\begin{array}{l}\text { O que pode melhorar } \\
\text { em } 2004\end{array}$ & $\begin{array}{l}\text { * O que será notícia em } \\
2004 \text { e quais são as } \\
\text { perspectivas para a } \\
\text { política, a economia, a } \\
\text { ciência, a cultura, os } \\
\text { esportes e muito mais } \\
\text { * No governo, o desafio } \\
\text { de Lula será manter a } \\
\text { popularidade em alta }\end{array}$ & $\begin{array}{l}\text { Capa em fundo branco com diversas } \\
\text { fotos em tamanho pequeno, } \\
\text { reproduzidas numa tira de filme. } \\
\text { Algumas delas vazam dos limites dos } \\
\text { quadros: Lula, sorridente, com o rosto } \\
\text { quase em close; a ginasta Dayanne dos } \\
\text { Santos, saltando; e a modelo Gisele } \\
\text { Bündchen, de costas como rosto virado } \\
\text { para frente. A tira é dupla e faz uma } \\
\text { volta na capa da revista, sinalizando ao } \\
\text { mesmo tempo a retrospectiva do ano } \\
\text { terminado e o início de um novo ano. o } \\
\text { logotipo com o nome da revista é } \\
\text { invariante no caso da Época, escrito em } \\
\text { preto sobre fundo vermelho, e com o } \\
\text { globo que o caracteriza. }\end{array}$ \\
\hline $\begin{array}{l}\text { 12/04/2004 } \\
\text { Edição } 308\end{array}$ & $\begin{array}{l}\text { Segunda } \\
\text { adolescência }\end{array}$ & $\begin{array}{l}\text { * Criados os filhos, } \\
\text { homens e mulheres cada } \\
\text { vez mais partem para } \\
\text { uma nova fase - a busca } \\
\text { da qualidade de vida } \\
{ }^{*} \text { Cumpridos os } \\
\text { compromissos da fase } \\
\text { adulta, homens e } \\
\text { mulheres partem para } \\
\text { uma nova etapa - com } \\
\text { dinheiro, tempo e } \\
\text { disposição, querem curtir } \\
\text { a vida }\end{array}$ & $\begin{array}{l}\text { O fundo da capa é azul claro e a } \\
\text { chamada está em vermelho. A foto de } \\
\text { um casal de meia idade, sorridente e } \\
\text { sentado em cima das malas, ocupa } \\
\text { toda a capa, confundindo-se com as } \\
\text { chamadas. A mulher está sentada no } \\
\text { colo do homem, supostamente seu } \\
\text { marido, e a alegria estampada em seus } \\
\text { rostos representa a liberdade por não } \\
\text { ter mais preocupações com os filhos e } \\
\text { a possibilidade de aproveitar } \\
\text { novamente a vida. }\end{array}$ \\
\hline $\begin{array}{l}\text { 19/07/2004 } \\
\text { Edição } 322\end{array}$ & Síndrome da barriga & $\begin{array}{l}\text { *Não apenas os obesos } \\
\text { devem se preocupar com } \\
\text { a saúde. Magros com } \\
\text { "barriga de cerveja" } \\
\text { também correm riscos. Há } \\
\text { diferentes tipos de } \\
\text { gordura, e alguns são } \\
\text { mais perigosos que outros } \\
\text { *Excesso de gordura na } \\
\text { cintura desequilibra o } \\
\text { metabolismo e pode } \\
\text { desencadear graves } \\
\text { problemas de saúde, } \\
\text { como diabetes, } \\
\text { hipertensão e câncer }\end{array}$ & $\begin{array}{l}\text { A capa tem como fundo a foto do tronco } \\
\text { de um corpo feminino, de maiô, com a } \\
\text { barriga à mostra. O corpo é magro e } \\
\text { sem barriga, emoldurado em tom azul } \\
\text { claro e servindo de fundo para os textos } \\
\text { das chamadas. Em tons claros e não } \\
\text { contrastantes com a cor da pele da } \\
\text { modelo, a foto evoca o culto ao corpo } \\
\text { mas também ao bem estar, pois suas } \\
\text { chamadas referem-se não apenas à } \\
\text { estética, mas sobretudo a problemas de } \\
\text { obesidade. }\end{array}$ \\
\hline $\begin{array}{l}\text { 25/10/2004 } \\
\text { Edição } 336\end{array}$ & Limites da vaidade & $\begin{array}{l}{ }^{*} \text { Homens e mulheres } \\
\text { estão dispostos a ir cada } \\
\text { vez mais longe na busca } \\
\text { do corpo escultural e do } \\
\text { rosto perfeito. Como fugir } \\
\text { dessa armadilha e } \\
\text { preservar a saúde } \\
{ }^{*} \text { Embalados pela } \\
\text { indústria da beleza, } \\
\text { homens e mulheres fazem } \\
\text { de tudo em nome da } \\
\text { vaidade - e acabam } \\
\text { pagando um preço alto } \\
\text { por isso }\end{array}$ & $\begin{array}{l}\text { Uma vez mais, a saúde é } \\
\text { aparentemente destacada em capa que } \\
\text { trata de questões estéticas e corporais. } \\
\text { Sobre fundo branco e deitada em um } \\
\text { espelho, vemos em destaque o rosto de } \\
\text { uma modelo. A foto apresenta a mulher } \\
\text { até a altura dos ombros, descobertos, e } \\
\text { evoca a imagem de Narciso } \\
\text { contemplando sua própria beleza. A } \\
\text { modelo, maquiada e com cabelo } \\
\text { impecável, ocupa principalmente o lado } \\
\text { direito da capa e nos olha fixamente, de } \\
\text { frente, e de maneira dupla - pois sua } \\
\text { imagem especular também nos fita ao } \\
\text { contrário. }\end{array}$ \\
\hline
\end{tabular}




\begin{tabular}{|c|c|c|c|}
\hline \multicolumn{4}{|c|}{ TABELA XIII - REVISTA CARTA CAPITAL (2004) } \\
\hline Data/Edição & Capa & Chamada & Descrição \\
\hline $\begin{array}{l}\text { 14/01/2004 } \\
\text { Edição } 273\end{array}$ & $\begin{array}{l}\text { Em busca do Brazil } \\
\text { ideal }\end{array}$ & $\begin{array}{l}\text { Mirem-se no Velho } \\
\text { Mundo }\end{array}$ & $\begin{array}{l}\text { O logotipo da revista aparece } \\
\text { sempre em branco sobre fundo } \\
\text { vermelho, na parte superior da } \\
\text { capa, ocupando toda sua largura. A } \\
\text { edição traz uma capa com fundo } \\
\text { branco-acinzentado, em degradê } \\
\text { até chegar ao preto, na qual se } \\
\text { destaca a letra "z", em cinza } \\
\text { escuro, na palavra "Brazil", escrita } \\
\text { em amarelo. É uma capa sem } \\
\text { fotos, de padrão mais gráfico do } \\
\text { que utilizando figuras. O desenho } \\
\text { apresentado assemelha-se a um } \\
\text { telescópio que observa o globo } \\
\text { terrestre; em sua lente podemos } \\
\text { ver, em amarelo, o mapa do Brasil. }\end{array}$ \\
\hline $\begin{array}{l}\text { 14/04/2004 } \\
\text { Edição } 286\end{array}$ & $\begin{array}{l}\text { A mídia passa o } \\
\text { chapéu }\end{array}$ & $\begin{array}{l}\text { A discussão sobre o } \\
\text { marco regulatório para } \\
\text { a mídia é empurrada } \\
\text { com a barriga desde } \\
1997\end{array}$ & $\begin{array}{l}\text { O fundo da capa é preto e a } \\
\text { chamada vem em vermelho. Em } \\
\text { primeiro plano, no centro da capa, } \\
\text { vemos a imagem de um cartão } \\
\text { magnético, de fundo azul, em que } \\
\text { se lêem em destaque as palavras } \\
\text { "BNDES" e "Mídia brasileira". Uma } \\
\text { mão não identificada segura o } \\
\text { cartão, e o fundo abaixo dele tem } \\
\text { uma coloração amarelada, como se } \\
\text { estivesse iluminado. A imagem é } \\
\text { opaca e tem características de } \\
\text { ilustração, e não de fotografia. }\end{array}$ \\
\hline $\begin{array}{l}\text { 21/07/2004 } \\
\text { Edição } 300\end{array}$ & Meio século de rock & $\begin{array}{l}\text { Dos irmãos Campello } \\
\text { aos Raimundos, } \\
\text { passando por Rita Lee } \\
\text { e o alucinógeno enterro } \\
\text { de Raulzito }\end{array}$ & $\begin{array}{l}\text { A capa tem fundo amarelo vibrante, } \\
\text { em três tons, e chamada em letras } \\
\text { pretas estilizadas. Ao centro vemos } \\
\text { a figura de um roqueiro, olhando } \\
\text { para baixo, segurando sua guitarra. } \\
\text { O músico veste roupas de couro } \\
\text { preto, tem cabelo espetado um } \\
\text { pouco grisalho e simula um acorde, } \\
\text { dobrando os joelhos com pés no ar. }\end{array}$ \\
\hline $\begin{array}{l}\text { 27/10/2004 } \\
\text { Edição } 314\end{array}$ & Eleições & $\begin{array}{l}\text { A aposta em Lula } \\
\text { continua }\end{array}$ & $\begin{array}{l}\text { A capa tem tons azulados (do mais } \\
\text { escuro ao mais claro) e aspecto } \\
\text { positivado, otimista. A foto de Lula } \\
\text { aparece cercada por um tom } \\
\text { esbranquiçado, como se fosse uma } \\
\text { luz ao seu redor. O presidente olha } \\
\text { para o alto, com olhos abertos, e } \\
\text { sorri. Veste terno e camisa sem } \\
\text { gravata, em postura informal, } \\
\text { ocupando toda a capa. Seu rosto } \\
\text { pende para a esquerda e a imagem } \\
\text { serve de fundo para a chamada das } \\
\text { eleições. Com aspecto confiante, a } \\
\text { imagem parece construir um } \\
\text { quadro favorável a Lula. }\end{array}$ \\
\hline
\end{tabular}

* Por problemas técnicos, a versão eletrônica a que tivemos acesso não permitiu que pudéssemos ler as frases associadas às chamadas de capa. Limitamo-nos, na pesquisa, às próprias chamadas e à versão digital das capas. 
Observando as tabelas, notamos que nem todas as matérias de capa referem-se ao tema dos estigmas sociais. As que apresentam tal relação o fazem de maneira mais ou menos direta e predominantemente positivada. Essa característica distingue as revistas semanais dos outros formatos jornalísticos apresentados (jornais diários e telejornais), nos quais os estigmas aparecem quase sempre de maneira negativa e carregados de valores morais, muitas vezes preconceituosos e estereotipados de maneira unívoca. Pela combinação de diversos elementos visuais, cores, tipologia variada, figuras (desenhos, ilustrações, fotos), as capas de revistas aparentam maior mobilidade discursiva e multiplicidade de sentidos, compondo narrativas mais polifônicas e abertas.

Excluindo as capas diretamente voltadas à política e à economia - ainda que, em alguns casos, elas pudessem estar relacionadas aos estigmas, como vimos em outros momentos - limitamo-nos a destacar, entre as 16 capas acima descritas, aquelas que se referem explicitamente ao que estamos definindo, no trabalho, como estigmas sociais.

$\mathrm{Na}$ revista Veja, as matérias de capa parecem estar todas articuladas, de alguma forma, aos estigmas, fato que marca um aspecto dessa publicação. Ainda assim, uma delas faz referência mais direta ao tema: a edição 1849, "Beleza para todos", não apenas reforça estereótipos do padrão estético vigente, mas apela a outro estigma - aquele que atesta que cirurgias plásticas, cosméticos e tratamentos clínicos são acessíveis apenas às camadas mais ricas da população. Ao fazê-lo, realiza uma espécie de estigmatização inversa, pois além de impor a todos os mesmos padrões - como se só fosse possível ser aceito socialmente igualando-se aos mais abastados - sugere uma inclusão perversa que onera o orçamento dos que pagam seus tratamentos em prestações. A personagem da capa, destacada em um caso real, não apenas seguiu as regras de "silicone, lipo e botox" mas pagou “em doze prestações”. Não havia saída para os feios e pobres, diria Veja, mas agora "eles" também podem se juntar a "nós".

As outras três capas de Veja, de modo semelhante, engendram inversões e sinalizam para uma aparente transformação no tratamento de estigmas pelas mídias, mas que resulta nos mesmos efeitos: duas delas se referem ao estigma (positivo) da genialidade (Ayrton Senna e Leonardo da Vinci), em que preconceitos ou estereótipos depreciativos não se revelam. Coincidentemente, a capa sobre Senna tenta revelar seus "segredos", e a de da Vinci seus "mistérios". Na última capa, ainda que o tema não seja em si mesmo próximo à questão dos estigmas - pois trata da educação dos filhos, algo associado ao campo da informação -, a imagem da adolescente é carregada de estereótipos: o chiclete, o olhar desafiador, os piercings no nariz e na sobrancelha. 
Talvez o tabu que cerca, hoje, a educação dos filhos - tornando-a algo muito mais complexo do que era percebido pelas gerações anteriores - seja, ele próprio, um estigma. Os filhos devem ser "entendidos" e "ajudados", mesmo que representem um desafio a ser vencido. No conjunto das capas, são um assunto a ser compreendido - e aqui Veja se coloca como o lugar do saber, como o fazer jornalístico que tem algo a ensinar - do mesmo modo que as cirurgias plásticas, a vida pessoal de Ayrton Senna e a inteligência de Leonardo da Vinci.

Nas capas de IstoÉ, os temas políticos também se fazem presentes. Ao mesmo tempo em que afirma que "Lula está confiante", a revista anuncia que a soberania do país está “ameaçada". A capa sobre dietas para não engordar no inverno reproduz, como em Veja, a dominância de determinados padrões estéticos e a necessidade de se manter magro para ser socialmente aceito. A abordagem, entretanto, não estabelece - como em Veja - relações econômicas ou comportamentais de forma tão direta. A última capa de $I S t o E ́$ se destaca das outras - não apenas desta própria revista, mas do conjunto das capas selecionadas - porque trata de um assunto controverso e proibido: a pedofilia.

Com implicações legais, jurídicas, morais e éticas, a simplicidade da capa aponta para seus interditos, para um discurso que ao tratar de sexo (e muitas vezes de morte) envolvendo crianças, não pode ser de fato enunciado. É apenas de maneira implícita, sugerindo o tema e sua gravidade, que a matéria de capa se constrói. Pelo jogo de apagamentos e destaques, pelo anúncio contido e a tentativa de atenuá-lo com a referência à internet (já que, nesse caso, o assédio se torna virtual), essa matéria de capa é a que mais fortemente permeia o campo dos estigmas sociais em suas correlações mais contundentes. A aparente generalização - visual e verbal - apresentada na capa serve como compensação ao incômodo causado pelo tema.

Ao tratar das capas da revista Época, encontramos um mosaico diferenciado: com imagens mais eufóricas e em tons mais claros, há um certo otimismo e leveza percorrendo suas matérias. Em duas delas, vemos a recorrência de um dos assuntos predominantes não apenas nessa amostragem, mas nas revistas em geral: os cuidados com o corpo, a saúde, a beleza, a busca de padrões estéticos pré-determinados, o bemestar e a longevidade, temática frequente nas revistas semanais e naquelas voltadas a públicos específicos, como mulheres, adolescentes e, mais recentemente, homens.

Em Época, mais do que nas outras revistas, há uma tentativa de fazer predominar nessas duas matérias de capa questões relativas à saúde, como se a beleza se tornasse consequência da prática de exercício, alimentação saudável e hábitos de vida 
adequados. Ao mesmo tempo em que apresenta mulheres bonitas e magras, a revista nos diz que não podemos ceder a essa imposição, e que é preciso fugir das síndromes e encontrar limites para a vaidade. Da mesma forma que em Veja, uma aparente contradição se revela nesse discurso, camuflando um mercado altamente rentável e as fortes pressões da indústria de cosméticos e das clínicas de tratamentos estéticos.

A última revista, Carta Capital, é a mais recente no mercado editorial e se coloca como partidária de outro modo de fazer jornalismo, de forma mais posicionada e comprometida. Valores comuns aos veículos da grande imprensa, como neutralidade, objetividade, imparcialidade, entre outros, não fazem parte de sua linha editorial. Carta Capital foi a revista que surpreendeu os leitores, na primeira eleição de Lula, em 2002, quando publicou abertamente em seu editorial que apoiava este candidato, expondo as razões para tal posicionamento e as justificativas para praticar um jornalismo engajado.

Nas capas selecionadas, três tratam de temas políticos e econômicos, e uma apresenta um tema cultural. Diferentemente das outras revistas, não há ênfase em questões de moda, beleza, saúde e comportamento; e os temas são colocados de maneira mais equilibrada, ainda que com frases de impacto. Surpreendentemente, o tema dos estigmas não parece ocupar as matérias de capa de Carta Capital: ao contrário das outras publicações, mesmo ao tratar de temas polêmicos, essa revista não aborda diretamente de preconceitos e estereótipos, possuindo caráter mais analítico. Talvez pudéssemos pensar em estigmas políticos - ainda que não de forma negativa - quando a revista grafa Brasil com "z" (revelando também preconceitos e estereótipos na relação de país periférico com o centro dominante), ou quando supervaloriza a imagem de Lula ao tratar das eleições utilizando a palavra "aposta".

Após estabelecer essas distinções entre as revistas, destacamos nesse momento as capas de Veja e Carta Capital, por considerá-las as mais distanciadas uma da outra. Em Veja, a articulação narrativa - e, consequentemente, o discurso que aparece como predominante - aponta para uma correlação direta com os estigmas sociais. Ainda que não reproduza propriamente preconceitos e estereótipos detratores de determinados grupos sociais (o que se acentuaria cada vez mais ao longo da última década), há em Veja uma mobilização em torno de "palavras de ordem" e "dispositivos disciplinares" (como definidos em Deleuze e Foucault) ${ }^{9}$, como se pudesse de fato determinar padrões de comportamento, regras de convívio social e formas de viver em sociedade.

\footnotetext{
${ }^{9}$ Para acompanhar o estudo desse tema de maneira ampla, ver Mayra Rodrigues Gomes, Poder no jornalismo (São Paulo: Hacker/Edusp, 2003).
} 
Ao se relacionar, dessa forma, a questões envolvendo a dinâmica entre indivíduos e grupos - e, portanto, questões correlatas às formas de identificação e identidade social (Gomes, 2008) -, a revista Veja parece ser a que mais diretamente se associa à temática dos estigmas em seu sentido usual. Mesmo não sendo propriamente positivas ou negativas, suas matérias estabelecem correlações explícitas com estereótipos, preconceitos, inclusão/exclusão, hierarquização social e discriminação por meio de catalogações e classificações. Ao fazê-lo, entretanto, não parece criar espaços de passagem, mas apenas de reforço, construindo um discurso conservador que visa manter a ordem estabelecida e os padrões vigentes por meio do controle social.

Finalmente, a revista Carta Capital, selecionada na amostragem para compor o momento de aprofundamento das análises, mostrou-se bastante singular: ainda que seu logotipo siga um padrão fixo nas capas das edições estudadas, não há a manutenção de um mesmo padrão quando se trata de suas capas. Contendo mais elementos textuais do que as outras revistas estudadas, as capas de Carta Capital revezam o uso de fotografias, desenhos e ilustrações em suas chamadas. O uso de cores é mais sóbrio com predominância das cores primárias, do preto e do branco - e, embora haja uma matéria principal, outros temas dividem com ela o espaço da capa.

Das quatro capas, duas tratam de assuntos nacionais (política e economia), uma terceira trata das próprias mídias (também se referindo a temas econômicos) e apenas uma traz assunto mais diverso - a música -, inserindo-se na editoria de artes e cultura. Das capas, portanto, nenhuma traz temas propriamente relacionados aos estigmas sociais, apresentando neutralidade em sua abordagem e uma visão mais equilibrada.

Tal ausência, do mesmo modo que a presença em todas as capas de Veja, parece indicar um mesmo lugar: de modo semelhante, ainda que por caminhos inversos, as duas revistas não operam com a possibilidade de transpor os estigmas sociais predominantes, mas realizam uma manutenção desses mesmos estigmas - por excesso ou por carência - ao superdimensionar sua característica normalizante ou alocá-los apenas no polo desviante. Nas sínteses possíveis entre duas publicações aparentemente antagônicas - ao menos em seus conteúdos, mas não tanto em suas formas - vemos desdobrar-se outro aspecto cambiante dos estigmas sociais. 


\section{Estigmas em telejornais diários: primeiras chamadas}

Nas análises de telejornais, optamos por selecionar as chamadas de abertura - ou escaladas, no jargão jornalístico -, destacando as narrativas sobre estigmas sociais nelas presentes. A escolha dessas manchetes justifica-se na medida em que nelas temos um complexo processo de seleção e combinação de elementos apresentados de forma hierárquica e, portanto, apontando para o lugar de fala dos telejornais em sua tentativa de estabelecer laços sociais para além de seu aspecto referencial.

No jornalismo televisivo, as escaladas representam um momento de apresentação da edição diária, em que os repórteres e editores do jornal se posicionam de forma supostamente mais espontânea do que nos outros espaços do telejornal (geralmente transmitido ao vivo, mesmo nas cenas em que há imagens previamente filmadas). Nas escaladas, os repórteres se dirigem ao público e evidenciam o caráter de tempo real do telejornal. Além disso, as chamadas de abertura destacam o que é considerado mais relevante para o telejornal, sintetizando sua linha editorial.

\subsection{Corpus da pesquisa em mídia audiovisual (telejornais)}

A pesquisa de mídia audiovisual engloba três telejornais, escolhidos por apresentarem características peculiares: Jornal Nacional (Rede Globo de Televisão), telejornal de maior audiência do país (apresentado na época da pesquisa, e até 2012, pelo casal de jornalistas William Bonner, que é também editor do jornal, e Fátima Bernardes, antiga repórter); Jornal da Cultura (TV Cultura), único telejornal produzido por empresa não privada, de caráter público, e com variações de formato decorrentes de tal característica (espaço para comentários, aprofundamento das matérias, menor personalização dos apresentadores, entre outras); e Jornal da Record (Rede Record), telejornal baseado na figura de um âncora (na época, o jornalista Boris Casoy).

Assim como no caso de jornais e revistas, os telejornais foram selecionados, sobretudo, devido a critérios de abrangência (alcance nacional), variedade (cobertura nacional), audiência (número de espectadores) e representatividade (credibilidade e reconhecimento). Como o material totalizado é muito extenso, constituímos uma amostragem representativa do mesmo para desenvolvimento da análise. Para os telejornais foram gravadas seis semanas completas (edições diárias integrais), compondo um período de duas semanas em meses diferentes para cada um deles. 
As gravações ocorreram de forma consecutiva (não concomitante), ou seja: escolhemos um período do ano que não estivesse relacionado a um evento específico (esportivo, comemorativo ou sazonal) e utilizamos uma mesma ordem entre os telejornais, gravando em sequência três semanas de transmissões (uma semana para cada um dos jornais) e, em seguida, mais três semanas. Durante o processo de gravação, acompanhamos as edições dos telejornais, armazenando as imagens em formato digital.

Optamos por trabalhar com um número limitado de edições de telejornais devido à maior heterogeneidade de seus elementos verbais, visuais, sonoros, técnicos e estéticos, já que a televisão constitui, em si mesma, um mídia de discurso sincrético. No momento seguinte, estabelecemos uma segunda classificação entre os telejornais e elegemos, nas considerações apresentadas, tratar não apenas um ou dois telejornais (como para a mídia impressa), mas pontuar o percurso narrativo de um mesmo tema nas imagens reportadas. As tabelas referentes aos telejornais são apresentadas a seguir.

\begin{tabular}{|l|l|l|}
\hline \multicolumn{3}{|c|}{ TABELA XIV - TELEJORNAIS DIÁRIOS (2005) } \\
\hline $\begin{array}{c}\text { Jornal Nacional } \\
\text { segunda a sábado / } 20 \mathrm{~h}\end{array}$ & $\begin{array}{c}\text { Jornal da Cultura } \\
\text { segunda a sexta / 21h }\end{array}$ & $\begin{array}{c}\text { Jornal da Record } \\
\text { segunda a sábado / 20h30 }\end{array}$ \\
\hline $17 / 10 / 2005$ (segunda-feira) & $24 / 10 / 2005$ (segunda-feira) & $31 / 10 / 2005$ (segunda-feira) \\
\hline $18 / 10 / 2005$ (terça-feira) & $25 / 10 / 2005$ (terça-feira) & $01 / 11 / 2005$ (terça-feira) \\
\hline $19 / 10 / 2005$ (quarta-feira) & $26 / 10 / 2005$ (quarta-feira) * & $02 / 11 / 2005$ (quarta-feira) ${ }^{*}$ \\
\hline $20 / 10 / 2005$ (quinta-feira) * & $27 / 10 / 2005$ (quinta-feira) & $03 / 11 / 2005$ (quinta-feira) \\
\hline $21 / 10 / 2005$ (sexta-feira) & $28 / 10 / 2005$ (sexta-feira) & $04 / 11 / 2005$ (sexta-feira) \\
\hline $22 / 10 / 2005$ (sábado) & - & $05 / 11 / 2005$ (sábado) \\
\hline
\end{tabular}

\begin{tabular}{|l|l|l|}
\hline \multicolumn{3}{|c|}{ TABELA XV - TELEJORNAIS DIÁRIOS (2005) } \\
\hline $\begin{array}{c}\text { Jornal Nacional } \\
\text { segunda a sábado / } 20 \mathrm{~h}\end{array}$ & $\begin{array}{c}\text { Jornal da Cultura } \\
\text { segunda a sexta / 21h }\end{array}$ & $\begin{array}{c}\text { Jornal da Record } \\
\text { segunda a sábado / 20h30 }\end{array}$ \\
\hline $07 / 11 / 2005$ (segunda-feira) & $14 / 11 / 2005$ (segunda-feira) & $21 / 11 / 2005$ (segunda-feira) \\
\hline $08 / 11 / 2005$ (terça-feira) & $15 / 11 / 2005$ (terça-feira) & $22 / 11 / 2005$ (terça-feira) \\
\hline $09 / 11 / 2005$ (quarta-feira) & $16 / 11 / 2005$ (quarta-feira) & $23 / 11 / 2005$ (quarta-feira) \\
\hline $10 / 11 / 2005$ (quinta-feira) & $17 / 11 / 2005$ (quinta-feira) & $24 / 11 / 2005$ (quinta-feira) \\
\hline $11 / 11 / 2005$ (sexta-feira) & $18 / 11 / 2005$ (sexta-feira) & $25 / 11 / 2005$ (sexta-feira) \\
\hline $12 / 11 / 2005$ (sábado) & - & $26 / 11 / 2005$ (sábado) \\
\hline
\end{tabular}


Notemos que as possibilidades descritivas e analíticas do corpus ultrapassam os limites de nosso relato. Dessa forma, cada uma das edições poderia ser exaustivamente explorada, tanto em termos de seus elementos estéticos como em seus desdobramentos éticos. Como nas análises de mídia impressa, apresentamos uma amostra de tais possibilidades, esperando relacionar esse material com outros elementos e indagações. Nossa busca por uma definição de estigmas será demonstrada, a seguir, por meio dos telejornais selecionados para compor a análise, momento em que apresentaremos algumas considerações sobre as (con)figurações de estigmas sociais nos discursos jornalísticos em suas múltiplas formas para, posteriormente, apresentarmos as análises relativas à análise de filmes.

\subsection{Primeiras chamadas: redundâncias e ressonâncias}

Ao tratar das relações entre estigmas sociais e mídias privilegiamos, nesse momento, os discursos jornalísticos, definindo-os como aqueles que operam no campo da informação e da referencialidade - e, supostamente, da factualidade - e que visam produzir um efeito de realidade por meio da produção de notícias. Mas, afinal, o que é notícia? Se tomarmos a acepção clássica de gêneros jornalísticos, divididos entre informativos e opinativos, podemos entendê-la como uma das formas de narrar do jornalismo, somando-se às entrevistas, reportagens, artigos, editoriais, crônicas, entre outros, todos considerados, de forma geral, matérias jornalísticas.

Dessa forma, se assumirmos como postulado que o jornalismo constitui-se, sobretudo, como "fato de língua" - entendendo por essa definição "a língua como instituição social fundante" (Gomes, 2000: 15) - é possível efetuar o deslocamento de alguns de seus pressupostos, especialmente a questão da objetividade vista como algo externo aos discursos - e, portanto, externo também aos sujeitos que falam -, para entendê-lo, de maneira mais ampla, como uma narrativa. Ou seja: o jornalismo se faz não a partir de definições extrínsecas a ele, em nome das quais deva se pautar periodicidade, atualidade, difusão, imparcialidade, universalidade - mas a partir de si próprio como instituição que desempenha uma "função organizadora das hierarquias sociais" (Gomes, 2000: 19), organização esta que é feita discursivamente. Uma pequena distinção entre narrativa e discurso faz-se necessária: partimos da definição clássica de narrativa como "relato de uma transformação, a passagem de um estado inicial para o final" (Gomes, 2000: 49) e de discurso como "laço social” (Lacan, 1998). 
Narrar é contar uma história; os discursos, quaisquer que sejam eles - inclusive os discursos jornalísticos - possuem uma estrutura narrativa, ou seja, são definidos por funções a serem desempenhadas pelos sujeitos no desenrolar da história contada imprimindo transformações por meio de ações movidas pelo desejo de seus atuantes. A partir dessa concepção, mais do que informações que registram eventos - relatos estes que se pretendem fiéis a uma suposta realidade externa a eles - as notícias (os acontecimentos narrados pelo jornalismo) passam a ser vistas como "formas culturais" (Schudson, 1995: 27) construindo, ao demarcar o espaço social, a "arena simbólica da sociedade" (ou a própria realidade): "O objetivo mais importante das notícias, portanto, é fornecer à arena simbólica e à cidadania imagens abrangentes e representativas (ou construtos) da nação e da sociedade" (Gans, 1980: 312).

Uma última observação se faz fundamental: se afirmamos que os discursos jornalísticos possuem uma estrutura narrativa, estamos afirmando, consequentemente, que a narrativa não é privilégio do relato ficcional, constituindo também o relato factual. Dessa forma, "quando o jornal diário noticia um fato qualquer, como um atropelamento, já traz aí, em germe, uma narrativa. O desdobramento das clássicas perguntas a que a notícia pretende responder (que, o que, como, quando, onde, por quê) constituirá de pleno direito uma narrativa" (Sodré e Ferrari, 1986: 11). Observemos ainda que o ficcional e o factual - como pode ser percebido não só no jornalismo, mas também em telenovelas e reality shows - são campos que têm permeado, cada vez mais, os limites entre suas fronteiras, afastando-se da distinção comumente estabelecida entre relatos falsos/verdadeiros, ou imaginários/reais, como veremos posteriormente.

\subsubsection{Telejornais diários}

Em nossas análises, como dissemos, optamos por selecionar as aberturas de telejornais diários, privilegiando as narrativas sobre estigmas sociais presentes nessas chamadas. A escolha da escalada dos telejornais, a exemplo das primeiras páginas de jornais e capas de revistas como objeto de análise, justifica-se na medida em que nelas temos um elaborado processo de seleção e combinação de elementos distintos e, portanto, que apontam para o lugar de fala dos telejornais e para os complexos processos de edição de produtos audiovisuais. 
Apresentamos as tabelas e leituras realizadas, transcrevendo dia-a-dia as chamadas dos telejornais. A amostragem inclui as escaladas de três grandes telejornais diários (Jornal Nacional, Jornal da Cultura, Jornal da Record, que serão denominados, respectivamente, como $J N, J C$ e $J R$ ), num total de duas semanas por telejornal, perfazendo 12 edições $(J N$ e $J R)$ e 10 edições $(J C)$ gravadas para cada um. Temos, portanto, 34 edições de telejornais; excetuando os dias em que ocorreram problemas técnicos (três noites), nossa amostragem é formada por 31 telejornais diários.

O $J N$ é apresentado diariamente, de segunda-feira a sábado, em horário nobre na Rede Globo de Televisão. Sua transmissão se faz entre duas telenovelas e o horário não é rígido: dependendo da grade de programação do dia, o telejornal pode começar entre 8 h15 e 8h30, tendo duração de aproximadamente 30 minutos. O JN é apresentado, no corpus, pelo casal de jornalistas William Bonner - que também ocupa o cargo de editor chefe do jornal - e Fátima Bernardes - que é também editora executiva do jornal. Além dos dois, há a figura do editor chefe adjunto (na época da pesquisa, Liliane Yusim). As manchetes do $J N$ duram em média 2 minutos, sendo lidas de forma intercalada pelos dois apresentadores. O número de chamadas varia entre seis e dez a cada edição.

O $J C$ tem edições diárias de segunda a sexta-feira, sempre às $21 \mathrm{~h}$, com duração de aproximadamente 30 minutos. Na época da amostragem, era apresentado por um casal de jornalistas, dividindo uma mesma bancada (como no Jornal Nacional), mas raramente enquadrados no mesmo plano, sendo que a jornalista Laila Dawa revezava a apresentação de um minuto das manchetes com os jornalistas Celso Zucattelli, Éderson Granetto e, em um número maior de vezes, com o jornalista Heródoto Barbeiro. Diariamente temos até quatro chamadas no $J C$.

$\mathrm{O} J R$ diferencia-se dos outros dois por ser apresentado apenas por um âncora, que faz breves comentários ao longo do telejornal. Na época da amostragem, o âncora era Boris Casoy, jornalista que imprimiu uma marca pessoal e polêmica ao telejornal. Mais longo que os demais, o $J R$ tem duração de aproximadamente uma hora, e a escalada segue por cerca de dois minutos, com até oito chamadas.

Primeiramente, construímos um quadro geral das chamadas presentes nos três telejornais para, num segundo momento, focalizar aspectos encontrados em um grupo de matérias escolhidas por sua especificidade temática em relação aos estigmas sociais. Ao fazê-lo, estabelecemos outra classificação entre as chamadas e optamos por tratar não apenas de um ou dois telejornais (como no caso da mídia impressa), mas abordar o percurso narrativo de um mesmo tema nas imagens reportadas. 


\begin{tabular}{|c|c|c|}
\hline \multicolumn{3}{|c|}{ TABELA XVI - TELEJORNAIS DIÁRIOS (2005) } \\
\hline \multicolumn{3}{|c|}{ OUTUBRO-NOVEMBRO (primeira semana) } \\
\hline $\begin{array}{c}\text { Jornal Nacional } \\
\text { segunda a sábado / 20h15 }\end{array}$ & $\begin{array}{c}\text { Jornal da Cultura } \\
\text { segunda a sexta / } 21 \mathrm{~h}\end{array}$ & $\begin{array}{c}\text { Jornal da Record } \\
\text { segunda a sábado / 20h30 }\end{array}$ \\
\hline $\begin{array}{l}\text { 17/10/2005 (segunda-feira) } \\
\text { William Bonner (à esquerda da tela) e } \\
\text { Fátima Bernardes (à direita) } \\
\text { 1. Dois deputados acusados de } \\
\text { envolvimento no Mensalão renunciam } \\
\text { para escapar da cassação / Mas onze } \\
\text { passam a responder a processo em } \\
\text { que podem perder o mandato } \\
\text { 2. Brasileiros sem água / A estiagem } \\
\text { põe municípios do Pará e de Minas em } \\
\text { situação de emergência } \\
\text { *Imagens da seca } \\
\text { 3. Agrava-se problema da febre aftosa / } \\
\text { Surgem três novos focos em Mato } \\
\text { Grosso do Sul } \\
\text { 4. O Congresso descobre que não tem } \\
\text { dinheiro para pagar os aumentos } \\
\text { salariais que aprovou } \\
\text { 5. } 76 \text { voltas em torno do planeta / E os } \\
\text { dois astronautas chineses retornam } \\
\text { com segurança à Terra } \\
\text { *Imagens dos astronautas } \\
\text { 6. Mais um estudante é morto por } \\
\text { acidente em São Paulo / O segundo em } \\
\text { menos de vinte dias } \\
\text { 7. Mais um torcedor paulista é vítima de } \\
\text { assassinato / O terceiro em menos de } \\
\text { vinte horas } \\
\text { 8. No Campeonato Brasileiro, clubes } \\
\text { que já conquistaram dez títulos fogem } \\
\text { do rebaixamento } \\
\text { * Imagens de times de futebol }\end{array}$ & $\begin{array}{l}\text { 24/10/2005 (segunda-feira) } \\
\text { Celso Zucatelli e Laila Dawa } \\
\text { 1. José Dirceu vai novamente ao } \\
\text { Supremo tentar evitar a cassação } \\
\text { 2. A maioria dos brasileiros decidiu } \\
\text { não proibir a venda de armas de } \\
\text { fogo, mas há lugares violentos } \\
\text { onde o "sim" venceu } \\
\text { 3. Mais dois países anunciam } \\
\text { restrições à carne brasileira por } \\
\text { causa da febre aftosa } \\
\text { 4. Os estragos do furacão Wilma } \\
\text { na Flórida e mais três atentados } \\
\text { em Bagdá também estão no Jornal } \\
\text { da Cultura }\end{array}$ & $\begin{array}{l}\text { 31/10/2005 (segunda-feira) } \\
\text { com Boris Casoy } \\
\text { 1. O Planalto deixa para o PT } \\
\text { responder denúncia sobre dinheiro } \\
\text { cubano em campanha de Lula } \\
\text { *Imagens do Planalto } \\
\text { 2. Berzoini anuncia que o PT vai à } \\
\text { Justiça contra a revista Veja, que } \\
\text { publicou a acusação } \\
\text { *Imagens de Berzoini } \\
\text { 3. PSDB e PFL dizem que é hora de } \\
\text { investigar o caso, e não de pedir } \\
\text { impeachment } \\
\text { *Imagens dos presidentes dos dois } \\
\text { partidos } \\
\text { 4. Relator lê novo relatório sobre a } \\
\text { cassação de José Dirceu e critica } \\
\text { decisão do Supremo } \\
\text { * Imagens do relator } \\
\text { 5. No Rio, a febre transmitida por } \\
\text { carrapato pode ter provocado a } \\
\text { segunda morte } \\
\text { * Imagens do carrapato } \\
\text { 6. O Ministério Público denuncia por } \\
\text { homicídio duplamente qualificado o } \\
\text { estudante que matou colega na USP } \\
\text { * Imagens do estudante indiciado } \\
\text { 7. A cirurgia de Roger é bem sucedida } \\
\text { mas ele só volta ao Corinthians no ano } \\
\text { que vem } \\
\text { * Imagens de Roger no hospital e em } \\
\text { jogo de futebol }\end{array}$ \\
\hline $\begin{array}{l}\text { 18/10/2005 (terça-feira) } \\
\text { William Bonner e Fátima Bernardes } \\
\text { 1. Surgem suspeitas de mais dois focos } \\
\text { de aftosa em Mato Grosso do Sul / E } \\
\text { não há controle do rebanho perto da } \\
\text { fronteira com o Paraguai } \\
\text { *Imagens de gado } \\
\text { 2. Na Amazônia sem chuvas, peixes } \\
\text { agonizam no que resta de água nos } \\
\text { rios } \\
\text { *Imagens de peixes } \\
\text { 3. Conselho de Ética recebe pedido de } \\
\text { cassação de José Dirceu / E escolhe } \\
\text { relatores para os processos contra } \\
\text { onze deputados } \\
\text { 4. Os Tribunais de Justiça recebem um } \\
\text { ultimato para exonerar parentes de até } \\
\text { terceiro grau de juízes } \\
\text { 5. A Polícia Federal recupera mais uma } \\
\text { parte do dinheiro roubado na Sede no } \\
\text { Rio } \\
\text { 6. Veja também a nova confusão na } \\
\text { distribuição de ingressos para jogos } \\
\text { remarcados } \\
\text { *Imagens de times de futebol de } \\
\text { multidão } \\
\text { 7. Na Alemanha, o árbitro que } \\
\text { manipulou resultados pode pegar } 10 \\
\text { anos de cadeia }\end{array}$ & $\begin{array}{l}\text { 25/10/2005 (terça-feira) } \\
\text { Celso Zucatelli e Laila Dawa } \\
\text { 1. Sobe para quatro o número de } \\
\text { mortos na Indonésia por causa da } \\
\text { gripe das aves } \\
\text { 2. No Brasil, o governo federal e o } \\
\text { de São Paulo anunciam medidas } \\
\text { para evitar a doença } \\
\text { 3. O Supremo Tribunal Federal } \\
\text { nega novo pedido de suspensão } \\
\text { do processo de cassação de José } \\
\text { Dirceu } \\
\text { 4. E os estragos do furacão Wilma } \\
\text { e da tempestade tropical Alfa, na } \\
\text { América do Norte e no Caribe, } \\
\text { também estão no Jornal da Cultura }\end{array}$ & $\begin{array}{l}\text { 01/11/2005 (terça-feira) } \\
\text { com Boris Casoy } \\
\text { 1. Conselho de Ética pede o } \\
\text { arquivamento do processo de cassação } \\
\text { de Sandro Mabel, do PL, por falta de } \\
\text { provas } \\
\text { * Imagens de Sandro Mabel } \\
\text { 2. A oposição quer que Justiça Eleitoral } \\
\text { investigue suposta doação de Cuba à } \\
\text { campanha de Lula } \\
\text { * Imagens do prédio da Justiça Eleitoral } \\
\text { em Brasilia } \\
\text { 3. O Planalto acha que a denúncia está } \\
\text { vencida mas tenta impedir que o caso } \\
\text { chegue à CPI dos Bingos } \\
\text { *Imagens de Brasília } \\
\text { 4. Ontem foi Arthur Virgílio, hoje é ACM } \\
\text { Neto que se diz espionado pela Abin e } \\
\text { fala em dar uma surra em Lula } \\
\text { * Imagens dos dois deputados } \\
\text { 5. Saldo da Balança Comercial até } \\
\text { outubro supera o de todo ano passado } \\
\text { *Imagens de porto e de estrada } \\
\text { 6. Juros americanos sobrem } 4 \% \text { ao ano } \\
\text { * Imagens da fachada da Federal Reserve } \\
\text { norte-americana } \\
\text { 7. Quebra-quebra numa estação de trens em } \\
\text { Buenos Aires deixa pelo menos dezoito } \\
\text { feridos e } 87 \text { presos } \\
\text { * Imagens da estação de trem }\end{array}$ \\
\hline
\end{tabular}


19/10/2005 (quarta-feira)

William Bonner e Fátima Bernardes

1. O Supremo derruba o recurso de José Dirceu / E mantém o processo de cassação

2. A conexão tucana do Valerioduto / Tesoureiro confirma caixa-dois na campanha de Eduardo Azeredo em 98 / Mas diz que o candidato não sabia

3. O Banco Central reduz juros em 0,5 ponto percentual

4. Iraque - A interrupção do julgamento dá mais tempo para Saddam Hussein se defender

* Imagens de Saddam Hussein

5. Furacão mais forte de todos os tempos mata no Caribe

6. O governo brasileiro anuncia medidas de prevenção da gripe das aves

7. São Paulo - Família pagou o resgate mais o seqüestrado não é libertado / É um dos acusados do roubo milionário do Banco Central

* Imagens da família

8. O homem que comprou resultados dos jogos do Brasileirão levanta suspeitas sobre mais uma partida e mais um árbitro / E Ronaldo decide tratar o tornozelo no Brasil

* Imagens de futebol e de Ronaldo

\section{1/10/2005 (sexta-feira)}

William Bonner e Fátima Bernardes

1. O ladrão do Banco Central seqüestrado é encontrado morto 2. A polícia identifica o homem que matou o torcedor do Palmeiras * Imagens de câmera de segurança 3. O Supremo manda soltar Paulo Flávio Maluf
27/10/2005 (quinta-feira)

Éderson Granetto e Laila Dawa 1. O relatório do Conselho de Ética que pedia a cassação do deputado José Dirceu vai ter que ser refeito

2. A acareação entre envolvidos no suposto esquema do Mensalão mostra muitas contradições

3. Especialistas pedem cuidado a quem consome remédio vendido sem a necessidade de receita médica

4. E a Câmara dos Deputados aprova a nova MP do Bem, que promete diminuir os impostos. Jornal da Cultura Tudo isso e muito mais agora, no

\section{3/11/2005 (quinta-feira)}

com Boris Casoy

1. A CPI dos Correios aponta o Banco do Brasil como origem de 10 milhões de reais para esquema Valério-PT * Imagens da CPI

2. Deputados querem antecipar o processo de cassação de José Dirceu no plenário / O presidente da Câmara resiste

* Imagens da Câmara e de Brasília 3. Rebelo pede ao Ministério da Justiça apuração rigorosa sobre grampos nos telefones de Osmar Serralho, Ricardo Izar e ACM Neto

* Imagens dos deputados

4. Movimentos sociais preparam manifestações contra visita de Bush ao Brasil

* Imagens de Brasília

5. Exame confirma morte por febre maculosa no Rio

* Imagens de prédio histórico

6. Pecuaristas minimizam prejuízos das exportações de carne por causa da aftosa

* Imagens de pecuaristas

\section{8/10/2005 (sexta-feira)}

Celso Zucatelli e Laila Dawa

1. O Supremo Tribunal Federal devolve o cargo de Senador a João Capiberibe

2. Choveu forte em São Paulo - A capital e o interior sofreram com alagamentos, falta de luz e trânsito intenso

\section{4/11/2005 (sexta-feira)}

com Boris Casoy

1. Governo e PT se mobilizam para desmentir a acusação de que dinheiro do Banco do Brasil foi desviado para Partido

* Imagens do governo em Brasília e de fachada do $B B$ 


\begin{tabular}{|c|c|c|}
\hline $\begin{array}{l}\text { 4. Uma manobra adia a votação do } \\
\text { processo contra o deputado José } \\
\text { Dirceu } \\
\text { 5. Mais dez países embargam a carne } \\
\text { brasileira por causa da aftosa / E o } \\
\text { governo promete indenizar os } \\
\text { produtores } \\
\text { 6. A gripe das aves mata um homem na } \\
\text { Tailândia } \\
\text { 7. O furacão Wilma provoca a retirada } \\
\text { de milhares de pessoas } \\
\text { * Imagens de carros deixando a cidade } \\
\text { 8. A seca na Amazônia atinge a } \\
\text { produção da Zona Franca de Manaus } \\
\text { 9. E Ronaldo descarta operação no } \\
\text { tornozelo na chegada ao Brasil } \\
\text { *Imagens de Ronaldo na rua }\end{array}$ & $\begin{array}{l}\text { 3. No dia do funcionário público, o } \\
\text { Jornal da Cultura mostra como } \\
\text { funciona o famoso ponto facultativo } \\
\text { 4. E Maradona diz a Fidel Castro } \\
\text { que vai liderar protesto contra Bush } \\
\text { na Argentina. Agora no Jornal da } \\
\text { Cultura }\end{array}$ & $\begin{array}{l}\text { 2. Exclusivo - Servidor que investigou } \\
\text { corrupção na Fundacentro na gestão } \\
\text { Fernando Henrique se diz perseguido } \\
\text { pelo grupo de José Dirceu } \\
\text { *Imagens da Fundacentro } \\
\text { 3. Conselho de Ética mantém decisão } \\
\text { de cassar José Dirceu por } 13 \times 1 / \\
\text { Defesa vai de novo ao Supremo } \\
\text { *Imagens de Brasilia } \\
\text { 4. Lula participa da Cúpula das } \\
\text { Américas na Argentina e não fala da } \\
\text { crise no Brasil / Chávez é a estrela das } \\
\text { manifestações contra Bush } \\
\text { *Imagens de Lula e Chávez } \\
\text { 5. Sondagem da CNI revela } \\
\text { empresários com menos intenções de } \\
\text { investir } \\
\text { *Imagens de fábricas } \\
\text { 6. O dólar cai à menor cotação em } \\
\text { quatro anos } \\
\text { *Imagens de notas de dólar } \\
\text { 7. PF prende mais de cinqüenta } \\
\text { pessoas em cinco Estados por } \\
\text { contrabando } \\
\text { *Imagens da Polícia Federal } \\
\text { 8. Paris tem mais uma noite de } \\
\text { violência / Os protestos começam a se } \\
\text { espalhar por outras cidades francesas } \\
\text { *Imagens de violência }\end{array}$ \\
\hline $\begin{array}{l}\text { 22/10/2005 (sábado) } \\
\text { Chico Pinheiro e Renato Machado } \\
\text { 1. O Brasil no referendo - Mais de } 120 \\
\text { milhões de eleitores vão às urnas / E o } \\
\text { Exército usa helicópteros para garantir } \\
\text { a votação nos lugares isolados pela } \\
\text { seca } \\
\text { *Imagens do exercito e da seca } \\
\text { 2. O furacão Wilma perde a força mas } \\
\text { ventos de } 195 \mathrm{~km} / \mathrm{h} \text { causam destruição } \\
\text { na costa do México } \\
\text { *Imagens de vendavais } \\
\text { 3. A crise no PT - o ex-tesoureiro } \\
\text { Delúbio Soares é expulso do partido } \\
\text { 4. Febre aftosa - São Paulo e Santa } \\
\text { Catarina montam barreiras na divisa } \\
\text { com Paraná } \\
\text { 5. Exames confirmam mais um caso de } \\
\text { gripe das aves na Europa } \\
\text { 6. O líder - Corinthians vence mais um } \\
\text { no Campeonato Brasileiro } \\
\text { *Imagens de jogo de futebol } \\
\text { 7. Dois ex-campeões perdem de novo e } \\
\text { seguem ameaçados pelo rebaixamento } \\
\text { *Imagens de jogo de futebol } \\
\text { 8. O sucesso de Brasileirinho / E } \\
\text { Dayanne dos Santos leva o ouro em } \\
\text { etapa da Alemanha da Copa do Mundo } \\
\text { de Ginástica } \\
\text { *Imagens da atleta }\end{array}$ & - & $\begin{array}{l}\text { 05/11/2005 (sábado) } \\
\text { Salette Lemos (aos sábados) } \\
\text { 1. A CPI dos Bingos ouve } \\
\text { reservadamente testemunhas do } \\
\text { seqüestro de Celso Daniel } \\
\text { *Imagens de Celso Daniel } \\
\text { 2. Bush chega hoje à Brasília sob forte } \\
\text { esquema de segurança / Em São Paulo } \\
\text { protesto acaba em pancadaria } \\
\text { *Imagens de ruas com manifestantes } \\
\text { 3. Divergências sobre a Alca atrasam } \\
\text { encerramento do Encontro em Mar del } \\
\text { Plata } \\
\text { *Imagens de presidentes } \\
\text { 4. Onda de violência nos subúrbios } \\
\text { de Paris já dura nove noites e se } \\
\text { espalha por mais cinco cidades } \\
\text { *Imagens de tumultos nas ruas } \\
\text { 5. Gols do Brasileirão - O São Paulo } \\
\text { passa fácil pelo Juventude / O Grêmio e } \\
\text { a Lusa embolam a luta pelo acesso } \\
\text { *Imagens de jogos de futebol }\end{array}$ \\
\hline
\end{tabular}




\begin{tabular}{|c|c|c|}
\hline \multicolumn{3}{|c|}{ TABELA XVII - TELEJORNAIS DIÁRIOS (2005) } \\
\hline \multicolumn{3}{|c|}{ NOVEMBRO (segunda semana) } \\
\hline $\begin{array}{c}\text { Jornal Nacional } \\
\text { segunda a sábado / 20h15 }\end{array}$ & $\begin{array}{c}\text { Jornal da Cultura } \\
\text { segunda a sexta } / 21 \mathrm{~h}\end{array}$ & $\begin{array}{c}\text { Jornal da Record } \\
\text { segunda a sábado / 20h30 }\end{array}$ \\
\hline $\begin{array}{l}\text { 07/11/2005 (segunda-feira) } \\
\text { William Bonner e Fátima Bernardes } \\
\text { 1. Onze noites de fogueiras na França / A } \\
\text { primeira morte provocada pelo } \\
\text { vandalismo é confirmada / E o governo } \\
\text { autoriza municípios atingidos a decretar } \\
\text { toque de recolher } \\
\text { * Imagens das ruas de Paris em chamas } \\
\text { 2. Cinco anos em fuga / E o ex-presidente } \\
\text { Alberto Fujimori é preso no Chile } \\
\text { *Imagens de Fujimori em automóvel } \\
\text { 3. Liberdade para o padre libertino / O } \\
\text { religioso preso em flagrante num motel } \\
\text { com menores de idade sai da cadeia no } \\
\text { Maranhão } \\
\text { 4. O presidente do Conselho de Ética diz } \\
\text { que foi encontrado um objeto estranho no } \\
\text { gabinete dele / E a suspeita é de grampo } \\
\text { 5. O enfarto do motorista provoca } \\
\text { acidente com um carro da comitiva do } \\
\text { presidente Lula / Três pessoas morreram } \\
\text { * Imagens de carro batido e ambulância } \\
\text { 6. O deputado José Dirceu entra com } \\
\text { novo recurso contra a cassação do } \\
\text { mandato } \\
\text { 7. A CPI dos Correios anuncia que vai } \\
\text { pedir indiciamento de Marcos Valério e } \\
\text { Delúbio Soares } \\
\text { 8. A prevenção contra a gripe das aves / } \\
\text { Pássaros que migraram para o Brasil são } \\
\text { examinados na Bahia } \\
\text { * Imagens de aves para consumo } \\
\text { 9. O dólar atinge a menor cotação em } \\
\text { mais de quatro anos } \\
\text { 10. O Corinthians chega mais perto do } \\
\text { título do Brasileirão } \\
\text { *Imagens do time fazendo um qol }\end{array}$ & $\begin{array}{l}\text { 14/11/2005 (segunda-feira) } \\
\text { Heródoto Barbeiro e Laila Dawa } \\
\text { 1. O Ministro da Fazenda Pallocci } \\
\text { está de folga no feriadão / Em } \\
\text { Brasília, aumentam os rumores de } \\
\text { que ele pode ser convocado para } \\
\text { depor na CPI / Lula já avalia quem } \\
\text { poderia substituí-lo / E Pallocci } \\
\text { ganhou um aliado de peso, o } \\
\text { deputado Delfim Neto } \\
\text { 2. Um dos presos acusados de } \\
\text { seqüestrar o prefeito de Santo } \\
\text { André, Celso Daniel, diz que } \\
\text { confessou o crime sob tortura } \\
\text { 3. No Dia Mundial de Combate ao } \\
\text { Diabetes um alerta: metade das } \\
\text { pessoas que tem a doença não } \\
\text { sabe disso } \\
\text { 4. E a cidade de Torrinhas, no sul } \\
\text { da Bahia, se prepara para exportar } \\
\text { tilápias. Isso e muito mais você vê } \\
\text { agora no Jornal da Cultura }\end{array}$ & $\begin{array}{l}\text { 21/11/2005 (segunda-feira) } \\
\text { com Boris Casoy } \\
\text { 1. Tentando barrar boatos de queda } \\
\text { de ministro, Lula dá forte apoio a } \\
\text { Pallocci } \\
\text { *Imagens de Lula e Pallocci } \\
\text { 2. A CPI dos Bingos ouve amanhã } \\
\text { Paulo Okamoto, que diz ter pago } \\
\text { empréstimo do PT a Lula } \\
\text { *Imagens de Paulo Okamoto } \\
\text { 3. Presidente do TSE entrega ao } \\
\text { Congresso propostas para endurecer } \\
\text { combate à corrupção eleitoral } \\
\text { *Imagens do TSE e Congresso } \\
\text { 4. Relator da CPI da Terra vai pedir o } \\
\text { indiciamento de ruralistas e eles } \\
\text { reagem atacando o MST } \\
\text { *Imagens da CPI } \\
\text { 5. O roubo do Banco Central - } \\
\text { Mulher do vigia preso é seqüestrada } \\
\text { e paga resgate com dinheiro suspeito } \\
\text { *Imagens dos acusados e do } \\
\text { dinheiro } \\
\text { 6. O Internacional se recusa a } \\
\text { desculpar o juiz e recomenda que se } \\
\text { dê logo a taça ao Corinthians } \\
\text { *Imagens de jogo de futebol }\end{array}$ \\
\hline $\begin{array}{l}\text { 08/11/2005 (terça-feira) } \\
\text { William Bonner e Fátima Bernardes } \\
\text { 1. A BR } 101 \text { interditada pela segunda vez } \\
\text { em uma semana / Agora, uma ponte é } \\
\text { destruída por uma enxurrada } \\
\text { * Imagens de enchente } \\
\text { 2. Uma suspeita grave no Maranhão / } \\
\text { Outros padres teriam participado da } \\
\text { exploração sexual de menores } \\
\text { 3. O dólar cai de novo a menos de R\$ } \\
\text { 2,20 } \\
\text { 4. Veja também os principais trechos da } \\
\text { entrevista do presidente Lula / E as } \\
\text { reações da oposição e dos aliados } \\
\text { 5. Mais um advogado no julgamento de } \\
\text { Saddam Hussein é assassinado no Iraque } \\
\text { * Imagens do advogado } \\
\text { 6. Schwarzenegger enfrenta um teste nas } \\
\text { urnas americanas } \\
\text { *Imagens de Schwarzenegger } \\
\text { 7. E na madrugada em que a violência } \\
\text { diminui em Paris, os protestos se } \\
\text { agravam no interior da França }\end{array}$ & $\begin{array}{l}\text { 15/11/2005 (terça-feira) } \\
\text { Heródoto Barbeiro e Laila Dawa } \\
\text { 1. Os estrategistas do século } \\
\text { passado diziam que a melhor } \\
\text { defesa é o ataque / O ministro } \\
\text { Antonio Pallocci antecipou } \\
\text { depoimento no Senado / Ele quer } \\
\text { neutralizar a oposição, que pede } \\
\text { sua saída do Ministério da } \\
\text { Fazenda / E amanhã nós vamos } \\
\text { saber se essa estratégia ainda } \\
\text { funciona } \\
\text { 2. As mulheres vão às compras } \\
\text { mesmo no feriado } \\
\text { 3. Problema para a família imperial } \\
\text { japonesa: só nascem mulheres } \\
\text { 4. E na Rússia um problema ainda } \\
\text { maior: a população está } \\
\text { encolhendo. Agora no Jornal da } \\
\text { Cultura }\end{array}$ & $\begin{array}{l}\text { 22/11/2005 (terça-feira) } \\
\text { com Boris Casoy } \\
\text { 1. Pallocci não desmente nem } \\
\text { confirma rumores de demissão / Lula } \\
\text { diz que o ministro está firme no cargo } \\
\text { *Imagens de Pallocci e Lula } \\
\text { 2. Okamoto não explica como parte } \\
\text { da dívida de Lula com PT foi paga } \\
\text { *Imagens de Paulo Okamoto } \\
\text { 3. A popularidade de Lula cai mais } \\
\text { ainda na pesquisa CNT-Census / A } \\
\text { opinião dominante é que o presidente } \\
\text { participou da corrupção } \\
\text { *Imagens de gráfico da pesquisa } \\
\text { 4. Sondagem mostra indústria mais } \\
\text { pessimista para o ano que vem } \\
\text { *Imagens de fábrica } \\
\text { 5. Rebelião violenta na Febem Paulista / } \\
\text { Entre os feridos há funcionários e internos } \\
\text { em estado grave } \\
\text { *Imagens da rebelião } \\
\text { 6. A Itália apreende } 30 \text { milhões de litros } \\
\text { de leite Nestlé para bebês contaminados } \\
\text { pela embalagem } \\
\text { *Imagens de leite }\end{array}$ \\
\hline
\end{tabular}




\begin{tabular}{|c|c|c|}
\hline & & $\begin{array}{l}\text { 7. A seleção masculina estréia com } \\
\text { vitória na Copa dos Campeões de } \\
\text { Vôlei } \\
\text { *Imagens de foto da seleção }\end{array}$ \\
\hline $\begin{array}{l}\text { 09/11/2005 (quarta-feira) } \\
\text { William Bonner e Fátima Bernardes } \\
\text { 1. Terror no Oriente Médio / Homens- } \\
\text { bomba explodem em três hotéis da } \\
\text { Jordânia / } 53 \text { pessoas morrem e mais de } \\
120 \text { estão feridas } \\
\text { * Imagens externas do hotel } \\
\text { 2. A França decide expulsar imigrantes } \\
\text { com antecedentes envolvidos em } \\
\text { confrontos de rua } \\
\text { 3. O ex-ministro Anderson Adauto admite } \\
\text { ter usado dinheiro de caixa-dois em onze } \\
\text { campanhas eleitorais } \\
\text { 4. A Receita Federal encontra uma nota } \\
\text { fiscal fria e milionária de uma empresa de } \\
\text { Marcos Valério para a Visanet } \\
\text { 5. Conselho de Ética aprova pedido de } \\
\text { cassação do deputado Romeo Queiroz } \\
\text { 6. O governo sofre uma derrota bilionária } \\
\text { no Supremo } \\
\text { 7. O padre flagrado com menores num } \\
\text { motel volta para a prisão / Mas os irmãos } \\
\text { Cravinhos deixam a cadeia / Eles são } \\
\text { réus confessos do assassinato do casal } \\
\text { Richthofen }\end{array}$ & $\begin{array}{l}\text { 16/11/2005 (quarta-feira) } \\
\text { Heródoto Barbeiro e Laila Dawa } \\
\text { 1. O Ministro da Fazenda, Antonio } \\
\text { Pallocci, parte para o contra- } \\
\text { ataque: desqualifica as denúncias } \\
\text { de corrupção na prefeitura de } \\
\text { Ribeirão Preto e na campanha de } \\
\text { Lula / De quebra, elogia Pedro } \\
\text { Malan e rebate críticas de membro } \\
\text { do governo dizendo que não } \\
\text { 'enxuga gelo' } \\
\text { 2. Greve dos médicos do INSS } \\
\text { provoca filas nos postos da } \\
\text { Previdência / Eles não recebem } \\
\text { salário desde julho } \\
\text { 3. Mudanças na telefonia fixa a } \\
\text { partir de janeiro prometem } \\
\text { melhorar o serviço no Brasil } \\
\text { 4. E } 170 \text { países discutem o } \\
\text { controle da internet. Tudo isso e } \\
\text { muito mais, agora, no Jornal da } \\
\text { Cultura }\end{array}$ & $\begin{array}{l}\text { 23/11/2005 (quarta-feira) } \\
\text { com Boris Casoy } \\
\text { 1. Os juros caem 0,5 ponto } \\
\text { percentual } \\
\text { * Imagens de dinheiro } \\
\text { 2. Lula diz que Pallocci é } \\
\text { imprescindível e fica } \\
\text { * Imagens de Lula } \\
\text { 3. Ausência de um Ministro adia } \\
\text { decisão final do Supremo sobre José } \\
\text { Dirceu } \\
\text { *Imagens de José Dirceu } \\
\text { 4. Relator de CPI dos Bingos vai } \\
\text { pedir indiciamento de Sergio Sombra, } \\
\text { Klinger e Ronan por corrupção } \\
\text { *Imagens dos indiciados } \\
\text { 5. Agências dizem que Marcos } \\
\text { Valério repassou recursos da Visanet } \\
\text { Banco do Brasil a partir de } 2003 \\
\text { *Imagens da CPI } \\
\text { 6. Morre um dos menores feridos na } \\
\text { rebelião de ontem da Febem Paulista } \\
\text { *Imagens da rebelião na Febem } \\
\text { 7. Chuva forte provoca enchente e } \\
\text { engarrafamento na Grande São } \\
\text { Paulo } \\
\text { * Imagens das marginais } \\
\text { congestionadas } \\
\text { 8. Dayanne dos Santos vai à final do } \\
\text { Mundial de Ginástica com a melhor } \\
\text { nota } \\
\text { *Imagens de fotos da atleta }\end{array}$ \\
\hline $\begin{array}{l}\text { 10/11/2005 (quinta-feira) } \\
\text { Chico Pinheiro e Fátima Bernardes } \\
\text { 1. A adolescente americana que sumiu } \\
\text { em Minas é encontrada na Bahia / Mas } \\
\text { Mackenzie Martin não sabe explicar } \\
\text { porquê fugiu } \\
\text { *Imagens da adolescente em vários } \\
\text { momentos desde seu encontro } \\
\text { 2. O ex-campeão mundial de boxe é dito } \\
\text { no Brasil / Mike Tyson é acusado de } \\
\text { agredir um cinegrafista em São Paulo } \\
\text { *Imagens do boxeador } \\
\text { 3. A rede terrorista Al Qaeda assume a } \\
\text { autoria dos atentados na Jordânia / E de } \\
\text { mais um ataque em Bagdá em que } \\
\text { morreram } 35 \text { pessoas } \\
\text { *Imagens da cidade } \\
\text { 4. A CPI dos Correios é prorrogada até } \\
\text { abril de } 2006 \text { / E divulga relatório pedindo } \\
\text { indiciamento de Marcos Valério e Delúbio } \\
\text { Soares } \\
\text { 5. A CPI dos Bingos ouve depoimentos de } \\
\text { suposto envio de dólares de Cuba ao PT } \\
\text { 6. O presidente Lula intervém nas } \\
\text { divergências sobre a política econômica } \\
\text { entre Casa Civil e Ministério da Fazenda } \\
\text { 7. E a Justiça decide o futuro político da } \\
\text { governadora do Rio e do secretário } \\
\text { Anthony Garotinho }\end{array}$ & $\begin{array}{l}\text { 17/11/2005 (quinta-feira) } \\
\text { Heródoto Barbeiro e Laila Dawa } \\
\text { 1. Homens brancos ganham mais } \\
\text { do que homens negros / Mulheres } \\
\text { brancas ganham mais do que } \\
\text { mulheres negras / Um estudo do } \\
\text { Ipea constatou a diferença entre os } \\
\text { dois extremos da desigualdade } \\
\text { social e étnica / As mulheres } \\
\text { negras ganham um terço do que } \\
\text { ganham os homens brancos } \\
\text { 2. Na CPI do Mensalão, nem os } \\
\text { deputados sabem as datas e se os } \\
\text { trabalhos vão ser prorrogados } \\
\text { 3. Rebelião em Alagoas: até o } \\
\text { secretário de Segurança está } \\
\text { preso } \\
\text { 4. E em Londres, a polêmica sobre } \\
\text { a abertura dos bares até mais } \\
\text { tarde. Agora no Jornal da Cultura }\end{array}$ & $\begin{array}{l}\text { 24/11/2005 (quinta-feira) } \\
\text { com Boris Casoy } \\
\text { 1. Lula reafirma que assassinato de } \\
\text { Celso Daniel foi crime comum e } \\
\text { acusa promotores de uso eleitoral do } \\
\text { caso } \\
\text { * Imagens de Lula } \\
\text { 2. A cassação de José Dirceu - } \\
\text { Quarta-feira sai a decisão do } \\
\text { Supremo, e o plenário faz a votação } \\
\text { * Imagens de José Dirceu } \\
\text { 3. A CPI dos Bingos aprova convocar } \\
\text { o compadre de Lula, Ricardo } \\
\text { Teixeira, para depor } \\
\text { * Imagens de José Dirceu } \\
\text { 4. Racha na CPI da Terra / Ruralistas } \\
\text { apresentam outro relatório e a } \\
\text { votação é adiada } \\
\text { * Imagens da CPI } \\
\text { 5. Um quadro de Portinari avaliado } \\
\text { em } 1 \text { milhão de dólares é roubado } \\
\text { em São Paulo } \\
\text { *Imagens da tela } \\
\text { 6. O IBGE mostra desemprego } \\
\text { estável e renda em queda no país } \\
\text { * Imagens de pessoas } \\
\text { 7. O Corinthians admite não ter como } \\
\text { garantir a permanência de Tevez } \\
\text { * Imagens de Tevez }\end{array}$ \\
\hline
\end{tabular}


1. Exclusivo / Gravações revelam a face violenta do contrabando internacional / seqüestros e assassinatos

2. As manobras do governo fracassam / $E$ a CPI dos Correios será mesmo prorrogada até 2006

3. Pouso forçado em São Paulo / Um helicóptero pára debaixo de um viaduto numa das principais avenidas

* Imagens do helicóptero

4. Na França, a polícia proíbe reuniões no fim de semana

5. Na Coréia do Sul, um acidente faz o mundo prender a respiração

* Imagens de uma estação de trem ou metrô, com cenas de acidente

6. Veja também o encantamento que a seleção brasileira produz nos árabes

* Imagens e jogadores brasileiros e

7. E a China apresenta os mascotes das Olimpíadas de 2008

* Imagens dos mascotes

\section{1/11/2005 (sexta-feira)} Um crime que envolve também homens árabes
18/11/2005 (sexta-feira)

Heródoto Barbeiro e Laila Dawa

1. Ato falho: o presidente Lula diz em entrevista que é candidato à reeleição para Presidente da República / Depois, volta atrás / Os tucanos ignoram a gafe e dizem que estão preparados também para voltar ao poder / A corrida eleitoral começa a um ano da eleição presidencial

2. Senadores esvaziam a votação, e cai a 'super-receita'

3. O interior do Brasil já responde por metade da riqueza que o país produz

4. No Iraque, oitenta pessoas morrem e mais de cem ficam feridas em três ataques terroristas. Essas e outras notícias agora, no Jornal da Cultura
25/11/2005 (sexta-feira)

com Boris Casoy

1. O vice José Alencar vai além da crítica aos juros e faz duro ataque à economia

* Imagens de José Alencar

2. Lula chama os críticos do governo de aves de mau agouro

* Imagens de Lula

3. O IBGE mostra que a concentração de renda diminuiu no país, embora continue alta * Imagens de pessoas na rua

4. Polícia e Receita Federal investigam fraude na liberação de mercadorias no Porto de Santos

* Imagens de carga no porto 5. Saem os retratos-falados dos ladrões da obra de Portinari em SP * Imagens dos retratos-falados

6. Uma central telefônica começa a receber denúncias de violência contra mulheres

* Imagens da central telefônica 7. Em prisão domiciliar, Pinochet completa 90 anos e recebe o comandante do Exército chileno

* Imagens do comandante

8. Tevez faz mistério sobre seu futuro e diz que antes de tudo quer ser campeão brasileiro

* Imagens de Tevez

\section{6/11/2005 (sábado)}

Salette Lemos (aos sábados)

Márcio Gomes e Sandra Annenberg

1. A nova rota do tráfico internacional de mulheres / Elas são aliciadas em Marabá no Pará / A promessa é de emprego /

Mas o destino é a prostituição

2. O arcebispo de São Luís diz que sabia do comportamento do padre acusado de pedofilia

3. Novas denúncias no escândalo do Valerioduto / $\mathrm{E}$ a superintendente do Banco Rural diz que empréstimos ao PT e a Marcos Valério eram operações de fachada

4. Eis diretor do Banco do Brasil diz que repasses suspeitos para uma agência de Marcos Valério foram determinados pelo ex-ministro Gushiken

5. O presidente Lula reafirma que não muda política econômica / E que Antonio Pallocci fica na Ministério da Fazenda 6. Na mira da Câmera / Americanos que empregam imigrantes ilegais são fotografados e denunciados

* Imagens de alguém fotografando um carro com pessoas

7. A França mergulha em mais uma noite de protesto

* Imagens das ruas na França

8. O sábado de gols no Brasileirão

* Imagens de jogos de futebol

9. E o passeio da seleção no amistoso contra os Emirados Árabes
1. O traficante Fernandinho Beira-

Mar é transferido da prisão pela

sétima vez

* Imagens da transferência

2. Temporal no Rio provoca desabamentos / Dois irmãos adolescentes morreram

* Imagens de chuva em favela

3. A oposição acredita em saída negociada para amenizar tensão entre o Congresso e o Supremo * Imagens do Congresso

4. Técnicos estudam os documentos da CPI dos Correios para apressar a conclusão das investigações

* Imagens da CPI

5. Novatos e veteranos de cursinho enfrentam amanhã Fuvest, o maior vestibular do país

* Imagens de alunos

6. Grêmio de Porto Alegre e Santa Cruz do Recife voltam para a Série A do Brasileirão

* Imagens de jogo de futebol 7. Diego Hipólito é o primeiro brasileiro a conquistar o Mundial de Ginástica Artística Masculina * Imagens do atleta em movimento 8. Palestinos já podem cruzar a fronteira com o Egito sem controle israelense

* Imagens da fronteira 
Antes de tratar dos aspectos relativos a cada telejornal, ao final da coleta temos o seguinte quadro em relação ao número de chamadas:

\begin{tabular}{|c|c|c|c|c|c|c|}
\hline \multicolumn{7}{|c|}{$\begin{array}{c}\text { TABELA XVIII - TELEJORNAIS DIÁRIOS (2005) } \\
\text { Número de Chamadas - Aberturas }\end{array}$} \\
\hline \multicolumn{3}{|c|}{ Jornal Nacional } & \multicolumn{2}{|c|}{ Jornal da Cultura } & \multicolumn{2}{|c|}{ Jornal da Record } \\
\hline Dias & $\begin{array}{c}1^{\mathrm{a}} \\
\text { semana }\end{array}$ & $\begin{array}{c}2^{\mathrm{a}} \\
\text { semana }\end{array}$ & $\begin{array}{c}1^{a} . \\
\text { semana }\end{array}$ & $\begin{array}{c}2^{a} . \\
\text { semana }\end{array}$ & $\begin{array}{c}1^{\mathrm{a}} \\
\text { semana }\end{array}$ & $\begin{array}{c}2^{\mathrm{a}} . \\
\text { semana }\end{array}$ \\
\hline $2^{a}$ & 08 & 10 & 04 & 04 & 07 & 06 \\
\hline $3^{a}$. & 07 & 07 & 04 & 04 & 07 & 07 \\
\hline $4^{a}$ & 08 & 07 & 0 & 04 & 0 & 08 \\
\hline $5^{a}$. & 0 & 07 & 04 & 04 & 06 & 07 \\
\hline $6^{a}$. & 09 & 07 & 04 & 04 & 08 & 08 \\
\hline sábado & 08 & 09 & - & - & 05 & 08 \\
\hline Total & 40 & 47 & 16 & 20 & 33 & 44 \\
\hline $\begin{array}{l}\text { Total } \\
\text { geral }\end{array}$ & \multicolumn{2}{|c|}{87} & \multicolumn{2}{|c|}{36} & \multicolumn{2}{|c|}{77} \\
\hline
\end{tabular}

Em termos quantitativos, o $J N$ é o que apresenta maior número de chamadas, seguido pelo $J R$. O $J C$ tem número fixo de chamadas a cada dia, e em quantidade menor que os outros telejornais. Tratemos agora das especificidades de cada uma das escaladas dos telejornais, primeiramente de modo geral (características formais e temáticas) e, num segundo momento, destacando as chamadas relativas aos estigmas sociais. É importante destacar que, embora muitos elementos se mantenham, à época da coleta a influência da internet (em termos de conteúdo e de forma) não era tão marcante como hoje, em que vemos grandes transformações estéticas e tecnológicas nos telejornais.

O Jornal Nacional, apresentado à época por William Bonner e Fátima Bernardes (apenas nos dias de folga do casal, geralmente aos sábados, outros jornalistas, em sistema de plantão, assumem a bancada), tem como marca registrada a música, de tons enfáticos, e o logotipo em três dimensões. Com cenário amplo e futurista, os recursos tecnológicos que caracterizam a emissora são apresentados ao fundo dos apresentadores, juntamente com o ambiente de uma redação ampla e moderna. Os tons de azul e cinza predominam no cenário, e as roupas dos apresentadores geralmente são em tons sóbrios, mais escuros para Bonner e mais claros para Bernardes. Os patrocinadores do telejornal são colocados logo no início, antes das chamadas. 
A ordem das chamadas é geralmente aquela mostrada no interior do telejornal, que entretanto apresenta muito mais notícias do que as selecionadas na escalada. Ao final das manchetes, temos a frase assertiva "Agora, no Jornal Nacional" (ou "Veja agora no $J N^{\prime}$ ”), seguida do "Boa noite" de saudação e da primeira matéria (nem sempre a primeira da escalada). O apresentador que diz "Agora" é invariavelmente o mesmo que inicia o telejornal, que alterna, assim como na escalada, a apresentação das notícias entre cada um dos jornalistas. Há sempre elementos diversos ao fundo (imagens, fotos, vinhetas, externas).

Com muitos correspondentes, repórteres e imagens para cobrir as notícias, o $J N$ apresenta maior número de chamadas e também maior número de matérias, ainda que não sejam longas. No caso das chamadas, a leitura do texto é feita em tom forte e bastante cadenciado, com modulações de voz entre graves e agudos, entonação bem marcada e ênfase em determinadas palavras, boa dicção dos apresentadores, expressões faciais bem definidas, imprimindo uma característica eufórica à leitura das notícias de abertura. As edições sempre terminam com matérias sobre esportes, geralmente futebol, enfatizando a ampla cobertura esportiva da Globo. O formato das chamadas do $J N$ assemelha-se de modo mais direto às manchetes dos jornais impressos, como se a primeira frase fosse aquela destacada em letras maiores, seguida da linha fina ou subtítulo do texto. Em tom objetivo e com frases curtas, a cadência se faz não apenas na entonação, mas na própria seleção e combinação das palavras lidas.

Em termos temáticos, notamos uma distribuição equilibrada das editorias nas chamadas do $J N$. Política, economia, esportes são as principais, mas há também notícias internacionais, variedades, comportamento. Pode-se dizer que seu alcance é nacional, pois traz notícias de várias regiões do país e não privilegia o Rio de Janeiro, local em que é filmado. Notamos ainda uma espécie de simetria nas escaladas do $J N$, pois a cada dia a sequência temática é semelhante, assim como sua composição, demonstrando rigor e planejamento atento das edições diárias. Também é possível observar que alguns temas repetem-se ao longo da semana, com uma chamada complementando a outra, assumindo que o espectador assiste ao jornal diariamente. No período analisado, política e economia abriam as chamadas do $J N$ quase todos os dias, e os escândalos envolvendo o governo foram predominantes nessas editorias.

O Jornal da Cultura anuncia logo no início de suas imagens a diferença que pretende instaurar. Sob a vinheta "jornalismo público", que antecede o telejornal, vemos imprimir-se sua marca: a Cultura é a única rede pública com programação regular em 
telejornais diários. Algumas variações estéticas podem ser notadas, muitas delas fruto do menor orçamento da emissora: o design mais simples, com menos recursos computacionais nas vinhetas e logotipos; a ausência de um cenário elaborado para o telejornal (não se vê ao fundo, como nas outras emissoras aqui tratadas), a redação do telejornal, ou pessoas trabalhando e os equipamentos utilizados. Há apenas telas de televisão ao fundo, que reproduzem a imagem dos próprios apresentadores, configurando um cenário quase totalmente estático.

No período analisado, o $J C$ não contava com apresentadores fixos, como dissemos. Nas semanas estudadas, o casal que mais se fez presente foi o dos jornalistas Heródoto Barbeiro e Laila Dawa; em alguns dias, entretanto, a apresentadora revezava a bancada com outros apresentadores, entre eles Celso Zucattelli e Ederson Granetto. A disposição do homem sentado à esquerda da tela, e da mulher à direita, repete-se no $J C$. Em termos de vestuário, não há diferença significativa: o homem geralmente veste terno escuro, e a mulher roupas mais coloridas, talvez, do que no $J N$. Atualmente, o jornal é apresentado por Willian Corrêa, coordenador geral de jornalismo da emissora, contando com uma equipe de comentaristas que se revezam a cada edição.

Em relação às chamadas de abertura do $J C$, um elemento se destaca e atesta a simplicidade anteriormente notada: não há nenhuma imagem no momento da escalada, apenas a alternância entre o casal de apresentadores. No interior do telejornal também notamos um número menor de imagens. Mais curta do que nos outros telejornais, a abertura do $J C$ indica, desde o início, que teremos talvez menos assuntos, compensados pela tentativa de aprofundá-los e explorá-los por ângulos muitas vezes não tratados nos outros telejornais. Talvez para atenuar o menor número de correspondentes, repórteres e imagens externas - atributos caros ao jornalismo -, o JC propõe-se a realizar um trabalho editorial mais elaborado, com matérias mais extensas e em menor quantidade.

Nesse aspecto, é bastante diferente do $J N$, cujas notícias aparecem em ritmo acelerado, lembrando o formato de videoclipes e sem pausas entre os vários assuntos. Ao contrário do que poderíamos supor, o $J C$, por seu caráter mais analítico, mostra-se mais opinativo (no sentido de assumir uma posição em relação aos temas abordados) do que o $J R$, fundado no padrão de um âncora que expressaria abertamente suas posições. A polifonia ensaiada no $J C$, entretanto, é apenas relativa, pois as vozes se fazem em consonância. Mesmo os comentaristas que participam do jornal - sobretudo para relatar matérias de economia, não parecendo haver uma regularidade nas suas participações não estabelecem uma dissonância em relação ao tom editorial predominante. 
Surpreendentemente, muitas vezes um jornal mais padronizado (como o $J N$ ) pode apresentar espaços mais variados na construção de suas narrativas, seja pela variedade de fontes, seja pelas diversas posições chamadas a compor seus textos e imagens ${ }^{10}$.

O telejornal começa com a saudação do apresentador, que é mais informal do que nos outros jornais, bem como sua postura durante a apresentação das notícias: "Olá amigos, começa agora o Jornal da Cultura". Ou ainda: "São 9h, começa agora o Jornal da Cultura". Ao final temos nova saudação, com o tradicional "uma boa noite para você e até amanhã”. O formato das chamadas apresentadas na abertura do telejornal é diverso em relação aos outros tratados, pois as frases são mais coloquiais, mais diretas, e não parecem seguir os padrões usuais para o discurso televisivo. Aproximando o leitor devido a uma sensação de estabelecimento de diálogo entre público e apresentadores, o texto da escalada poderia ter sido escrito para compor as notícias apresentadas no interior do jornal; ou ainda, pode ser pensado como a introdução daquilo que terá continuidade na edição diária.

Com a entrada de Heródoto Barbeiro, conhecido jornalista e profissional engajado, houve uma transformação das chamadas de abertura do $J C$, não apenas porque estas passaram a ser mais longas, e de caráter mais editorial - como se estabelecessem, de fato, uma conversa com o telespectador -, mas porque o jornal passou a contar com uma primeira chamada, apresentada por Heródoto de modo não formatado, e três chamadas mais curtas. Em termos temáticos, há recorrência de matérias de política e economia. As notícias sobre esportes não apresentam destaque no $J C$, nem mesmo o futebol, presença marcante nos outros telejornais.

Outro fator também se mostra singular: não há apresentação da previsão do tempo, com seus gráficos e vinhetas eletrônicas. Uma característica importante é o tom informativo e formativo que o $J C$ imprime a suas notícias, desde sua chamada na abertura do telejornal. É como se a cada dia o apresentador pudesse escolher os assuntos mais relevantes para o país, e apresentasse uma provocação - uma visão dos fatos analisados - para estabelecer um debate com o público. Temas muitas vezes ausentes dos outros jornais (como controle da internet) aparecem no $J C$, caracterizando um espaço de interlocução pouco comum na televisão. A tematização de aspectos menos debatidos na sociedade fornece caráter original ao $J C$, originalidade presente em suas manchetes e notícias.

\footnotetext{
${ }^{10}$ Sobre este tema, ver Arlindo Machado, A televisão levada a sério (São Paulo: Senac, 2000).
} 
O Jornal da Record, por sua vez, diferencia-se dos outros dois por contar com apenas um apresentador (Boris Casoy, à época diretor do telejornal) e, além disso, por ser mais longo. Casoy não é apenas um jornalista, mas seu nome aparece junto à vinheta do jornal, no início, personalizando-o: “Jornal da Record - Com Boris Casoy”. Um dos elementos que mais se destaca no $J R$ nas chamadas de abertura é o tom mais pausado com que são apresentadas, sem tantas modulações de voz, atribuindo um aspecto mais formal e sério ao jornal, caracterizando-se mais como um programa noticioso.

Um aspecto interessante é que todas as chamadas da escalada são acompanhadas de imagens, ao contrário dos outros jornais (o $J N$ tem algumas chamadas com imagens, o $J C$ não traz nenhuma imagem). A imagem do próprio apresentador não aparece durante a escalada e as imagens das notícias anunciadas surgem sobre o fundo da redação. As roupas de Boris Casoy são sempre escuras (geralmente um terno preto), com gravatas em cores diferentes a cada dia, porém sóbrias.

Uma das peculiaridades do $J R$ - os pequenos comentários de Boris Casoy feitos em tom coloquial ao longo do jornal - imprimem um caráter mais pausado ao telejornal. O tom predominante, entretanto, é mais sério e menos frenético que o do $J N$. A exemplo deste telejornal, o cenário do $J R$ também possui tons azulados, mas é menos repleto de elementos do que o do $J N$. Os planos para filmar os apresentadores são mais fechados, algumas vezes em close, e não há tanta valorização do fundo do estúdio. Não se vê, por exemplo, movimentação de pessoas ou da equipe, e as imagens de fundo são em menor número, mais discretas do que no $J N$. No alto da tela, entretanto, vemos um luminoso circular no qual aparecem algumas manchetes. Logo após a escalada, a imagem volta imediatamente para o âncora, então sozinho no estúdio.

As notícias apresentadas não seguem a ordem das chamadas, e parece haver menos rigor na sequência do telejornal, como se a cada dia pudesse ser destacado em primeiro lugar um tema diferente, não necessariamente de política ou economia (temas predominantes nos três telejornais). No início do telejornal, ao terminarem as chamadas, o âncora diz "boa noite" ao telespectador e, em tom pausado, anuncia: "Essas são as manchetes do Jornal da Record". Ao final do telejornal, a imagem se abre em uma panorâmica do estúdio, mostrando a redação por meio de um travelling da câmera. Nesse momento, o apresentador saúda o público, despedindo-se quase sempre com a frase: "E aqui termina o Jornal da Record. Obrigado pela atenção e pela companhia. Boa noite". Como elemento original, notamos no $J R$ a inserção de propaganda dos patrocinadores em pequenas vinhetas colocadas no canto inferior da tela. 
Em relação aos temas tratados, há uma clara predominância de chamadas de política e de economia, e o esporte não é recorrência ao final da escalada. Em termos formais, a jornalista Salette Lemos, que substitui Boris Casoy na apresentação do jornal aos sábados, faz comentários diários, ao vivo no estúdio, sobre conjuntura econômica e política nacional. Notamos maior continuidade dia após dia nas matérias apresentadas, e também uma repetição de imagens na ilustração da escalada quando o tema é o mesmo do dia anterior. Chama a atenção, nessas imagens, o grande número de cenas situadas em Brasília, sede do governo federal, e a figura do presidente Luis Inácio Lula da Silva.

Em relação aos textos, as chamadas são mais longas, escritas não como simples anúncios (ou manchetes), mas com frases mais extensas e períodos completos. Essa opção, juntamente com a locução menos veloz, distende o ritmo do telejornal e cria um espaço diacrônico na construção das notícias, em tom mais atrativo e com enfoque mais atual. Ainda assim, caracterizam-se como chamadas televisivas, e não simplesmente como textos dissertativos (que poderiam estar num jornal impresso), como no $J C$.

Tomando os temas mais recorrentes nos três telejornais em relação aos estigmas sociais, notamos de modo geral que as escaladas não privilegiam essas questões, mais presentes nos jornais impressos do que em telejornais (ou em discursos audiovisuais). Dentre eles, o Jornal Nacional apresenta um número grande de temas que podem ser relacionados, de modo mais ou menos direto, aos estigmas sociais. No total, de 87 chamadas transcritas do $J N$ podemos assinalar pelo menos vinte como relacionadas aos estigmas. Como exemplo, temos questões relativas à violência urbana, à violência no futebol, a ataques terroristas no Oriente Médio, ao tráfico de mulheres e à imigração ilegal, entre outros. Pelo menos. A maioria dessas chamadas é recoberta por imagens, sobretudo aquelas que envolvem diretamente alguma personalidade ou pessoa comum colocada em foco na notícia, por meio de entrevistas.

Para fins da nossa análise, aqui sintetizada, destacamos do $J N$ duas narrativas predominantes e recorrentes: a onda de violência na França, demarcando conflitos entre grupos sociais, etnias e questões relativas à imigração, e o caso de pedofilia envolvendo a figura de um padre encontrado com menores frequentando motéis, no Maranhão, temas recorrentes também hoje. A questão da pedofilia é bastante velada e aponta para um espaço de tabu e silenciamento em relação a um assunto fundante para entendermos a dinâmica dos estigmas: não há entrevistas, nem fontes dispostas a dar declarações; não há nenhuma imagem dos envolvidos (vítimas ou acusados); e o telejornal, ainda que tematize o assunto, é bastante lacônico em suas formas de narrar. 
No caso da França, ao contrário, as imagens muitas vezes lembram aquelas que vemos em filmes de ficção, com movimentação nas ruas em cenas geralmente noturnas, atos de vandalismo, incêndios, equipes de resgate e, eventualmente, entrevistas com transeuntes ou pessoas envolvidas nos conflitos. As chamadas estão a nos dizer, repetidamente, que a violência não acontece apenas perto, no Brasil, mas também em um país considerado um dos pilares da cultura ocidental, explicitando o momento conflituoso em que se encontra o mundo em tempos de globalização, especialmente na Europa. Os conflitos, tematizados também no cinema, acentuaram-se nos últimos anos.

O Jornal da Cultura, por sua vez, é bastante focado em temas de política e economia nacionais. Como afirmamos, por contar com poucos correspondentes, sobretudo internacionais, tem como diferencial uma visão mais crítica e sistemática das questões relacionadas ao Brasil, não se caracterizando, nesses temas, como um jornal local ou regional. Exemplo desta constatação é o baixo número de matérias, entre as 36 chamadas deste jornal, relacionadas aos estigmas: elegemos nessa categoria apenas seis manchetes, um número menor, em termos relativos, do que aquele apresentado pelo $J N$.

Entre essas, entretanto, um dado chama a atenção: os temas encontrados são diferenciados e possuem uma preocupação social mais clara, muitas vezes não estando presentes em outros telejornais. Entre os mais comuns, temos a caso do prefeito de São Paulo à época, Celso Daniel, que também aparece no $J R$, e referências a atentados terroristas no Iraque. Além desses, um assunto polêmico, relativo a mulheres, manifesta-se em três momentos ao mesmo tempo complementares e excludentes: o fato das mulheres serem mais consumistas que os homens, de acordo com pesquisa apresentada no telejornal; o fato do nascimento apenas de mulheres representar um problema para a sucessão imperial japonesa; e uma abordagem mais crítica e posicionada, relatando uma pesquisa do Ipea que aponta que as mulheres negras ganham um terço da renda dos homens brancos, numa escala que relaciona questões de gênero e etnia, temas fundamentais para pensarmos os estigmas sociais.

Finalmente, o Jornal da Record apresenta um maior número de chamadas e variedade temática, relembrando que os destaques feitos no início também são mais descritivos do que aqueles do $J N$. Entre as manchetes do $J R$, selecionamos onze como mais pertinentes aos estigmas sociais, entre elas as que se referem a questões de violência urbana e criminalidade (sobretudo tráfico de drogas, contrabando e homicídios, com destaque para a morte de um estudante na USP, assassinado por um colega de curso), e também as que envolvem assuntos internacionais ligados a ataques 
terroristas ou ao mundo árabe, visto invariavelmente, nos telejornais, como um outro ao qual devemos temer e nos afastar. Uma chamada sobre a destruição de uma estação de trem em Buenos Aires também compõe esse cenário de violência urbana presente nas manchetes do $J R$, que uma vez mais aponta para a reiteração e pregnância dessas temáticas, para além de seus conteúdos, nos telejornais e programas jornalísticos atuais.

A chamada sobre a transferência de um traficante de alta periculosidade Fernandinho Beira-Mar - opera um deslocamento temático e formal na abertura do $J R$ : majoritariamente marcado por matérias de cunho político (e na época da amostragem estávamos em plena crise do governo, com diversas denúncias sobre corrupção e CPIs instauradas) - o que explica o relativo baixo número de matérias sobre estigmas (onze) em relação ao total das chamadas (77) -, a notícia sobre Fernandinho veio em primeiro lugar na edição daquele dia. Além dela, destacamos a referência aos 90 anos de Augusto Pinochet, figura polêmica no cenário internacional por seu passado ditatorial, e as manifestações contra Bush em sua visita ao Brasil e outros países da América Latina.

Como destaques, nomeamos a recorrência dos relatos sobre a onda de violência em Paris, com presença em mais de um dia, e uma pequena notícia sobre violência contra mulheres, tema que aparece, de outra forma, no JC. Selecionamos ainda, para pontuar os resultados encontrados em torno dos estigmas sociais, uma sequência de chamadas sobre uma rebelião ocorrida na Febem de São Paulo, em que várias pessoas ficaram feridas (funcionários e adolescentes), e onde ocorreu uma morte entre esses feridos (de um interno). Consideramos esse um tema privilegiado para pensar as figurações dos estigmas sociais em telejornais.

O fato do $J R$ trazer imagens para cada uma de suas chamadas cria um campo de redundâncias, mas também de ressonâncias, bastante peculiar. Se assistirmos às manchetes sem som, veremos uma sequência de imagens frenéticas, muitas vezes, em tons escuros e com muitas cenas externas, transmitindo, no caso dos estigmas sociais, as tensões pressupostas nos temas abordados. Sabemos que os telejornais - sobretudo as aberturas e suas chamadas, mas também as notícias internas - poderiam ser largamente explorados no âmbito da temática dos estigmas. $\mathrm{Na}$ pesquisa, esperamos ter apontado elementos importantes para as análises, buscando aprofundar aspectos particulares do discurso televisivo em suas interfaces com as mídias audiovisuais, sobretudo cinema e internet, além de demonstrar sua pertinência, mesmo após inúmeras transformações nos formatos jornalísticos, mas talvez poucas mudanças em seus conteúdos. 
Nas narrativas engendradas pelos discursos (tele)jornalísticos, portanto, apontamos as (con)figurações articuladas em torno dos estigmas sociais. Tal escolha não foi aleatória, mas partiu do princípio de que, como instituição ordenadora do espaço social, o (tele)jornalismo recorta espaços de inclusão/exclusão e, ao fazê-lo, demarca as margens daquilo que será reconhecido como "normal” ou “desviante" (Foucault, 2002) em uma determinada sociedade, reforçando e estabilizando determinados discursos

Da mesma forma, outros produtos audiovisuais, notadamente filmes em longa metragem (ficcionais ou documentais), estabelecem recortes semelhantes. A fim de melhor apontar tal relação, retomamos alguns dos conceitos norteadores de nossa concepção de estigmas sociais antes de passarmos às imagens e leituras dos filmes selecionados. Pensando os dois formatos de maneira semelhante - por se tratarem de discursos audiovisuais - gostaríamos de estabelecer seus pontos de afastamento e aproximação, como veremos na parte específica sobre cinema. Em comparação aos filmes, os telejornais - ainda que caracterizados por um discurso heteróclito - parecemnos menos diversos em suas formas de reportar os estigmas. Esperamos encontrar, nos filmes analisados, uma maior polifonia e dissonância, assinalando maior diversidade nas encenações e representações dos estigmas sociais.

\section{Estigmas em filmes: primeiras imagens}

Nesse momento, gostaríamos de rearticular alguns dos pressupostos teóricos anteriormente tratados, preparando-nos para a apresentação dos resultados em relação à produção audiovisual. A palavra estigmas pode ser definida de diversas formas. Em nossa pesquisa, optamos por diferenciá-la de algumas outras às quais tem sido frequentemente associada - os estereótipos, os preconceitos, as discriminações às minorias. Como dissemos, tomamos o conceito de estigmas - especialmente em sua adjetivação como sociais - como mais abrangente e, possivelmente, estruturante, dessas palavras correlatas. Enquanto os preconceitos podem ser pensados de forma mais localizada (não são poucos os exemplos de discursos preconceituosos nas mídias), e os estereótipos podem ser caracterizados como modelos cristalizados (a partir dos quais determinados grupos são definidos), os estigmas apresentam-se como categorias invariantes (ou que se repetem não em termos de conteúdos, mas de articulações). 
Tais categorias não necessariamente - ainda que majoritariamente - possuem conotação negativa, enquanto os estereótipos e os preconceitos dirigem-se, prioritariamente, a grupos excluídos ou periféricos em relação à dinâmica social dominante: “Observe-se, também, que nem todos os atributos indesejáveis estão em questão, mas somente os que são incongruentes com o estereótipo que criamos para um determinado tipo de indivíduo" (Goffman, 1978: 13). Não podemos esquecer, entretanto, que a questão dos estigmas se complexifica quando estes se encontram interrelacionados a estereótipos e preconceitos fortemente arraigados na sociedade. Isso acontece no caso de temas como racismo, violência, questões de gênero, entre outros.

Alguns aspectos, desse modo, são fundamentais para conceituarmos e diferenciarmos os estigmas sociais: 1) seu caráter invariante não os torna estáticos (são inúmeros os recobrimentos que recebem em cada contexto histórico, social, cultural); 2) sua dinâmica é, sobretudo, relacional (um estigma só opera em relação a outros elementos colocados em um determinado sistema de interações sociais); 3) sua definição retoma as origens da palavra: estigmas são marcas que se destacam no sujeito e, ao fazê-lo, ressaltam determinados atributos; 4) tal marcação realiza, ao mesmo tempo, processos de inclusão/exclusão que unem e separam aqueles implicados nessa relação; 5) as definições e consensos sobre aquilo que é considerado normal ou desviante determinam os alcances e limites dos estigmas sociais.

Acrescentamos que os estigmas surgem apenas quando o sujeito estigmatizado encontra-se em um lugar no qual não deveria estar, ou seja, quando atributos desejáveis ou indesejáveis deixam de ocupar seu lugar como estabelecidos ou estigmatizados e tentam romper tais barreiras. A tentativa de manter a ordem e restabelecer hierarquias procedimentos característicos da atribuição de estereótipos e preconceitos a certos grupos sociais - radicaliza os processos de inclusão/exclusão, levando à articulação desses atributos em torno de estigmas sociais: “O termo estigma, portanto, será usado em referência a um atributo profundamente depreciativo, mas o que é preciso, na realidade, é uma linguagem de relações e não de atributos. Um atributo que estigmatiza alguém pode confirmar a normalidade de outrem, portanto ele não é, em si mesmo, nem honroso nem desonroso" (Goffman, 1978: 13).

Como exemplo, podemos citar a minissérie "Um só coração" (2004), da Rede Globo. Ao lermos no jornal Folha de S. Paulo (Ilustrada, 21/03/2004) que esta "Série tem ibope com familiares e na USP”, vemos surgir uma sobreposição de estigmas: o da televisão como veículo massivo e, portanto, de má qualidade; o dos intelectuais como 
avessos à televisão; o da USP como reduto da elite; o dos familiares como opostos à suposta capacidade crítica da universidade; além daquele enunciado na chamada de capa do caderno - "Modernismo para as massas" -. no qual a população em geral é colocada como oposta ao campo da cultura dita "erudita". Todas essas tematizações apontam para os diversos estigmas presentes nos textos citados.

Pela breve exposição acima, percebemos que os estigmas são um campo de difícil apreensão. Mas é preciso retomar algo crucial: ainda que tivéssemos uma definição unívoca de estigmas, por não estarmos tratando abstratamente deste termo seria necessário olhar as produções culturais para buscar uma aproximação a este conceito a partir de suas tematizações, ou seja: ler/ver os discursos contemporâneos para deles extrair uma definição de estigmas, refletindo sobre o que há em comum na diversidade dos temas, em um movimento que parte dos conceitos para a eles retornar. Tal movimento pode ser percebido também nas análises de filmes ficcionais e documentais, etapa da pesquisa que estende os limites dos discursos jornalísticos a outros campos das práticas midiáticas. Lembramos que, inicialmente, não havia a necessidade de diferenciar os filmes entre ficção e documentário.

O maior número de produções documentais e as diversas formas de cruzamentos assinaladas recentemente entre esses dois gêneros levou-nos a esse caminho, estabelecendo uma categorização que considera também tais especificidades. Num segundo momento, levamos em conta a distinção entre o campo da fícção e da nãoficção de forma mais sistematizada, por meio da seleção de filmes de ambos os gêneros. Em termos formais, a proximidade dos documentários (filmes de não-ficção) com os telejornais (especialmente as reportagens) tornou-se evidente ${ }^{11}$. Além disso, evocamos os modos variados de inserção de elementos factuais nas narrativas ficcionais (como em telenovelas), e também o processo inverso, de ficcionalização da realidade.

Tomamos como eixo articulador a análise de filmes em longa-metragem, ficcionais ou documentais, exibidos em circuito comercial. Considerando o crescimento recente (e relevante) das produções cinematográficas brasileiras após o chamado período da retomada (segunda metade da década de 1990), optamos por tratar apenas de filmes nacionais. Como recorte temporal, elegemos inicialmente os anos de 2002 a 2011 e, posteriormente, os anos de 2012 a 2014.

\footnotetext{
${ }^{11}$ A relação entre filmes documentários e reportagens televisivas foi tema de pós-doutorado desenvolvido junto à Unicamp (2010-2012).
} 
Constituímos, assim, uma amostragem não aleatória a partir do acompanhamento dos lançamentos dos primeiros anos da década de 2000, sem uma preocupação exaustiva seja no sentido de abordar qualitativamente todos os filmes lançados, seja no sentido de explorar um conjunto completo de filmes em termos quantitativos. Os filmes lançados em 2002 foram selecionados entre os considerados relevantes para a amostragem e, de certo modo, precursores daqueles lançados em 2003. No período assinalado, elaboramos uma listagem com filmes escolhidos a partir de critérios pré-determinados ${ }^{12}$.

Em primeiro lugar, definimos a escolha por meio do conceito de estigmas sociais, já apresentado; em segundo lugar, optamos por abordar filmes que representam uma tendência no cinema brasileiro contemporâneo ao tratar de temáticas políticas e sociais, quase sempre de forma crítica e engajada; finalmente, em terceiro lugar buscamos montar um mosaico variado de produções nacionais recentes, elegendo para as análises filmes que apresentam aspectos singulares e, sobretudo, diferenciados entre si. Em termos metodológicos, optamos por não analisar cada filme exaustivamente, mas neles isolar percursos narrativos que tematizam os estigmas, especialmente por meio de seus personagens.

Também por questões metodológicas e afinidades de produção, distribuição e recepção, nas primeiras análises os filmes foram divididos em dois períodos: 2002-2006 e 2007-2011, sendo que no segundo período organizamos a amostragem em dois grupos, o primeiro tratando das produções realizadas entre 2007-2009 e o segundo daquelas feitas entre 2010-2011, relacionando estas últimas àquelas apresentadas sobre os filmes de 2012-2014. Aspectos narrativos, estéticos, estilísticos e tecnológicos determinaram tais divisões, o que não se justifica apenas por razões cronológicas mas, sobretudo, pelos traços comuns presentes nos filmes delas constantes.

Apresentamos abaixo uma tabela contendo títulos e principais características dos primeiros filmes selecionados (2002-2006) para, em seguida, destacarmos dois filmes específicos deste período, considerados modelares para demonstrar as hipóteses.

\footnotetext{
${ }^{12}$ Os dados constantes das tabelas foram pesquisados pela internet, com indicação dos sites utilizados. Em alguns casos, anotações pessoais e artigos de jornal complementaram essas informações.
} 


\subsection{Filmes em longa-metragem (ficcionais e/ou documentais)}

$\mathrm{Na}$ análise de filmes em longa-metragem, pretendemos relacionar os discursos jornalísticos aos discursos midiáticos, considerando o termo "mídias" em sentido amplo. Os filmes exibidos em circuito comercial de cinema são parte integrante desses discursos das mídias, sem que, com isso desconsideremos o cinema também como uma indústria (em seus modos de produção e distribuição) e uma arte (em suas formas de concepção e recepção). Além dessas distinções, o estatuto da autoria e o lugar do narrador no cinema constituem-se em indagações fundamentais sobre os discursos midiáticos audiovisuais.

A partir do mapeamento realizado, apresentamos uma seleção de filmes relacionados aos estigmas sociais ${ }^{13}$. Reforçamos o fato de a amostragem ter sido constituída de forma não aleatória, ao contrário das precedentes. No caso dos jornais, revistas e telejornais montamos uma organização a partir de dados cronológicos, e não temáticos.

\begin{tabular}{|c|c|c|c|c|c|}
\hline \multicolumn{6}{|c|}{ TABELA XIX } \\
\hline & Título & Diretor & Ano & Gênero & Duração \\
\hline 1. & Cidade de Deus & Fernando Meirelles & 2002 & Ficção & $135 \min$ \\
\hline 2. & Durval Discos & Anna Muylaert & 2002 & Ficção & $96 \min$ \\
\hline 3. & Edifício Master & Eduardo Coutinho & 2002 & Documentário & $110 \mathrm{~min}$ \\
\hline 4. & O invasor & Beto Brant & 2002 & Ficção & $97 \mathrm{~min}$ \\
\hline 5. & Janela da alma & João Jardim & 2002 & Documentário & $73 \mathrm{~min}$ \\
\hline 6. & Madame Satã & Karim Ainouz & 2002 & Ficção & $105 \min$ \\
\hline 7. & Uma onda no ar & Helvécio Ratton & 2002 & Fiç̧ão & $92 \mathrm{~min}$ \\
\hline 8. & Ônibus 174 & José Padilha & 2002 & Documentário & $133 \mathrm{~min}$ \\
\hline & $\begin{array}{l}1,99 \text { - Um supermercado } \\
\text { de palavras }\end{array}$ & Marcelo Masagão & 2003 & Ficção & $72 \mathrm{~min}$ \\
\hline 10 & Amarelo manga & Cláudio Assis & 2003 & Ficção & $100 \min$ \\
\hline 11 & O caminho das nuvens & Vicente Amorim & 2003 & Ficção & $100 \mathrm{~min}$ \\
\hline 12 & Carandiru & Hector Babenco & 2003 & Ficção & $146 \min$ \\
\hline 13 & O homem do ano & José Henrique Fonseca & 2003 & Ficção & $116 \mathrm{~min}$ \\
\hline 14 & O homem que copiava & Jorge Furtado & 2003 & Ficção & $124 \min$ \\
\hline 15 & Houve uma vez dois verões & Jorge Furtado & 2003 & Ficção & $75 \mathrm{~min}$ \\
\hline 16 & Passaporte húngaro & Sandra Kogut & 2003 & Documentário & $71 \mathrm{~min}$ \\
\hline
\end{tabular}

${ }^{13}$ É importante assinalar que os resultados parciais da pesquisa têm sido divulgados regularmente em forma de comunicações em congressos e artigos, apontando para sua consolidação e sistematização.

${ }^{14}$ Filmes lançados em 2002, considerados relevantes para a pesquisa, foram incluídos na amostragem. Dentre os lançamentos de filmes brasileiros no período, selecionamos aqueles que tratavam da temática dos estigmas sociais. Foram consideradas as datas em que os filmes entraram em cartaz no circuito comercial de cinema, ainda que alguns tenham sido produzidos em anos anteriores, havendo divergência em alguns casos, o que se repete nas tabelas seguintes. 


\begin{tabular}{|c|c|c|c|c|c|}
\hline \multicolumn{6}{|c|}{$\begin{array}{c}\text { TABELA XX } \\
\text { FILMES DE FICÇÃO E NÃO-FICÇÃO (2004-2005) }\end{array}$} \\
\hline & Título & Diretor & Ano & Gênero & Duração \\
\hline 17. & Cazuza - O tempo não pára & $\begin{array}{l}\text { Sandra Werneck e } \\
\text { Walter Carvalho }\end{array}$ & 2004 & Ficção & $90 \mathrm{~min}$ \\
\hline 18. & Contra todos & Roberto Moreira & 2004 & Ficção & $95 \mathrm{~min}$ \\
\hline 19. & De passagem & Ricardo Elias & 2004 & Fiç̧ão & $87 \mathrm{~min}$ \\
\hline 20. & Entreatos & João Moreira Salles & 2004 & Documentário & $117 \min$ \\
\hline 21. & Fala tu & Guilherme Coelho & 2004 & Documentário & 74 min \\
\hline 22. & As filhas do vento & Joel Zito Araújo & 2004 & Ficção & $85 \mathrm{~min}$ \\
\hline 23. & Garotas do ABC & Carlos Reichenbach & 2004 & Ficção & $124 \mathrm{~min}$ \\
\hline 24. & À margem da imagem & Evaldo Mocarzel & 2004 & Documentário & $72 \mathrm{~min}$ \\
\hline 25. & Narradores de Javé & Eliane Caffé & 2004 & Fiç̧ão & $100 \mathrm{~min}$ \\
\hline & Olga & Jayme Monjardim & 2004 & Fiç̧ão & $141 \mathrm{~min}$ \\
\hline 27. & O outro lado da rua & Marcos Bernstein & 2004 & Ficção & $97 \mathrm{~min}$ \\
\hline 28. & Pelé eterno & Aníbal Massaini & 2004 & Documentário & $120 \mathrm{~min}$ \\
\hline 29. & Peões & Eduardo Coutinho & 2004 & Documentário & $85 \mathrm{~min}$ \\
\hline $\begin{array}{l}30 . \\
\text { ferro }\end{array}$ & O prisioneiro da grade de & Paulo Sacramento & 2004 & Documentário & $123 \mathrm{~min}$ \\
\hline & Redentor & Claudio Torres & 2004 & Fiç̧ão & $95 \mathrm{~min}$ \\
\hline 32. & Brilhante & Conceição Senna & 2005 & Documentário & $75 \mathrm{~min}$ \\
\hline 33. & Cabra cega & Toni Venturi & 2005 & Ficção & $107 \mathrm{~min}$ \\
\hline 34. & Cidade baixa & Sérgio Machado & 2005 & Fiç̧ão & $93 \mathrm{~min}$ \\
\hline 35. & Cinema, aspirinas e urubus & Marcelo Gomes & 2005 & Ficção & $90 \mathrm{~min}$ \\
\hline 36. & 2 filhos de Francisco & Breno Silveira & 2005 & Fiç̧ão & $132 \min$ \\
\hline 37. & Família Alcântara & Daniel e Lilian Solá & 2005 & Documentário & $56 \mathrm{~min}$ \\
\hline 38. & O fim e o princípio & Eduardo Coutinho & 2005 & Documentário & $110 \min$ \\
\hline 39. & Garrincha - Estrela solitária & Milton Alencar & 2005 & Fiç̧ão & $110 \min$ \\
\hline 40. & Do luto à luta & Evaldo Mocarzel & 2005 & Documentário & 75 min \\
\hline & Meninas & Sandra Werneck & 2005 & Documentário & $71 \mathrm{~min}$ \\
\hline 42. & Meu tio matou um cara & Jorge Furtado & 2005 & Ficção & $85 \mathrm{~min}$ \\
\hline & Olhar estrangeiro & Lucia Murat & 2005 & Documentário & $70 \mathrm{~min}$ \\
\hline 44. & A pessoa é para o que nasce & Roberto Berliner & 2005 & Documentário & $84 \mathrm{~min}$ \\
\hline 45. & Preto e branco & Carlos Nader & 2005 & Documentário & $74 \mathrm{~min}$ \\
\hline & Pro dia nascer feliz & João Jardim & 2005 & Documentário & $88 \mathrm{~min}$ \\
\hline 47. & Quanto vale ou é por quilo? & Sérgio Bianchi & 2005 & Ficção & $104 \min$ \\
\hline & Quase dois irmãos & Lucia Murat & 2005 & Fiç̧ão & $102 \min$ \\
\hline & Vlado: 30 anos depois & João Batista Andrade & 2005 & Documentário & $90 \mathrm{~min}$ \\
\hline
\end{tabular}




\begin{tabular}{|c|c|c|c|c|}
\hline \multicolumn{5}{|c|}{ FILMES DE FICÇÃO E NÃO-FICÇÃO (2006) } \\
\hline Título & Diretor & Ano & Gênero & Duração \\
\hline 1972 & José Emílio Rondeau & 2006 & Ficção & $100 \min$ \\
\hline Achados e perdidos & José Joffily & 2006 & Fiç̧ão & $100 \mathrm{~min}$ \\
\hline $\begin{array}{l}\text { 52. O ano em que meus } \\
\text { pais saíram de férias }\end{array}$ & Cao Hamburger & 2006 & Fiç̧ão & $110 \mathrm{~min}$ \\
\hline 53. $\quad$ Anjos do sol & Rudi Lagemann & 2006 & Ficção & $92 \min$ \\
\hline Antônia & Tata Amaral & 2006 & Ficção & $90 \mathrm{~min}$ \\
\hline Árido movie & Lírio Ferreira & 2006 & Ficção & $115 \min$ \\
\hline $\begin{array}{l}56 . \quad \text { Boleiros } 2- \\
\text { Vencedores e vencidos }\end{array}$ & Ugo Giorgetti & 2006 & Fiç̧ão & 86 min \\
\hline 57. Brasília $18 \%$ & Nelson Pereira dos Santos & 2006 & Ficção & $102 \min$ \\
\hline Cafundó & Paulo Betti e Clóvis Bueno & 2006 & Ficção & $101 \mathrm{~min}$ \\
\hline Cafuné & Bruno Vianna & 2006 & Ficção & $73 \mathrm{~min}$ \\
\hline O céu de Suely & Karim Aïnouz & 2006 & Fiç̧ão & $88 \mathrm{~min}$ \\
\hline A concepção & José Eduardo Belmonte & 2006 & Ficção & $96 \min$ \\
\hline Crime delicado & Beto Brant & 2006 & Ficção & $87 \mathrm{~min}$ \\
\hline Os 12 trabalhos & Ricardo Elias & 2006 & Ficção & $90 \min$ \\
\hline Estamira & Marcos Prado & 2006 & Documentário & $115 \min$ \\
\hline Eu me lembro & Edgard Navarro & 2006 & Fiç̧ão & $108 \mathrm{~min}$ \\
\hline $\begin{array}{ll}66 . & \text { Falcão - Meninos do } \\
\text { tráfico } & \end{array}$ & $\begin{array}{l}\text { MV Bill, Celso Athayde e } \\
\text { Centro de Audiovisual da } \\
\text { Central Única das Favelas }\end{array}$ & 2006 & Documentário & $125 \mathrm{~min}$ \\
\hline Intervalo clandestino & Eryk Rocha & 2006 & Documentário & 95 min \\
\hline O maior amor do mundo & Carlos Diegues & 2006 & Ficção & $106 \mathrm{~min}$ \\
\hline À margem do concreto & Evaldo Mocarzel & 2006 & Documentário & $85 \mathrm{~min}$ \\
\hline Mulheres do Brasil & Malu Martino & 2006 & Ficção & $113 \mathrm{~min}$ \\
\hline No meio da rua & Antonio Carlos Fontoura & 2006 & Ficção & $89 \mathrm{~min}$ \\
\hline $\begin{array}{l}72 . \quad \text { O passageiro: } \\
\text { segredos de adulto }\end{array}$ & Flávio Tambellini & 2006 & Ficção & $105 \min$ \\
\hline $\begin{array}{l}73 . \quad \text { O Sol - Caminhando } \\
\text { contra o vento }\end{array}$ & Tetê Moraes & 2006 & Documentário & $90 \mathrm{~min}$ \\
\hline 74. Zuzu Angel & Sergio Rezende & 2006 & Ficção & $110 \min$ \\
\hline
\end{tabular}

* As tabelas apresentam um grande número de filmes, tomando como critério principal sua correlação ao tema dos estigmas sociais. Notemos que a variação em termos de número de espectadores, tempo em cartaz e repercussão na crítica é bastante acentuada, trazendo desde filmes com menos de 100 mil espectadores até filmes com 5 milhões de espectadores.

** Dados pesquisados em www.ancine.gov.br (lançamentos por ano).

*** Para fichas técnicas completas, elenco, sinopses e demais informações sobre os filmes, ver www.adorocinemabrasileiro.com.br.

*** As tabelas relativas aos anos de 2007, 2008 e 2009 serão apresentadas no próximo tópico. 
Um aspecto fundamental diz respeito ao alargamento das hipóteses para tratar de discursos constituídos de modo distinto do jornalismo em relação aos estigmas sociais. Após observar jornais impressos, revistas e telejornais, no campo cinematográfico os filmes documentários parecem indicar uma possibilidade na qual inserir o debate proposto, pois visam produzir um efeito de sentido de realidade. De outro lado, os filmes definidos como ficcionais engendram formas narrativas singulares em seus discursos. Ao buscar em cada filme sequências e personagens relacionados aos estigmas, podemos justificar sua pertinência ao âmbito do trabalho.

Se notarmos os dados compilados pelo site Filme B, temos que "de 1995 (ano tido como marco do início da 'retomada' do cinema nacional) até 2003, estrearam uma média de 23 títulos nacionais por ano. Em 2004 esse número pulou para 47 filmes. Se em 2005 houve um leve recuo para 39 estreias, apenas no primeiro semestre de 2006 foram lançados 31 filmes nacionais. Com mais 27 estreias previstas até o final do ano totalizaríamos um recorde no período: 58 estreias brasileiras em salas de cinema" ${ }^{\text {. }}$. Reunindo os totais apresentados nas tabelas, a saber: 8 títulos em 2002; 8 títulos em 2003; 15 títulos em 2004; 18 títulos em 2005; e 25 títulos em 2006, veremos que o número de filmes selecionados é significativo (74).

Uma das questões que nos colocamos nesse momento é sobre o significado desses números. O que revelam para a pesquisa? O que sinalizam em relação ao cinema brasileiro? Em princípio, acreditamos que a forte tônica em filmes políticos e de crítica social já determina sua vinculação ao tema dos estigmas sociais. De maneira mais ou menos direta, grande parte dos filmes brasileiros (com exceção, no caso da amostragem, de comédias, comédias românticas, filmes de época, adaptações literárias, fílmes experimentais) tematiza, de algum modo, questões relativas aos estigmas.

Como forma de ressaltar recorrências, apresentamos algumas considerações em torno de dois filmes escolhidos como exemplares para tematizar os estigmas sociais no cinema. Os filmes são Cidade de Deus, de Fernando Meirelles, e Uma onda no ar, de Helvécio Ratton, ambos lançados em 2002, e serão analisados a partir dos eixos de reforço ou transposição de estigmas sociais, conceitos que guiarão também a análise posterior de produtos audiovisuais. Buscamos apontar, nessas duas produções, figurações simbólicas e formas narrativas articuladas em torno da crescente exploração da miséria e ambientes a ela relacionados, elegendo este recorte para tratar da questão

\footnotetext{
${ }^{15}$ Disponível em: www.filmeb.com.br. Acesso em: 24/03/2008.
} 
dos estigmas sociais. Esperamos demonstrar como os discursos produzidos pelos filmes analisados são figurativizados (as formas que os recobrem) e tematizados (como se articulam suas narrativas), especialmente naquilo que se refere a espaços fronteiriços em que possíveis deslocamentos (ou transposições) podem ser notados. Por tratarmos de filmes que abordam a questão da pobreza e a crítica social à realidade brasileira, situamos a análise na questão dos estigmas presentes nessas imagens ${ }^{16}$.

É interessante notar que, nos últimos anos, vimos um movimento que parte do cinema para a televisão no que diz respeito a essas temáticas, como nas séries televisivas Cidade dos Homens (2002-2005) e Carandiru (2005), realizadas a partir dos longas-metragens que as antecederam. Tal movimento aponta para o processo recente de hibridização e convergência das mídias (Santaella, 1996), potencializado pelas tecnologias digitais de comunicação. Aponta, ainda, para a relevância que a mídia assume, na sociedade contemporânea, para a legitimação e a circulação de discursos, os quais ordenam nossas formas de ver e agir no mundo (Foucault, 1996).

Entre eles, destacamos aqueles que corroboram ou questionam determinados estigmas na sociedade, gerando efeitos de sentido a partir de suas figurações e narrativas. Dessa forma, as mídias podem ser pensadas como lugares de divulgação e legitimação de discursos, tomando-os como bases de ação - práticas sociais - que os materializam, “até porque a imagem não é uma mera atuação estilística, e sim algo que conduz a um comportamento concreto, traz resultados tangíveis" (Gregori, 2000: 43).

Como vimos, o cinema brasileiro contemporâneo tem se caracterizado pelo enfoque predominante em temáticas sociais e políticas. Inúmeras produções atestam este fato - entre elas, os filmes Ônibus 174 (2002), de José Padilha, Edifício Master (2002), de Eduardo Coutinho, e outros, tais como O homem do ano (2003), de José Henrique Fonseca, e Amarelo manga (2003), de Cláudio Assis. Os filmes escolhidos para nossa análise - Cidade de Deus (2002), de Fernando Meirelles, e Uma onda no ar (2002), de Helvécio Ratton - inserem-se nessa dinâmica. Ao abordá-los, gostaríamos de lançar algumas questões: quais as imagens mostradas por esses filmes em relação aos estigmas da pobreza e suas figurações simbólicas? Quais as narrativas neles apresentadas? Quais as convergências e divergências que os dois filmes trazem em suas figurações e narrativas? Haveria, de fato, no cinema brasileiro, um movimento de estetização da pobreza, transformando-a em mais um produto pronto para consumo?

\footnotetext{
${ }^{16}$ Uma versão preliminar, já publicada, dos elementos tratados a seguir em relação aos dois filmes foi desenvolvida juntamente com a pesquisadora Cíntia Liesenberg (PUC-Campinas).
} 
Apresentaremos, primeiramente, uma síntese dos filmes e os principais conceitos teóricos que fundamentam as análises para, em seguida, desenvolver um traçado contrastivo entre eles, a fim de apontar as diferentes formas que seus discursos assumem, em torno da figuração simbólica da pobreza, no reforço ou transposição de estigmas sociais que marcam os sujeitos inseridos nesse espaço e as relações entre eles.

O filme Cidade de Deus já foi vastamente discutido e difundido. Um aspecto chama a atenção em relação a sua produção: as filmagens foram antecedidas por um intenso trabalho de preparação dos atores que, moradores de diversas comunidades do Rio de Janeiro (RJ), integraram um projeto do grupo "Nós do Morro" para inserção desses rapazes e moças em produções televisivas, cinematográficas e teatrais. A história contada tem início na década de 1960, em que ações governamentais deslocaram para a periferia da cidade do Rio de Janeiro populações pauperizadas e desabrigadas. Desprovidos de acesso a serviços básicos de saneamento, educação, transporte e infraestrutura, esses locais se transformaram em grandes favelas e passaram a concentrar, à medida que o tráfico de drogas ampliava seu alcance, inúmeros problemas crônicos de grandes cidades, especialmente violência, desemprego, miséria social.

O filme, baseado no romance de mesmo nome escrito por Paulo Lins, em 1997, foi criticado justamente por enfatizar de maneira árida e crua - ainda que permeada por uma filmagem impecável e edição ousada - os aspectos negativos daquele lugar. É como se, na favela, não houvesse possibilidade de ação ou transposição; como se aquelas pessoas estivessem desde sempre condenadas à segregação e ao abandono. Vale destacar que a história, além de trabalhar com atores que vivem em comunidades semelhantes à Cidade de Deus concreta, apresenta fortes elementos factuais - embora não se pretenda um documentário e sem utilizar recursos próprios desse gênero, notamos uma busca de referencialidade em suas imagens.

Partindo dessas observações - e reconhecendo as qualidades de uma obra que se tornou mundialmente conhecida -, o filme Uma onda no ar, lançado no mesmo ano, parece-nos oferecer um contraponto significativo a Cidade de Deus, especialmente no que diz respeito às formas de representar o ambiente da favela e suas relações com o entorno da cidade, e aos modos de narrar as histórias vividas por seus personagens. Como lemos no site de Uma onda no ar, o filme "é ficção com os pés na terra, a realidade é matéria prima de sua fantasia. No filme, fatos verdadeiros se misturam aos imaginários e os personagens cinematográficos se inspiram, com liberdade, nos personagens reais". 
O filme conta a história da rádio Favela, uma rádio livre que surgiu nos anos 1980 em uma comunidade de Belo Horizonte (MG), com programação diferenciada que pretendia ser "a voz do morro". Mais do que falar sobre ou para a favela, a rádio buscava ter um alcance maior e passou a contar com inúmeros ouvintes, até sua legalização em 2000. É interessante notar como são apresentadas as relações da favela como "mais um lugar para se viver", sempre ressaltando as redes sociais ali presentes e as formas de atuação de seus moradores.

Ao contrário de Cidade de Deus, Uma onda no ar evoca outras maneiras de se pensar o ambiente da favela, em que violência, tráfico e crime estão presentes, mas não de forma exclusiva, o que abre passagem para a criação de uma rádio naquele ambiente. Como ponto em comum nesses filmes, além de serem de alguma forma baseados em fatos e dotados de estrutura referencial, temos uma representação da sociedade brasileira que estabelece demarcações precisas entre centro e periferia, cidade e favela, riqueza e pobreza: "É uma sociedade na qual a população das grandes cidades se divide entre um 'centro' e uma 'periferia', o termo periferia sendo usado não apenas no sentido espacialgeográfico, mas social, designando bairros afastados nos quais estão ausentes todos os serviços básicos, situação, aliás, encontrada no 'centro', isto é, nos bolsões de pobreza, as favelas" (Chauí, 1986: 58-59).

Se tomarmos como pressuposto a definição de estigmas como relacionados à ideia de estagnação e mobilidade, podemos dizer que eles aparecem justamente nos lugares em que há tentativas de deslocamento. Um morador de favela que se integre ao mundo do tráfico de certo modo cumpre aquilo dele esperado; um morador de favela que desenvolva o projeto de uma rádio é visto como fora do lugar a ele reservado.

Esse contraste inicial nos revela as pontuações possíveis nos dois filmes selecionados em relação aos estigmas sociais: tomados como estigmas de reforço ou de transposição, temos que quando permanecem onde supostamente deveriam estar os estigmas não incomodam (e cumprem seu papel como demarcadores de diferenças entre os diversos grupos sociais). A partir do momento em que se deslocam e passam a ocupar posições antes insuspeitadas, surge o desconforto. A questão da pobreza e suas figurações simbólicas e formas narrativas nos parece apropriada para pensar os processos de deslocamento dos estigmas.

Filmes como Central do Brasil (1998), de Walter Salles, Cidade de Deus (2002), de Fernando Meirelles e $O$ homem que copiava (2003), de Jorge Furtado, caracterizam de modos distintos um elemento comum: fundados em temáticas sociais que trazem 
entre seus elementos uma forte crítica à realidade brasileira, esses filmes nos lembram que ainda que não seja possível mudar de lugar nesta sociedade - justamente por não podermos precisar suas margens, não há um lugar para o qual pudéssemos ir - os próprios personagens demarcam esse lugar - e por isso permanecem (i)mobilizados em suas posições.

De modo geral, em Cidade de Deus é como se a despeito de se deslocarem para outros ambientes as pessoas voltassem sempre para o mesmo lugar; em Uma onda no ar, temos a impressão de relações sociais que apontam para mudanças de espaço. No primeiro filme, os estigmas são reforçados e mantidos; no segundo, podemos perceber elementos que vão além da estigmatização. Iremos demonstrar, nos filmes, como tais afirmações podem ser ou não confirmadas, relacionando-os ao tema dos estigmas sociais e ampliando nosso questionamento para as mídias: como perceber, em seus discursos, relações que podem aprofundar ou minimizar os estigmas presentes na sociedade? Como perceber os sentidos agregados aos estigmas sem tomá-los como positivos ou negativos a priori mas concebendo-os a partir de um sistema relacional de posições e oposições na linguagem?

A partir dos filmes, podemos notar que mesmo que o estigma surja como elemento simbólico, os estigmatizados têm que se colocar no lugar ao qual são destinados; eles ou incorporam ou reforçam os estigmas pelos quais querem lutar encenando aquilo que é esperado deles, como acontece em estudo de Elias e Scotson (2000) em relação a grupos considerados situados à margem de um grupo já estabelecido na localidade analisada: “(...) a única maneira que conheciam de mostrar aos que os tratavam como 'ninguém' que de fato eles eram 'alguém' era inteiramente negativa, a exemplo do sentimento que eles tinham a respeito de sua identidade" (Elias e Scotson, 2000: 144-145).

Ainda assim, há brechas e espaços para a transgressão e transposição de estigmas, dependendo do modo como se estabelecem as relações entre os diversos atores sociais (estabelecidos ou estigmatizados) e os discursos sobre eles construídos (e que os constroem). Dessa forma, os estigmas podem ser pensados como marcas identitárias que caracterizam (ou descaracterizam) os grupos sociais que, ao serem retratados pelas mídias (jornais, televisão, cinema, entre outras), têm suas marcas destacadas. Muitas vezes, ao se colocar como algo que é já de antemão esperado, o estigma é neutralizado, mantendo a ordem estabelecida; outras vezes, se deslocado e levado a um processo de inclusão, os traços característicos do estigma podem ser 
anulados por meio da atribuição de valores positivos ou negativos. Conseguir ser visto de outra forma sem perder sua identidade - sua marca - parece ser uma questão colocada a grupos excluídos da lógica predominante de organização social.

Nas relações estabelecidas pelos discursos, nem sempre a mera citação de um grupo excluído torna-se fator de inclusão; em outros momentos, mencionar a diferença pode incluir um outro grupo nas redes simbólicas da sociedade. Algumas das diferenças sociais "percebidas, elaboradas e objetivadas" (Telles, 2001: 58) no espaço social por meio de figurações simbólicas e formas narrativas em Cidade de Deus e Uma onda no ar serão apresentadas a seguir.

$\mathrm{Na}$ procura por elementos que pudessem ser indicativos das figurações e narrativas articuladas em torno da exploração da pobreza, e considerando que "para uma sociedade, uma posição e um momento definidos apenas uma parte do dizível é acessível, que esse dizível forma um sistema e delimita uma identidade" (Maingueneau, 2000: 68-69), recorre-se a estudos de Lévi-Strauss (1996) sobre as estruturas do mito, como auxílio para o levantamento de variantes comuns entre os filmes estudados, na busca de aspectos importantes e constitutivos daquilo que se pretende identificar. Segundo este autor, o mito é formado por unidades, as quais "somente adquirem função significante sob a forma de (...) combinações de um traço comum que se trata de evidenciar" (Lévi-Strauss, 1996: 237-265). Um processo de mediação que se faz pela oposição e relação de seus termos.

No caso deste estudo, o quadro elaborado pelo autor inspira a esquematização que se segue. Os "traços comuns", ou variáveis a se evidenciar, estão selecionados e agrupados nos tópicos apresentados a seguir, para levantamento de ocorrências em relação à figuração da pobreza, como um possível trajeto de aprofundamento de estudo das recentes produções fílmicas brasileiras em torno do tema. Desse modo, a título de exercício, foram observadas as seguintes variáveis: 1) Caracterização em torno dos protagonistas: personagem "Buscapé", em Cidade de Deus, e "Jorge", em Uma onda no ar; 2) Caracterização em torno dos antagonistas: personagem de "Zé Galinha", em Cidade de Deus, e "Roque", em Uma onda no ar; 3) Relações estabelecidas entre protagonista e antagonista; 4) Caracterização e relações entre personagens secundários; 5) Representação do ambiente interno, considerado como a favela; 6) Representação dos ambientes externos a ela; 7) Deslocamentos em relação ao ambiente da favela e estigmas a ele relacionados; 8) Representações da mídia - que tem menção evidenciada em ambos os filmes. 


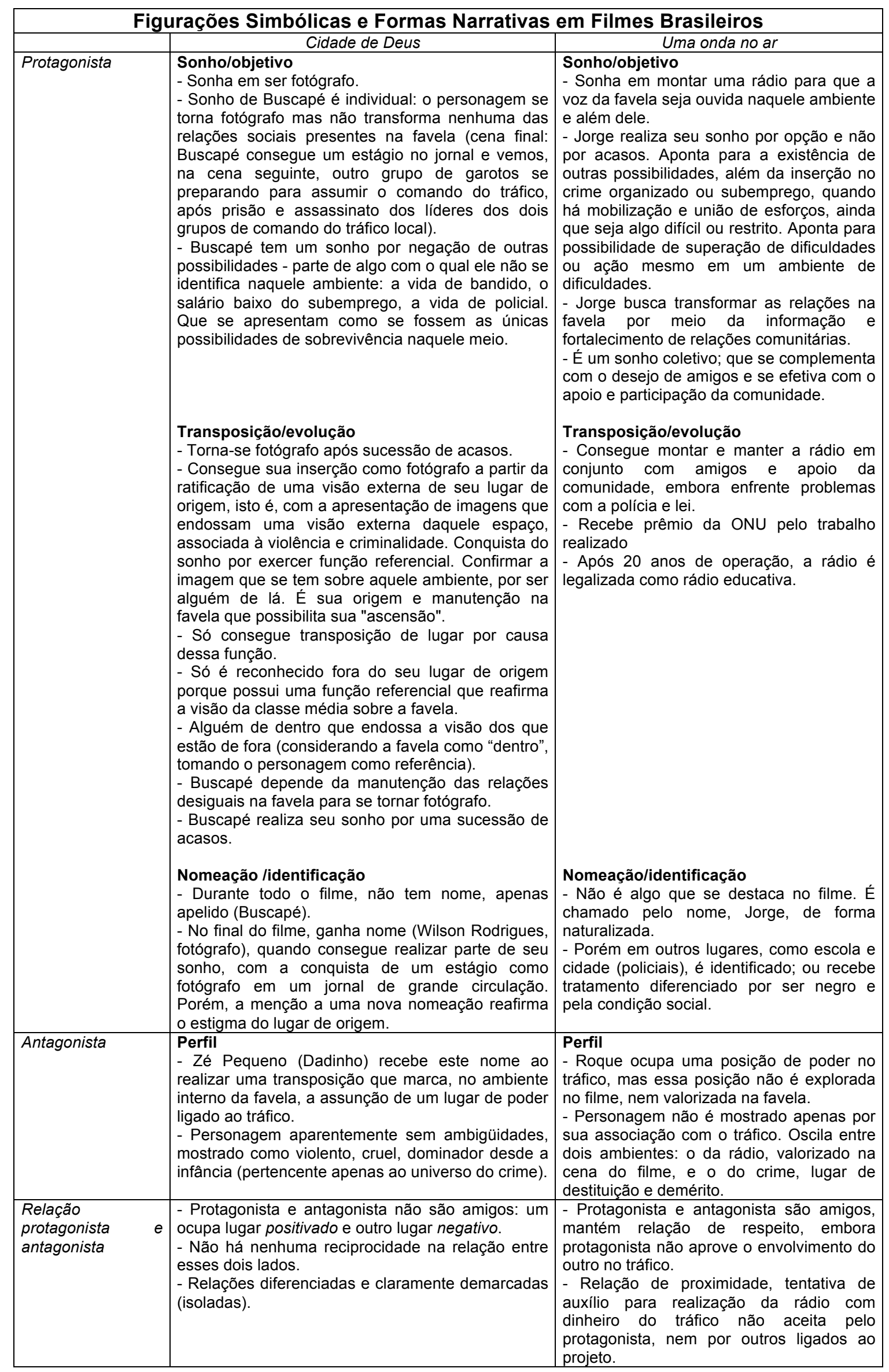




\begin{tabular}{|c|c|c|}
\hline $\begin{array}{l}\text { Personagens } \\
\text { secundários }\end{array}$ & $\begin{array}{l}\text { - Em geral, relacionados ao tráfico. } \\
\text { - A história de cada personagem reforça a ideia de } \\
\text { dificuldade de transposição ou transformação } \\
\text { daquele ambiente. } \\
\text { - Deterioração das relações entre personagens } \\
\text { (família, amigos, conhecidos, patrões). }\end{array}$ & $\begin{array}{l}\text { - Grande variedade } \text { de personagens } \\
\text { secundários, pouca ênfase àqueles } \\
\text { relacionados ao tráfico, embora também } \\
\text { apareçam no filme e se relacionem ao } \\
\text { antagonista. }\end{array}$ \\
\hline Ambiente interno & $\begin{array}{l}\text { - Tráfico coloca-se como forma de ascensão social } \\
\text { (do trabalho fora da favela, com salário miserável, } \\
\text { passando pelo roubo e chegando ao tráfico como } \\
\text { lugar máximo). } \\
\text { - Tráfico confere legitimidade e visibilidade aos } \\
\text { seus integrantes por ser reconhecido como forma } \\
\text { de organização dessas relações. } \\
\text { - Tráfico define os traços de virilidade e } \\
\text { masculinidade (fumar, beber, roubar, matar). } \\
\text { - Tráfico representa um lugar de lei e ordenação } \\
\text { das relações na favela. } \\
\text { - Apagamento de outros tipos de relações internas } \\
\text { (black, crentes, samba, "cocotas" são mencionados } \\
\text { apenas em uma cena do filme) em detrimento das } \\
\text { relações do tráfico. }\end{array}$ & $\begin{array}{l}\text { - Tráfico, embora apresentado como lugar } \\
\text { de maior oportunidade de ganhos } \\
\text { financeiros naquele ambiente, não é } \\
\text { ressaltado como valor, nem como lugar de } \\
\text { poder, nem como lugar almejado pela } \\
\text { maioria dos habitantes para maior status no } \\
\text { grupo. } \\
\text { - Maior variedade de relações e estilos de } \\
\text { vida, com apresentação de momentos de } \\
\text { sociabilidade e convívio comunitário, como } \\
\text { apresentação de rap em praça da cidade, } \\
\text { rodas de samba e grupo de cantoras que } \\
\text { se apresenta na rádio. }\end{array}$ \\
\hline $\begin{array}{l}\text { Ambientes } \\
\text { externos }\end{array}$ & $\begin{array}{l}\text { - Pouca presença de ambientes externos. } \\
\text { - A cidade chega por meio da polícia, da imprensa, } \\
\text { da venda de armas, dos usuários de drogas (do } \\
\text { externo para o interno). } \\
\text { - A favela sai de seu ambiente por meio de ações } \\
\text { de roubo, situações de subemprego ou exceções, } \\
\text { como Buscapé se tornar fotógrafo ou o morador da } \\
\text { favela trabalhar no laboratório do jornal. }\end{array}$ & $\begin{array}{l}\text { - Interação constante com ambientes } \\
\text { externos } \\
\text { - A cidade também chega por meio da } \\
\text { polícia, com enfoque para ações } \\
\text { relacionadas ao funcionamento ilegal da } \\
\text { rádio, chega por meio de pessoas } \\
\text { interessadas pelo trabalho desenvolvido } \\
\text { pela rádio e premiação pela ONU. } \\
\text { - A favela chega à cidade e a outras } \\
\text { classes por meio da rádio, de ações da } \\
\text { rádio na cidade, da circulação de } \\
\text { personagens entre outros ambientes, como } \\
\text { o trabalho e a escola. }\end{array}$ \\
\hline Deslocamentos & $\begin{array}{l}\text { - Ainda que haja personagens buscando sair } \\
\text { daquele meio, o entrelaçamento das diversas } \\
\text { histórias sempre reforça a ideia de que não há } \\
\text { saída, não há possibilidade de transformação, a } \\
\text { não ser por acaso ou sorte. }\end{array}$ & $\begin{array}{l}\text { - Os personagens se deslocam, mas o foco } \\
\text { da narrativa não é a saída daquele local, e } \\
\text { sim um maior conhecimento, discussão e } \\
\text { questionamento das relações e condições } \\
\text { do ambiente, visando sua melhoria e } \\
\text { visibilidade em outros pontos da cidade. } \\
\text { Em lugares que são vistos apenas pelos } \\
\text { olhos e visão, e de outros que não habitam } \\
\text { o lugar. }\end{array}$ \\
\hline $\begin{array}{l}\text { Representações da } \\
\text { mídia }\end{array}$ & $\begin{array}{l}\text { - Lugar de poder no sentido de conferir visibilidade } \\
\text { à favela. O filme associa a presença da imprensa } \\
\text { como fator de aparição e atuação da polícia no } \\
\text { local. } \\
\text { - Lugar de status social (é importante para } \\
\text { traficantes aparecerem no jornal enquanto } \\
\text { detentores do poder). } \\
\text { - Jogo de poder entre o que imprensa espera ver } \\
\text { da favela, o que sociedade espera ler nos jornais, o } \\
\text { que polícia sabe ser esperado. }\end{array}$ & $\begin{array}{l}\text { - Exposição de tipos distintos de mídia: } \\
\text { rádios comerciais que trazem produtos } \\
\text { consumidos pela favela, mas que não } \\
\text { apresentam uma fala própria daquele lugar; } \\
\text { a imprensa de massa, e seu papel } \\
\text { ambíguo: em que contribui na divulgação } \\
\text { da prisão do protagonista, mas que não } \\
\text { abre grande espaço para o cotidiano do } \\
\text { trabalho desenvolvido, ainda que haja } \\
\text { repórter interessada no tema, e a própria } \\
\text { rádio, como um lugar que permite levar a } \\
\text { voz de uma comunidade silenciada pela } \\
\text { segregação física e social. } \\
\text { - Apresenta rede de relações entre } \\
\text { veículos, como forma de mobilização } \\
\text { contra a ação policial e aplicação de leis } \\
\text { consideradas injustas pela comunidade. } \\
\text { - Lugar de poder, cuja visibilidade interfere } \\
\text { na ação policial, seja como mídia de } \\
\text { massa, cuja visibilidade inibe a ação; seja } \\
\text { como rádio da comunidade; cujas } \\
\text { acusações contra a atuação policial, geram } \\
\text { maio repressão. }\end{array}$ \\
\hline
\end{tabular}


Assim, dentre os diversos aspectos observados, ressalta-se a dissociação entre as narrativas dos filmes estudados, ou seja, o direcionamento conferido no sentido de sua abrangência ou restrição em torno da complexidade e diversidade de relações sociais apresentadas.

Em Cidade de Deus nota-se o acento a uma narrativa que se centra entre polos caracterizados como o lugar do "bem" e do "mal", recaindo sobre a favela e a maioria dos seus membros o estigma de uma impossibilidade de saída ou transposição daquele ambiente amaldiçoado, fadado à convivência e conivência em relação a toda forma de crime, brutalidade e fatores ligados ao tráfico. Lugar de "encarnação" do mal, cuja saída se dá apenas como expressão do acaso, para aqueles poucos contemplados pela sorte do destino e que ainda não se deixaram corromper.

Uma narrativa simplificada, que se fecha em torno do lugar e do poder que o tráfico ocupa, no preenchimento de lacunas pela falta de ação do Estado e precariedades de um sistema social cuja exclusão econômica de grande parte de seus membros é fator intrínseco, apesar dos constantes apelos de consumo e de uma imagem de sucesso e desenvolvimento medida pelo poder de compra. Como afirma Bauman, "atualmente, (...) o progresso tecnológico e administrativo é avaliado pelo 'emagrecimento' da força de trabalho, fechamento de divisões e redução de funcionários" (Bauman, 1998: 50, grifos do autor), porém "a sedução do mercado é, simultaneamente, a grande igualadora e a grande divisora. (...) Os que não podem agir em conformidade com os desejos induzidos dessa forma são diariamente regalados com o deslumbrante espetáculo dos que podem fazê-lo. (...) Eles também aprendem que possuir e consumir determinados objetos, e adotar certos estilos de vida, é a condição necessária para a felicidade, talvez até para a dignidade" (Bauman, 1998: 55).

Nesse sentido, embora se possa afirmar uma qualidade técnica e estilística no que tange à produção e recursos cinematográficos, ao se enfocar a narrativa e os estigmas que o filme Cidade de Deus reforça em torno de uma visão da pobreza e dos ambientes e relações a ela associados, conclui-se por uma narrativa que, embora imbuída de uma crítica social, torna o debate restrito e localizado, diante da complexidade que o tema suscita. E "quando a complexidade da situação é descartada, fica fácil apontar para aquilo que está mais à mão como sendo causa das incertezas e ansiedades modernas" ${ }^{\prime 17}$, o que leva à conclusão de uma narrativa simplista.

\footnotetext{
${ }^{17}$ Zygmunt Bauman em entrevista a Maria Lúcia Garcia Pallares-Burke para o Caderno Mais, Folha de $S$. Paulo, 19/10/2003.
} 
Em contrapartida, Uma onda no ar apresenta uma variedade maior de relações a serem observadas nesse contexto e ambiente relacionados à pobreza, as quais conferem maior multiplicidade de elementos para análise, e enfocam outras formas de relações identitárias, além daquelas associadas à criminalidade, ao tráfico e ao subemprego - que embora presentes, não marcam a tônica da enunciação.

A partir da criação e manutenção de uma rádio com objetivos comunitários, da mobilização de diversas pessoas em torno desse objetivo e da participação da população local em torno de sua viabilização, o filme demonstra que não é por morar em um ambiente de pobreza que aquelas pessoas estão fadadas aos estigmas a elas relacionados de forma intransponível. Elas detêm o poder de deslocamento, da ocupação de outros lugares sociais, e ainda, que há espaço para valores diferentes daqueles ditados por um sistema dominante, ainda que em disputa constante. Talvez por isso, e não pelo fato de ser tecnicamente menos sofisticado, o filme não tenha conquistado o mesmo espaço e a mesma bilheteria nas salas de cinema, sem entrar no mérito da discussão que pode suscitar em torno da legislação sobre o sistema de telecomunicações do país.

O filme demonstra ainda que, mesmo permanecendo no ambiente da favela, aquela é uma população que, pela organização, consegue superar os lugares aos quais supostamente deveria se restringir, indicando o valor da mobilização, dos laços comunitários e dos objetivos do grupo como elementos que conferem poder de ação sobre seu meio, sem a necessidade de associação a grupos ligados ao poder do tráfico, como estigma e único caminho daqueles que habitam as favelas. Como demonstra o estudo de Elias e Scotson (2000: 22), a coesão entre os elementos de um grupo é fator decisivo para sua parcela de poder, e esta situação se evidencia em Uma onda no ar, contribuindo para uma visão propositiva da ação em sociedade empreendida por essa camada pauperizada e subalternizada da população, numa superação de estigmas associados à incivilidade, desagregação e violência.

É importante salientar uma vez mais o embasamento em fatos como argumentos de ambos os filmes. Estes são concluídos com depoimentos das pessoas que inspiraram um personagem em cada um - cenas de entrevista do Jornal Nacional com um dos integrantes do tráfico, quando preso, em Cidade de Deus; e entrevista com o locutor da Rádio Favela em Uma onda no ar - além da menção de que as histórias se baseiam em fatos. $\mathrm{O}$ recurso à referencialidade se faz importante, pois confere um tom de veracidade e credibilidade à narrativa. Recursos "com os quais se monta a narração sem que ela se denuncie como montagem" (Gomes, 2003: 97), escondendo seus próprios artifícios. 
De onde a importância de um estudo sobre essas narrativas e os estigmas que carregam consigo, na busca pelo direcionamento dos discursos que tais promovem, considerando suas implicações na reprodução e ratificação, ou transformação e deslocamento de realidades sociais. Tal busca se torna fundamental quando se pretende problematizar a questão das desigualdades, principalmente em uma sociedade tão complexa, diversa e contraditória como a brasileira.

Nesse sentido, as cenas iniciais dos filmes exemplificam aquilo de prioritário ressaltado pela análise: em Cidade de Deus as tomadas fechadas parecem apontar para o círculo em torno da dificuldade de transposição das barreiras impostas pelos estigmas da pobreza e circunscrição do espaço ao qual supostamente devem estar fadados os habitantes das favelas, como um cenário do exótico que coabita em nossa sociedade, mas que é aceito enquanto restrito ao seu lugar de origem. Já em Uma onda no ar, a panorâmica da favela e sua localização como parte de um cenário maior da cidade, além dos planos gerais mais abertos, aponta para sua interação com os demais ambientes urbanos e para a abrangência de relações que ali podem ser articuladas.

Na sequência, pretendemos demonstrar a partir de outros produtos audiovisuais (filmes de ficção e de não-ficção dos anos de 2007 a 2011) as características acima assinaladas, oscilando entre as fronteiras de "estigmas de reforço/manutenção" e/ou “estigmas de transposição/transformação". Esses conceitos serão retomados adiante.

Um exemplo nos cinemas - entre outros possíveis - reafirma algumas das hipóteses e dos resultados. No ano de 2006, foi lançada uma minissérie televisiva chamada "Antônia", coprodução da O2 (de Fernando Meirelles) e da Globo Filmes. Veiculada na Rede Globo em cinco episódios ${ }^{18}$, às sextas feiras, após a programação em horário nobre, a minissérie atingiu 32 pontos no Ibope (número considerado alto para o horário). Além da própria minissérie, a divulgação do filme em longa-metragem foi intensa, com a participação das atrizes-cantoras em diversos programas da emissora, antecedendo o lançamento de Tata Amaral. O bom desempenho televisivo levou a uma expectativa elevada de público para a estreia no cinema: diretora e produtores esperavam que o filme chegasse a 500 mil espectadores e, nas primeiras quatro

\footnotetext{
18 Os episódios televisivos de Antônia foram exibidos em 17/11, 24/11, 01/12, 08/12 e 15/12/2006. Ambientada no bairro Brasilândia, na periferia de São Paulo, a minissérie foi baseada no longa-metragem de Tata Amaral e lançada na televisão antes do longa-metragem estrear nos cinemas (09/02/2007). Todas as atrizes-cantoras possuem trabalhos musicais anteriores ou posteriores à minissérie, que teve roteiros escritos por autores diferentes a cada episódio, entre eles: Elena Soárez, Fernando Meirelles, Jorge Furtado, Claudia Tajes e a própria Tata Amaral (informações: www.globo.com/antonia).
} 
semanas, o número estava em pouco mais de 75 mil, muito abaixo do necessário para atingir a meta inicialmente prevista ${ }^{19}$.

A história (minissérie e filme) relata a vida de quatro amigas, "diferentes em suas personalidades mas iguais no sonho, lutando contra o preconceito em meio à cultura hip-hop e tentando mostrar seu talento por meio de uma atitude corajosa e batalhadora" ${ }^{20}$. Buscando sobreviver fazendo aquilo que mais gostam - cantar - as quatro mulheres formam o grupo musical "Antônia", sem nenhum recurso financeiro para sua produção e divulgação, e tentam torná-lo possível em meio a suas rotinas de trabalho, desemprego, falta de dinheiro, filhos, namorados, família.

O filme Antônia, em nossa análise, encontra pontos de cruzamento com o que apontamos acima sobre o filme Uma onda no ar, distanciando-se de uma narrativa (verbal, visual) como aquela encontrada em Cidade de Deus. Em Antônia, temos a tematização e figurativização de estigmas de transposição, mostrando a vida da periferia em suas dificuldades e problemas - pobreza, violência, desemprego, machismo -, mas também em seus desafios e conquistas - são as casas e cotidianos de pessoas comuns que vemos ali, tentando buscar soluções e, não necessariamente, convivendo o tempo todo com aspectos conflituosos de seu cotidiano.

Talvez por isso o filme, a exemplo de Uma onda no ar, tenha tido pouca repercussão: ao mostrar o lado positivo e criativo da periferia de modo não esquemático (ao contrário do que fazem alguns programas televisivos) - o que aproximaria os seus supostos "eles" (os pobres) de "nós" (a classe média) -, Antônia afasta o público desta mesma classe média dos cinemas, talvez mais interessado (ou habituado) a ver nas telas apenas elementos que reforçam os estigmas, estereótipos e preconceitos presentes em nosso imaginário.

Filmes que subvertem as usuais dicotomias centro/periferia, ricos/pobres, dominantes/dominados - ou outras categorias comuns em estudos sociológicos tendem a ter menos público (considerando que o critério de bilheteria é fator importante

\footnotetext{
${ }^{19}$ Conforme matéria publicada no jornal Folha de S. Paulo em 12/03/2007, intitulada "Antônia - Por que o filme não brilhou" (uma alusão à música tema, cujo refrão diz "Antônia brilha...”), outras minisséries televisivas originaram filmes de grande bilheteria. Um deles foi A grande família, que em pouco mais de um mês já havia levado quase 2 milhões de pessoas ao cinema. Ainda assim, uma observação faz-se necessária: a ideia de que o sucesso (ou a qualidade) de um filme se mede por sua audiência pode ser questionada, revelando, ela própria um estigma que cerca as produções nacionais. $\mathrm{O}$ fato de Antônia ter tido menos público do que o esperado não deveria significar, necessariamente, que fracassou enquanto filme. Mas pode apontar, em nosso ponto de vista, para um espaço de arejamento e abertura advinda de uma produção que rompe os padrões usuais nas formas de tratar a periferia.

${ }^{20}$ Ver www.globo.com/antonia.
} 
na consolidação do cinema brasileiro, ainda carente de uma variedade de gêneros narrativos, como vemos no cinema norte-americano). Desse ponto de vista, Antônia não representa propriamente um "fracasso" de bilheteria, como afirmaram alguns críticos, mas de certa forma pode ter sido superestimado por se confundir, na superfície, com a abordagem social e política feita por outros filmes situados nas regiões mais carentes das cidades. Ao deslocar as posições usualmente ocupadas pela periferia e trazê-las ao centro, aproximando os estabelecidos dos outsiders, filmes como Antônia acabam perdendo seu lugar: não reforçam nosso imaginário sobre eles, os supostos "outros", mas também não fazem com que estes "outros" se integrem ao sistema hegemônico de produção cultural, atuando da forma como "nós" esperamos.

Com a observação de outros filmes de ficção e não-ficção, esperamos mapear os territórios e pontos de passagem de tais relações. Antes, entretanto, gostaríamos de enfatizar que o tema dos estigmas sociais tem despertado um interesse cada vez mais marcante, especialmente no que diz respeito às temáticas de pobreza e violência (Hamburger, 2005). A cada etapa percorrida - seja em termos de estudos teóricos, seja em termos das leituras das mídias (especialmente jornais, revistas e telejornais) deparamo-nos com novas inquietações e configurações possíveis, obrigando-nos a rever conceitos e métodos. Além disso, temos tido contato com outras pesquisas que, por caminhos diferentes, apontam na mesma direção. Exemplo disso são os estudos, cada vez mais difundidos, sobre as identificações (ou identidades sociais) e suas correlações nas mídias (Gomes, 2008), bem como pesquisas que tratam de questões envolvendo estereótipos ou preconceitos sociais (Batista e Leite, 2011).

\subsection{Estigmas sociais em filmes brasileiros}

Os espaços de reforço e/ou transposição de estigmas sociais, bem como os lugares ocupados por seus diferentes atores e suas possibilidades de deslocamento serão tomados como ponto de partida nessa etapa das análises. Trataremos especificamente de discursos audiovisuais a fim de estabelecer uma discussão teórica sobre a delimitação das fronteiras entre fato e fantasia em filmes não-ficcionais e ficcionais. Assumindo que a ficção é elemento articulador de qualquer forma narrativa, a tematização dos estigmas sociais nos filmes se dará de modo transversal, percorrendo por meio de determinados elementos as formas de relatar os estigmas presentes no cinema. 
$\mathrm{Na}$ variedade de seus discursos verbais e visuais, esperamos estabelecer os espaços de passagem entre consolidação e transgressão nas imagens analisadas. Como apontamos, considerando o crescimento recente (e relevante) das produções cinematográficas brasileiras, optamos por tratar apenas de filmes nacionais. Como recorte temporal, dividimos o período inicial e elegemos os anos 2002-2006 e 20072011 para compor as análises.

Apresentamos, anteriormente, os resultados encontrados a partir da seleção de filmes brasileiros lançados entre 2002 e 2006, seguida agora da relação dos filmes lançados entre 2007 e 2009 (primeiro grupo do segundo período). Encerrando o segundo quinquênio, apontaremos os filmes lançados em 2010 e 2011, destacados devido a suas singularidades, adensando os resultados anteriores e desdobrando-se nas análises do período 2012-2014. As datas constantes nas tabelas referem-se ao ano de lançamento dos filmes em circuito comercial, e não ao de sua produção, muitas vezes estendendo-se por alguns anos. Os países referenciados após os diretores são aqueles que realizaram coproduções com o Brasil, característica percebida mais recentemente. $\mathrm{Na}$ etapa de análise audiovisual a pesquisa ganhou caráter exploratório, o que justifica a forma não aleatória de constituição da amostragem a partir dos seguintes critérios:

- Filmes que representam uma tendência no cinema brasileiro contemporâneo ao tratar de temáticas políticas e sociais, quase sempre de forma crítica e engajada.

- Filmes cujas temáticas estejam relacionadas, ainda que de modo tangencial, à problemática dos estigmas sociais.

- Variedade de filmes nacionais, elegendo aqueles que apresentam aspectos singulares ou que sejam diferenciados entre si.

- $\quad$ Filmes realizados no Brasil, documentais ou ficcionais, excluindo filmes infantis, comédias, adaptações televisivas, educativos ou de animação.

- $\quad$ Filmes lançados entre os anos de 2002 e 2011.

- Relação estabelecida entre os filmes e o conceito de estigmas sociais.

Como afirmamos, após percorrer jornais impressos, revistas e telejornais, nas análises de narrativas audiovisuais cinematográficas trataremos de filmes documentais ou ficcionais. A partir dos critérios apontados e complementando as tabelas propostas, estabelecemos os seguintes quadros com filmes brasileiros relacionados aos estigmas sociais para o triênio 2007-2009. 


\begin{tabular}{|c|c|c|c|c|}
\hline \multicolumn{5}{|c|}{$\begin{array}{c}\text { TABELA XXII } \\
\text { FILMES DE FICÇÃO E NÃO-FICÇÃO (2007) }\end{array}$} \\
\hline Título & Diretor & Ano & Gênero & Duração \\
\hline 500 almas & Joel Pizzini & 2004 & Documentário & $105 \min$ \\
\hline Ainda orangotangos & Gustavo Spolidoro & 2007 & Fiç̧ão & $85 \mathrm{~min}$ \\
\hline Baixio das bestas & Cláudio Assis & 2007 & Ficção & $80 \min$ \\
\hline Batismo de sangue & Helvécio Ratton & 2007 & Ficção & $110 \min$ \\
\hline Cão sem dono & Beto Brant & 2007 & Ficção & $82 \mathrm{~min}$ \\
\hline Caparaó & Flavio Frederico & 2006 & Ficção & $77 \mathrm{~min}$ \\
\hline A casa de Alice & Chico Teixeira & 2007 & Ficção & $92 \mathrm{~min}$ \\
\hline Chega de saudade & Laís Bodansky & 2007 & Ficção & $95 \min$ \\
\hline Cidade dos homens & Paulo Morelli & 2007 & Ficção & $110 \mathrm{~min}$ \\
\hline É proibido proibir & Jorge Duran & 2006 & Ficção & $105 \mathrm{~min}$ \\
\hline Estômago & Marcos Jorge & 2007 & Ficção & $100 \mathrm{~min}$ \\
\hline Faixa de areia & $\begin{array}{l}\text { Daniela Kalmann e Flávia } \\
\text { Silva }\end{array}$ & 2007 & Fiç̧ão & $94 \min$ \\
\hline Histórias do rio Negro & Luciano Cury & 2006 & Ficção & $86 \min$ \\
\hline Jogo de cena & Eduardo Coutinho & 2007 & Documentário & $105 \mathrm{~min}$ \\
\hline Juízo & Maria Augusta Ramos & 2007 & Documentário & 90 min \\
\hline $\begin{array}{l}\text { 90. Maré, nossa história } \\
\text { de amor }\end{array}$ & Lúcia Murat & 2007 & Ficção & $104 \min$ \\
\hline 91. $\quad$ Mutum & Sandra Kogut & 2007 & Fiç̧ão & $95 \mathrm{~min}$ \\
\hline Não por acaso & Philippe Barcinski & 2007 & Ficção & $90 \mathrm{~min}$ \\
\hline Nome próprio & Murilo Salles & 2007 & Ficção & $130 \mathrm{~min}$ \\
\hline Ódiquê & Felipe Joffily & 2004 & Fiç̧ão & $90 \mathrm{~min}$ \\
\hline Querô & Carlos Cortez & 2006 & Fiç̧ão & $88 \mathrm{~min}$ \\
\hline $\begin{array}{ll}96 . & \text { Saneamento básico, o } \\
\text { filme } & \\
\end{array}$ & Jorge Furtado & 2007 & Fiç̧ão & $112 \min$ \\
\hline Santiago & João Moreira Salles & 2007 & Documentário & $79 \mathrm{~min}$ \\
\hline Serras da desordem & Andrea Tonacci & 2006 & Documentário & $135 \mathrm{~min}$ \\
\hline Tropa de elite & José Padilha & 2007 & Ficção & $118 \min$ \\
\hline
\end{tabular}

* As tabelas apresentam um grande número de filmes, tomando como critério principal sua correlação ao tema dos estigmas sociais; por isso a diversidades entre eles em vários sentidos.

** Dados pesquisados em www.ancine.gov.br (lançamentos por ano). Para fichas técnicas completas, elenco, sinopses e demais informações sobre os filmes, ver www.adorocinemabrasileiro.com.br. 


\begin{tabular}{|c|c|c|c|c|}
\hline \multicolumn{5}{|c|}{$\begin{array}{c}\text { TABELA XXIII } \\
\text { FILMES DE FICÇÃO E NÃO-FICÇÃO (2008) }\end{array}$} \\
\hline Título & Diretor & Ano & Gênero & Duração \\
\hline $\begin{array}{l}\text { 100. } 5 \text { frações de uma } \\
\text { quase história }\end{array}$ & Cristiano Abud e outros & 2007 & Fiç̧ão & 96 min \\
\hline 101. O aborto dos outros & Carla Gallo & 2008 & Documentário & $72 \mathrm{~min}$ \\
\hline $\begin{array}{l}\text { 102. Bezerra de Menezes - } \\
\text { O diário de um espírito }\end{array}$ & Glauber $\mathrm{F}^{\circ}$. e Joel Pimentel & 2008 & Ficção & 75 min \\
\hline 103. A dança da vida & Juan Zapata & 2007 & Documentário & $80 \mathrm{~min}$ \\
\hline 104. Deserto feliz & $\begin{array}{l}\text { Paulo Caldas } \\
\text { (Alemanha) }\end{array}$ & 2007 & Ficção & $92 \mathrm{~min}$ \\
\hline 105. Devoção & Sergio Sanz & 2008 & Documentário & $85 \mathrm{~min}$ \\
\hline $\begin{array}{l}\text { 106. Ensaio sobre a } \\
\text { cegueira }\end{array}$ & $\begin{array}{l}\text { Fernando Meirelles } \\
\text { (Japão/Canadá) }\end{array}$ & 2008 & Ficção & $118 \min$ \\
\hline 107. Era uma vez & Breno Silveira & 2008 & Ficção & $118 \min$ \\
\hline 108. A erva do rato & $\begin{array}{l}\text { Júlio Bressane e Rosa } \\
\text { Dias }\end{array}$ & 2008 & Ficção & $80 \mathrm{~min}$ \\
\hline 109. Feliz natal & Selton Mello & 2008 & Ficção & $100 \min$ \\
\hline 110. Fim da linha & Gustavo Steinberg & 2008 & Ficção & $76 \mathrm{~min}$ \\
\hline 111. Linha de passe & $\begin{array}{l}\text { Walter Salles e Daniela } \\
\text { Thomas }\end{array}$ & 2008 & Ficção & $108 \min$ \\
\hline 112. Meu nome não é Johnny & Mauro Lima & 2008 & Fiç̧ão & $124 \min$ \\
\hline $\begin{array}{l}\text { 113. Nossa vida não cabe } \\
\text { num Opala }\end{array}$ & Reinaldo Pinheiro & 2008 & Ficção & $104 \min$ \\
\hline $\begin{array}{l}114 . \quad \text { Onde andará Dulce } \\
\text { Veiga? }\end{array}$ & $\begin{array}{l}\text { Guilherme de Almeida } \\
\text { Prado }\end{array}$ & 2007 & Ficção & $135 \mathrm{~min}$ \\
\hline 115. Otávio e as letras & Marcelo Masagão & 2007 & Fiç̧ão & $83 \mathrm{~min}$ \\
\hline 116. Pequenas histórias & Helvécio Ratton & 2008 & Fiç̧ão & $80 \min$ \\
\hline $\begin{array}{l}\text { 117. Pindorama - A } \\
\text { verdadeira história dos sete anões }\end{array}$ & Roberto Berliner & 2007 & Documentário & $75 \mathrm{~min}$ \\
\hline 118. $\quad$ Pretérito perfeito & Gustavo Pizzi & 2006 & Documentário & $71 \mathrm{~min}$ \\
\hline $\begin{array}{l}\text { 119. Sobreviventes - Filhos } \\
\text { da Guerra de Canudos }\end{array}$ & Paulo Fontenelle & 2007 & Documentário & $78 \mathrm{~min}$ \\
\hline 120. O tempo e o lugar & Eduardo Escorel & 2008 & Documentário & $97 \mathrm{~min}$ \\
\hline Última parada 174 & Bruno Barreto & 2008 & Fiç̧ão & $110 \mathrm{~min}$ \\
\hline
\end{tabular}




\begin{tabular}{|c|c|c|c|c|}
\hline \multicolumn{5}{|c|}{$\begin{array}{c}\text { TABELA XXIV } \\
\text { FILMES DE FICÇÃO E NÃO-FICÇÃO (2009) }\end{array}$} \\
\hline Título & Diretor & Ano & Gênero & Duração \\
\hline $\begin{array}{l}\text { 122. } 23 \text { anos em } 7 \text { segundos } \\
-O \text { fim do jejum corinthiano }\end{array}$ & Di Moretti e Julio Xavier & 2009 & Documentário & $84 \mathrm{~min}$ \\
\hline 123. Alô, alô Terezinha! & Nelson Hoineff & 2008 & Documentário & $90 \mathrm{~min}$ \\
\hline Anabazys & $\begin{array}{l}\text { Paloma Rocha e Joel } \\
\text { Pizzini }\end{array}$ & 2007 & Documentário & $142 \mathrm{~min}$ \\
\hline Besouro & João Daniel Tikhomiroff & 2009 & Ficção & $95 \mathrm{~min}$ \\
\hline Cantoras do rádio & Gil Barone & 2008 & Documentário & $85 \mathrm{~min}$ \\
\hline Cidadão Boilesen & Chaim Litewski & 2009 & Documentário & $92 \mathrm{~min}$ \\
\hline Contratempo & Mini Kerti e Malu Mader & 2008 & Documentário & $98 \mathrm{~min}$ \\
\hline O contador de histórias & Luiz Villaça & 2009 & Ficção & $100 \mathrm{~min}$ \\
\hline À deriva & Heitor Dhalia & 2009 & Ficção & $103 \mathrm{~min}$ \\
\hline A festa da menina morta & Matheus Nachtergale & 2008 & Ficção & $115 \mathrm{~min}$ \\
\hline Fiel - O filme & Andréa Pasquini & 2009 & Documentário & $92 \mathrm{~min}$ \\
\hline Filmefobia & Kiko Goifman & 2009 & Documentário & $80 \min$ \\
\hline 134. $\quad$ Fumando espero & Adriana Dutra & 2008 & Documentário & $96 \min$ \\
\hline Garapa & José Padilha & 2008 & Documentário & $110 \mathrm{~min}$ \\
\hline Herbert de perto & Roberto Berliner & 2006 & Documentário & $97 \mathrm{~min}$ \\
\hline O homem da cabine & Cristiano Burlan & 2008 & Documentário & $90 \mathrm{~min}$ \\
\hline 138. Hotel Atlântico & Suzana Amaral & 2009 & Ficção & $107 \min$ \\
\hline 139. A ilha da morte & $\begin{array}{l}\text { Wolney de Oliveira } \\
\text { (Cuba/Espanha) }\end{array}$ & 2006 & Fiç̧ão & $88 \mathrm{~min}$ \\
\hline 140. Jean Charles & $\begin{array}{l}\text { Henrique Goldman } \\
\text { (Reino Unido) }\end{array}$ & 2008 & Ficção & $93 \mathrm{~min}$ \\
\hline Lóki - Arnaldo Batista & Paulo Henrique Fontenelle & 2007 & Documentário & $120 \mathrm{~min}$ \\
\hline Lula - O Filho do Brasil & Fábio Barreto & 2009 & Ficção & $128 \mathrm{~min}$ \\
\hline Mataram a irmã Dorothy & Daniel Junge & 2009 & Documentário & $94 \min$ \\
\hline 144. O menino da porteira & Jeremias Moreira Filho & 2009 & Ficção & $94 \mathrm{~min}$ \\
\hline 145. O milagre de Santa Luzia & Sérgio Roizenblit & 2009 & Documentário & $104 \min$ \\
\hline Moscou & Eduardo Coutinho & 2009 & Documentário & $78 \mathrm{~min}$ \\
\hline Praça Saens Peña & Vinicius Reis & 2008 & Ficção & $100 \min$ \\
\hline É proibido fumar & Anna Muylaert & 2009 & Fiç̧ão & $88 \mathrm{~min}$ \\
\hline 149. O sal da terra & Eloi Pires Ferreira & 2007 & Ficção & $90 \mathrm{~min}$ \\
\hline Salve Geral & Sergio Rezende & 2009 & Ficção & $120 \mathrm{~min}$ \\
\hline Se nada mais der certo & José Eduardo Belmonte & 2008 & Fiç̧ão & $120 \mathrm{~min}$ \\
\hline $\begin{array}{l}\text { 152. Simonal - Ninguém } \\
\text { sabe o duro que dei }\end{array}$ & $\begin{array}{l}\text { Cláudio Manoel, Micael } \\
\text { Langer e Calvito Leal }\end{array}$ & 2008 & Documentário & $86 \min$ \\
\hline 153. Terra vermelha & Marco Bechis (Itália) & 2008 & Ficção & $108 \mathrm{~min}$ \\
\hline 154. Verônica & Mauricio Farias & 2008 & Ficção & $109 \min$ \\
\hline
\end{tabular}


No cinema, o gênero documentário ${ }^{21}$ traz parâmetros consistentes para pensarmos a questão dos estigmas sociais, pois utiliza elementos de referencialidade de modo semelhante às reportagens jornalísticas ${ }^{22}$. De outro lado, os filmes de ficção colaboram para acrescentar novos aspectos à temática, sobretudo por utilizarem formas narrativas fabulares. Ainda assim, é importante lembrar que as fronteiras entre o documental e o ficcional têm sido constantemente desafiadas, estreitando seus limites, como tratado por diversos autores ${ }^{23}$. Como forma de apontar tais elementos, ensaiamos considerações em torno de filmes tidos como exemplares para tematizar os estigmas no cinema, retomando os eixos: documental/ficcional e consolidação/transgressão. A partir dos quadros, iremos apontar alguns elementos observados.

Para os filmes, importa sua demarcação temática no período de tempo assinalado e, desse modo, as tabelas apresentam uma lista abrangente daqueles que consideramos pertinentes aos estigmas sociais. Entretanto, explorar cada um deles em suas características verbais e visuais é tarefa que foge aos alcances da proposta, bem como o estabelecimento de subcategorias e subtemas. Sendo assim, realizamos uma ampla busca e uma rigorosa seleção em relação à amostragem e chegamos a alguns filmes específicos, não tanto no intuito de excluir os demais como não pertinentes, mas de buscar os mais representativos para um panorama do cinema nacional.

Os dados sobre os anos de 2007, 2008 e 2009 encontram-se dispersos nas fontes consultadas, mas temos os seguintes números aproximados de lançamentos de filmes brasileiros em circuito comercial: em 2007, por volta de 70 filmes foram lançados; em 2008, por volta de 80 filmes; e, em 2009, mais uma vez por volta de 70 filmes. Observando as tabelas, temos 25 títulos relacionados aos estigmas sociais em 2007, 22 títulos em 2008 e 24 títulos em 2009. O número total das tabelas é de 71 filmes, ou seja, um terço dos 220 filmes, aproximadamente, lançados nos três anos. Mais uma vez, é interessante indagar o que esses números revelam. Afinal, o que esses filmes apontam em relação ao cinema brasileiro? Como dissemos, acreditamos que a forte tônica em filmes políticos e de crítica social já determina sua vinculação aos estigmas. Retomamos as questões propostas para os filmes do período anterior (2002-2006), reforçando a grande presença de temas ligados aos estigmas sociais nas produções cinematográficas brasileiras.

\footnotetext{
21 A discussão sobre os gêneros cinematográficos e a definição do documentário enquanto gênero é ampla. Para uma abordagem atual, ver Teixeira (2004), Nichols (2005) e Ramos (2008).

${ }^{22}$ Ver artigos anteriormente publicados (Soares, 2005).

${ }^{23}$ Sobre essa questão, ver Stam e Miller (2000).
} 
A amostragem poderia ser mais extensa se não tivéssemos excluído os filmes adaptados de seriados televisivos, as comédias (incluindo suas variações de gênero, como as comédias românticas), os filmes infantis e de animação, bem como aqueles voltados para questões do cotidiano que não trazem em sua abordagem aspectos relacionados aos estigmas sociais. Desses filmes, destacamos algumas características que julgamos relevantes.

Um primeiro aspecto a ser notado é o progressivo aumento do número de produções documentais, especialmente nos últimos cinco anos. Esse movimento pode ser apontado desde a década de 1990 mas, nos anos 2000, tem sido particularmente intensificado. Nessa produção documental, há enorme variedade de filmes, de projetos mais ambiciosos até aqueles mais modestos; de cinebiografias até recriações históricas; de trabalhos feitos por cineastas experientes até aqueles realizados por iniciantes; de filmes com formato mais próximo do próprio documentário ou das reportagens jornalísticas. Nesse mosaico, chama atenção, especialmente nos últimos três anos, a grande quantidade de documentários musicais, que já podem ser considerados um subgênero específico entre esses filmes. Notemos que não se trata de clipes ou shows para veiculação em dvd, mas de produções sofisticadas e tão variadas quanto os próprios formatos do documentário, abrangendo aspectos históricos, culturais, sociais e políticos ao tratar de temas musicais.

Uma segunda característica, que será retomada posteriormente, diz respeito ao borramento de fronteiras entre os campos do documentário e da ficção. A maioria dos filmes realizados nos últimos anos poderia ser facilmente enquadrada em uma ou outra categoria, se não soubéssemos, de antemão ou por aviso da produção, em qual gênero se enquadra. Tal fato representa um momento relevante e singular do cinema nacional, apontando para superações e desafios em termos de linguagem audiovisual, tanto em aspectos técnicos como também estéticos e narrativos. Referencialidade e realismo misturam-se com fantasia e imaginação, deslocando as dicotomias entre realidade e ficção, tornando obsoletas separações rígidas e obrigando a novas formas de conceituação sobre esses elementos. Traços da linguagem documental e traços da linguagem ficcional podem ser percebidos, em maior ou menor grau, em praticamente todos os filmes apontados nas tabelas.

Ainda com respeito às fronteiras entre ficção e não-ficção, um terceiro aspecto chama nossa atenção na amostragem apresentada: entre os realizadores, também há transposição de fronteiras; ou seja, diretores iniciantes ou consolidados em determinado 
gênero (ficcional ou documental) fazem incursões (muitas vezes bem sucedidas) no gênero divergente, como se hoje também não fosse possível alocá-los em categorias estanques. Decorrente do movimento anterior, se os gêneros se misturam também os modos de criação e encenação podem ser desafiados.

Em relação aos anos específicos, em 2007 temos um total de 25 filmes associados aos estigmas sociais. Destes, destacamos os documentários Jogo de cena, Juízo e Santiago, e os filmes ficcionais Cidade dos homens, Saneamento básico e Tropa de elite. Notemos que entre eles há diversos pontos de contato, e que em sua maioria foram feitos por diretores com experiência. Entre os filmes de ficção, Cidade dos homens aproxima-se dos documentários por seu modo de realização; Tropa de elite, por sua vez, considerado um dos grandes expoentes do cinema nacional recente, além de guardar semelhanças com a linguagem documental foi dirigido por um documentarista.

Em outra proposta narrativa, destacamos Mutum, Estômago e Nome próprio, filmes de alcance mais restrito, mas extremamente inovadores em termos de elementos visuais, narrativos, estéticos e tecnológicos. Dos 25 filmes constantes da tabela, quatro são produções documentais. Separamos para análise os filmes Juízo e Tropa de elite, guardando em alguns momentos referências ao documentário Jogo de cena, de Eduardo Coutinho, especialmente pelas aproximações que estabelece com o outro documentário.

O ano de 2008, de um total de 22 filmes e inúmeros títulos de destaque, apresenta seis documentários. Entretanto, com exceção de $O$ tempo e o lugar, realizado por um diretor mais experiente, nenhum alcançou visibilidade durante este ano, o que acrescenta um dado peculiar à pesquisa. Entre as produções ficcionais, ao contrário, inúmeras tiveram destaque e repercussão, tanto em termos de debate como de bilheteria, e entre elas destacamos os filmes Ensaio sobre a cegueira, Era uma vez, Linha de passe, Meu nome não é Johnny e Última parada 174. Desses filmes, dois caracterizamse como produções transnacionais; um foi feito visando atingir um público mais amplo e os dois últimos guardam fortes elementos relacionados ao cinema documental (no caso de Última parada 174 essa relação é ainda mais explícita, pois evoca o documentário de José Padilha sobre o mesmo episódio).

Por essa razão, em 2008 optamos por tratar de dois filmes ficcionais - Meu nome não é Johnny e Última parada 174 - ainda que eles guardem em si diversos elementos que podem ser associados à linguagem documental, tanto em seus aspectos narrativos como de produção. Para além dos filmes diretamente identificados aos estigmas por suas temáticas mais contundentes e de crítica social, destacamos 5 frações de uma quase 
história, Nossa vida não cabe num Opala, Otávio e as letras e Pequenas histórias (este do mesmo diretor de Uma onda no ar, anteriormente tratado), como produções que apontam novas e inovadoras formas de se fazer cinema no Brasil, sem operar em dicotomias já consagradas ou estanques.

Em 2009, de um total de 24 títulos, chama atenção o alto número de documentários constantes da listagem: 13 filmes enquadram-se nesse gênero. Ainda que consideradas eventuais distorções numéricas, é significativo que esse número seja tão representativo, trazendo à tona os aspectos já apontados e sinalizando uma tendência não apenas de aumento da produção, mas também na divulgação desses documentários. É como se o gênero houvesse encontrado um lugar privilegiado na produção cinematográfica nacional, atendendo a diversas expectativas, temáticas e vieses.

Dos documentários de 2009, destacamos os filmes Fiel, Filmefobia, Lóki Arnaldo Batista e Simonal - Ninguém sabe o duro que dei, além de Garapa, retorno de José Padilha ao gênero documentário, e do recém-lançado Moscou, longa-metragem de Eduardo Coutinho. Das produções ficcionais, destacamos $\grave{A}$ deriva, A festa da menina morta, Jean Charles, O contador de histórias e Verônica, os três últimos bastante associados à tematização de questões sociais, violência e pobreza - e também por isso, mas não apenas, próximos da linguagem documental. A cinebiografia Lula - O filho do Brasil, com estreia ocorrida no início de 2010 e baseado na trajetória do ex-presidente do país, ocupou espaço importante em termos de público e crítica, somando 848 mil espectadores. De modo ao mesmo tempo variado e coincidente, os dados levantados apontam para um quadro abrangente do cinema brasileiro contemporâneo.

Como forma de sintetizar o que foi desenvolvido, além dos dois filmes destacados no ano de 2002 (Cidade de Deus e Uma onda no ar), tecemos algumas considerações em torno de filmes escolhidos como exemplares para tematizar os estigmas sociais no cinema. Considerando o período de 2002 a 2009, selecionamos para análise dois filmes por ano (um documental e um ficcional), compondo um total de doze filmes, que serão tratados a partir dos eixos de reforço ou transposição de estigmas sociais. Outro aspecto a ser destacado, como vimos, são os limites entre a produção considerada ficcional e sua suposta oposição, convencionalmente chamada de “documental”. É interessante notar que temos assistido a um esvaziamento dessa oposição, não apenas tornando mais tênues os limites que a separam mas, sobretudo, apontando para o caráter ficcional (no sentido de fabricação e construção) de qualquer obra audiovisual. 


\begin{tabular}{|c|c|c|c|}
\hline \multicolumn{4}{|c|}{$\begin{array}{c}\text { TABELA XXV } \\
\text { FILMES DE FICÇÃO E NÃO-FICÇÃO (2002-2009) }\end{array}$} \\
\hline Ano & Filme de não-ficção & Filme de ficção & Observações \\
\hline 2002 & $-x-$ & $\begin{array}{l}\text { Cidade de Deus } \\
\text { Uma onda no ar }\end{array}$ & $\begin{array}{l}\text { Filmes ficcionais } \\
\text { previamente analisados, } \\
\text { com grandes diferenças } \\
\text { em termos de produção, } \\
\text { temáticas e recepção, } \\
\text { fornecendo um aparato } \\
\text { metodológico e conceitual } \\
\text { no qual situar as análises } \\
\text { em torno de reforço e } \\
\text { transposição de estigmas. }\end{array}$ \\
\hline 2003 & Ônibus 174 & Carandiru & $\begin{array}{l}\text { O documentário Ônibus } \\
174 \text { é de } 2002 \text { e foi } \\
\text { selecionado por seu } \\
\text { impacto e relevância se } \\
\text { comparado aos filmes de } \\
2003 \text { do mesmo gênero. }\end{array}$ \\
\hline 2004 & De passagem & $\begin{array}{l}\text { O prisioneiro da grade } \\
\text { de ferro }\end{array}$ & $\begin{array}{l}\text { Serão feitas referências } \\
\text { aos documentários } \\
\text { Entreatos e Peões, por } \\
\text { suas características } \\
\text { interdiscursivas, e ao filme } \\
\text { Cazuza, por sua relação } \\
\text { com a temática da aids. }\end{array}$ \\
\hline 2005 & A pessoa é para o que nasce & Cidade baixa & $\begin{array}{l}\text { Serão feitas referências ao } \\
\text { documentário O fim e o } \\
\text { princípio e ao filme de } \\
\text { fiç̧ão Meu tio matou um } \\
\text { cara. }\end{array}$ \\
\hline 2006 & Falcão - meninos do tráfico & Os 12 trabalhos & $\begin{array}{l}\text { Serão feitas referências ao } \\
\text { documentário Estamira e } \\
\text { ao filme de ficção Árido } \\
\text { movie. }\end{array}$ \\
\hline 2007 & Juízo & Tropa de elite & $\begin{array}{l}\text { Será feita referência ao } \\
\text { filme Saneamento básico, } \\
\text { que de forma original traz } \\
\text { um documentário inserido } \\
\text { em sua ficção, e ao filme } \\
\text { Jogo de cena, } \\
\text { documentário que dialoga } \\
\text { com os demais. }\end{array}$ \\
\hline 2008 & $-x-$ & $\begin{array}{l}\text { Última parada } 174 \\
\text { Meu nome não é } \\
\text { Johnny }\end{array}$ & $\begin{array}{l}\text { Selecionamos para o ano } \\
\text { de } 2008 \text { dois filmes de } \\
\text { fição, pois houve poucos } \\
\text { lançamentos de } \\
\text { documentários que fossem } \\
\text { relacionados à pesquisa. }\end{array}$ \\
\hline 2009 & Garapa & O contador de histórias & $\begin{array}{l}\text { Destacamos em } 2009 \text { o } \\
\text { grande número de } \\
\text { documentários já } \\
\text { lançados, bem como as } \\
\text { referências que serão } \\
\text { feitas aos filmes Moscou, } \\
\text { Filmefobia e Simonal. }\end{array}$ \\
\hline
\end{tabular}


As fronteiras entre documentário e ficção, ou entre factualidade e fabulação, nos levaram a considerar os espaços de transição criados nos filmes relacionados à temática dos estigmas sociais. É nesse entremeio que vemos surgir possibilidades de um pensamento múltiplo, não dicotômico, para dar conta dessa discussão de forma abrangente. O tema das margens e das bordas, já desenvolvido em outros trabalhos ${ }^{24}$, permite-nos estabelecer aproximações entre essa abordagem e as narrativas audiovisuais referidas $^{25}$, percebidas como limiares justamente por tratarem de estigmas.

Margens podem ser pensadas enquanto molduras, apontando para alcances e limites, aberturas e fechamentos. Moldura como aquilo que é, ao mesmo tempo, contorno e ruptura, como aquilo que demarca um campo e, ao fazê-lo, deixa de fora outras tantas possibilidades. Metáfora feliz, podemos dizer com Lacan, já que evoca inúmeras relações, entre elas a possibilidade de perceber, por exemplo, que as letras, ao formar palavras, elas mesmas fazem/são molduras. Ou ainda, de pensar o que resta no espaço vazio entre uma moldura e outra, seja de palavras ou imagens. Essas observações encontram eco em outras palavras: “(...) any meaning created or released through use of a framing device - and when I say frame I mean that which cuts colours and lights into images and noise into words - lies not so much on the inside of what has been isolated, but rather on the edges of what has thus been set aside" (Wall, 1998: 5).

Pensada em sua forma usual, a moldura cria um espaço interno a ser preenchido para que possa significar, o que faz com que esqueçamos que a própria moldura é resultado de uma interação entre seus espaços internos e externos. Tal relação poderia ser pensada analogamente àquela estabelecida pelo signo linguístico: um significante enunciado atesta a ausência do referente - só está ali porque aquilo que demarca, naquele momento e lugar, não está, gerando espaços vazios. Se a moldura parece incluir algo, trazendo-o para dentro, é porque demarcou contornos, excluindo alguma outra coisa. Cabe então perguntar: como pensar um dentro e um fora em relação a ela? Qual seria o "fora" de uma moldura, já que ela está sempre a criar novas bordas? Haveria, por analogia, o "fora da palavra"?

\footnotetext{
${ }^{24}$ Em nossa tese de doutorado, defendida em 2002, tratamos a questão das "margens da comunicação", especialmente em suas relações com a filosofia e a psicanálise; nas produções em torno da temática do cinema de bordas, aprofundamos este conceito voltado à pesquisa audiovisual.

${ }^{25}$ Uma versão preliminar dos aspectos tratados a seguir sobre a relação entre documentário e fícção, e sobre verdade e realidade, foi desenvolvida em artigos publicados ao longo do biênio 2007-2009, contendo resultados parciais da pesquisa aqui expandida.
} 
Telas e janelas possuem molduras, ainda que distintas umas das outras. De fato, podemos associar a moldura de uma tela (seja de pintura ou de cinema) com a opacidade - ela apenas nos devolve uma imagem que já é passado, ainda que na pintura esta imagem seja estática e, no cinema, movimento - e a moldura de uma janela com a transparência - ela nos abre para o mundo, apresentando-nos seu presente. Assim como nas palavras, opacidade e transparência alternam-se para velar e revelar um suposto mundo interior/exterior.

Um dos artistas que melhor expressa esse jogo de dentro e fora das telas e janelas - margens, molduras - é o pintor René Magritte. O quadro O sorriso do diabo (1966), por exemplo, traz desenhado o buraco de uma fechadura que se abre para uma paisagem do outro lado. Do outro lado também está a chave que abriria aquela porta, como a nos perguntar: onde é dentro e onde é fora? Ainda em Magritte temos um recorrente jogo de permutações entre a tela do quadro e a janela que abre para o mundo. Muitas vezes sua pintura aponta para a fragilidade dessa divisão e a janela converte-se, ela mesma, em quadro que está sendo pintado, como em A condição humana (1934), em que vemos uma paisagem externa como se estivesse sendo olhada de dentro de um ambiente por alguém que a vislumbra por uma janela, mas cuja moldura é na verdade um cavalete de pintura. Há ainda outra tela, também intitulada $A$ condição humana (1935), em que realidade e reprodução misturam-se e confundem-se a tal ponto que não podemos mais estabelecer os limites entre a vista do mar e a imagem no cavalete.

Outro artista que subverteu os limites entre o dentro e o fora foi o cineasta Luis Buñuel em seu jogo de símbolos ${ }^{26}$ indefinidos e enigmas. No filme L'age d'or (1930), há uma sequência em que vemos uma penteadeira - o espelho e a base onde se vislumbram objetos femininos: flores, perfumes, joias. Uma mulher se encaminha para olhar-se no espelho. Deste pequeno gesto é que vem a ambiguidade que não se presta a interpretações simplistas: ao procurar nele sua imagem, é outra coisa que a mulher encontra. O espelho transforma-se em outro objeto (como nas telas-janelas de Magritte) e em vez de refletir o rosto da mulher esta desaparece para dar lugar a uma paisagem de nuvens agitadas por um forte vento.

\footnotetext{
${ }^{26}$ Sobre este conceito ver Peñuela Cañizal, "Emblema e símbolo no texto fílmico" (1996). O símbolo seria aquele que não se deixa apreender facilmente, remetendo ao universo "do estranhamento, do enigmático, do relato, da fragmentação, da analogia, do desejo e das pulsões".
} 
A ruptura que advém dessas imagens aponta, uma vez mais, para a indistinção entre interior e exterior, seja em relação ao sujeito, seja em relação ao mundo que supostamente o circunda: "O valor que o espelho tem na antiga crença de que haveria uma correspondência mágica entre a coisa e a cópia que ele faz dela é, de repente, deslocado: o espelho não copia o rosto da mulher que está na sua frente, mais sim uma outra coisa pertencente a um mundo que não cabe no quarto em que a protagonista foi confinada" (Peñuela Cañizal, 1996). Desaparece, assim, a oposição dentro/fora e tem lugar uma visão abrangente, e por isso difusa, das relações envolvidas na percepção das imagens, sejam aquelas que se passam na tela frente aos olhos do espectador, sejam aquelas que se passam no espelho frente aos olhos da protagonista. Telas e janelas podem ser percebidas em um movimento intercambiante, como molduras recobrindo e abrindo espaços, da mesma forma que as margens das narrativas audiovisuais em forma ficcional ou não-ficcional. Ao questionarmos a relação entre realidade e ficção, outra problemática se impõe: aquela que trata dos limites entre verdade e realidade.

Para responder a essa indagação, voltamo-nos nesse momento para Foucault e o discurso, tomado aqui em sua pluralidade de manifestações. Foucault inicia o livro $A$ ordem do discurso (1970) introduzindo a hipótese de que em toda sociedade a produção dos discursos é, sempre, “controlada, selecionada, organizada e redistribuída por certo número de procedimentos que têm por função conjurar seus poderes e perigos, dominar seu acontecimento aleatório, esquivar sua pesada e temível materialidade" (Foucault, 1996: 9). Tal controle e seleção seria realizado pelos chamados "procedimentos de exclusão", que Foucault assinala como sendo três: interdição (a palavra proibida); separação/rejeição (a segregação da loucura); oposição do verdadeiro e do falso (vontade de verdade). Vejamos brevemente do que se trata em cada um deles para chegarmos à "vontade de verdade". O primeiro princípio de exclusão, a interdição, opera em relação à palavra que pode ou não ser pronunciada, que pode ou não se fazer discurso: sabemos que não se pode dizer tudo, que não se pode falar sobre qualquer assunto em qualquer circunstância.

No discurso, há sempre zonas cinzentas de interdições, regiões proibidas. Entre elas, podemos citar, por exemplo, o sexo e a morte. Foucault aponta para o caráter revelador das interdições: "Por mais que o discurso seja aparentemente bem pouca coisa, as interdições que o atingem revelam logo, rapidamente, sua ligação com o desejo e com o poder" (Foucault, 1996: 10). A psicanálise já assinalara as relações do discurso com o desejo, não apenas como aquilo que o revela ou mascara, mas também "como 
aquilo que é objeto do desejo"; a história, por sua vez, ensina que "o discurso não é simplesmente aquilo que traduz as lutas ou os sistemas de dominação, mas aquilo por que, pelo que se luta, o poder do qual nos queremos apoderar" (Foucault, 1996: 10).

O segundo princípio de exclusão, a separação/rejeição, é apresentado nos termos da oposição razão/loucura. O discurso do louco é aquele que não pode circular como o dos outros; é, assim, segregado, isolado, seja pela atribuição à sua palavra de nulidade, seja pela atribuição à sua palavra de sobrenaturalidade. Por rejeição, ou a palavra (e, portanto, a verdade) está dele excluída (não devendo ser acolhida) ou está nele escondida (esperando ser revelada). De qualquer maneira, trata-se de exclusão: "Era através de suas palavras que se reconhecia a loucura do louco; elas eram o lugar onde se exercia a separação; mas não eram nunca recolhidas nem escutadas (...). Todo esse imenso discurso do louco retornava ao ruído" (Foucault, 1996: 11). Ainda hoje, quando a palavra deslo(u)cada parece encontrar seu lugar nas terapias médicas e na escuta psicanalítica, a separação permanece, pois é necessário que na escuta deste discurso intervenha, ainda, a voz de uma suposta razão (o suposto saber a ordená-la).

Mas é ao terceiro princípio que Foucault dedica maior atenção: a oposição entre $o$ verdadeiro e o falso. Nos dois sistemas anteriores já se fazia perceber a força da verdade como aquela que separa e estabelece o que se pode e o que não se pode dizer. Se pensarmos por essa via, o raciocínio se torna circular e a pergunta não encontra ainda resposta: se a verdade estabelece o que pode e o que não pode ser dito, quem estabelece a verdade? É o desejo de verdade - ou a vontade de saber, para usarmos as palavras de Foucault - que faz surgir a verdade: "Pois a vontade de verdade (ou de saber) se realiza pela colocação, pela inscrição de pontos-chaves pelos quais se identifica o verdadeiro. Portanto, é predominante sobre os dois primeiros processos de restrição e de exclusão, operando como uma exclusão mais abrangente" (Gomes, 2000: 47).

Ou seja: a vontade de verdade é que cria, por meio do discurso, a própria verdade; assim, até mesmo o discurso que pretende desvendar a verdade constrói, ao fazê-lo, sua própria verdade, uma entre outras possíveis. Do mesmo modo, só será considerado "verdadeiro" o discurso que participar dessa verdade instituída: "Mendel dizia a verdade mas não estava 'no verdadeiro' do discurso biológico de sua época (...); foi preciso toda uma mudança de escala, o desdobramento de todo um novo plano de objetos na biologia, para que Mendel entrasse 'no verdadeiro' e suas proposições aparecessem, então (em boa parte), exatas" (Foucault, 1996: 35). 
Dessa forma, o discurso institui a realidade e, ao fazê-lo, engendra também sua verdade, legitimando-se e legitimando-a. Trata-se, assim, de um processo de legitimação que funda a legitimidade, processo autorreferencial que estabelece o que se pode incluir e o que se pode excluir do campo do verdadeiro:

O discurso legitimado dá-se ao luxo de ver legitimadas as operações de legitimação pelas quais ele se constrói: acolhimento e exclusão. Tanto o acolhido quanto o excluído funcionam como sustentação e/ou legitimação do discurso que os sustenta num movimento reflexivo de termo a termo. É o jogo nesse processo de auto-referencialidade, que afirma e confirma (Gomes, 2000: 48).

Do discurso como lógos dos gregos (aquele que fala por si e, ao fazê-lo, determina as formas da realidade, submetendo o humano) passa-se à separação entre o discurso verdadeiro e o discurso falso. É o próprio lugar da verdade no/do discurso que se desloca: “A verdade mais elevada já não residia mais no que era o discurso, ou no que ele fazia, mas residia no que ele dizia: chegou um dia em que a verdade se deslocou do ato ritualizado, eficaz e justo, de enunciação, para o próprio enunciado: para seu sentido, sua forma, seu objeto, sua relação e sua referência” (Foucault, 1996: 15).

$\mathrm{Da}$ oposição entre vestígios e esquecimentos, de seus deslocamentos e deformações, é que a verdade pode ser feita e refeita, ou desfeita: "Todo deslocamento, toda deformação, são, então, o traço de um acontecimento acabado e recoberto" (Clément, 1973: 5). Assim, a verdade pode reaparecer porque foram deixados rastros, que podem "construir o que foi esquecido a partir dos traços deixados por esses esquecimentos" (Clément, 1973: 3), adicionando e associando vestígios, quando a conexão original foi perdida e transformou-se em verdade esquecida. A marca do acontecimento original é inacessível, por isso o relato e a verdade constroem-se "só depois": "O relato desse cenário reiterado induz a noção de um retardo: o acontecimento age a posteriori, a verdade é eficaz 'só depois"” (Clément, 1973: 8).

O acontecimento define-se, nesses termos, como "acontecido e desaparecido" (Clément, 1973: 4), constituindo-se no cruzamento da contingência e da necessidade. Para Freud, ele é ao mesmo tempo existente num passado acabado e não existente num presente repetitivo. Daí a necessidade de rememorar (o que existe) e reconstruir (o que não existe) "a partir dos cacos destruídos” (Clément, 1973: 4), lembrando que mesmo se todos os pedaços forem colados, eles não serão jamais recompostos exatamente como o original. Uma arqueologia dos cacos que ajunte os vestígios, restos, traços, ruínas, rastros, resíduos, mas sem a ambição de perfazer uma totalidade, uma plenitude. 
É dessa dinâmica entre o acontecimento-realidade e o discurso-verdade que se deduz outra relação entre a verdade suposta no documentário e a possível realidade da ficção, embaralhando suas margens não para desfazê-las, mas para criar outra forma discursiva. Nesse sentido, resgatamos uma reflexão quanto ao imbricamento entre ficção e ciência: a ficção (fictionis) presente nos discursos é pensada não no sentido de mentira, mas de fabricação e criação e, portanto, trazendo em si a impossibilidade de escapar de seu caráter testemunhal, ou seja, profundamente comprometida com aquele que fala - sujeito este que, desde Freud, sabemos não falar a partir de si mesmo, mas do inconsciente (Quéré, 1982).

Se o acontecimento é sempre fugidio, se escapa no momento mesmo de sua ocorrência, o relato sobre ele será sempre impreciso e precário. Da mesma forma, pensamos em referencialidade (algo próprio do domínio cientifico) não no sentido de rigor dedutivo ou raciocínio lógico, mas enquanto atividade que busca dotar seus relatos de certa precisão e objetividade (aquela possível a um sujeito que é, sobretudo, testemunha de uma falta, o que faz com que qualquer comunicação seja sobretudo um testemunho, ainda que malogrado).

Em relação ao cinema, vale evocar uma cena vista em um filme de grande alcance que evoca a antiga oposição verdade $\mathrm{x}$ esquecimento. Embora trate de temas diversos - como a oposição entre realidade e irrealidade (ou simulacro) - gostaríamos de destacar do longa-metragem Matrix (1999), de Andy e Larry Wachowski, uma passagem que consideramos emblemática: vivendo em um mundo concebido no filme como não real ("não verdadeiro"), em certo momento ao personagem principal é oferecida uma escolha: entre duas pílulas, uma vermelha e outra azul, deve tomar uma decisão (tomando uma delas) entre conhecer a verdade (ter acesso e ver um mundo ainda desconhecido - no filme, o "real") ou cair no esquecimento (esquecendo inclusive que a ele foi dada essa opção). Não nos interessa agora o enredo do filme, nem mesmo o que nele é caracterizado como "verdade" ou "esquecimento", como uma vida "real" ou uma vida "irreal", mas a inusitada escolha que se apresenta entre a verdade e o esquecimento, como na antiga alethéia grega ${ }^{27}$.

\footnotetext{
${ }^{27}$ A verdade como alethéia tem por seu oposto o esquecimento, e não a mentira ou a falsidade. Define-se como "aquilo que não foi esquecido; o que é recordado"; aquilo que é encontrado, lembrado; como se fosse possível ver a realidade (ter a ela acesso direto), e não representá-la: note-se que nesse momento não havia ainda se instaurado, na concepção de verdade, a cisão entre o olhar e a palavra (o discurso). Alethés, o verdadeiro, significa o não esquecido, o não escondido; veraz, sincero, justo, equitável, verídico, franco, não dissimulado (Chauí, 1988).
} 
Na relação entre memória e ficção, podemos lembrar ainda o conto "Funes el memorioso" (1944), de Jorge Luis Borges. O conto narra a vida do personagem que lhe dá título, Ireneo Funes, que após uma queda passa a conter a memória de todos os fatos passados, presentes e futuros - de todos os tempos, de todo o espaço. Funes, nas palavras de Borges, "al caer, perdió el conocimiento; cuando lo recobró, el presente era casi intolerable de tan rico y tan nítido, y también las memorias más antiguas y más triviales. (...) Ahora su percepción y su memoria eran infalibles” (Borges, 1998: 167).

No conto, o personagem nos fala de sua memória sem limites: “"Más recuerdos tengo yo solo que los que habrán tenido todos los hombres desde que el mundo es mundo'. Y también: 'Mis sueños son como la vigilia de ustedes'. Y también, hacia el alba: "Mi memoria, señor, es como vaciadero de basuras"” (Borges, 1998: 168). Funes tudo recordava, não apenas todos os objetos do mundo, mas quantas vezes havia pensado ou contemplado cada um deles. Abria-se, assim, para o passado e para o futuro, para o próprio reino sem limites de todos os possíveis: "Era el solitario y lúcido espectador de un mundo multiforme, instantáneo y casi intolerablemente preciso. (...) (Repito que el menos importante de sus recuerdos era más minucioso y más vivo que nuestra percepción de un goce físico o de un tormento físico)" (Borges, 1998: 171; 172).

O final do conto de Borges é, contudo, revelador das implicações que este tudo lembrar, tudo conter poderia trazer: "Sospecho, sin embargo, que [Funes] no era muy capaz de pensar. Pensar es olvidar diferencias, es generalizar, abstraer. En el abarrotado mundo de Funes no había sino detalles, casi inmediatos" (Borges, 1998: 172). Onde excedia a memória, faltava o pensamento, como se a saturação de informações levasse a uma soma de resultado nulo. Analogamente à prodigiosa memória de Funes, reconhecemos que a concepção dos documentários como sendo filmes que reproduzem a realidade de forma estrita - em oposição à ficção, que a recriaria livremente -, retira das narrativas audiovisuais seu caráter dinâmico, neutralizando os acontecimentos, pois aquilo que se conhece não pode ser considerado um ato.

Trata-se, portanto, nos filmes relacionados aos estigmas sociais, de um processo de construção discursiva - por meio de reforço, transposição ou oscilação - que é ao mesmo tempo instituinte da realidade e por ela instituído. A impossibilidade de separação entre elas já fora apresentada por Borges no fragmento "Del rigor en la ciencia" (comentado por estudiosos das mais diversas áreas), em que os cartógrafos de um determinado reino desenham um mapa tão detalhado que acaba por cobrir exatamente seu território: 
En aquel Imperio, el Arte de la Cartografía logró tal perfección que el Mapa de una sola Provincia ocupaba toda una ciudad, y el Mapa del Imperio toda una provincia. Con el tiempo, estos Mapas Desmesurados no satisfacieron y los Colegios de Cartógrafos levantaron un Mapa del Imperio, que tenía el tamaño del Imperio y coincidía puntualmente con él. Menos Adictas al Estudio de la Cartografía, las Generaciones siguientes entendieron que esse dilatado Mapa era inútil y no sin Impiedad lo entregaron a las Inclemencias del Sol y de los Inviernos. En los Desiertos del Oeste perduran despedazadas Ruinas del Mapa habitadas por Animales y por Mendigos; en todo el País no hay otra reliquia de las Disciplinas Cartográficas" ("Del rigor en la ciencia", El hacedor, Buenos Aires, Emecé, $2^{\mathrm{a}}$ reimp., octubre de 1961, p. 103).

Para representar com fidelidade o reino e agradar ao rei, o mapa deveria ter o tamanho exato da cidade, criando uma impossibilidade: ao ser cópia fiel, deixa de ser uma reprodução imaginária e passa a ser o próprio objeto que tentara representar. $\mathrm{O}$ referido fragmento, publicado também em Historia universal de la infamia (1954), no capítulo "Etc.", foi atribuído por Borges a Suárez Miranda na obra intitulada Viajes de varones prudentes (libro cuarto, cap. XIV, Lérida, 1658).

Ao contrário do conto de Borges, são os vestígios do real - e não os vestígios do mapa - que sobrevivem; não é o território que precede o mapa, mas o mapa precede o território. Eco, em artigo intitulado "Da impossibilidade de construir a carta do império em escala um por um" (1993), tratando do mesmo conto de Borges apresenta uma interpretação do mapa total a partir da "lógica dos paradoxos": a construção de tal mapa só seria possível se ele permitisse deslocamentos nos elementos que o compõem (ou seja, o mapa deveria acompanhar a dinâmica do reino), como se fosse uma espécie de mapa "transparente" e "permeável" a recobrir o território. Ainda assim, o mapa seria uma reprodução sempre inexata e precária do território, pois no momento mesmo em que fosse concluído e se cristalizasse em cópia, o território já seria outro (sendo impossível reproduzir uma a uma todas as posições de seus elementos, ou seja, a menos que mudasse a cada minuto o mapa estaria permanentemente desatualizado).

Eco aponta para a impossibilidade intrínseca à própria ideia de reprodução (pensando-a não como uma limitação mas, ao contrário, como uma infinita semiose produtora de sentidos) e dele nos aproximamos, afirmando que não se pode recobrir com representações uma suposta realidade antecedente a elas devido ao caráter dinâmico de construção da realidade pela linguagem: ao fazer o mapa, estaríamos traçando o próprio desenho do mundo. Trata-se, pois, da questão do estatuto da linguagem e de sua inseparabilidade em relação a ele. 
Afirmar, como fazemos, que o mundo é linguagem significa dizer que o mesmo não existe fora dela, apontando para o fato de que há que aceitar certo grau de incerteza como constituinte da realidade - o mundo é criado pela linguagem e tal construto não corresponde a um suposto real, mas está "no lugar de". Aproximando-nos dos filmes, encontramos suas redundâncias e ressonâncias. Ao deslizarem, os significantes constituintes de suas imagens cortam a cadeia discursiva estabelecida, gerando novos significados. A mensagem articulada nessa estrutura não seria apenas o que um emissor envia a um receptor, mas o lugar onde é possível gerar e fazer surgir um sentido, o "aparecimento miraculoso - de fato o supusemos miraculoso, plenamente satisfatório da satisfação, no Outro, dessa nova mensagem que foi criada" (Lacan, 1999: 95).

Os discursos correntes, para usar uma imagem proposta por Lacan, "zumbem" ao nosso redor, como um disco recorrente que gira sempre no mesmo lugar, falando sempre as mesmas coisas, um risco no disco. Ao ser instaurado um corte na cadeia significante, a partir dos discursos correntes surgiria a mensagem, algo que por apelar ao sujeito cria o novo onde só havia repetição. A mensagem surge e completa seu trajeto quando algo que vem de um lugar outro nos interpela e nos surpreende, como podemos perceber em alguns dos filmes selecionados.

A verdade do discurso, especificamente do discurso audiovisual (não a verdade engendrada por cada um dos discursos, mas as formações discursivas), estaria assim no lugar do outro, e não na realidade confirmada por suas imagens. A verdade, portanto, se produz quando o discurso gera um efeito, despertando algo, ou seja, quando se torna mensagem e se constitui em saber. A mensagem seria, pois, efeito do discurso, e daí sua pregnância em relação ao sujeito. Na maior parte do tempo, os discursos (verbais ou visuais) são estéreis, vazios. Ao falarem daquilo que o sujeito já tem conhecimento não produzem coisa alguma, pois não afetam nem apelam a ele, apenas repetindo um ciclo já estabelecido no cotidiano. É o que podemos observar na maior parte das produções audiovisuais atuais, operando como reforço de estigmas. Se, ao contrário, encontram resposta (ecos) no sujeito, os discursos o removem de sua rotina, questionando-o e mobilizando-o à ação.

É nesse momento que surge um efeito de ressonância, levando à transposição de estigmas sociais. É só a partir desse movimento - porque uma mensagem foi produzida e deslocada - que se pode criar uma verdade para o sujeito, ainda que não seja uma verdade absoluta ou definitiva. Como nas cartas, o discurso só se completa e se torna mensagem ao chegar a seu destino, ainda que seja uma carta extraviada. 
Por isso notamos tantos discursos que apenas nos consolam e afagam, girando em torno das mesmas ocorrências, fazendo-nos muitas vezes adormecer em frente às imagens. Discursos (re)correntes que não alcançam seu fim, ou seja, não engendram um sentido novo. As mídias estão repletas desses discursos vazios (e não estamos estabelecendo julgamentos morais ou juízos de valor) que, no entanto, captam o olhar. Alguns dentre eles, entretanto, perturbam porque carregam em si uma palavra iluminada que, ao ser ouvida, $f a z$ sentido e dota as coisas de sentido, como se tocasse os objetos e os revestisse de significação. Cabe então a pergunta: por que uma palavra teve efeito? Porque de alguma forma tocou o sujeito que, refazendo em espiral o percurso do discurso, fez com que se formasse a mensagem: "É pela ação da metáfora que se produz o surgimento do novo sentido, já que, tomando emprestados alguns circuitos originais, ela vem incidir no circuito corrente, banal, comumente aceito, da metonímia" (Lacan, 1999: 97). É na mensagem, portanto, que o sentido é criado, no momento em que algo escapa do instituído e deixa um rastro, surgindo como inesperado, realizando uma peripécia, um lance que muda a face das coisas.

Nas imagens dos filmes selecionados, algumas evocam reconhecimento e, ao fazê-lo, estabelecem lugares instituídos; outras, ao contrário, provocam estranhamento e nos levam a vislumbrar perspectivas diferenciadas. É essa estranha familiaridade do olhar que nos captura e nos toca, que diz algo diretamente àquele que olha, que gostaríamos de estabelecer uma possibilidade de pensar tais imagens. Gérard Wajcman, no livro L'objet du siècle (1998), fornece uma interessante aproximação a esse tema a partir da análise da obra de arte como aquilo que busca nos fazer ver aquilo que não queremos olhar:

O fazer-ver da arte diz respeito a um espectador no seu ser que eu qualificaria de não vidente. Digamos que a arte faz ver não somente o que é indistinto (como a linguagem ou a ciência instituem nossa perspectiva da realidade) mas também, especificamente, aquilo que, por uma certa recusa, ativamente, nós não queremos ver. Difícil, com efeito, não ver que somos todos não videntes que, na verdade, longe da ilusão de acuidade e de vigilância com a qual nos enganamos, de ser os sentinelas do século, nós nos obstinamos em manter os olhos fechados. Seja a arte o empreendimento de fazer ver àqueles que têm olhos para não (Wajcman, 1998: 215).

Ao contrário da arte, capaz de fazer ver os que não querem ver, o autor afirma que a profusão de imagens que caracteriza nosso século, antes de "nos dar a ver aquilo que ansiamos ver", existe para "gratificar em segredo a vontade obstinada de não [ver]" (Wajcman, 1998: 216). 
Wajcman estende suas considerações à televisão afirmando que, ao contrário do que se imagina - que ela seja um veículo de comunicação, de informação, de supremacia das imagens, de "porta aberta" em conexão com o mundo todo -, esta mídia vem satisfazer esse desejo de "não-ver-nem-saber" do espectador. O cinema, ao contrário, por estar mais próximo do campo da arte, pode articular, nos sujeitos, imagens dissonantes. O sujeito se situa em relação ao quadro do mundo quando colocado em moldura com os objetos que o enquadram. As imagens e o olhar do sujeito se encontram em algum ponto intermediário entre o olho e o ponto luminoso que nos capta; neste lugar intermediário formam-se as imagens vistas pelo sujeito. Assim, não é apenas nossa visão que é solicitada pelas imagens, mas o nosso olhar que é despertado:

Talvez que os traços que aparecem em nossos dias de maneira tão explosiva sob os aspectos
do que se chama mais ou menos propriamente os mass-media, talvez que nossa relação
mesma com a ciência que cada vez mais invade nosso campo, talvez que tudo isso se
esclareça pela referência a esses dois objetos, cujo lugar já lhes indiquei numa tétrade
fundamental - a voz, quase que planetarizada, senão estratosferizada por nossos aparelhos -
e o olhar, cujo caráter invasor não é menos sugestivo, pois por tantos espetáculos, tantas
fantasias, não é tanto a nossa visão que é solicitada mas o olhar que é suscitado (Lacan,
1990: 259).

A partir dessas considerações é que julgamos poder pensar também a articulação de discursos imagéticos, procurando estabelecer certa ortografia determinante da grafia das imagens das mídias. Assim como há regras para que um texto escrito seja grafado, levantamos a seguinte questão em relação às imagens: haveria também nelas um conjunto de regras determinantes de sua escrita? Em caso afirmativo, qual seria a ortografia da inscrição das imagens nas mídias? Quer seja no papel ou na tela, a inscrição dessas imagens é organizada a partir de regras (pois já se encontram no domínio do simbólico), que instauram a visibilidade, aquilo que se dá a ver.

Das imagens das mídias (especialmente na televisão e no cinema), já que há nelas algo que se repete - aquilo que as sustenta e organiza -, podemos afirmar que se constituem, também elas, em discurso. O que estabeleceria a possibilidade de falarmos de laços sociais constituídos pelos discursos imagéticos, para além dos laços discursivos fundados na fala. Nas oscilações entre redundâncias e ressonâncias, portanto, vemos surgir os efeitos de sentido de reforço ou transposição de estigmas, reafirmando posições já estabelecidas ou, ao contrário, transformando-as. 
Como vimos, o cinema brasileiro contemporâneo tem se caracterizado pelo enfoque predominante em temáticas sociais e políticas. Os filmes escolhidos para a análise inserem-se nessa dinâmica. Ao abordá-los, gostaríamos de retomar questões anteriores: quais as imagens mostradas por esses filmes em relação aos estigmas da pobreza e da violência? Quais as narrativas neles engendradas? Num primeiro momento, traremos uma síntese dos filmes para, em seguida, desenvolver as análises.

Apresentamos observações empreendidas a partir de categorias conceituais e metodológicas norteadoras das reflexões, aplicando-as a um conjunto de filmes. Dado o volume do material encontrado, iremos concentrar os resultados a partir das análises dos filmes pertencentes ao segundo quinquênio (2007-2011), ainda que os demais filmes selecionados (2003-2006) estabeleçam com eles diversos pontos de interseção. Nesse momento, tomaremos os filmes Juízo, Tropa de elite, Jogo de cena e Saneamento básico para, em seguida abordar os filmes Última parada 174 (referindo-nos também a Ônibus 174), Meu nome não é Johnny, Simonal - Ninguém sabe o duro que dei e Moscou e tratá-los a partir dos dois eixos apontados: estabelecer um panorama de sua relação com o reforço/transposição de estigmas sociais e das formas como neles se opera a diluição realidade/ficção. Antes, apresentamos uma síntese dos enredos ${ }^{28}$.

Das produções de 2007, Juízo é provavelmente o filme menos conhecido, por se tratar de um documentário com produção modesta. Sua proposta, no entanto, é extremamente original e inovadora ${ }^{29}$, justificando a escolha. $\mathrm{O}$ filme, dirigido por Maria Augusta Ramos, apresenta a trajetória de jovens menores de idade (terminologia geralmente usada para se referir a "meninos infratores" ou, de forma adequada, "jovens em situação de risco") desde a prisão até seu julgamento. Como a identificação de jovens com menos de 18 anos é proibida por lei, em Juizo eles são representados por jovens atores que vivem em condições sociais similares. As audiências, entretanto, foram filmadas na II Vara de Justiça do Rio de Janeiro, com os próprios juízes, que sempre recomendam, ao final de cada sessão, que os jovens tenham “juízo". A edição, feita a partir de duas filmagens diferentes - uma factual, documentada nas próprias audiências com os meninos "verdadeiros", e outra com os atores que iriam substituí-los

\footnotetext{
${ }^{28}$ As fichas técnicas e sinopses dos filmes foram consultadas em www.adorocinema.com.

29 Para uma interessante aproximação entre os documentários Juízo e Jogo de cena, ver o artigo “Encenação da realidade: fim ou apogeu da ficção?”, de Vera Lúcia Follain de Figueiredo, apresentado ao Grupo de Trabalho "Cultura das Mídias" do XVIII Encontro da Compós, na PUC Minas, em Belo Horizonte/MG, em junho de 2009.
} 
-, cria um interessante movimento no documentário, inovando e embaralhando suas premissas enquanto gênero referencial.

É nesse ponto que Juízo se encontra com Jogo de cena, documentário do reconhecido cineasta Eduardo Coutinho e que representa uma ruptura em sua produção, marcando uma fase de transição confirmada pelos filmes Moscou, lançado em 2009, e As canções, de $2011^{30}$. No primeiro, 23 mulheres respondem a um anúncio de jornal e contam a história de suas vidas, que posteriormente é interpretada por atrizes. Dirigido Coutinho (que realizou também Edificio Master e $O$ fim e o princípio), o elenco é formado por Marília Pêra, Andréa Beltrão e Fernanda Torres, além de atrizes desconhecidas e mulheres comuns que contam suas próprias histórias ou outras histórias enviadas. $O$ filme desloca os campos da factualidade e da ficcionalidade não para tornálos indistintos, mas para afirmar a força da ficção, tendo como cenário um teatro vazio. Diretor e entrevistas estão no palco, elas de costas para a plateia, que se encontra vazia.

Moscou, por sua vez, foca o palco e as coxias do Galpão Cine Horto, base dos ensaios do Grupo Galpão, em Belo Horizonte (MG). Ali, o diretor Enrique Diaz e seu elenco enfrentaram o desafio de montar, em apenas três semanas, a peça "As três irmãs", de Anton Tchekhov, para que fossem filmados por Coutinho.

O diretor acompanhou essa experiência, registrando fragmentos de workshops, improvisações e ensaios de uma peça que não teve e nem terá estreia. Como lemos nas informações sobre o filme, os atores só tomaram conhecimento do texto no dia da filmagem e aceitaram a proposta visando registrar a experiência, e não o resultado final. A peça relata a história de Olga, Maria e Irina que, sem perspectivas de vida na província, sonham em voltar para Moscou. É um drama sobre pessoas e problemas do cotidiano que podem tornar a vida quase insuportável, e que ao ser retratado nas telas coloca em cena, literalmente, diversas questões contemporâneas.

No campo ficcional, em 2007 tivemos a exibição - polêmica e bem-sucedida do longa-metragem Tropa de elite ${ }^{31}$. Embora bastante difundido, retomamos sua trama sem esquecer, contudo, os aspectos extra fílmicos suscitados pelo filme de José Padilha, tanto em termos de distribuição e recepção, como em relação a seus usos e apropriações

\footnotetext{
${ }^{30}$ Ainda que em 2014 tenha sido lançado o filme Últimas conversas (2014), editado por João Moreira Salles e Jordana Berg a partir de entrevistas com jovens filmadas por Coutinho (e de anotações por ele deixadas), As canções viria a ser o último documentário do diretor, morto no início de 2014.

${ }^{31}$ Para discussão dos diferentes aspectos envolvidos no filme Tropa de elite, ver artigo "Uma questão de ponto de vista: a recepção de Tropa de Elite na imprensa", de Vera Lúcia Follain de Figueiredo, apresentado ao Grupo de Trabalho Cultura das Mídias do XVII Encontro da Compós, realizado em São Paulo em 2008.
} 
no que tange o consumo cultural do mercado cinematográfico. Tropa de elite conta a história de um capitão do Bope (Nascimento, mesmo sobrenome de Sandro, retratado em Onibus 174) que quer deixar o posto e busca um substituto, ao mesmo tempo em que dois amigos se destacam por sua honestidade como policiais. Outro longa de ficção que pode ser destacado naquele ano é Saneamento básico. O filme foi dirigido por Jorge Furtado, produtor e diretor de séries televisivas na Rede Globo e também documentarista, tendo seu curta-metragem Ilha das flores (1989) como um dos mais conhecidos documentários brasileiros. O filme relata a saga dos moradores de uma pequena vila, no sul do país, que planejam a realização de um vídeo apenas para pegar a quantia oferecida pelo governo federal e usá-la na realização de uma obra de saneamento básico. Voltaremos a ele posteriormente, pois consideramos que o filme apresenta uma síntese de inúmeros elementos presentes nos demais, reunindo diversos aspectos relacionados à amostragem final e às questões que dirigimos a esse conjunto.

Dos filmes de 2008, foram selecionadas duas produções ficcionais, que serão contrastadas com os documentários Moscou e Simonal, de 2009. Última parada 174, de Hector Babenco, despertou grande interesse junto ao público e à crítica não apenas pela história contada, mas por realizar uma versão ficcional do documentário Ônibus 174, lançado em 2002 por José Padilha, mesmo diretor de Tropa de elite.

O filme conta a história de Sandro Nascimento por meio do relato de dois jovens de nomes parecidos e idades próximas, que passam a conviver devido à chacina da Candelária. Como lemos na sinopse ${ }^{32}$, o filme se passa no Rio de Janeiro, em 1983: "Marisa (Cris Vianna) amamenta o pequeno Alessandro (Marcello Melo Jr.), em sua casa na favela. Viciada em drogas, assiste impotente seu filho ser retirado de suas mãos pelo chefe do tráfico local, devido a uma dívida não paga. Dez anos depois Sandro (Michel Gomes), filho único, vê sua mãe ser morta por dois ladrões. Apesar de ficar sob os cuidados da tia, ele decide fugir e passa a conviver com um grupo de garotos que dorme na igreja da Candelária, onde têm acesso ao mundo das drogas". A história então se desdobra, pois mesmo sem saber ler nem escrever, "Sandro sonha em ser um famoso compositor de rap. Para tanto ele espera a ajuda de Walquíria (Anna Cotrim), que realiza um trabalho voluntário junto a meninos de rua. Só que Sandro testemunha mais uma tragédia, a chacina da Candelária, onde oito meninos de rua foram mortos pela polícia. O evento aproxima Sandro e Alessandro, que passam a ter um forte convívio".

\footnotetext{
${ }^{32}$ Disponível em: http://www.adorocinema.com/filmes/filme-143050/. Acesso em: 15/08/2015.
} 
A trama é bastante semelhante àquela contada por Padilha em seu documentário, que tem como foco a história de Sandro até o dia de sua morte, quando realiza o sequestro de um ônibus urbano no Rio de Janeiro, e morre nas mãos da polícia. $O$ documentário tem como característica singular a utilização de gravações exibidas pelos telejornais (que impressionam pelo tom realista, beirando o sensacionalismo, e pela quantidade de imagens disponíveis, algumas muito próximas ao ônibus e ao próprio Sandro), cenas de arquivo, imagens oficiais do sistema de trânsito do Rio de Janeiro e depoimentos daqueles que vivenciaram o dia do sequestro. A abordagem do filme de Padilha é bastante engajada e apresenta forte crítica perante uma sociedade que produz esses episódios, ao não cuidar de suas crianças carentes por meio de ações políticas.

Dirigido por Mauro Lima, o filme Meu nome não é Johnny estreou no início de 2008 e foi uma das grandes bilheterias do cinema nacional naquele ano. Sua trama narra a história de João Guilherme Estrella, carismático carioca de classe média que se tornou o maior vendedor de drogas do Rio de Janeiro e depois lidou com o sistema carcerário do país. Mais uma vez, o tema dos estigmas se faz presente de forma não usual, relacionando o mundo do crime com a classe média das grandes cidades brasileiras. Simonal, por sua vez, resgata a trajetória de uma emblemática figura da música brasileira dos anos 1960, Wilson Simonal, através de depoimentos de pessoas que o conheceram e imagens de época em que se tornou cantor de grande sucesso. Lançado por Carlos Imperial, Simonal vendeu milhões de discos e lotou estádios em shows até ser condenado ao ostracismo devido à acusação de ser informante da ditadura militar, o que sempre negou, e fato que jamais foi comprovado.

De família extremamente humilde, era presença negra na MPB em um momento singular da história do país, reconstruída em termos políticos e sociais, de forma contundente, pelo documentário. Documentário dirigido por três realizadores - Cláudio Manoel (integrante do grupo Casseta e Planeta), Micael Langer e Calvito Leal -, seu subtítulo "ninguém sabe o duro que dei" é tirado de uma das músicas cantadas por Simonal e, ao mesmo tempo, estabelece um posicionamento sobre sua história na perspectiva adotada pelo filme.

A fim de complementar as análises, destacamos dois outros filmes de 2009 - o documentário Garapa e a ficção O contador de histórias. O primeiro, terceiro longametragem de Padilha, busca a real compreensão sobre o que é passar fome. Como mostrado no filme, de acordo com a ONU mais de 920 milhões de pessoas sofrem de fome crônica ao redor do planeta. Para entender o significado deste problema busca-se 
acompanhar de perto como é a vida destas pessoas, tendo por base o cotidiano de três famílias do estado do Ceará. O filme teve recepção polêmica devido à dureza das imagens apresentadas e à radicalidade ao tratar da fome em situações de extrema miséria. As imagens se tornam ainda mais impactantes por serem filmadas em preto e branco, ao mesmo tempo nos aproximando da realidade das histórias contadas e delas nos afastando. O segundo filme, dirigido por Luiz Villaça, é uma produção ficcional e conta a história verídica de Roberto Carlos Ramos, pedagogo mineiro e um dos maiores contadores de história da atualidade. De infância problemática, criado na Febem, ele conhece aos 13 anos a pedagoga francesa Margherit Duvas, que mudou sua vida e despertou nele a vocação que mais tarde se tornaria uma profissão e uma missão.

Desse conjunto, destacamos um traço comum, explorado anteriormente: todos empreendem, a partir de distintas visadas, o embaralhamento entre os campos da ficção e do documentário, caracterizando um momento singular para o cinema brasileiro contemporâneo em que vemos surgir outro gênero, além e aquém dos dois tradicionalmente circunscritos. Os hibridismos presentes nos filmes corroboram tal afirmação, apontando para a consolidação de um modo de fazer cinema no país.

Outro traço pode ser tomado como recorrente: de algum modo, seja por suas temáticas, pela abordagem delas realizada, pelos modos de produção ou por características estéticas e tecnológicas, todos os filmes trazem como marca a possibilidade de transposição dos estigmas sociais tratados. Temos meninos em situação de risco no documentário Juizo, que contrastam com a polícia assertiva do Bope em Tropa de elite, passando pela abordagem de questões sociais de modo inusitado - como vemos na vida cotidiana das atrizes encenando para uma plateia vazia em Jogo de cena, ou nos moradores transformados em amadores para realização de um documentário de ficção em Saneamento básico. Os filmes não se prestam a lugares comuns, intercambiando posições e atores sociais, desmobilizando os estigmas a eles associados.

Além desses traços, a precariedade da situação da infância e da juventude é matizada pelos vieses de um adolescente submetido à brutal exclusão, retratado nos filmes de "ficção-documental" Última parada 174 e Ônibus 174, tendo seu correlato no adolescente de classe média que vê nos pais os mesmos elementos passíveis de gerar revolta e indignação, como se aos jovens de Meu nome não é Johnny (que mesmo sem ser uma biografia, não por acaso foi escrito a partir da história vivida de fato por seu personagem) não fosse mais possível encontrar um lugar ou um papel social. 
Os documentários Moscou e Simonal estabelecem no campo da arte, para além de dados factuais ou roteiros hermeticamente fechados visando construir uma verdade absoluta, possibilidades outras de transpor e, quem sabe, diluir estigmas enraizados em nossa sociedade. Antigas dicotomias e posições radicais são questionadas nos “documentários-ficcionais", em que o próprio lugar do realizador é problematizado. Mas não por acaso, destacamos Garapa, justamente por desafiar a abordagem buscada em torno de discursos híbridos. Ainda que calcado na perspectiva de denúncia frente à fome (e miséria) enfrentada por centenas de famílias brasileiras, é como se, por mostrar demasiadamente as imagens que pretende revelar, a elas sobrepusesse um véu, que paulatinamente afasta o espectador e faz com que este não consiga estabelecer um pacto em relação ao filme. De tanto revelar, Padilha vela as chocantes imagens, filmadas quase sempre em primeiro plano, e nos insere no ritmo apático da vida naquele lugar. $\mathrm{O}$ conceito psicanalítico de "semblante" nos ajuda a compreender esse processo: é como se, por excesso, as imagens mostradas não fizessem semblante, ou seja, não estabelecessem com o espectador um reflexo no qual apoiar-se para dotá-las de sentido, já que o semblante é o que faz frente ao horror do real, constituído pelos significantes imaginários que, ao mesmo tempo, descobrem e recobrem o imaginário social ${ }^{33}$.

\begin{abstract}
Abro a questão porque, na verdade, nada implica que a irrupção do discurso do inconsciente, por mais balbuciante que continue a ser, implique seja o que for, naquilo que a precedia, que estivesse submetido a sua estrutura. $\mathrm{O}$ discurso do inconsciente é uma emergência, é a emergência de uma certa função do significante. $O$ fato de ele haver existido até então como insígnia é justamente a razão de eu o haver situado para vocês no princípio do semblante (Lacan, 2009: 21).
\end{abstract}

A relação entre discurso e verdade - em estabelecer não se o que é dito é verdade, mas como aquilo que é dito se enuncia - faz com que desloquemos a maneira de olhar imagens referenciais, entre elas as presentes em documentários. De acordo com Lacan, "para o discurso, não existe nada de fato, só existe fato pelo fato de dizê-lo. O fato enunciado é, ao mesmo tempo, fato de discurso. É isso que designo com o termo artefato e, é claro, é isso que se trata de reduzir" (Lacan, 2009: 13). Não se trata, portanto, de testar um significado em relação a alguma coisa que exista fora dele, já que a interpretação "não é submetida à prova de uma verdade que se decida por sim ou não, mas desencadeia a verdade como tal. Só é verdadeira na medida em que é verdadeiramente seguida" (Lacan, 2009: 13).

\footnotetext{
33 Para uma aproximação rigorosa ao conceito de semblante, ver "De um discurso que não fosse semblante" (O Seminário, Livro 18, 1971), de Jacques Lacan (2009).
} 
O discurso de Garapa, ao contrário, não nos interpela naquilo que poderia desencadear como efeito de sentido, mas parece impor a nós uma voz unívoca em que seus personagens atuam apenas para corroborar tal voz. Entre "mostrar as coisas como elas são" e "contestar a realidade", para usar conceitos trazidos por Bill Nichols (2005) ao tratar da voz nos documentários, Garapa não encontra sua voz, pois em vez de fazer ecoar a voz de seus personagens é sempre uma voz autoritária, extra diegética, que vemos impor-se no filme. A imprecisão entre o didatismo do discurso direito, a vontade de verdade de certo cinema e o uso de entrevistas nas quais os personagens falam diretamente ao espectador afasta, enquanto efeito de sentido, a potência autorreflexiva do documentário, no qual ele não se pretende uma janela aberta para a realidade mas, ao contrário, apresenta o realizador como "testemunha participante" e "ativo fabricante" de sentidos. Ou seja: "Muito mais um produtor de discurso cinemático do que um repórter neutro ou onisciente da verdadeira realidade das coisas" (Nichols, 2005: 49). Ainda que empreenda, em termos narrativos, uma reafirmação de estigmas sobre a fome, a miséria e o abandono social, em termos estéticos o documentário almeja superar as formas tradicionais do gênero e, talvez por isso, mais além de suas formas, encontre um ponto de giro no qual realocar as temáticas trazidas pelas imagens.

Voltemos agora a Saneamento básico. Filme que traz dentro de si outro filme, vemos explicitadas em sua composição as relações anunciadas. Buscando estabelecer uma síntese, é deste(s) filme(s) que falaremos para concluir, de modo relacional, as ligações entre as narrativas audiovisuais privilegiadas até este ponto de nossa escuta. Nesse último longa-metragem, Jorge Furtado parece retomar os elementos presentes em seus filmes anteriores e realizar uma fusão que ao mesmo tempo guarda semelhanças e estabelece releituras em relação a eles, sobretudo por seu caráter metalinguístico - a exemplo de seus outros filmes, também neste Furtado trata do cinema do ponto de vista de sua produção - de suas escolhas narrativas, tecnológicas e estéticas ${ }^{34}$.

Contando uma vez mais com a participação do ator Lázaro Ramos e com elenco reconhecido pelo público por sua atuação em novelas ou outros filmes (Fernanda Torres, Camila Pitanga, Wagner Moura, Bruno Garcia), Saneamento básico traz novamente o tema da farsa e do burlesco na obra de Furtado - das aparências e dos modos de construção da realidade -, como vimos na impossibilidade de haver dois verões (título que evoca o clássico Houve uma vez um verão, de Robert Mulligan,

\footnotetext{
${ }^{34}$ Processo semelhante seria realizado pelo diretor em seu documentário $O$ mercado de notícias, lançado em 2014 e do qual trataremos adiante.
} 
1971), em que um se coloca como negativo do outro; nas cópias reproduzidas em $O$ homem que copiava; e nas fotomontagens do Meu tio matou um cara. O "filme dentro do filme" em Saneamento básico retoma elementos presentes no curta-metragem Ilha das flores e, ao fazê-lo, é como se afirmasse que o cinema brasileiro está novamente maduro, podendo falar de si (e, sobretudo, rir de si) em suas várias etapas (roteiro, montagem, produção, edição, elenco, distribuição, veiculação).

O filme mambembe dentro do filme globalizado (para ironizar apenas um dos estereótipos ou preconceitos que rondam o cinema brasileiro) explicita a complexidade da trama narrativa de Saneamento básico: Furtado realiza um filme brasileiro que não é nada trivial e apresenta, dentro deste seu filme, um filme brasileiro amador, como se debochasse do próprio cinema que rejeita sua precariedade. Tal precariedade, presente na produção local dos moradores em busca de saneamento (para suas vidas e para o cinema), termina por contaminar também o filme dirigido por Furtado, visto como dotado de seriedade em relação à comicidade do filme da comunidade.

Esse fino traço de humor pode ser percebido na atuação do elenco de inegável talento que, no filme de Furtado - e também no filme dentro do filme, chamado " $\mathrm{O}$ monstro da fossa" -, parece atuar de maneira forçada, quase artificial, tão precária quanto o amadorismo dos cidadãos comuns - transformados em atores - que representam os personagens no filme sobre o saneamento básico necessário à pequena cidade retratada em tons documentais. Nesse sentido, destacamos a atuação de Fernanda Torres como a diretora do filme local, mas sem atuar nele, e a de Paulo José, que realiza uma dupla interpretação: a de seu personagem no filme de Furtado, que atua de maneira rudimentar, e a atuação daquele que deve ser novo personagem no filme da cidade, surpreendendo a todos por seu profissionalismo. As inversões presentes nas narrativas desse diretor nos surpreendem também em Saneamento básico, fazendo eco àquelas percebidas em seus outros filmes.

$\mathrm{Na}$ combinação desses elementos, vemos surgir outro traço presente nesses filmes: a crítica social que se mescla com humor e, ao apresentar a realidade de um lugar trata dos problemas do país de forma precisa e profunda, sem a necessidade de discursos ácidos ou posicionamentos explícitos. O caráter amador da produção local se mistura com a necessidade de que haja uma fossa naquela comunidade, colocando em jogo elementos próprios da produção documental e também ressaltando os privilégios da forma ficcional. 
O filme se torna apenas um pretexto, mas ainda assim é realizado num misto de dedicação e distração por parte daqueles envolvidos em sua produção, que parecem oscilar entre os encantos de ser bem sucedido na realização do filme, ou fazê-lo apenas como meio para obter um benefício maior à comunidade, beneficio este não percebido de imediato na feitura do filme.

Podemos dizer que a exemplo dos outros filmes de Jorge Furtado, esse também engendra uma espécie de armadilha para sua audiência, pois o tempo todo oscilamos entre os dois filmes narrados e a impressão de que se trata de filmes mal feitos, como se o diretor pudesse rir de si mesmo e rir com seu público. Ao contrário do tom ácido ou desesperançado de muitos dos filmes brasileiros recentes, Furtado estabelece, por meio do humor, uma possibilidade de problematizar questões sociais, culturais e políticas, além de abordar aquilo considerado genuíno em oposição a algo tido como falso. Assim como nas narrativas literárias ficcionais, o filme dentro do filme não é falso porque não se pretende verdadeiro; ao contrário, assume seu caráter inventivo e fabuloso, misturando recursos tecnológicos com um riso às vezes aberto, às vezes constrangido, como aquele que se faz presente nas plateias de filmes brasileiros.

O filme sobre o saneamento básico encenado dentro do filme Saneamento básico trata não apenas de temáticas sociais, mas também daquelas muitas vezes relativas ao próprio cinema nacional em suas limitações de recursos, objetivos e finalidades, contemplando as etapas de produção, finalização e distribuição desses filmes. O cinema cria realidades ficcionais sempre que coloca em funcionamento seu aparato narrativo, tecnológico e estético - mesmo que seja em filmes que, como Saneamento (e ao contrário do filme da comunidade), pretendem-se comprometidos com uma exigência de veracidade, objetividade e realismo que só pode levar ao riso. O trânsito entre as bordas do documento e as da fantasia conduz os filmes de Furtado, encontrando diversas camadas de hibridismos e simulações, mesclando e ampliando fronteiras.

Os gêneros e as formas narrativas, as tecnologias e os seus formatos específicos, as temáticas sociais e as trocas entre mídias configuram e aproximam os filmes, que consideramos marcadamente híbridos também com respeito aos estigmas e posições ocupadas em hierarquias preestabelecidas. Ao subverter o campo do social e o campo do cinema, tornam-se filmes de difícil apreensão. Neles são explicitados os artifícios comuns ao documentário e à ficção, ao cinema dito comercial e ao experimental, recolocando também os questionamentos usuais em relação à estética cinematográfica, especialmente em um país que se encontra na periferia do sistema da produção mundial. 
Notamos nos filmes a reiteração de visualidades, apontando para a contaminação de formatos audiovisuais. Se tomarmos os processos comunicacionais como uma permanente negociação, entendemos que as mídias não podem ser vistas como totalizantes, mas como lugares de reconhecimento e de trânsito simbólico, como zonas de fronteira nas quais as reapropriações se fazem nas brechas. Os filmes parecem, assim, apontar para a dimensão política das práticas culturais em sentido amplo, dimensão esta em que espaço público e identidades sociais se confundem e se recriam.

Ao trabalhar em lugares de passagem, os filmes abrem espaços para pensarmos não apenas os sujeitos, mas as relações presentificadas na atualidade. Uma narrativa polifônica se apresenta, reorganizando as formas de ver e agir no mundo, atribuindo significados e rearticulando elementos antes lineares. Se não há a verdade dos fatos, mas a verdade de discursos que se mostram verdadeiros, podemos pensar, com os filmes, que os hibridismos sinalizam novas formas de codificação (produção) e decodificação (recepção) dos discursos midiáticos, e outros modos de inserção social a partir das lacunas presentes na realidade - e que se apresentam nas tramas impuras das imagens audiovisuais contemporâneas. 


\section{ArticulaÇões Discursivas nas Mídias}

\section{Narrativas audiovisuais: entre consolidação e transgressão}

Dando continuidade à amostragem de filmes brasileiros voltados à temática dos estigmas sociais, trataremos, nesse momento, daqueles lançados nos anos de 2010 e 2011. Como dissemos, este biênio foi destacado dos demais períodos devido a suas peculiaridades. Além disso, notamos um reforço crescente das três características apontadas, a saber: o grande número de produções documentais (com acento continuado nos documentários musicais); o borramento de fronteiras entre documentário e ficção, incluindo as produções de realizadores entre esses dois gêneros; e, ainda, o aumento de filmes nacionais em circuito comercial e de filmes que tematizam os estigmas sociais sob várias perspectivas.

Finalmente, destacamos como uma quarta característica histórias frequentemente compostas por personagens marcantes, atuando como fios condutores dos enredos e, muitas vezes, estabelecendo com outras vozes lugares ambivalentes na constituição da função de narrador no filme ${ }^{35}$. Nesse sentido, os sujeitos contemporâneos passam a ser retratados em suas contradições e desafios, como se a ideia de autoria deixasse de operar em oposição às formas genéricas e passasse a ser vista como elemento interno aos filmes por meio de seus personagens ${ }^{36}$. Notemos que o crescimento da produção não necessariamente implica na permanência da temática dos estigmas, mas a proporção notada nos faz reafirmar a relevância do recorte quando tratamos do cinema brasileiro.

Muitos dos filmes que tematizam os estigmas sociais o fazem a partir de uma abordagem singular, acentuando a possibilidade de transposição e transformação desses estigmas - para retomarmos os termos utilizados no trabalho - para além de seu reforço e manutenção. Narrativas divergentes se sobrepõem àquelas usualmente presentes nas mídias, apontando para novos regimes de visibilidade de atores sociais usualmente excluídos dos processos de representação e para outros deslocamentos desses atores nos espaços em que estão inseridos.

\footnotetext{
35 Para uma interessante aproximação aos lugares do autor, do narrador e do leitor em obras literárias (podendo ser estendida a outras formas textuais), ver Eco (1994).

${ }^{36}$ Não pretendemos, nesse momento, empreender um debate sobre a autoria no cinema, mas entendemos que a oposição simplista entre cinema de arte (ou cinema de autor) e o cinema comercial (ou cinema popular) não se sustenta ao olharmos essa produção. Ver Aumont e Marie (2003); Ramos (2008); e Bazin (2014).
} 
Essa tendência adquire contornos mais nítidos em 2010 e se confirma em 2011, apresentando temáticas urbanas e de situações limiares que não dizem respeito apenas às periferias das grandes cidades ou do país, mas também àqueles que por razões diversas se encontram à margem da sociedade. $\mathrm{O}$ dia a dia é retratado como inusitado $\mathrm{e}$ radical não apenas em termos de crítica social à violência à pobreza, mas também nas situações cotidianas em que cada um dos personagens tenta interagir com os outros.

\subsection{Referencialidade e ficcionalidade em filmes brasileiros}

A partir dos critérios anteriormente estabelecidos, propomos os seguintes quadros com filmes brasileiros relacionados aos estigmas sociais para os anos 20102011, selecionados de forma não aleatória a partir dos lançamentos de cada ano. Os filmes, uma vez mais, foram escolhidos de acordo com sua demarcação temática, sendo que as datas constantes nas tabelas referem-se ao ano de lançamento. Confirmamos, neste biênio, a presença de coproduções com outros países, tendência que se manteve no período analisado.

\begin{tabular}{|c|c|c|c|c|}
\hline \multicolumn{5}{|c|}{$\begin{array}{c}\text { TABELA XXVI } \\
\text { FILMES DE FICÇÃO E NÃO-FICÇÃO (2010) }\end{array}$} \\
\hline Título & Diretor & Ano & Gênero & Duração \\
\hline $\begin{array}{l}155 . \quad 400 \text { contra } 1-\text { Uma } \\
\text { história do crime organizado }\end{array}$ & Caco Souza & 2009 & Ficção & $98 \mathrm{~min}$ \\
\hline $\begin{array}{l}\text { 156. } 5 \times \text { favela - Agora por } \\
\text { nós mesmos }\end{array}$ & $\begin{array}{l}\text { Wagner Novais, Rodrigo } \\
\text { Felha, Cacau Amaral, } \\
\text { Luciano Vidigal, Cadu } \\
\text { Barcellos, Luciana } \\
\text { Bezerra, Manaíra } \\
\text { Carneiro }\end{array}$ & 2010 & Ficção & $103 \mathrm{~min}$ \\
\hline Acácio & Marilia Rocha & 2010 & Documentário & $80 \min$ \\
\hline 158. A alma do osso & Cao Guimarães & 2004 & Documentário & $74 \min$ \\
\hline $\begin{array}{l}159 . \\
\text { acabe }\end{array}$ & Ana Luiza Azevedo & 2009 & Ficção & $97 \mathrm{~min}$ \\
\hline $\begin{array}{l}\text { 160. Avenida Brasília } \\
\text { Formosa }\end{array}$ & Gabriel Mascaro & 2010 & Documentário & $85 \min$ \\
\hline $\begin{array}{l}\text { 161. B1 - Tenório em } \\
\text { Pequim }\end{array}$ & $\begin{array}{l}\text { Felipe Braga e Eduardo } \\
\text { Moura }\end{array}$ & 2009 & Documentário & $99 \min$ \\
\hline $\begin{array}{l}\text { 162. Bezerra do Silva - } \\
\text { Onde a coruja dorme }\end{array}$ & $\begin{array}{l}\text { Marcia Derraik e } \\
\text { Simplicio Neto }\end{array}$ & 2010 & Documentário & $72 \mathrm{~min}$ \\
\hline $\begin{array}{l}\text { 163. Depois de ontem, } \\
\text { antes de amanhã }\end{array}$ & Christine Liu & 2009 & Documentário & $73 \mathrm{~min}$ \\
\hline 164. Dzi Croquettes & $\begin{array}{l}\text { Tatiana Issa e Raphael } \\
\text { Alvarez }\end{array}$ & 2009 & Documentário & $110 \min$ \\
\hline Elevado 3.5 & $\begin{array}{l}\text { José Sodré, Maíra Buhler } \\
\text { e Paulo Pastoreto }\end{array}$ & 2007 & Documentário & $77 \mathrm{~min}$ \\
\hline
\end{tabular}




\begin{tabular}{|c|c|c|c|c|}
\hline Em teu nome & Paulo Nascimento & 2009 & Ficção & $102 \mathrm{~min}$ \\
\hline $\begin{array}{l}\text { 167. Estrada real da } \\
\text { cachaça }\end{array}$ & Pedro Urano & 2009 & Documentário & $98 \mathrm{~min}$ \\
\hline 168. Fabricando Tom Zé & Décio Matos Jr. & 2007 & Documentário & $89 \mathrm{~min}$ \\
\hline Federal & Erik de Castro & 2010 & Ficção & $92 \min$ \\
\hline $\begin{array}{l}\text { 170. O homem que } \\
\text { engarrafava nuvens }\end{array}$ & Lírio Ferreira & 2010 & Documentário & $106 \mathrm{~min}$ \\
\hline $\begin{array}{l}\text { 171. Os inquilinos - Os } \\
\text { incomodados que se mudem }\end{array}$ & Sergio Bianchi & 2009 & Ficção & $103 \mathrm{~min}$ \\
\hline $\begin{array}{l}\text { 172. Jards Macalé - Um } \\
\text { morcego na porta principal }\end{array}$ & $\begin{array}{l}\text { Marco Abujamra e João } \\
\text { Pimentel }\end{array}$ & 2008 & Documentário & $71 \mathrm{~min}$ \\
\hline 173. Marcha para a vida & Jessica Sanders & 2010 & Documentário & $81 \mathrm{~min}$ \\
\hline $\begin{array}{l}\text { 174. As melhores coisas do } \\
\text { mundo }\end{array}$ & Laís Bodanzky & 2009 & Ficção & $107 \mathrm{~min}$ \\
\hline 175. Meu mundo em perigo & José Eduardo Belmonte & 2007 & Fiç̧ão & $102 \mathrm{~min}$ \\
\hline 176. No meio do mundo & $\begin{array}{l}\text { Jean-Pierre Duret } \\
\text { (Brasil/França) }\end{array}$ & 2008 & Documentário & $90 \mathrm{~min}$ \\
\hline Olhos azuis & José Joffily & 2010 & Ficção & $105 \mathrm{~min}$ \\
\hline 178. Pachamama & Eryk Rocha & 2008 & Documentário & $105 \mathrm{~min}$ \\
\hline $\begin{array}{l}\text { 179. Programa Casé - O que } \\
\text { a gente não inventa, não existe }\end{array}$ & Estevão Ciavatta & 2010 & Documentário & $80 \mathrm{~min}$ \\
\hline $\begin{array}{l}\text { 180. Rita Cadillac - A lady } \\
\text { do povo }\end{array}$ & Toni Venturi & 2007 & Documentário & $75 \mathrm{~min}$ \\
\hline $\begin{array}{l}\text { 181. Seu Jorge - América } \\
\text { Brasil, o documentário }\end{array}$ & $\begin{array}{l}\text { Pedro Jorge e Mariana } \\
\text { Jorge }\end{array}$ & 2009 & Documentário & $103 \mathrm{~min}$ \\
\hline $\begin{array}{l}\text { 182. Só dez por cento é } \\
\text { mentira }\end{array}$ & Pedro Cezar & 2008 & Documentário & $76 \mathrm{~min}$ \\
\hline $\begin{array}{ll}\text { 183. Soberano - Seis } \\
\text { vezes São Paulo }\end{array}$ & $\begin{array}{l}\text { Carlos Nader e Mauricio } \\
\text { Arruda }\end{array}$ & 2010 & Documentário & $90 \mathrm{~min}$ \\
\hline 184. Sonhos roubados & Sandra Werneck & 2009 & Ficção & $85 \mathrm{~min}$ \\
\hline Terra deu, terra come & Rodrigo Siqueira & 2009 & Documentário & $88 \mathrm{~min}$ \\
\hline Terras & Maya Da-Rin & 2009 & Documentário & $75 \mathrm{~min}$ \\
\hline 187. Todo poderoso & $\begin{array}{l}\text { Ricardo Aidar e André } \\
\text { Garolli }\end{array}$ & 2010 & Documentário & $100 \mathrm{~min}$ \\
\hline $\begin{array}{l}\text { 188. Tropa de Elite } 2-0 \\
\text { inimigo agora é outro }\end{array}$ & José Padilha & 2010 & Ficção & $116 \mathrm{~min}$ \\
\hline 189. Uma noite em 67 & Renato Terra e Ricardo Calil & 2010 & Documentário & $93 \mathrm{~min}$ \\
\hline $\begin{array}{l}190 . \quad \text { Viajo porque preciso, } \\
\text { volto porque te amo }\end{array}$ & $\begin{array}{l}\text { Marcelo Gomes e Karim } \\
\text { Ainouz }\end{array}$ & 2009 & Ficção & $75 \mathrm{~min}$ \\
\hline 191. Vida sobre rodas & Daniel Baccaro & 2010 & Documentário & $110 \mathrm{~min}$ \\
\hline
\end{tabular}

Observando a tabela acima e a seguinte, podemos notar, na diversidade dos lançamentos, o deslocamento entre filmes documentais e ficcionais, tanto do ponto de vista da produção como da recepção. Essas imbricações se fazem presentes nos planos narrativo e discursivo, bem como nos modos como cada realizador apresenta tais elementos, tornando imprecisas as classificações. Desse modo, ao olharmos a atual produção brasileira somos levados a desafios que permitam analisar os filmes para além de categorias tradicionais. 
Em relação ao aumento expressivo de documentários ${ }^{37}$, podemos reconhecer, dentro do que se convencionou homogeneizar como um gênero, a possibilidade de organizar, de modo semelhante à ficção, a produção documental brasileira. Em pesquisa recente, encontramos uma interessante proposta de demarcação das diversas temáticas presentes em documentários que, a nosso ver, podem ser pensados como estilos (ou estéticas) documentais: documentários sobre questões sociais e políticas; documentários sobre esportes; documentários sobre música e/ou personagens musicais; documentários sobre temas variados ${ }^{38}$.

A respeito do primeiro grupo - questões sociais e políticas, que nos interessa mais de perto na relação com os estigmas sociais -, Ramos afirma que, desde o final dos anos 1990, "os dilemas do diálogo com o outro popular surgem como uma das correntes esteticamente mais densas do documentário brasileiro contemporâneo" (Ramos, 2008: 208), dado confirmado por nossas análises.

Os regimes de visibilidade (Rancière, 2009; Badiou, 2002) e as políticas da representação deste outro - ou, ainda nas palavras de Ramos, de um "outro popular criminalizado" - são aspectos que abordaremos posteriormente. Tal recorte não é exclusivo de documentários, sendo marcante também na produção ficcional. Entretanto, por eleger conflitos e questões sociais como sua tônica dominante (muitas vezes utilizando tal critério como fundante do documentário), os filmes de não-ficção apresentam inúmeras produções calcadas nesse viés.

Os documentários sobre música e/ou personagens musicais, por sua vez, de acordo com os exibidores, representam grande parcela do público deste gênero, fenômeno que vem se repetindo nos últimos anos, como vemos:

\footnotetext{
Desse conjunto de dados é interessante constatar que o tema música já aparece no ano de 2003, com os filmes Nelson Freire (2003) e Paulinho da Viola - Meu tempo é hoje (2003), ambos com um público na faixa dos 50 mil espectadores, sendo que a temática perde força em 2004 e retoma em 2005, marcado pelos lançamentos de Vinícius (2005) e Coisa mais linda (2005), que juntos contabilizam mais de 300 mil espectadores (Trindade, 2011: 62).
}

\footnotetext{
37 O número de espectadores de produções ficcionais brasileiras ainda é bastante superior aos de espectadores que assistem a documentários. Ainda assim, como veremos, o público destes últimos tem crescido consideravelmente.

${ }^{38}$ Para informações e análises detalhadas de filmes documentários realizados no Brasil a partir do ano 2000, ver Teresa Perosa em $O$ documentário chegou à sala de cinema. E agora? O lugar do documentário no mercado cinematográfico brasileiro a partir de seus agentes: da produção à exibição (2000-2009) (Unicamp, 2011). Ver, ainda, o site desenvolvido na Universidade Federal de Juiz de Fora (UFJF) com um levantamento abrangente da produção documental realizada no Brasil desde seus primórdios. Disponível em: www.documentariobrasileiro.org.
} 
Mesmo contando com apenas quatro lançamentos musicais, em 2008 o filme Mistério do samba levou 30 mil espectadores aos cinemas. Em 2009, dos 40 documentários lançados, 13 eram musicais, crescimento notável em termos de produção, distribuição e recepção ${ }^{39}$. Além disso, os documentários mais assistidos em 2009 e 2010 (com 45 lançamentos) foram, respectivamente, Simonal - Ninguém sabe o duro que dei (cerca de 70 mil espectadores) e Uma noite em 67 (cerca de 80 mil). Considerando a listagem geral de filmes, Simonal ocupou a $16^{\mathrm{a}}$. posição e, Uma noite em 67, a $17^{\mathrm{a}}$.

Em termos de adesão, tal fenômeno pode ser explicado pelo fato de o documentário musical não se limitar à divulgação comercial ou ao registro de turnês mas, ao contrário, apresentar "narrativas audiovisuais em longa-metragem que articulam em sua tessitura representações sobre os sujeitos sociais que constroem e sobre aspectos histórico-culturais das épocas retratadas" (Duccini, 2011: s/p). Em relação ao público dos filmes brasileiros, os dados sistematizados pela Agência Nacional do Cinema (Ancine) trazem números precisos sobre os lançamentos ${ }^{40}$.

Em 2010, segundo o "Informe de acompanhamento de mercado" (Ancine: Informe Anual, 2010) ${ }^{41}$, os lançamentos verificados no Brasil totalizam 224 filmes de ficção, 45 documentários e 13 animações. Entretanto, quando observamos os dados referentes ao público, notamos uma inversão: embora representem apenas $4 \%$ dos lançamentos, os filmes de animação conquistaram 18\% do público: “A média de espectadores por filme de animação lançado foi de 1.764 .895 , bem acima dos 414.806 espectadores por título dos filmes de fícção e dos 11.180 espectadores por documentário" (Ancine: Informe Anual, 2010). Em termos porcentuais, os documentários correspondem a menos de $1 \%$ de participação de público. Entre os filmes nacionais, temos, para 2010, 43 filmes de ficção, 32 documentários e nenhum filme de animação.

\footnotetext{
39 Para uma aproximação ao conjunto de documentários musicais contemporâneas e suas principais características, ver Mariana Duccini em "Um imaginário da redenção: sujeito e história no documentário musical” (XV Encontro da Sociedade Brasileira de Estudos de Cinema e Audiovisual - Socine, UFRJ, setembro de 2011).

${ }^{40}$ Os números apresentados foram extraídos dos sites FilmeB e Ancine, disponíveis, respectivamente, em: www.filmeb.com.br/portal/html/portal.php e www.ancine.gov.br/cgi/cgilua.exe/sys/start.htm?tpl=home. Acesso em: 23/02/2012.

${ }^{41}$ Para acesso aos dados completos, ver "Informe de acompanhamento de mercado" (resultados de 2010). Disponível em: www.ancine.gov.br.
} 


\begin{tabular}{|c|c|c|c|c|}
\hline \multicolumn{5}{|c|}{$\begin{array}{c}\text { TABELA XXVII } \\
\text { FILMES DE FICÇÃO E NÃO-FICÇÃO (2011) }\end{array}$} \\
\hline Título & Diretor & Ano & Gênero & Duração \\
\hline 192. 2 coelhos & Afonso Poyart & 2011 & Ficção & $108 \mathrm{~min}$ \\
\hline $\begin{array}{l}\text { 193. } \quad 4 \times \text { Timão }-\mathrm{A} \\
\text { conquista do tetra corinthiano }\end{array}$ & Di Moretti & 2011 & Documentário & $96 \min$ \\
\hline 194. Além da estrada & $\begin{array}{l}\text { Charly Braun } \\
\text { (Brasil/Uruguai) }\end{array}$ & 2010 & Fiç̧ão & $85 \mathrm{~min}$ \\
\hline Amanhã nunca mais & Tadeu Jungle & 2011 & Ficção & $78 \mathrm{~min}$ \\
\hline Amor? & João Jardim & 2011 & Fiç̧ão & $100 \mathrm{~min}$ \\
\hline As canções & Eduardo Coutinho & 2011 & Documentário & $90 \min$ \\
\hline Um assalto de fé & Cibele Amaral & 2011 & Fiç̧ão & $96 \min$ \\
\hline Bahêa minha vida & Márcio Cavalcante & 2011 & Documentário & $100 \mathrm{~min}$ \\
\hline $\begin{array}{l}\text { 200. Bollywood Dream - O } \\
\text { sonho bollywoodiano }\end{array}$ & $\begin{array}{l}\text { Beatriz Seigner } \\
\text { (Brasil/Índia/EUA) }\end{array}$ & 2009 & Fiç̧ão & $83 \mathrm{~min}$ \\
\hline 201. $\quad$ Bróder & Jefferson De & 2009 & Ficção & $92 \min$ \\
\hline 202. Bruna Surfistinha & Marcus Baldini & 2010 & Ficção & $109 \mathrm{~min}$ \\
\hline $\begin{array}{l}\text { 203. O céu sobre os } \\
\text { ombros }\end{array}$ & Sergio Borges & 2010 & Documentário & $72 \mathrm{~min}$ \\
\hline $\begin{array}{l}\text { 204. Daquele instante em } \\
\text { diante }\end{array}$ & Rogerio Velloso & 2011 & Documentário & $110 \mathrm{~min}$ \\
\hline 205. Diário de uma busca & Flavia Castro & 2010 & Documentário & $105 \min$ \\
\hline E aí Hendrix? & Pedro Paulo Carneiro & 2010 & Documentário & $82 \min$ \\
\hline Efeito reciclagem & Sean Walsh & 2010 & Documentário & $105 \mathrm{~min}$ \\
\hline Elvis e Madonna & Marcelo Laffitte & 2010 & Fiç̧ão & $105 \mathrm{~min}$ \\
\hline Elza & $\begin{array}{l}\text { Izabel Jaguaribe e } \\
\text { Ernesto Baldan }\end{array}$ & 2010 & Documentário & $82 \mathrm{~min}$ \\
\hline 210. $\quad$ Estamos juntos & Toni Venturi & 2011 & Ficção & $95 \min$ \\
\hline $\begin{array}{l}\text { 211. Família Braz - Dois } \\
\text { tempos }\end{array}$ & Dorrit Harazim & 2011 & Documentário & $80 \mathrm{~min}$ \\
\hline 212. Família vende tudo & Alain Fresnot & 2010 & Fiç̧ão & $89 \min$ \\
\hline 213. A fuga da mulher gorila & Felipe Bragança & 2011 & Ficção & $82 \mathrm{~min}$ \\
\hline Inversão & Edu Felistoque & 2010 & Ficção & $91 \mathrm{~min}$ \\
\hline Lixo extraordinário & $\begin{array}{l}\text { Karen Harley, João } \\
\text { Jardim e Lucy Walker } \\
\text { (Brasil/Reino Unido) }\end{array}$ & 2010 & Documentário & $90 \mathrm{~min}$ \\
\hline Mamonas para sempre & Claudio Kahns & 2009 & Documentário & $90 \min$ \\
\hline Meu mundo em perigo & José Eduardo Belmonte & 2007 & Ficção & $102 \min$ \\
\hline Meu país & André Ristum & 2011 & Fiç̧ão & $90 \mathrm{~min}$ \\
\hline O mineiro e o queijo & Helvécio Ratton & 2011 & Documentário & $72 \min$ \\
\hline $\begin{array}{l}220 . \quad \text { Não se pode viver sem } \\
\text { amor }\end{array}$ & Jorge Durán & 2010 & Ficção & $102 \min$ \\
\hline O palhaço & Selton Mello & 2011 & Ficção & $88 \mathrm{~min}$ \\
\hline Quebradeiras & Evaldo Mocarzel & 2010 & Documentário & $71 \mathrm{~min}$ \\
\hline Quebrando o tabu & Fernando G. Andrade & 2011 & Documentário & $80 \mathrm{~min}$ \\
\hline $\begin{array}{l}\text { 224. O samba que mora em } \\
\text { mim }\end{array}$ & $\begin{array}{l}\text { Geórgia Guerra-Peixe } \\
\text { (Brasil/Portugal) }\end{array}$ & 2010 & Documentário & $72 \mathrm{~min}$ \\
\hline Sequestro & Wolney Atalla & 2010 & Documentário & $94 \min$ \\
\hline Simples mortais & Mauro Giuntini & 2011 & Ficção & $80 \mathrm{~min}$ \\
\hline Solidão e fé & Tatiana Lohmann & 2010 & Documentário & $89 \mathrm{~min}$ \\
\hline $\begin{array}{l}\text { 228. Top models - Um } \\
\text { conto de fadas brasileiro }\end{array}$ & Richard Luiz & 2009 & Documentário & $82 \mathrm{~min}$ \\
\hline 229. Trabalhar cansa & $\begin{array}{l}\text { Juliana Rojas e Marco } \\
\text { Dutra }\end{array}$ & 2011 & Ficção & $99 \min$ \\
\hline 230. Vips & Toniko Melo & 2010 & Ficção & $96 \min$ \\
\hline $\begin{array}{l}\text { 231. Vips, histórias reais de } \\
\text { um mentiroso }\end{array}$ & Mariana Caltabiano & 2010 & Documentário & $71 \mathrm{~min}$ \\
\hline
\end{tabular}


Ainda segundo a Ancine, o público total de cinema no Brasil, em 2010, foi superior a 134 milhões de espectadores, com renda total do mercado de exibição de mais de R\$ 1 bilhão, o maior público desde 1982, com um crescimento de $19 \%$ e de cerca de 30\% na renda em relação a 2009: "Esse aumento se deveu, em grande parte, ao bom desempenho das produções brasileiras: o público do cinema nacional foi de 25.227.757 espectadores, 57\% acima do registrado em 2009” (Ancine: Informe Anual, 2010), o melhor desempenho desde 2003. Entre os filmes brasileiros exibidos em 2010, quinze ultrapassaram a marca de 100 mil espectadores, três a mais do que em 2009. Cinco deles conquistaram mais de 1 milhão de ingressos vendidos, a saber: Tropa de elite $2^{42}$; Nosso lar; Chico Xavier; Muita calma nessa hora; Xuxa e o mistério de Feiurinha.

Os dados de $2011^{43}$ confirmam a tendência de aumento de público desse biênio: naquele ano, o número total de ingressos vendidos chegou a 143 milhões, com renda bruta de 1,4 bilhão de reais. Os lançamentos totais contam com 266 filmes de ficção, 58 documentários e 18 filmes de animação. Para os filmes brasileiros, foram vendidos quase 18 milhões de ingressos, com arrecadação de 163 milhões de reais, números que figuram entre as três melhores bilheterias dos últimos dez anos.

Foram lançados, no total, 99 filmes brasileiros, sendo 57 filmes de ficção, 40 documentários, uma animação e um filme não classificado, o maior número da última década, sendo que sete títulos brasileiros venderam mais de 1 milhão de ingressos (Ancine: Informe Anual, 2011). Os filmes De pernas pro ar, Cilada.com e Bruna Surfistinha ficaram entre as vinte maiores bilheterias no país ${ }^{44}$; e os títulos Assalto ao banco central, O palhaço, O homem do futuro e Qualquer gato completam o grupo de filmes com mais de 1 milhão de ingressos. Ainda assim, os filmes brasileiros apresentaram uma queda de $30 \%$ em relação a 2010, tanto em termos de ingressos vendidos como de renda bruta.

De acordo com o Informe Anual da Ancine (2011), tal fato deve ser relativizado pois, em 2011, não houve filmes comparáveis, em termos de abrangência, a Tropa de

\footnotetext{
${ }^{42}$ Segundo o Informe Anual da Ancine (2010), "com 11.023.475 espectadores, Tropa de elite 2, dirigido por José Padilha e distribuído de forma inovadora pela Zazen, foi o filme de maior público em 2010: quebrou um recorde de mais de 30 anos, superando o grande sucesso de Dona Flor e seus dois maridos (1976), que teve 10.735.524 espectadores nas salas de cinema. Tropa de elite 2 superou em mais de 3,6 milhões o segundo filme mais visto do ano, Shrek para sempre". Na sequência, Nosso lar e Chico Xavier tiveram público de 4.060 .304 e 3.412 .969 , respectivamente.

${ }^{43}$ Dados completos em "Informe de acompanhamento do mercado" (resultados de 2011). Disponível em: www.ancine.gov.br.

${ }^{44}$ Nessa ordem, o total de público foi de 3.095.894, 2.998 .560 e 2.166 .461 espectadores.
} 
elite 2 ou Nosso lar, principais responsáveis pelos números de 2010. Em 2011, foram lançados 40 documentários. Entre eles, os mais vistos foram Bahêa minha vida (com cerca de 75 mil espectadores), sobre os torcedores do time Bahia, Lixo extraordinário (quase 50 mil espectadores), baseado em trabalho do artista plástico Vik Muniz com material coletado no aterro do Jardim Gramacho (Rio de Janeiro), e Rock Brasília - Era de ouro (34 mil espectadores), sobre a geração dos jovens de Brasília dos anos 1980, que mudou o cenário da música brasileira, especialmente o rock.

As tabelas, como nos outros anos, apresentam uma lista abrangente de produções que consideramos pertinentes à questão dos estigmas. Dentre eles, elegemos alguns filmes que julgamos os mais representativos para as análises. Os dados sobre 2010 e 2011 totalizam 174 filmes. Desses, observando as tabelas, temos 37 títulos relacionados aos estigmas sociais em 2010 e 40 títulos em 2011. O número total das tabelas é de 77 filmes (no triênio anterior, o total foi de 71 filmes), ou seja, quase a metade dos filmes lançados nos dois anos, um aumento significativo em relação ao período anterior.

Dos 37 filmes de 2010 que tematizam os estigmas sociais, 25 deles são documentários, dado que aponta para, ao menos, dois aspectos: a ênfase do cinema brasileiro de não-ficção em questões sociopolíticas e o aumento dessa produção. É neste ano que temos forte presença de documentários musicais, destacando - exatamente por sua relação controversa aos estigmas, com acento em sua reafirmação ou subversão Dzi Croquettes, O homem que engarrafava nuvens, Uma noite em 67 e Rita Cadillac.

Os documentários de personagens (ou biográficos) também encontram lugar marcante, muitos também voltados a histórias musicais, tais como Bezerra do Silva Onde a coruja dorme, Fabricando Tom Zé, Jards Macalé - Um morcego na porta principal e Seu Jorge - América Brasil, o documentário. Outras abordagens, menos frequentes, são tratadas: espaciais ou geográficas (Avenida Brasília Formosa e Elevado 3.5); esportivas (Soberano - Seis vezes São Paulo e Todo poderoso); literárias ou poéticas (Só dez por cento é mentira, filme singular valendo-se do estilo de criação e de escrita do poeta Manoel de Barros (morto em 2014) para contar sua vida e revelar sua obra artística). Dessa extensa lista, é importante notar a variedade de enredos e estilos; ainda que seja possível agrupar os filmes por certas características comuns - o uso de entrevistas e o recurso à história e imagens de arquivo são frequentes -, os filmes se diferenciam bastante em termos de distribuição e recepção, não apenas quanto ao número de ingressos vendidos e à renda bruta, mas dos circuitos culturais aos quais se 
voltam, muitos deles relacionados ao protagonismo e/ou assujeitamento dos personagens retratados ou construídos.

Dos filmes de ficção, destacamos a combinação de um modo lírico de narrar com o enredo juvenil - seja por nostalgia ou conquista - presente em Antes que o mundo acabe, As melhores coisas do mundo e Viajo porque preciso, volto porque te amo. Ainda que os dois primeiros estejam mais claramente associados, os três filmes abordam ritos de passagem, em sentido literal ou figurado, enfocando as desventuras vividas pelos personagens, que se deparam com os seus conflitos e as alternativas que a eles se mostram. De modo mais contundente, em 400 contra 1 - Uma história do crime organizado, 5 x favela - Agora por nós mesmos, Sonhos roubados e Tropa de elite 2 O inimigo agora é outro, os estigmas sociais surgem de modo polêmico.

Mesmo com diferenças relevantes em termos de produção e recepção (não podemos esquecer que Tropa 2 se destaca não apenas neste ano, mas na trajetória do cinema brasileiro como um todo), os quatro filmes não se furtam ao enfrentamento de polêmicas e tabus comumente escamoteados na sociedade, nem à inovação formal, demonstrando a inseparabilidade entre política e estética quando se trata da produção audiovisual. Violência, crime, tráfico, poder público, força policial, pobreza, políticas sociais, engajamento e alternativas de participação surgem como temas prementes por meio de imagens fragmentadas e dispersas da contemporaneidade. Um dos filmes, $5 x$ favela, amplia esse escopo ao efetuar, de modo direto, a filmagem com aqueles que comumente são personagens atuando também como realizadores.

O ano de 2011, de um total de 40 filmes e diversos títulos de destaque, apresenta 20 documentários. Ainda que, em números absolutos, haja um decréscimo em relação a 2010, a potência dos filmes de não-ficção permanece na amostragem voltada aos estigmas sociais, atingindo pela primeira vez metade dos filmes selecionados e trazendo títulos desafiadores às análises, não só na escolha dos temas mas, especialmente, pela maneira incomum de abordá-los. Desses documentários, entretanto, não há algum que se destaque de modo marcante dos demais mas vemos, ao contrário de 2010, a presença de um realizador experiente e reconhecido, Eduardo Coutinho, com o filme As canções. É interessante apontar que o filme de Coutinho, mesmo ao tratar do tema da música, não se caracteriza como um documentário musical, ainda que evoque essa ênfase crescente do cinema brasileiro. Dentre esses, temos Elza, Mamonas para sempre e O samba que mora em mim. 
De temática esportiva, o filme $4 \times$ Timão $-A$ conquista do tetra corinthiano (sobre o time paulista Corinthians) e Bahêa minha vida (documentário mais visto em 2011) estão entre os destaques. Finalmente, daqueles diretamente voltados à temática dos estigmas, apontamos: O céu sobre os ombros (documentário que traz personagens incomuns no campo dos estigmas, como uma travesti que dá aulas em uma universidade em Minas Gerais); Quebrando o tabu (sobre a liberalização das drogas, com participação do ex-presidente Fernando Henrique Cardoso); Lixo extraordinário (trabalho de Vik Muniz em um aterro sanitário no Rio de Janeiro); Família Braz - Dois tempos (acompanhando uma mesma família há dez anos, mostrando sua ascensão social e as transformações no país) e Top models - Um conto de fadas brasileiro (colocandose em lugar estigmatizado entre os documentários, pois trata do universo de modelos brasileiras famosas no exterior).

Entre as produções ficcionais, diversos hibridismos compõem os filmes destacados; em termos temáticos, deslocamentos cotidianos, modos de viver e relações interpessoais constroem uma espécie de lirismo narrativo que se reflete em Amor? (que parte de histórias reais para se transformar em ficção), Estamos juntos (sobre a história de um casal em crise), Meu país (que retrata conflitos familiares de três irmãos por meio da doença mental de um deles), Bollywood Dream - O sonho bollywoodiano (sobre atrizes brasileiras que sonham atuar na Índia) e $O$ palhaço (retratando o universo onírico dos antigos circos mambembes). O filme Família vende tudo é reportado por exibir, de modo raramente tão claro, o reforço de estigmas sociais sob o gênero humorístico.

Encontramos, de forma marcante, filmes que agregam em sua estética elementos documentais, reafirmando o espaço da não-ficção no cinema brasileiro, e uma exceção em termos de bilheteria: o filme Bruna Surfistinha levou aos cinemas mais de 2 milhões de espectadores. Desenvolvido a partir de uma história verídica, contada em livro pela garota de programa que se torna conhecida por meio de seu blog, o alcance desse filme não se repete em outros mas, de certo modo, sintetiza a densa imbricação entre realidade e ficção manifesta nesses filmes. Um deles, Bróder, se apropria e ressignifica os modos de narrar presentes em obras emblemáticas, tais como Cidade de Deus e Tropa de elite, ao retratar os dilemas enfrentados nas periferias urbanas. De modo mais explícito, Vips e Vips, histórias reais de um mentiroso polemizam as fronteiras entre documentário e ficção nos filmes e nos debates extra fílmicos.

Considerando o biênio 2010-2011, selecionamos para análise quatro filmes. Diferentemente do período anterior, elegemos dois documentários por ano, e não um 
filme documental e um ficcional, por considerarmos relevantes os dados apontados sobre a produção brasileira de não-ficção. Não nos valemos, portanto, de critérios quantitativos, posto que, em 2010, Tropa de elite 2 levou mais de 10 milhões de pessoas aos cinemas e, em 2011, sete filmes venderam mais de 1 milhão de ingressos. De forma diversa, elegemos documentários que propõem novas maneiras de pensar os circuitos de reforço e/ou transposição de estigmas e sua relação com as formações discursivas mais ou menos hegemônicas presentes na sociedade.

Os filmes Uma noite em 67 e Dzi Croquettes foram escolhidos para 2010. Ambos são documentários musicais que extrapolam a tematização sobre a música ou seus protagonistas, reconstruindo um momento político e social do Brasil e propondo sobre ele uma leitura original. Dzi croquettes, além disso, traz estranheza nas imagens e na forma de mostrá-las, com enfoques controversos sobre moral, costumes, sexualidade. De modo análogo, elegemos dois documentários para 2011, As canções e O céu sobre os ombros. O primeiro, dirigido por Eduardo Coutinho, torna-se relevante não apenas em relação à temática dos estigmas, mas também como filme modelar para certa produção documental que, a todo momento, evoca o modo de filmar desse realizador para dele aproximar-se ou afastar-se. O segundo filme foi escolhido justamente por se contrapor a isso: lançado na internet e distribuído de modo independente, propõe uma maneira própria de filmar documentários e impõe-se, com força, por sua temática incômoda. Reproduzimos a seguir a tabela dos filmes escolhidos para cada ano.

Na sequência, temos uma síntese ${ }^{45}$ dos filmes do último biênio para, em seguida, articulá-los entre si. Completamos, assim, as considerações sobre os filmes do período 2007-2011, preparando as análises dos próximos anos (2012-2014). Os documentários Uma noite em 67 e Dzi Croquettes, além de Rita Cadillac, Só dez por cento é mentira, e os longas-metragens 5 x favela e Tropa de elite 2, de 2010, juntamente com os filmes As canções, O céu sobre os ombros, Bahêa minha vida, Quebrando o tabu, e também Bróder e Bruna Surfistinha, de 2011, serão apresentados a partir de suas redundâncias e ressonâncias. Lembramos, uma vez mais, que dois eixos principais articulam as leituras dos filmes: a diluição das fronteiras entre realidade e ficção, e o reforço ou transposição de estigmas sociais. Acreditamos que a temática dos estigmas não se apresenta de modo gratuito, mas está diretamente imbricada nas oscilações entre fato e fantasia, propondo a cada movimento novas combinações de elementos referenciais e ficcionais.

\footnotetext{
${ }^{45}$ As fichas técnicas e sinopses dos filmes foram consultadas em www.adorocinema.com.
} 


\begin{tabular}{|c|c|c|c|}
\hline \multicolumn{4}{|c|}{$\begin{array}{c}\text { TABELA XXVIII } \\
\text { FILMES DE FICÇÃO E NÃO-FICÇÃO }(2002-2011)\end{array}$} \\
\hline Ano & Filme de não-ficção & Filme de ficção & Observações \\
\hline 2002 & $-x-$ & $\begin{array}{l}\text { Cidade de Deus } \\
\text { Uma onda no ar }\end{array}$ & $\begin{array}{l}\text { Filmes ficcionais previamente } \\
\text { analisados, com grandes } \\
\text { diferenças em termos de } \\
\text { produção, temáticas e } \\
\text { recepção, fornecendo um } \\
\text { aparato metodológico e } \\
\text { conceitual no qual situar as } \\
\text { análises em torno de reforço } \\
\text { e transposição de estigmas. }\end{array}$ \\
\hline 2003 & Ônibus 174 & Carandiru & $\begin{array}{l}\text { O documentário Ônibus } 174 \text { é } \\
\text { de } 2002 \text { e foi selecionado por } \\
\text { seu impacto e relevância se } \\
\text { comparado aos filmes de } \\
2003 \text { do mesmo gênero. }\end{array}$ \\
\hline 2004 & De passagem & $\begin{array}{l}\text { O prisioneiro da grade de } \\
\text { ferro }\end{array}$ & $\begin{array}{l}\text { Serão feitas referências aos } \\
\text { documentários Entreatos e } \\
\text { Peões, por suas marcas } \\
\text { interdiscursivas, e ao filme } \\
\text { Cazuza, por sua relação com } \\
\text { a temática da aids. }\end{array}$ \\
\hline 2005 & A pessoa é para o que nasce & Cidade baixa & $\begin{array}{l}\text { Serão feitas referências ao } \\
\text { documentário O fim e o } \\
\text { princípio e ao filme de ficção } \\
\text { Meu tio matou um cara. }\end{array}$ \\
\hline 2006 & Falcão - meninos do tráfico & Os 12 trabalhos & $\begin{array}{l}\text { Serão feitas referências ao } \\
\text { documentário Estamira e ao } \\
\text { filme de ficção Árido movie. }\end{array}$ \\
\hline 2007 & Juízo & Tropa de elite & $\begin{array}{l}\text { Será feita referência ao filme } \\
\text { Saneamento básico, que de } \\
\text { forma original traz um } \\
\text { documentário inserido em } \\
\text { sua ficção, e ao filme Jogo de } \\
\text { cena, documentário que } \\
\text { dialoga com os demais. }\end{array}$ \\
\hline 2008 & $-x-$ & $\begin{array}{l}\text { Última parada } 174 \\
\text { Meu nome não é Johnny }\end{array}$ & $\begin{array}{l}\text { Selecionamos para o ano de } \\
2008 \text { dois filmes de ficção, } \\
\text { pois houve poucos } \\
\text { lançamentos de } \\
\text { documentários que fossem } \\
\text { relacionados à pesquisa. }\end{array}$ \\
\hline 2009 & Garapa & O contador de histórias & $\begin{array}{l}\text { Destacamos em } 2009 \text { o } \\
\text { grande número de } \\
\text { documentários, bem como as } \\
\text { referências que serão feitas } \\
\text { aos filmes Moscou, } \\
\text { Filmefobia e Simonal. }\end{array}$ \\
\hline 2010 & $\begin{array}{l}\text { Dzi Croquettes } \\
\text { Uma noite em } 67\end{array}$ & $-x-$ & $\begin{array}{l}\text { Além do aumento de filmes } \\
\text { lançados em 2010, os } \\
\text { documentários mantém a } \\
\text { tendência de crescimento; } \\
\text { aos filmes selecionados, é } \\
\text { imprescindível acrescentar o } \\
\text { fenômeno em torno do filme } \\
\text { Tropa de elite } 2 \text {. }\end{array}$ \\
\hline 2011 & $\begin{array}{l}\text { As canções } \\
\text { O céu sobre os ombros }\end{array}$ & $-x-$ & $\begin{array}{l}\text { Em 2011, } 50 \% \text { da produção é } \\
\text { documental; não há um filme } \\
\text { com público marcante, mas } \\
\text { um novo filme de Eduardo } \\
\text { Coutinho e filmes de ficção } \\
\text { com grande bilheteria, como } \\
\text { Bruna Surfistinha. }\end{array}$ \\
\hline
\end{tabular}


Entre os documentários, Uma noite em 67 recria, com inúmeras imagens de arquivo e entrevistas atuais com os músicos que estiveram no festival - e que, naquele momento, eram ainda desconhecidos ou iniciantes -, a etapa final do Festival da Música Popular Brasileira da TV Record, gravado em 21 de outubro de 1967. Os principais prêmios daquele ano traziam concorrentes como Caetano Veloso, Gilberto Gil, Edu Lobo e Chico Buarque, além de Os Mutantes, Roberto Carlos e Sérgio Ricardo. As apresentações de músicas como "Roda Viva", "Alegria Alegria", "Domingo no Parque" e "Ponteio" não se prestam apenas à compilação de um momento representativo do cenário musical brasileiro, mas a sua rememoração.

O filme guarda caráter histórico ao registrar a formação do tropicalismo, as divisões artísticas e políticas na época da ditadura e o surgimento de artistas que se consolidariam a partir daquela década e continuam, até o tempo presente, ocupando lugar de destaque na chamada música popular brasileira. Mas vai além ao ressignificar esses eventos à luz do atual momento, demonstrando, justamente, o caráter fugidio dos fatos históricos, continuamente recriados no contraponto entre passado e presente, memória e atualidade, dinâmica à qual voltaremos posteriormente. De modo análogo, mas ainda mais surpreendente, especialmente se considerarmos suas imagens a partir da tentativa de transpor certos estigmas sociais, Dzi Croquettes empreende o mesmo movimento, apresentando um determinado contexto social, cultural e político para recriá-lo com elementos só possíveis a partir de dados do presente.

O primeiro filme atesta o estranhamento, inscrito não apenas na figura dos jovens músicos - eles mesmos transgressores -, mas de um momento histórico de grande repressão política que contrastava com a liberdade presente naquelas manifestações artísticas. O segundo documentário, Dzi Croquettes, procura reinscrever, também no contexto musical e das rupturas sociais nele antecipadas, a história de um grupo que, ainda hoje, seria considerado ousado não apenas por seus padrões artísticos, mas pela maneira com que seus integrantes viviam, rompendo tabus morais, comportamentais e sexuais. O grupo teve seu primeiro show apresentado em 1972, período similar àquele de Uma noite em 67 , com homens travestidos de mulheres sem mostrar formas ou corpos femininos, confirmando o espírito de contracultura presente na época e a irreverência como modo de contestação política.

Voltados para a recriação de um contexto histórico específico - não por coincidência, o mesmo período - os dois filmes se encontram também nos elementos estéticos utilizados, com inúmeras imagens de arquivo e entrevistas que funcionam 
como elos não apenas da própria narrativa, mas do trânsito entre passado e presente. Os filmes, ainda que não recriem de modo ficcional suas histórias, imprimem a elas um caráter ficcionalizante pela releitura e ampliação dos eventos retratados, bem como dos personagens mostrados que, vistos aos olhos de hoje, não podem mais ser olhados como os jovens que vemos nas imagens antigas, atualizando nossa percepção.

É justamente a jornada de seus personagens que Eduardo Coutinho, novamente, retrata no filme As canções. Entrevistando homens e mulheres selecionados para cantar músicas que marcaram suas vidas, Coutinho volta ao ambiente teatral para encenar, dessa vez, histórias afetivas pontuadas por canções que acompanham as trajetórias desses sujeitos, quase todos tão estranhos quanto aqueles jovens músicos e artistas incomuns dos outros dois documentários. Aparentando ser um documentário musical sem que este seja seu mote, As canções não pretende reconstituir a história de um país mas, ao contrário, o significado da própria música nessa história, como se pudesse nos dizer, afinal, porque são feitos tantos filmes sobre essa arte e porque nos dispomos a vêlos. São as próprias canções e as memórias afetivas que se inscrevem por meio delas que ocupam o palco do filme, protagonizado por contadores de histórias que podem ressignificar essas memórias.

O documentário que apresenta os momentos mais importantes da vida e da carreira de Rita Cadillac, também por meio de depoimentos, entrevistas, imagens inéditas e material de arquivo, interessa-nos, sobretudo, pela forma um tanto desconfortável de construir sua personagem. Como em $O$ céu sobre os ombros, não apenas o tema, mas também os sujeitos retratados parecem perturbar pela simples visualização de suas figuras. Rita Cadillac, supostamente pertencente ao mundo artístico, causa tanto incômodo quanto a travesti, prostituta e professora; o atendente de telemarketing, torcedor fanático de futebol, skatista e integrante do movimento Hare Krishna; e o escritor angolano, de tendência suicida e que nunca teve um emprego, pai de uma criança portadora de doença mental, todos eles personagens de $O$ céu sobre os ombros. Figuras anônimas da periferia de Belo Horizonte (MG), no filme a cidade não tem caráter geográfico, mas subjetivo, na inscrição de personagens sempre deslocados e, desse modo, sempre em deslocamento, como se não pudessem encontrar seu lugar. A eles ninguém lhes dá ouvidos e, tampouco, à sociedade interessa que tais figuras, voluntária ou compulsoriamente alijadas do sistema de produção vigente, tenham qualquer sentido de pertença ou de presença. 
Alheios ao mundo transcendente e mobilizador da arte ou da política, os personagens assumem sua condição de exclusão ao mesmo tempo em que tentam se desvencilhar dos estigmas, todos aparentes, que carregam. De estética naturalista, o filme busca um olhar sobre a realidade que ao mesmo tempo dê conta de suas incongruências e possa, também, mostrá-las em sua radicalidade, sem visar a domesticação dos sujeitos retratados. Produzido pelo coletivo de realizadores mineiros Teia $^{46}$, o documentário se distingue nos modos de criação e distribuição de outros filmes recentes, tendo veiculação intensa na internet (inclusive com a exibição de trechos que não fazem parte do filme) e a exibição em festivais e salas alternativas.

A indistinção entre realidade e ficção se faz presente no modo de filmar e na montagem, tornando impossível, ao espectador, estabelecer o que de fato é referencial ainda que as imagens tenham inscrição documentarizante, não há explicações, entrevistas ou contextualizações como na maior parte dos documentários. Nesse aspecto, O céu sobre os ombros radicaliza o que outros documentários já haviam experimentado nas oscilações entre referencialidade e ficcionalidade. Mais do que isso, entretanto, importa-nos enquanto atitude radical frente à tematização e figurativização de estigmas sociais, posto que trata de personagens desviantes que não carregam a menor perspectiva de assimilação: vê-los é aceitar tal radicalidade, explícita no corpo ou na mente que não se pretendem normatizados, tampouco normalizados mas, ao contrário, buscam operar justamente nas contradições e identidades multifacetadas de cada um.

A fala que se apresenta é um balbucio, um busca do discurso em encontrar seu giro, seu lugar, mas é no vazio deste eixo ordenador que as histórias são contadas. É nesse ponto que, por contraste, O céu sobre os ombros se aproxima de Rita Cadillac: enquanto o primeiro assume o deslugar de seus sujeitos, o segundo tenta, ainda que sem a força histórica presente em Uma noite em 67 e Dzi Croquettes - "desajustados" que hoje encontram seu lugar como ícones da contracultura - explicar sua personagem para que não se apresente como tão marginal e estranha aos padrões sociais ou, nos termos de Foucault, a certas formações discursivas de seu tempo.

\footnotetext{
${ }^{46}$ Criado em 2003, o coletivo Teia já ganhou diversos prêmios em festivais brasileiros e seus filmes foram exibidos internacionalmente em festivais como Sundance, Locarno e Roterdã. Na época do lançamento, entre seus integrantes encontram-se Helvécio Martins Jr., Pablo Lobato, Clarissa Campolina, Marília Rocha, Leonardo Barcelos e Sérgio Borges, voltados para a experimentação de imagens em filmes de estética documental, mas que exploram também os limites da ficção.
} 
De modo diverso, mas encontrando eco na indistinção entre realidade e ficção e na fidelidade a certa autenticidade dos personagens retratados - o documentário Só dez por cento é mentira apresenta a biografia (inventada) e os versos do poeta matogrossense Manoel de Barros, contados através de depoimentos do escritor, de estudiosos e de leitores da sua obra. Filme único no cenário recente, a exemplo da trilogia literária Memórias inventadas, do autor, a história que vemos ser narrada é, ela mesmo, inventada, seguindo a inspiração do verso que dá nome ao filme: "Noventa por cento do que escrevo é invenção. Só dez por cento é mentira". Afirmação genial e coerente com o universo poético de Manoel de Barros, um duplo sentido se estabelece, ao dizer que a literatura é apenas invenção (portanto, não é a realidade) e que apenas a invenção é verdadeira (pois ela não faz parte da mentira). Desafiando, ironicamente, uma das tradições do documentário, um incômodo acompanha o filme de modo mais direto, pois, a exemplo de $O$ céu sobre os ombros, jamais sabemos se o que vemos são entrevistas "verdadeiras" ou "mentirosas", se os personagens são "reais" ou "imaginados", se os lugares e objetos existem "de fato" ou são "cenários".

Nos dois filmes, para obter informações referenciais é necessário recorrer a elementos extra fílmicos (textos, notícias, sites). As figuras desconcertantes de $O$ céu se repetem em Só dez por cento, ainda que neste último possam ser melhor assimiladas por pertencerem, em princípio, ao mundo fabuloso da poesia. Em ambos os casos, são preconceitos, estereótipos e estigmas que ganham forma no corpo dos personagens, verídicos ou imaginados, e dos sujeitos retratados em sua singularidade. A afirmação de que, no campo do discurso, qualquer narrativa é sempre invenção, recoloca os modos de ver e dar a ver tais imagens, alargando o campo do documentário e o da fíç̧ão ao propor uma questão outra: as margens da invenção e as possibilidades de imaginar as margens sem que estas percam sua potência de transformação.

De modo mais explícito, os temas tratados em Bahêa minha vida e Quebrando o tabu são, neles mesmos, recortados por processos de estigmatização. O primeiro é um longa-metragem que retrata, a exemplo de outros, a paixão dos torcedores baianos por seu time. Ao mesmo tempo, aponta aos não-torcedores aspectos incongruentes dessa paixão, vista como fanatismo pelos que não compartilham de tal prática social. $O$ segundo, embora traga com muito destaque a figura bastante conhecida do ex-presidente Fernando Henrique Cardoso, o que pode comprometer a abordagem do tema, qual seja, debater possíveis soluções para o grave problema do tráfico e da violência - além dos danos sociais e individuais - associados ao uso das drogas. 
Interessante notar que, de modo inverso aos filmes anteriores, ainda que os temas sejam voltados aos estigmas e as abordagens proponham processos de transformação, podemos considerar mais conservadoras essas perspectivas, pois seus discursos encontram um lugar estabilizado, ainda que diverso do usual. Ou seja, para além da tematização, que pode se aproximar ou distanciar mais ou menos dos discursos circulantes, também a figurativização deve acompanhar tal movimento, ou o efeito de deslocamento pretendido tende a se esvaziar.

Nesse sentido, retomamos a diferenciação entre preconceitos, estereótipos e estigmas: enquanto os primeiros circulam em torno da afirmação ou contestação dos discursos manifestos, o último diz respeito a embates entre formações discursivas em posições hegemônicas ou contra-hegemônicas. Os preconceitos e estereótipos visam acomodação e restabelecimento da ordem social, fazendo que mesmo aqueles considerados outsiders sejam mantidos em seu lugares, sem perturbá-la; os estigmas, por sua vez, são desestabilizadores, pois podem propor reordenamentos e a irrupção de uma nova ordem, que só encontrará lugar se houver ruptura nos discursos correntes.

É nesse ponto que os dois últimos documentários possibilitam uma ligação com os quatro filmes ficcionais que gostaríamos de pontuar, começando por $5 \times$ favela Agora por nós mesmos e Bróder para, num segundo momento, tratar de Tropa de elite 2 - O inimigo agora é outro e Bruna Surfistinha, excepcionais por se constituírem como filmes de grande visibilidade tanto no campo da produção, como da recepção e da crítica, especialmente Tropa 2, fenômeno ao qual nos referimos anteriormente.

A partir de procedimentos diversos, que respondem por mudanças mais efetivas nos circuitos de produção - especialmente em relação aos primeiros cinco anos da amostragem -, os filmes 5 x favela e Bróder contam com propostas originais que nos são apresentadas no plano das imagens (modos de filmar, estilo de montagem, efeitos visuais) e no plano narrativo (maneiras de tematizar questões sociais, multiplicidade de pontos de vista, foco nos sujeitos retratados) ${ }^{47}$. O primeiro, produzido por Cacá Diegues e retomando seu filme $5 \times$ favela, de 1962, foi feito por moradores de periferias urbanas usualmente retratados por meio de olhares externos e que, na maior parte das vezes, são vistos como outros de suas próprias narrativas. Jovens de comunidades do Rio de Janeiro tornaram-se diretores de suas histórias, por meio de diversos coletivos culturais que promovem palestras, cursos debates e projeções.

\footnotetext{
47 Sobre formas e figuras no cinema, ver artigo de Buscombe (2005) a respeito dos gêneros cinematográficos.
} 
$\mathrm{Na}$ contramão do que se convencionou chamar "cinema de favela", além da abordagem de estigmas o filme apresenta a realidade das comunidades como parte integrante do Brasil (tanto em termos culturais como sociais) e narra com frescor aquele cotidiano em suas contradições e dificuldades, mas também com perspectivas e propostas frente aos problemas. Composto por cinco episódios, o filme revela facetas pouco exploradas, mesclando de modo não convencional elementos referenciais e elementos próprios da narrativa ficcional, sem se pretender documental, e introduzindo novos cenários subjetivos e afetivos no dia-a-dia da periferia das grandes cidades.

O filme Bróder, rodado na periferia da zona sul de São Paulo, em Capão Redondo, conta sua história por meio de três garotos, amigos de infância, que seguem rumos diferentes quando adultos: um se torna jogador de futebol, o segundo traficante e o terceiro se mantém na favela, tentando sobreviver por meio de trabalhos mal remunerados. As imagens mimetizam o estilo documental muitas vezes presente nos filmes voltados aos estigmas, com forte acento realista, mas utilizam também a linguagem fragmentada dos videoclipes, inserindo no enredo elementos factuais e mesclando atores amadores ou profissionais. Bróder venceu o Festival de Gramado de 2010, a exemplo do O céu sobre os ombros, vencedor do Festival de Brasília em 2011.

Tanto 5 x favela como Bróder aproximam-se dos documentários selecionados pela espontaneidade das atuações, gestos e falas dos personagens, evocando um certo improviso encenado que possibilita aos atores constituírem as verdades dos sujeitos retratados sem distinção entre naturalismo ou interpretação, e ressaltando marcas presentes nas favelas para além da tríade pobreza-crime-violência, ênfase pouco recorrente em filmes de ficção, mesmo entre aqueles que propõem a reconfiguração de estigmas, tais como Bruna Surfistinha e Tropa de elite 2. Aproximando-se dos documentários e dos filmes de ficção acima mostrados, Bruna Surfistinha reconstitui, em uma narrativa convencional, a história de uma jovem de classe média paulistana, estudante de um colégio tradicional da cidade, que resolve se tornar garota de programa.

Ao narrar suas histórias em um blog, tornou-se conhecida e lançou o livro $O$ doce veneno do escorpião, em 2005, best seller na época que projetou sua autora. De modo semelhante a outros filmes, o modo de retratar a personagem ousa tocar em tabus morais e sexuais arraigados na sociedade, mas também reforça os modos usuais de percebermos tais barreiras. Ao mesmo tempo em que denuncia preconceitos e estereótipos dirigidos às mulheres nessa condição, sobretudo as que afirmam escolher livremente tal profissão, o filme não problematiza suficientemente essa situação, 
mantendo inalterados os estigmas sociais que retrata. $\mathrm{O}$ filme transgride, ao encenar a história de modo bastante direto, mas também apazigua, ao recolocar a ordem, presente na história da personagem, por meio de seu desfecho: o casamento e a mudança de vida de Bruna Surfistinha, agora Raquel Pacheco, seu nome de batismo, confirmam a narrativa de superação da protagonista, interpretada por Deborah Secco. Ao chegar aos cinemas, Raquel já é uma "ex-prostituta" e "ex-garota de programa", oferecendo sem grandes riscos sua história e, de modo didático, trilhando a jornada de sua redenção após inúmeros percalços, erros e desvios.

Com mais de 2 milhões de espectadores, o longa ficou em terceiro lugar entre as maiores bilheterias do cinema brasileiro em 2011 - número que parece pequeno se comparado a Tropa de elite 2, com seus mais de 11 milhões de espectadores -, mas que é surpreendente no circuito de filmes nacionais, especialmente se considerarmos a temática controversa e a abordagem franca com que é tratada. A transformação do herói após ser desafiado em sua jornada, enfrentando obstáculos, inimigos e provações, e encontrando sua recompensa ao final, harmonizando o conflito inicial, pode ser percebida também em Tropa de elite 2. Ao contrário do primeiro Tropa, que ao mesmo tempo contentou e descontentou público e crítica, alcançando grande bilheteria em ambiente de forte polêmica, Tropa 2 restabelece não apenas a ordem na diegese fílmica como também assume elementos extra fílmicos para com eles dialogar.

Seu personagem principal, capitão Nascimento (agora coronel), realiza seu retorno ao mesmo tempo em que o diretor do filme, José Padilha, procura responder a seus algozes. Abandonando as cenas de ação em favor da tese social, Tropa 2 se aproxima da referencialidade não apenas em sua temática, mas também nos modos de debater a realidade brasileira. O título já sinaliza esse movimento com a expressão "o inimigo agora é outro": na narrativa, a corrupção política; na realização do filme, aqueles que o acusarem de conservadorismo político e reacionarismo social.

Em camadas sobrepostas, a tensão realidade/fantasia ganha corpo, bem como a problematização dos estigmas sociais. O filme, entretanto, esvazia sua potência contestadora ao sintetizar, nas imagens finais, uma única fonte como causadora - e, portanto, portadora de respostas - de nossas mazelas sociais. Ainda assim, é um filme contundente ao explicitar problemas graves presentes nas grandes cidades brasileiras, especialmente em bairros mais carentes ou comunidades, nos quais há poucas alternativas para seus moradores, que se deslocam entre o crime organizado, a força policial corrupta e o descaso do poder público. Sob esse aspecto, ainda que seu desfecho 
seja convencional, o filme responde às críticas anteriormente dirigidas a ele, problematiza aspectos cruciais sobre processos de estigmatização e apresenta, em suas imagens, não apenas a manutenção mas também transposições nas maneiras de mostrar os supostos outros dos quais trata.

Os filmes indicados estabelecem, a despeito de sua diversidade, inúmeros pontos de contato na maneira como articulam aspectos documentais ou ficcionais, bem como na tematização e figurativização de estigmas sociais, o que nos possibilita ensaiar algumas considerações a respeito desses elementos.

\subsection{Convergências e hibridismos em narrativas audiovisuais}

Após percorrer a variedade de filmes apresentados, podemos apontar algumas relações entre convergências das mídias (especialmente audiovisuais) e hibridismos de gêneros no cinema brasileiro da última década, propondo algumas perspectivas nas quais pensar suas narrativas como constituintes de um gênero impuro. Nesse sentido, entendemos a polifonia do termo narrativa a partir da seguinte acepção:

\footnotetext{
Parto do princípio de que a narrativa é um código e se ordena segundo as regras de três níveis: o da fábula, o das personagens e o da maneira de contar. Portanto, ancorado nesse molde, tenho para mim, na esteira dos estudos de narratologia, que a narração constitui a instância em que o narrador, enquanto sujeito manipulador, têm mais possibilidades de desenvolver sua imaginação criativa. Disso se tem prova quando o leitor centra seu interesse não exclusivamente nas peripécias ou desempenho dos atores, mas também na maneira de arranjar esses elementos (Peñuela Cañizal, 2007: s/p).
}

Evocamos o conceito de gênero impuro como aquele que recorta um conjunto de filmes híbridos em relação às formas genéricas que os constituem e, ainda assim, distinto das categorias de cinema periférico, paracinema ou cinema trash, bem como de gêneros específicos como terror, comédias românticas, western ou ficção científica. Tomando os gêneros não como tipologias rígidas mas, ao contrário, como formas baseadas em transposições - tanto em termos de seus modos de criação como de circulação -, propomos apontar relações entre os conceitos de convergências das mídias e hibridismos de gêneros, considerando, sobretudo, as novas linguagens audiovisuais resultantes de tais processos.

Retomaremos, nessa abordagem, os conceitos de remediação (a partir dos estudos de mídias digitais) e de intertextualidade (a partir dos estudos de discurso) para analisar um cinema brasileiro urdido ao redor de fragmentos de gêneros, estabelecendo 
articulações entre apropriações e remixagens na cultura audiovisual contemporânea ${ }^{48}$. Desse modo, os filmes não se reportam a uma suposta obra original, anterior a eles, mas a sua pilhagem. De acordo com Jameson, a pilhagem da história não é, de fato, um fenômeno contemporâneo, mas uma tentativa de "pensar historicamente o presente em uma época que já esqueceu como pensar dessa maneira” (Jameson, 2006: 13). Trata-se de uma característica das narrativas sobre o passado que, talvez,

através das possibilidades postas pelos meios tecnológicos de comunicação e difusão de informações, tenha se exacerbado a ponto de percebermos com maior exatidão e a partir de uma maior extensão estas montagens que modificam e ressignificam o decorrido através de uma reorganização de seus elementos (Casadei, 2010: 233).

As contaminações se fazem em várias direções: do cinema para a televisão e, anteriormente, desta para o cinema, acentuando as interseções entre convergências e hibridismos. Tais fluxos discursivos "não são novos, embora tenham chegado ao paroxismo com as tecnologias digitais" (Figueiredo, 2010: 12), já que os trânsitos e pilhagens do teatro para o cinema, do rádio para a televisão, do jornal para o livro e, mais recentemente, do livro para o cinema, do roteiro para o livro, da televisão para o cinema, do cinema para os videojogos e destes para o celular - todos eles atravessados pela internet - contaminam não apenas os espaços legitimados, mas também as bordas da cultura. Ao compartilhar uma cultura de bordas mais abrangente, relacionada a diversas manifestações artísticas, os filmes híbridos mobilizam processos de convergências midiáticas, subvertendo gêneros cinematográficos ${ }^{49}$ e formatos televisivos integrantes da cultura audiovisual.

A questão que se coloca, e que exploramos a seguir, indaga: de que maneira esses filmes estabelecem interseções com as narrativas migrantes das mídias? Em meio à profusão de conceitos mobilizados para demarcar os limites das convergências midiáticas, Figueiredo apresenta aportes para a problematização dos padrões estéticos dominantes nos contextos histórico e tecnológico em que estão inseridos. Para a autora, “merece atenção especial o fenômeno de deslizamento das narrativas de um meio para

\footnotetext{
48 Em artigo anterior, desenvolvemos esses conceitos em relação ao cinema brasileiro de bordas, constituído por filmes realizados na periferia dos sistemas de produção e recepção (Soares, 2011a).

49 O debate sobre gêneros cinematográficos (e, de modo mais extenso, sobre gêneros audiovisuais, incluindo a televisão) pode ser aprofundando a partir de diversos autores. Destacamos, entre eles, Altman (2006) em sua teoria dos gêneros audiovisuais, estabelecendo uma análise semântica e sintática como possibilidade de estudo do sistema de produção, dos textos fílmicos e do sistema de recepção. Além dele, lembramos as contribuições de Berry-Flint (1999) e Neale (1980) sobre os gêneros cinematográficos; e de Mittel $(2001 ; 2004)$ e Odin $(2000 ; 2012)$ sobre gêneros televisivos.
} 
outro, de um suporte para outro - o processo contínuo de reciclagem das intrigas ficcionais, recriadas para circular por diferentes plataformas” (Figueiredo, 2010: 11), síntese produtiva que abrange, em uma única expressão - narrativas migrantes - um cenário conceitual mais amplo. Tal encenação diz respeito, sobretudo, às

\begin{abstract}
alterações na hierarquia cultural provocadas pela intensificação desse movimento de intercâmbio, tanto no que diz respeito à literatura, cujo prestígio esteve sempre estreitamente relacionado à aura do suporte livro, quanto no que se refere ao cinema, em decorrência da expansão de narrativas audiovisuais transmidiáticas, cujo conteúdo se desdobra em filmes veiculados nas salas de cinema, em videojogos, histórias em quadrinhos, seriados televisivos (Figueiredo, 2010: 12).
\end{abstract}

Continuamente em migração, a noção de uma cultura de bordas é tributária de debates em diversos campos do conhecimento, especialmente literatura e psicanálise. Ferreira, em artigo publicado em 1989 (e reeditado em 2010), assim a define:

Com isso quero enfatizar a exclusão do centro, aquilo que fica numa faixa de transição entre uns e outros, entre as culturas tradicionais reconhecidas como folclore e a daqueles que detêm maior atualização e prestígio, uma produção que se dirige a públicos populares de vários tipos, inclusive àqueles das periferias urbanas (Ferreira, 2010: 30, grifos nossos).

A autora trata da obra de um escritor de bordas, Rubens Lucchetti, pretendendo "lançar questões referentes a este tipo de autor, tentar entendê-lo num conjunto" (Ferreira, 2010: 32) com o intuito de "perceber a delimitação de circuitos, seguir fenômenos de produção e recepção entre públicos populares urbanos no Brasil" (Ferreira, 2010: 32). Um debate emergente, revisitado nas reflexões sobre culturas da convergência, ganhara corpo ao enfatizar sua vocação para "pensar em problemas teóricos mais amplos e recolher elementos para uma teoria do texto e da comunicação popular, que tem várias gradações possíveis entre a predominância do popular ou do 'massivo', quando a recepção se embute diretamente no que se produz e as mediações são muito tênues" (Ferreira, 2010: 32).

$\mathrm{Na}$ literatura, impunha-se de outro modo a dinâmica alto/baixo, com o embate entre textos considerados eruditos e aqueles tidos como triviais: "A verificação objetiva de alguns procedimentos textuais, técnicas e modos 'formulares', valorização de sentenças e de frases feitas, cumulação do sentido sensacionalista e emocional, perda do sentido de distância e do critério de originalidade, carga de clichês e constante descritividade" (Ferreira, 2010: 33). 
A trivialização, segundo a autora, abriu brechas para uma criatividade fecunda $\mathrm{e}$ uma adaptação imaginosa de fórmulas e clichês - dinâmica enfatizada ao pensarmos nas convergências e hibridismos atuais. A atualidade dessas questões interpela tanto as renitentes narrativas em migração, como as pregnantes narrativas híbridas, nas quais "prevalecem os modos do sistema popular (oralidade, corporalidade, exterioridade etc.), mas esses modos estão irremediavelmente 'contaminados' pelas formas do sistema massivo que mais se aproximam deles"” (Lyra, 2008). As bordas do cinema não se desvelam como lugar estruturado entre centro e periferia, mas emergem entre os discursos que as conformam. Sobre os filmes triviais, Lyra e Santana afirmam:

\footnotetext{
Esse tipo de filmes emerge de formas de produção, gêneros e técnicas comumente voltadas para o sentimento e a ação. Entre eles, estão os melodramas dos anos 30 e 40, as chanchadas dos anos 50 e 60, as pornochanchadas dos anos 70 e 80 e toda uma série de filmes, como os filmes de ficção científica, os filmes de horror, os policiais baratos, os filmes domésticos, as comediazinhas românticas e outros que fazem emergir uma experiência de cinema vinculada ao corpo, ao entretenimento trivial e ao divertimento distanciado de toda e qualquer preocupação subjetivamente cognitiva (Lyra e Santana, 2006: 14).
}

Muitas das características atribuídas à literatura trivial, portanto, encontram eco nas formulações sobre gêneros cinematográficos. Ainda que ancorando suas narrativas naquelas difundidas no diapasão do entretenimento trivial, os filmes híbridos parecem caminhar na contramão da insuficiência ficcional muitas vezes acentuada em programas televisivos, tais como os reality shows: "Os exemplos citados aqui - a telenovela, o reality show, o cinema - embora bastante distintos entre si, convergem em um ponto: a noção, em nosso contexto, do entretenimento fraturado, insuficientemente ficcional ou de caráter híbrido" (Serelle, 2010: s/p). Não nos deparamos, nas narrativas híbridas, com um discurso resignado ou conciliatório, mas com a emergência (no sentido de aparição e de necessidade) de um outro "pacto de leitura" (Eco, 2002) estabelecido entre indústria, autor, texto e leitor (seja em produtos verbais, visuais ou audiovisuais).

Ao tomarmos como referência filmes contemporâneos, deparamo-nos com conceitos que vêm atualizar as noções vigentes sobre os trânsitos entre as culturas popular, massiva e erudita, agora articuladas em torno de uma cultura midiática (Kellner, 2001). A cultura das mídias estende-se a outras perspectivas, entre elas aquela apresentada por Santaella, escrito em 1992. De acordo com a autora, há um fenômeno que não pode deixar de ser considerado: a crescente hibridização das mídias e a formação de redes, fenômeno denominado de redes entre as mídias, representando 
(1) os trânsitos, complementaridades e intercâmbios de um meio de comunicação para outro e outros, e que chamei de redes entre as mídias; (2) a crescente onipresença da informatização invadindo todos os setores da vida social e privada; (3) as possibilidades abertas pelas formas de comunicação interativas; (4) as novas modalidades de criação artística presentes na exploração dos potenciais de uma estética das mídias e entre as mídias (Santaella, 1996: 10).

Podemos ampliar, dessa forma, o conceito de cultura das mídias, relacionando-o às formas sincréticas nelas presentes. Nesse movimento, as relações entre os polos de produção e recepção se transformam, trazendo novos regimes de identificação e de cooperação por meio de contratos comunicacionais específicos. Ao pensar os gêneros como matrizes e territórios (Borelli, 1996), assumimos a possibilidade de migração de um campo cultural para outro, dialogando nas fronteiras da literatura, da oralidade, do audiovisual. Mais do que isso, afastamo-nos da discussão tradicional sobre gêneros canônicos ou hegemonias genéricas. Além das migrações culturais, se considerados em seu caráter transitório os gêneros possibilitam, no campo do audiovisual, transposições entre mídias ou, nas palavras de Jenkins, a emergência de uma narrativa transmidiática "que se desenrola através de múltiplos suportes midiáticos, com cada novo texto contribuindo de maneira distinta e valiosa para o todo" (Jenkins, 2008: 135).

Estudos recentes tematizam esses novos formatos narrativos audiovisuais (considerando seus aspectos de interatividade, colaboração, fragmentação, nãolinearidade e hipertextualidade $)^{50}$. Entre eles, citamos a teoria da remediação, de Bolter e Grusin (1999), que estabelece como eixos definidores das convergências midiáticas de Jenkins processos de imediação (em que o meio se torna transparente, como se não houvesse mediação) e de hipermediação (em que a consciência do meio se faz presente, explicitando a opacidade da representação) a partir de diferentes modos de apropriação, remodelação e transformação. Com relação aos conceitos de "transparência" e “opacidade", Xavier (1984) enfatiza as possibilidades de representação pressupostas no cinema a partir do efeito-janela propiciado por sua tela (transparência) e do efeito da tela como superfície visualmente composta (opacidade). De acordo com o autor, em diferentes obras os dispositivos (aparatos econômico e tecnológico) colocam-se de modo mais ou menos revelador.

\footnotetext{
${ }^{50}$ Gene Youngblood antecipara as noções de convergência e transmidialidade na obra Expanded cinema (New York: Dutton, 1970), apontando processos de contaminação entre diversas formas de arte, especialmente vídeo e cinema, mediados pela crescente determinação das tecnologias digitais (efeitos especiais, arte por computador, ambientes multimídia).
} 
No caso da transparência, tais dispositivos são mobilizados de modo a gerar maior ilusão; no caso da opacidade, os dispositivos interpelam o espectador, possibilitando distanciamento ao revelar a própria presença dos sujeitos. Notemos que os conceitos se colocam em relação aos discursos construídos, e não à possibilidade de tudo dizer como algo intrínseco ao cinema.

O que essas definições trazem em comum na diversidade de suas denominações? Se retomarmos a noção de intertextualidade, estendendo-a aos conceitos de dialogismo, polifonia e heterogeneidade como apresentados por Bakhtin (1987), encontramos possibilidades nas quais pensar os processos atuais como potencialização das relações de um discurso - imagético, verbal - com outros. Conceitos centrais à obra de Bakhtin, especialmente se articulados à noção de intertextualidade, estabelecemos como suas definições gerais as seguintes: o dialogismo apresenta-se como princípio constitutivo da linguagem, enquanto a polifonia diz respeito às vozes polêmicas presentes em um discurso, colocando em causa a unicidade do sujeito falante. Há, portanto, gêneros dialógicos monofônicos (uma voz predomina sobre as outras) e gêneros dialógicos polifônicos (várias vozes polemizam entre si). A heterogeneidade diz respeito à presença (mostrada ou constitutiva) de outros discursos no discurso, já que este encontra sua unidade ao ser delimitado e constituído pela instância do outro (Brait, 2005).

De acordo com Stam, os gêneros discursivos seriam um aspecto específico da intertextualidade, definida como uma rede de "possibilidades infinitas e abertas geradas pelas práticas discursivas de uma cultura, não apenas em termos de influências reconhecidas, mas também por meio de um processo de "disseminação"” (Stam, 2000: 154). As transposições entre mídias, portanto, levam-nos à ampliação da noção de convergências, que diriam respeito não apenas a aspectos tecnológicos mas, sobretudo, a processos culturais, apontando ao mesmo tempo imprecisão e imiscuição de fronteiras. E conduzem-nos a um traço destacável em grande parcela da produção audiovisual brasileira: a impureza de suas formas.

A partir da crescente valorização de processos de hibridização cultural assumimos a concepção de Stam (1997) de que, à luz dos estudos pós-coloniais, a apropriação de um discurso existente por aqueles antes por ele subjugados inverte os vetores de dominância. Concepções estéticas, tais como realismo fantástico, estética da fome, cinema imperfeito, incapacidade criativa de copiar, estética do lixo, antropofagia, tropicália colocam-se como posturas alternativas que revalorizam, por 
inversão, o que era anteriormente visto como negativo (Stam, 1997: 275) ${ }^{51}$. Temos, assim, uma importante assunção do hibridismo como mestiçagem produtiva:

\begin{abstract}
As práticas cinematográficas de oposição tanto no Primeiro como no Terceiro Mundo têm explorado uma variedade de estéticas alternativas. Essa variedade inclui filmes e vídeos que desafiam as convenções formais do realismo dramático em favor de abordagens e estratégias tais como o carnavalesco, a antropofagia, o realismo mágico, o modernismo reflexivo e a resistência pós-moderna. Tais estéticas alternativas muitas vezes remetem a práticas não realistas, a tradições culturais não-ocidentais que possuem ritmos históricos diversos, outras estruturas narrativas e diferentes visões sobre o corpo, a sexualidade, a espiritualidade e a vida coletiva (Shohat e Stam, 2006: 407).
\end{abstract}

Em relação aos filmes destacados, a estética do lixo, tomada a partir da noção de hibridismos de gêneros, parece-nos um ponto nodal no qual amarrar as convergências midiáticas buscadas. O cinema, desse modo, afirma-se como locus privilegiado no qual realizar essa estética multitemporal, fundada em três aspectos: a) hibridismo constitutivo; b) multiplicidade cronotópica; c) elogio dos detritos/restos. Sem nos determos demasiadamente sobre eles, apontamos algumas de suas características.

No primeiro caso, ressaltamos a valorização da impureza - ou da contaminação - como constitutiva de certo discurso contemporâneo que se estende também ao cinema. A esse respeito, Said já apontara que a palavra contaminação refere-se a "uma certa ideia da literatura e, na verdade, de toda a cultura, como algo híbrido (no sentido complexo que Homi Bhabha atribui à palavra) e emaranhado ou entrelaçado, sobreposto, com elementos habitualmente considerados estranhos" (Said, 1995: 389). Antes dele, Bakhtin estabelecera relações entre uma estética do grotesco e modos de ressignificação cultural que subvertem antigas oposições (bom/mau, ascético/sujo, belo/feio), instaurando formas de comunicação em que normas e barreiras sociais são temporariamente suspensas, violando regras habituais da vida coletiva, como nos festejos populares do carnaval. Para o autor, "o exagero, o hiperbolismo, a profusão, o excesso são, segundo opinião geral, os sinais característicos mais marcantes do estilo grotesco" (Bakhtin, 1987: 265) ${ }^{52}$. O termo carnavalização, em Bakhtin, merece nossa atenção por sua relação com as noções de hibridismo e contaminação:

\footnotetext{
${ }^{51}$ Para desdobramentos, ver do mesmo autor Introdução à teoria do cinema (2003), especialmente o capítulo "A busca de uma estética alternativa", no qual afirma que "os filmes alinhados com essas práticas de resistência não são nem homogêneos nem estáticos; variam ao longo do tempo ou de região a região" (Stam, 2003: 180). Ver, ainda, Crítica da imagem eurocêntrica (Shohat e Stam, 2006), notadamente o capítulo "A estética da resistência".

52 Retomamos a definição de uma mitologia do escandaloso em analogia com o estilo grotesco: "A mitologia do escandaloso que, desde o século XIX, confirma-se com um conjunto de estudos que propõe como objeto o infame, o monstruoso, o repugnante e aquilo que causa arrepios de horror, apresenta o
} 
Esse processo de reunião, sob o termo de "carnaval", de fenômenos locais heterogêneos, o fato de que fossem designados por um mesmo termo, correspondia a um processo real. Com efeito, ao desaparecerem e degenerarem, as diferentes formas da festa popular levavam ao carnaval alguns de seus elementos: ritos, atributos, efígies, máscaras. E por causa disso, o carnaval tornou-se o reservatório onde se guardavam as formas que não tinham mais existência própria (Bakhtin, 1987: 190).

A releitura do hibridismo como sintoma do momento atual - destacada por Stam em filmes -, desloca a concepção usual que associava o mestiço à degeneração e à infertilidade. Tomado enquanto diversidade produtiva, os processos de hibridização apontam para um jogo de identificações que desafia a concepção de identidades ontologicamente constituídas, no qual a pureza abre espaço à contaminação. Posturas fixas cedem lugar a posicionalidades, nas quais as identidades do sujeito tornam-se um "processo em andamento (...) sempre sendo formada" (Hall, 2001: 39), possibilitando, como anunciara Stam, que "fronteiras rígidas se tornem porosas e que limites demarcados se transformem em imagens fluidas" (Stam, 1997: 276).

Seguindo a leitura de Stam, o discurso anterior do imperialismo das mídias cede lugar às formas de reciprocidade e apropriação por parte da audiência, abrindo caminho para outras bricolagens - ainda que neste encontro as tensões permaneçam presentes, apontando para questões relativas a disputas de poder e hegemonias. Entre as diversas acepções de hibridismo, algumas modalidades são apontadas: imposição colonial, assimilação obrigatória, apropriação de cima para baixo, subversão de baixo para cima, exploração comercial, cooptação política, dominação cultural (Stam, 1997: 276), revelando suas assimetrias, descontinuidades e a multiplicidade espaço-temporal que caracteriza o segundo aspecto da estética do lixo.

Finalmente, no terceiro modo, temos uma espécie de redenção estratégica daquilo usualmente tido como sujo, baixo, descartável, imperfeito, residual (a exemplo da carnavalização), como se os detritos, restos e sobras pudessem engendrar mudanças sociais a partir das margens de seus discursos (Stam, 1997: 277). Sobreposições entre o antigo e o novo fazem-se presentes, numa espécie de "temporalidade dissonante que combina um passado comunitário imaginário com um também imaginário futuro utópico" (Stam, 1997: 279), impondo rupturas com as convenções da narrativa linear, e com o peso do tempo cronológico e do espaço físico.

espetáculo desse duplo movimento pelo qual o causador da repulsa é também o que atrai, como o pretendia a máquina oculta no grego skandalon - o laço da armadilha que abriga a isca" (Freitas, 2002, mimeo.). 
O cinema se manifesta, assim, como "espaço privilegiado para expressar hibridismos culturais e temporais" (Stam, 1997: 279). Temporalmente, mostra-se híbrido em sentido intertextual (pois agrega formas e tradições imagéticas de todos os tempos) e também em termos técnicos (já que mistura diversos tempos e espaços tanto em sua produção como em sua recepção). A tessitura das imagens audiovisuais constitui-se, portanto, como uma tapeçaria feita de sobreposições, justaposições, inserções digitais, multiplicidade de imagens e sons (sintéticos ou captados). Considerando a estética do lixo, o cinema define-se como um discurso transgressor em seus diversos modos de manifestação e disseminação.

Como anuncia Machado, trata-se, no caso brasileiro, de um hibridismo das alternativas: "O cinema lentamente se torna eletrônico, mas, ao mesmo tempo, o vídeo e a televisão também se deixam contaminar pela tradição de qualidade que o cinema traz consigo ao ser absorvido" (Machado, 1997: 215). O autor antecipa movimentos frequentes em anos recentes: "Muitos filmes que hoje podem ser vistos nas salas de cinema, inclusive aqueles totalmente realizados com meios cinematográficos habituais, foram, na realidade, pensados e produzidos em virtude de sua funcionalidade na tela pequena da televisão" (Machado, 1997: 215), seja por razões econômicas, de mercado ou de audiências. Estabelecidas essas linhas, o que se mostra, então, enquanto olhamos os filmes brasileiros? Nas reverberações percebidas entre cinema e história, crítica e estética, delineamos contornos nos quais compreender tal proposição.

\subsubsection{Vestígios de discursos na televisão e no cinema}

O conjunto de narrativas aqui reunidas permite-nos apontar para convergências e hibridismos presentes em formas audiovisuais específicas. Destacamos, nesse momento, o discurso jornalístico em forma de reportagens televisivas e o discurso cinematográfico em forma de filmes documentários, visando o fechamento e a expansão do debate. As tensões entre "referencialidade" e "ficcionalidade" ou, de modo mais complexo, entre verdade e ficção, têm acompanhado teorizações em diversos campos, dentre os quais destacamos a literatura, a filosofia e a antropologia. De acordo com Watt, na literatura as diferenças entre o romance realista e o romantismo, forma narrativa que o antecede, levaram “os historiadores a considerarem o 'realismo' a diferença essencial entre a obra dos romancistas do início do século XVIII e a fícção anterior" (o que não quer dizer que todas as formas anteriores perseguiam o irreal). 
O autor prossegue: “Em filosofia, por sua vez, o termo 'realismo' aplica-se estritamente a uma visão da realidade oposta à do uso comum, ou seja, para os escolásticos realistas as verdadeiras 'realidades' são os universais, classes ou abstrações, e não os objetos particulares, concretos, da percepção sensorial” (Watt, 1990: 12-13). Assim, "o romance realista se aproxima do atual significado de realismo, afastando-se de sua origem clássica e medieval e rejeitando os universais" (Watt, 1990: 14).

A aparente oposição entre textos literários e/ou científicos acompanha também os debates em antropologia, como se atribuir a esta um caráter metafórico implicasse no enfraquecimento de sua capacidade de verossimilhança, posto que a credibilidade de seus relatos adviria da extensão das descrições. Ao contrário dessa visão limitante sobre o modo como se "estabelecem os fatos" na ciência - para lembrar a discussão proposta por Geertz -, podemos enunciar que "a capacidade dos antropólogos de nos fazer levar a sério o que dizem tem menos a ver com uma aparência factual, ou com um ar de elegância conceitual, do que com sua capacidade de nos convencer de que o que eles dizem resulta de haverem realmente penetrado numa outra forma de vida" (Geertz, 2005: 15). Ou seja, as peculiaridades da escrita antropológica estão relacionadas à crença dos antropólogos "realmente haverem, de um modo ou de outro, 'estado lá'. E é aí, ao nos convencer de que esse milagre dos bastidores ocorreu, que entra a escrita" (Geertz, 2005: 15).

A esse propósito, o historiador Gay, em Represálias selvagens (2010), "mostra como, por ser de ficção, um texto não está impossibilitado de expor profundas verdades humanas, bem como, por ser realista, um texto não está isento de expressar a mais intensa subjetividade do autor" (Telles, 2010: 5). Em resenha ao livro, Telles afirma que "as antinomias entre o realismo literário e a realidade atingem um ponto de tensão máxima no chamado "romance histórico", pois este, mesmo oferecendo ao historiador "uma grande massa de informação sobre os costumes, a moral, as formas dos relacionamentos pessoais e a organização social”, não pode ser considerado como "sociologia" ou "estudo histórico", já que no realismo literário as alterações inseridas pelo autor deslocam o próprio conceito e, muitas vezes, fazem com que as narrativas se voltem para a realidade psíquica de seus personagens.

Buscando desconstruir a oposição simplista entre realismo e idealismo, presente em muitas das análises sobre os discursos referenciais, propomos pensar as mídias - 
especialmente o jornalismo ${ }^{53}$ - como formas narrativas. Tal proposição implica um deslocamento no modo de conceber as práticas midiáticas e de articulá-las nas oscilações entre verdade e ficção. Antes de tratarmos dessa questão, entretanto, uma pequena distinção entre narrativa e discurso deve ser retomada: partimos da definição clássica de narrativa como "relato de uma transformação" e de discurso como "laço social". Se narrar é contar uma história, a partir de uma concepção de narrativa que integra a fábula, os personagens e o relato ${ }^{54}$, podemos pensar o jornalismo como um dos lugares em que se constroem narrativas midiáticas.

Em entrevista sobre o livro Duas vidas, uma biografia de Gertudre Stein, Janet Malcolm declara: "Biografia é um gênero problemático, viciado. Escrevi em algum lugar (...) que nunca há dúvidas sobre os 'fatos' na ficção. Eles são o que os escritores dizem ser. Há apenas uma versão. Não há alternativa. Na não-ficção, que inclui biografia, há diversas versões possíveis sobre o que 'realmente' aconteceu” (Malcolm, 2008: s/p). Dessa forma, podemos afirmar que o factual e o ficcional - como pode ser percebido não só no jornalismo, mas também no cinema, na teledramaturgia ou nos reality shows - são campos que têm borrado, cada vez mais, os limites entre suas fronteiras, afastando-se da distinção comumente a eles atribuída entre relatos verdadeiros ou falsos, reais ou imaginários.

A problematização de conceitos tributários da história e da filosofia vem somarse às reflexões sobre as narrativas midiáticas. As noções de verdade, realidade e linguagem (atravessando as teorias da representação e da apresentação do mundo) são tidas como fundamentais no debate acadêmico sobre as formações discursivas constituintes do imaginário contemporâneo e sobre o estatuto das imagens. Dessa forma, o estabelecimento das fronteiras entre fato e ficção tem ocupado, há algum tempo, o campo de estudos do audiovisual ${ }^{55}$.

\footnotetext{
${ }^{53}$ De modo preliminar, destacamos a recente proliferação de programas jornalísticos televisivos nãoconvencionais, entre eles Profissão Repórter (em exibição desde 2006), e posteriormente Brasileiros e Globo Mar (a partir de 2010), todos voltados para grandes reportagens e veiculados na Rede Globo. Além destes, o Globo Repórter segue na grade da emissora.

${ }^{54}$ A esse respeito, ver Peñuela Cañizal: "Enquanto disciplina, a narratologia começa a ganhar corpo com os estudos estruturais feitos por Propp sobre o conto popular russo e por Lévi-Strauss sobre os mitos. Cresceu com os pensadores da Escola de Tartu e com os semioticistas da chamada Escola de Paris. A fase estruturalista cedeu passo a outras formulações e, no contexto atual, os autores que contribuíram para a renovação de velhos modelos são, sem dúvida, Gaudreault e Jost. É de se reconhecer também a importância de Branigan e Bordwell” (2007: s/p).

55 Para referências sobre os conceitos, ver: Odin, R. e Lyant, J. C. (éds.). Cinémas et réalités. SaintEtienne: Universidade de Saint-Etienne, 1984; Nichols, B. Representing reality. Indiana: Indiana University Press, 1991; Rancière, J. "Les mots de 1'histoire du cinéma" (entretien). Cahiers de Cinéma, novembre 1995; Mourão, M. D.; Labaki, A. O cinema do real. São Paulo: Cosac Naify, 2005.
} 
Ao fazê-lo, assumimos de modo radical a não-disjunção entre fato e ficção e, de modo mais abrangente, entre realidade e fantasia. Retomamos, portanto, como ponto de partida, um axioma postulado por Lacan, enunciando que "a verdade tem estrutura de ficção" ${ }^{, 56}$. Verdade e realidade apresentam-se como interdependentes nos discursos referenciais e naqueles que tomam a representação fiel e objetiva do mundo histórico como seu modo de operação. Os discursos referenciais (entre eles, o discurso da história) assumem, muitas vezes, o apagamento de suas marcas enunciativas, como se a eles fosse possível tudo dizer. Além disso, colocam-se como arautos da verdade de uma realidade que estaria fora deles, ocultando seu papel na construção e criação de realidades/verdades que não existiriam autonomamente. Ao contrário dessa visão totalizante, é na psicanálise que encontramos uma interessante aproximação à verdade em suas injunções com a realidade:

\begin{abstract}
A psicanálise nos aponta que a verdade é sempre não toda, impossível de ser apreendida em sua consistência. Não existe uma verdade única, sendo que cada um constrói a sua ficção sobre a sua história e em torno d'isso sustenta-se um saber que é transmitido e repetido "como se" fosse a verdade, mas é uma construção absolutamente particular (Vitorello, 2005: s/p).
\end{abstract}

A verdade, na concepção lacaniana, possui uma estrutura de ficção pois, assim como o amor, tem como função "criar uma tela protetora diante dos enigmas sem decifração. As verdades que se propagam e que se defendem por aí seriam, na melhor das hipóteses, meias-verdades, apresentando-se como tal na falta da verdade inteira, isto é, do que não se sabe mas se precisa saber” (Bernardo, 2004: 281). Dessa forma, partimos do princípio de que a realidade só o é enquanto realidade discursiva, não preexistindo à linguagem. Dentre as possibilidades analíticas, buscamos nas reportagens jornalísticas ${ }^{57}$ e nos filmes documentários ${ }^{58}$ apontar a forma como o "real" se insere em suas narrativas, estabelecendo um "pacto de leitura" (Eco, 1994) calcado na naturalização de seus artifícios.

\footnotetext{
${ }^{56}$ A esse respeito, ver: "Não se trata, pois, de questionar ou desnudar a mentira, mas de ratificar sempre a verdade. Lacan diz que a ficção mítica mantém uma relação singular com alguma coisa que está sempre implicada atrás dela - a verdade. (...) Em toda ficção corretamente estruturada, pode-se constatar essa estrutura que, na própria verdade, pode ser designada como a mesma da ficção" (França, 2009: s/p).

57 Os programas jornalísticos são uma constante na produção televisiva brasileira, especialmente os telejornais. Nesse momento, entretanto, são consideradas produções jornalísticas que não estejam enquadradas nesse formato, buscando justamente os programas em que as questões do gênero jornalístico são problematizadas nas fronteiras com a produção ficcional televisiva.

${ }^{58}$ A possibilidade de pensar o cinema documentário como gênero é uma das questões exploradas. De modo abrangente, consideramos os documentários não apenas como gênero cinematográfico, mas como um discurso específico na produção cinematográfica, que pode trazer, assim como os filmes tidos como "ficcionais", variações em suas formas genéricas (musical, terror, comédia, romance, entre outros).
} 
Em Diálogos sobre a Nova História ${ }^{59}$, Duby e Lardreau discutem o estatuto da História enquanto discurso narrativo e objeto científico. $\mathrm{O}$ debate se dá em torno do confronto entre "realismo" e "nominalismo", a partir do argumento que coloca o ponto de vista nominalista como aquele que afirma que o "passado", enquanto tal, "é sempre e apenas como a necessária espessura que cada presente atribui a si próprio, um dos modos segundo os quais o presente se apresenta inventando para si a profundidade de uma origem, e através disso se garante e se autoriza, propriamente (...)" (Lardreau, 1989: 13). O realismo, por sua vez, parte justamente da premissa de que "tudo é história" e que, portanto, não há passado, para subtrair o ponto de onde se fala:

O realista pode fazer do passado um real. Não se tratará por certo de negar a existência de um passado que não passe dessa proliferação de discursos, puro imaginário e exibido pelo nominalista - bastará admitir que há um ponto, rigorosamente exorbitante em relação à série desses discursos, a partir do qual se pode construir numa Idade Média real, sobre a qual se pode dizer a verdade (...) (Lardreau, 1989: 14).

$\mathrm{Na}$ busca por encontrar um caminho do meio, no capítulo "Um nominalismo bem temperado" Duby e Lardreau trazem considerações interessantes sobre a construção do "real" pela história, chegando ao conceito de "vestígios" recriação do passado pelo presente: “Alguns desses vestígios são inteiramente 'concretos', estão inscritos na paisagem; são objectos materiais que a arqueologia revela (...). Depois há outros vestígios, que são vestígios de discursos. Discursos que os contemporâneos produziam sobre si próprios; palavras, sinais postos ao lado uns dos outros, frases" (Duby, 1989: 36).

Ao se estabelecerem relações avulsas entre esses vestígios, a imaginação intervém e, dessa forma, "o vestígio só é vestígio com valor histórico a partir do momento em que já faz parte de um discurso" (Lardreau, 1989: 37). Essa afirmação de Lardreau, ao pontuar a observação de Duby, é nosso ponto de inflexão para chegarmos à origem desta proposta: se o vestígio se inscreve como tal apenas ao ser organizado em discurso, podemos afirmar, com as ciências da linguagem, que não existe realidade prédiscursiva.

\footnotetext{
59 Braudel usou pela primeira vez o termo "História Nova" em aula inaugural no Collége de France (1950). Dos historiadores da Escola dos Annales, temos os da primeira geração (Marc Bloch, Fernand Braudel e Lucien Febvre) e os da segunda (entre eles, de acordo com Peter Burke, Jacques Le Goff e Georges Duby), que trazem debates fundamentais a outros campos do conhecimento (Burke, 1997).

${ }^{60}$ Ver Clément (1973).
} 
Nesse sentido, "o discurso está sempre presente. Mesmo uma data só se torna facto (sic) de história no seio do discurso que decidiu exumá-la da triste repetição do calendário" (Lardreau, 1989: 37), ou seja, os fatos - ou aquilo que chamamos de realidade - são, na verdade "vestígios de discursos", enredando-se na cadeia imaginária de eventos instituídos na e pela linguagem. No debate entre historiador e filósofo, este prossegue afirmando que o fato de haver vestígios "mais ou menos reais" - de alguns terem mais pregnância, legitimidade ou credibilidade em relação à suposta realidade que pretendem articular - não implica na assunção de possibilidade de uma representação (ou reconstrução) fiel da realidade, tampouco remete à própria materialidade desses vestígios. O que se revela neste "mais ou menos de realidade" é justamente o fato de que alguns vestígios são mais condicionadores do que outros. Nas palavras de Lardreau:

Quero com isto dizer que os nossos discursos esbarram com alguns desses vestígios; daí que me pareça que o historiador toca, mesmo assim, em qualquer coisa que é da ordem de um limite, ou seja, se é verdade que o historiador pode produzir $n$ discursos sobre vestígios, nem todos são possíveis. Por outras palavras, parece-me que a "realidade" desses vestígios de história deveria uma vez mais encontrar-se ao nível do discurso, do lado do discurso, como aquilo que torna certos discursos impossíveis (Lardreau, 1989: 38).

Ou, como afirma Foucault em A ordem do discurso (1996), conforme citado, Mendel - a exemplo de outros cientistas - sabia a "verdade", mas não estava de acordo com o "verdadeiro" de sua época. Duby complementa essa reflexão:

Não se pode produzir um discurso qualquer sobre o passado nem, aliás, sobre seja o que for - e seria necessário voltar à minha comparação, pois, o romancista também não pode contar uma coisa qualquer, há limites que se lhe impõem, que são menos visíveis, mas que talvez sejam igualmente fortes, igualmente condicionadores (Duby, 1989: 39).

De modo análogo ao debate de longa data empreendido no campo da História, chegamos aos discursos que nos interessam para reconhecê-los, assim, enquanto construtos, ou "vestígios" (Soares, 2010). Uma vez mais, como vimos tratando desde a introdução, primeiramente no jornalismo e depois no cinema encontramos a matéria prima de nossa investigação, aproximando-os enquanto discursos fundados sobre a referencialidade, mas que possuem como elemento articulador a ficcionalidade. Em Bloch encontramos eco para essas hipóteses, ao se referir ao "edifício teórico" como uma espécie de "edifício de imaginação",61.

\footnotetext{
${ }^{61}$ Para aprofundamento dos conceitos, ver Mannoni (1979).
} 
Ou seja, ao aproximar a referencialidade à ficcionalidade, a materialidade do mundo à imaginação, os teóricos da Nova História trouxeram para este campo do saber o imaginário. Se assumirmos, com Freud, a escuta como condição de possibilidade ao discurso do outro - uma espécie de discurso dos vestígios -, podemos extrair pontos de contato e de separação entre reportagens e documentários. No contraste entre esses dois discursos, ensejamos por outros caminhos a possibilidade de apresentar novos contrastes - como falado inicialmente - entre as formas de narrar (ficcionais) presentes nessas duas formas discursivas (referenciais).

Tomemos como exemplos paradoxais dois cineastas contemporâneos, Walter Salles e Eduardo Coutinho. Enquanto o primeiro, embora seja diretor de filmes de ficção, parece empreender uma busca pelo "real" fundada em uma suposta crença na realidade dos fatos e sua fiel representação, o segundo opera a partir da escuta de um discurso outro para articular uma espécie de ficção subjetiva em seus filmes nãoficcionais. Os dois diretores constroem de forma assimétrica sua relação com a realidade e os discursos que a constituem. De modo semelhante às ideias de Duby, Coutinho toma como "fonte" o desejo de seus entrevistados, demonstrando em cada filme (especialmente em Jogo de cena, de 2007, e Moscou, de 2009) que a realidade é sempre formada por vestígios. Ao par de opostos "realidade x ficção", outro se coloca, de modo não-contraditório e, antes, complementar: mundo histórico/mundo imaginário, em que o mundo histórico teria tanta ficção quanto o imaginário, e este teria tanta realidade quanto o mundo histórico.

Retomamos, assim, aos termos "referencialidade" e "ficcionalidade" para nos referir aos discursos audiovisuais contemporâneos que tentam dar conta dos fatos e de sua suposta realidade. Buscando desdobrar os conceitos, propomos problematizar as noções de fato e ficção, deslocando a questão para as relações entre verdade e fantasia. Ao atribuir aos discursos referenciais a possibilidade de tudo dizer, de modo inverso ao que vimos em relação ao cinema, um duplo movimento se coloca: deles é exigido que sejam "verdadeiros" no sentido aristotélico, estabelecendo correspondência direta entre verdade e realidade, como se fosse possível excluir a distância sempre presente entre os signos e aquilo que designam.

Retomando definições anteriormente apresentadas, temos que a verdade como alethéia - "aquilo que deve ser lembrado" (que tem como par o esquecimento, e não a falsidade) - cede lugar, a partir de Platão mas especialmente em Aristóteles, à concepção de verdade como orthótes - adequação do conceito à realidade -, muito 
próxima da definição que atualmente identifica verdade e realidade e, por outro lado, opõe verdade e ficção. Além desta, duas outras noções corroboram a forma como definimos, de modo geral, a verdade do mundo histórico: a palavra latina veritas (veracidade de um relato) e a palavra hebraica emunah (confiança numa promessa). Nessa acepção da verdade como algo que corresponde à realidade, o estatuto da ficcionalidade seria desde sempre barrado, pois não diria respeito à verdade dos acontecimentos ou dos discursos (muitos deles transformados em fatos jornalísticos, mas não em atos discursivos), mas à fidelidade de sua reprodução.

Nas tensões entre verdade e ficcionalidade, portanto, é que novamente propomos estabelecer o escopo teórico e metodológico para as reflexões sobre as narrativas midiáticas no jornalismo e no documentário contemporâneos. Nas reportagens televisivas, o personagem em destaque é geralmente o repórter, que cria a situação para sua ação; ele é objeto do registro da câmera (como em programas jornalísticos tradicionais, entre eles Jornal Nacional e Globo Repórter), e aqui se estabelece uma distinção em relação aos filmes documentários. Em vez de se colocar como testemunha de um acontecimento que deve ser reportado aos espectadores, o cineasta se coloca em cena como aquele que desencadeia a ação para que um outro surja. Se pudéssemos buscar, de modo simplificado, as definições de "cinema direto" e "cinema verdade", diríamos que o jornalismo, ao tentar estabelecer uma relação imediata com a realidade, aproxima-se do primeiro; nos documentários, por sua vez, há espaço para instituir uma "verdade" que não venha da realidade, mas da materialidade do próprio filme.

Essas fronteiras, bem como aquelas entre ficção e realidade, tornam-se cada vez mais difusas quando tratamos de discursos referenciais, pois frequentemente somos confrontados, na televisão e no cinema, com reportagens e documentários que embaralham os limites entre mundo histórico e mundo imaginário. Essa temática, portanto, insere-se nos limites difusos entre formatos cada vez mais hibridizados em termos tecnológicos, estéticos, éticos e narrativos. A busca pelo estabelecimento das diferenças entre reportagens e documentários, e o interesse por reportagens que se constituam nesse intervalo - por vermos nelas uma possibilidade maior ao jornalismo televisivo para além de suas repetições estéreis -, coloca-se como eixo articulador das reflexões. Priorizamos reportagens que, ao mesmo tempo, dialogam com documentários e deles se afastam, negando e reafirmando seu estatuto enquanto gênero jornalístico primordial. 
De modo semelhante, alguns documentários contemporâneos tomam a estética da reportagem em suas narrativas, ainda que produzidos para exibição no cinema e não na televisão. Podemos nos perguntar se esses movimentos de hibridização não levariam ao surgimento de discursos que se assemelham cada vez mais, ao buscar aproximações com outras formas narrativas. Talvez os reality shows, e sua crescente e variada proliferação, surjam na trilha dessas margens.

As proximidades e distanciamentos entre as narrativas de reportagens e de documentários são o locus no qual demonstrar que os discursos midiáticos contemporâneos se constituem a partir de hibridismos entre elementos factuais e ficcionais e, mais do que isso, a partir de uma reafirmação da possibilidade ou não de representação fiel (ou verdadeira) da realidade. A "paixão pelo real" (em expressão de Badiou, 2002), ou o "retorno do real" (nas palavras de Foster, 1999), fazem-se presentes em diversos discursos das mídias, de modo especial no jornalismo televisivo e no cinema documentário, sinalizando a presença marcante de elementos de realismo/naturalismo ou delineando o "deserto do real" e seu potencial catártico (como afirma Zizek, 2003).

Buscando aportes teóricos nos quais pensar as mídias como narrativas, é como mediação que elas se colocam. No caso do jornalismo, "antes de registrar, informar, antes de ser colocado pelas condições que o caracterizam, por exemplo, periodicidade, universalidade, atualidade, difusão (...) o jornalismo é ele próprio um fato de língua. Seu papel e sua função na instituição social implica o de organizar discursivamente, o que, aliás, é a prática jornalística por excelência" (Gomes, 2000: 19). Considerando a língua como instituição social fundante, como afirmamos anteriormente, o campo da análise do discurso nos traz, em sua multiplicidade, interessantes contribuições para pensarmos as mídias enquanto narrativas. Maingueneau (1997) afirma que a linguagem não é concebida como um simples suporte para a transmissão de informações, mas como o que permite construir e modificar relações entre interlocutores, enunciados e referentes:

É a própria noção de "comunicação lingüística" que, desta forma, é deslocada: o fato de que um enunciado supõe um enunciador, um destinatário, uma relação com outras enunciações reais ou virtuais, que esteja atravessado, pelo implícito etc.; tudo isto não é uma dimensão que se acrescentaria posteriormente a uma estrutura lingüística já construída, mas algo que condiciona radicalmente a organização da língua (Maingueneau, 1997: 20-21).

Dessa forma, podemos afirmar, com Kristeva, que a "linguagem é antes de tudo o mais uma prática. Prática cotidiana que preenche cada segundo da nossa vida, 
incluindo o tempo dos nossos sonhos, elocução ou escrita, é uma função social que se manifesta e se conhece no seu exercício" (Kristeva, 1974: 319). O termo discurso, por sua vez, designa a manifestação da língua na comunicação viva, como também qualquer enunciação que integre nas suas estruturas o locutor (ou enunciador) e o destinatário, com o desejo do primeiro de influenciar o segundo.

Em Maingueneau, entende-se como análise do discurso "a disciplina que, em vez de proceder a uma análise linguística do texto em si, ou a uma análise psicológica ou sociológica do seu contexto, visa articular sua enunciação sobre um certo lugar social" (Maingueneau, 1997: 13). A análise do discurso coloca-se, portanto, "em relação com os gêneros de discurso trabalhados nos setores do espaço social ou nos campos discursivos" (Maingueneau, 1997: 14). O discurso é considerado como espaço heterogêneo, sempre em movimento e cuja unidade se faz em relação a discursos outros, que se manifestam, muitas vezes, naquilo que é dito justamente em uma instância de não-dito, e/ou em marcas que facilitam ou indicam caminhos para identificação da cena enunciativa. Tal noção permite aproximar as perspectivas teóricas apresentadas aos objetos empíricos referidos.

A fim de dar conta da polissemia e da não estabilidade da noção de discurso, Maingueneau propõe uma possível delimitação a partir do conceito de "formações discursivas" de Foucault, definido como "um conjunto de regras anônimas, históricas, sempre determinadas no tempo e no espaço que definiram uma época dada, e para uma área social, econômica, geográfica ou linguística dada, as condições de exercício da função enunciativa" (Foucault, 1997: 136). Se as narrativas constituem uma das práticas discursivas possíveis, notadamente em sua diversidade midiática, podemos afirmar:

Por este termo é possível entender o que Pêcheux chama de "superfície discursiva", que corresponde ao conjunto dos enunciados realizados, produzidos a partir de uma certa posição; mas também pode-se interpretá-lo como o sistema de restrições que permite analisar a especificidade desta superfície discursiva (Maingueneau, 1997: 24).

É, portanto, como elemento instituidor de realidades e por elas instituído que o discurso se apresenta. Essa visada aponta para a correlação e a reciprocidade entre processos de constituição social e textual, ponto crucial se considerarmos o fazer jornalístico, especialmente a função testemunhal que lhe é atribuída. A referencialidade presente em reportagens jornalísticas produz como efeito de sentido a exclusão do âmbito simbólico e o apagamento das marcas construídas no processo de mediação. 
Constituído na linguagem e imerso em uma ordem simbólica que o precede, ao sujeito não é possível ter acesso direto ao "real" (ainda que o jornalismo tente apagar tal apagamento para criar efeitos de realidade, objetividade e verdade $)^{62}$.

No jornalismo impresso, citações, tabelas e fotografias funcionam como recurso de remetência e, ao mesmo tempo, de autenticação do "real", estratégia operada por meio do obscurecimento da ordem simbólica e da colocação de um suposto "real" como espaço de "pura concretude". No jornalismo televisivo, além de elementos textuais, apresentadores, repórteres e entrevistados aparecem como marcadores visuais nos quais ancorar a verdade presumida de seus discursos:

Se lembramos da dessimetria, da condição tripartida do signo, era justamente para mostrar uma ordem de mediações, mostrar a distância imposta pela ordem simbólica. Assim, qualquer estratégia que opere pelo apagamento desses fatos e coloque um real como apreensível e descritível diretamente só pode constituir-se como efeito (Gomes, 2000: 25).

A esse respeito, Barthes já afirmara que, em relação à referencialidade, "o real concreto se torna a justificativa suficiente do dizer", como se a realidade fosse de fato transparente: 'Em outros termos, na história 'objetiva', o 'real' nunca é mais do que um significado não formulado, abrigado atrás da onipotência aparente do referente. Essa situação define o que se poderia chamar de efeito de real" (Barthes, 1988: 156). É interessante notar, portanto, que nessa passagem de um lugar a outro, do fato ao relato, é um processo de narrativização que se inscreve no discurso jornalístico, no qual determinadas formas narrativas contribuem para produzir efeitos de sentido que corroboram seus pressupostos. Constituindo-se no intervalo desse processo, o jornalismo apresenta-se como dotado de uma heterogeneidade constitutiva, mas que se torna apagada em suas marcas enunciativas. No discurso cinematográfico, por sua vez, a heterogeneidade mostrada se revela em sua própria constituição ${ }^{63}$.

Por meio, portanto, de relatos, discursos indiretos, paráfrases, citações, aspas, pressuposições, vozes de autoridade, entre outros elementos que compõem o que a análise do discurso chama de "heterogeneidade mostrada", o discurso jornalístico

\footnotetext{
${ }^{62}$ Ver, sobre esse tópico, os já mencionados conceitos de "transparência" e "opacidade" desenvolvidos por Xavier (1984). De modo paradoxal, eles apontam para uma falsa dicotomia, como se a existência do real pudesse opor-se à suspeição do real. As sobreposições entre uma visão positiva da história e sua perspectiva narrativa (White, 1994) problematizam essa visão: de um lado, há o "tudo ficcional" como forma de resistência à tentação do realismo, como se mostrar cada vez mais os modos de realização de um discurso fosse sinônimo de transparência. De outro, o excesso de ficcionalização termina por corroborar o realismo/naturalismo, modos próprios de expressão jornalística e documental.

${ }^{63}$ A esse respeito, ver, especialmente, os conceitos de "dialogismo", "polifonia" e "intertextualidade" como definidos por Bakhtin (2008).
} 
estabelece espaços de dialogismo e polifonia, uma intensa conversação com outras vozes e outros discursos que atravessam o seu próprio. Ao contrário do que se afirma comumente, não é em textos literários ou em filmes documentários que notamos os sinais evidentes dessa heterogeneidade, mas no texto jornalístico que, paradoxalmente, tenta se negar como heterogêneo para estabelecer seus pressupostos: atualidade, objetividade, isenção, negando suas próprias escolhas.

Ou seja, é na polêmica multiplicidade de vozes que compõem seu discurso que o jornalismo se afirma como narrativa coesa e unívoca, camuflando seus desvios e equívocos. No discurso cinematográfico, de modo mais evidente, há sempre um outro que se coloca como presente, de forma explicitamente marcada ou apenas pressuposta. Independente de suas marcas visíveis, todo discurso é constituído a partir de um debate com a alteridade, com o outro que o constitui; no caso do discurso jornalístico, diferentemente do cinematográfico, esse debate é, ao mesmo tempo, revelado em sua superfície e negado por seus princípios fundantes.

A polifonia e a heterogeneidade discursivas não se devem apenas à presença de sujeitos diversos em um mesmo enunciado, mas podem resultar da construção pelo locutor de níveis distintos no interior de seu próprio discurso. Por meio desse movimento, a possibilidade de articulação de um sentido estável - que levaria a uma interpretação sem ambiguidades - é problematizada (Maingueneau, 1997: 19-20). Se sentido e contexto não são preestabelecidos, mas interdependentes, a enunciação é sempre assimétrica, mobilizando saberes diversos. Aquele que interpreta os enunciados reconstrói seus sentidos a partir de indicações presentes nos enunciados produzidos, mas nada garante que o que ele reconstrói coincida com as representações do enunciador.

As polêmicas passagens que envolvem as formações discursivas não surgem, portanto, do exterior, mas presumem a partilha do mesmo campo discursivo e das leis que lhe são associadas. Se o discurso constrói, em um mesmo movimento, sua identidade e sua relação com outros discursos, verdade e ficção se entrelaçam em tramas complexas, possibilitando caminhos outros nos quais tecer as narrativas midiáticas. Os aportes trazidos por meio dos conceitos acima desenvolvidos nos permitem traçar, após termos percorrido tal temática em filmes cinematográficos, considerações sobre o jornalismo televisivo e filmes publicitários voltados à questão dos estigmas sociais. 


\subsubsection{Regimes de visibilidade e políticas da representação}

Os relatos jornalísticos têm ocupado lugar de destaque entre os programas televisivos contemporâneos ${ }^{64}$. Nos últimos anos acompanhamos a progressiva substituição, em horário nobre da Rede Globo, do programa Linha Direta por Profissão Repórter. Ambos têm em comum a apresentação de propostas tidas como inovadoras em termos jornalísticos e abordagens que valorizam o caráter narrativo de seus relatos.

Ainda que com possíveis divergências nas concepções sobre jornalismo e narrativa, os dois programas estabelecem diálogo com formas variadas comumente presentes em documentários televisivos ou cinematográficos. Por meio de uma abordagem contrastiva de Linha Direta e Profissão Repórter a partir das teorias da enunciação, procuraremos demonstrar que tais programas, aparentemente tão diversos, estão fundados sobre estratégias discursivas semelhantes, reafirmando o lugar de autoridade do jornalismo e produzindo, desse modo, efeitos de sentido equivalentes junto a seus espectadores.

O programa Linha Direta ${ }^{65}$ - no ar por vários anos e apresentando temas ligados, sobretudo, à violência, por meio de reconstituições e investigações policiais concebidas em contraposição ao chamado "jornalismo tradicional” - apresenta inúmeras diferenças em termos expressivos e de conteúdo se comparado a Profissão Repórter, inicialmente um quadro dentro do programa dominical Fantástico e com formato bastante distinto do atual, mais próximo de grandes reportagens. Ao nos voltarmos para programas televisivos, buscamos demonstrar que tal deslizamento, para além de possíveis mudanças nos contextos de produção e circulação dos discursos jornalísticos contemporâneos - incidindo também em seus usos e apropriações -, opera, ao contrário, como reforço de certo modo de pensar tais discursos.

\footnotetext{
${ }^{64} \mathrm{O}$ programa televisivo Profissão Repórter foi objeto de análise de um grupo de pesquisadores integrantes do MidiAto (ECA-USP). Ao longo de dois anos, desenvolvemos leituras e análises sobre o programa que culminaram na realização do Simpósio Profissão Repórter em Diálogo, em 2011, que reuniu participantes de outras universidades brasileiras, além de representantes da equipe do programa. Para acesso aos artigos completos, ver o livro Profissão Repórter em diálogo (293pp.), organizado por Rosana de Lima Soares e Mayra Rodrigues Gomes e publicado pela editora Alameda (SP), em 2012. As ideias expostas a seguir foram expandidas a partir de artigo publicado no referido livro. Maiores informações em: http://www.usp.br/midiato/simposio/profissao_reporter/.

${ }^{65}$ O programa semanal Linha Direta foi exibido, pela primeira vez, em 1990, e retomado de 1999 a 2007. Passando por diferentes fases, no início guardava semelhanças com outros programas jornalísticos de caráter popularesco, em que a ênfase em temas relacionados à violência prevalecia de forma sensacionalista e pouco afeita às definições clássicas do jornalismo em televisão. Dentre suas formas narrativas, podemos destacar a reconstituição de crimes, o apelo à denúncia, a reencenação de casos exemplares, a simulação de processos investigativos. Para um estudo aprofundado do programa, ver Mendonça $(2002 ; 2010)$.
} 
Comecemos por situar, ainda que brevemente, o programa do qual partimos. Linha Direta, apresentado pelo jornalista Marcelo Rezende, anunciava-se ao telespectador em tom amedrontador: "Medo. Impotência. Desamparo. São sentimentos cada vez mais presentes no cotidiano de todos nós. Nós que vivemos no dia-a-dia cercados por uma violência cega, uma violência que nos oprime. A partir de hoje você está em linha direta com seu direito, em linha direta com a cidadania". Em meio a outros programas informativos em que terror e insegurança constituíam o cerne de suas narrativas, uma inovação estética era proposta: apresentar ao espectador, em episódios semanais sobre crimes hediondos, possibilidades de solução da violência por meio da punição ostensiva e de um discurso totalitário em termos políticos e sociais, atribuindo ao criminoso a responsabilidade pelos atos cometidos, provocada usualmente por sua ausência de caráter. Tributário de uma ideologia conservadora, o programa apelava aos que, como o apresentador, indignavam-se com o fato de que os "malfeitores" pudessem prevalecer sobre os "homens de bem". Audiência assegurada, o programa manteve-se por muitos anos em horário nobre da Rede Globo.

De acordo com Mendonça, Linha Direta baseava-se em dois artifícios: "A simulação como produtora de uma verdade capaz de mobilizar o telespectador; e um conflito constante com a Justiça, na medida em que a sensação de insegurança, decorrente da alegada inoperância do sistema jurídico, é tomada como a razão principal para a existência dos casos apresentados" (Mendonça, 2002: 10). Em sua narrativa,

ao contrário das determinações dos manuais de jornalismo, o programa utiliza recursos poucos ortodoxos na construção das simulações dos crimes hediondos. No entanto, o uso destas não poderá levantar dúvidas acerca da veracidade dos fatos apresentados. Portanto, o programa abre mão de alguns recursos característicos da objetividade fria do jornalismo tradicional, mas em momento algum irá abandonar seu papel de veiculador de (supostas) verdades (Mendonça, 2002: 10).

Com o declínio não apenas deste, mas de outros programas que faziam da violência e de seu suposto combate o motor de seus discursos, Linha Direta é paulatinamente substituído por outras formas narrativas audiovisuais. Em seus últimos meses de exibição, aproxima-se do formato documental de histórias policiais e científicas, até ser definitivamente excluído da programação da emissora, em $2007^{66}$.

\footnotetext{
${ }^{66}$ Em 25/11/2010, o portal Comunique-se divulgou uma nota em que afirmava a volta do programa Linha Direta à grade de programação da Rede Globo, em 2011, fato que não se confirmou, com apresentação do jornalista Roberto Cabrini, apresentador do programa Conexão Repórter (SBT). Disponível em: carlosferreirajf.blogspot.com/2010/11/roberto-cabrini-rede-globo-cogita.html. Acesso: 10/08/2011.
} 
Nesse período, divide espaço com Profissão Repórter em horários alternados; no momento em que este se torna um programa autônomo ocupa, por alguns meses, o mesmo horário do extinto Linha Direta, fato que nos motiva às considerações propostas.

Em sua teoria da enunciação, Benveniste (1989) demonstra o dinamismo das categorias de pessoa, espaço e tempo quando tratamos do discurso. De modo não exaustivo, tomamos tais conceitos para pensar formas enunciativas presentes em Profissão Repórter. Nas oscilações entre o "eu-aqui-agora" e o "ele-lá-então", notamos a presença/ausência desses elementos em diversos telejornais. Não por acaso, o antigo telejornal Aqui Agora ${ }^{67}$ evocava, em seu nome, o efeito de sentido de aproximação ao telespectador, incorporando recursos antes incomuns no telejornalismo, como narrador em primeira pessoa, presença no local e transmissão em tempo real, como se não apenas o repórter, mas também o apresentador e seu público estivessem vivenciando os fatos no momento de sua ocorrência, e com a maior autenticidade possível.

Câmera na mão, entonação frenética, sons ruidosos e imperfeições na imagem, além de entrada de outros personagens (transeuntes, policiais, repórteres) corroboravam o efeito de objetividade jornalística pretendido, ainda que subvertendo os moldes usuais do jornalismo tradicional. Este, por sua vez, tem sido pautado pelo efeito enunciativo de distanciamento em relação ao telespectador, que se encontra frente a uma linguagem asséptica e, aparentemente, unívoca, ao receber relatos em terceira pessoa, com qualidade e apuro técnico inquestionáveis em termos de som e imagem. Podemos dizer que Profissão Repórter inova ao mesclar dois elementos singulares, como se pudesse agregar a vivacidade da narrativa próxima e a credibilidade de seu encobrimento.

Em notícia publicada em 07 de maio de 2006, no jornal Folha de S. Paulo, lemos sobre a chegada de um novo "quadro jornalístico" no programa semanal Fantástico: "Como o olhar de cada repórter pode influenciar na maneira de contar uma história na TV? A partir de hoje, o jornalista Caco Barcellos tenta responder à pergunta com um novo quadro no Fantástico, o Profissão Repórter, que mostrará o comportamento de oito jovens recém-formados na profissão e suas diferentes visões

\footnotetext{
${ }^{67}$ Exibido no SBT entre 1991 e 1997, retornando durante um curto período em 2008, foi um dos primeiros telejornais a romper com o formato clássico, de inspiração norte-americana, adotado pela Rede Globo, trazendo propostas estéticas, narrativas e tecnológicas diversas desse modelo convencional. Com vários apresentadores que se revezavam na leitura das notícias, um de seus diferenciais era o forte acento em temáticas relacionadas à violência e aos conflitos sociais, e o posicionamento explicitamente opinativo - e nem sempre politicamente correto - de seus apresentadores, em um período no qual a informação e o entretenimento ainda não se encontravam mesclados como ocorreria posteriormente na televisão. Seu slogan de estreia prometia um novo padrão jornalístico: "Um jornal vibrante, uma arma do povo, que mostra na TV a vida como ela é". Ver: www.arquivosbt.com/2008/07/aqui-agora.html.
} 
diante de um mesmo fato durante a produção de uma reportagem para televisão". Notemos que a frase inicial, sobre a "influência" do repórter na maneira de contar uma história, aponta para uma mudança na maneira de conceber o jornalismo como "retrato da realidade" ou "janela para o mundo", modo usual de defini-lo. A notícia informa, ainda, que a ideia do programa é mostrar "que quem apresenta a notícia também está sujeito a ela, com uma carga de emoção e sua vivência social ou cultural",68.

Essa perspectiva é anunciada no chapéu, onde se lê que o "novo quadro mostra visão de oito jornalistas diante do mesmo fato", seguido do alerta de que não se trata de um reality show, mas de "uma nova forma de apresentar uma reportagem", nas palavras de Caco Barcellos, em que a "estrela" seria o próprio relato, e não o repórter. A referência aos reality shows, menos consolidados mas já bastante numerosos naquela época, aponta para a necessidade de estabelecer uma fronteira entre o telejornalismo e outros gêneros televisivos informativos associados ao entretenimento, entre eles os próprios realities, os docudramas ou aqueles de caráter popularesco.

Profissão Repórter entra na programação, portanto, objetivando não apenas mostrar (e vencer) os desafios da reportagem, mas também aqueles do próprio jornalismo em busca de outros formatos. Sua estreia oficial ocorrera em caráter experimental, com a exibição de um episódio especial, no Globo Repórter, sobre o trânsito de São Paulo. O jornalista Marcel Souto Maior, diretor do programa até o início de 2011, declarou à Folha: "Esperamos que o público se identifique com eles [os repórteres] e acompanhe a dinâmica do trabalho do repórter, pois passamos por desafios, dúvidas e conflitos éticos e pessoais. Normalmente, na TV, a gente esconde isso". É nesse ponto que retomamos nossa questão: como pensar, para além dos enunciados propostos - incluindo formato e temática do programa -, suas possíveis inovações enunciativas? Se a proposta visava estabelecer um contrato comunicacional próprio com o telespectador, possibilitando que este "trocasse de lugar" com o repórter ou, ao menos, identificasse qual seria esse "lugar outro", explicitando algo antes velado, podemos indagar sobre os modos de enunciação construídos em Profissão Repórter.

A categoria "pessoa" refere-se, em Benveniste, à relação com a alteridade e ao pacto estabelecido entre um "eu" e um "tu", lugares cambiáveis que podem ser assumidos ora por um dos sujeitos, ora por outro, numa relação indissociável. Em Profissão Repórter, podemos notar a ocupação desses lugares ora pelo jornalista Caco

\footnotetext{
${ }^{68}$ A notícia "Barcellos testa formato no Fantástico" foi publicada sob a rubrica Telejornalismo e redigida por Marcelo Bartolomei (Folha de S. Paulo, caderno Ilustrada, 07/05/2006).
} 
Barcellos (que alterna os papéis de repórter, narrador e enunciador), ora pelos repórteres (aprendizes que fazem as vezes de narradores e personagens), ora pelos entrevistados (sujeitos retratados nas matérias a partir de diferentes posicionamentos, em alguns momentos atuando como protagonistas, em outros como adjuvantes da própria reportagem, eixo central do programa). Se assumirmos que a língua se articula em fala singular no ato de enunciação do discurso, notamos que não apenas os lugares do "eu" e do "tu", mas uma série de outros dêiticos são acionados no momento mesmo da enunciação - ele, ela, este, esta, longe, perto, ali, aqui -, demarcando as relações da pessoa do discurso com o espaço e o tempo nele construídos. Espaço e tempo estabelecem a experiência subjetiva dos enunciadores e coenunciadores do discurso, para além dos indivíduos que produzem e recebem as narrativas, ou nelas atuam.

Se a realidade é criada por meio dos discursos, que não se colocam como sua representação mas, ao contrário, estabelecem regimes de visibilidade em relação a diversos atores sociais, o jornalismo atua no sentido de cristalizar narrativas e, ainda, possibilitar sua dissolução, propondo construções múltiplas e diversas do mundo (Benveniste, 1989b: 70). Nessas construções, o tempo cronológico, o tempo dos acontecimentos e o tempo linguístico concorrem para o estabelecimento de narrativas, constituindo elemento fundamental quando consideramos o tempo sempre atual pressuposto no discurso jornalístico. Definido como uma função do discurso, o tempo linguístico é sempre presente, posto que ligado à instância da "fala colocada em ato".

Nos relatos jornalísticos como aqueles em Profissão Repórter, uma pergunta se coloca: se o tempo é pessoal e subjetivo, como tal experiência pode ser transmitida ao outro? De acordo com Benveniste, exatamente "porque a temporalidade que é minha quando organiza meu discurso é aceita pelo outro como sua" (Benveniste, 1989b: 77), podendo ser reconstruída, estabelecendo um locus comum, intersubjetivo, que ao mesmo tempo coloca os enunciadores em relação e cria um espaço não fixo para sua atuação. Em narrativas jornalísticas, o tempo dos acontecimentos é identificado com o tempo linguístico no momento em que o discurso está sendo proferido (quem fala "hoje", refere-se ao tempo em que está falando); para tornar o "hoje" inteligível fora do tempo linguístico do presente, é preciso relacioná-lo a uma divisão explícita do tempo cronológico (uma data específica, por exemplo), estabelecendo uma disjunção entre os três modos temporais (Benveniste, 1989b: 78-79). O tempo cronológico é, assim, uma convenção que permite que o tempo linguístico seja apreendido pelos enunciadores do discurso ao mesmo tempo em que constrói uma temporalidade a ele intrínseca. 
De modo semelhante, temos a construção do espaço e de suas marcações em reportagens jornalísticas, que só possibilitam a identificação de um local comum por meio de referências explícitas ou implícitas presentes nas imagens mostradas. Se tempo e espaço, assim como outros sistemas de significação, são construções históricas e simbólicas instauradas no instante da enunciação, a suposta transparência das narrativas jornalísticas é problematizada, apontando para o caráter provisório e ficcionalizante desses relatos. Assim sendo, pessoa, espaço e tempo não existem em si mesmos, ou em uma realidade a eles externa, mas são elementos discursivamente organizados por meio de articulações narrativas.

A enunciação, portanto, coloca em relação um conjunto de enunciados por meio de um ato singular de utilização da língua, sendo definida como o "ato mesmo de produzir um enunciado, e não o texto do enunciado, que é a fala" (Benveniste, 1989b: 82), e analisada a partir de três aspectos: a fala, as situações nas quais ela se realiza e os meios utilizados para tal realização. De acordo com Benveniste, esses elementos são caracterizados pela maior ou menor acentuação da "relação discursiva com o parceiro, seja este real ou imaginado, individual ou coletivo" (Benveniste, 1989b: 89), em que diversos recursos são utilizados não para gerar significados, mas para estabelecer laços sociais no discurso, como as inúmeras imagens e expressões que se repetem em reportagens jornalísticas, especialmente televisivas. Nesse sentido, podemos sustentar a hipótese de que estratégias discursivas presentes em Linha Direta são retomadas em Profissão Repórter, reafirmando os lugares de autoridade do jornalista-enunciador e do repórter-narrador presentes em programas telejornalísticos, sejam eles mais ou menos tributários das convenções (e coerções) genéricas às quais respondem.

Ao tomarmos as narrativas jornalísticas presentes em Profissão Repórter, observamos os modos pelos quais formas distintas articulam processos semelhantes de enunciação, engendrando a troca de papéis - mas, ao mesmo tempo, seu retorno às posições originais - entre repórteres e entrevistados, todos alçados à condição de personagens dos relatos apresentados aos telespectadores, também eles um "eu” e um "tu" instaurados no tempo-espaço do discurso jornalístico. Oscilando entre reafirmação e contestação dos princípios fundantes do jornalismo (entre eles objetividade, imparcialidade e atualidade), assistimos nas telas a programas tradicionais, como Jornal Nacional e Fantástico, e outros vistos como inovadores, como Linha Direta e Profissão Repórter. Vale ressaltar que, mesmo entre os relatos jornalísticos convencionais, têm ocorrido mudanças significativas em termos estilísticos, estéticos e editoriais. 
Nossa observação afirma que tal renovação, ao contrário do que poderia sugerir, não busca o outro, e sim o mesmo, em termos de concepção do fazer jornalístico. Ainda que tenhamos como objeto de estudo programas tidos como não tradicionais, estendemos essa hipótese também aos programas convencionais, afirmando que os modos de articulação de sua enunciação resultam em efeitos de sentido semelhantes junto aos destinatários, como se para preservar sua legitimidade o jornalismo precisasse se transformar. Na perspectiva da enunciação, portanto, tal movimento, aparentemente transgressor, visa à manutenção do lugar usualmente ocupado pelos relatos televisivos.

Entre os programas assumidos como não tradicionais (e também em alguns episódios de Globo Repórter ou quadros específicos do Fantástico), as reportagens de Profíssão Repórter apresentam características singulares em relação às demais. Entretanto, para além de sua narrativa inovadora, o programa estabelece uma suposta continuidade com seus antecessores na grade de programação da Rede Globo.

Nesse sentido, vemos a paulatina transposição, do ponto de vista da produção, de um relato jornalístico para outro, como se o próprio fazer jornalístico houvesse deslocado suas margens. Do ponto de vista da recepção, os dois programas contribuem para reforçar o imaginário social que atribui ao jornalismo estatuto de representação fiel da realidade, atestando seu caráter referencial e ocultando seus vestígios. A representação pretendida, em vez de ser percebida como construção discursiva, opera exatamente na disjunção entre fato e discurso, acentuando uma vez mais a dicotomia entre "transparência" e "opacidade" (Xavier, 1984).

Tanto a ascensão de Profissão Repórter, e sua consolidação, quanto o progressivo declínio de Linha Direta, até sua extinção, trazem importantes questionamentos para os relatos jornalísticos televisivos: seria essa transformação tributária da queda de audiência dos programas ditos sensacionalistas e de viés popularesco, de certa forma representados por Linha Direta? Ou poderíamos vislumbrar nessa troca de lugares a proposição de outro modo de pensar o fazer jornalístico contemporâneo, estabelecendo um lugar mais flexível e ficcionalizante em suas narrativas ${ }^{69}$ ? Ambos os programas oscilam entre referencialidade e ficcionalidade, objetividade jornalística e subjetividade cinematográfica, reportagem e documentário.

\footnotetext{
${ }^{69}$ Utilizamos, propositadamente, o termo ficcionalizante para diferenciar tal perspectiva da ficção literária ou do aspecto fictício atribuído ao imaginário. Tomamos a concepção de Odin (2012), que estabelece o que chama de "leitura documentarizante" e "leitura fictivizante", baseadas na maneira como o espectador reconhece o "eu" enunciador presente no discurso fílmico. O autor afirma que tanto o "documento" como a "ficção" dizem respeito a uma realidade construída por meio de narrativas e, desse modo, filmes de
} 
Nos últimos anos, notamos na televisão o aumento de programas de temática policial concebidos nos moldes do cinema brasileiro (entre eles, a série Força Tarefa, da Globo, e a telenovela Vidas Opostas, da Record), bem como de programas jornalísticos voltados para a mostração de seus bastidores e modos de construção. O slogan de Profissão Repórter sintetiza esse movimento ao prometer dar a ver "os bastidores da notícia, os desafios da reportagem", evocando uma visão romântica do jornalismo e de seus protagonistas. Dessa forma, sensacionalismo, narrativização, ficcionalização, oposição entre representação e realidade, reconstituição posterior dos fatos - elementos de Linha Direta - parecem se transmutar em Profissão Repórter, no qual assistimos à fabulação da reportagem, encenada para o telespectador por meio de personagens verídicos, estabelecendo pontos de ruptura e contato entre programas tão distintos.

A partir das análises, podemos afirmar que diferentes estratégias discursivas produzem, para o público, efeitos de sentido semelhantes, pois têm em comum a crença compartilhada nos fatos reais apresentados. Ainda que em Linha Direta o mais importante seja a encenação do fato e, em Profissão Repórter, a encenação da reportagem sobre o fato (assumindo a reportagem como personagem que compõe o fato narrado), os dois programas dizem respeito a um mesmo imaginário. Profissão Repórter inova, portanto, para reafirmar sua profissão de fé no jornalismo, ao contrário do filme Passageiro - Profissão: Repórter (1975), de Michelangelo Antonioni, em que realidade e ficcionalidade, objetividade e subjetividade, veracidade e fantasia, confundem-se nos relatos do protagonista e na maneira de problematizar o jornalismo.

Tomando como referência os conceitos apontados, podemos afirmar que, na diversidade de suas tematizações e figurativizações, Linha Direta e Profissão Repórter ocupam, na programação da Rede Globo, um lugar próximo em relação aos procedimentos enunciativos neles engendrados e à concepção de jornalismo da emissora, ainda que apresentando inovações estilísticas, estéticas e editoriais. Essas mudanças acompanham também transformações no contexto de recepção e no lugar ocupado pelo jornalismo junto à sociedade. Tal percepção será demonstrada por meio de episódios voltados para a tematização de conflitos sociais, recorrentes em Profissão Repórter, selecionados a partir de amostragem ampliada. Em 2 de junho de 2008 o programa se tornou autônomo, como lemos em chamada no site oficial: “A partir desta

ficção possuem caráter referencial e filmes documentários apresentam aspectos fabulosos. Eliminando as rígidas fronteiras que, aparentemente, parecem separar esses gêneros, Odin alerta para a inconsistência em buscar definições, nos discursos audiovisuais, por meio desses conceitos. 
terça-feira, o Profissão Repórter passou a ser semanal! No primeiro programa dessa nova fase, Caco Barcellos e sua equipe de jovens jornalistas acompanharam o drama dos brasileiros que vivem à espera de um coração" 70 .

De um total de 149 episódios pesquisados ${ }^{71}$, identificamos três fases (em termos de formato) e três momentos (em termos narrativos) nos quais situar o programa. Inicialmente, Profissão Repórter foi criado como um quadro dominical no programa Fantástico (09/03/2006-09/03/2008; 02/09/2008; 15/09/2009). Posteriormente, tornouse um programa Especial, sendo exibido em dias esporádicos (14/12/2006; 28/12/2006; 30/08/2007; 18/10/2007; 13/12/2007). Finalmente, torna-se programa semanal, com horário fixo na grade, a partir junho de 2008, sendo exibido até o presente momento.

Em termos narrativos, notamos, na primeira fase (2006-2008), ênfase na discussão sobre o jornalismo e seus bastidores, tendência crescente na época, em que as reportagens voltavam-se sobre a profissão e seus repórteres, caracterizando uma espécie de metajornalismo que se desvelava aos olhos do público. No momento subsequente (2008-2009), a ênfase nos bastidores se torna acentuada, como se o programa assumisse, para além do protagonismo das próprias reportagens, a possibilidade de mostrar, radicalmente, a realidade e as maneiras de relatá-la. Notemos que é nesse período que o esgarçamento da linguagem de Linha Direta, com sua tônica na cobertura supostamente "verdadeira" dos fatos, conduz ao término deste programa.

Finalmente, a partir de 2010 e ao longo de 2011, percebemos um amadurecimento das reportagens (e dos repórteres), transformando Profissão Repórter em um programa consolidado, que divide com outros o espaço privilegiado, no jornalismo, da realização de grandes reportagens. Notemos que, no último período, outros programas compartilham desse cenário, alguns deles incorporando estratégias narrativas de Profissão Repórter que, muitas vezes, fazem-se presentes também nos telejornais da Rede Globo. Nesse sentido, outro aspecto se destaca: as pautas tornam-se cada vez mais semelhantes entre os diversos programas (renunciando à tentativa inicial de diversificação) e sua abordagem passa a ser feita de modo mais unívoco (preocupando-se cada vez menos em mostrar as "diversas maneiras de contar uma história" ou a crítica de reportagens realizadas). Sobre os anos recentes de Profissão Repórter e os atuais formatos telejornalísticos, trataremos em capítulo posterior.

\footnotetext{
${ }^{70}$ Para acesso às chamadas e episódios integrais de Profissão Repórter, ver: www.globo.com.

71 Para listagem completa, ver capítulo "Profissão Repórter, um panorama" (em Soares e Gomes, Profissão Repórter em diálogo, 2012), no qual é apresentado o banco de dados da pesquisa sobre o programa.
} 
Entendemos que a assunção de reprodução fiel da realidade é uma das premissas do jornalismo, sendo, portanto, essencial à sua definição. A fim de problematizarmos essa premissa, indagamos se seria possível, ao telejornalismo, narrar de outro modo sem perder sua credibilidade junto ao público. Dois eixos são priorizados nesse momento: 1) a relação entre os planos da enunciação e dos enunciados nos episódios tratados (ou entre seu dizer e seus ditos), apontando em qual deles seus modos de enunciar se tornam mais semelhantes ou mais dissonantes; 2) a questão dos contratos comunicacionais (ou pactos de leitura) estabelecidos entre enunciador e coenunciador (ou entre autor-modelo e leitor-modelo), não apenas no plano empírico de realizadores e audiência, mas considerando, sobretudo, as relações entre referencialidade e ficcionalidade presentes no discurso hibridizado desse programa telejornalístico.

Para empreender o trajeto, recortamos do corpus de 149 episódios aqueles que tratam de temáticas voltadas à violência e temas correlatos - a fim de aproximar o programa da questão dos estigmas sociais -, privilegiando o ano de 2008, época em que o programa passa a ser exibido sem a presença de Linha Direta. Julgamos ser esse o período mais adequado para nossa abordagem, pois notamos que, de forma metonímica, Profissão Repórter supre a lacuna supostamente deixada por Linha Direta de modo mais condizente com o telejornalismo atual, propondo inovações em seu discurso.

As temáticas tratadas apontam para questões recorrentes: violência, polícia, crime, conflitos. Ainda que tais aspectos estivessem presentes nos meses iniciais do programa, tornam-se preponderantes até 2011, estabelecendo aquela que julgamos ser sua principal articulação enunciativa: as relações sempre ambíguas, quase sempre antagônicas, entre os diversos atores sociais. Ou seja: é por meio da explicitação dos conflitos entre cada um e todos os outros e, portanto, de relações de identidade e alteridade, que Profissão Repórter estabelece sua enunciação, configurando, ainda que de modo mais propositivo, os conflitos de Linha Direta.

Vale a ressalva, entretanto, de que sob o ponto de vista dos enunciados os dois programas se afastam consideravelmente, até mesmo pelas radicais mudanças em termos históricos e contextuais. Se Linha Direta surgia como lugar de explicitação das diferenças por meio de soluções extremas e segregadoras, com um discurso baseado em formas políticas reacionárias, Profissão Repórter se sustenta no eixo de reconhecimento e respeito às diferenças, lançando um olhar conciliatório e crítico em relação aos temas abordados, operando, frequentemente, na manifestação de conflitos como algo intrínseco à sociedade e na busca por compreender o ponto de vista do outro. 
Selecionamos dentre as temáticas as rubricas "Policial" e "Cotidiano", e os subtemas "Periferia" e "Violência". Destes, elegemos o subtema "Violência" como aquele no qual pontuar alguns episódios que possam corroborar a argumentação apresentada de que, ao ser questionado em seu caráter predominantemente referencial como consequência da ficcionalização explícita encenada nos telejornais popularescos , outro formato jornalístico se apresenta, guardando as formas narrativas antes excluídas dos jornais tradicionais mas reafirmando, em seu "modo de fazer",72, o caráter verossímil das narrativas jornalísticas.

Entre os subtemas apontados na totalidade de episódios de Profissão Repórter, "Violência \& Conflitos" apresentam 28 ocorrências. Destas, 25 referem-se ao subtema "Violência", com a seguinte distribuição temática: "Policial" = 15 (de um total de 19 episódios), "Cotidiano" $=7^{73}$, "Educação" = 1, "Esporte" =1, "Comportamento" $=1$.

Não há aumento significativo de episódios se considerarmos a temática "Policial" e o subtema "Violência" no período anterior ou posterior ao cancelamento de Linha Direta, mas notamos variação nas abordagens das reportagens, sobretudo nos títulos dos episódios - que se tornam mais contundentes -, como vemos a seguir: a) episódios até maio de 2008 (Fantástico e Especial): "Julgamento que virou circo" (11/06/2006), "Violência contra a mulher" (13/08/2006), "O roubo de carros nas grandes cidades" (17/09/2006), "Estudantes africanos no Brasil" (04/01/2007), “A cidade mais violenta do país" (03/04/2007), “O caos na praça da Sé” (05/06/2007), "Profissão Repórter apura crime que chocou interior paulista" (09/03/2008); b) episódios a partir de junho de 2008 (Regular): "Hospital de guerra" (23/06/2008), "Na linha de tiro" (22/07/2008), "Heliópolis" (10/06/2009), "Guerra entre gangues" (28/07/2009), “A vida na cadeia" (18/08/2009), "Violência entre casais" (22/09/2009), "Violência contra mulher" (20/07/2010), "Bope" (21/12/2010).

\footnotetext{
${ }^{72}$ Não por acaso, a expressão intitula o livro de William Bonner sobre o Jornal Nacional: Jornal Nacional - Modo de fazer (São Paulo: Globo, 2009), em que não se pretende apresentar "a receita tradicional, imutável, de um bolo", mas "mostrar, de maneira clara, mesmo para quem não seja profissional do jornalismo, como é construído, dia a dia, o telejornal de maior audiência do Brasil" (apresentação). Os "bastidores" colocam-se em primeiro plano e parecem anular seu efeito de opacidade, ocultando, uma vez mais, os procedimentos enunciativos das narrativas jornalísticas.

73 Dois episódios originalmente inseridos em "Cotidiano" foram realocados em "Violência" para efeitos da pesquisa: "Violência entre casais" (22/09/2009) e "Violência contra mulher" (20/07/2010).
} 
Para as análises, privilegiamos três episódios exibidos em 2008 sob a rubrica "Violência/Policial"" , apontando algumas de suas constâncias em relação ao programa Linha Direta. Os episódios "Profissão Repórter apura crime que chocou interior paulista" (Fantástico), "Hospital de guerra" (Regular) e "Na linha de tiro" (Regular) tratam, respectivamente, da história da investigação que levou ao esclarecimento do assassinato do jornalista Luis Carlos Barbon, crime cometido em um bar do interior de SP; do acompanhamento da rotina em um hospital no meio da luta entre traficantes e policiais nos morros cariocas; e, um mês depois, do drama de quem vive no fogo cruzado entre polícia e tráfico, no Rio de Janeiro e em Recife ${ }^{75}$.

\section{9 de março - "Profissão Repórter apura crime que chocou interior paulista"}

Gabriela Lian, Nathália Fernandes, Felipe Gutierrez, Caco Barcellos

"O jornalista Luis Carlos Barbon foi assassinado num bar movimentado em Porto Ferreira (SP). Dez meses depois, a equipe de Profissão Repórter se divide para contar a história desta investigação que levou ao esclarecimento do crime ${ }^{, 76}$.

Este episódio, que integra um dos quadros do Fantástico, tem lugar na cidade de Porto Ferreira, localizada no interior de São Paulo. O assassinato de um jornalista local é o mote da reportagem, com ênfase, assim como as duas seguintes, nas rubricas "Cotidiano" e "Policial", tônica que perpassa quase a totalidade dos episódios de Profissão Repórter. Tributário da primeira fase do programa, tem a reportagem iniciada por Caco Barcellos, em tom assertivo, atribuindo aos "jovens repórteres" papel de protagonistas na narrativa que vai "contar, de todos os lados, a história dessa investigação, que levou, nessa semana, ao esclarecimento do crime".

Seguindo os acusados, procurando pistas e ouvindo amigos e parentes das vítimas, os jornalistas encenam, como em um docudrama, não apenas a reconstituição da investigação, mas também se tornam autores das revelações encontradas e do processo de desvendamento do crime. Talvez pela justaposição entre a vítima retratada, jornalista assassinado enquanto se encontrava em um bar, e os jornalistas que partem em

\footnotetext{
${ }^{74}$ Em 2008, foram exibidos 28 episódios (apenas dois antes de junho). Destes, cinco fazem parte da editoria "Policial" e três foram inseridos no subtema "Violência". Além dos já citados, em "Policial" temos os episódios "Desaparecidos" (26/08/2008) e "Os bastidores de um julgamento polêmico"/“"Acusados de matar jovem voltam para a cadeia” (25/11/2008). Em relação às demais editorias, temos a seguinte distribuição: "Cotidiano" (onze episódios), "Comportamento" (seis episódios), "Saúde/Bem estar" (três episódios), "Cultura" (dois episódios), "Esportes" (um episódio). Notemos que, na temática "Cotidiano", diversos episódios também poderiam ser pensados na relação conflitos/violência.

${ }^{75}$ Informações retiradas do site g1.globo.com/platb/programaprofissaoreporter.

${ }^{76}$ Disponível em: fantastico.globo.com/Jornalismo/FANT/0,,MUL698651-15607-170,00.html.
} 
busca da solução do crime, este episódio destaca o papel dos repórteres no estabelecimento da justiça. Isso pode ser atestado pelo uso frequente de câmeras portáteis, filmadas enquanto filmam, criando um efeito em cascata. O jornalista, ausente, é construído como personagem por meio de depoimentos de pessoas próximas a ele e pela narração, que destaca seu caráter heroico ao denunciar a prostituição e o aliciamento de menores por parte de policiais.

Construindo um efeito de estranhamento junto ao espectador, duas repórteres mulheres são destacadas para conversar com as famílias dos policiais acusados, que se recusam a falar com as jornalistas. Caco Barcellos nos alerta de que aquela seria "a primeira reportagem policial" das duas jovens. A sequência final do episódio denuncia a proteção destinada aos acusados quando estes são autoridades (no caso, policiais) e as dificuldades, justamente por essa razão, em se entrevistar suas famílias. Em pelo menos dois momentos é Caco Barcellos quem interfere e aconselha as jovens repórteres, mimetizando uma espécie de discussão de pauta com as aprendizes.

Ao contrário da maioria dos episódios - em que a intervenção de Caco Barcellos se faz no momento da edição -, como não há imagens ou entrevistas captadas pelas repórteres o cenário da rua serve como estúdio no qual orientar as jovens. É o próprio jornalista sênior quem encerra o programa, de modo inconclusivo, já que o inquérito deve continuar. Essa reportagem, integrante da primeira fase do programa, anuncia seus princípios e enfatiza o caráter pedagógico da proposta inicial, visando formar não apenas os jovens repórteres, mas o próprio público e, de modo mais amplo, os fundamentos do jornalismo.

\section{5 de junho - "De cara para a violência"}

Gabriela Lian, Felipe Gutierrez, Júlia Bandeira, Caio Cavechini, Thais Itaqui, Natalia Fernandes, Caco Barcellos

"Foram 24 horas no Getúlio Vargas, no Rio de Janeiro. Cercado por 21 favelas, perto do Complexo do Alemão, o hospital é o que mais atende a vítimas de tiro no Brasil",77.

A metáfora da guerra é mais uma vez evocada no episódio "Hospital de guerra", modo como é nomeado no site. Situações de crime e violência são enfatizadas, e nas histórias contadas - todas sobre pacientes graves no atendimento emergencial do hospital Getúlio Vargas, no Rio de Janeiro - vemos imagens escuras, enquadramentos oblíquos e cenas fora de foco.

\footnotetext{
${ }^{77}$ Disponível em: especiais.profissaoreporter.globo.com/programa/2008/06/23/hospital-de-guerra/.
} 
No início, a narração de Caco Barcellos, em tom grave, alerta: "Nossos jovens repórteres nunca estiveram tão perto da violência", enquanto a legenda indica " 6 a feira à noite", e uma repórter caminha pelo hospital sombrio, como se estivesse entre escombros de um local destruído. O imaginário da guerra, presente também no episódio abaixo ao mostrar as periferias de Recife e Rio de Janeiro, e os tiroteios que levam à morte de inocentes, faz-se notar nas cenas que destacam "mais um dia de guerra entre polícia e traficantes no Rio de Janeiro". O eixo narrativo se constrói em torno do socorro às vítimas no hospital Getúlio Vargas, especialmente no acompanhamento de pessoas feridas por tiros (acidental ou deliberadamente, no caso de supostos criminosos) atendidas no serviço de emergência do hospital. Durante 24 horas, a equipe de Profissão Repórter acompanhou, nas palavras do narrador Caco Barcellos, "a luta de médicos e enfermeiros para salvar vidas".

Diferentemente de outros episódios, o cenário é composto por meio da construção do local como um hospital de guerra, improvisado, tenso e precário. A estética de reality shows televisivos passados em hospitais se mistura com aquela presente na cobertura jornalística de conflitos armados, mescladas com uma banda sonora diversa e insistente, repleta de choros, gritos, vozes sem identificação. Em diversos momentos, a narração enfatiza que o Getúlio Vargas é um "centro de saúde especializado em violência" devido à sua localização singular, na Penha, zona norte do Rio, perto do mesmo Complexo do Alemão - composto por 21 favelas - mostrado no episódio sobre a escola localizada na linha de tiro da polícia e do tráfico. Esses mesmos atores são retratados no episódio, intercambiando os lugares de vítimas e algozes, e a complexa rede que os conecta. $\mathrm{Na}$ troca de tiros entre policiais e traficantes, os feridos são variados, incluindo, além deles, pessoas comuns habitantes do local. No hospital, são mostradas cenas normalmente reservadas, trazendo ao espectador imagens bastante privadas sobre a rotina hospitalar.

Entrevistas com profissionais da área médica são misturadas às imagens que, embora de cunho realista, não parecem documentais. Ao contrário, a edição frenética, as cenas desfocadas, o uso de filtros em tons avermelhados e amarelados, o close nos rostos dos personagens e o forte apelo emocional criam a ilusão de que se trata de uma reconstituição teledramatúrgica. Nesse episódio, a exemplo do anterior, notamos a presença de Caco Barcellos como uma espécie de vigilante do poder público: quanto mais tensas se tornam as imagens ao mostrar o "mundo cão" do crime e de um hospital a ele relacionado, mais a intervenção dos repórteres se faz sentir de forma intensa. 
Em meio às muitas vítimas dos tiros trocados entre policiais e traficantes, vemos diversas câmeras que filmam os repórteres, atuando não apenas como jornalistas, mas também como personagens misturados àqueles presentes na cena. Em dado momento, dois repórteres, vestidos com roupas cirúrgicas, filmam uma operação, mostrando lugares aos quais nem mesmo os pacientes têm acesso. Ao final, Caco Barcellos apresenta o balanço do pronto socorro: 248 pessoas atendidas, quatro mortes. As cenas mostradas, oscilando entre moradores da comunidade, policiais feridos ou mortos em combate e pacientes suspeitos (tratados com mais violência que os demais), não seriam jamais exibidas caso se tratasse de um hospital de elite, especialmente no que diz respeito à forte presença policial e à quantidade de armas no interior do hospital.

\section{2 de julho - "A vida na linha de tiro"}

Julia Bandeira, Gabriela Lian, Caio Cavechini, Caco Barcellos

"Conheça o drama de quem vive no fogo cruzado entre a policia e o tráfico. No Rio de Janeiro, inocentes são mortos em operações policiais desastradas. Um relógio conta os homicídios em Recife ${ }^{, 78}$.

O episódio "Na linha de tiro" apresenta quatro microrreportagens: cena do crime, sobre homicídios em Recife, uma das cidades mais violentas do Brasil; na mira do tráfico, sobre um juiz federal jurado de morte, que necessita de proteção policial 24 horas por dia; na mira dos pistoleiros, sobre vítimas de conflitos de terra no Pará; e fogo cruzado, sobre tiroteios entre policiais e traficantes na cidade do Rio de Janeiro. As histórias são narradas de forma intercalada, e todas se caracterizam por enfatizar cenários urbanos fora do eixo sul-sudeste ou, no caso da reportagem no Rio de Janeiro, em áreas suburbanas.

Se tomarmos as categorias de pessoa, espaço e tempo, notaremos, nas quatro narrativas, a ênfase em estigmas da pobreza e da violência, recorrente também nos outros episódios destacados. No primeiro bloco, Recife e Rio de Janeiro são mostrados como lugares de crime e violência deliberada, numa espécie de "faxina social" (expressão usada no programa) que aponta para a ausência do poder público na periferia das grandes cidades. Começando por Recife, vemos nas imagens uma população humilde e acuada pelo alto número de homicídios nos bairros populares, em semanas recentes, fazendo com que as imagens evoquem, uma vez mais, as zonas sitiadas de países em guerra ou guerrilha urbana.

\footnotetext{
${ }^{78}$ Disponível em: g1.globo.com/videos/profissao-reporter\#/programas/20080722.
} 
A marcação do tempo presente se faz por meio de entrevistas com pessoas comuns, afetadas pelos crimes, e com policiais que acompanham esses eventos, especialmente na remoção das vítimas. $\mathrm{O}$ uso de câmeras desfocadas, ainda uma vez, e a recorrência de closes nas entrevistas, quase sempre em cenas noturnas, imprimem um caráter de urgência ao quadro relatado pelos repórteres, que se movimentam pelos bairros da Grande Recife.

$\mathrm{O}$ drama de pessoas inocentes mortas em disparos de policiais contra traficantes e a morte de policiais durante sua rotina de trabalho integram a segunda reportagem do programa, alternada com aquela sobre Recife. Nos episódios relatados na matéria, são enfatizados jovens negros e crianças de uma escola pública do Rio de Janeiro localizada ao lado do Complexo do Alemão. O apelo sensacional se faz de modo evidente na construção dos personagens, em sua maioria crianças entrevistadas na reportagem. Histórias de alunos feridos, depoimentos de crianças e entrevistas com professores afastados do trabalho por distúrbios psicológicos causados pela violência frequente são mostrados por meio de imagens recortadas, edição acelerada e enquadramento em primeiro plano, alternando imagens da escola e de seus arredores marcadas pelos tiros trocados entre policiais e traficantes. A presença policial, bem como o desamparo dos moradores, são recorrentes nestas duas reportagens, de Recife e Rio de Janeiro.

A terceira e a quarta reportagens compõem o segundo bloco do programa, relatando o cotidiano de um juiz federal - que conta com sistema de vigilância 24 horas por dia - e os aparatos de segurança por ele utilizados (colete à prova de balas, grupo de vinte policiais como guarda-costas, armamento pesado para defesa). A condenação de vários traficantes na fronteira do Brasil com o Paraguai, em Ponta Porã, é a causa das ameaças que o juiz, hoje atuando em Campo Grande (MS), recebe. A declaração, dada por ele, de que o lugar no qual se sente mais seguro é o presídio, é repetida ao longo da reportagem. $\mathrm{O}$ foco no personagem e a presença menos intensiva dos repórteres marcam o modo de contar essa narrativa. Com motivações diferentes, mas também ameaçadas de morte, pessoas envolvidas em conflitos e disputas de terra no Pará são destacadas na última reportagem do episódio, apresentando denúncias e mobilização popular.

Esses dois últimos episódios, separados por aproximadamente um mês, retomam, do ponto de vista da enunciação, elementos muito semelhantes para construir enunciados voltados a temáticas diversas. Tanto em relação ao uso de recursos imagéticos - planos, edição, enquadramentos, iluminação, trilha sonora -, como nos elementos narrativos - cenários, temporalidade e personagens -, vemos a retomada de 
elementos comuns, especialmente ao mostrar regiões distantes e empobrecidas de grandes metrópoles e ao construir as reportagens em torno de heróis, vilões e vítimas especialmente "policiais" e "criminosos". Os repórteres também desempenham papel semelhante nos episódios (ambos integrantes da fase em que o programa é apresentado regularmente), atuando não apenas como profissionais, mas interagindo com os personagens criados por eles próprios nas narrativas mostradas. Uma sobreposição - ou dobradura - se faz perceber nesse movimento em que repórteres entrevistam personagens e, além disso, tornam-se personagens de si mesmos.

Partindo desses elementos, procuramos demonstrar que, embora aparentemente antagônicos em termos de suas estratégias discursivas, Linha Direta e Profissão Repórter projetam, junto ao público um mesmo imaginário acerca do fazer jornalístico, articulando efeitos de sentido semelhantes. A partir dos episódios destacados, pudemos demonstrar que à primeira vista o programa Profissão Repórter se insere, desde a fase inicial, como um programa jornalístico inovador, mas que, do ponto de vista de sua enunciação, produz junto ao público efeitos de sentido semelhantes àqueles de programas jornalísticos tradicionais, como Jornal Hoje, Jornal Nacional e Jornal da Globo. Recentemente, notamos que os formatos híbridos contaminam, retroativamente, os telejornais e programas esportivos convencionais, transformando-os.

Buscando refletir sobre os formatos jornalísticos contemporâneos em suas injunções com outras formas audiovisuais, entre elas o documentário, confrontamos, nos discursos jornalísticos, programas que corroboram seu estatuto de referencialidade e aqueles que, a exemplo de Profissão Repórter, apresentam formas narrativas predominantemente encenadas por meio de reconstituições e dramatizações, aproximando-se, mesmo que de modo reverso, dos chamados formatos sensacionalistas (Borges e Enne, 2007) ou popularescos (Venancio, 2010).

Nesses programas, o jornalismo assume determinadas estratégias discursivas a fim de criar efeitos de sentido que o aproximem das narrativas de entretenimento, em oposição àquelas de informação, sem abandonar, contudo, o efeito de realidade buscado numa suposta fidelidade à representação do mundo. Ou seja: ainda que explicitando, ao menos no plano dos enunciados, suas estratégias discursivas, no plano da enunciação temos a reafirmação de uma suposta "transparência" do discurso jornalístico (que, ao tentar revelar-se, encobre ainda mais essas estratégias), como se nele não houvesse esses mesmos artifícios presentes na ficção. Tal formato, próprio dos programas jornalísticos tradicionais, tem sido cada vez menos (explicitamente) utilizado. 
Se tomarmos os formatos jornalísticos pensados a partir das relações entre entretenimento e ficção, poderemos identificar movimentos de recuo e avanço nas relações com o sensacionalismo, desde os telejornais aparentemente neutros da Rede Globo até o popularesco e policialesco Aqui Agora (SBT). Nos formatos sensacionalistas, é como se a ficcionalidade fosse exacerbada nos exageros narrativos que os transformam em um jornalismo quase-fantástico. Nessas oscilações, como conceber o jornalismo - a partir de seus efeitos de sentido mais conservadores ou mais críticos? Programas televisivos como Cidade Alerta, da Rede Record, Repórter Cidadão, da Rede TV, e Brasil Urgente, da Rede Bandeirantes, apresentados por locutores carismáticos - entre eles José Luiz Datena, Marcelo Rezende e Roberto Cabrini, que evocam o estilo radiofônico de Gil Gomes e Afanásio Jazadji -, encontram-se no limiar entre sensacionalismo e jornalismo, ultrapassando as questões sobre referencialidade e ficcionalidade propostas.

A suposta crença na verossimilhança, visando produzir um efeito de sentido de que o que se conta é verdadeiro, parece ter se esgotado, enquanto estratégia narrativa, quando os jornais sensacionalistas chegaram ao limite ético, apelando para histórias absurdas que acabaram afastando sua audiência e levando ao esvaziamento de sua fórmula. É como se, nesse momento, esses jornais narrativizados (e, na definição clássica do jornalismo, mais ficcionalizados) tivessem deixado de ser a presentificação do "real" justamente por não guardar, da ficcionalidade, sua aparência de realidade e efeitos de naturalização. Ao se tornarem "pura ficção", esses jornais perderam espaço televisivo e precisaram deslizar para outras possibilidades, também não contempladas no jornalismo tradicional.

Se o jornalismo não pode ser tão fabuloso quanto a ficção - como pretendiam os programas ditos sensacionalistas -, um limite se impõe, limite este rompido por Linha Direta e restituído por Profissão Repórter, restaurando o lugar da verdade dos fatos no jornalismo e, desse modo, expandindo suas fronteiras. É nesse ínterim que seu formato parece reunir dois elementos: o caráter referencial do jornalismo tradicional e o caráter narrativo do jornalismo popularesco, combinados de modo original em Profissão Repórter. Nesse sentido, o programa empreende um movimento diverso, explicitando tanto do ponto de vista dos enunciados, como da enunciação, suas estratégias discursivas. Entretanto, os dois modelos parecem concorrer, nos discursos jornalísticos televisivos, para os mesmos objetivos, qual seja, a afirmação dos princípios fundantes do jornalismo. 
Ao fazê-lo, asseguram a possibilidade de mostrar a realidade de modo verdadeiro, ainda que diferenciado das formas enunciativas convencionais do jornalismo, devido à fragmentação das imagens e à relativização dos relatos. Nos últimos anos, esse formato jornalístico convencional, bem como aquele de caráter mais claramente sensacionalista, vem sendo aos poucos substituído por outro, do qual Profissão Repórter pode ser considerado um exemplo modelar. Gostaríamos de encerrar estas observações com a assunção radical, já enunciada, de que se toda verdade tem estrutura de ficção, programas pretensamente referenciais também são engendrados pela ficcionalidade neles presente. A oposição se daria nos interstícios entre referencialidade/verdade e ficcionalidade/invenção. Os limites entre mito/fantasia, realidade/fato e fabricação/ficção não são apenas sobrepostos, mas colocam-se, nos discursos audiovisuais, como indissociáveis. Desse modo, o jornalismo se constitui, também ele, como um mito, caracterizado, ao mesmo tempo, como fato e como ficção.

O mesmo movimento pode ser notado se observarmos alguns filmes publicitários veiculados na televisão aberta brasileira relacionados aos estigmas sociais, apontando para outras interseções e reconfigurações presentes na cultura audiovisual contemporânea. Selecionamos filmes que trazem a presença de atores/atrizes negros/as e/ou referência direta a espaços, experiências e vivências cotidianas periféricas, buscando mapear os lugares de redundância ou ressonância nelas presentes por meio de efeitos de sentido produzidos em torno do reforço ou transposição de estigmas. As propagandas serão analisadas em suas recorrências a partir de três eixos: tematização de imagens e imaginários nelas presentes, políticas de representação da identidade negra e emergência de novos regimes de visibilidade presentes nos discursos audiovisuais ${ }^{79}$.

Os modos como os estigmas se fazem presentes em tais filmes publicitários serão contrastados, estabelecendo recorrências entre eles a fim de propor um olhar crítico em relação a tais narrativas. Ao estabelecer seu lugar de fala em um determinado grupo social, historicamente discriminado, as peças publicitárias anunciam e silenciam a presença de determinados atores sociais. A proposta pretende desenvolver os modos pelos quais as figurativizações de preconceitos e estereótipos são ressignificadas em tais filmes, sobretudo por meio da problematização de seus enunciadores e coenunciadores, e pelas posicionalidades de sujeito a partir das quais tais discursos são proferidos.

\footnotetext{
${ }^{79}$ Ver sobre o tema o livro O negro nos espaços publicitários brasileiros, organizado por Leandro Leonardo Batista e Francisco Leite (São Paulo: Cone, 2011).
} 
Um dos possíveis elementos constituintes desses discursos é o humor, ou um efeito de comicidade, apontando para interditos (brechas e vazios) e, assim, para um jogo ambíguo entre deslocamento e permanência de estigmas, já que ao mesmo tempo em que incluem novos interlocutores na cena audiovisual, apontam seu lugar deslocado por meio de elementos narrativos operando à margem dos sistemas tradicionais.

Ao articular os conceitos de "identidade" e "consumo", estendemos a questão proposta à problematização do estatuto do sujeito na contemporaneidade. Nas palavras de Hall, "uma vez que a identidade muda de acordo com a forma como o sujeito é interpelado ou representado, a identificação não é automática, mas pode ser ganhada ou perdida" (Hall, 2001: 21). Desse modo, os regimes de visibilidade encenados pelas mídias constituem a identidade dos sujeitos, tornando explícitas as formas de articulação dessas identidades, que se tornam, nas palavras de Hall, "politizadas": "Esse processo é, às vezes, descrito como constituindo uma mudança de uma política de identidade (de classe) para uma política de diferença" (Hall, 2001: 21).

O percurso ensaiado - ou um itinerário - remete aos mapas e seus traçados, que apontam para a cartografia do lugar sem, contudo, especificar os aclives e declives que de fato o configuram, obstáculos estes que só encontramos ao tentar, efetivamente, percorrer os caminhos delineados no itinerário que o mapa traz (Gomes, 2002: 12). Se considerarmos as dissoluções experimentadas pelos sujeitos na contemporaneidade, veremos novas formas de subjetividade permeadas por práticas cotidianas de consumo (não apenas material, mas também simbólico), contidas em narrativas múltiplas e pontos de interseção entre as diversas posicionalidades de sujeito.

Nessa perspectiva, o consumo cultural - e os discursos publicitários nele articulados - incide sobre a subjetividade, gera um deslocamento que possibilita ao sujeito pequenas construções de sua identidade, "diariamente" revisitadas. O consumo ao mesmo tempo individualiza e socializa os sujeitos; é desse processo ambíguo que deriva a identidade, constituindo-se como prática social: "A identidade surge não tanto da plenitude da identidade que já está dentro de nós como indivíduos, mas de uma falta de inteireza que é preenchida a partir de nosso exterior, pelas formas através das quais nós imaginamos ser vistos por outros" (Hall, 2001: 39). Mais do que se configurar como simples ato de comprar, o consumo é caracterizado como uma forma de interação, uma apropriação individual que insere cada um em um todo social, relacionando identidade e sociabilidade. A relação entre identidade e consumo configura uma subjetividade não apenas individual, mas também coletiva (já que o humano é, desde sempre, social): 
Quanto mais a vida social se torna mediada pelo mercado global de estilos, lugares e imagens, pelas viagens internacionais, pelas imagens da mídia e pelos sistemas de comunicação globalmente interligados, mais as identidades se tornam desvinculadas desalojadas - de tempos, lugares, histórias e tradições específicos e parecem "flutuar livremente" (Hall, 2001: 75).

O conceito de "performatividade" desloca, assim, a ênfase na identidade da descrição como aquilo que é para a ideia de tornar-se, para uma concepção da identidade como movimento e transformação. A questão do consumo nas sociedades contemporâneas mostra-se multifacetada e extrapola as discussões simplistas que a localizam com o mero ato de comprar produtos, bens e serviços, caracterizando-o como uma das formas privilegiadas para a operação do par identidade-identificação em relação aos sujeitos, ou seja: por meio do consumo, cada um reconhece-se como singular e, ao mesmo tempo, como pertencente a um grupo determinado, estabelecendo vínculos sociais:

O amor por si mesmo só conhece uma barreira: o amor pelos outros, o amor por objetos. Se nos grupos o amor a si mesmo narcisista está sujeito a limitações que não atuam fora deles, isso é prova irresistível de que a essência de uma formação grupal consiste em novos tipos de laços libidinais entre os membros do grupo (ideais) (Freud, 1997: s/p).

Tal perspectiva retoma, assim, a distinção estabelecida por Freud em termos do eu-ideal (aquele que procura estabelecer diferenças e semelhanças a partir do próprio indivíduo) e o ideal-do-eu (que opera a partir de ideais culturais compartilhados). $\mathrm{O}$ processo de estabelecimento de laços sociais está baseado, portanto, no que Freud chama identificação. A identificação opera a partir de dois mecanismos básicos: o reconhecimento de si mesmo (identidade) e o reconhecimento dos outros (identificação ou identidade social):

Cada indivíduo é uma parte componente de numerosos grupos, acha-se ligado por vínculos de identificação em muitos sentidos e construiu seu ideal do ego segundo os modelos mais variados. Cada indivíduo partilha de numerosas mentes grupais - as de sua raça, classe, credo, nacionalidade etc. - podendo também elevar-se sobre elas, na medida em que possui um fragmento de independência e originalidade (Freud, 1997: s/p).

A esse respeito, um interessante paradoxo se explicita: o sujeito contemporâneo, ao mesmo tempo em que tem (e deseja ter) uma vida cada vez mais regrada e regulada, também busca o espanto, o inesperado - ainda que de forma segura e confiável (como nos perigos-sem-perigos oferecidos pelos esportes radicais, por exemplo). 
O consumo se inscreve, atualmente, nesse intervalo entre a busca pelo jáconhecido e a aspiração pelo ainda-não visto, regulado pela relação do indivíduo com o tempo e o espaço atuais:

\begin{abstract}
Assim, somos levados a propor, como uma das leituras possíveis da divisão do sujeito, o fato de um sujeito estar sob o ascendente de dois mandamentos antinômicos: o primeiro é esse mandamento que me é dado para que me torne Outro que aquele que sou (...). $\mathrm{O}$ segundo, o da censura, que prescreve ao sujeito: "não se deixe siderar" (...), "vontade de não mudar" (Didier-Weill, 1997: 127).
\end{abstract}

Daí a importância que a discussão levantada sobre a questão das imagens e do olhar adquire em relação à temática tratada. O olhar, em sua complexidade, não se refere apenas ao indivíduo que olha os objetos do mundo, mas também às relações que apontam para aquele que é, permanentemente, olhado por esses objetos-sujeitos. Temos, assim, o olho, o olhar e a visão; o ver e o ser visto; o ver-se vendo (o mundo); o ver-se sendo visto (pelo mundo): "O que vemos só vale - só vive - em nossos olhos pelo que nos olha. Inelutável porém é a cisão que separa dentro de nós o que vemos daquilo que nos olha. Seria preciso assim partir de novo desse paradoxo em que o ato de ver só se manifesta ao abrir-se em dois" (Didi-Huberman, 1998: 29).

O consumo é apresentado, acertadamente, como um dos elementos (entre outros) que constituem a identidade de cada um em suas relações com a subjetividade. Nas relações eu-outro, nas oscilações entre aceitação e rejeição, identificação e projeção, articula-se uma crítica aos ditames da sociedade de consumo vista como uma estrutura monolítica, estabelecendo que o ato de comprar (até mesmo o windowshopping, o "ver vitrines sem comprar"), não se coloca apenas como dominação, manipulação ou subjugação dos indivíduos, mas também como espaço de experimentação por onde transita e circula o desejo de cada um, desejo que move os indivíduos e é, também ele, móvel. Dessa forma, o consumo estaria relacionado ao desejo, e não à necessidade (esta sim passível de ser satisfeita). Movente e móvel, o desejo - ao contrário da necessidade - não é jamais satisfeito, sendo sempre, por isso mesmo, desejo de outra coisa. O desejo (desiderio) nos impede de siderar, ou de eclipsar: a palavra sideração, "ao transmitir a ideia de uma causa que, vinda do além - do sideral - faz cair das nuvens o sujeito estupefato que, ao colocar os pés no chão, fica abismado, tal conexão significante através da qual o além e o cá embaixo se ligam é feliz” (Didier-Weill, 1997: 118). 
Um recorrente debate a respeito da deterioração da identidade do sujeito contemporâneo, submetido a uma sociedade de consumo narcísica e individualista, desloca-se quando tratamos das relações entre identidade e consumo: ainda que haja uma suposta deterioração da individualidade (marcada também, em alguns casos, pelo aumento do individualismo), ela pode ser recriada nesse processo por meio de ressignificações discursivas. É nessa dualidade que a dinâmica identidade e consumo se interpõe. Não se trata, pois, apenas de fragmentação e exclusão, mas também de reagrupamento e inclusão em novos moldes. Essas microrrevoluções, ou revoluções moleculares (Guattari, 1987), incidem sobre a constituição da subjetividade em meio às rápidas transformações vividas especialmente no campo da tecnologia, da biologia e da ecologia, em que as mídias potencializam grandes transformações históricas, econômicas, culturais e sociais. Tais transformações passam a espalhar-se pelo tecido social a partir de formas renovadas e inusitadas dos sujeitos procederem a suas escolhas a partir de inúmeras possibilidades combinatórias, constituindo o campo do simbólico a partir de um imaginário a um só tempo individual e coletivo, pessoal e social.

Nesse sentido, o apagamento da presença do negro na publicidade televisiva brasileira ou, de modo diverso, sua presença por meio das ausências explicitadas nas propagandas audiovisuais constituem outro modo de inserção, ressaltando, pela falta, aquilo que insiste em ocupar um lugar no simbólico. Se considerarmos o consumo cultural - e a publicidade em sentido ampliado -, podemos conceber, por meio dele, o estabelecimento de uma identidade social por meio da demarcação de diferenças de cada sujeito em relação aos demais, imprimindo a esse processo a dinâmica identificações/diferenciações:

Primeiramente, a identidade não é uma essência; não é um dado ou um fato - seja da natureza, seja da cultura. A identidade não é fixa, estável, coerente, unificada, permanente. A identidade tampouco é homogênea, definitiva, acabada, idêntica, transcendental. Por outro lado, podemos dizer que a identidade é uma construção, um efeito, um processo de produção, uma relação, um processo performativo. A identidade é instável, contraditória, fragmentada, inconsistente, inacabada. A identidade está ligada a estruturas discursivas e narrativas. A identidade está ligada a sistemas de representação. A identidade tem estreitas conexões com relações de poder (Silva, 2000: 97).

O mesmo e o outro se articulam de forma intrínseca, trazendo à cena midiática figuras de alteridade que confirmam e confrontam as hierarquias sociais estabelecidas. O consumo configura-se, assim, em seu sentido agregador de relações sociais e subjetividades. 
Novas práticas de consumo apontam, portanto, para novos modos do ser e de agir no mundo, numa dinâmica entre exclusões e inclusões que moldam a identidade dos sujeitos. As questões de identidade referem-se, ao mesmo tempo, àquilo que está fora e àquilo que está dentro de um determinado contorno do social.

As relações entre imagem e consumo, e os afastamentos e proximidades entre imagem e imaginário, apontam para um paradoxo: ao mesmo tempo em que percebemos a erosão do papel do imaginário, temos, por outro lado, a explosão contemporânea das imagens (Durand, 2001). Tal movimento nos remete às práticas midiáticas em suas injunções com as tecnologias de comunicação, retomando também a discussão sobre o olhar e a visão. O consumo caracteriza-se, então, não apenas como consumo de objetos, mas também como consumo de imagens tornadas objetos, configurando as chamadas imagens cênicas que irão se presentificar nos filmes publicitários televisivos.

Em artigo publicado no jornal Folha de S. Paulo, o psicanalista Contardo Calligaris estabelece uma interessante distinção a respeito da subjetividade nas diferentes épocas: primeiro, tivemos a prevalência do ser (em que apenas aqueles vindos de famílias já tradicionais, registradas em seus sobrenomes, poderiam ter visibilidade social); em seguida, passamos para a era do ter (tempo de novos ricos e suas extravagâncias). Um terceiro tempo aponta para a ascensão do parecer: não era preciso ser, nem ter, mas apenas parecer-ser e parecer-ter (aqui encontramos contato com os simulacros de Baudrillard, 1991; ou a hiper-realidade de Eco, 1984). Embora ainda tenhamos a sensação de nos encontrarmos nesse terceiro tempo, Calligaris aponta para o surgimento de novas formas de sociabilidade e de subjetividade, articuladas em torno do fazer, resgatando um sentido de coletividade (como nos movimentos da sociedade civil, nas ongs, no voluntariado) (Calligaris, 2002). Como pensar tais distinções em relação ao consumo e suas transformações?

Como sabemos desde Foucault, as relações do sujeito consigo mesmo articulam as relações do sujeito com o outro e com a sociedade. Nesse sentido, o sujeito constitui para si um determinado estilo de vida; é preciso, portanto, buscar o modo como se dá tal constituição, ou seja, os modos de subjetivação dos sujeitos por meio dos discursos:

Bem sei que é muito abstrato separar, como acabo de fazer, os rituais da palavra, as sociedades do discurso, os grupos doutrinários e as apropriações sociais. A maior parte do tempo, eles se ligam uns aos outros e constituem espécies de grandes edifícios que garantem a distribuição dos sujeitos que falam nos diferentes tipos de discurso e a apropriação dos discursos por certas categorias de sujeito (Foucault, 1996: 44). 
Lembramos, ainda com Foucault, que a identidade - longe de ser unidade aponta para o outro que somos, "faz com que o outro e o externo se manifestem com evidência":

O diagnóstico assim entendido não estabelece a autenticação de nossa identidade pelo jogo das distinções. Ele estabelece que somos diferença, que nossa razão é a diferença dos discursos, nossa história a diferença dos tempos, nosso eu a diferença das máscaras. Que o diferença, longe de ser origem esquecida e recoberta, é a dispersão que somos o que fazemos (Foucault, 1997: 151).

Conhecer a si mesmo, ou pensar na identidade do sujeito, pressupõe, portanto, um desvio pelo discurso do outro, um desvio do olhar e da escuta, ou da apropriação que fazemos do que está fora de nós - um assujeitamento ao outro. Foucault (1997) ainda afirma que as técnicas de si são os procedimentos pressupostos ou prescritos aos indivíduos para fixar sua identidade, mantê-la ou transformá-la graças a "relações de domínio ou de conhecimento de si sobre si", apontando para a questão não mais de "conhecer-se a si mesmo" (como em Sócrates, no sentido de uma essencialidade verdadeira), mas de saber "o que fazer de si mesmo na atualidade" - para usar os termos propostos por Santiago (2001), com quem dialogamos ao falar de Foucault -, pergunta esta que pode nos auxiliar a pensar algumas das provocações ensejadas.

Nesse sentido, o processo de subjetivação não está relacionado à vida privada de um único indivíduo, mas ao modo como um grupo social se relaciona com as formas "estabelecidas" e as formas "estigmatizadas" de poder e saber presentes em uma sociedade: "A estigmatização, como um aspecto da relação entre estabelecidos e outsiders, associa-se, muitas vezes, a um tipo específico de fantasia coletiva criada pelo grupo estabelecido. Ela reflete e, ao mesmo tempo, justifica a aversão - o preconceito que seus membros sentem perante os que compõem o grupo outsider" (Elias e Scotson, 2000: 35). Se tomarmos a temática proposta - apontar anúncios publicitários televisivos em que a figura do negro ganha lugar -, encontraremos algumas recorrências, que serão privilegiadas nesse momento por meio da articulação de dois grandes grupos: as propagandas de хатри e as propagandas de produtos esportivos. Vale ressaltar que o foco de interesse não diz respeito à análise fílmica ou de conteúdo desses anúncios, mas aos grandes eixos temáticos neles articulados.

As tematizações e figurativizações presentes na cultura audiovisual serão pontuadas, portanto, a partir da presença/ausência de personagens negros em filmes publicitários televisivos. 
Antes de tratar desses aspectos, é importante ressaltar que a premissa colocada apresenta-se, de fato, como uma impossibilidade: personagens negros e negras são, com poucas exceções, inexistentes na propaganda televisiva, bem como em outros espaços publicitários. Fato facilmente constatável, uma indagação se coloca a partir dele: seria tal ausência absoluta, explicável apenas pelo racismo e por hierarquias étnicas historicamente constitutivas da sociedade brasileira?

Ou podemos tomar, a exemplo de Shohat e Stam na análise de filmes musicais norte-americanos da década de 1940, a ausência do negro na publicidade brasileira como uma forma de presença? A questão da alteridade - e das formas de representação do "outro" - são pensadas pelos autores na perspectiva da intertextualidade, buscando "apontar o multiculturalismo reprimido, mesmo nos textos dominantes" (Shohat e Stam, 2006: 314). Ainda que concebidos a partir de representações dominantes, os grupos marginalizados (ou estigmatizados) exercem influência cultural explicitada por meio de contradições, sincretismos e hibridismos que circulam nas imagens construídas, no caso, pelo cinema.

Os autores afirmam ser possível empreender análises de filmes em que as figuras de negros são silenciadas, pois acreditam que "reconstruindo as vozes culturais abafadas ou reduzidas a um sussurro, começa-se a ouvir outras vozes" (Shohat e Stam, 2006: 316). Tal visada vai ao encontro daquela proposta por Orlandi: "Falar em 'efeitos de sentido' é pois aceitar que se está sempre no jogo, na relação das diferentes formações discursivas, na relação entre diferentes sentidos". Daí "a necessidade do equívoco, do sem-sentido, do sentido 'outro' e, consequentemente, do investimento em 'um' sentido. Aí se situa o trabalho do silencio" (Orlandi, 1997: 21). Desse modo, os espaços silentes falam e expressam, por meio de significantes em deslocamento, inúmeros significados.

Tal perspectiva contribui para a problematização dos estigmas sociais referentes aos negros na sociedade: a ausência destes atores sociais em inúmeros fóruns denota, ao mesmo tempo, os modos de inclusão/exclusão no qual estão inseridos. Lembramos, assim, que na dinâmica social, tudo aquilo que é excluído, por um lado, inclui-se em outro, de outra maneira, mesmo que de forma perversa. Desse modo, a ausência também constrói um discurso, e em alguns exemplos, tratados a seguir, é a presentificação que se torna depreciativa. Em relação aos dois grupos, um intrincado jogo se imprime.

No caso das propagandas de xampu, majoritariamente voltadas para mulheres, a inclusão se faz de modo tendencioso, pois ao mesmo tempo em que evoca, na figura de celebridades (dentre elas, a atriz Thaís Araújo se coloca como um símbolo), um modo 
de inclusão pelo glamour que a moda e a indústria cosmética oferecem, ao mesmo tempo qualifica os cabelos negros (crespos, cacheados, ondulados) de "rebeldes", "indisciplinados", "sem vida", "difíceis de pentear", "volumosos", adjetivos que deslizam dos penteados afros para as próprias mulheres que "lutam" para "combater" tais "problemas".

As metáforas bélicas, bem como um aparato de ataque aos fios não lisos (até recentemente chamados de "cabelos ruins"), evocam uma vasta gama de estereótipos e preconceitos relacionados aos cabelos, como se não ter cabelos finos, lisos e fáceis de lidar se tornasse um problema crucial, impondo aos cabelos não lisos o padrão de penteados e ditames da estética branca dominante. Não causa surpresa descobrir que o penteado de Thaís Araújo na novela Viver a vida (2009-2010) - em que foi bastante frisado o fato da personagem principal da novela de Manoel Carlos, Helena, ser uma atriz negra - não era natural: a atriz, de cabelos crespos curtos, realizou um aplique (ainda que crespo) para tornar o cabelo afro um cabelo aceitável. O penteado, para chegar àquela forma, passou por processos de alisamento, amaciamento e relaxamento de fios, práticas conhecidas pelas mulheres que frequentam salões de cabeleireiro.

Paradoxalmente, entretanto, na época da novela diversas mulheres com cabelos crespos afirmaram ter tido a chance de "assumir" seus cachos, sem os ditames das escovas e chapinhas térmicas utilizadas para alongar os fios. Revestidas de um discurso transformador - "assuma seus cachos", "black is beautiful", "cabelo negro é cabelo bom", slogans comuns nessas campanhas -, tais filmes publicitários televisivos não deslocam, de fato, os estigmas que pretendem combater, tampouco os preconceitos associados às mulheres negras. Ao contrário, reforçam estereótipos por não problematizar o eixo hegemônico em torno do qual propor tais discursos.

Nas propagandas de produtos esportivos, por sua vez, notamos a presença maciça de jogadores de futebol, ídolos de brancos e negros, bem sucedidos em sua profissão, o que os torna, também, celebridades com fama, dinheiro e sucesso. Predominantemente protagonizadas por homens, as propagandas esportivas - dentre as quais o futebol se destaca, mas também aquelas que ressaltam modalidades do atletismo, tais como corrida e salto - operam de modo diferenciado em relação àquelas de xampu: ainda que positivadas por um discurso de superação, vitória e conquista, seu tom eufórico não esconde o reforço dos estigmas e, nesse caso, de processos de dominação e discriminação. 
Aos negros é assegurada a possibilidade, ainda que excepcional, de ascender socialmente por meio de esporte ou música. Ao fazê-lo, tais atores sociais apontam a possibilidade de certa mobilidade mas, ao mesmo tempo, fixam os lugares que lhes foram designados, deixando de buscar transformação nas estruturas sociais. Por um movimento engenhoso, sua visibilidade os torna, novamente, invisíveis, pois em tais propagandas não são os negros que se afirmam enquanto grupo, mas sua forma de inserção os embranquece, como se a superação da pobreza fosse também a superação da cor negra. Ao ascenderem socialmente, aproximam-se do grupo branco que reconhece seu status, além de serem exaltados por seus atributos físicos, força muscular e vigor.

Em termos de processos de construção de identidades negras, a escassa presença de negros em propagandas televisivas reafirma sua ausência, posto que silencia a possibilidade de identificação, por parte de outros cidadãos negros, dessas figuras ali representadas. Para os brancos, tanto nas propagandas de xampu, como nas esportivas, as mulheres e os homens nelas retratados não são figuras de alteridade, mas a repetição do mesmo sob outras cores e formas, sobretudo pela valorização do sucesso econômico presente na sociedade. Para os negros que não alcançam esse destaque, tais propagandas não possibilitam qualquer forma de rearticulação de suas subjetividades, já que não fornecem imagens representativas (sejam elas femininas ou masculinas) que possam assumir um lugar dissonante. Em geral, quando negros e negras aparecem em filmes publicitários televisivos vemos um processo redundante em que os estigmas a eles associados são reiterados, ao contrário de certos filmes cinematográficos que buscam, justamente, a construção de uma identidade negra para os negros.

Entre eles, podemos citar o diretor afro-americano Spike Lee (e seu filme Faça a coisa certa, de 1989), e o herói negro John Shaft, personagem de um antigo seriado reeditado em filme, que deu continuidade à história contada, em 1971, por Gordon Parks. Retomamos o contexto de seu lançamento: “O filme original marcou uma época e uma geração. Antes de Shaft os heróis americanos eram todos parecidos com John Wayne, Burt Lancaster, Kirk Douglas: todos brancos. Os negros norte-americanos não se viam no cinema, muito menos como heróis. A ideia de se ter um detetive negro, que agia e se vestia como negro, foi revolucionária para o cinema americano" (Baptista, 2009: s/p). O filme policial, lançado em 2000 e realizado por John Singleton, evoca a possibilidade - por que não? - de haver um super-herói negro, caminhando altivamente pelas ruas do Harlem, a exemplo dos garotos negros e pobres descritos por Kehl (2003) ao caminharem nas ruas de uma metrópole como São Paulo. 
Ainda que nas propagandas de xampu para cabelos negros haja ênfase em aspectos étnicos (de manter, cuidar e realçar os cachos), o que faz com que as mulheres negras apareçam enquanto tal, é um padrão de beleza universal que se busca nos tratamentos (os cabelos lisos, ao contrário, dificilmente precisam ser "tratados"). No caso das propagandas esportivas, os atletas nelas retratados não aparecem como negros, tampouco evocam aspectos étnicos, mas, como dissemos, alcançam uma condição de sucesso justamente por se destacarem de seu grupo de origem.

Ao tratarmos da articulação entre publicidade televisiva e estigmas sociais, alguns deslocamentos podem ser percebidos nas relações de poder entre grupos hegemônicos e contra hegemônicos, problematizando dicotomias e polarizações a respeito de disputas étnicas e/ou raciais no Brasil. É no sentido de contribuir com o debate que propomos as considerações seguintes.

Em seu artigo "As máquinas falantes”, Kehl trata das relações entre o "eu” e o “corpo", apontando três maneiras de concebê-las: 1) o corpo como propriedade do eu (corpo bioquímico); 2) o corpo que se confunde com o próprio eu (corpo psicológico); e 3) o corpo como objeto social (corpo psicanalítico). Elegendo a terceira perspectiva, a autora afirma que cada um é fruto de uma formação que o antecede e o determina, ou seja, o campo do simbólico. Desse modo, somos forjados naquilo que o Outro nos destina, o que torna também "o corpo próprio como corpo do Outro".

Se os corpos não existem fora da linguagem, como afirma Kehl, as práticas discursivas determinam a aparência, a expressividade e até mesmo a saúde dos corpos, possibilitando deslocamentos nas hierarquias entre os grupos sociais. A autora toma como exemplo os corpos dos jovens pobres no Brasil, afirmando algo controverso:

\footnotetext{
De duas ou três décadas para cá, os corpos dos jovens pobres brasileiros não se distinguem, a não ser pela cor da pele, dos corpos dos jovens da elite. Não são mais os corpos humilhados, cabisbaixos, submetidos. (...) Até mesmo na fome e na privação os jovens pobres de hoje ostentam corpos altivos, belos, erotizados. (...) Mas o padrão de beleza imposto pelo imaginário televisivo e publicitário poderia excluir os pobres e negros, como de fato exclui. A inclusão deles não é efeito de imagem, é efeito de discurso. É efeito do apelo à autoestima dos negros (Kehl, 2003: 246, grifos nossos).
}

Se assumirmos que os "corpos se modificam por efeito do que se diz sobre eles e do novo lugar social que se produz para os jovens pobres a partir dessa 'rede de apoio' discursiva que faz apelo a um modo diferenciado de estar "dentro da própria pele"” (Kehl, 2003: 264), podemos conceber, considerando as formas expressivas da cultura midiática, que a música ocupa lugar central nessa transformação empreendida por meio 
dos discursos circulantes. Ao apontar o deslizamento nas cadeias significantes que definem os sujeitos, a autora abre caminho para refletirmos sobre a questão, já que a trilha sonora de filmes publicitários televisivos, mas também aquela utilizada em outros formatos, estabelece lugares de presença da cultura e identidade negras, ainda que de forma implícita. Em um diálogo com o hip-hop e, mais especificamente, com o rap expressão musical de afirmação identitária de jovens negros e pobres das periferias urbanas - Kehl afirma, no artigo "As frátrias órfãs" (2008), no qual analisa as músicas do Racionais MC's e sua relação com os fãs, ser este um lugar de voz desses excluídos:

O tratamento de "mano" não é gratuito. Indica uma intenção de igualdade, um sentimento de frátria, um campo de identificações horizontais, em contraposição ao modo de identificação/dominação vertical, da massa em relação ao líder ou ao ídolo. A força dos grupos de rap não vem de sua capacidade de excluir, de colocar-se acima da massa e produzir fascínio, inveja. Vem de seu poder de inclusão, da insistência na igualdade entre artistas e público, todos negros, todos de origem pobre, todos vítimas da mesma discriminação e da mesma escassez de oportunidades (Kehl, 2008: 96).

Por meio da leitura das músicas e de seu posicionamento radical, a autora aponta a postura extrema adotada por Mano Brown, nos anos 1990, ao não dialogar com a mídia e manter-se avesso à engrenagem englobante da indústria musical: o artista não se volta para a classe média branca que critica duramente, mas para os garotos pobres da mesma periferia onde nasceu e ainda vive. A classe média, quando chega a ele (como o fez), não é por meio de convite ou concessão, mas de maneira paradoxal:

Acontece que os Racionais não estão interessados nem em reinar sobre a miséria (o que seria isto? Uma forma mais sedutora de dominação?) nem em esconder a miséria para inglês ver. Seu público alvo não é o turista - são os pretos pobres como eles. Não, eles não excluem seus iguais, nem se consideram superiores aos anônimos da periferia. Se eles excluem alguém, sou eu, é você, consumidor de classe média - "boy", "burguês", "perua", "babaca", "racista otário" - que curtem o som dos Racionais no toca-cd do carro importado "e se sente parte da bandidagem" (KL Jay) (Kehl, 2008: 97).

Trazemos alguns questionamentos: será que essas músicas tratam o outro "negro" assumindo as diferenças na perspectiva de uma alteridade radical ou, ao contrário, buscando sua domesticação e a manutenção dos lugares já hegemônicos? Ao falar, supostamente, de um lugar outro (o lugar do "não branco") mas alcançar, também, o público "branco", não estaria o rap esvaziando a potência transgressora de suas canções? Será possível, como afirma Kehl, distinguir entre "música de branco" e "música de negro", como preza a cultura norte-americana, bastante diversa da brasileira em termos artísticos e políticos no que diz respeito ao movimento negro? 
Segundo Kehl, ao contrário de ser incorporado à produção homogeneizante das mídias, o rap permanece como lugar de demarcação de estigmas, aquilo que irrompe e perturba certa ordem instaurada pelas dominâncias discursivas presentes na sociedade. Dessa forma, por meio da cena musical temos o estabelecimento de marcas identitárias que afirmam, de modo propositivo, um modo singular de ser, estar e fazer.

Em 2011, vimos surgir, na cena midiática musical, o rapper Criolo Doido (Kleber Gomes), compositor há 23 anos. Com uma proposta contundente, o artista fala a partir de seu lugar e instaura um discurso de ruptura que incomoda os habitantes da metrópole paulista ao escancarar seus lugares de exclusão. Ao enunciar, categoricamente, "não existe amor em SP" ${ }^{80}$, Criolo nos atinge e mobiliza, tangenciando os estigmas de pobreza e etnia de modo extremo, e deslocando - em vez de fixar - os lugares sociais usuais. Se o estigma é aquilo que se encontra fora do lugar, e por isso nos desafia, uma última questão se coloca: como diferenciar, por meio da análise, a contestação acomodada de uma postura crítica transformadora? Seguindo sua vocação, as artes nos desarmam, dissolvendo posições enraizadas, como se por meio delas fosse possível pontuar o real que insiste, por estar ainda alheio, em pertencer a um imaginário sempre redutor, sempre precário, mas único espaço possível de trocas simbólicas.

Como vimos, a temática do negro na publicidade televisiva brasileira, a exemplo de outras questões voltadas aos estigmas, apresenta-se de forma enigmática. Como uma paisagem na neblina, a exemplo do filme do cineasta grego Theo Angelopoulos (1988), inscrevemos um possível itinerário (uma cartografia) a partir de sinais, pegadas, traços. Por transitar entre fronteiras, o risco de se perder no caminho é sempre maior. O matemático Gödel, nos anos 1930, já nos alertara desse perigo em seu teorema da incompletude: quanto mais abrangente o campo conceitual, menores as certezas apresentadas pelos conceitos - se abrimos muito o campo, ganhamos em abrangência, mas perdemos em precisão; se fechamos o campo, ganhamos em precisão mas delimitamos por demais os objetos.

\footnotetext{
${ }^{80}$ A música "Não existe amor em SP" abriu caminho para a divulgação do primeiro álbum, Nó na orelha, de Criolo Doido (como é conhecido no rap). Lançado na internet e posteriormente em cd e vinil, esta canção do disco alcançou 25 mil downloads em três dias (www.blogs.estadao.com.br/link/vida-digitalcriolo/). O rapper, de 35 anos, nascido no Grajaú e criado em Santo Amaro, zona sul de São Paulo, foi capa dos principais jornais do país, que lhe atribuíram o mérito de "mudar" o circuito usual do rap feito na periferia de São Paulo, e também o próprio gênero, "ampliando o circuito do rap nacional". A música "Não existe amor em SP" tem tom melancólico ao denunciar as desigualdades sociais da capital paulista. Sobre um suposto desencanto presente em sua canção, o compositor responde: "Uma coisa é desesperança, outra é enxergar a realidade. Falar disso de um modo contundente não significa que você está desesperançoso". Ver: www.estadao.com.br/estadaodehoje/20110326/not_imp697442,0.php.
} 
A abrangência do campo e a precisão conceitual tornam-se, assim, inversamente proporcionais; cabe estabelecer limites e alcances, riscos e passagens desse precário

equilíbrio. À inquietação da pesquisa - quais os regimes de visibilidade e políticas da representação dos estigmas sociais nas mídias? -, respondemos com uma nova indagação, para além de dualismos e simplismos, mas sem nos perdermos na neblina.

\section{Novos realismos no cinema e na televisão}

A presente pesquisa é tributária de investigação realizada ao longo da última década, na qual vêm sendo analisados discursos jornalísticos (revistas, jornais e telejornais) e discursos cinematográficos (filmes ficcionais e documentários) articulados em torno de estigmas sociais. Os resultados deste trabalho vêm sendo apresentados em diversos fóruns de debates e publicados em forma de artigos científicos, no Brasil e no exterior, como atestado na produção científica documentada ${ }^{81}$. A pesquisa, portanto, desdobra-se a partir desse percurso, consolidando e adensando os referenciais teóricos, expandindo os procedimentos metodológicos e estendendo o corpus a objetos empíricos distintos, além de expandir seu escopo em uma perspectiva internacional, indispensável para seu amadurecimento tanto em termos conceituais quanto aplicados.

A partir dos resultados que vêm sendo alcançados, do ponto de vista conceitual confirmamos e ampliamos os autores presentes na bibliografia; do ponto de vista metodológico, definimos o alcance das análises no campo de estudos da linguagem e do audiovisual; e do ponto de vista do objeto, reordenamos o eixo da amostragem para articularmos no presente capítulo, em uma mesma perspectiva, filmes documentários e reportagens televisivas, especialmente em suas formas híbridas.

Destacamos os avanços acumulados em duas direções: em termos teóricometodológicos, um conjunto variado de autores foi explorado, indicando uma maneira dinâmica de pensar a articulação "mídias e estigmas sociais" e, sobretudo, questões relativas aos estudos do audiovisual, notadamente a televisão. Em termos temáticos, como vimos, em lugar de apontar apenas as variações entre reforço ou transformação de

\footnotetext{
${ }^{81}$ Além dos artigos publicados, destacamos mais recentemente três capítulos de livros: "Saneamento básico, o filme, ou como fazer um filme de bordas" (Consumo midiático e culturas da convergência, org. João Carrascoza e Rose Rocha, São Paulo, Miró, 2011); "Para além dos gêneros: humor e amor em filmes de bordas" (Cinema de bordas, org. Gelson Santana, São Paulo, À lápis, 2012); "O global e o local na construção de identidades étnicas e regionais na música popular brasileira: o movimento hip hop paulistano" (Cultura pop, org. Simone Pereira de Sá et. al., Salvador, Edufba, 2015).
} 
estigmas, preconceitos e estereótipos, deparamo-nos com intrincadas relações entre eles, agregando à reflexão categorias operatórias não dicotômicas.

Sobre a constituição da amostragem nessa última etapa, para além da divisão entre filmes de ficção e filmes documentários reafirmamos a crescente hibridização de gêneros audiovisuais, tendência que pode ser percebida no aumento de formatos que se articulam no entremeio desses campos, especialmente quando se trata de produções realizadas sob a rubrica da reality $t v$. Como apontado em inicialmente, as análises privilegiam os modos de construção da representação de estigmas sociais em narrativas audiovisuais contemporâneas a partir dos processos de identificação e de partilha do sensível nelas evocadas, analisando nesse momento os chamados discursos de caráter referencial ou factual. Desse modo, ainda que alguns filmes ficcionais possam ser pensados nesse registro, iremos nos deter em reportagens e documentários.

Outro deslocamento, finalmente, deve ser destacado: para além da demarcação entre filmes e reportagens, reconhecemos o alcance do trabalho no estabelecimento de parâmetros analíticos em relação à cultura audiovisual contemporânea, em que cinema e televisão dialogam com formas presentes na internet e, de algum modo, em material impresso, radiofônico e visual. O estatuto da imagem em suas formas de produção, circulação e consumo tem ocupado espaço privilegiado nas reflexões acadêmicas de diversas áreas das humanidades, não só em relação às mídias audiovisuais, mas também na dinâmica de novas sociabilidades determinadas pelas tecnologias da comunicação em múltiplas plataformas. Refletir sobre tal dinâmica é um dos objetivos da pesquisa, o que vem sendo feito por diferentes perspectivas.

Se tomarmos como pressuposto que as mídias constituem-se como lugar de mediação, podemos afirmar que suas narrativas não cumprem uma função apenas informativa, mas performativa. Ao considerarmos a reportagem televisiva (ou grande reportagem) como um dos gêneros presentes no discurso jornalístico, podemos estabelecer aproximações entre essa forma e os documentários cinematográficos (ou mesmo televisivos). Assim como o jornalismo, o documentário possibilita nosso recorte a partir da questão dos estigmas sociais. Não selecionamos filmes de ficção, mesmo aqueles que adotam em suas narrativas procedimentos e recursos estilísticos, formais ou visuais próprios do documentário, mas reafirmamos que, atualmente, as fronteiras entre o documental e o ficcional têm sido constantemente desafiadas, estreitando seus limites. Nossa visada será no sentido de estabelecer que os discursos, sejam eles factuais ou imaginativos, são sempre narrativos - e, portanto, ficcionais. 
A presença de temas políticos e de crítica social estabelece a articulação com os estigmas. Em relação a isso, notamos duas questões: a primeira diz respeito à maior visibilidade dos documentários e às transformações em seus modos de produção devido ao uso de equipamentos digitais na filmagem e edição; se incluíssemos ficções que se valem de estratégias discursivas próprias do documentário, esse número seria ainda maior. A segunda questão confirma um aspecto dos anos anteriores, com grande presença de filmes relacionados aos estigmas sociais na produção brasileira recente.

Dessa forma, os estigmas se destacam a partir de três perspectivas: a) como temática, justamente por estarem diretamente relacionados às narrativas referenciais; b) por se mostrarem como enfoque recorrente a partir do acompanhamento desses filmes; c) como forma de estabelecer um recorte dentre as narrativas audiovisuais presentes no cinema e na televisão. Em relação aos filmes, uma tendência se fortalece: a constituição de um gênero específico no cinema brasileiro, híbrido em sua origem e não apenas no que diz respeito a aspectos formais ou temáticos, rompendo antigas dicotomias $\mathrm{e}$ experimentando novos parâmetros nos quais pensar as narrativas audiovisuais. Essa questão se estende às reportagens televisivas, pois reconhecemos nelas a mesma tendência e apontamos, como nos documentários, pontos de ancoragem semelhantes tanto na seleção da amostragem, como nos conceitos mobilizados para as análises.

Em relação aos discursos das mídias, encontramos um ponto de inflexão fundamental. Ao observar resultados anteriores, vemos que a temática dos estigmas pode ser problematizada sob uma vertente peculiar: ao tomarmos os conceitos de redundância e ressonância, referimo-nos à variação (e não à oposição) entre estigmas de reforço e de transformação, observando que muitos desses discursos realizam em graus maiores ou menores o movimento entre esses polos. Mais do que uma distinção, redundância e ressonância podem ser pensadas como processos de construção de imaginários e identidades. Em alguns casos, notamos um alto grau de redundância e de manutenção dos lugares sociais já estabelecidos. Os estigmas de reforço operam como marcadores desses lugares, articulando narrativas que se repetem mesmo entre diferentes veículos e produtos. Em outros casos, as imagens revelam graus maiores de ressonância, oferecendo aberturas, transposições e passagens.

Constatamos, assim, que os eixos articuladores dos estigmas sociais constituem espaço privilegiado para análise dos discursos das mídias, entre eles as narrativas audiovisuais. Isso se dá pelo fato de percebermos, tanto no cinema como na televisão, uma forte ênfase em temáticas relacionadas à exclusão, pobreza, violência, conflitos, e 
aos modos de superá-los. De modo geral, podemos definir os estigmas como marcas visíveis (embora nem toda marca seja um estigma, todo estigma carrega uma marca) que despertam nos outros, ao mesmo tempo, um sentimento de atração e repulsa. Dizer isso é afirmar que, em sua origem, os estigmas não são, necessariamente, positivados ou negativados. É a atribuição de valorações que os hierarquiza em termos de aceitação ou rejeição, variando de acordo com diferentes contextos históricos e culturais.

Em relação ao último período (2012-2014), apresentamos a seguir três tabelas com filmes de ficção e não-ficção lançados no Brasil. Nesse triênio, ao contrário dos anteriores, as tabelas trazem as vinte maiores bilheterias de cada ano, informação possível devido a uma melhor sistematização dos dados relativos ao cinema brasileiro. Devido a mudanças no mercado, no circuito exibidor e no público, notamos no período a consolidação de certos gêneros, como lemos em relatório da Ancine: "O público e a renda dos cinemas em 2012 superaram os números dos anos anteriores, alcançando 146,5 milhões de bilhetes vendidos e gerando mais de $\mathrm{R} \$ 1,6$ bilhão. Os títulos brasileiros fecharam o ano com uma participação no público total correspondente a $10,62 \%$. No último trimestre do ano, essa participação alcançou mais de $22 \%$ como consequência do lançamento de quatro dos cinco títulos brasileiros que venderam mais de um milhão de ingressos em 2012" (Ancine: Informe Anual, 2012). Ainda assim, os filmes estrangeiros totalizaram $90 \%$ de renda e público nas salas de cinema no Brasil em 2012, em que três títulos ultrapassaram 8 milhões de espectadores (Os vingadores The avengers, A saga crepúsculo: Amanhecer-Parte 2, A era do gelo 4).

$\mathrm{Na}$ sequência, tecemos alguns comentários gerais e, ainda que as tabelas apresentem também filmes de ficção (que são predominantes), destacamos duas produções documentais para cada ano a fim de estabelecer parâmetros semelhantes àqueles anteriormente apresentados. A amostragem final para análise, portanto, foi constituída de modo não aleatório e as datas referem-se ao ano de lançamento dos filmes, dos quais selecionamos os que tratam da temática dos estigmas sociais, a partir de diferentes abordagens, enredos e formatos. Notemos que, nesse triênio, a produção de comédias populares se consolidou e representa a totalidade das bilheterias que atingiram mais de 1 milhão de espectadores no país para filmes nacionais ${ }^{82}$. A produção de documentários, embora constante e expressiva, não alcançou destaque em termos de público, ao contrário do que ocorreu em outros anos.

\footnotetext{
82 Dados pesquisados em www.ancine.gov.br (lançamentos por ano). Para fichas técnicas completas, elenco, sinopses e demais informações sobre os filmes, ver www.adorocinema.com.br.
} 


\begin{tabular}{|c|c|c|c|c|}
\hline \multicolumn{5}{|c|}{$\begin{array}{c}\text { TABELA XXIX } \\
20 \text { Maiores Bilheterias Brasileiras - } 2012 \text { (Informe Ancine 2012) }\end{array}$} \\
\hline & Título & Diretor & Gênero & Público \\
\hline 1 & Até que a sorte nos separe & Roberto Santucci & Ficção (104') & 3.322 .561 \\
\hline 2 & E aí, comeu? & Felipe Joffily & Ficção (100’) & 2.576 .213 \\
\hline 3 & Os penetras & Andrucha Waddington & Ficção (90’) & 2.228 .318 \\
\hline 4 & Gonzaga - De pai para filho & Breno Silveira & Ficção (120’) & 1.457 .988 \\
\hline 5 & De pernas pro ar 2 & Roberto Santucci & Ficção (98') & 1.058 .421 \\
\hline 6 & $\begin{array}{l}\text { As aventuras de Agamenon, o } \\
\text { repórter }\end{array}$ & Victor Lopes & Ficção (74') & 937.980 \\
\hline 7 & Totalmente inocentes & Rodrigo Bittencourt & Ficção (90’) & 523.577 \\
\hline 8 & Paraísos artificiais & Marcos Prado & Ficção (96’) & 402.852 \\
\hline 9 & Xingu & Cao Hamburger & Ficção (103’) & 377.887 \\
\hline 10 & E a vida continua & Paulo Figueiredo & Ficção (97’) & 370.624 \\
\hline 11 & Dois coelhos & Afonso Poyart & Ficção (108') & 336.460 \\
\hline 12 & Na estrada - On the road & Walter Salles & Ficção (140’) & 288.838 \\
\hline 13 & Billi Pig & José Eduardo Belmonte & Ficção (95’) & 257.664 \\
\hline 14 & O diário de Tati & Mauro Farias & Ficção (90') & 206.318 \\
\hline 15 & Raul, o início, o fim e o meio & Walter Carvalho & $\begin{array}{l}\text { Documentário } \\
\left(120^{\prime}\right)\end{array}$ & 170.471 \\
\hline 16 & À beira do caminho & Breno Silveira & Ficção (102') & 159.109 \\
\hline 17 & Reis e ratos & Mauro Lima & Ficção (110’) & 128.396 \\
\hline 18 & Heleno & José Henrique Fonseca & Ficção (110’) & 91.798 \\
\hline 19 & A música segundo Tom Jobim & $\begin{array}{l}\text { Nelson Pereira dos } \\
\text { Santos }\end{array}$ & $\begin{array}{l}\text { Documentário } \\
\left(90^{\prime}\right)\end{array}$ & 74.901 \\
\hline 20 & Tropicália & Marcelo Machado & $\begin{array}{l}\text { Documentário } \\
\left(90^{\prime}\right)\end{array}$ & 70.775 \\
\hline
\end{tabular}

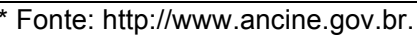

\section{TABELA XXX}

\section{Maiores Bilheterias Brasileiras - 2013 (Informe Ancine 2013)}

\section{Título}

$1 \quad$ Minha mãe é uma peça

2 De pernas pro ar 3

3 Meu passado me condena

$4 \quad$ Vai que dá certo

5 Somos tão jovens

6 Crô - O filme

7 Faroeste caboclo

$8 \quad$ O concurso

9 Mato sem cachorro

10 Até que a sorte nos separe 2

11 O tempo e o vento

12 Cine Holliúdy

13 Odeio o dia dos namorados

14 Serra Pelada

15 Se puder... Dirija!

16 Tainá - A origem

17 A busca

18 Os penetras

19 Flores raras

20 Giovanni Improtta

\section{Diretor}

André Pellenz

Roberto Santucci

Júlia Rezende

Mauricio Farias

Antonio C. Fontoura

Bruno Barreto

René Sampaio

Pedro Vasconcelos

Pedro Amorim

Roberto Santucci

Jayme Monjardim

Halder Gomes

Roberto Santucci

Heitor Dhalia

Paulo Fontenelle

Rosana Svartman

Luciano Moura

Andrucha Waddington

Bruno Barreto

José Wilker

\section{Gênero}

Ficção (85')

Ficção (110')

Ficção (102')

Ficção (90')

Ficção (104')

Ficção (100')

Ficção (110')

Ficção (90')

Ficção (113')

Ficção (112')

Ficção (127')

Ficção (90')

Ficção (110')

Ficção (120')

Ficção (84')

Ficção (80')

Ficção (90')

Ficção (90')

Ficção (104')

Ficção (100')
Público

4.600.145

3.787 .852

3.137 .795

2.729 .340

1.715 .763

1.652 .949

1.469 .743

1.320 .102

1.134 .563

1.047 .498

711.435

485.259

457.523

405.609

360.808

353.690

352.914

320.123

275.484

188.436

${ }^{*}$ Nenhum filme documentário ficou entre os 20 primeiros mais vistos. Elena, o documentário de maior público, teve 58 mil espectadores. O nascimento do parto, em segundo lugar, teve 27 mil espectadores. 


\begin{tabular}{|c|c|c|c|c|}
\hline \multicolumn{5}{|c|}{ TABELA XXXI } \\
\hline & Título & & Gênero & Público \\
\hline 1 & Até que a sorte nos separe 2 & Roberto Santucci & Ficção (102’) & 2.930 .693 \\
\hline 2 & O candidato honesto & Roberto Santucci & Ficção (110') & 2.237 .537 \\
\hline 3 & $\begin{array}{l}\text { Os homens são de Marte e é } \\
\text { para lá que eu vou }\end{array}$ & Marcus Baldini & Ficção (110’) & 1.794 .385 \\
\hline 4 & SOS mulheres ao mar & Cris D'Amato & Ficção (110') & 1.776 .579 \\
\hline 5 & Muita calma nessa hora 2 & Felipe Joffily & Ficção (90’) & 1.429 .862 \\
\hline 6 & Vestido pra casar & Gerson Sanginitto & Ficção (100') & 1.267 .600 \\
\hline 7 & Alemão & José Eduardo Belmonte & Ficção (110') & 955.841 \\
\hline 8 & $\begin{array}{l}\text { Confissões de adolescente - } \\
\text { O filme }\end{array}$ & Daniel Filho & Ficção (110') & 798.222 \\
\hline 9 & Tim Maia & Mauro Lima & Ficção (140’) & 776.824 \\
\hline 10 & Copa de elite & Vitor Brandt & Ficção (110') & 646.224 \\
\hline 11 & $\begin{array}{l}\text { Os caras de pau em o } \\
\text { misterioso roubo do anel }\end{array}$ & Felipe Joffily & Ficção (90') & 618.200 \\
\hline 12 & Getúlio & João Jardim & Ficção (100') & 508.901 \\
\hline 13 & Made in China & Estevão C. Pantoja & Ficção (100') & 381.782 \\
\hline 14 & A noite da virada & Fábio Mendonça & Ficção (90’) & 314.726 \\
\hline 15 & $\begin{array}{l}\text { Trash - A esperança vem do } \\
\text { lixo }\end{array}$ & Stephen Daldry & Ficção (120’) & 258.824 \\
\hline 16 & Na quebrada & Fernando G. Andrade & Ficção (94’) & 253.762 \\
\hline 17 & Hoje eu quero voltar sozinho & Daniel Ribeiro & Ficção (100') & 204.748 \\
\hline 18 & Irmã Dulce & Vicente Amorim & Ficção (90’) & 200.739 \\
\hline 19 & Julio sumiu & Roberto Berliner & Ficção (100') & 181.913 \\
\hline 20 & Boa sorte & Carolina Jabor & Ficção (90') & 144.702 \\
\hline
\end{tabular}

* Nenhum filme documentário ficou entre os 20 primeiros mais vistos. O documentário Tarja branca, na $37^{a}$. posição, teve 26,5 mil espectadores; e O mercado de notícias, de Jorge Furtado, teve 26 mil.

* Fonte: http://www.ancine.gov.br (dados relativos a nove meses, consolidados na época da consulta em abril de 2015).

Segundo dados da Ancine ${ }^{83}$, no ano de 2012 foram lançados 83 títulos nacionais. Destes, as comédias populares foram os que alcançaram maior público: Até que a sorte nos separe (3,3 milhões); E aí, comeu? (2,5 milhões); Os penetras (2,2 milhões). É interessante destacar que o filme Gonzaga, de pai para filho (Breno Silveira), uma cinebiografia, teve 1,5 milhão de pessoas, à frente da comédia De pernas pro ar, com 1 milhão. Outros 17 filmes alcançaram mais de 100 mil espectadores, entre eles Paraísos artificiais (Marcos Prado), com temática juvenil e 397 mil espectadores, e o filme ficcional Xingu (Cao Hamburger), que conta a saga dos irmãos Villas-Boas na criação do Parque Indígena do Xingu de modo inovador, com 378 mil. Entre os filmes considerados independentes, com maior destaque junto à crítica, citamos Eu receberia as piores notícias dos seus lindos lábios (Beto Brant), com 46 mil espectadores, e Febre do rato (Claudio Assis), com 25 mil. Alguns filmes, entretanto, não encontraram seu público: $O$ contestado, Vale dos esquecidos e Expedicionários estão entre os menos vistos, o primeiro com 2 mil pessoas e os dois últimos com menos de 500 pessoas.

\footnotetext{
${ }^{83}$ Para obter aos dados completos, ver "Informe de acompanhamento de mercado" (resultados de 2012, 2013 e 2014). Disponível em: www.ancine.gov.br. Acesso em: 19/04/2015.
} 
Os documentários apresentam, em 2012, uma característica peculiar: confirmando sua força dentro da produção nacional, os três primeiros filmes mais vistos pelo público são documentários de temática musical: Raul, o início, o fim e o meio (Walter Carvalho), com 170 mil pessoas, destaca-se como uma obra de grande alcance, especialmente junto aos fãs do cantor, marcando uma inovação na produção documental biográfica. Na sequência, temos A música segundo Tom Jobim (Nelson Pereira dos Santos), com 74 mil espectadores, e Tropicália (Marcelo Machado), com 70 mil. Além destes, Vou rifar meu coração (Ana Rieper), documentário sobre a música brega romântica - que se destaca do ponto de vista dos estigmas, pois trata os cantores com seriedade e traz o ponto de vista de pessoas vinculadas a esse gênero - alcançou 11 mil pessoas. Ainda tratando da música, o filme Futuro do pretérito: Tropicalismo now! (Ninho Moraes e Francisco Cesar Filho), distingue-se por seu experimentalismo, mas teve pouca presença no circuito de exibição. Entre as temáticas mais voltadas à crítica social, 5 x pacificação (Cacá Diegues; vários), e Muito além do peso (Estela Renner), tiveram, nessa ordem, 4,6 mil e 2,7 mil pessoas, debatendo temas sociais importantes e contextualizando suas narrativas na atualidade.

Em 2013, há um recorde histórico no número de lançamentos nacionais (127 títulos), com destaque para as distribuidoras brasileiras e crescimento do mercado de salas de exibição, ainda que em sua maior parte voltadas para filmes estrangeiros, sobretudo norte-americanos. Dos filmes nacionais, dez deles tiveram público de mais de 1 milhão de pessoas e 24 com mais de 100 mil pessoas, um número considerado expressivo se comparado aos anos anteriores. São eles: Minha mãe é uma peça (4,5 milhões); De pernas pro ar 2 (3,7 milhões); Meu passado me condena (3,1 milhões); Vai que dá certo (2,7 milhões); Somos tão jovens (1,7 milhão); Crô (1,6 milhão); Faroeste caboclo (1,4 milhão); O concurso (1,3 milhão); Mato sem cachorro (1,1 milhão); Até que a sorte nos separe 2 (1 milhão). Dos filmes mais voltados à questão dos estigmas sociais e com número expressivo de público, interessa-nos abordar, ainda que guardadas as diferenças entre eles, Flores raras (Bruno Barreto), com 397 mil espectadores, e $O$ som ao redor (Kleber Mendonça Filho), com 94 mil espectadores e reconhecimento por parte da crítica especializada.

Dos lançamentos, as maiores bilheterias mantêm a tendência de comédias populares, consolidando este gênero cinematográfico junto ao público, estabelecendo interfaces com a televisão (não apenas no formato ou enredo, mas também em relação 
aos atores ${ }^{84}$ ) e dialogando com as tradicionais chanchadas brasileiras que, do algum modo, são atualizadas nessas obras, nas quais escolhas narrativas e formas estéticas mais tradicionais se fazem presentes. Temos, assim, um contraste entre as chamadas “produções populares" e os "filmes independentes", dentre eles os documentários.

Destes, em 2013 apenas Elena (Pietra Costa) obteve público de mais de 50 mil pessoas. Ainda que notemos um aumento quantitativo de 2012 para 2013 (de 34 para 50 títulos), houve queda de quase $50 \%$ de público de documentários, segundo dados da Ancine, o que é percebido na tabela acima. Mesmo com esse cenário, $O$ renascimento do parto (Eduardo Chauvet) alcançou 27 mil pessoas denunciando a grave situação obstétrica mundial e, sobretudo, brasileira, na realização de cesáreas; e $O$ dia que durou 21 anos (Camilo Tavares), sobre a suposta colaboração americana no golpe militar brasileiro, contou com 25 mil espectadores. De temática musical, Jorge Mautner, de Pedro Bial (9,6 mil espectadores), e A luz do Tom, também de Nelson Pereira dos Santos (8,8 mil), foram os mais vistos após os três filmes acima apontados.

De temática política, Dossiê Jango (Paulo Henrique Fontanelli) alcançou 8 mil pessoas, enquanto os documentários Cidade cinza, de Marcelo Mesquita (7,7 mil), Doméstica, de Gabriel Mascaro (3,2 mil), Raça, de Joel Zito Araújo (2 mil), e Olhe para mim de novo, de Claudia Priscilla e Kiko Goifman (1,5 mil espectadores) são aqueles mais voltados à problematização dos estigmas. Quer sejam mais contundentes ou mais condescendentes, as narrativas desses últimos filmes são menos convencionais nos modos de dar a ver os sujeitos nelas retratados e também em suas escolhas estéticas.

Finalmente, em 2014, em relação ao circuito geral de exibição (segundo dados da Ancine) há um aumento de arrecadação de 12\% em relação a 2013, mas ocorre uma diminuição do público (27,8 milhões em 2013 e 19 milhões em 2014). Os filmes brasileiros tiveram também uma redução em número de lançamentos, totalizando 114 obras, das quais seis atingiram mais de 1 milhão de espectadores, a saber: Até que a sorte nos separe (3,3 milhões); O candidato honesto (2,5 milhões); Os homens são de marte e é para lá que eu vou (1,8 milhão); SOS mulheres ao mar (1,7 milhão); |Muita calma nessa hora 2 (1,4 milhão); Vestida para casar (1,3 milhão). Mantêm-se, assim, a grande plateia de comédias populares e confirma-se a tendência não apenas deste gênero, mas da produção de sequências de filmes e paródias. Ainda assim, o filme

\footnotetext{
${ }^{84}$ É curioso observar que o ator Leandro Hassum atuou em quatro dos filmes brasileiros de maior público, além da recorrência dos diretores neles envolvidos (não apenas em sequências, mas em títulos diversos), diferentemente do que ocorreu em anos anteriores.
} 
Alemão - um filme de ação que apresenta o cenário social brasileiro a partir do morro do Alemão, no Rio de Janeiro - obteve 950 mil espectadores e, como traço peculiar de 2014, tivemos o lançamento de Rio 2, produção norte-americana que alcançou 5,2 milhões de espectadores no Brasil. Em termos comparativos, o filme brasileiro de maior bilheteria ocupa apenas o $17^{\circ}$. lugar no ranking geral de público no país.

Dos outros lançamentos nacionais, 21 obtiveram mais de 100 mil espectadores, dos quais destacamos quatro que gostaríamos de relacionar com o temática dos estigmas sociais por seu caráter problematizador: Trash - a esperança vem do lixo (uma coprodução Brasil-Reino Unido, dirigida por Stephen Daldry), que contou com 269 mil espectadores; Na quebrada (Fernando Andrade), com 254 mil; Hoje eu quero voltar sozinho (Daniel Ribeiro), com 204 mil, e Praia do futuro (Karim Ainouz), com 127 mil espectadores. Os dois últimos, assim como $O$ homem das multidões (Marcelo Gomes e Cao Guimarães) - ainda que este tenha tido apenas 11 mil espectadores -, também encontraram boa repercussão junto à crítica especializada. Por ser um ano mais recente e com lançamentos significativos, destacamos ainda as produções ficcionais Confissões de adolescente - o filme (Daniel Filho), Tim Maia (Mauro Lima), Copa de elite (Vitor Brandt) e Getúlio (João Jardim), todas com mais de 500 mil espectadores (800 mil, 776 mil, 646 mil e 500 mil, respectivamente). O filme Tim Maia, com número expressivo de espectadores, foi alvo de polêmicas junto ao meio artístico e à família do cantor devido ao modo como foram obtidas e utilizadas as informações biográficas sobre o cantor.

No campo documental, que nos interessa particularmente, houve um total de 36 lançamentos (ainda que menor do que em 2013, trata-se de um número significativo), muitos deles próximos à temática dos estigmas sociais. Os mais assistidos são também os que nos mobilizam em termos dos temas abordados: Tarja branca - a revolução que faltava (Cacau Rhoden) e O mercado de notícias (Jorge Furtado) tiveram ambos por volta de 26 mil espectadores, número importante no mercado de filmes de não-ficção (em termos comparativos, Tarja branca ocupa a $37^{\mathrm{a}}$. posição, pontuando a inconstância que acompanha a relação do público com documentários, especialmente os brasileiros). Uma vez mais dois documentários musicais se destacam em termos de audiência, reafirmando a força desse gênero na produção de não-ficção: Dominguinhos (Mariana Aydar, Eduardo Nazarian, Joaquim Castro), com 10 mil espectadores, e Olho nu (Joel Pizzini), sobre a vida do cantor Ney Matogrosso, com 9 mil, reafirmam o espaço das biografias musicais, seja em formato documental ou ficcional. 
Mais próximos de temas políticos e sociais, temos os documentários Em busca de Iara (Flavio Frederico), com 7,5 mil espectadores, e dois filmes que ousam em termos narrativos e estéticos: Sem pena (Eugenio Pupo) e Ilegal (Raphael Erichsen e Tarso Araújo), com 7 mil e 5,5 mil espectadores, respectivamente, tematizando de modo controverso os assuntos retratados. De temáticas variadas, mas com boa recepção de público, os filmes Brincante (Walter Carvalho), Helio Oiticica (Cesar Oiticica Filho) e Junho - o mês que abalou o Brasil (João Wainer) obtiveram 4,8 mil, 4 mil e 3,7 mil espectadores, números que isoladamente não são tão expressivos mas que se tornam relevantes para a pesquisa pelas temáticas tratadas e os modos de produção ensejados.

Se observarmos os dados desde 2009, há certa constância na produção. Naquele ano, tivemos o lançamento de 45 filmes de ficção e 39 documentários; em 2010, 43 ficções e 31 documentários; em 2012, 58 e 42; em 2012, 49 e 34; em 2013, 79 ficções e 50 documentários, ano com aumento mais expressivo; e em 2014, 78 ficções e 36 documentários. Em cada um desses anos, um elemento merece ser destacado por representar uma crescente transformação: o aumento de filmes de caráter híbrido especialmente no que diz respeito às fronteiras entre documentário e ficção - coloca-se como um dado relevante, apontando para o esgotamento de classificações estanques e abrindo caminho para que possamos explorar algo já sugerido anteriormente.

$\mathrm{O}$ ano de $2015^{85}$, ainda em curso e contando com dados parciais, lança uma questão interessante para a produção documental. Após a morte do cineasta Eduardo Coutinho, em 2014, dois filmes parecem abrir possibilidades para o debate desse gênero: Eduardo Coutinho, 7 de outubro, uma entrevista realizada em 2013 por Carlos Nader, também documentarista, e agora lançada em filme; e Últimas conversas, dirigido por João Moreira Salles e Jordana Berg a partir das entrevistas gravadas por Coutinho para aquele que teria sido seu próximo filme, sobre adolescentes e jovens. Muitos caminhos serão confirmados ou desafiados nos desdobramentos da pesquisa, como veremos a seguir. Antes, entretanto, reproduzimos a tabela acrescentando a ela os filmes do último triênio, que vêm se somar àqueles constantes das análises de 2002-2011, data em que encerramos uma importante etapa sobre presença de estigmas nas mídias.

\footnotetext{
${ }^{85}$ Nos meses iniciais de 2015, as comédias Loucas para casar (Roberto Santucci), Meu passado me condena 2 (Julia Rezende), Vai que cola (César Rodrigues) e Até que a sorte nos separe 3 (Roberto Santucci ) confirmam as tendências das comédias, sequências e franquias com grande alcance de público.
} 


\begin{tabular}{|c|c|c|c|}
\hline \multicolumn{4}{|c|}{$\begin{array}{c}\text { TABELA XXXII } \\
\text { FILMES DE FICÇÃO E NÃO-FICÇÃO (2002-2014) }\end{array}$} \\
\hline Ano & Filme de não-ficção & Filme de ficção & Observações \\
\hline 2002 & $-x-$ & $\begin{array}{l}\text { Cidade de Deus } \\
\text { Uma onda no ar }\end{array}$ & $\begin{array}{l}\text { Filmes ficcionais previamente } \\
\text { analisados, com grandes } \\
\text { diferenças em termos de } \\
\text { produção, temáticas e } \\
\text { recepção, fornecendo um } \\
\text { aparato metodológico e } \\
\text { conceitual no qual situar as } \\
\text { análises em torno de reforço } \\
\text { e transposição de estigmas. }\end{array}$ \\
\hline 2003 & Ônibus 174 & Carandiru & $\begin{array}{l}\text { O documentário Ônibus } 174 \text { é é } \\
\text { de } 2002 \text { e foi selecionado por } \\
\text { seu impacto e relevância se } \\
\text { comparado aos filmes de } \\
2003 \text { do mesmo gênero. }\end{array}$ \\
\hline 2004 & De passagem & $\begin{array}{l}\text { O prisioneiro da grade de } \\
\text { ferro }\end{array}$ & $\begin{array}{l}\text { Serão feitas referências aos } \\
\text { documentários Entreatos e } \\
\text { Peões, por suas } \\
\text { características } \\
\text { interdiscursivas, e ao filme } \\
\text { Cazuza, por sua relação com } \\
\text { a temática da aids. }\end{array}$ \\
\hline 2005 & A pessoa é para o que nasce & Cidade baixa & $\begin{array}{l}\text { Serão feitas referências ao } \\
\text { documentário O fim e o } \\
\text { princípio e ao filme de ficção } \\
\text { Meu tio matou um cara. }\end{array}$ \\
\hline 2006 & Falcão - meninos do tráfico & Os 12 trabalhos & $\begin{array}{l}\text { Serão feitas referências ao } \\
\text { documentário Estamira e ao } \\
\text { filme de ficção Árido movie. }\end{array}$ \\
\hline 2007 & Juízo & Tropa de elite & $\begin{array}{l}\text { Será feita referência ao filme } \\
\text { Saneamento básico, que de } \\
\text { forma original traz um } \\
\text { documentário inserido em } \\
\text { sua ficção, e ao filme Jogo de } \\
\text { cena, documentário que } \\
\text { dialoga com os demais. }\end{array}$ \\
\hline 2008 & $-x-$ & $\begin{array}{l}\text { Última parada } 174 \\
\text { Meu nome não é Johnny }\end{array}$ & $\begin{array}{l}\text { Selecionamos para o ano de } \\
2008 \text { dois filmes de ficção, } \\
\text { pois houve poucos } \\
\text { lançamentos de } \\
\text { documentários que fossem } \\
\text { relacionados à pesquisa. }\end{array}$ \\
\hline 2009 & Garapa & O contador de histórias & $\begin{array}{l}\text { Em } 2009 \text { temos um grande } \\
\text { número de documentários, } \\
\text { entre eles referências aos } \\
\text { filmes Moscou, Filmefobia e } \\
\text { Simonal. }\end{array}$ \\
\hline 2010 & $\begin{array}{l}\text { Dzi Croquettes } \\
\text { Uma noite em } 67\end{array}$ & $-x-$ & $\begin{array}{l}\text { Além do aumento de filmes } \\
\text { lançados em 2010, os } \\
\text { documentários mantém a } \\
\text { tendência de crescimento; } \\
\text { aos filmes selecionados, é } \\
\text { imprescindível acrescentar o } \\
\text { fenômeno em torno do filme } \\
\text { Tropa de elite } 2 \text {. }\end{array}$ \\
\hline 2011 & $\begin{array}{l}\text { As canções } \\
\text { O céu sobre os ombros }\end{array}$ & $-x-$ & $\begin{array}{l}\text { Em 2011, } 50 \% \text { da produção é } \\
\text { documental; não há um filme } \\
\text { com público marcante, mas } \\
\text { um novo filme de Eduardo } \\
\text { Coutinho e filmes de ficção } \\
\text { com grande bilheteria, como } \\
\text { Bruna Surfistinha. }\end{array}$ \\
\hline
\end{tabular}




\begin{tabular}{|c|c|c|c|}
\hline 2012 & $\begin{array}{l}\text { Raul, o início, o fim e o meio } \\
\text { Tropicália }\end{array}$ & $-x-$ & $\begin{array}{l}\text { Em 2012, observamos } \\
\text { significativo aumento da } \\
\text { produção de filmes brasileiros } \\
\text { e a consolidação do mercado, } \\
\text { inclusive com mudanças nos } \\
\text { circuitos de distribuição e } \\
\text { exibição, incluindo canais } \\
\text { televisivos. Dentre os filmes } \\
\text { de ficção, vale notar que } \\
\text { Gonzaga, de pai para filho, } \\
\text { esteve entre aquele com mais } \\
\text { de } 1 \text { milhão de espectadores; } \\
\text { Xingu, por sua vez, coloca-se } \\
\text { no entremeio entre o cinema } \\
\text { ficcional e o documental. }\end{array}$ \\
\hline 2013 & $\begin{array}{l}\text { Elena } \\
\text { O renascimento do parto }\end{array}$ & $-x-$ & $\begin{array}{l}\text { Em 2013, apenas o } \\
\text { documentário Elena alcançou } \\
\text { mais de } 50 \text { mil espectadores. } \\
\text { Dos filmes de ficção, } \\
\text { destacamos Flores raras e } 0 \\
\text { som ao redor, que fogem ao } \\
\text { padrão das comédias } \\
\text { populares. Entretanto, houve } \\
\text { grande crescimento numérico } \\
\text { em termos de lançamentos, } \\
\text { público e salas de exibição } \\
\text { para o cinema brasileiro. }\end{array}$ \\
\hline 2014 & $\begin{array}{l}\text { Tarja branca - a revolução que } \\
\text { faltava } \\
\text { Mercado de notícias }\end{array}$ & $-x-$ & $\begin{array}{l}\text { Neste ano, seis filmes } \\
\text { alcançaram mais de } 1 \text { milhão } \\
\text { de espectadores e } 21 \text { filmes } \\
\text { mais de } 100 \text { mil } \\
\text { espectadores, dentre eles } \\
\text { Hoje eu quero voltar sozinho, } \\
\text { Praia do futuro e O homem } \\
\text { das multidões. }\end{array}$ \\
\hline
\end{tabular}

Dos seis documentários acrescentados, já destacamos algumas de suas características, ampliando-as nesse momento. Em 2012, Raul, o início, o fim e o meio e Tropicália consolidam os lançamentos musicais, dialogando com um público familiarizado com suas temáticas e personagens. O primeiro tem como destaque a extensa pesquisa de arquivo e a visão panorâmica trazida sobre o cantor, trazendo imagens, áudios, depoimentos, entrevistas (familiares, amigos, artistas) e construindo de modo complexo a vida e a obra de Raul Seixas. Ainda que mantendo um formato documental tradicional, ao utilizar estratégias narrativas e procedimentos estilísticos semelhantes àqueles presentes em biografias ficcionais (como o filme Tim Maia, sem querermos com isso desconsiderar que este alcançou um público dez vezes maior que Raul) o filme estabelece um diálogo com os espectadores e os insere em seu enredo. Tropicália, por sua vez, encontra conexões com documentários recentes que trazem não apenas a apresentação da variedade e importância da música brasileira, mas refazem e recontam a própria história do país por meio de sua música. 
Importante movimento dos anos 1960, o filme resgata a cena musical da época e retrata seus festivais da canção por meio de entrevistas e imagens de arquivo, registrando as marcas singulares do período retratado. Mais do que uma (justa) homenagem ou uma biografia dos cantores, o filme conecta a história do país à história da música de modo crítico e ousado.

Em 2013, os filmes Elena e $O$ renascimento do parto foram escolhidos por sua adesão junto ao público e por tratarem, ambos, de temáticas voltadas ao feminino. Sobre o primeiro trataremos adiante, dedicando a ele maior espaço devido a seus traços singulares. Em um ano com muitos lançamentos, o segundo filme nos permite refletir sobre um aspecto dos documentários nem sempre presente: o engajamento em causas sociais de caráter coletivo, o estabelecimento de premissas e de uma tese a ser demonstrada e, mais do que isso, a interferência em uma realidade concreta por meio da mobilização dos espectadores para que assumam o ponto de vista mostrado, por concordância ou convencimento em relação a ele. Ao inserir o debate sobre a situação médica mundial em relação aos nascimentos por parto normal ou cesárea, o filme aproxima-se de pautas presentes em reportagens jornalísticas, mas destas se diferencia ao assumir claramente um posicionamento e demandar posturas éticas em relação ao tema. De formato convencional, com entrevistas e imagens de pessoas que vivenciaram as situações retratadas, sua inovação se faz na articulação entre elementos científicos, depoimentos e o chamado a uma consciência mais global em relação à humanidade.

Em 2014, os documentários Tarja branca e $O$ mercado de notícias, ainda que bastante diversos, não são apenas representativos da resposta do público, mas também dos caminhos do documentário brasileiro. O primeiro traz, já em seu título, a visada que pretende enunciar: referindo-se aos remédios utilizados em tratamentos psíquicos e chamados "tarja preta", a tarja branca faz referência a terapias alternativas para o equilíbrio dos indivíduos. Estabelecendo contato com $O$ nascimento do parto, vemos em suas imagens a crítica a uma vida cada vez mais acelerada e dominada por aparatos tecnológicos, que se estende às crianças nas grandes cidades. Mostrando brincadeiras infantis e seu uso por adultos, o filme é taxativo ao afirmar sua causa: que cada um deve guardar um espaço lúdico, como as brincadeiras infantis, para que não precise dos medicamentos de tarja preta. Com depoimentos variados em termos de idades, origens sociais, profissões e regiões do país, o documentário realiza, ao mesmo tempo, um inventário e um tributo ao "ato de brincar" e sua importância na vida humana. 
Finalmente, destacamos o filme $O$ mercado de notícias, documentário realizado por Jorge Furtado - conhecido cineasta e produtor de televisão - que há vários anos não se dedicava a esse gênero. De estrutura demarcadamente híbrida, como são os filmes do diretor, a história tematiza o jornalismo contemporâneo por meio de três camadas narrativas interconectadas: os depoimentos de jornalistas profissionais para discutir o papel da mídia (especialmente em sociedades democráticas); a encenação da peça cômica "O mercado de notícias", de Ben Jonson, escrita em 1625 e que dá nome ao filme, narrando o surgimento da imprensa no século XVII e seus desdobramentos nos tempos atuais; finalmente, há uma encenação dos bastidores dos ensaios, onde os atores da peça - e do filme - conversam sobre sua realização e dispositivo, acompanhados pela presença do próprio Furtado, que se torna também personagem.

Para firmar seu ponto de vista sobre o jornalismo contemporâneo, o diretor volta no tempo e explicita momentos atuais da imprensa: a notícia sobre um (suposto) quadro de Picasso, encontrado em uma repartição pública brasileira e tomado como "original" quando na verdade não passava de uma reprodução, serve de metáfora não apenas para tratar do jornalismo, mas do próprio país e, acima de tudo, de questões sempre presentes na obra do realizador. Entre elas, destacamos a problematização dos limites entre realidade e fantasia e, por extensão, entre documentário e ficção. Além disso, Furtado reafirma sua crença na possibilidade de representação do mundo vivido e na busca por uma postura crítica em relação a esses modos de representação, incluindo o cinema.

\subsection{Representações da (in)visibilidade em discursos audiovisuais}

Nesse momento, a partir dos filmes destacados, propomos uma análise do discurso cinematográfico a fim de apontar possíveis articulações em torno da questão da invisibilidade social ${ }^{\mathbf{8 6}}$. Para tanto, iremos nos deter em três obras lançadas em 2013, por considerarmos que são exemplares para as análises, transitando do espaço dos estigmas para a questão das visibilidades sociais. Este tem sido um desafio teórico para os estudos fílmicos desde o estabelecimento, por contraponto, da noção de uma sintaxe do visível (Metz, 1972; Aumont, 1995).

\footnotetext{
${ }^{86}$ Uma versão ampliada das análises apresentadas foi desenvolvida juntamente com a pesquisadora Andrea Limberto (ECA-USP) e publicada em periódico acadêmico, como indicado em nossa produção científica.
} 
Assumimos que exista uma barreira lógica para a representação de sujeitos em situação de invisibilidade, o que de modo algum tem impedido que ela seja tematizada frequentemente em filmes. Ou ainda, que opere como uma marca sobre determinados sujeitos, periféricos, atuando como estandartes de identidades minoritárias nos modos de se tornarem visíveis. Ao mesmo tempo, não podemos deixar de ressaltar a aparição poética desses mesmos sujeitos como ocupando também uma posição política - e dizemos, com Nichols (1991), que se trata de uma imagem ideológica -, ambas associadas numa forma de representar.

Entendemos, com Rancière (1996; 2005), que a criação na linguagem implica, invariavelmente, um engajamento poético e uma representação política. Observamos, num aparente paradoxo, que identidades consideradas minoritárias têm tido espaço para a construção de seus modos de representação em discursos audiovisuais (notadamente em filmes que tematizam a periferia, o crime, a violência, a homossexualidade, o racismo, as questões de gênero etc.) assumindo, desse modo, um espaço de visibilidade. Independentemente, identificamos a invisibilidade como uma dimensão fundamental na maneira como os processos de representação se apropriam desses sujeitos.

Ao tratarmos de novas políticas da representação, voltamo-nos, principalmente, para o campo da produção e da circulação de discursos. Entretanto, quando observamos as práticas midiáticas não podemos deixar de considerar a questão da recepção, ou seja, do consumo cultural em suas múltiplas formas. Novos atores sociais entram em cena para compor, de modo complexo, tramas narrativas que contemplem, ao mesmo tempo, os desafios da sociedade contemporânea organizada em rede e as demandas dos sujeitos em suas diferentes posições. Como afirma De Certeau (1996), a relação entre estratégias e táticas imprime novas relações de força entre os diversos sujeitos, possibilitando o contorno de outros cenários culturais na busca por afirmações identitárias alternativas:

\footnotetext{
Chamo de estratégia o cálculo (ou a manipulação) das relações de forças que se torna possível a partir do momento em que um sujeito de querer e poder (uma empresa, um exército, uma cidade, uma instituição científica) pode ser isolado. A estratégia postula um lugar suscetível de ser circunscrito como algo próprio e ser a base de onde se podem gerir as relações com uma exterioridade de alvos ou ameaças (os clientes ou os concorrentes, os inimigos, o campo em torno da cidade, os objetivos e objetos de pesquisa etc.) (De Certeau, 1996: 99).
}

No campo da produção audiovisual, práticas de consumo recentes provocam e são provocadas pela revitalização do gênero documental na última década, quando vemos a propagação de filmes que se dirigem a novas audiências e, ao mesmo tempo, 
retratam outros agentes sociais, ampliando o campo do visível e, consequentemente, os regimes de visibilidade nele presentes. Em sua definição mais geral, ou seja, filmes que retratam o mundo vivido por meio de escolhas técnicas, estéticas e narrativas visando contar determinadas histórias, os documentários encontram junto a seu público o espaço de construção de interpretações, remetendo suas formas discursivas àquilo convencionado como realidade.

A relação com a realidade estabelece, ainda, outro pacto, qual seja, o compromisso dos documentários com a suposta verdade dos fatos encenados, escamoteando, muitas vezes, as estratégias de sua fabulação. Na relação entre produção e recepção, ainda que se espere que os documentários contem histórias verdadeiras sobre o "mundo real", tal expectativa pertence ao pacto de leitura estabelecido:

Não se espera que tais histórias sejam contadas de modo objetivo, tampouco que sejam completamente verdadeiras. O realizador pode se valer, ocasionalmente, do uso de licença poética no relato e se referir simbolicamente à realidade. (...) Mas espera-se que os documentários sejam uma representação justa e honesta de uma experiência vivida por alguém (Aufderheide, 2007: 3, tradução nossa).

É na interface entre o repertório do público, seu interesse pelos fatos narrados e a maneira como os realizadores apresentam tais fatos que se estabelece um intervalo no qual vislumbrar possíveis efeitos de sentido. De certo modo, não há regras extrínsecas ao filme documentário que possam defini-lo enquanto tal, apenas escolhas que dizem respeito aos modos de tecer suas narrativas para torná-las consistentes e credíveis em relação aos contratos comunicacionais selados com a audiência. Outro aspecto soma-se a esse pacto, incluindo na tessitura dos documentários questões relacionadas ao mercado de produção e distribuição, que se encontra com as possibilidades de sua circulação e apropriação. À medida que os documentários passam a ocupar espaços ampliados no circuito audiovisual, sua definição enquanto gênero discursivo se fortalece, não apenas no cinema, mas também na televisão e na internet, especialmente se considerarmos as mídias digitais e os aparatos móveis utilizados para sua propagação:

Como representação expressiva das tensões e contradições nas práticas socioculturais contemporâneas, o cinema convida ao deleite e também à reflexão. De fato, o espectador que se dispõe a compor sua sensibilidade com o fluxo imagético na tela e imergir na narrativa ficcional do filme que está assistindo terá a oportunidade de interagir - e mesmo de desvelar - outras visões de mundo, vivenciando de um tipo de experiência que poderá levá-lo a pensar e atribuir sentido às questões de nosso tempo a partir de novas perspectivas (Castro, 2013: 2). 
Por meio da inserção dos documentários como integrantes da dinâmica de consumo cultural, portanto, buscamos apontar os modos de estabelecimento de vínculos sociais na contemporaneidade, visando a problematização das formas de construção de identidades, subjetividades e sociabilidades presentes nas interações cotidianas. É assim que cenários em constante transformação geram práticas e usos diferenciados em termos de consumo cultural midiático, possibilitando a realização de documentários que, para além de sua vocação original, ampliam as possibilidades de representação do outro, tornando-o mais radical em sua alteridade, menos domesticado em relação àquilo estabelecido como normatização ou normalização social:

A realidade não é algo que esteja lá fora, mas aquilo que conhecemos, entendemos e compartilhamos uns com os outros sobre o que está lá fora. As mídias interferem na realidade mais valiosa que existe, aquela que está em nossas mentes. Documentários são uma importante forma de comunicação e formatação da realidade, justamente por evocarem a verdade. Eles são sempre fundados na realidade e pretendem nos contar alguma coisa que valha a pena ser conhecida (Aufderheide, 2007: 5, tradução nossa).

É um extremo que vemos surgir, muitas vezes, nas telas de cinema, trazendo à tona regimes de visibilidade que alargam as políticas da representação usualmente aceitas. A circulação de documentários que tematizam identidades minoritárias e estigmas já aponta para o alargamento nas trocas de bens simbólicos, em que a invisibilidade se torna um modo de inserção social. Essa circulação está relacionada à acumulação de capital, material ou simbólico, que pode reverter em recursos financeiros e reconhecimento pessoal tanto para realizadores como para personagens. A proliferação de imagens em páginas da internet, seja com vídeos no YouTube, perfís em redes sociais como Facebook e Twitter, ou trailers oficiais em sites corrobora as análises, apontando para o caráter expansivo do consumo na atualidade. Um duplo movimento apresenta-se como eixo articulador dessa perspectiva: se, por um lado, vemos aumentarem as possibilidades de tornar visíveis sujeitos antes obscurecidos, por outro vemos surgirem, cada vez mais, imagens que se conformam à ordem visual vigente, ou seja, discursos realistas dirigidos ao estabelecimento de verdades factuais.

No livro Testemunha ocular (2004), Burke tematiza a questão da objetividade e da fidelidade na representação dos fatos por meio da análise de imagens fotográficas, questionando-as enquanto provas de evidência histórica. Dentre os vários conceitos trazidos, o autor apresenta uma série de problemas advindos da crença na autenticidade e veracidade das imagens fotográficas: o problema das fotografias fabricadas, dos 
interesses daqueles que as encomendam, de pressões externas (editores, veículos). Segundo o autor, o conceito de "testemunha ocular" - alguém capaz de fielmente "representar o que, e somente o que, poderia ter visto de um ponto específico num dado momento" (Burke, 2004: 18) - reforça a crença na possibilidade de um testemunho preciso e verdadeiro, esquecendo as diferenças sempre presentes tanto no que os discursos (verbais ou visuais) deixam transparecer, como naquilo que ocultam.

Notamos na produção cinematográfica recente um conjunto de filmes que problematizam de modo singular a questão da objetividade nos relatos e da fidelidade aos fatos. Dentre eles, destacamos: os filmes iranianos Salve o cinema (Mohsen Makhmalbaf, 1995), Cópia fiel (Abbas Kiarostami, 2010) e Isto não é um filme (Mojtaba Mirtahmasb e Jafar Panahi, 2010); e, novamente, os documentários brasileiros Jogo de cena (2007), Moscou (2009) e As canções (2011), realizados por Eduardo Coutinho $^{87}$. Ainda que reconheçamos sua variedade estilística, apontamos algumas articulações discursivas presentes em suas narrativas, notadamente híbridas.

Já na década de 1990, Salve o cinema, como outros filmes iranianos, mescla encenação e registro, numa espécie de ficção documental na qual o diretor convoca possíveis atores, por meio de um anúncio de jornal, a realizarem testes para seu próximo filme. Makhmalbaf filma os testes e, ao ser interpelado sobre quando teriam início as filmagens com os escolhidos, responde que o filme havia acabado de ser realizado.

Na ficção Cópia fiel (no original, cópia autenticada), Kiarostami indaga, durante todo o filme, o que seria autêntico e veraz em contraponto àquilo tomado como artificial e falso ao apresentar um roteiro em espiral que polemiza o valor da cópia em obras de arte e se desdobra em camadas interpretativas. É o diretor Panahi quem nos oferece, em Isto não é um filme, uma síntese dos dois filmes anteriores: proibido de realizar filmes (veto por ele obedecido) e anunciando se tratar de um "documentário" - denominação pouco comum no realismo do cinema iraniano -, o diretor é filmado e encena, em prisão domiciliar (que perdurou por dois meses e só foi encerrada após uma greve de fome), um dia completo de confinamento como forma de relatar as privações impostas a ele e, metonimicamente, ao próprio cinema em seu país.

Em seus documentários, Coutinho evoca diversos modos ficcionais para contar as histórias vividas pelos entrevistados - transformados em personagens - e desafiar as fronteiras entre factualidade e fabulação. Os filmes podem ser vistos como uma espécie

\footnotetext{
${ }^{87}$ Para informações e críticas dos filmes, ver site www.adorocinema.com.br. Acesso em: 11/02/2014.
} 
de trilogia (ou reiteração) a respeito do cinema e de seus modos de realização, além de retomar a crítica ao conceito de representação. Encenados no ambiente de teatro, em Jogo de cena, composto apenas por personagens femininas, vemos a mistura entre histórias verídicas e inventadas, atrizes e mulheres anônimas, espontaneidade e indução. Os depoimentos são apresentados em cenário minimalista, no qual as mulheres sentamse à frente de Coutinho, de costas para a plateia vazia, invertendo as posições normalmente vistas no teatro e questionando os limites da interpretação. Moscou, por sua vez, retrata os bastidores do grupo de teatro mineiro Galpão, ensaiando em um teatro vazio a peça "As três irmãs", de Tchekhov, jamais apresentada ao público.

Finalmente, As canções desenvolve uma premissa aparentemente simples: cada um dos entrevistados deve contar (e cantar) a história de uma música que tenha marcado sua vida. Mais uma vez o cenário é um teatro, mas o ponto de fuga situa-se nos fundos do palco, entre cortinas, lugar por onde entram e saem os personagens. Ao contrário de dicotomizar suas narrativas, tais documentários se movimentam nas imbricações entre fato/relato, referencialidade/ficcionalidade, realidade/fantasia. A exemplo dos filmes anteriores, essas imagens nos alertam, reiteradamente, para a precariedade na apreensão fidedigna da realidade, ressaltando a impossibilidade de objetivação dos relatos e a pregnância do processo tradutório que se impõe a qualquer discurso sempre que os artifícios da narrativa são acionados. Respondendo de modo contundente à tentativa de domesticação percebida em imagens pretensamente referenciais, tais filmes reafirmam seu pacto ficcional com os espectadores, como se dissessem, paradoxalmente, isto é apenas um filme.

Nos interstícios de uma realidade oculta que pretende se fazer ver e de uma visibilidade englobante que pretende tudo mostrar, vemos desfilar imagens mais ou menos reais, mais ou menos verdadeiras, mas sempre engajadas na tensão entre visibilidade e invisibilidade dos sujeitos nelas representados, como nos filmes tratados a seguir. Analisaremos nesse momento articulações feitas por três documentários brasileiros recentes, exibidos em circuito comercial e que, privilegiando um discurso referencial e de caráter realista, apresentam como personagens alguns sujeitos marcados por modos de vida diversos e, muitas vezes, por ocuparem posições periféricas em relação a papéis sociais tradicionalmente estabelecidos.

O empenho realista nos interessa por operar um movimento de afirmação da marca dos sujeitos representados, aprovando-a como se ela fosse, no âmbito do filme e no âmbito da vida, exatamente como mostrada. Por outro lado, as fabulações neles 
contidas - especialmente por serem documentários - tornam-se contundentes ao estabelecerem relações diretas na composição da imagem de um outro, ou seja: para além de sua vocação documental de se voltar ao outro, tais filmes tematizam também sua interferência na construção dessa imagem por meio dos personagens apresentados.

Desse modo, as invisibilidades sociais, tão frequentemente relatadas em documentários, são de fato problematizadas nos filmes, que não apenas se contrapõem ao que normalmente é tornado visível - trazendo figuras divergentes -, mas acentuam os modos de fazê-lo, ampliando o campo do visível e autenticando, assim, novas políticas da representação dos sujeitos filmados. Sob essas premissas, trataremos a seguir de Elena (Petra Costa, 2013), Cidade cinza (Marcelo Mesquita e Guilherme Valiengo, 2013) e Olhe pra mim de novo (Kiko Goifman e Claudia Priscila, 2011).

Para além de semelhanças estilísticas - que se acentuam nos tempos atuais -, reportagem e documentário posicionam-se diferentemente em relação às formas de construção da representação e às relações desta com o imaginário. Ao ressignificar os fatos para representá-los culturalmente, ainda que tenham como base os acontecimentos (ou atualidades), é de um processo de criação que se trata, inventando uma história por meio de fabulações narrativas. De distintos modos de dar a ver o outro, por meio de formas mais extremas ou mais domesticadas, espaços de visibilidades e invisibilidades apresentam-se nas telas da televisão e do cinema, apontando para diferentes concepções estéticas e narrativas.

No caso dos programas telejornalísticos, a presença do repórter no local em que se passa a notícia e a importância da transmissão ao vivo, tornando-o, ao mesmo tempo, narrador e sujeito da ação, confirmam sua atuação como personagem da narrativa e representante do espectador (uma espécie de testemunha do testemunho atestado pelo jornalismo), colocando-se em seu lugar e construindo a cena como se o espectador estivesse nela presente. A realidade encenada (ou telerrealidade) insere-se nesse espaço de atuação que distancia as reportagens dos documentários. Estes últimos, como afirmamos, não são apenas filmes de caráter informativo ou didático, mas reconstroem a realidade a partir de um ponto de vista subjetivo que se estabelece no intervalo entre cineasta e personagem, um “eu” e um "outro" colocados em relação.

Em vez de desenrolar a narrativa aos olhos do espectador, o documentarista, normalmente fora de quadro mas presente por meio dos enfoques buscados, tem como desafio ocupar o lugar de escuta do outro, mais do que tornar audível sua própria voz. Ao contrário de atuar como personagem, o sujeito que se inscreve nos documentários 
não se pretende uma representação fiel da pessoa retratada em seu cotidiano, mas tornase, nas palavras de Eduardo Coutinho, "a melhor versão daquela pessoa": "No cotidiano as pessoas são tão naturais quanto artificiais. Que processo a pessoa levou para atingir o seu natural? É a criação da mentira verdadeira. É óbvio que uma pessoa assume dez pessoas diferentes no seu cotidiano" (Coutinho; Xavier; Furtado, 2005: 119). Ao deslocar o foco da legitimidade para a legitimação, o documentarista alcança, por meio do fingimento, o que há de mais singular no sujeito simulado nas imagens:

\begin{abstract}
A respeito da relação entre pessoa e personagem, ocorre algo interessante. Na filmagem, encontro-me com uma pessoa durante uma hora, sem a conhecer de antemão, e às vezes nunca mais a vejo depois disso. E na montagem, durante meses, lido com ela como se fosse um personagem. Ela é, de certa forma, uma ficção, por isso a chamo de personagem, já que ela "inventou", numa hora de encontro, uma vida que nunca conheci. Se o filmo durante uma hora, ficam na edição final cinco ou sete minutos. Faço dela um concentrado daquilo que eu acho que é o melhor que ela possa ter (Coutinho; Xavier; Furtado, 2005: 121).
\end{abstract}

De modo paradoxal, ao ausentar-se da tela o realizador nela deixa suas marcas por meio dos encontros discursivos, não presenciais, atestados pelas imagens da câmera. Nos moldes da teoria da enunciação, uma espécie de autoria partilhada instaura possibilidades de reversibilidade entre um "eu" e um "outro" que intercambiam lugares para que cada um possa ganhar voz e tomar corpo. Nas reportagens jornalísticas, ao contrário, o lugar do realizador é usualmente ocupado pelos repórteres. Mesmo que esses não direcionem a narrativa - ao contrário, o jornalismo apregoa a neutralidade do relato e produz, como efeito de sentido, o apagamento das marcas do enunciador -, sua presença física se faz sentir a cada passo, demarcando de modo mais incisivo os vieses da narrativa e unificando, ao menos na superfície, seu relato.

Ainda que ambos, reportagem e documentário, apresentem sujeitos concretos, histórias acontecidas e situações pertencentes ao mundo vivido - explicitando seu caráter referencial e testemunhal -, os documentários ocupam-se menos da busca pela verdade das pessoas e dos fatos retratados, e dedicam-se mais a interpretações sobre tais pessoas e fatos, elaborando suas narrativas a partir das informações e histórias de vida colhidas por meio das interações verbais com seus personagens. O problema da objetividade e da autenticidade, certificadas pelo repórter que vivencia as histórias ao mesmo tempo em que as apresenta ao telespectador, não se coloca para o documentarista, que assume o caráter provisório de seu relato, tecido sempre $a$ posteriori, em outro tempo e lugar que não os da própria ação. Como afirma Coutinho: 
No documentário é preciso sair de si. (...) O documentário é isso: o encontro do cineasta com o mundo, geralmente socialmente diferentes e intermediados por uma câmera que lhe dá um poder, e esse jogo é fascinante. Portanto, o fundamental do documentário ou acontece no instante do encontro ou não acontece. E se não acontece, não tem filme. E como você depende inteiramente do outro para que aconteça algo, é preciso se entregar para ver se acontece (Coutinho; Xavier; Furtado, 2005: 121).

Estabelecemos duas formas pelas quais a questão da invisibilidade tem permeado a produção fílmica: o ímpeto de representá-la enquanto ausência e a visibilidade dada aos sujeitos em situação de invisibilidade. No limite, há sempre algo de invisível que não poderá ser captado, do mesmo modo que, numa dimensão imponderável, a câmera aponta para sujeitos incluindo-os em sua invisibilidade positivada (representada pela presença de uma ausência) ou visibilidade indiferente (caso em que a própria indiferença se torna a marca). Esses traços estão relacionados aos tipos de vínculos estimulados na produção fílmica em negociação com a realidade.

Observamos a composição cênica em que esses sujeitos são mostrados (planos, enquadramentos, montagem), a perspectiva de um olhar organizador (identificado como aquele que concede o direito à visibilidade) e a articulação entre os elementos visíveis e aqueles que dialogam com um espaço do não dito, que se faz presente na cena por meio dessa relação. Finalmente, argumentamos que as cenas não precisam ser obscuras para que ocorra sua invisibilização. Antes, a figura dos sujeitos engajados com outros sujeitos e objetos do entorno cênico será a característica determinante de sua situação.

Elena (2013), dirigido por Petra Costa, é um documentário brasileiro aclamado em diversas premiações nacionais e internacionais. Interessa-nos, sobretudo, por lidar justamente com a falta de Elena, que será presentificada, durante o filme, com fragmentos de vídeos costurados como uma composição na memória. Outra relação de ausência-presença marca o filme: trata-se da implicação autoral de Petra Costa, a diretora, e sua ausência, para deixar que a memória da irmã fale. Além disso, Elena segue uma carreira artística que é referência em todo o filme - a dança, o teatro. A experiência artística da personagem é respondida com um filme documentário, na berlinda entre o referencial e o poético da composição fílmica, tornando o relato ao mesmo tempo factual e ficcional.

Para além das anotações que podemos fazer na proposta anunciada do documentário, e que o inclui diretamente no debate sobre os limites entre visibilidade e invisibilidade, os elementos da composição fílmica desenham mais precisamente as nuances desse encontro. 
A trilha sonora desempenha um papel importante para situar o espectador no tempo da memória, e não no tempo presente de Elena, pois é a música que distancia o que se vê hoje da experiência factual passada. Ela conduz, no âmbito daquilo que nos é apresentado como imagem, um corpo que se torna fluído, etéreo e de contornos dificilmente definidos. Desse modo, a presença de Elena pode ser novamente vivida, ainda que mediada pela fluidez da água, pelo etéreo da dança e pela embaçamento possibilitado por vídeos amadores.

Elena viaja para Nova York com o mesmo sonho da mãe: ser atriz de cinema. Deixa para trás uma infância passada na clandestinidade durante a ditadura militar, e uma adolescência vivida entre peças de teatro e filmes caseiros. Também deixa Petra, sua irmã de 7 anos. Duas décadas mais tarde, Petra também se torna atriz e embarca para Nova York em busca de Elena. Tem apenas pistas: fitas de vídeo, recortes de jornais, diários e cartas. A qualquer momento, Petra espera encontrar Elena andando pelas ruas. Aos poucos, os traços das duas se confundem. Já não se sabe quem é uma e quem é a outra. No espaço entre o corpo invisível de Elena e a presentificação tornada visível por sua irmã, vemos materializar-se os contornos do irrepresentável: trata-se do desaparecimento causado pela morte, já que esta encerra qualquer possibilidade de imagens referenciais, mesmo que se trate de um documentário em busca de seus sujeitos ou, mais do que isso, em busca dos limites de seu discurso.

O filme Elena articula a relação com o visível imergindo suas personagens em ambientes difusos. A cena inicial mostra uma tomada do corpo feminino visto de cima, movendo-se como em uma dança na água. A horizontalidade da cena não nos remete tanto ao ambiente aquático que identificamos quanto a um movimento no ar, como se estivéssemos olhando para o céu. A movimentação da roupa soma-se àquela do corpo, contribuindo para o obscurecimento de contornos. A imagem causa um estranhamento por unir um corpo vestido à água, e o movimento lento da atriz também contribui para um estado semelhante de não saber qual a referência exata da cena. Ainda não identificamos e não podemos reconhecer as mulheres, personagens femininas envolvidas na narrativa do filme. Estamos diante, simplesmente, de um corpo flutuante, situando o espectador num tempo distinto - o da memória - e possibilitando uma aproximação afetiva, com tomadas disruptivas em relação à narrativa do filme.

Numa segunda imagem, o ambiente aquático dá lugar a uma cena de impressões amadoras ou caseiras em que surge uma menina, centro das atenções, em close. A movimentação que se produz é mais rápida, a focalização da personagem menos segura 
e mais fugidia. Se na cena anterior ela nos escapava e se fazia invisível pela falta de reconhecimento, nessa notamos uma marca referencial, mas o fato ainda escapa ao foco. Adiciona-se a isso, considerando a experiência do espectador, a distância temporal marcada pelo rosto e sorriso de menina. No quadro seguinte, temos uma personagem já madura. Sendo ela a representação de um tempo atualizado (passagem de criança a adulta), mas não presente (a adulta vive somente na memória), a mulher aparece-nos de costas, afastando-se. Dessa forma, também escapa em sua invisibilidade e, uma vez mais, acompanhamos o borramento pela movimentação que se imprime na cena.

Nosso segundo exemplo é Cidade cinza (2013), com direção de Guilherme Valiengo e Marcelo Mesquita, que participou do festival de produção audiovisual "É tudo verdade" ${ }^{\nexists 8}$. O filme apresenta grafites feitos pelos artistas OsGêmeos, Nunca e Nina, na cidade de São Paulo (SP), e que são tornados invisíveis pela decisão da prefeitura da cidade em eliminar o que considerava ser "poluição visual" (grafites, pichações, cartazes, outdoors, pôsteres, luminosos) por meio da repintura dos muros da metrópole. O documentário se monta, assim sobre uma disputa institucionalizada a respeito das cores que devem revestir a cidade: o colorido dos grafites ou seu recobrimento pela uniformização acinzentada.

O filme apresenta uma tomada panorâmica da cidade de São Paulo, marcando o adensamento da área construída e de sua lavagem cinza-concreto. O grafite é então recuperado como forma de reação à erupção do concreto, como uma marca visível nas paredes construídas. A relação com a invisibilidade, nesse caso, faz-se com o cinza que ele encobre, cor original de tudo o que é concreto. Os grafites reapresentados em cena produzem uma segunda pintura, que é aquela documentada pelo filme e mostrada ao espectador, trazendo os artistas como protagonistas da encenação, sobre os muros cinzas, de algo que antes estava ali e foi recoberto. Vemos os grafites à medida que vão sendo realizados: a justaposição de cenas contrasta com o cinza que recobre a cidade e para o qual ela havia retornado. Dessa forma, a passagem de uma cena a outra faz do espaço urbano um campo de batalhas simbólicas, um embate entre representações. Onde os olhos poderiam ver uniformidade, há a marca de uma disputa que é, ao mesmo tempo, estética e política, sobre um território aparentemente indomado, pertencente a cada um dos sujeitos que nele transitam.

\footnotetext{
${ }^{88}$ Festival internacional de documentários, reunindo importantes obras. Realizado anualmente, encontrase em sua 19a . edição. Mais informações em: http://etudoverdade.com.br. Acesso em: 25/03/2014.
} 
O filme estabelece um contraponto visual entre a verticalidade da cidade, percebida na estrutura dos prédios, e a horizontalidade da execução dos grafites em seus muros. A ação em cena é executada por veículos representando a prefeitura da cidade, invadindo a paisagem e se postando na frente dos muros para as pinturas. A partir dessa intervenção, ocorre um questionamento sobre o lugar da arte no espaço urbano, em que percebemos, por um lado, a visibilidade de uma luta por assepsia sobre a qual está instaurado um modelo de cidade e, por outro, a "sujeira" dos grafites, intervenção artística que a transforma como se fosse um ruído na homogeneidade de suas cores.

Parece-nos um compromisso do documentário, ou um código a ser aplicado à escrita fílmica, oferecer um quadro que represente a visão geral do tema numa imagem sintetizadora. No caso de Elena, vemos corpo dançante na água, oferecendo poucos elementos referenciais sobre um espaço-tempo. Já em Cidade cinza, a inauguração da narrativa é feita com a referência explícita à cidade de São Paulo em sua forte presença. Nem por isso deixamos de considerar que o quadro selecionado seja também, oceânico, extravasando seus limites ao fazer imaginar uma infinita extensão cinza para além dele. Curiosamente, da mesma forma que em Elena, temos uma perspectiva de olhar mais incomum, de cima para baixo ou de baixo para cima. Esse posicionamento do olhar, somado ao do espectador, empodera-o com um lugar de ver ao mesmo tempo em que torna invisível o que não está captado no que seria uma tomada mais ampla.

Outros quadros que se seguem procurarão recobrir tal falta, acionada na elaboração da narrativa imagética. Ao longo do documentário, o colorido do grafite ganha seu espaço em cena. Em outro quadro, a imagem está recortada, mas presente atrás dos artistas-grafiteiros em primeiro plano. Notemos que ele reproduz o modelo tradicional da reportagem informativa para a apresentação da fala das personagens. $O$ efeito que se tem é o endosso àquele que fala, pelo que consideramos que este seja um lugar de invisibilidade e, desse modo, aberto para pessoas que estão tanto socialmente à margem (com sua arte), quanto invisíveis atrás de suas próprias obras como artistas.

Na sequência das imagens, vemos a verticalidade das construções cinzentas ser desafiada pela horizontalidade longilínea do muro grafitado. O espaço do muro cinza combinado com o asfalto, que não seria comumente notado, e a própria estrutura da cidade, ganha estatuto de espaço de arte. Cidade cinza mostra a atividade do grafite como uma iniciativa de ocupação do espaço invisível para a esfera do notável. Ao mesmo tempo, o movimento de atrair o olhar faz do muro grafitado um lugar de contenda entre o incômodo estímulo ou seu apaziguamento monótono. 
O terceiro filme é o documentário Olhe pra mim de novo (2011), definido como uma espécie de "filme de estrada" e dirigido por Kiko Goifman e Claudia Priscilla. Notemos que Goifman já dirigira os documentários 33 (2002) e Filmefobia (2008), entre outros, tratando de situações limítrofes no que diz respeito à construção de identidades periféricas e às formas instituídas de sua representação, como se pudesse captar o inapreensível por meio de imagens extremas. No filme, o transexual Silvyio Luccio é retratado no sertão nordestino em que mora com sua esposa. Uma fala do personagem interpreta o ato de tirar a roupa como um desvelamento, um deixar cair a máscara da visibilidade masculina que o protagonista sustenta. O título aponta para este mesmo movimento de duplo olhar, de retorno para verificar o que verdadeiramente se vê. A complexidade do filme reside, justamente, na incerteza que faz repousar a visão sobre um imaginário pouco marcado, ou melhor, recortado, filmado em cortes.

Nesse caso, para além da representação, trabalha-se a invisibilidade pela falta declarada do órgão sexual masculino. Ao mesmo tempo em que ele se faz presente na construção dos diálogos e na concatenação das cenas, Silvyio pede que outros ponham a mão em seu corpo para que possam verificar a ausência daquilo que todos pensam que ele teria. O documentário resume tal situação, aparentemente contraditória por oscilar entre o visível e o invisível: "Eu pensava que você era um homem que tinha desistido de ser homem e agora procura ser de novo".

A cena em plano mais geral que marca o documentário é a imagem de uma estrada aberta para circulação, mas sem outros veículos, como se houvesse no horizonte uma busca de identidade. Um outro quadro apresenta o personagem em momento de fala, tornando-o visível dentro do cenário da cidade em que ele se encontra com sua companheira. Durante o filme há uma clara tentativa de desestabilizar os limites entre os comportamentos esperados de acordo com os gêneros masculino ou feminino. Em um terceiro quadro, vemos uma personagem falando de si e de sua presença no mundo, dita para "incomodar". Ela fala à noite, entre sombras, e sua atuação marca ainda o que podemos reconhecer como uma gesticulação feminina em um homossexual masculino.

Em Olhe pra mim de novo, a questão da invisibilidade está marcada pela apresentação dos espaços e das condições pelas quais a sexualidade pode ser socialmente expressa, manifestada e vivida. $\mathrm{O}$ filme traz à tona, para o âmbito do visível e para a luz do dia, o que pertencia ao privado. Ao mesmo tempo, a privacidade está imbuída de um ímpeto de reconhecimento e aceitação públicos. O documentário circula entre essas duas esferas, transitando pelas estradas daquilo que estaria dentro, voltado 
para a intimidade, e daquilo que estaria fora, projetado para a exposição, exigindo assim não apenas um segundo olhar (de novo), mas um olhar duplo sobre seus personagens.

Pretendemos, com os exemplos, apresentar a relação entre "um" e "outro", espectador e personagem - por semelhança e identificação, ou por contraste e repulsa em documentários representativos dos estigmas sociais. Tal articulação se estabelece no campo visual e é própria do fazer documental por meio do ímpeto de ver o diferente. $\mathrm{O}$ debate estende-se ao entendermos o olhar como porta de entrada para um circuito de circulação que depende de uma identificação inicial com o objeto visto e de sua apropriação, oferecida como produto audiovisual.

De maneira mais abrangente, podemos dizer que a experiência identificada como estética e política passa pelos mesmos canais midiáticos que a possibilidade de consumo cultural. Além disso, tais objetos culturais complementam essa experiência na medida em que passam a ser sua própria representação identitária, uma vivência de sua certeza totalizante: "Os enunciadores das máquinas comunicacionais ritualizam a especialização estética da mercadoria, já que as atividades de leitura, audição, televisão e imersão convocam o receptor a vivenciar experiências multissensoriais, voltadas à construção de uma vida desejável" (Prado, 2013: 30). Nesse sentido, a apresentação de personagens com identidades minoritárias se dá de forma desejavelmente estética, apelativa, circulante e, associado a isso, vendável. A dimensão política do olhar, assim, está marcada por uma lógica do aceitável como limite cultural em favor de satisfazer desígnios do imaginário: "Em vez de politizar a existência, os agentes ficam sem cessar fazendo indagações e ouvindo os enunciadores dos dispositivos, de modo a construir suas identidades e chegar à plenitude imaginária" (Prado, 2013: 43).

De todo modo, não podemos assumir que, com isso, tal dimensão política do olhar esteja sufocada, visto que os limites do que é culturalmente desejável são fluidos. O que reforçamos ao analisar os exemplos é que há um limiar desafiador sobre o qual eles operam. E o fazem sob uma visibilidade instituída, ainda que não hegemônica, conformando-se nela ao mesmo tempo em que a desafiam. Identidades minoritárias ganham, assim, em presença, mas desaparecem na invisibilidade de tudo aquilo que não cabe na ordem do visível. O exercício do documentário, dessa forma, instaura uma distância entre o espectador e o outro que ele aborda por meio do olhar, assegurado pela mediação da tela. Ao mesmo tempo, recobre tal distância, na medida em que transporta o espectador para dentro da cena. Ele é colocado no que podemos chamar de uma posição de consumidor escópico, aproximando-se do outro e afastando-se dele. 
Acreditamos que, dessa forma, a prática documental oferece um apelo à veracidade dos fatos que estão sendo retratados e uma forma de engajamento por meio deles. O espectador é chamado a se posicionar politicamente diante de uma dita verdade. A aderência a essa visibilidade revela-nos um ato de fé assentado sobre a articulação dos fatos proposta pelas imagens. Quanto mais referenciada e codificada a imagem do outro, mais a sensação de estranhamento pode ser avivada enquanto opção estética e política, dosada pela aceitabilidade do olhar de um determinado público. Quanto mais poético, menos o filme estará comprometido com a implicação de uma resposta do espectador a uma situação descrita. Temos duas propostas diversas para formas de inscrição documental, uma delas apelando para a fruição e outra para o engajamento, uma como mecanismo de participação passiva e outra como chamado à participação ativa, ainda que em ambas ocorram diferentes graus de participação.

Rancière refere-se à imagem que causa esse tipo de estranhamento como uma “imagem intolerável”, citando seu aspecto de demonstração "da exibição da verdade do espetáculo como uma forma ainda mais intolerável de seu reinado, pois sob a máscara da indignação, ela oferecia ao olhar dos observadores não só a bela aparência, mas também a realidade abjeta" (Rancière, 2012: 83). O autor se questiona sobre a validade estética e política da circulação de tais imagens, se por mera curiosidade perversa ou se por ímpeto revolucionário. Se considerarmos que a intolerância pode ser entendida como reação à proximidade, àquilo que antes distante se torna visível de maneira não domesticada, de alguma forma a aproximação pode provocar reações passionais.

O movimento de retorno na circulação dessas cenas se faz justamente pela via do abjeto. Se uma imagem é entendida como tolerável, ela tem sua circulação aberta pelas vias de um senso comum, pautada pelos códigos instituídos de visibilidade. Se, de outro modo, ela é considerada intolerável, ainda assim o chamado para a aproximação em relação ao outro cumpre sua vocação de circular. O trajeto do grotesco se revela como o avesso do mesmo regime de visibilidade no qual estão englobados um e outro. Ambos são retratados a partir da mesma materialidade audiovisual, dependente de uma adequação a certo código de construção fílmica que os antecede.

Devemos considerar a ação do documentário como um relevo sobre os sujeitos que toca. Ele os insere no âmbito do visível, congelando-os identitariamente, ao mesmo tempo em que promove seu reconhecimento e ressignificação. O aspecto documental faz também com que personagens concretos percebam sua inserção social transformada para além da esfera fílmica. 
Apontamos para esse aspecto sem que, necessariamente, estejamos estabelecendo juízos de valor em relação a ele, especialmente nos casos de filmes sobre identidades minoritárias. Ao contrário, identificamos uma camada a mais na qual engendrar a possibilidade de circulação fílmica, qual seja: o lastro representacional de qualquer produção na cultura. As identidades alçadas para o âmbito do visível não se iniciam com o ato do documentário, mas dependem de prévios atos documentais de outra ordem. A extensão da grande tela que abarca os sujeitos tornados visíveis em filmes é cambiante e acompanha a marca social que se interpõe - e, como temos dito, caracteriza - a circulação de identidades minoritárias.

Certos documentários rasgam a cena de representações estabelecidas e se colocam como um ato criativo em direção ao novo, tendo aceitação e tolerância mais arriscada, à medida que o terreno de sua instauração social é da mesma forma incerto: "Trata-se realmente de afetos que embaralham as falsas evidências dos esquemas estratégicos; são disposições do corpo e do espírito em que o olho não sabe de antemão o que está vendo, e o pensamento não sabe o que deve fazer com aquilo" (Rancière, 2012: 101). Podemos tratar, assim, de uma adesão afetiva à novidade documentada. Se por um lado ela representa um risco, por outro resolve a aposta por reconhecimento de identidades ainda não estabilizadas, caracterizando a circulação de filmes baseada na identificação como detentora de uma implicação estética e política.

Nos exemplos apresentados, há uma profanação dos objetos tornados visíveis - a morte, a arte, o corpo - por meio de sua concretização em cena. Ao mesmo tempo, a possibilidade de que parte deles não seja reconhecível, sendo recoberta por um tão determinado e central desejo de invisibilidade, faz movimentar a dinâmica fílmica. Entendemos, assim, que mais do que tornar visível aquilo que comumente não chega à cena, está na base do fazer documental a tentativa de tomada sobre um objeto fugidio à constituição cênica e que, por isso mesmo, não pode oferecer-se por completo, nem a própria cena pode sobreviver sem obscurecer um desejo por totalidade.

Fizemos um percurso em três tempos para a análise dos filmes: retomamos a vocação referencial do documentário, instauramos a polêmica em relação à tomada documental tratando da questão da captura do outro e, finalmente, procuramos desenhar as vias de escape dessa lógica da cena instituída apresentando formas da (in)visibilidade documentada. Ainda que a perspectiva tradicional do documentário procure filiar-se ao registro do verdadeiro, há em filmes recentes uma presença forte e constante da ficcionalização do relato, seja por meio de narrativas de busca ou naquelas tidas como 
autorreferenciais. Esse ímpeto está ligado, como o entendemos, à forma de percorrer a distância entre um "eu” e um "outro", não apenas em relação ao realizador dos filmes, mas também ao público, que se soma àqueles que documentam uma parcela da realidade, e também aos outros que compõem recortadamente a cena e nela se fazem.

Nesse primeiro tempo, há uma latente necessidade de recobrir a distância entre ambos num desejo de reparação narrativa, e o documentário o faz elevando traços de uma diferença. Não anotamos se tal diferença é considerada positiva ou negativa, mas destacamos sua condição de ser algo de interesse para ser visto. Há sempre, dessa forma, um olhar que marca o outro e o insere na ordem do visível. Ao mesmo tempo, como afirmamos, o outro se apresenta e se instaura a partir de sua entrada em cena. Desse modo, há sempre um momento que aponta para a questão da invisibilidade, inclusive e especialmente nos casos analisados à guisa de demonstração.

Ao documentar, torna-se visível um outro de alguma forma distante, seja espacialmente, temporalmente ou, ainda, psicologicamente. Ou seja, outrem que não estava visível a olho nu no convívio cotidiano presentifica-se segundo a perspectiva daquele que o reporta e, ao fazê-lo, aponta também para o lugar de sua invisibilidade. Novos atores sociais são postos em cena de modo mais ou menos disciplinado, ou como sujeitos enquadrados em regimes de visibilidades vigentes, ou como sujeitos em quadro que ampliam as políticas da representação usuais.

O segundo tempo do endereçamento à invisibilidade é a apresentação desse outro numa cena em que tal invisibilidade vem à tona, muitas vezes tematizada como ideia central do próprio documentário. Nesse sentido, atribui-se a missão de fazer ver o que estava obscurecido ou que não pode ser facilmente feito imagem, como no caso de documentários que tratam de identidades minoritárias ou de temas socialmente ignorados. Nesses casos, a presença do outro na cena é assumida de forma positivada, como movimento afirmativo de inclusão. Temos, assim, um processo criativo de tradução da questão do outro-personagem em formato de discurso audiovisual.

Tal criação apresenta um desafio que tem, de um lado, a possibilidade de evidenciar o outro e, ao mesmo tempo, o risco de aprisioná-lo nas escolhas cênicas. Assim, documentários são polêmicos em seus discursos e escolhas éticas, estéticas e políticas. Esse processo pode ser identificado tanto na construção da narração, como na articulação imagética. Se a narração pode apontar caminhos, ressaltando com palavras o que é visto, as imagens apelam para os olhos e conduzem o espectador para dentro da cena. 
É nesse sentido que devemos ressaltar um terceiro e último aspecto dos documentários em relação à questão da invisibilidade. A marca da presença do outro em cena é atestado de sua ausência e, de certa forma, o contrário também é válido: a ausência do outro em cena é seu nível de máxima presença. Ou seja, a documentação audiovisual sobre o outro é um processo de criação narrativa e sua presença é interferida pela associação com outros objetos em cena, que concorrem para construí-lo ou desmontá-lo. Assim, muitas vezes ao tentar reportar o outro, tornando-o visível, devolvemos a ele uma posição de invisibilidade. Ao mesmo tempo, a latência de sua representação pode se tornar sua maior possibilidade de inteireza, como numa cena em que um personagem não está presente, mas seus efeitos visíveis se fazem sentir.

Os processos de invisibilidade, portanto, são fundantes na criação documental, tanto na aproximação com o outro por meio de temáticas específicas, como na inserção lógica de cenas que articulam os discursos audiovisuais: "É a voz de um corpo que transforma um acontecimento sensível em outro, esforçando-se por nos fazer 'ver' o que ele viu, por nos fazer ver o que ele nos disse" (Rancière, 2012: 92). Nessas duas perspectivas, podemos dizer que a invisibilidade torna plástica e maleável a composição cênica, sendo a principal responsável pela estruturação de uma dinâmica fílmica aberta a diferentes modos de representação e a novas formas de visibilidade.

\subsection{Factualidade e ficcionalidade em programas televisivos}

Como apontado, a proposta tem como objetivo o estudo de discursos das mídias de caráter realista a fim de estabelecer uma análise contrastiva entre eles. Buscamos demonstrar que o estabelecimento das fronteiras entre fato e relato se faz no tensionamento dessas posições, alargando os limites entre "referencialidade" e "ficcionalidade" em narrativas audiovisuais, contribuindo para a reflexão sobre o estatuto da imagem na atualidade. Fatos e relatos colocam-se, assim, como estratégias complementares na organização desses discursos, embaralhando as fronteiras entre realidade e fabulação. Por meio da observação de documentários e reportagens, exploramos a questão dos novos realismos presentes nos discursos das mídias a partir de uma perspectiva histórica sobre as formas de endereçamento do mundo concreto, passando pelas injunções das imagens técnicas frente a uma cultura audiovisual cada vez mais marcada por processos que visam produzir determinados efeitos de realidade, oscilando entre o retorno do real e o elogio da ficção. 
Tomamos a expressão "novos realismos" na definição de Jaguaribe, que aponta no cinema iraniano, no manifesto do grupo escandinavo Dogma, no cinema engajado britânico, em documentários contemporâneos e filmes latino-americanos sobre conflitos urbanos, entre outros, os "novos registros do realismo" como um fenômeno global presente não apenas no cinema, mas também na literatura, na fotografia e nas mídias que contribui para os modos de percepção da realidade: "No Brasil, os novos realismos despontam dentro de gêneros como o romance policial e a narrativa da violência marginal, ou em retratos do cotidiano que esmiúçam, com maior ou menor pendor psicológico ou naturalista, os impasses de vidas anônimas" (Jaguaribe, 2007: 11).

Sabemos ser este um tema abrangente e, desse modo, iremos nos deter em exemplos recentes voltados à construção da representação de diferentes sujeitos nas mídias. Buscamos identificar, nas imagens, as maneiras pelas quais se estabelecem os espaços de visibilidade/invisibilidade em relação a grupos minoritários estigmatizados no cenário social. Nas oscilações entre reforço ou transposição de estigmas, tais narrativas audiovisuais empreendem, em relação ao "outro" para o qual se voltam, processos de assujeitamento ou, ao contrário, de protagonismo. Nesse confronto de representações, para além de visões hegemônicas, uma pergunta norteia a proposta: se as realidades são discursivamente construídas, como propor modos de representação do "outro" da forma mais ativa (e altiva) possível?

Ao apontar que, recentemente, as contradições sociais têm sido tematizadas, na produção teórica e audiovisual contemporânea, por meio das relações entre estética e política, Figueiredo nos alerta: "Se, no passado, ao fazer referência ao abismo entre as elites e o povo, falava-se dos que tinham ou não tinham voz, hoje, fala-se, cada vez mais, dos que possuem ou não possuem visibilidade" (Figueiredo, 2012: 11). Mais do que a proliferação de imagens ou o excesso de exposição, "é a imagem mais do que a palavra, o espectador, mais do que o ouvinte ou o leitor, que servem de ponto de partida quando se trata de refletir sobre a necessidade de alterar a distribuição de papéis e competências hierarquicamente estabelecidos" (Figueiredo, 2012: 11), fato que nos coloca frente às especificidades da cultura audiovisual contemporânea, sobre a qual iremos refletir em alguns de seus aspectos. Desse modo, a estética realista e a hiperrealidade; a retórica testemunhal e a ênfase em visualidades precárias; as políticas de partilha do sensível e os novos regimes de visibilidade, entre outros, são elementos fundamentais para problematizarmos o estatuto das imagens hoje. 
A dimensão da cultura, e os processos de sua legitimação por meio dos discursos circulantes, possibilita que pensemos a produção audiovisual como sintoma de uma época pautada pelo desajuste, pelo transbordamento e pelo conflito, aspectos que se fazem presentes, portanto, em tal produção. Ao nos indagarmos sobre as maneiras pelas quais a autenticação da realidade se impõe nas narrativas da televisão e do cinema, indagamo-nos, também, sobre as possibilidades de delinear os contornos de um realismo crítico e político, oscilando entre uma forma documental de expressividade e o melodrama ficcional narrativo. Para além da construção de efeitos de realidade, em que ocorre o mascaramento dos processos de ficcionalização nela implicados, vemos nas narrativas audiovisuais uma espécie de retorno pregnante do real (na forma de paixão, retorno ou choque) ${ }^{89}$ contrapondo-se ao elogio disperso da ficção (na encenação reiterada do mundo vivido) ${ }^{90}$.

Se, a partir da psicanálise, o Real é aquilo que insiste, mas não resiste à simbolização, é no registro do imaginário que podemos investigar as atuais políticas de construção da representação frente às posições de totalização ou inadequação, adesão ou fricção, transparência ou opacidade, presentes nas narrativas audiovisuais, pensadas não como categorias estanques, mas como formas genéricas: "Contra a ficção que pretende existir por si mesma, como reflexo do real, é proposto o discurso que fala sobre suas próprias condições de existência e, portanto, afirma-se como reflexo do trabalho de produção e de suas funções sociais e materiais" (Xavier, 1984: 134).

Assim como a opacidade permite que seja desvelado o dispositivo, ao negar a transparência da ficção o discurso audiovisual aponta para outros modos de dar a ver o visível. Ao nos voltarmos para os modos de construção da realidade em narrativas audiovisuais assumimos, portanto, que processos de ficcionalização se fazem presentes para o engendramento da referencialidade pretendida em tais discursos, tanto no caso de produções de caráter factual, como naquelas propriamente ficcionais (Soares e Freire, 2013).

\footnotetext{
${ }^{89}$ A expressão "choque do real", cunhada por Beatriz Jaguaribe em livro homônimo, é por ela definida como sendo "a utilização de estéticas realistas visando suscitar um efeito de espanto catártico no leitor ou espectador" (Jaguaribe, 2007: 100). Para a autora, o impacto do "choque" não vem de seu caráter extraordinário, mas de sua intensificação.

${ }^{90}$ Nesse sentido, lembramos a obra de Wolfgang Iser, especialmente no que diz respeito ao princípio da representação, em que o realismo seria, também ele, fictício ou imaginário - pois estes se apresentam como "disposições antropológicas" com poder libertário em relação às normas culturais estabelecidas (Iser, 2013). A obra de Umberto Eco, especialmente ao tratar dos conceitos de autor e leitor modelos (ou implícitos), aproxima-se de Iser em sua dimensão da recepção como um modo ativo de participação (Eco, 1994). Além desses autores, Peter Gay, aponta os modos diversos de endereçamento da realidade em obras de ficção, notadamente naquelas de cunho predominantemente realista (Gay, 2010).
} 
Nas palavras de Jaguaribe, “o paradoxo do realismo consiste em inventar ficções que parecem realidades" (Jaguaribe, 2007: 16). Mais do que isso, desde a modernidade compreende-se que as realidades são socialmente fabricadas, ou seja, "que os imaginários culturais são parte da realidade e que nosso acesso ao real e à realidade somente se processa por meio de representações, narrativas e imagens" (Jaguaribe, 2007: 16). Interessa-nos, assim, explorar as tensões advindas dessa relação e seus modos de inscrição nos discursos das mídias, produzindo efeitos de sentido que vão da ilusão da objetividade ao testemunho da verdade em tais narrativas: "Só podemos conhecer o real comparando-o ou equiparando-o ao imaginável” (White, 1994: 115).

Do ponto de vista metodológico, buscamos abordar os novos realismos por meio da temática dos estigmas sociais presentes em narrativas audiovisuais. Nas diferentes posições ocupadas pelos sujeitos no tecido social; nos embates entre cada um e todos os outros; nas demarcações entre estigmas, estereótipos e preconceitos; nos modos de estabelecimento dos espaços de visibilidade e invisibilidade social; e nas disputas por formas hegemônicas de construção da representação nos discursos circulantes, identificamos um terreno fértil para a problematização de tal questão. Se o retorno do real surge como resposta ao elogio da ficção, novos realismos parecem também apontar para novos modos de ficcionalização.

\subsubsection{Narrativas audiovisuais: o caso brasileiro}

A produção televisual recente, notadamente documentários cinematográficos, grandes reportagens televisivas e reality shows (estes últimos considerados não enquanto programas isolados, mas como um gênero televisivo que se espraia por diversos outros gêneros) constitui a amostragem ampliada nesse momento. Com esse intuito, destacamos as produções integrantes daquilo que se convencionou chamar de "reality $t v "$ (ou "factual tv", incluindo documentários jornalísticos), do qual fazem parte não apenas reality shows, mas também documentários, séries, seriados, reportagens, programas de auditório ou de variedades, enfim, uma imensa gama de gêneros e formatos que confluem para este que seria, a partir de nossas observações, o modo privilegiado presente na televisão atual (Machado e Vélez, 2009; Kavka, 2012).

A partir da observação da programação televisiva e da aderência aos reality shows - tanto do lado da produção, como da recepção -, notamos que, ao contrário do que acontecia anteriormente, as formas de inscrição da realidade na televisão tem se 
pautado por novos realismos. Nesse sentido, a realidade é encenada através de diferentes formas narrativas oriundas da ficção. A reality tv torna-se a narrativa televisiva predominante, para além dos reality shows, como se os gêneros televisivos se endereçassem de algum modo a ela. Essa demarcação é tomada como uma espécie de marca distintiva (ou até mesmo uma vocação da produção televisiva), apontando sua inserção na produção audiovisual recente. Ao observarmos os programas televisivos, tomamos como ponto de partida formas narrativas impuras.

Para alcançar nosso intuito, estabelecemos diálogos com a produção inglesa, buscando demonstrar como as questões dos hibridismos e dos novos realismos se apresentam em diferentes culturas, enfatizando os conceitos articuladores das análises. Desse modo, buscamos tratar não apenas de um dos grandes eixos no estudo das imagens hoje, mas também iluminar, ainda que de modo tangencial, a dinâmica da produção audiovisual - em que a televisão assume lugar de protagonismo, mas na qual vemos crescer, no caso brasileiro, também o cinema -, considerando os modos de produção, distribuição e recepção que tornam singulares seus diferentes discursos.

Em termos conceituais, investigamos os espaços da presença/ausência de atores sociais não hegemônicos, bem como os pontos de redundâncias e ressonâncias dos estigmas sociais nos discursos das mídias; as formações discursivas como espaços de intertextualidade e heterogeneidade, comumente referidas nos debates sobre convergências midiáticas e hibridismos narrativos; as novas posicionalidades do sujeito em meio à proliferação de imagens e, consequentemente, as transformações no imaginário social; as políticas de representação ou as atuais formas de "partilha do sensível" (Rancière, 2005), especialmente aquelas relacionadas a figuras de alteridade, estabelecendo as tensões entre as narrativas do mesmo e do outro nelas apresentadas (Prado, 2008).

Em relação à amostragem, interessam-nos os "contratos comunicacionais" (ou "pactos de leitura") frente aos novos "regimes de visibilidade" em que os discursos referenciais ${ }^{91}$ deslizam para narrativas híbridas presentes nas mídias por meio de novos realismos: "Para nós que discutimos os regimes de visibilidade dos media, construídos em torno dos contratos de comunicação voltados a modalizar formas de ser e de fazer o corpo e com o corpo, sustentando-se em valores simbólicos ligados ao mundo do

\footnotetext{
${ }^{91}$ Discursos voltados à experiência da realidade, em que elementos históricos são tomados de forma supostamente objetiva para compor os relatos sobre os fatos, ao contrário do que é suposto nos discursos ficcionais, em que modos de fabulação são prioritariamente acionados na composição de suas narrativas (Barthes, 1988).
} 
consumo, tais formas de ver e de ser olhados pelos objetos culturais é preciosa" (Prado, 2012: 181). Desse modo, o discurso jornalístico (reportagens televisivas) e discurso cinematográfico (filmes documentários) não são vistos de maneira estanque, ressaltando as interfaces presentes na televisão e no cinema.

Assumindo, portanto, o hiato desde sempre incontornável entre linguagem e referente, e embasados pelos debates sobre convergências midiáticas e hibridismos discursivos, vislumbramos um conjunto de imagens que oscila entre as fronteiras movediças das narrativas impuras, mescladas por meio do trânsito entre elementos estéticos e tecnológicos. A crítica ao conceito de representação e sua desconstrução, como apontamos no início do artigo, é um importante eixo teórico-metodológico para as análises, problematizando tensionando narrativas de caráter referencial a partir dos modos de "dar a ver" as figuras de alteridade nelas presentes e as políticas de representação nelas ensaiados. Entendemos "política" na acepção dada por Rancière a este conceito: "A atividade política é a que desloca um corpo do lugar que lhe era designado ou muda a destinação de um lugar; ela faz ver o que não cabia ser visto, faz ouvir como discurso o que só era ouvido como barulho", alterando, assim, os regimes de visibilidade (Rancière, 1996: 42).

Dentro desse cenário, a questão dos modos de construção da representação especialmente de sujeitos tradicionalmente deles excluídos - pode ser elaborada a partir de alguns apontamentos, em que os discursos (ou seus vestígios) articulam-se, inicialmente, a partir da aproximação a um outro diverso e distante. Vemos surgir nessas narrativas um outro não representável e que, ao longo delas, oscila entre ausência e presença, invisibilidade e visibilidade. Em termos de posições discursivas, podemos afirmar que o outro, qualquer que seja ele, pontua desdobramentos que vão dos não ditos à inclusão consentida para, finalmente, assumir lugar de protagonismo, apontando para momentos de afirmação e identificação. Nas palavras de Geertz, ao tratar das relações entre aqueles que podem propor modos de representar o outro e aqueles neles representados, "o fim do colonialismo alterou radicalmente a natureza das relações sociais entre os que perguntam e observam e os que são perguntados e observados" (Geertz, 2005: 172), problematizando os relatos produzidos sobre os outros, próximos ou distantes, e acentuando o caráter conflituoso desse encontro com a alteridade. 
Nesse momento, apresentamos os principais resultados de novas análises sobre o programa televisivo Profissão Repórter, que vêm se somar àquelas anteriormente vistas. Mais especificamente, destacamos episódios que tratam do uso de drogas, sobretudo o crack, e outros, mais recentes, em que destacamos mudanças no posicionamento do repórter frente aos sujeitos que pretendem retratar em suas matérias televisivas.

Em Profissão Repórter, programa exibido pela Rede Globo de Televisão e no ar desde 2006 (inicialmente como quadro dominical do Fantástico e semanalmente desde 2008), notamos forte ênfase em temas voltados à apresentação de conflitos sociais, envolvendo questões sobre violência urbana, criminalidade, segurança, prostituição, trabalho infantil, desemprego ou subemprego, desigualdades sociais, entre outras. Tal ênfase coloca os estigmas como eixo articulador dos episódios, reforçando o caráter de denúncia e crítica presentes no jornalismo, bem como sua inclinação para a exibição de pontos de vista diversos sobre um mesmo assunto ou acontecimento, aspecto ressaltado pela edição alternada das histórias narradas, sempre contrastantes entre si em termos de enfoques, personagens e cenários ${ }^{92}$. Ainda assim, o reforço de perspectivas socialmente estabilizadas em relação ao tema reincide nos episódios.

Dentre as reportagens ${ }^{93}$, destacamos aquelas que abordam a questão da dependência de drogas, notadamente o crack, considerando suas marcas enunciativas, referências discursivas, espectador pressuposto e elementos de contexto e apontando para o caráter polifônico de tais narrativas. Entre 2006 e 2012, temos seis episódios em torno dessa temática, a saber: 1) "Crack" (30/06/2009), sobre consumo entre jovens de classe média, em São Paulo, e uma família de classe média, em Porto Alegre, em que a mãe matou o filho, usuário de crack, para se defender. 2) "Crack 2" (14/07/2009), em que Caco Barcellos vai à Cracolândia, no centro de São Paulo, para acompanhar ação da polícia e protesto de comerciantes contra a presença de dependentes de drogas, e à zona sul da cidade, para mostrar local de permanência de usuários para utilizar o crack. 3) “Crack 3" (04/05/2010), sobre hospital que realiza atendimento a mulheres grávidas usuárias de crack, em Porto Alegre, e encaminhamento de morador de rua, em São Paulo, para tratamento em uma clínica no interior do Estado. 4) "Crack 4" (16/11/2010),

\footnotetext{
${ }^{92}$ Para análises sobre o programa desde seu início, ver Profissão Repórter em diálogo (Soares e Gomes, 2012), que apresenta perspectivas diversas nas quais pensar o telejornalismo contemporâneo.

${ }^{93}$ A íntegra das reportagens está disponível no site http://g1.globo.com/profissao-reporter/videos. Até 2010, o programa apresentou 151 episódios; em 2011, foram exibidos por volta de 20 episódios e, em 2012, cerca de 35 episódios, totalizando, de 2006 até aquele ano, mais de 200 reportagens. Em 2015, o programa somou cerca de 300 episódios exibidos, sendo mais de 20 por ano e contando os 40 episódios iniciais enquanto quadro do programa Fantástico.
} 
em que são mostradas situações de familiares em busca de seus filhos dependentes para levá-los a centros de tratamento, em São Paulo. 5) "Jovens e drogas" (19/07/2011), filmado em Salvador, Rio de Janeiro e São Paulo, abordando dramas familiares e encaminhamento de jovens dependentes para tratamento. 6) "Crianças vítimas do crack" (02/10/2012), acompanhando crianças internadas compulsoriamente pela prefeitura do Rio de Janeiro, em 2011, e famílias que buscam tratamento em Belo Horizonte.

Do total de episódios do programa, a temática tem pouca presença em números absolutos, mas pode ser estendida a questões correlatas, como o uso de álcool, a questão do tráfico ou da violência urbana, geralmente presentes nas editorias de Polícia, Cidades ou Cotidiano. É interessante notar como a questão dos estigmas se faz presente por meio da ênfase em personagens específicos, em pequeno número a cada reportagem; da realização de entrevistas nas quais os repórteres interferem no enfoque, interagindo com eles, chegando até mesmo a exprimir sua opinião; da abordagem de elementos do cotidiano em que a dependência de drogas se torna um problema familiar e próximo.

As reportagens abordam questões particulares, representadas pela vida de indivíduos específicos (dependentes, familiares), mais do que questões coletivas, o que pode ser percebido na ausência de entrevistas com médicos, policiais ou representantes do poder público. Visando humanizar as reportagens e voltando-se a um apelo emocional (muitas vezes acompanhando as opiniões do senso comum), os episódios não chegam a contextualizar a problemática em relação ao tráfico e às supostas causas da dependência, bem como às possíveis soluções em termos políticos. Nesse sentido, ainda que tematizem questões relevantes do ponto de vista social, limitam-se a mostrar fragmentos, sem complexificar a temática, imputando aos próprios sujeitos retratados a responsabilidade - seja no sentido de culpabilização ou de cura - por sua situação e a possível manutenção ou transformação desta. Os estigmas permanecem, então, calcados nos próprios sujeitos, como marcas das quais eles não podem se separar.

Ao contrário de visões totalizantes, vimos surgir, nos últimos anos, um acirramento dos embates entre os modos de visibilidade e/ou invisibilidade inscritos na cultura contemporânea, em que binarismos simplistas não são suficientes para refletir sobre os processos de legitimação cultural e as cada vez mais constantes transposições presentes no campo das trocas simbólicas. Os mecanismos de reprodução social e sua eficácia, organizando o mundo vivido por meio de discursos que buscam atestar a ordem estabelecida, de acordo com Bourdieu (2008), são desafiados pelos diversos atores sociais por meio de diferentes usos e apropriações. 
No jogo entre identidades é que podemos compreender determinada parcela da produção telejornalística, como aquela representada por Profissão Repórter, e certa produção de documentários contemporâneos, como os destacados anteriormente. Ao tematizar os estigmas sociais, os regimes de visibilidade acionados para estabelecimento de lugares sociais em conflito (por meio de personagens considerados incomuns ou transgressores), desafiam a demarcação de fronteiras explícitas, tanto em termos formais, como temáticos, seja na questão da referencialidade construída por suas representações, seja em relação às estratégias narrativas utilizadas. Isso pode ser percebido tanto em produções televisivas, como cinematográficas, lembrando que, nesse momento, destacamos as de caráter referencial, ou seja, aquelas em que os acontecimentos do mundo histórico colocam-se como primordiais.

O dinamismo e a longevidade do programa nos permitem avançar em nossas considerações, trazendo-nos, como apontamos anteriormente, às crescentes transformações no telejornalismo convencional que, no primeiro semestre de 2015, têm mobilizado as colunas de críticos de televisão (entre eles, Mauricio Stycer e Daniel Castro, respectivamente colunistas dos sites UOL e Notícias da TV) em torno de seus erros e acertos. Ainda que haja certo exagero no tom informal dos apresentadores, autorizados que estão a expressar suas opiniões sobre as notícias, a interação com o público, motivada pelo uso da internet, agrega valores antes não vistos nos telejornais. Essas mudanças devem-se, em grande parte, àquelas inauguradas por Profissão Repórter e potencializadas pela difusão das mídias digitais e o crescimento das redes sociais.

Se no início Profissão Repórter foi definido como um formato inovador de reportagens, em que pautas pouco usuais permitiam a apresentação de olhares diversos sobre seus temas, hoje um movimento reverso é percebido: as formas jornalísticas, as estratégias estilísticas e as escolhas estéticas por ele propostas se espalharam por outros gêneros, reconfigurando programas tradicionais de reportagens. Além de inserir pontos de vista variados sobre as notícias e seus bastidores, Profissão Repórter vem transformando os lugares de fala e de escuta até então predominantes no jornalismo, posicionando produtores e receptores no interior dos fatos narrados. Assim, elementos técnicos, recursos tecnológicos e artifícios narrativos atestam a impossibilidade da neutralidade da reportagem, pois há sempre intervenção e presença da equipe. Ao mostrar o ato de filmar - e ao selecionar o que será mostrado ao público -, o programa reafirma sua credibilidade ao falar de si e ao contar com o saber pressuposto no espectador. 
$\mathrm{O}$ efeito de realidade (ou de verossimilhança) surge desse encontro entre a reportagem, o repórter e o público, numa espécie de narrativa ampliada que conecta essas posições, modificando as formas narrativas dos programas jornalísticos. De modo análogo, ao demonstrar que os repórteres também estão sujeitos às noticias, imprimindo nelas suas vivências sociais e culturais, os episódios do programa - sobretudo aqueles mais recentes - constroem este lugar subjetivo como espaço legítimo de articulação do discurso jornalístico. Enquanto discurso, o formato proposto assume para si uma perspectiva polifônica, articulando diversas vozes em suas narrativas e mobilizando de modo dinâmico os que produzem as reportagens e aqueles que a elas assistem.

O programa Profissão Repórter, a exemplo do filme de Antonioni (1975), parece referir-se a estratégias narrativas e discursivas próprias dos documentários (em seus variados estilos) no que diz respeito à possibilidade de reposicionamento dos repórteres diante das câmeras. O diretor Dziga Vertov, no filme $O$ homem com a câmera (1929), antecipara não apenas o formato documental, mas também o que viria a ser o jornalismo gravado em imagens: a filmagem de um dia típico, em cenas externas que retratam o amanhecer de cidades soviéticas e seu progressivo movimento, retrata pessoas comuns em seus afazeres cotidianos, encontra ecos nas inúmeras reportagens que povoam as telas de televisão e da internet.

É assim que vemos a repórter Eliane Scardovelli viajar aos Estados Unidos para conhecer a família de uma criança nascida menina, mas que não se identifica com o gênero em que nasceu, enquanto no Brasil são mostrados jovens e adultos que mudaram de gênero por escolha pessoal, muitos deles com apoio do sistema público de saúde. A questão da "Transexualidade" é o tema do episódio de 18 de novembro de $2014^{94}$, reportagem na qual fica patente o cuidado por não invadir a privacidade das fontes, nem forçá-las a falar sobre seus problemas ou preconceitos, e como fazem para enfrentá-los. $\mathrm{Na}$ parte sobre a família americana, a sensibilidade da repórter e sua empatia com os personagens que retrata ficam patentes nas imagens e na narração, como quando afirma: "É muito difícil tocar nesse assunto, temos que respeitar o tempo dele. E se ele não quiser falar sobre isso, não tem problema". No começo, a repórter conta para os espectadores o que está acontecendo, mostrando sua familiaridade com a história que irá mostrar ao público. Ouvimos também a conversa entre ela e o câmera, na qual discute se deveria tentar se aproximar da criança de novo, registrando seu convívio com a fonte.

\footnotetext{
94 Ver: http://g1.globo.com/profissao-reporter/videos/t/programas/v/transexuais-falam-sobre-adequacaosexual-e-como-encaram-a-sociedade-parte-1/3774317/.
} 
É também Eliane Scardovelli quem nos guia em um relato mais conflituoso, a respeito da morte de um homem, supostamente causada por ação policial. No programa "Polícia"95, exibido em 24 de fevereiro de 2015, o episódio aponta que as mortes causadas por policiais tiveram um aumento de 80\% em um ano em São Paulo. Em 2014, 801 pessoas foram mortas por policiais militares no estado e 10 policiais foram mortos em serviço na capital e Grande São Paulo no mesmo ano. Na história narrada pela repórter, sobre um surfista de Santa Catarina morto por um policial militar que estava em dia de folga, ao tentar entrevistar a família do policial acusado pelo crime três viaturas surgem na antes deserta rua, exigindo que as filmagens sejam interrompidas.

A cena é mostrada de longe pelo cinegrafista, que não aparece nas imagens, mas que se posiciona dizendo que está em uma via pública e que vai continuar a gravar. Ao fazer isso, também a repórter - mesmo assustada - sustenta seu lugar e inicia um diálogo com um dos policiais, que após ter dito que não autoriza que sua imagem fosse mostrada na televisão, aceita conversar. Não se trata, nesse caso, do confronto entre ela e o guarda, mas justamente da marcação de um lugar de fala que defende a vitima da violência policial, assumindo um posicionamento claro dentro da narrativa e revelando o abuso policial sofrido pela equipe.

Na reportagem "HIV"96, exibida em 2 de dezembro de 2014, aprendemos sobre a parceria entre Brasil e Moçambique elaborada e colocada em prática pela Fiocruz, contribuindo para o aumento de tratamento do HIV naquele país com a produção de medicamentos, já que $41 \%$ dos infectados não têm acesso a eles. A parte filmada na capital (Maputo) nos mobiliza por mostrar a repórter Valéria Almeida anunciando em primeira pessoa o que significa para ela, negra, estar naquele continente: "É uma emoção ser recebida na África desse jeito. Sempre sonhei pisar em solo africano". Na sequência vemos o esforço por integrar-se aos hábitos locais e conviver com aquelas pessoas tão diversas e tão próximas de nós, ao mesmo tempo em que somos apresentados a uma realidade desafiadora e precária em relação à epidemia da aids. Em toda a reportagem, dados referenciais e sociológicos se mesclam ao encontro da repórter com lideres comunitários, autoridades e pacientes, sempre respeitando estes últimos quando se recusam a falar da doença.

\footnotetext{
95 Ver: http://globotv.globo.com/rede-globo/profissao-reporter/t/para-assinantes/v/profissao-reporterpolicia-24022015/3990966/.

96 Ver: http://g1.globo.com/profissao-reporter/videos/t/programas/v/parceria-entre-brasil-e-mocambiqueaumenta-tratamento-de-hiv-no-pais-parte-1/3805009/.
} 
Ao final do programa, a repórter tenta conversar com uma curandeira para mostrar o contraste entre os tratamentos médicos, que diz que dará a entrevista apenas se for paga. Ela demonstra sua dúvida mas se recusa a pagar, mesmo sabendo que abordar a medicina local seria importante. Ao ser questionada na ilha de edição por Caco Barcellos, a repórter afirma de modo contundente que jamais pagou para conversar com uma fonte e que não se sentiu confortável para fazer isso. Independentemente de nossa concordância ou não com a decisão, somos levados a nos posicionar sobre o ocorrido, assim como Valéria Almeida teve que se posicionar e assumir uma função ativa naquele momento, sendo cobrada depois por sua escolha.

Dentre os episódios mais recentes, um último exemplo confirma a primazia da experiência e do testemunho como elementos não apenas de humanização da reportagem, mas de reposicionamento dos repórteres. No programa "Carnaval"97, exibido em 17 de fevereiro de 2015, notamos a presença participante dos repórteres, que acompanham os últimos dias dos preparativos para os desfiles, inserindo-se no contexto das pessoas envolvidas no carnaval de grandes e pequenas escolas. No Rio de Janeiro, Thiago Jock e Danielle Zampollo alugam uma casa no bairro que é sede da escola de samba Portela (além de três outras escolas de samba), em Madureira, um mês antes do carnaval. Nas imagens vemos os repórteres se instalando na casa, preparando-se para o calor carioca e relatando sua experiência como novos inquilinos e o contato próximo com os moradores da região. No último ensaio da escola, já no Sambódromo, a repórter nos convida: "Esse ônibus vai levar a ala da comunidade... E como de certa forma a gente faz parte da comunidade agora também, a gente vai com eles".

Em São Paulo, o repórter francês Pierre Morel é convidado para mostrar os preparativos do evento. Filmado e entrevistado por Valéria Almeida, ele se apresenta e conta para a câmera que "só viu o carnaval pela televisão", mas "agora vai ver de verdade". O desconhecimento do repórter imprime uma peculiaridade ao episódio: ao demonstrar suas dúvidas e fazer perguntas que qualquer um de nós poderia fazer, ele não apenas se reposiciona em relação às fontes mas, sobretudo, troca de lugar com o espectador, inserindo-nos diretamente na narrativa. Ao ser convidado para desfilar na avenida com a escola, a edição nos mostra o repórter telefonando para Caco Barcellos, perguntando se pode aceitar o pedido, que é atendido com uma ressalva: "Eu não concordaria se fosse toda sua matéria você lá sambando. Mas como você está fazendo

$97 \quad$ Ver: http://globotv.globo.com/rede-globo/profissao-reporter/v/profissao-reporter-carnaval-2015$17022015 / 3973800 /$ 
essa matéria com outras, com postura de repórter mais tradicional, pode ter uma de modo diferente, mais próximo, mais de perto". Ao que ele responde: "De toda maneira, eu sambando não vai acontecer não".

Nesse breve diálogo, realizado durante a gravação e mostrado ao telespectador, retomamos os elementos anteriormente apontados: as mudanças no telejornalismo, a maior participação dos repórteres e o consequente reposicionamento de seu papel na reportagem e na relação com o público. Ao final, o francês desfila vestido de índio e torna-se também um personagem da reportagem, comentando suas impressões e ansiedade frente ao desafio do desfile na escola paulistana Nenê da Vila Matilde.

Nos episódios isolados acima, há um exercício de entendimento do outro e de suas motivações, mostrando um universo controverso e por vezes bastante distante dos repórteres e também dos espectadores, levando-nos a considerar opiniões diferentes de modo menos estereotipado ou preconceituoso mas, ao mesmo tempo, assumindo que o ponto de vista do observador (ou do repórter) interfere naquilo que é observado (a reportagem). Nesse sentido, alguns desafios se agregam à proposta de Profissão Repórter: como retratar realidades e pessoas diferentes de mim? Como apresentá-las de modo autêntico e coerente com elas mesmas? Para além do reposicionamento dos repórteres, impõe-se a questão da alteridade e seus modos de representação.

Mais do que relatos em primeira pessoa, prática comum ao jornalismo, o que temos é a possibilidade do próprio jornalismo se posicionar frente aos fatos narrados, para além da imparcialidade antes almejada. A diferença se dá exatamente na atuação do repórter: sua voz, ainda que em primeira pessoa, não fala necessariamente de seu ponto de vista, mas coloca-se no lugar do outro, introduzindo o espectador também nesse lugar e permitindo seu engajamento e um modo mais ativo de recepção das reportagens. Essa mudança ética tem precedentes anteriores à proposta estética na inversão do posicionamento do repórter enquanto formulador de questões para um espaço que se abre a questões alheias.

Já na década de 1950, o antropólogo Jean Rouch experimentara em seus filmes a mistura entre documentário e ficção, transformando as relações dos cineastas com aqueles por eles filmados. Em vez de serem tratados como sujeitos passivos diante da câmera, os personagens passaram a ser construídos ao longo da própria filmagem, construindo uma realidade encenada e não apenas reproduzindo os fatos narrados de modo supostamente objetivo. A "verdade provocada" (Rouch, 2003) pelos personagens deveria produzir a "verdade do filme", sempre aberta ao imprevisto. 
Amplificando o procedimento instaurado por Rouch em seus filmes etnográficos, vemos colocar-se, no programa, uma dupla perspectiva: por um lado, busca-se construir o lugar da alteridade e aproximar-se de um outro diverso a partir de seu próprio ponto de vista, instaurando não a verdade do fato (princípio tão caro ao jornalismo convencional), mas a verdade do relato (como aquela buscada nos documentário). Por outro, um deslocamento é percebido: além de instaurar os sujeitos retratados como narradores (e personagens) de suas histórias, Profissão Repórter coloca o próprio repórter nesse lugar de narrador e, mais ainda, de protagonista do relato, compartilhando com os entrevistados os pontos de vista apresentados.

A exemplo da "antropologia compartilhada" de Rouch (2003), vemos nascer um “jornalismo partilhado", no qual, assim como o antropólogo que se põe em interação com os sujeitos observados (desconstruindo ideias preconcebidas a seu respeito), o jornalista também inverte, momentaneamente, sua posição, trocando de lugar com os sujeitos entrevistados e encenando a reversibilidade de papeis entre aquele que revela algo e aquele que é revelado na reportagem. A ação reveste-se de um risco inerente a esse movimento, que poderia resultar na perda do lugar do jornalista (e consequentemente, do jornalismo), como instituidor de realidades. Entretanto, a troca de posições entre repórteres e entrevistados insere de modo direto o espectador na narrativa, reforçando seu caráter relacional e apontando para um jogo dinâmico entre aquilo que se esconde e aquilo que se mostra na cena.

Se a apresentação da realidade dos fatos é premissa e promessa do jornalismo, o reposicionamento dos repórteres reafirma esse pacto junto ao telespectador, assumindo a subjetividade como componente da reportagem. Ao mostrar os bastidores das notícias, reafirma-se a objetividade dos fatos, ainda que contados a partir de um ponto de vista especifico. Reafirma-se, assim, o compromisso com o público, a dimensão politica, a perspectiva ética e o lugar autoral do jornalismo enquanto instituição social.

Ocorre, desse modo, uma espécie de equilíbrio entre a exterioridade dos fatos e a interioridade dos relatos, no qual subjetividade e objetividade se encontram por meio dos entrevistados, que legitimam a percepção do repórter em relação a suas vivências. Se as experiências subjetivas dos repórteres podem constituir relatos objetivos a respeito dos sujeitos entrevistados, vemos surgir duas posturas distintas (e simultâneas) no telejornalismo contemporâneo: a imparcialidade e o engajamento dos repórteres, articulando ao mesmo tempo a proximidade e o distanciamento entre eles e as fontes. 
Obviamente sabemos não ser possível, ao jornalismo, subverter completamente as posições de entrevistadores e entrevistados, ou de observadores e observados. Nas imagens do programa, as demarcações de campo e contracampo, as oscilações do microfone que torna audível diferentes vozes, e a duplicação das câmeras que se filmam umas às outras - além da apresentação de aspectos da captação e edição das reportagens -, são bastante enfatizadas. Não se trata, portanto, de simplesmente colocar o jornalista no lugar daqueles que retrata, invertendo seus papéis, mas de propor uma mudança significativa em sua posição: para além de protagonizar a reportagem, agindo como aquele que detém o ponto de vista privilegiado sobre a história narrada e que deve realizar a ação contada, o jornalista assume lugar de protagonismo na empatia estabelecida com o outro, buscando ver o mundo a partir de seus olhos.

Isso não significa, vale dizer, um gesto apenas solidário de compreender o outro mas, muito além disso, o gesto humanizado de sentir sua dor e estabelecer um foco narrativo que tome partido daqueles com os quais se solidariza. Os repórteres do programa televisivo, assim reposicionados, transformam-se por alguns instantes em "pessoas comuns" a fim de mostrarem a seus espectadores que podem ser seus olhos e seus ouvidos no acompanhamento da história contada. Se assumirmos que uma das questões cruciais ao jornalismo é justamente a relação que estabelece com a construção da alteridade - daquilo que é distinto de nós, como vemos muitas vezes nos episódios de Profissão Repórter -, temos que, ao repórter, é destinado um lugar fundamental: é ele quem deve intermediar o contato do espectador com esse outro retratado nas imagens.

Ao permitir que o repórter se construa como personagem na narrativa, Profissão Repórter não apenas confirma a vocação da grande reportagem jornalística em buscar a alteridade, mas acrescenta outro elemento a ela. Se ele deve, além de mostrar ou relatar os fatos, testemunhá-los e vivenciá-los, a factualidade dos eventos e a autenticação da presença trazem credibilidade às reportagens, inserindo o jornalismo na rede de discursos que se voltam para aquilo que é diverso e que, portanto, nos mobiliza de modo afetivo. Repórteres, entrevistados e espectadores são, assim, afetados pelas histórias contadas e nelas interferem. No equilíbrio entre reconhecimento e estranhamento, na apresentação da realidade por meio do esboço do cotidiano, na participação como alguém que fala com o outro e não por ele, na elaboração de narrativas que contam os fatos e refletem sobre as formas de contá-los, encontramos elementos singulares. Esse reposicionamento discursivo possibilita um arranjo consistente e flexível para o fazer jornalístico, alterando também o imaginário construído a partir de suas narrativas. 


\subsubsection{Narrativas audiovisuais: a televisão inglesa}

A produção televisiva inglesa é amplamente reconhecida por meio da rede de televisão inglesa $\mathrm{BBC}$ - British Broadcasting Corporation -, uma emissora pública do Reino Unido fundada em 1922. Regulamentada pelo Estado, produz um grande e variado volume de programas, por meio de diversas estações de rádio e canais de televisão, atuando tanto em nível nacional como internacional. Tradicionalmente tida como produtora de programas de qualidade, tanto no rádio como na televisão, a BBC tem atuado na criação e renovação de gêneros audiovisuais, contribuindo para o estabelecimento de modos inovadores de fazer televisão.

De formato único, combinando um modelo de gestão pública e estatal, nos últimos anos a emissora tem passado por crescentes transformações, especialmente após a entrada, no mercado britânico, de emissoras privadas, entre elas o Channel Four Television Corporation, criado em 1982 por um ato do Parlamento Britânico. Em termos de audiência, a rede é a quarta maior emissora de televisão do Reino Unido, atrás apenas da ITV (uma emissora comercial), da BBC One e da BBC Two. A exemplo de outras emissoras britânicas, por ser uma empresa de serviço público o Channel Four deve exibir conteúdo diversificado e de qualidade, ainda que não receba, como a BBC, financiamento público.

Notemos, curiosamente, que ao contrário do que ocorre em canais brasileiros a categoria reality shows não é encontrada separadamente nos sites da $\mathrm{BBC}^{98}$ ou do Channel Four" (entre as seções, temos "drama", "comédia", "entretenimento" e "factual"), sinalizando uma importante questão, qual seja: a de que em um dos países mais destacados na produção televisiva, tal formato está espraiado em vários outros, confirmando uma das hipóteses. Da vasta produção televisiva inglesa iremos nos deter, portanto, na programação factual, termo utilizado no site das emissoras citadas ou, de modo mais abrangente, na chamada reality $t v$, destacando sua originalidade $\mathrm{e}$ singularidade naquele país.

Ao percebermos o alcance da "telerrealidade" para além de seu formato mais direto (os reality shows) podemos afirmar que, longe de se caracterizar como um gênero específico, a reality tv surge, no atual momento, como o próprio modo de operação da

\footnotetext{
${ }^{98}$ Disponível em: www.bbc.com. Acesso em 21/03/2015.

${ }^{99}$ Disponível em: www.channel4.com. Acesso em 06/09/2015.
} 
televisão, notadamente na Inglaterra ${ }^{100}$. A fim de demonstrar essa premissa e as linhas principais de sua observação, iremos tecer algumas considerações sobre o programa "Make Bradford British"101, documentário televisivo ${ }^{102}$ que mescla elementos de grandes reportagens, programas de entrevistas e reality shows. Lembramos, nesse momento, a importância que os gêneros factuais possuem tradicionalmente na televisão britânica, apontando para uma realidade bastante específica e instigante: a grande produção de documentários televisivos sem pensá-los de modo reducionista, colocandoos lado a lado com séries, seriados, reportagens, telejornais e realities. A pregnância das formas narrativas definidoras da reality tv é preponderante, contando com bastante aceitação não apenas por parte da audiência, mas também de produtores e realizadores.

Desse modo, a maior ênfase na produção de teledramaturgia por meio de séries, seriados e novelas, além de reality shows propriamente ditos, é uma característica que perpassa a programação inglesa, confirmando também a tendência na produção de documentários e reportagens com estratégias ficcionais em suas narrativas.

Uma importante característica da produção televisiva britânica se sobressai: o hibridismo de gêneros se faz de diversos modos, tanto em termos estilísticos, como tecnológicos. As fronteiras entre sensacionalismo, entretenimento, documentário e informação não estão claramente demarcadas, pois o que observamos é a presença crescente de programas que utilizam, em diferentes graus, esses elementos. Talvez a combinação de aspectos factuais e ficcionais seja justamente aquela que propicia a estruturação de um padrão de programação baseado no que estamos chamando de reality t $v$. No caso do Reino Unido, a diversidade étnica e cultural coloca em primeiro plano problemas relacionados ao multiculturalismo, imigração, xenofobia e segregação racial, temática na qual se insere o documentário televisivo "Make Bradford British", desenvolvido para o Channel Four em $2012^{103}$ e dirigido por Heenan Bhatti ${ }^{104}$,

\footnotetext{
${ }^{100}$ Uma vasta bibliografia sobre o tema tem sido produzida por estudiosos de televisão, dentre eles destacamos: Holmes, S.; Jermyn, D. (eds.) (2004). Understanding reality television. New York: Routledge; Murray, S.; Ouellette, L. (eds.). (2004). Reality TV: remaking television culture. New York: New York University Press; Hill, A. (2005). Reality TV: audiences and popular factual television. New York: Routledge; Ouellette, L. (ed.) (2014). A companion to reality tv. Oxford: John Wiley \& Sons.

${ }^{101}$ Informações detalhadas em: www.channel4.com/programmes/make-bradford-british.

102 Adotamos a terminologia utilizada pelo diretor, condizente com a visada inglesa, ainda que, nos estudos de televisão no Brasil, o programa provavelmente seria chamado de "série televisiva".

${ }^{103} \mathrm{O}$ documentário televisivo, composto de duas temporadas, foi realizado em quatro meses e produzido em um ano, contando com aproximadamente cem horas de gravação por episódio e sete semanas de edição. Cada episódio custou por volta de 150 mil libras, valor elevado mesmo se comparado àqueles relativos a um capítulo de uma telenovela da Rede Globo, e pouco frequente, no caso brasileiro, em outros formatos televisivos dramatúrgicos ou informativos. Bradford foi escolhida por ser uma das cidades consideradas mais segregadas no Reino Unido. Em 2014, outra temporada, chamada Make
} 
realizador que produziu filmes, séries e documentários (como diretor e roteirista), além de atuar, anteriormente, como repórter para jornais e telejornais.

O programa contou com a participação de oito personagens, que foram agrupados em duplas compostas por pessoas com formações culturais bastante distintas para que cada um pudesse viver a vida do outro no cotidiano, dividindo com ele o mesmo espaço. Diferenças étnicas, raciais, geracionais, educacionais, profissionais, regionais, de gêneros, religiosas, culturais, políticas e econômicas foram ressaltadas para que os participantes pudessem pensar sobre as vantagens e desvantagens de se viver mais próximos ou distantes de pessoas radicalmente distintas deles mesmos, enfrentando os conflitos decorrentes desse convívio. Na maior parte, os embates foram travados em torno de questões raciais e étnicas, justamente em um programa que busca tematizar o multiculturalismo presente na sociedade britânica. Preconceito racial contra de brancos para negros, entre mulheres cristãs ou muçulmanas, entre brancos e muçulmanos, e mesmo divergências religiosas entre muçulmanos foram algumas das situações retratadas nos episódios a partir de duplas de personagens.

É assim que Rashid (37 anos, ex-jogador de rúgbi e pertencente à comunidade árabe), Maura (66 anos, juíza aposentada e moradora de um dos bairros mais ricos da cidade), Mohammad (41 anos, motorista de táxi de origem árabe), Jens (71 anos, policial aposentado e morador de uma região predominantemente formada por moradores brancos), Audrey (48 anos, mãe de três filhos e gerente de um pub), Sabbiyah (22 anos, muçulmana de origem paquistanesa nascida na Inglaterra e formada em filosofia e política), Damon (24 anos, metalúrgico e morador de um bairro em que 90\% dos moradores são brancos), Desmond (47 anos, trabalhador em serviço de limpeza e um dos poucos negros a morar em um bairro branco) se encontram e iniciam seu convívio com situações diversas das suas. Alguns dos momentos que demonstram as dificuldades dessa experiência se deram, justamente quando Rashid insistentemente paralisava sua participação no programa para suas orações cinco vezes ao dia, ou no desconforto de Sabbiyah ao trabalhar no pub gerenciado por Audrey.

\footnotetext{
Leicester British, foi produzida nos mesmos moldes e com a mesma equipe, reunindo quatro participantes ingleses e quatro imigrantes de países diversos (três de países europeus e um da Somália) para tratar questões relativas à imigração e identidade, tema recorrente no debate sobre países europeus. Ver: http://www.channel4.com/programmes/make-leicester-british.

${ }^{104}$ Em nossa pesquisa de pós-doutorado, tivemos a oportunidade de acompanhar uma palestra e realizar uma entrevista com o diretor, além de assistir ao making of e a alguns episódios do programa, na Birmingham City University (Inglaterra), em 28 de novembro de 2013.
} 
Em sua entrevista, Bhatti afirmou que define seus trabalhos a partir de uma inquietação: quais são as histórias que valem a pena ser contadas e qual a melhor forma de fazer isso? Cada história, segundo ele, é singular e deve ser destacada dentre outras, seja em formato cinematográfico ou televisivo. No caso da televisão, o menor tempo de produção pode determinar alguns dos resultados, mas os assuntos voltados a atualidades, seja em forma de notícias ou reportagens, encontram mais espaço nessa mídia. Tradicionalmente, os documentários televisivos têm se dedicado a temas culturais, enfatizando a importância em narrar histórias de diferentes atores sociais e buscando a melhor maneira de contar essas histórias por meio de personagens fortes. Um aspecto importante foi ressaltado pelo diretor ao afirmar que há diferentes maneiras de se filmar uma história, inclusive em termos de escolhas narrativas e de gêneros, mas que atualmente é possível realizar narrativas hibridizadas e que misturem, inclusive, entretenimento e informação visando apresentar ao público a maior variedade possível de temas históricos, culturais, sociais e políticos.

Buscando agregar um grupo de pessoas que pudesse representar, de modo abrangente, aspectos multiculturais presentes em diversas regiões do Reino Unido reproduzindo uma espécie de microcosmos com indivíduos variados - e que, ao mesmo tempo, fosse capaz de compreender as diferentes comunidades constituintes da sociedade britânica e da cidade retratada, o programa visava construir seus personagens da maneira mais aprofundada possível. Para definir os oito participantes, partiu-se de candidatos que não haviam passado em um exame de cidadania aplicado pela imigração britânica. A seleção se mostrou bastante complexa por ser, na opinião da equipe de produção, a chave definidora do programa, já que este deveria falar sobre sujeitos diversos e a posição que cada um deles ocupa na sociedade britânica. Encontrar boas histórias em comunidades de diferentes origens étnicas e culturais seria possível, segundo Bhatti, apenas se os produtores conseguissem criar bons personagens a partir dos participantes, capazes de ao mesmo tempo entreter, cativar e desafiar a audiência.

Foram utilizados entre três e quatro meses para a seleção dos personagens, um dos momentos cruciais do trabalho e que, na maneira como foi desenvolvido, guarda semelhanças como processo presente em documentários brasileiros, notadamente aqueles realizados por Eduardo Coutinho, que afirmava ser este "a arte do encontro" em vários níveis: entre realizador e entrevistado, entre realizador e personagem, entre personagem e público, entre público e realizador (Coutinho; Xavier; Furtado, 2005). A passagem do indivíduo ao personagem - e a naturalidade com que atores não- 
profissionais poderiam interpretar papéis que representassem a eles mesmos - foi um dos desafios apontados pelo diretor. Além disso, a questão da edição foi colocada com um dos pontos fundamentais da produção, já que tanto a narrativa como os personagens, de acordo com Bhatti, são construídos no momento da montagem. Muitas vezes um personagem pode parecer excelente no momento da filmagem e, ao chegar o momento da edição das imagens, sua presença se dilui em detrimento de outro.

Nesse ponto é interessante apontar um aspecto inusitado ao pensarmos as produções televisivas britânicas e brasileiras: enquanto no Reino Unido o modelo de produção televisiva parece acompanhar aquele da produção documental (inclusive com a forte presença de documentários televisivos), no Brasil ocorre algo oposto, afastando a televisão da estética documental. No caso brasileiro, tradicionalmente a televisão (incluindo séries, reportagens ou novelas, com pequena presença de documentários) tem utilizado procedimentos de produção bastante distintos daqueles utilizados nos documentários, fato que podemos observar ao nos debruçarmos sobre entrevistas, depoimentos e relatos de realizadores, diretores e roteiristas. De modo análogo, a própria definição de “documentário" parece ser mais ampla no Reino Unido, podendo contemplar vários formatos neste gênero, incluindo educacionais, reflexivos, científicos, tradicionais, ficcionais, jornalísticos e até mesmo, como mostrado, produções seriadas.

Isso aponta para uma de nossas questões fundamentais: para além da distinção entre jornalismo e cinema, ou entre reportagens e documentários, tratando-os como gêneros ou formatos separados, interessa-nos ressaltar seus pontos de contato, suas zonas de aproximação e seus espaços limítrofes, justamente pensados em produções hibridizadas em termos de discursos audiovisuais e seus efeitos de sentido (Nichols, 1991; Winston, 2005). É importante sublinhar, nesse sentido, a preocupação da produção do documentário televisivo no que diz respeito à relação dos gêneros integrantes da chamada "telerrealidade" com a realidade concreta - e lembramos uma vez mais que o diretor, em momento algum, define seu documentário como reality show, mas concebe-o simplesmente como um documentário.

Assim como nos documentários que visam a construção do outro de modo relacional e reversível, subvertendo as posições hierarquizadas entre realizador e entrevistado, o programa analisado não se preocupa com o maior ou menor grau de verdade nele presente, mas com a construção dos personagens feita por meio da filmagem e da montagem. Mais do que se perguntar sobre se as situações criadas são artificiais ou verídicas, ou se aconteceram de fato da maneira como são mostradas, o 
documentário ressalta justamente seu aspecto narrativo e a fabulação implicada em sua fatura, qual seja, a de que tanto os personagens como a história emergem do processo de interação entre cada um deles e o próprio realizador, mediados pelos dispositivos estéticos, políticos, éticos e tecnológicos presentes em qualquer produção audiovisual.

A exemplo de outros realities televisivos, esse documentário - e notamos uma distinção importante em relação à televisão brasileira, já que, como dissemos, o programa não foi simplesmente classificado como uma serie, tampouco como um reality show -, ao contrário de apresentar desafios de transformação, talentos ou competição, propôs a convivência entre diferentes sujeitos em um mesmo espaço físico, caracterizando-se como uma espécie de "experimento" ou, de modo mais extenso, possibilitando uma aproximação à questão dos conflitos e intolerâncias decorrentes do convívio entre $\operatorname{todos}^{105}$. Indagado sobre a existência ou não de uma hipótese prévia à realização do programa, Bhatti afirmou não partir de uma tese que devesse ser comprovada mas, ao contrário, possuir apenas uma premissa.

Tomando como base o multiculturalismo formador da atual sociedade britânica e problematizando o senso comum de que, para ser seu cidadão, um estrangeiro deve ser capaz de passar em um teste que prove o quão britânico ele é, o documentário televisivo partiu de duas perguntas: o que faz de alguém um britânico? O que é comum a todos os britânicos hoje? As questões se referem a um tema especifico mas dizem respeito a aspectos mais gerais sobre como tratar temáticas densas e socialmente relevantes de modo reflexivo e, ao mesmo tempo, atraente.

Nesse sentido, destacamos tanto na produção ficcional inglesa como naquela factual o esforço por produzir programas inovadores, sejam séries, reportagens ou documentários, estes últimos uma das marcas de tal produção. Para além da percepção de que o formato reality tv diz respeito a "pessoas reais fazendo coisas reais em lugares reais", da pré-produção até a pós-produção, incluindo filmagem, edição e finalização, o documentário televisivo "Make Bradford British" buscou agregar elementos ficcionais e jornalísticos em sua realização.

\footnotetext{
105 Ainda que o programa tenha buscado tratar da questão multicultural como um modo de integração e não de separatismo, alguns setores da sociedade protestaram contra sua veemência em termos de crítica social. A pergunta colocada pelo diretor na apresentação do programa parece guiar sua narrativa: "How do we, despite class, cultural and religious differences, find a way to live together? What makes us all British today?". Por meio dos personagens e de seus conflitos, vemos possíveis respostas a essa questão, inserindo a televisão como agente no debate público sobre questões sociais. O mesmo ocorreu na temporada filmada em Leicester. Para mais informações, ver: www.channel4.com/programmes/makebradford-british/articles. Acesso em 21/03/2015.
} 
Para o diretor, a separação entre reality shows e documentários televisivos, bem como aquela entre sensacionalismo e humanização, ou entre fabulação e jornalismo, não pode ser facilmente estabelecida, já que todos esses gêneros tornam-se cada vez mais hibridizados e visam, ainda que de maneiras distintas, contar histórias por meio da criação de personagens em interação. Na perspectiva do diretor, seriam eles os que estabelecem demarcações entre os gêneros, já que se tornam mais autênticos à medida que são criados pelos próprios sujeitos, e não a partir de imposições do realizador, a exemplo do que vemos em documentários que deslizam entre uma ou outra posição autoral: aquela mais exterior, voltada para a construção dos personagens, ou aquela mais subjetiva, realizada a partir deles.

De certo modo, um dos aspectos mais relevantes foi a percepção de que mais do que separar uma produção televisiva ficcional de uma factual, podemos identificar elementos constituintes da ficcionalidade ou da factualidade de um programa em diferentes graus. Mais do que isso, cabe ao espectador decifrar, em sua "leitura", a ênfase em um ou outro desses elementos, como propõe Odin ao tratar da "leitura ficcionalizante" e da "leitura documentarizante" de obras audiovisuais (Odin, 2012: 14). No caso de "Make Bradford British", há uma clara tendência de aproximação à linguagem dos documentários no modo de articulação narrativa, como se pudéssemos reconhecer a aglutinação de elementos não evidentes em documentários tradicionais mas presentes em novos documentários, propondo um possível formato de reality documentary, ou mesmo uma espécie de documentário seriado.

Se pensarmos na relação entre reportagens e documentários, a partir da observação da produção inglesa veremos que ocorre a emergência de um novo formato de produção de filmes e séries, enquanto o jornalismo ainda se mantém 'fechado em modelos mais convencionais. De certo modo, tal descoberta vai ao encontro das hipóteses iniciais, e também de conclusões obtidas em pesquisas anteriores, no que diz respeito aos estigmas sociais em termos de seu reforço ou transformação. Em relação a essa questão, ainda que haja um grande volume de produções televisivas que não colocam essa preocupação em primeiro plano, confirmamos uma tendência já observada no caso da televisão brasileira: a forte presença de temas polêmicos, geralmente de cunho social, chamando ao posicionamento e ao engajamento não apenas de produtores, mas também da audiência. Em "Make Bradford British", a questão dos estigmas se coloca em evidência, a começar pelo elemento aglutinador do documentário: a temática do multiculturalismo, da imigração e das formas de convívio. 
Como dissemos, os episódios mostram os participantes convivendo nas casas uns dos outros e divididos em duplas formadas por sujeitos que, a princípio, possuem diferenças inconciliáveis entre $\mathrm{si}^{106}$. É assim que vemos um típico garoto inglês de origem operária ser inserido na família de um muçulmano; a mulher muçulmana colocada no cotidiano de uma negra inglesa que trabalha em um bar; a senhora idosa convivendo com uma jovem, e assim por diante.

Seja em termos étnicos, religiosos, geracionais, as diferenças entre cada um - e os modos de lidar com elas - colocam-se como definidoras do documentário. Ou seja, uma vez mais, a questão do convívio e do conflito entre cada um e todos (o outro próximo e o outro distante) aparece como preponderante e configura, assim, uma aproximação aos estigmas sociais. No caso do programa, isso ocorre de modo transgressor, já que aprender a lidar com as diferenças, por meio da subversão da pergunta sobre se há algo que possa definir a "britanicidade" de um cidadão do Reino Unido, é justamente seu objetivo. País de longa história no que diz respeito à presença de imigrantes - sejam eles de origem negra, árabe ou indiana, de ex-colônias ou outros lugares, entre eles o Brasil -, a premência dessa questão salta aos olhos quando nos deparamos com os desafios encenados no documentário televisivo, que deriva seu aspecto realista não apenas na definição de um formato, mas na problemática tratada.

Em termos dos personagens, confirmamos o modo como o documentário desmobiliza lugares comuns: ao revezar entre realizador e audiência o espaço de construção narrativa, movimento esse contemplado na produção de reality shows, os personagens não são simplesmente encaixados na história - como muitas vezes acontece no jornalismo - mas colaboram com sua narração, determinando e sendo por ela determinados. É nesse sentido que a mistura entre realidade e ficção pode ser apontada, pois o aspecto de fabulação advindo dessa escolha - ao mesmo tempo estética e politica - corrobora a aposta factual do formato documental. É dessa síntese que vemos delinear-se a "telerrealidade", percebida como um lugar próprio da linguagem televisiva contemporânea que coloca em operação a triangulação entre autor, leitor e texto (nos termos de Eco, 1994; Iser, 2013), ou entre realizador, público e programa.

\footnotetext{
${ }^{106}$ É interessante observar que o diretor brasileiro Cao Guimarães, no filme Rua de mão dupla (2002), utiliza um dispositivo semelhante como estratégia para a realização de um documentário, colocando em contato pessoas que antes não se conheciam e formando duplas que, transformadas em personagens, deveriam trocar de casa durante 24 horas. Munidos de câmeras de vídeo e com liberdade para filmar o que quisessem, cada participante tentou elaborar uma "imagem mental" do outro morador, sendo posteriormente entrevistados pelo diretor para relatar suas impressões sobre como teriam imaginado esse "outro" desconhecido e delas distinto. Disponível em: http://www.caoguimaraes.com/obra/rua-de-maodupla/. Acesso em: 28/06/2015.
} 
Uma espécie de factual entertainment, como colocado pelo diretor, faz-se presente nesses formatos híbridos, propondo novos modos de produzir, assistir e refletir sobre a televisão. Bhatti aponta que o documentário, especialmente o televisivo, não se encontra tão distante dos formatos de entretenimento como desejaríamos e, desse modo, programas televisivos como "Make Bradford British" podem tratar de temas relevantes e densos por meio de uma abordagem mais lúdica e emocional e, ainda assim, problematizar estigmas sociais relacionados a questões de identidade, alteridade e representação social. Não se trata, portanto, de simplesmente classificar diferentes programas mas, ao contrário disso, reconhecer um conjunto deles que possa integrar esse lugar híbrido que desliza entre formas documentais diversas, sejam elas referenciais, convencionais ou popularescas. É desse modo que a realidade passa a ser intertextualmente encenada, por meio de documentários, reportagens, séries e reality shows, complexificando os novos realismos presentes na televisão e no cinema.

Finalmente, um último aspecto merece ser apontado no estabelecimento da relação entre documentários, reportagens e realities. De acordo com Bhatti e em consonância com análises anteriormente realizadas (Soares e Limberto, 2014), percebemos nas várias possibilidades factuais da programação televisiva a importância da relação entre realizador e entrevistado. Se baseada na reciprocidade, nos termos em que o filósofo Buber (2001) utiliza este conceito, é um pacto de confiança - e de fidúcia - que se estabelece entre ambos. É dessa maneira que a relação aparentemente dual entre realizador e entrevistado se torna uma relação triádica entre realizador, entrevistado e personagem e, posteriormente, destes com o espectador.

As diferenças entre a produção audiovisual brasileira e a britânica se colocam então como prementes, justamente devido às características singulares de cada uma e à forte presença, no caso da produção inglesa, de formatos híbridos em termos narrativos e estéticos, e de documentários televisivos (gênero ainda pouco presente na televisão brasileira, que ainda se pauta, como notamos, por divisões mais rígidas de formatos). Além da hibridização em termos de gêneros televisivos, na produção inglesa isso se reflete no modo de demarcação dos estigmas, que se tornam mais diluídos e, portanto, potencialmente mais transformadores, levando a uma baixa frequência de redundâncias e aumentando as ressonâncias de suas imagens, mesmo que polêmicas. 
Os estigmas sociais presentes nas formas audiovisuais, as políticas de representação e os regimes de visibilidade a eles relacionados se fazem na tensão entre esses sujeitos, empíricos e discursivos, colocados em cena e em tela. Mais do que reproduzir imagens de minorias ou de grupos sociais, trata-se da apresentação de diferentes culturas, construindo novas realidades. Ainda que os limites da representação sejam dados pela impossibilidade de tudo representar ou pela irredutibilidade de um outro desde sempre não representável, quando tratamos de estigmas podemos notar certos deslocamentos nos intervalos entre ausência/presença, invisibilidade/visibilidade. Nos intervalos entre os ditos, inclusão e protagonismo deslizam possibilidades de dar a ver o outro e a ele responder, demarcando distintos posicionamentos discursivos e, consequentemente, outros modos de representação da alteridade.

Se tomarmos os processos comunicacionais como uma permanente negociação, entendemos que as mídias podem ser vistas como lugares de reconhecimento e trânsito simbólico, como zonas de fronteira e passagem nas quais as reapropriações se fazem nas bordas dos contratos discursivos estabelecidos, transformando os modos de construção da representação, especialmente quando tratamos dos espaços de visibilidade e invisibilidade neles articulados.

Em pesquisas futuras, os estigmas continuarão compondo critérios de escolha dos filmes, mas a problemática dos novos realismos no cinema e na televisão, as políticas de representação e os regimes de visibilidade serão os eixos teóricos principais. Para além desse recorte, pretendemos analisar as narrativas audiovisuais em perspectiva crítica, como será apontado nas considerações finais. 


\section{IV. À Guisa de CONCluSÃo}

Partindo das definições inicialmente apresentadas, buscamos apontar ao longo do trabalho algumas configurações de estigmas sociais presentes nas mídias. Desse modo, acreditamos ter investigado, ao mesmo tempo, os regimes de visibilidade nelas presentes e seus possíveis efeitos de sentido em relação à reafirmação ou questionamento de estigmas sociais cristalizados e (re)produzidos. Esperamos, dessa forma, ter contribuído para a compreensão dos modos de articulação dos discursos midiáticos no estabelecimento de laços sociais, reconhecendo-os como campo profícuo para futuros estudos. Da necessidade de elaboração de um pensamento crítico sobre as mídias é que tecemos essas considerações finais.

$\mathrm{Na}$ finalização do trabalho, lançamos aberturas a novos campos de investigação que, inspirados pelos desafios e achados da pesquisa, chegam a um lugar questionante e problematizante (para evocar os termos de Deleuze em seu livro Diferença e repetição): lugar de rupturas críticas que, ao final de um percurso, visam desconstruir, uma vez mais, os resultados encontrados, colocando-os em crise. Para o autor, os problemas e as questões "são atos vivos, investindo as objetividades especiais do inconsciente, destinados a sobreviver ao estado provisório e parcial que, ao contrário, afeta as respostas e as soluções" (Deleuze, 1988: 180): os problemas corresponderiam à própria organização das séries da realidade (constituídas a partir do disfarce de seus termos e relações) e as questões corresponderiam ao deslocamento efetuado nas séries (deslocamento do objeto virtual em função do qual as séries se desenvolvem).

Ao pensarmos o estatuto da imagem na contemporaneidade, marcado sobretudo por práticas midiáticas cada vez mais hibridizadas, torna-se imperativo, como dissemos, fazê-lo em perspectiva crítica $^{107}$. Nesse sentido, uma questão se coloca: se não estamos mais situados no campo da literatura ou do cinema enquanto artes modernas, qual o lugar da crítica frente a objetos diversificados, em que modos de produção e circulação passam a fazer parte dos próprios discursos difundidos?

\footnotetext{
${ }^{107}$ Nos últimos três anos, temos pesquisado a questão da crítica de mídia, especialmente audiovisual. Tal interesse resultou na publicação dos artigos "A crítica de TV no Brasil: valores e repertórios" (em coautoria com Márcio Serelle, PUC-MG), "Para pensar a crítica de mídias" e "Lugares da crítica na cultura midiática" (ambos em coautoria com Gislene Silva, UFSC). Além dos textos, organizamos o Simpósio "Por uma crítica do visível", em 2014, e o Ciclo de Estudos "Cartografias da crítica", em 2015, ambos realizados pelo MidiAto - Grupo de Estudos de Linguagem: Práticas Midiáticas. Ver: www.usp.br/midiato.
} 


\section{Para além dos estigmas: crítica de mídia e práticas culturais}

Uma questão nos interpela nessas considerações provisoriamente conclusivas: como reunir elementos dispersos da crítica - seja ela autorizada, especializada ou informal - para estabelecer critérios e valores que possam dar conta do universo multifacetado das mídias? Para além da compreensão da crítica de mídia como a avaliação sistemática e permanente dos meios em relação à cultura (social e profissional) na qual se inserem, propomos pensar a crítica como uma desconstrução não apenas dos objetos sobre os quais se volta, mas também das condições de possibilidade que engendram sua materialidade.

Desse modo, ampliamos a proposição de que a crítica se volta apenas para o estabelecimento de juízos de valor, mais ou menos adequados, sobre a mídia, realizando uma espécie de "dobra" em que não há origem possível para a interpretação, posto que esta é rastro de algo para sempre inapreensível. No caso da televisão, em que os espectadores também tomam parte de seus processos de codificação e decodificação, para além da mera transmissão de conteúdos buscamos articular uma visada externa capaz de, ao mesmo tempo, dialogar com a crítica produzida no interior de seus relatos, seja por especialistas, seja pelo público.

Ainda que o acervo de críticas publicadas sobre a programação não seja sempre reconhecido, nos meios acadêmicos, como uma fortuna crítica televisiva, faz-se necessário reconhecer a constituição de um repertório televisual, em que a análise expressiva dos programas aponta para inovações técnicas, estéticas, narrativas e, mais do que isso, para certos modos de endereçamento de formatos e de públicos específicos. À medida que a formação de uma cultura televisiva se consolida, os embates entre elitização e popularização, a relevância dos índices de audiência, a definição da grade e de padrões de qualidade, bem como os desafios éticos pressupostos nesse debate são problematizados, possibilitando que surja uma crítica da mídia engendrada nela mesma.

Como exposto por Fuchs (2010: 180), produtos críticos também podem estar inseridos em meios de comunicação mainstream desde que adotem formatos ou conteúdos que exponham histórias e pontos de vista alternativos, critiquem limites impostos pela representação midiática tradicional, contestem discursos reproduzidos como consensuais, ou adotem novas propostas de linguagem em formatos que comumente não encontram caminhos nos grandes meios. Entretanto, algumas questões centrais surgem nesse sentido: qual a especificidade do discurso da crítica sobre outros 
meios de comunicação, que, por ser também midiatizada por sua publicação, poderia ser chamada de "metacrítica"? Como essa crítica sugere e apoia-se na recepção do público nessa instância intermidiática? E, para além dos discursos orais ou textuais, como as imagens por si só podem propor (ou decompor) discursos críticos?

Sobre o conceito de "metacrítica", Fuchs nos oferece uma interessante contribuição ao afirmar que a crítica não se dá apenas nos enunciados de um discurso seus conteúdos -, tampouco exclusivamente de modo direto. Ao contrário, o autor argumenta que também o formato de determinado produto pode conter, na maneira como é feito - em sua enunciação -, um discurso alternativo crítico. Nesse sentido, a crítica de mídia feita na/pela mídia seria, primeiramente, uma "metacrítica":

Critical media, in contrast, are characterized by critical form and content. There is oppositional content that provides alternatives to dominant repressive heteronomous perspectives that reflect the rule of capital, patriarchy, racism, sexism, nationalism, etc. Such content expresses oppositional standpoints that question all forms of heteronomy and domination. (...) There are forms of presentation that are not onedimensional, but are demanding and challenging the recipients in order to advance their imagination and complex thinking (e.g. Brecht's concept of dialectical form in epic theatre, radical discontinuities that shock people) (Fuchs, 2010: 179).

A exemplo de programas televisivos que propõem inovações estéticas, estilísticas e narrativas, o documentário Um dia na vida, de Eduardo Coutinho, oferece caminhos para pensarmos tal definição. Feito a partir de 19 horas de gravação contínua e aleatória de diversos canais abertos da televisão brasileira, o filme, realizado em 2010, é construído no momento da montagem: a seleção das imagens editadas, que vemos à nossa frente, embora sejam cenas banais e ordinárias do que vemos na televisão diariamente, oferece outra visão sobre esse meio. Partindo de uma ácida crítica à pasteurização e repetição presente nas imagens da televisão, Coutinho assume uma visada crítica e leva seu espectador a olhar de uma nova maneira o veículo:

Trata-se de produzir menos um "retrato do Brasil" do que um retrato da própria TV, que surge ali como um mundo autônomo, vagamente monstruoso, quase diabólico. Ou antes, isso é o que o filme produz, o que está lá. É o mundo-TV que se mostra a nós, tal qual. O diretor interfere o menos possível (queira ou não, ele seleciona, monta). (...) Ao fím nos damos conta de que a TV é o mundo dos demiurgos: algo que não retrata o mundo ou o que somos senão indiretamente, pois mais ruidoso e mais infernal (Araújo, 2010: 1).

O filme de Coutinho realiza uma crítica - não apenas à sociedade mas à própria televisão - e, ao mesmo tempo, é objeto da crítica cinematográfica publicada por um especialista em um jornal diário. 
Nessa perspectiva, a crítica de mídia não seria apenas aquela institucionalmente denominada enquanto tal ou aquela que, para falar dos discursos midiáticos, cria novos discursos sobre as mídias. Ainda que alguns produtos e programas se proponham a fazer a crítica de mídia (a exemplo de observatórios ou debates e entrevistas), a crítica não é feita apenas neles. De modo mais complexo, a produção de novos produtos e programas - pensados sob o viés da inovação - constitui um espaço para a realização da crítica de mídia, ao propor mudanças.

Fuchs acredita, justamente, que é de práticas midiáticas alternativas que poderá surgir uma perspectiva crítica mais autônoma em relação às mídias, definindo tal posicionamento como "critical media", em que os próprios meios empreendem a crítica sobre as práticas midiáticas. Para ele, a inserção da crítica de mídia na/pela mídia acaba por corroborar aquilo que pretende criticar, já que feita dentro de limites impostos pelos próprios meios. Seja a crítica feita por especialistas ou pelo público, haveria certa domesticação de seus alcances por estar submetida a protocolos e códigos previamente estabelecidos. A respeito do público, o autor estabelece papel central na crítica de mídia, apontando três posicionamentos advindos do polo da recepção: a adesão, a contestação, a exacerbação. Ao fazê-lo, problematiza, como vimos em autores anteriormente citados, os papéis tradicionais de produtores e receptores, autores e espectadores.

Ao incluir no cenário midiático aquilo que pretende criticar - reconhecendo de modo autoconsciente sua inclusão nessa cena -, tanto os programas analisados, como seu público, tornam-se parte desse cenário. Ou seja: ao criticar a mídia dentro da própria mídia, temos que o discurso crítico se torna, ele próprio, passível de ser criticado - ou, de modo mais pessimista, coloca-se sob o risco de perder seu efeito crítico.

Observando o processo comunicativo por meio da articulação de diferentes momentos - produção, circulação, distribuição, reprodução -, Hall desenvolve, ainda na década de 1970, um modo de interpretação dos processos de codificação e decodificação de programas televisivos:

O processo, desta maneira, requer, do lado da produção, seus instrumentos materiais - seus "meios" - bem como seus próprios conjuntos de relações sociais (de produção) - a organização e combinação de práticas dentro dos aparatos de comunicação. Mas é sob a forma discursiva que a circulação do produto se realiza, bem como sua distribuição para diferentes audiências. Uma vez concluído, o discurso deve então ser traduzido transformado de novo - em práticas sociais, para que o circuito ao mesmo tempo se complete e produza efeitos. Se o sentido não é articulado em prática, ele não tem efeito (Hall, 2003: 388). 
De modo semelhante, ao inserir a recepção no processo de produção, embora reconhecendo nesta última o ponto de partida do discurso televisivo (objeto de seu estudo), Hall estabelece o caráter interdependente entre autor e espectador, apontando, ao final de seu texto, três posições a partir das quais a "decodificação" de um discurso e sua consequente "recodificação" - pode ser construída: a posição "hegemônicadominante" (o telespectador decodifica a mensagem a partir de sua referencialidade); a posição do "código negociado" (o telespectador reconhece as definições hegemônicas, mas as adapta a sua realidade local); e a posição "globalmente contrária" (o telespectador decodifica de modo alternativo o discurso). Essa terceira posição nos parece produtiva para pensarmos a crítica de mídia constituída no espaço intermediário entre produtor e receptor, no entremeio em que o público, por oposição, contesta o discurso hegemônico e o ressignifica (Hall, 2003: 402).

Em vários de seus trabalhos, Hall procurou compreender as relações das mídias com a cultura, a linguagem e a ideologia. Para o autor, elas atuariam na construção seletiva do conhecimento social pelo qual percebemos as realidades vividas por outros e, assim, construiríamos imaginariamente um mundo inteligível. As mídias proveriam um inventário constante de léxicos, estilos de vida e ideologias objetivadas, classificariam e ordenariam os diferentes tipos de conhecimento social, providenciando contextos referenciais que contribuem para dar sentido ao mundo. Além disso, elas organizariam essa classificação seletiva, produzindo "consensos e legitimidades". De acordo com Hall, deparamo-nos, então, com um falso dilema: com os processos de mundialização da cultura, pensamos que a identidade vai acabar de um modo ou de outro - ou retornado às suas raízes, ou desaparecendo através da assimilação e da homogeneização. Mas é justamente a "tradução" que se coloca como outra possibilidade (Hall, 2001: 88).

Ao tratar do conceito de "tradução cultural", Hall apresenta sua teoria da articulação. Para ele essa palavra reveste-se de dois sentidos: articular significa, em inglês e também em português, proferir, expressar uma ideia ou raciocínio, num sentindo de construção na linguagem, de discurso, de expressar-se bem (dizemos de uma pessoa que fala bem que ela é articulada). Mas também significa que duas partes distintas estão conectadas (como dizemos de um ônibus articulado), mas não necessariamente precisariam estar ligadas uma à outra. As duas partes conectadas por meio de um elo específico podem ser quebradas, separadas, divididas. 
Uma articulação é, assim, a forma de conexão que pode constituir uma unidade de dois elementos diferentes sob certas condições. É um elo que não é necessário, determinante ou essencial todo o tempo para os elementos relacionados e, dessa forma, pode ser desfeito. Sob que circunstâncias, então, pode ser estabelecida uma conexão? Hall aponta que podemos ter como exemplo dessa definição a questão do discurso. A chamada "unidade" do discurso é de fato a articulação de distintos elementos que podem ser rearticulados de formas variadas porque não possuem necessariamente um sentido de pertença uns aos outros. A unidade que importa é o elo, o laço, a ligação entre este discurso articulado e as forças sociais com as quais ele pode - mas não necessariamente precisa -, em certas circunstâncias históricas, estar conectado. Uma teoria da articulação é tanto um caminho para entender como elementos ideológicos surgem, em certas condições, para se agrupar em um discurso, quanto um caminho para perguntar como eles se tornam ou não articulados, em conjunturas específicas, para certos sujeitos políticos.

A teoria da articulação, para Hall, pergunta como uma ideologia descobre seu sujeito mais do que como um sujeito pensa os pensamentos necessários e inevitáveis que pertencem a ela; pensa como uma ideologia fortalece as pessoas, capacitando-as a começar a dotar de sentido sua situação histórica, sem reduzir essas formas de inteligibilidade a suas condições específicas (Hall, 2003). O conceito de tradução reveste-se desse aspecto ao mesmo tempo coeso e fluido presente na noção de articulação. Traduzir (fatos, textos) seria, portanto, rearticular (separar, reunir) as diversas partes de uma cultura. É justamente esse processo que os relatos sustentados nas noções de objetividade e imparcialidade visam camuflar e elidir.

Por outro caminho, Martín-Barbero elabora o conceito de "mediação" como aquele a partir do qual pensarmos as formas de tradução presentes nos discursos midiáticos: "Por isso, em vez de fazer a pesquisa partir da análise das lógicas de produção e recepção, para depois procurar suas relações de imbricação ou enfrentamento, propomos partir das mediações, isto é, dos lugares dos quais provêm as construções que delimitam e configuram a materialidade social e a expressividade cultural das mídias” (Martín-Barbero, 1997: 292). Tal noção, que propõe o estudo das mídias em sua materialidade discursiva e não nos polos tradicionalmente isolados de "produção" e "recepção", conduz-nos a um ponto nodal: questionar a tradição da objetividade e da fidelidade ao texto por meio da assunção do caráter narrativo desses discursos e das marcas culturais neles presentes. 
A noção de texto - concebido não apenas em sentido linguístico, mas como qualquer manifestação discursiva, seja ela verbal, visual ou audiovisual - é o conceito em torno do qual gostaríamos de pensar as relações entre identidade e diferença (e seus modos de tradução nas mídias), especialmente ao considerarmos os estigmas sociais. $\mathrm{O}$ texto é tomado, ao mesmo tempo, como artefato verbal e como evento cultural. Para Barthes, "o texto é assim definido não como uma linha de palavras a produzir um sentido único (...), mas como um espaço de dimensões múltiplas, onde se casam e se contestam escrituras variadas, das quais nenhuma é original" (Barthes, 1988: 68). Desse modo, "o texto é um tecido de citações, saídas dos mil focos da cultura. (...) o escritor só pode imitar um gesto sempre anterior, jamais original; seu único poder está em mesclar as escrituras, em fazê-las contrariar-se umas pelas outras, de modo a nunca se apoiar em apenas uma delas" (Barthes, 1988: 69).

No campo do discurso (Bakhtin, 1987), portanto, ao contrário da possibilidade de estabelecimento de uma origem, não haveria um começo e um final, mas o entremeio, lugar de desdobramentos incessantes, espaço este permanentemente atualizado pelo leitor: "A realidade mais essencial é a mais escondida, não se situando nem na ausência do discurso, nem no explícito deste, mas no entremeio de sua latência, necessitando, portanto, de uma escuta ou leitura particular a fim de o revelar a si mesmo" (Dosse, 1993: 336). Da necessidade de construir narrativas representativas de nossas subjetividades e pertencimentos, entretanto, deriva este desejo de verdade (autenticidade, legitimidade, fidelidade) que vemos presente na produção audiovisual, esquecendo-se que, justamente por estar à deriva, o desejo é sempre desejo de outra coisa: ao chegarmos a ele, já é de outro lugar que falamos. Nas palavras de Deleuze, aproximamo-nos da perspectiva que postula a não anterioridade do real à linguagem: "A linguagem é um imenso há, na terceira pessoa, ou seja, o oposto da pessoa: uma linguagem intensiva, que constitui seu estilo" (Deleuze, 1992: 143). De modo paradoxal, os relatos referenciais (como o jornalismo), ao mesmo tempo em que se pretendem objetivos e isentos, realizam todo o tempo um trabalho de tradução dos fatos em narrativas, desdobrando-se em uma dupla camada de mediações e transposições ${ }^{108}$.

\footnotetext{
${ }^{108}$ Acreditamos que algumas das concepções estabelecidas entre discurso e história podem ser aplicadas ao jornalismo, especialmente na relação entre fatos e relatos: "Há de sempre criarmos uma diferenciação entre fatos e discursos. Não ao final do processo, pois para o historiador não será possível enxergar tal diferenciação no resultado obtido. Essa simbiose entre fato e discurso se dá no fazer-se. Seria imperativo, portanto, voltarmo-nos às ruínas iniciais, aos vestígios do entremeio e ao leve fantasma discursivo para podemos rastrear essas diferenças" (Baptista, 2009: 17).
} 
Ao contrário do acesso à verdade e à representação fiel da realidade, é um processo de descontinuidades que se inscreve em tais relatos. Deleuze e Guattari, ao tratarem das relações entre discurso e realidade, afirmam a impossível busca (incessante) do jornalismo em compreender o caos:

\footnotetext{
Os jornais, as notícias, procedem por redundância, pelo fato de nos dizerem o que é "necessário" pensar, reter, esperar etc. A linguagem não é informativa nem comunicativa, não é comunicação de informação, mas - o que é bastante diferente - transmissão de palavras de ordem, seja de um enunciado a um outro, seja no interior de cada enunciado, uma vez que o enunciado realiza um ato e que o ato se realiza no enunciado (Deleuze e Guattari, 1997: 16).
}

Se o enunciado realiza um ato e o ato nele se realiza, o pressuposto de que haveria um momento inicial (seja um fato ou um texto) sobre o qual estabelecer o processo tradutório (do fato ao relato) não se sustenta, posto que a ideia de tradução pressupõe, em todo caso, a noção de cultura em suas imbricações com o imaginário social. O fato, após acontecido, é sempre imaginado - traduzido. A literatura e o cinema proporcionam narrativas emblemáticas que constituem nosso imaginário, tornando-nos capazes de ficcionalizar relatos representativos de nós mesmos (Soares, 2011a). Sobre essa questão, Calligaris nos oferece uma visada original ao tratar do lugar que as "ficções" ocupam em nossa formação, apontando pelo menos dois aspectos. O primeiro diz respeito ao fato de a ficção apresentar a diversidade do mundo e constituir um repertório do possível: "No meio das diferenças particulares entre grupos, ela inventa experiências singulares que revelam a humanidade que é comum a todos, protagonistas e leitores. A ficção de uma vida diferente da minha me ajuda a descobrir o que há de humano em mim". Esta seria sua "mágica". O segundo, aponta o que vimos tentando estabelecer ao tomarmos as mídias como tradução:

Há uma outra idéia, menos comum, segundo a qual a vida da gente pode (e talvez deva) ser vivida como uma narração. Não tanto para que ela se transforme num roteiro mirabolante, mas para que nosso cotidiano (por humilde e banal que seja) assuma uma relevância e uma intensidade que o tornem digno de ser vivido (Calligaris, 2007: 1).

Na perspectiva apresentada, as dicotomias anteriormente apontadas se desfazem, diluindo a oposição entre verdade e linguagem, realidade e fantasia, pois o que temos são fabulações narrativas engendrando imaginários sociais, especialmente se tomarmos os discursos midiáticos como lugar privilegiado para tal articulação. 
Estabelecidas essas premissas, outra indagação se faz premente: por que, afinal, os relatos referenciais tangenciam essas questões sem jamais parecer ultrapassá-las? Talvez porque um de seus pressupostos seja, justamente, aquele que os considera como lugares de organização da realidade, estabelecimento do senso comum e reiteração da ordem social. Ao se considerar uma instância que traduz a realidade para aqueles que não podem vê-la (em sentido literal ou figurado), o jornalismo oblitera seu fundamento enquanto prática linguageira e, por isso mesmo, produção incansável de discursos sobre discursos (Soares, 2010). Desse modo, o texto jornalístico não é verdadeiro ou falso; é um texto, ponto de chegada, que guarda traços do acontecimento, ponto de partida.

Se os relatos referenciais são uma forma de tradução dos fatos, inserem-se no campo da "tradução cultural" e dos modos de construção de imaginários sociais ${ }^{109}$. O texto jornalístico, mesmo em programas como Profissão Repórter, é tomado constantemente como transparente, estabelecendo uma distinção entre discurso e realidade impensável nos estudos de linguagem, que reconhecem sua opacidade (Soares, 2010). Estão implicadas concepções de verdade e de correspondência entre textos e relatos, ou seja, uma visão realista (e instrumental) da linguagem.

O chamado "fato jornalístico" seria, portanto, tecido no entremeio dessas narrativas, sempre provisório e contextual, traduzido nos interstícios da cultura. Além disso, tal texto estabelece um complexo jogo de relações em que o leitor, construído pelo texto no ato mesmo da leitura (Eco, 1994), interage com o autor e traduz, tantas vezes quantas forem as leituras empreendidas, o texto, a exemplo do que Hall apontara em relação à televisão. Para Eco, leitor e autor não são sujeitos empíricos ou biográficos mas, ao contrário, funções constituídas no interior do texto:

O leitor-modelo de uma história não é o leitor empírico. O leitor empírico é você, eu, todos nós, quando lemos um texto. Os leitores empíricos podem ler de várias formas, e não existe lei que determine como devem ler, porque em geral utilizam o texto como um receptáculo de suas próprias paixões, as quais podem ser exteriores ao texto ou provocadas pelo próprio texto (Eco, 1994: 14).

\footnotetext{
109 A visão eurocêntrica na História, bem como na Antropologia, apregoava a possibilidade de uma narrativa única aos fatos; o que se reconhece nas teorias da Nova História e da Nova Antropologia é, justamente, a visão de que um mesmo fato gera várias interpretações, várias histórias, como retratado pelo direto Clint Eastwood em seus filmes A conquista de honra e Cartas de Iwo Jima, ambos de $2006 \mathrm{e}$ produzidos nos Estados Unidos.
} 
De modo análogo, o autor afirma que podemos "reconhecer o autor-modelo como um estilo, e o estilo será tão claro e inconfundível que veremos que sem dúvida se trata da mesma voz de outras obras" (Eco, 1994: 21). Essa "voz" é definida como uma "estratégia narrativa, um conjunto de instruções que nos são dadas passo a passo e que devemos seguir quando decidimos agir como leitor-modelo" (Eco, 1994: 21). A fim de desdobrar tal questão, tomamos como locus de sua demonstração discursos audiovisuais que asseveram o caráter sempre provisório das interpretações, buscando estabelecer, em nossas considerações finais, uma análise crítica de possíveis relações entre mídias e estigmas a partir das tensões entre identidade e alteridade manifestas em suas narrativas.

\section{Crítica audiovisual: visibilidades e invisibilidades encenadas}

Historicamente, a aplicação das noções de crítica ao julgamento de produtos culturais tem passado por transformações que vão desde a consciência do artista enquanto tal até a formação de um público qualificado. Se, na tradição filosófica a partir da segunda metade do século XVIII, a estética passou a dividir, juntamente com a razão, lugar privilegiado nas teorias do conhecimento, a obra kantiana, com sua Crítica da faculdade de julgar, constitui grau zero do que viria a ser a crítica moderna.

Em suas três críticas, o filósofo estabelece que o julgamento da razão, em si mesma e para si mesma, pode deliberar não apenas sobre o conhecimento teórico (razão pura) ou prático (razão prática), mas também estabelecer juízos reflexivos, que reuniriam os juízos analíticos e os sintéticos, numa espécie de conjugação entre as duas formas possíveis de conhecimento: puro (a priori) e empírico (a posteriori). Ao propor uma nova maneira de conceber as relações entre conhecimento e objetos, Kant estabelece, como fontes de conhecimento, a sensibilidade e o entendimento, definindo, em sua estética, "a sensibilidade como uma faculdade de intuição, através da qual os objetos são apreendidos pelo sujeito cognoscente", mediante as categorias apriorísticas do entendimento (Chauí, 1987: X).

A faculdade de julgar seria o momento de síntese entre a razão pura e a razão prática, distinguindo-se por dois tipos de juízos: determinantes e reflexionantes, estes últimos divididos entre teleológicos (dotados de uma finalidade objetiva) ou estéticos (relacionados a um fim subjetivo). Os juízos estéticos têm como fonte sentimentos de prazer e desprazer, "conciliando a faculdade de conhecer e a de desejar", ou seja, evocando um "sentimento de eficácia sentido pelo homem diante desse objeto" (Chauí, 
1987: XVII). Por estarem condicionados aos estados do sujeito, são os juízos estéticos que "autorizam a atribuir aos objetos que os suscitam o predicado 'belo", estabelecendo, ao mesmo tempo, "as condições inerentes ao sujeito que possibilitam tais juízos de gosto" (Nunes, 2007: 52).

$\mathrm{Na}$ crítica moderna, herdeira dessa tradição que se desdobrou ao longo do século XIX, é notória a assunção do texto crítico como mediação, "tornada necessária em função de uma arte cujos códigos estão constantemente em ruptura com relação ao estado atual do gosto, isto é, às capacidades espontâneas de compreensão existentes normalmente nos públicos" (Leenhardt, 2007: 22), concepção esta atravessada por questionamentos inerentes à crítica contemporânea. Por meio da problematização do conceito de "gosto", desdobrado da noção anterior de juízo, encontramos, na segunda metade do século XX, novos posicionamentos da crítica, colocando em crise sua própria credibilidade e as formas de reconhecimento por ela legitimadas. Enquanto avaliação, interpretação e descrição, a crítica estabelece apreciações, como ocorre no caso da literatura:

Por pertencer a essa órbita, a literatura ingressa na experiência individual do crítico, cada vez atualizada pela sua leitura, como modo de acesso ou de discernimento da obra. Ora, nem isolada nem puntiforme, pois que a obra conhecida se relaciona com outras muitas, tanto horizontalmente, num dado momento, quanto verticalmente na ordem da sucessão temporal, a experiência individual é também social, porque se acha sob condições culturais e históricas determinadas (Nunes, 2007: 52).

Assumindo o gosto do público e a implicação do crítico, enquanto sujeito social, no próprio empreendimento da crítica, os modos de se fazer crítica cultural - entre elas a crítica televisiva - passaram por inúmeras crises e mutações. Às polêmicas recorrentes entre a "leitura" dos críticos, a "escrita" dos autores e a "interpretação" do público, entretanto, uma pergunta se coloca: por meio de quais "conceitos" e "critérios" (Nunes, 2007: 61) se estabelece a crítica hoje? Como, então, a crítica contemporânea no Brasil lida com essas noções?

O termo valor evoca, em sua origem, os sentidos de avaliação e validação, por reconhecimento do vigor, mérito ou importância de um determinado objeto. Se o juízo se refere a um conceito ou opinião emitidos com seriedade, circunscrevendo o campo do direito e dos possíveis, o valor qualifica o juízo, atribuindo-lhe permanência (ou duração, como na música) e, desse modo, tornando-se passível de orientar ações futuras. 
Definido enquanto um conjunto de elementos metodicamente dispostos, como em um inventário, o repertório não se limita a um conteúdo rigorosamente organizado, mas refere-se, também, a um conjunto de conhecimentos que, na origem latina do termo, engendra o sentido de descoberta, produzindo algo novo a partir de suas combinatórias. Ao ser reconhecido como dotado de valor, um objeto passaria a integrar esse inventário; por sua vez, os elementos constantes dessa coleção, ao serem rearticulados, fazem surgir outros valores. Tal concepção pode ser trazida ao pensarmos a crítica das mídias, em que valores são dinamicamente transformados nos repertórios por elas constituídos e nas reapropriações de tais repertórios ao sabor do gosto popular visando a formação de juízos.

Nas tensões entre o estabelecimento de "valores" e a constituição de "repertórios", portanto, antigas distinções de "gosto" (erudito, popular, massivo, midiático) são desafiadas por meio da crítica contemporânea, a exemplo das contribuições de teóricos que destacam a importância dessas interações. Antes de nos voltarmos mais detidamente ao debate na crítica contemporânea das mídias, julgamos imprescindível retomar, para além de possíveis referências às críticas literária e cinematográfica, a obra de teóricos tão variados quanto Bakhtin, Bourdieu e De Certeau, justamente por nos situarem em relação à associação comumente feita entre crítica e qualidade (ou sua ausência) nos discursos midiáticos. De modo diverso, tais autores articulam os conceitos de cultura erudita e cultura popular (e suas derivações) em torno da questão dos juízos de valor cunhados nos campos da produção cultural.

Ao tratar da "cultura popular" a partir da obra de François Rabelais, ensaio produzido em 1965, Bakhtin (1987) assevera a impossibilidade de um juizo sobre ela: ao não se ajustar aos cânones de sua época, as formas e manifestações populares de cultura não poderiam jamais ser valoradas (ou valorizadas) sem que houvesse uma profunda modificação nos próprios critérios de julgamento. Ao denominar "realismo grotesco" as imagens da cultura cômica popular em todas as suas manifestações, o autor rompe com as demarcações entre alta e baixa cultura - caras à crítica tradicional -, apontando que suas representações não encontram lugar na "estética do belo" forjada na época moderna, exigindo novas regulações.

Em outro diapasão, mas fundamentado em uma radical crítica à intenção pura nas obras de arte, Bourdieu desafia a noção de "distinção" em seus aspectos ideológicos, afirmando que se trata, no estabelecimento de juízos estéticos, de uma operação (seja ela consciente ou inconsciente) na qual "a obra de arte só adquire sentido 
e só tem interesse para quem é dotado do código segundo o qual ela é codificada" (Bourdieu, 2008: 10), processo elidido no movimento de autolegitimação da crítica e que deixa, em seu entorno, os objetos por ela não reconhecidos. $O$ autor aponta, de modo polêmico, que a estética popular é tomada, justamente, como o "avesso" da estética kantiana, em que o "ethos popular opõe, implicitamente, uma tese que contradiz a analítica do Belo em cada uma de suas proposições" (Bourdieu, 2008: 10).

Movimento análogo pode ser estabelecido em De Certeau (1996), para quem a "cultura popular" seria um estilo de trocas sociais, invenções técnicas e resistência moral, isto é, "uma economia do dom (de generosidades como revanche), uma estética de golpes (de operações de artistas) e uma ética da tenacidade (mil maneiras de negar à ordem estabelecida o estatuto de lei, de sentido ou fatalidade)" (De Certeau, 1996: 88). Ao contrário de uma filiação crítica que exclui, de diversas narrativas, a possibilidade de uma estética e a inscrição de uma ética, o autor define as formas populares (especificamente, as formas verbais) não como "um corpo considerado estranho, estraçalhado a fim de ser exposto, tratado e 'citado' por um sistema que reproduz, com os objetos, a situação que impõe aos sujeitos" (De Certeau, 1996: 89), mas como modos de reapropriação de estratégias dominantes por meio de usos e táticas criativos.

Se os valores são mutáveis e relacionais, os repertórios são, ao mesmo tempo, por eles constituídos e deles constituintes. Em seu artigo "Televisão: a questão do repertório", Machado aponta que, para além das questões de audiência e mercado, a televisão brasileira - referência importante na pesquisa -, ao completar cinquenta anos, acumulou um conjunto volumoso de obras criativas, "um repertório suficientemente denso e amplo para que se possa incluí-la sem esforço entre os fenômenos culturais mais importantes de nosso tempo" (Machado, 2008: 21). Catálogo de imaginários e coleção de imagens, a televisão, comumente percebida como um meio "popularesco" e "de massa" (como afirma o autor, na pior acepção dessas palavras), acumula experiências de qualidade e confirma sua inscrição como produção cultural relevante e autônoma.

Os estudos sobre televisão, segundo Machado, ainda estão limitados ao acompanhamento de sua programação como um fluxo exibido por meio de um sistema de difusão abrangente, em vez de se voltarem para "o conjunto dos trabalhos audiovisuais que a televisão efetivamente produz e a que os espectadores efetivamente assistem" (Machado, 2008: 24), conjunto este constitutivo do repertório televisual, genericamente organizado em programas. Desse modo, a televisão não seria mera 
tecnologia de transmissão, empreendimento mercadológico, sistema de controle político-social, sustentáculo do regime econômico ou máquina de moldar o imaginário (Machado, 2008: 24), mas, ao contrário, constitui-se como um "acervo" heterogêneo de trabalhos audiovisuais que deve ser abordado a partir de uma "perspectiva valorativa" inscrita na materialidade de seus programas. Ou seja:

É preciso (também) pensar a televisão como o conjunto dos trabalhos audiovisuais (variados, desiguais, contraditórios) que a constituem, assim como o cinema é o conjunto de todos os filmes produzidos e a literatura o conjunto de todas as obras literárias escritas ou oralizadas, mas sobretudo daquelas obras que a discussão pública qualificada destacou para fora da massa amorfa da trivialidade. O contexto, a estrutura externa, a base tecnológica também contam, é claro, mas eles não explicam nada se não estiverem referidos àquilo que mobiliza tanto produtores quanta telespectadores: as imagens e os sons que constituem a "mensagem" televisual (Machado, 2008: 26).

Conhecer amplamente o que a televisão tem produzido, nacional e internacionalmente, é fundamental para a conformação de um repertório próprio (ao crítico, ao público) a partir desse amplo repertório de imagens. Para Machado, a tarefa de uma crítica televisiva - e, por extensão, uma crítica das mídias - insere-se, justamente, nesse intervalo, visando

estabelecer critérios de seleção, tão rigorosos quanto possível (...) que permitam elevar os níveis de exigência da audiência e, sobretudo, premiar, com estudos e comentários críticos, os esforços daqueles que, contra todos os obstáculos e a despeito de todas as estruturas e modelos, fazem a melhor televisão do mundo (Machado, 2008: 27).

O autor assume, nesse ponto, o debate sobre a "televisão de qualidade", alertando para a ambiguidade desta expressão e propondo sua extensão de modo a não operar, dicotomicamente, entre os polos da produção popularesca e massiva (sem qualidade) e da produção sofisticada e elitista (de qualidade), em que "a única função respeitável que se pode esperar da televisão é sua modesta contribuição no sentido de introduzir o público leigo e bárbaro dentro do campo da cultura secular e legítima" (Machado, 2008: 29), difundindo amplamente obras qualitativas para, tautologicamente, gerar uma televisão qualificada. Para Machado, a crítica sobre a "qualidade na televisão" deve considerar a criação artística presente neste meio, e não apenas demandas comerciais e contextos industriais; deve, ainda, considerar a polissemia de tal expressão, vista como uma virtude que permite qualificar, de modo complexo, produtos e processos os mais diversos possíveis por meio da análise de programas e gêneros, "os modos mais estáveis de referência à televisão como fato cultural” (Machado, 2008: 33). 
No início da pesquisa, partimos de algumas inquietações: como se dariam, nos gêneros discursivos, as articulações entre mídias e estigmas sociais? Seriam as primeiras promovedoras de criação dos últimos ou, ao contrário, poderiam também promover novos modos de interpretação deles? Haveria diferenças significativas entre narrativas ficcionais ou não-ficcionais nas mídias quando olhadas sob o prisma dos estigmas? A esses problemas, outras questões se somaram, adensando o trajeto e conduzindo-nos às políticas da representação e aos regimes de visibilidade presentes nos discursos midiáticos quando estes abordam atores sociais estigmatizados. Ao buscar aportes críticos nos quais estabelecer tal debate, chegamos ao conceito de visibilidades encenadas, que conduzirá nesse momento a reflexão sobre a causa indígena e seus modos de endereçamento nas mídias.

Recentemente, um livro chamou nossa atenção: trata-se de $A$ queda do céu, escrita por Davi Kopenawa, xamã e líder político dos Yanomami, em parceria com o antropólogo francês Bruce Albert. No trecho destacado em sua epígrafe, lemos: “ $A$ floresta está viva. Só vai morrer se os brancos insistirem em destruí-la. Se conseguirem, os reios vão desaparecer debaixo da terra, o chão vai se desfazer, as árvores vão murchar e as pedras vão rachar no calor. A terra ressecada ficará vazia e silenciosa. Os espíritos xapiri, que descem das montanhas para brincar na floresta em seus espelhos, fugirão para muito longe. Seus pais, os xamãs, não poderão mais chamá-los e fazê-los dançar para nos proteger. (...) Então morreremos, um atrás do outro, tanto os brancos quanto nós. Todos os xamãs vão acabar morrendo. Quando não houver mais nenhum deles vivo para sustentar o céu, ele vai desabar”.

Kopenawa relata seu convívio com o "homem branco", por ele chamado de "o povo da mercadoria", apontando o traço predador desse encontro desigual com aqueles vistos pelo xamã e seu povo como "forasteiros"110. No prefácio à obra, Eduardo Viveiros de Castro destaca um aspecto que nos interessa particularmente: as diferenças, no campo das visibilidades sociais, entre aqueles considerados um outro domesticado e os demais, mais inquietos, que se estabelecem, na luta por representação, como um outro radical. São dele as palavras: "Este livro é sobre o Brasil, mas de um modo muito especial, é um livro sobre nós, dirigido a nós, os brasileiros que não se consideram índios".

\footnotetext{
${ }^{110}$ A queda do céu, palavras de um xamã yanomami (São Paulo, Companhia das Letras, 2015, 720pp.).
} 
Ressaltando um elemento fundamental ao pensamento de Kopenawa, Viveiros de Castro cita, em seu texto, o seguinte trecho do xamã: "Na floresta, a ecologia somos nós, os humanos. Mas são também, tanto quanto nós, os xapiri, os animais, as árvores, os rios, os peixes, o céu, a chuva, o vento e o sol! É tudo o que veio à existência na floresta, longe dos brancos; tudo o que ainda não tem cerca. (...) Somos habitantes da floresta. Nascemos no centro da ecologia e lá crescemos". Como se habitassem duas ordens discursivas diferentes, brancos e índios parecem se posicionar em lugares antagônicos na esfera social e, também, em suas visibilidades encenadas. No cenário da crítica midiática, nesse momento iremos elaborar a questão dos estigmas associados aos povos indígenas - frequentemente alvo de violência concreta e também simbólica - a partir de alguns apontamentos sobre o filme Xingu (2012), de Cao Hamburger. O filme problematiza os discursos correntes sobre os indígenas, que usualmente o retratam como um outro distante, questionando determinadas políticas da representação desses povos, sempre vistos como estranhos, exóticos, quase estrangeiros em seu próprio país.

Ao tratarmos dos estigmas, portanto, uma questão se impõe: a problemática das “proximidades compulsórias" (Figueiredo, 2012: 2), reordenando a questão das relações entre o mesmo e o outro por meio de alguns desafios: a) a urbanização em massa e as migrações confundem os contornos entre interioridade/exterioridade, abalando identidades constituídas em fronteiras estáveis; b) o outro distante, das viagens turísticas, dos cartões postais ou espetacularizado pelas mídias, não se coloca como ameaça à identidade; c) a tecnologia da comunicação parece diluir a cada dia os obstáculos relacionados com o tempo e o espaço, potencializando deslocamentos simbólicos, desestabilizando identidades e complexificando a cultura das visualidades e as estratégias de visibilidade pública (Figueiredo, 2012).

Como pensar, então, o partilhamento de espaços públicos com o outro que agora está perto e não apenas de passagem, ou seja, enfrentar os problemas das fronteiras invisíveis, dos recursos da visibilidade, da dúvida sobre a suposta condescendência multiculturalista do Ocidente e do retorno da reflexão da política sob o viés da estética, nos termos que nos propõe Rancière ao tratar da "partilha do sensível" (Rancière, 1996: 120)? Ao pensarmos tais questões à luz do filme analisado, algumas considerações se fazem prementes. Se nos deslocarmos da "cultura da visualidade", entendida como experiência cultural, para as "políticas de visibilidade", compreendendo visibilidade como estratégia política, como mecanismos socioculturais compartilhados que conferem reconhecimento a determinadas imagens visuais (Figueiredo, 2012: 4), podemos nos 
colocar parâmetros a partir dos quais considerar os estigmas em relação à questão indígena nas mídias ${ }^{111}$ e o modo como ela foi retratada no filme Xingu.

No filme, notamos um deslocamento discursivo que retira o "índio" da invisibilidade, inserindo-o no diapasão do exotismo (como é comum em reportagens de telejornais, a exemplo do programa Globo Repórter, exibida em 8 de junho de 2012) para, ao final, assumi-lo como outro extremo, diverso, mas com uma identidade e cultura próprias. Parece-nos que o filme tangencia a distinção proposta por Figueiredo (2012: 2) do "outro distante" (que, enquanto assim permanece, não incomoda) e do "outro próximo" (que passa a nos incomodar justamente por se tornar mais presente e semelhante). No caso indígena, percebemos que a ideia de preservação é harmônica com a tentativa de manter os índios distantes, ou ainda, de tentar "compreender" sua cultura e "civilizá-los".

Justamente no lugar da interação, quando os conflitos deveriam ser negociados, é que a tensão se acirra, pois não sabemos o que fazer com o outro quando ele "invade" nosso espaço próximo - como quando os índios exigem direitos de cidadania, comércio, território, de serem reconhecidos como "brasileiros", no contraste entre identidade e alteridade. Integrantes que somos de um país colonizado e, no caso brasileiro, supostamente aberto às diferenças étnicas e raciais, perguntamos então qual seria nosso outro - e talvez o índio seja, ainda, um outro radical para nós, por seu modo de vida, cultura, valores, religião, organização social e por, aparentemente, não desejar o desenvolvimento econômico, estando em um lugar simbólico estabilizado no tempo.

Xingu, o filme, trata de uma questão ainda obscura e de complexa tematização nas mídias (em seus discursos correntes), a questão indígena no Brasil. A contradição encontra-se justamente no fato de que, assumindo essa hipótese, o nosso outro distante e radical seria, justamente, aquilo que temos de mais próximo, de mais local, de mais autóctone na nossa cultura, de mais tradicional, de mais próprio (ao menos do ponto de vista de um suposto imaginário fundante), que é justamente a cultura indígena.

\footnotetext{
${ }^{111}$ Lembramos aqui de algumas reportagens televisivas sobre disputas de terra, em que os índios sempre são retratados como os outros distantes - bárbaros -, como nos conflitos ocorridos no sul da Bahia, em que em que fazendeiros e índios são colocados como oponentes em disputa (os primeiros como vítimas, os segundos como invasores), veiculadas em diversos telejornais em diversos jornais em abril de 2012. A questão indígena nas mídias não se restringe à televisão, sendo também frequente em jornais diários ou revistas semanais, abordando conflitos relativos, sobretudo, à demarcação de terras no Brasil. Ver, a título de exemplo, matéria na Folha Online sobre liberação de trecho da Estrada de Ferro Carajás, operada pela empresa Vale, que, segundo o jornal Folha de S. Paulo havia sido bloqueada por índios das comunidades guajajara e awá-guajá como protesto quanto às resoluções envolvendo o julgamento da Terra Indígena Raposa Serra do Sol (“Índios desocupam trecho da Estrada de Ferro Carajás”, 05/10/2012).
} 
Nesse sentido, o "outro distante" e o "outro próximo" se encontram: trata-se de uma questão de posição do sujeito ou, justamente, de um momento de tensão em que o outro "distante" deixa de ser "domesticado" (acomodado em seu lugar) e se torna um outro "extremo" (colocando-se fora do lugar em que deveria estar), remetendo aos estigmas. Pensamos novamente na proposição de Hall (2001), naquelas identidades desalojadas de "tempos, lugares, histórias e tradições", identidades que "flutuam" no contexto de uma vida social globalizada em seus estilos, com participação ativa das redes de comunicação interligadas e das imagens da mídia. Nesse sentido, podemos afirmar que o "outro" opera de modo relacional com o "mesmo"; incomoda justamente quando se torna mais semelhante a este. A questão dos estigmas aponta para esse aspecto: diferentemente dos preconceitos, eles dizem respeito ao outro que se torna próximo quando, ao contrário, deveria permanecer "em seu lugar" ${ }^{112}$, não encontrando espaço nos discursos circulantes, "uma soma empírica de enunciados com visada definicional sobre o que são os seres, as ações, os acontecimentos, suas características, seus comportamentos e os julgamentos a eles ligados" (Charaudeau, 2006: 118).

Em sua cena final, Xingu nos coloca frente a frente com um outro anunciado, no filme, como isolado: vemos em close um homem indígena de uma tribo à época ainda não encontrada, que nos olha de frente de modo altivo, desafiador, como se instaurasse sua radicalidade enquanto outro não domesticado. Ao mesmo tempo, entretanto, o filme problematiza esse encontro e possibilita que vislumbremos, no tempo futuro da narrativa fílmica que é nosso tempo presente, os processos de dominação daí decorrentes. Ao contrário de grupos tidos como minorias sociais (negros, mulheres), o indígena nunca poderá se tornar um "branco", um de "nós" - nem mesmo por meio das tentativas de "aculturação" ou, ao contrário, de preservação de sua "autenticidade".

Ao abordarmos a problemática do "outro distante" e do "outro próximo", e suas visibilidades pelo deslocamento da cultura colonizadora para a dos colonizados, é sobre a questão das identidades - sobre as quais se fundam os estigmas - que nos voltamos. Tomada dessa maneira, tal questão dialoga com aquela tratada por Rancière ao falar da “partilha do sensível” (2009) e por Spivak ao perguntar sobre a "subalternidade" (2010). É a partir dessa trilha que seguiremos.

\footnotetext{
${ }^{112}$ Não por coincidência, a biografia de Edward Said, criador do conceito de "orientalismo" (que aponta o Oriente como uma invenção do Ocidente), intitulada Out of place: a memoir (New York: Vintage, 2000), dialoga com as reflexões de Stuart Hall (precursor dos estudos culturais e crítico severo das relações de dominação de raça, gênero, classe) sobre a diáspora, como lemos em "Pensando a diáspora: reflexões sobre a terra do exterior" (traduzido em Da diáspora, Belo Horizonte, UFMG, 2003).
} 
No documentário Santiago, de João Moreira Salles (2007), a cena final ecoa a narração contundente daquele que seria seu realizador: "Não existem planos fechados Santiago está sempre distante. A maneira como conduzi as entrevistas me afastou dele, o que pode explicar o desconforto de Santigo. (...) Na filmagem, eu nunca deixei de ser o dono da casa e ele nunca deixou de ser o nosso mordomo. E no fim, quando Santiago tentou me falar do que lhe era mais íntimo, eu não liguei a câmera". Interrompido por seu diretor durante mais de uma década, os cinco dias de filmagem são transformados em imagens apenas após a morte do personagem, acentuando o desconforto que sentimos ao ver suas imagens. É o incômodo de nos depararmos com a presença próxima do outro, em sua alteridade radical, que nos desafia quando assistimos a esse documentário, em que o mordomo, sempre acuado e mal compreendido em seu português espanholado, interpela-nos nos espaços conhecidos de nossa identidade, mantendo-se como subalterno, posto que silenciado, sem direito à fala.

Quais seriam, portanto, as possibilidades, deslocamentos e transformações a partir de diferentes políticas da representação (notadamente em gêneros referenciais), $o$ momento de giro nos discursos? Na pergunta que intitula o ensaio de Spivak (2010), pode o subalterno ${ }^{113}$ realmente falar? Ele será ouvido ou permanecerá calado frente a vozes hegemônicas? Entre a estridência e o silêncio, uma questão se coloca: como ouvir a voz do outro, em fez de falar por ele ou com ele? Como escutar o outro deixando que ele fale, sem sermos por ele siderados, em deslumbramento ou aquiescência? De acordo com Spivak (2010), o subalterno deve falar por si mesmo, mas não pode fazê-lo, pois se não for investido de alguma forma de agenciamento, não poderá construir um espaço de interação que implique em reversibilidade dos enunciadores no discurso.

Para a autora, tributária dos estudos pós-coloniais, não se pode falar "pelo subalterno", mas se pode falar "contra a subalternidade", aprendendo a ouvir sua resposta, desconstruindo nosso lugar privilegiado e desaprendendo os discursos instituídos. Ainda que o subalterno não possa falar enquanto tal, pois não seria ouvido, seus modos de constituição devem ser problematizados, inclusive na recusa à busca de uma possível autenticidade em relação a ele.

\footnotetext{
${ }^{113} \mathrm{Na}$ apresentação à tradução brasileira, Sandra Regina Almeida afirma que Spivak rejeita o uso do termo "subalterno" para se referir a todo e qualquer marginalizado, mas apenas àqueles cujas vozes "não podem ser ouvidas", descrevendo "as camadas mais baixas da sociedade constituídas pelos modos específicos de exclusão dos mercados, da representação política e legal, e da possibilidade de se tornarem membros plenos no estrato social dominante" (Spivak, 2010: 12, apresentação).
} 
A emergência de sujeitos tradicionalmente excluídos dos discursos midiáticos, como os indígenas, pode assim ser pensada a partir desses questionamentos em relação ao lugar do outro e aos modos de representá-lo. Sem pertencer a um lugar no qual possa, efetivamente, ser ouvido e considerado em sua heterogeneidade, ainda que se autorrepresente o subalterno não poderá falar. Se a representação ${ }^{114}$ pressupõe, portanto, um falante e um ouvinte (um enunciador e um coenunciador, um eu e um outro), esta só se torna um "ato de fala" se houver equilíbrio entre eles, estabelecendo posições discursivas intercambiáveis, como vimos em alguns dos documentários brasileiros anteriormente analisados. Daí a impossibilidade, segundo Spivak, "de se articular um discurso de resistência fora dos discursos hegemônicos" (Spivak, 2010: 16. apresentação). Ao mesmo tempo, essa impossibilidade coloca um desafio a mais para o estabelecimento de discursos efetivamente contra-hegemônicos, já que a incorporação dos sujeitos marginalizados, a exemplo do que vimos em relação à causa indígena, pode se dar de modo domesticada, reforçando visibilidades já reconhecidas.

Ao perguntarmos se o subalterno fala, devemos indagar como, onde, para quem fala; como, onde e por quem é ouvido; como se opera a construção de sua representação - política ou filosófica -, falando com ele ou reapresentando-o como outro. Em cada caso, cabe uma inquietação que aponte a posição por ele ocupada em sua outridade e nos embates discursivos que o definem enquanto subalterno. Spivak é contundente em suas proposições anunciando que seu ensaio "se deslocará, por uma rota necessariamente tortuosa, a partir de uma crítica aos esforços atuais do Ocidente para problematizar o sujeito, em direção à questão de como o sujeito do Terceiro Mundo é representado no discurso ocidental" (Spivak, 2010: 20).

No caso das mídias, a voz que nelas fala parece se amplificar, mas nem sempre com a mesma potência, pois pode ser ouvida como uma voz própria, como a voz do outro, como a voz que fala por si ou pelo outro, a partir de si ou do outro. Ainda assim, nem sempre os deslocamentos narrativos serão percebidos de uma mesma maneira em suas narrativas. Finalmente, uma última questão nos interpela: quando o outro me afeta (nos dois sentidos da palavra: como sentimento e como incômodo), quando sou por ele afetado, de que modo devo reagir a esse afeto sem transformá-lo em algo estéril?

\footnotetext{
${ }^{114}$ Sobre a questão da representação, Spivak apresenta duas definições que, ao longo do tempo, acabaram subsumidas: "O primeiro termo se refere ao ato de assumir o lugar do outro numa acepção política da palavra, e o segundo, a uma visão estética que prefigura o ato de performance ou encenação" (Spivak, 2010: 13, apresentação).
} 
Entre a materialidade dos objetos e a produção de sentidos, uma possibilidade se vislumbra para a continuidade dessas inquietações: estudar o entremeio - e não apenas o texto acabado ou o contexto de sua realização. Em nosso próximo projeto de pesquisa, intitulado "Crítica audiovisual: novos realismos no cinema e na televisão", vemos surgir uma possibilidade de investigação de práticas audiovisuais marcadas por discursos que visam produzir determinados efeitos de realidade, que, paradoxalmente, apontam para a inscrição de processos de ficcionalização em seus relatos. Destacamos que questões teóricas e metodológicas ainda nos desafiam sobremaneira, pois a cada nova leitura ou reflexão somos forçados e rever os conceitos articuladores do trabalho. Nesse sentido, entendemos que não se trata de apenas realizar um novo levantamento bibliográfico extenso e sua aplicação a objetos empíricos específicos, mas de empreender, de modo crítico, a articulação produtiva dos conceitos.

Das práticas midiáticas analisadas que contribuem para consolidar ou criar novas imagens sobre os estigmas sociais, notamos diferentes encenações de seus temas e personagens, ausências e presenças colocadas na narrativa e demarcações de identidades e diferenças. É justamente nesse ponto que concluímos uma importante etapa de pesquisa, em que pudemos delinear discursos midiáticos referenciais e ficcionais em termos de suas tematizações e figurativizações, estabelecendo relações entre sua enunciação e seus enunciados, e explorando os efeitos de sentido por eles produzidos. Como observamos em outros momentos, chegamos ao final sabendo que uma pesquisa se faz de muitos cruzamentos, encruzilhadas, idas e vindas. Mais do que isso, temos certeza que o momento de chegada é sempre ponto de partida para novas descobertas e futuras indagações.

Esperamos poder continuar, nos próximos anos, a seguir as pegadas deixadas por esse processo, as marcas que ficaram no caminho e em nós mesmos. Finalmente, destacamos a importância de relatar este percurso para sistematizar seu trajeto e resultados, achados e formas de prosseguir. Processo que faz sentido em nossa permanente busca por sentidos, e que consolida de forma inequívoca a tradição da universidade, visando à produção acadêmica, sua divulgação e consolidação. 


\section{Bibliografia}

AGAMBEN, G. O que é o contemporâneo? e outros ensaios. Chapecó: Argos, 2009.

AHMAD, A. Linhagens do presente. São Paulo: Boitempo, 2002.

ALTMAN, R. "Que se suele entender por género cinematográfico". In: Los géneros cinematográficos. Buenos Aires/México: Paidós, 2000.

. Film/Genre. London: British Film Institute, 2006.

ANDREW, D. Concepts in film theory. New York: Oxford University Press, 1984.

APPADURAI, A. Après le colonialisme. Paris: Payot \& Rivages, 2005.

ARAÚJO, I. "Eduardo Coutinho inova ao retratar um dia de televisão". Folha de S. Paulo, Ilustrada, 30/10/2010.

AUFDERHEIDE, P. Documentary film. A very short introduction. New York: Oxford University Press, 2007.

AUGÉ, M.; DIDI-HUBERMAN, G.; ECO, U. L'expérience des images. Paris: INA, 2011.

AUMONT, J. A imagem. Campinas: Papirus, 1993.

. O olho interminável. Cinema e pintura. São Paulo: Cosac Naify, 2004.

AUMONT, J. et al. A estética do filme. Campinas: Papirus, 1995.

AUMONT, J.; MARIE, M. Dicionário teórico e crítico de cinema. Campinas: Papirus, 2003.

BADIOU, A. Pequeno manual de inestética. São Paulo: Estação Liberdade, 2002.

O século. Aparecida: Idéias e Letras, 2007.

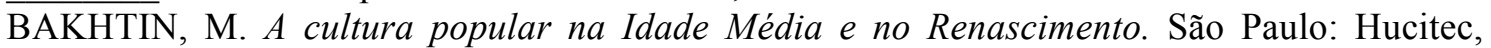
1987.

Problemas da poética de Dostoiévski. 4ª ed. Rio de Janeiro: Forense, 2008.

BAPTISTA, T. "Clark Kent do Harlem". Cine Madalena. Disponível em: cinemadalena.wordpress.com. Acesso em: 11/08/2011.

BATISTA, L. L.; LEITE, F. (orgs.). O negro nos espaços publicitários brasileiros. Perspectivas contemporâneas em diálogo. São Paulo: Cone, 2011.

BARNOW, E. Documentary. A history of non-fiction film. Oxford/New York: Oxford University Press, 1993.

BARROS, D. L. P. Teoria semiótica do texto. $2^{a}$ ed. São Paulo: Ática, 1994.

BARSAM, R. M. Non-fiction film. A critical history. Indianapolis: Indiana University Press, 1992.

BARTHES, R. "Introdução à análise estrutural da narrativa". In: Análise estrutural da narrativa. Petrópolis: Vozes, 1976. . S/Z. Lisboa: Edições 70, 1980.

O rumor da língua. São Paulo: Brasiliense, 1988.

Crítica e verdade. $3^{\mathrm{a}}$. ed. São Paulo: Perspectiva, 1999.

$\overline{\text { BAUDRY, }}$ A. et al. Comment peut-on anticiper le reel? Entretiens. Collection Cinéma documentaire. Paris: L'Harmattan/Addoc, 2001.

BAUMAN, Z. O mal-estar da pós-modernidade. Rio de Janeiro: Jorge Zahar, 1998.

BAUDRILLARD, J. A transparência do mal. Ensaio sobre os fenômenos extremos. Campinas: Papirus, 1990.

. Simulacros e simulação. Lisboa: Relógio d'Água, 1991 (col. Antropos).

BAZIN, A. O que é o cinema. São Paulo: Cosac Naify, 2014.

BENJAMIN, W. "Madame Ariadne, segundo pátio à esquerda". In: Obras escolhidas. Volume 2. São Paulo: Brasiliense, 1987.

. "O narrador". In: Magia e técnica, arte e politica. São Paulo: Brasiliense, 1989.

BENVENISTE, E. Problemas de lingüistica geral I. Campinas: Pontes, 1989a.

. Problemas de lingüistica geral II. Campinas: Pontes, 1989b.

BERNARDET, J.-C. Cineastas e imagens do povo. São Paulo: Companhia das Letras, 2003.

BERNARDO, G. "A teoria do amor". Matraga. Estudos Lingüisticos e Literários. V. 16, jan.dez. 2004. Disponível em: http://www.pgletras.uerj.br/matraga/matraga16/matraga16a22.pdf. Acesso em: 20/07/2010.

BERRY-FLINT, S. "Genre". In: MILLER, T.; STAM, R. (eds.). A companion to film theory. Oxford: Blackwell, 1999. 
BESSE, B.; DESORMEAUX, D. Construire le reportage télévisé. Paris: Victoires, 2011.

BHABHA, H. K. O local da cultura. 2a . reimp. Belo Horizonte: UFMG, 2003.

BIFI. Filmer le réel. Ressources sur le cinéma documentaire. Paris: Bibliothèque du Film, 2001. BLACK, J. The reality effect - film culture and the graphic imperative. New York: Routledge, 2002.

BOLTER, J. D.; GRUSIN, R. Remediation: understanding new media. Cambridge: The MIT Press, 1999.

BOORSTIN, D. J. Image. A guide to pseudo events in America. New York: Vintage, 1992.

BORDWELL, D.; CARROLL, N. (eds.). Post theory. Reconstructing Film Studies. Madison: University of Wisconsin Press, 1996.

BORELLI, S. H. S. Ação, suspense, emoção. Literatura e cultura de massa no Brasil. São Paulo: Educ/Estação Liberdade, 1996.

BORGES, J. L. "Del rigor en la ciencia". El hacedor. 2 'reimp. Buenos Aires: Emecé, 1961. "Funes el memorioso". In: Ficciones. Buenos Aires: Emecé, 1998.

BORGES, W.; ENNE, A. L. S. "Sensacionalismo e modernidade: como uma relação intrinsecamente ambígua se transformou em estratégia de distinção cultural?". Revista Rumores. Ano 1, n. 1, jul.-dez. de 2007.

BOUGNOUX, D. La crise de la représentation. Paris: La Découverte, 2007.

BOURDIEU, P. O poder simbólico. Rio de Janeiro: Bertrand Brasil, 2003.

2008. A distinção. Crítica social do julgamento. São Paulo: Edusp; Porto Alegre: Zouk,

BRACHET, C. Peut-on penser à lá télévision? La cultura sur um plateau. Le Bord de l'Eau: Lormont; INA: Bry-sur-Marne, 2010.

BRAIT, B. Bakhtin: dialogismo e construção de sentido. Campinas: Editora da Unicamp, 2005.

BROOKS, P. Realist vision. New Haven: Yale University Press, 2005.

. The melodramatic imagination. New Haven: Yale University Press, 1995.

BRUNE, F. "Le médias pensent comme moi!". Fragments du discours anonyme. Paris: L'Harmattan: 1997.

BUBER, M. Eu e tu. São Paulo: Centauro, 2001.

BUCCI, E.; KEHL, M. R. Videologias. São Paulo: Boitempo, 2004.

BURKE, P. A Escola dos Annales: 1929-1989. São Paulo: Unesp, 1997.

. Testemunha ocular. Bauru: Edusc, 2004.

BUSCOMBE, E. "A idéia de gênero no cinema americano". In: RAMOS, F. P. (org.) Teoria contemporânea do cinema. Pós-estruturalismo e filosofia analítica. São Paulo: Senac, 2005.

CALlIGARIS, C. Hello Brasil! Notas de um psicanalista europeu viajando ao Brasil. São Paulo: Escuta, 1991. $\overline{09 / 01 / 1998 .}$ "Cinema é catálogo da imaginação ocidental". Folha de S. Paulo. Ilustrada,

"Crise do mercado ou crise do sujeito?". Folha de S. Paulo, Ilustrada, 02/08/2002.

"Para que servem as ficções". Folha de S. Paulo, Ilustrada, 18/01/2007.

CANGUILHEM, G. O normal e o patológico. Rio de Janeiro: Forense Universitária, 1990.

CAPELATO, M. H.; MORETTIN, E.; NAPOLITANO, M.; SALIBA, E. T. (orgs.). História e cinema. São Paulo: Alameda, 2007.

CASADEI, E. B. Jornalismo e reconstrução do passado: os fatos históricos nas notícias de hoje. São Paulo: ECA-USP, 2010 (dissertação de mestrado).

CASTORIADIS, C. A instituição imaginária da sociedade. Rio de Janeiro: Paz e Terra, 1995.

CASTRO, G. "(In)Comunicação, consumo e sociabilidade na cena urbana: breve reflexão a partir do cinema”. Revista Rumores. Vol. 7, n. 14, jul.-dez. de 2013.

CAVELL, S. The world viewed. Cambridge; London: Harvard University Press, 1979.

CHARAUDEAU, P. O discurso das mídias. São Paulo: Contexto, 2006.

CHARTIER, R. Os desafios da escrita. São Paulo: Unesp, 2002.

CHAUÍ, M. Conformismo e resistência - aspectos da cultura popular no Brasil. São Paulo: Brasiliense, 1986.

“Kant: vida e obra”. In: Os pensadores. Kant. São Paulo: Nova Cultural, 1987. 
"Janela da alma, espelho do mundo". In: NOVAES, A. (org.). O olhar. São Paulo: Companhia das Letras, 1988.

CHARTIER, R. A história ou a leitura do tempo. Belo Horizonte: Autêntica, 2010.

CLÉMENT, C. B. "Continuidade mítica e construção histórica". In: Le pouvoir des mots. Symbolique et idéologique. Paris: Maison Mame, 1973 (mimeo.).

COMOLLI, J.-L. Ver e poder. A inocência perdida: cinema, televisão, ficção, documentário. Belo Horizonte: UFMG, 2008.

COSTA, A. Compreender o cinema. $2^{\text {a }}$. ed. São Paulo: Globo, 1989.

COSTA, J. F. A inocência e o vício. Rio de Janeiro: Relume Dumará, 1994.

COUTINHO, E.; XAVIER, I.; FURTADO, J. "O sujeito (extra)ordinário". In: MOURÃO, M.

D.; LABAKI, A. (orgs.). O cinema do real. São Paulo: Cosac Naify, 2005.

CRUGLAK, C. Clínica de la identificación. Rosario: Homo Sapiens, 2000.

CUBITT, S. The cinema effect. Cambridge; London: The MIT Press, 2004.

CURRAN, J.; STATON, J. Power without responsibility: the press and broadcasting in Britain.

$3^{\text {a }}$. ed. London/New York: Routledge, 1988.

DE CERTEAU, M. A cultura no plural. Campinas: Papirus, 1995.

. A invenção do cotidiano. Artes de fazer. Volume 1. Petrópolis: Vozes, 1996.

. História e psicanálise: entre ciência e fiççõo. Belo Horizonte: Autêntica, 2011.

DEBORD, G. A sociedade do espetáculo. Rio de Janeiro: Contraponto, 1997.

DELEUZE, G. Diferença e repetição. Rio de Janeiro: Graal, 1988. . Conversações. São Paulo: Editora 34, 1992.

DELEUZE, G.; GUATTARI, F. Mil platôs. Volume 2. São Paulo: Editora 34, 1997.

DERRIDA, J. Positions. Chicago: University of Chicago Press, 1981. . A escritura e a diferença. São Paulo: Perspectiva, 1995. . Résistances. Paris: Galilée, 1996.

DIDI-HUBERMAN, G. O que vemos, o que nos olha. São Paulo: Editora 34, 1998.

DIDIER-WEILL, A. Os três tempos da lei. Rio de Janeiro: Jorge Zahar, 1997.

DOSSE, F. História do estruturalismo. O campo do signo. Volume 1. Campinas: Editora da Unicamp, 1993.

DUBOIS, P. O ato fotográfico e outros ensaios. $6^{\text {a }}$. ed. Campinas: Papirus, 2003. . Cinema, vídeo, Godard. São Paulo: Cosac Naify, 2004.

DUBY, G.; LARDREAU, G. Diálogos sobre a Nova História. Lisboa: Dom Quixote, 1989.

DUCROT, O. O dizer e o dito. Campinas: Pontes, 1987.

DURAND, G. O imaginário. Rio de Janeiro: Difel, 2001.

ECO, U. Viagem na irrealidade cotidiana. Rio de Janeiro, Nova Fronteira, 1984. Interpretação e superinterpretação. São Paulo: Martins Fontes, 1993a.

"Da impossibilidade de construir a carta do império em escala um por um". $O$

segundo diário mínimo. Rio de Janeiro: Record, 1993b.

. Seis passeios pelos bosques da ficção. São Paulo: Companhia das Letras, 1994.

Lector in fabula. 2a . ed. São Paulo: Perspectiva, 2002.

ELIAS, N. A sociedade dos individuos. Rio de Janeiro: Jorge Zahar, 1994.

ELIAS, N.; SCOTSON, J. L. Os estabelecidos e os outsiders. Rio de Janeiro: Jorge Zahar, 2000.

FAIRCLOUGH, N. Discourse and social change. London: Blackwell, 1993.

FEATHERSTONE, M. "A Aids e o pânico globalizante". In: Cultura global: nacionalismo, globalização e modernidade. Petrópolis: Vozes, 1994.

FERREIRA, J. C. P. Cultura das bordas. Edição, comunicação, leitura. Cotia: Ateliê, 2010.

FERRO, M. Cinéma et histoire. Paris: Denoël; Gonthier, 1977.

FIDLER, R. Mediamorphosis: understanding new media. Thousand Oaks: Pine Forge, 1997.

FIGUEIREDO, V. L. F. de. Narrativas migrantes. Rio de Janeiro: Sete Letras, 2010.

"A partilha do espaço urbano e a questão do outro próximo: repercussões no discurso

teórico e na ficção cinematográfica". Revista Galáxia. São Paulo, n. 24, 2012.

FIORIN, J. L. Elementos de análise do discurso. $4^{a}$ ed. São Paulo: Contexto, 1994.

FLAUBERT, G. Bouvard et Pécuchet. Paris: Bookking International, 1994.

FLUSSER, V. A filosofia da caixa preta. Rio de Janeiro: Relume-Dumará, 2005. 
O mundo codificado. São Paulo: Cosac Naify, 2007.

FOSTER, H. The return of the real. Cambridge: The MIT Press, 1999.

FOUCAULT, M. Vigiar e punir. $6^{\text {a }}$. ed. Petrópolis: Vozes, 1988a. . Microfisica do poder. $7^{\mathrm{a}}$. ed. Rio de Janeiro: Graal, $1988 \mathrm{~b}$.

A ordem do discurso. São Paulo: Loyola, 1996.

. Arqueologia do saber. Rio de Janeiro: Forense Universitária, 1997.

História da loucura. $6^{\mathrm{a}}$. ed. São Paulo: Perspectiva, 2002.

"Sobre a arqueologia das ciências". In: Ditos e Escritos II. Rio de Janeiro: Forense

Universitária, 2008.

FRANÇA, A. "Sobre O feiticeiro e sua magia". Aprendizes de feiticeiro (blog). Universidade Federal do Alagoas, 2009. Disponível em: http://estagiodeclinica.blogspot.com/2009/03/ofeiticeiro-e-sua-magia.html. Acesso em: 20/07/2010.

FRASER, N. "Rethinking the public sphere". In: CALHOUN, C. (ed.). Habermas and the public sphere. Massachusetts: The MIT Press, 1992.

. "Rethinking recognition". New Left Review. Vol. 3, 2000.

FREITAS, J. M. M. Bemaldivida. São Paulo: Edusp, 1992a (col. campi).

Comunicação e psicanálise. São Paulo: Escuta, 1992b (col. ensaio).

Mídia e mitologia do escandaloso. Disciplina ministrada no Programa de Pós-

Graduação em Comunicação. São Paulo: ECA-USP, 2002 (mimeo.).

FREUD, S. "O mal estar na civilização". In: Obras psicológicas completas de Sigmund Freud. Volume XXI. Rio de Janeiro: Imago, 1974.

"Além do princípio do prazer, psicologia de grupo e outros trabalhos". In: Obras psicológicas completas de Sigmund Freud. Volume XVIII. Rio de Janeiro: Imago, 1974.

. A interpretação dos sonhos. $2^{\mathrm{a}}$. ed. Volumes I e II. Rio de Janeiro: Imago, 1987.

"Psicologia de grupo e a análise do ego". In: Edição Eletrônica das Obras

psicológicas completas de Sigmund Freud. Volume XVIII. Rio de Janeiro: Imago, 1997.

FUCHS. C. "Alternative Media as Critical Media". European Journal of Social Theory. Vol. 13,

n. 2, 2010. Disponível em: http://fuchs.uti.at/wp-content/uploads/altmedia.pdf. Acesso em:

$17 / 11 / 2014$

GABLER, N. Vida, o filme: como o entretenimento conquistou a realidade. São Paulo: Companhia das Letras, 1999.

GAINES, J. M.; RENOV, M. (eds.). Collecting visible evidence. Minneapolis; London: University of Minnesota Press, 1999 (col. Visible Evidence, 6).

GANS, H. Deciding what's news. New York: Vintage Books, 1980.

GAUDREAULT, A.; JOST, F. (éds.). "La croisée des médias". Revue Sociétés \& Représentations. Paris: Credhess/Université Paris I, n. 9, avril 2000.

GAUTHIER, G. Le documentaire, un autre cinema. $2^{\mathrm{a}}$. ed. Paris: Armand Colin, 2005.

GAY, P. Represálias selvagens. São Paulo: Companhia das Letras, 2010.

GEERTZ, C. Obras e vidas. O antropólogo como autor. 2a . ed. Rio de Janeiro: URFJ, 2005.

GINZBURG, C. "Ekphrasis e citação". A micro-história e outros ensaios. Lisboa: Difel; Rio de Janeiro: Bertrand Brasil, 1989.

. Mitos, emblemas, sinais. 2a . ed. São Paulo: Companhia das Letras, 2007.

GOFFMAN, E. Estigma. 2a . ed. Rio de Janeiro: Jorge Zahar, 1978.

GOMES, M. R. Jornalismo e ciências da linguagem. São Paulo: Hacker/Edusp, 2000. .Ética e jornalismo. São Paulo: Escrituras, 2002.

2003. Poder no jornalismo: discorrer, disciplinar, controlar. São Paulo: Hacker/Edusp, Comunicação e identificação. Ressonâncias no jornalismo. Cotia: Ateliê, 2008. "Ao abrigo dos discursos circulantes". Revista Rumores. Ano 6, n. 2, 2012.

GRAMSCI, A. Cadernos do cárcere. Volume 1. Rio de Janeiro: Civilização Brasileira, 1999.

GREGORI, M. F. Viração - experiências de meninos nas ruas. São Paulo: Companhia das Letras, 2000.

GREIMAS, A. J. Semântica estrutural. São Paulo: Cultrix, 1976.

GRUNER, C.; DE NIPOTI, C. Nas tramas da ficção. História, literatura e leitura. Cotia: Ateliê, 2008. 
GRUPO M. "Sémiotique et rhétorique du cadre". Texto distribuído no curso Poética da intertextualidade, ministrado pelo prof. dr. Eduardo Peñuela Cañizal. ECA/USP, $1^{\circ}$. semestre de 1998 (mimeo.).

GUARESCHI, N. M. F.; BRUSCHI, M. E. (orgs.). Psicologia social nos estudos culturais. Petrópolis: Vozes, 2003.

GUATTARI, F. Revolução molecular. Pulsações políticas do desejo. São Paulo: Brasiliense, 1987.

GUYNN, W. Un cinéma de non-fiction. Le documentaire classique à l'épreuve de la théorie. Aix-en-Provence: Université de Provence, 2001.

HALL, S. A identidade cultural na pós-modernidade. $5^{\text {a }}$. ed. Rio de Janeiro: DP\&A, 2001.

UFMG, 2003.

Da diáspora: identidades e mediações culturais. Org. Liv Sovik. Belo Horizonte:

HAMBURGER, E. O Brasil antenado. A sociedade da novela. Rio de Janeiro: Jorge Zahar, 2005.

HAMBURGER, C. “A outra civilização. Xingu, maio de 2008”. Folha de S. Paulo, Ilustríssima, 22/04/2012.

HOBSBAWM, E.; RANGER, T. (orgs.). A invenção das tradições. Rio de Janeiro: Paz e Terra, 1984.

HOLLIER, D. (org.). Panorama des sciences humaines. Paris: NRF, 1973.

ISER, W. O fictício e o imaginário: perspectivas de uma antropologia literária. $2^{\mathrm{a}}$. ed. Rio de Janeiro: Eduerj, 2013.

JAGUARIBE, B. O choque do real. Rio de Janeiro: Rocco, 2007.

JAKOBSON, R. Lingüistica e comunicação. São Paulo: Cultrix, s/d.

JAMESON, F. Pós-modernismo: a lógica cultural do capitalismo tardio. São Paulo: Ática, 2006.

JENKINS, H. Cultura da convergência. São Paulo: Aleph, 2008.

JOST, F. Seis lições sobre televisão. Porto Alegre: Sulina, 2004.

. Compreender a televisão. Porto Alegre: Sulina, 2007.

. De quoi les séries américaines sont-elles le symptôme? Paris: CNRS, 2011.

KAVKA, M. Reality TV - Television genres. Edinburgh: Edinburgh University Press, 2012.

KEHL, M. R. "As máquinas falantes". In: NOVAES, A. (org.). O homem-máquina. A ciência manipula o corpo. São Paulo: Companhia das Letras, 2003.

. "A fratria órfã. O esforço civilizatório do rap na periferia de São Paulo". In: A fratria órfã: conversas sobre a juventude. São Paulo: Olho d'Água, 2008.

KELLNER, D. A cultura da mídia - Estudos culturais. Bauru: Edusc, 2001.

KOSSOY, B. Os tempos da fotografia. O efêmero e o perpétuo. Cotia: Ateliê, 2007. Realidades e fiç̧ões na trama fotográfica. $4^{\mathrm{a}}$. ed. Cotia: Ateliê, 2009.

KOYRÉ, A. Estudos de história do pensamento filosófico. São Paulo: Forense/UnB, 1982.

KRISTEVA, J. História da linguagem. Lisboa: Edições 70, 1974 (col. Signos).

LACAN, J. "Os quatro conceitos fundamentais da psicanálise". O Seminário. Livro 11. 4". ed. Rio de Janeiro: Jorge Zahar, 1990.

Escritos. Rio de Janeiro: Jorge Zahar, 1998.

1999.

"As formações do inconsciente". O Seminário. Livro 5. Rio de Janeiro: Jorge Zahar,

. "De um discurso que não fosse semblante". O Seminário. Livro 18. Rio de Janeiro: Jorge Zahar, 2009.

LANCIEN, T. Le journal télévisé. Construction de l'information et compétences d'interprétation. Paris: Didier. 1995.

"Télévision et traitement du réel: du journal télévisé au documentaire". In: JACQUINOT, G.; LEBLANC, G. (éds.). Les genres télévisuels dans l'enseignement. Paris: CNDP/Hachette, 1996.

"Du récepteur à l'interacteur sur internet: la co-construction des messages

d'information". Études de Linguistique Appliquée, n. 117. Paris: Didier-Érudition, 2000.

. (éd.). "Multimédia: les mutations du texte". Les cahiers du Français contemporain,

n. 6. Fontenay/Saint-Cloud: ENS Éditions, 2000. 
LATOUR, B. Jamais fomos modernos. São Paulo: Editora 34, 1994.

. Reassembling the social. An introduction to actor-network theory. Oxford: Oxford

University Press, 2005.

LEENHARDT, J. "Crítica de arte e cultura no mundo contemporâneo". In: MARTINS, M. H. (org.). Rumos da crítica. 2a . ed. São Paulo: Senac/Itaú Cultural, 2007.

LEÓN, B. (ed.). Telerrealidad. El mundo tras el cristal. Sevilha: Comunicación, 2009.

"Télévision et traitement du réel: du journal télévisé au documentaire". In:

JACQUINOT, G.; LEBLANC, G. (éds.). Les genres télévisuels dans l'enseignement. Paris: CNDP; Hachette, 1996.

LE GOFF, J.; NORA, P. História: novos problemas. Rio de Janeiro: Francisco Alves, 1976.

LEMAIRE, A. "Os dois grandes eixos da linguagem". Jacques Lacan, uma introdução. 4". ed. Rio de Janeiro: Campos, 1989.

LÉVI-STRAUSS, C. "Introdução à obra de Marcel Mauss". In: MAUSS, M. Sociologia e antropologia. Volume I. São Paulo: EPU/Edusp, 1974. . Antropologia estrutural. 5a . ed. Rio de Janeiro: Tempo Brasileiro, 1996.

LIPOVETSKY, G.; SERROY, J. L'écran global. Du cinéma au smartphone. $2^{\text {a }}$. ed. Paris: Seuil, 2011.

LOPES, L. P. M. (org.). Discursos de identidades. Campinas: Mercado de Letras, 2003.

LYOTARD, J. F. A condição pós-moderna. $2^{\mathrm{a}}$. ed. Lisboa: Gradiva, 1989.

O inumano: considerações sobre o tempo. Lisboa: Estampa, 1990.

LYRA, B. Singularidades dos gêneros cinematográficos em filmes brasileiros. XVII Encontro da Compós. São Paulo: Universidade Paulista, 2008.

LYRA, B.; SANTANA, G. A experiência do cinema e os filmes triviais no Brasil. XV Encontro da Compós. Bauru: Unesp, 2006.

MACHADO, A. “Anarquia do audiovisual”. Pré-cinemas \& Pós-cinemas. Campinas: Papirus, 1997.

. A televisão levada a sério. São Paulo: Senac, 2000.

MACHADO, A. "Televisão: a questão do repertório". In: BORGES, G.; REIA-BAPTISTA, V. Discursos e práticas de qualidade na televisão. Lisboa: Livros Horizonte/UAL-Ciac, 2008.

MACHADO, A.; VÉLEZ, M. L. "Persistência da reality tv". Revista Significação. São Paulo: ECA-USP, $n^{\circ} .32,2009$.

MAINGUENEAU, D. Novas tendências em análise do discurso. Campinas: Pontes/Editora da Unicamp, 1997.

Termos-chave da análise do discurso. Belo Horizonte: UFMG, 2000.

MALCOLM, J. "Mergulho na obra de Gertrude Stein". Entrevista. Agência Estado, 11/05/2008.

MAMBER, S. Cinéma verité in America. Studies in uncontrolled documentary. Cambridge/London: The MIT Press, 1974.

MANN, J. et al. (orgs.) A Aids no mundo. Rio de Janeiro: Relume Dumará/IMS-UERJ, 1993.

MANNONI, M. La théorie comme fiction. Paris: Seuil, 1979.

MANOVICH, L. The language of new media. Cambridge: The MIT Press, 2001.

MARTÍN-BARBERO, J. Dos meios às mediações. Comunicação, cultura e hegemonia. Rio de Janeiro: UFRJ, 1997.

MAZZARA, B. M. Estereotipos e prejuicios. Madri: Acento Editorial, 1999.

MENDONÇA, K. A punição pela audiência - um estudo do Linha Direta. Rio de Janeiro: Quartet/Faperj, 2002.

."Em Linha Direta com os novos padrões para o telejornalismo". In: RIBEIRO, A. P. G.; SACRAMENTO, I.; ROXO, M. (orgs.). História da televisão no Brasil: do início aos dias de hoje. São Paulo: Contexto, 2010.

MENOUD, L. Qu'est-ce que la fiction? Paris: Vrin, 2005.

MERLEAU-PONTY, M. O visivel e o invisivel. $3^{\text {a }}$. ed. São Paulo: Perspectiva, 1999.

METZ, C. A significação no cinema. São Paulo: Perspectiva, 1972.

MIGLIORIN, C. Ensaios no real. O documentário brasileiro hoje. Rio de Janeiro: Azougue, 2010.

MILLER, T.; STAM, R. A companion to film theory. Oxford: Blackwell, 1999. 
MITTEL, J. "A cultural approach to television genre theory". Cinema Journal. SCMS, 40, n. 3 , 2001.

Genre and television. New York: Routledge, 2004.

MOSCOVICI, S. Representações sociais. Investigações em psicologia social. Petrópolis: Vozes, 2003.

MOTTA, N. Vale Tudo - o som e a fúria de Tim Maia. Rio de Janeiro: Objetiva, 2007.

MOURÃO, M. D.; LABAKI, A. (org.). O cinema do real. São Paulo: Cosac Naify, 2005.

NAGIB, L. World cinema and the ethics of realism. New York: Continuum, 2011.

NAGIB, L.; MELlO, C. (eds.). Realism and the audiovisual media. London: Palgrave Macmillan, 2009.

NEALE, S. Genre. Londres: British Film Institute, 1980.

NICHOLS, B. Ideology and the image. Bloomington: Indiana University Press, 1981. Representing reality. Bloomington: Indiana University Press, 1991.

. Blurred boundaries. Questions of meaning in contemporary culture. Bloomington:

Indiana University Press, 1994.

"A voz do documentário". In: RAMOS, F. P. (org.). Teoria contemporânea do

cinema. Volume II. São Paulo: Senac, 2005.

NINEY, F. Le documentaire et ses faux-semblants. Paris: Klincksieck, 2009.

NÖTH, W. A semiótica no século XX. São Paulo: Annablume, 1996 (col. E).

NUNES, B. "Crítica literária no Brasil, ontem e hoje". In: MARTINS, M. H. Rumos da crítica. $2^{\text {a }}$. ed. São Paulo: Senac/Itaú Cultural, 2007.

ODIN, R. De la fiction. De Boeck Université: Bruxelles, 2000.

. "Filme documentário, leitura documentarizante". Revista Significação. Ano 39, n.

37, jan.-jun. 2012.

ORLANDI, E. As formas do silêncio. 4a . ed. Campinas: Editora da Unicamp, 1997.

ORTIZ, R. Cultura brasileira e identidade nacional. São Paulo: Brasiliense, 1985.

. Mundialização e cultura. São Paulo: Brasiliense, 1994.

PARKER, R.; GALVÃO, J.; BASTOS, C.; PEDROSA, J. S. (orgs.). A Aids no Brasil. Rio de Janeiro: Relume Dumará/IMS-UERJ, 1994.

PEÑUELA CAÑIZAL, E. "Emblema e símbolo no texto fílmico". Texto apresentado no XIX Congresso da Intercom, Universidade Estadual de Londrina (PR), setembro de 1996.

"Manifestação de recursos poéticos em dois filmes do Cinema Novo". Revista Rumores. Ano 1, n. 1, jul.-dez. de 2007.

PINEL, V. Écoles, genres et mouvements au cinema. Paris: Larousse, 2000.

PONTE, C. Leituras das notícias. Contributos para uma análise do discurso jornalístico. Lisboa: Horizonte: 2004.

PRADO, J. L. A. A invenção do Mesmo e do Outro na mídia semanal. Hipermídia. Grupo de Pesquisas em Mídia Impressa, PUC-SP, 2008.

Regimes de visibilidade em revistas. Análise multifocal dos contratos de comunicação. Hipermídia. Grupo de Pesquisas em Mídia Impressa, PUC-SP, 2011.

jan.-jun. 2012. "Política da imagem na era da convocação". Revista Significação. Ano 39, n. 37,

Educ/Fapesp, 2013.

PROPP, W. Morfologia do conto maravilhoso. Rio de Janeiro: Forense, 1984.

QUÉRÉ, L. Des miroirs équivoques. Paris: A.-M., 1982.

RAMOS, F. P. Mas afinal... o que é mesmo documentário? São Paulo: Senac, 2008.

RAMOS, F. P. (org.). Teoria contemporânea do cinema. Pós-estruturalismo e filosofia analitica. Volume I. São Paulo: Senac, 2005.

. (org.). Teoria contemporânea do cinema. Documentários e narratividade ficcional.

Volume II. São Paulo: Senac, 2005.

RAMOS, S. (org.). Mídia e racismo. Rio de Janeiro: Pallas, 2002.

RANCIÈRE, J. O desentendimento: política e filosofia. São Paulo: Editora 34, 1996.

La fable cinématographique. Paris: Seuil, 2001.

O inconsciente estético. São Paulo: Editora 34, 2005. 
"Are some things unrepresentable?". In: The future of the image. London; New

York: Verso, 2007.

. A partilha do sensivel. 2a . ed. São Paulo: Exo/Editora 34, 2009.

O espectador emancipado. São Paulo: Martins Fontes, 2012.

O destino das imagens. Rio de Janeiro: Contraponto, 2013.

RENOV, M. Theorizing documentary. New York: Routledge, 1993.

RICOUER, P. Tempo e narrativa. A intriga e a narrativa histórica. Volume 1. São Paulo: Martins Fontes, 2010.

RISÉRIO, A. Carnaval Ijexá. Salvador: Corrupio, 1981.

ROCHA, J. C. C. Teoria da ficção. Indagações à obra de Wolfgang Iser. Rio de Janeiro: Eduerj, 1999.

ROUCH, J. "The camera and the man". In: HOCKINGS, P. (ed.). Principles of visual anthropology. Berlin/New York: Mouton de Gruyter, 2003.

SAID, E. Cultura e imperialismo. São Paulo: Companhia das Letras, 1995.

. Orientalismo. New York: Pantheon Books, 1996.

SANTAELLA, L. Cultura das mídias. 2a. ed. São Paulo: Experimento, 1996.

SANTIAGO, S. "Cadê Zazá? A vida com obra de arte". Folha de S. Paulo. Mais!, 09/09/2001. O cosmopolitismo do pobre. Belo Horizonte: UFMG, 2004.

SANTOS, M. "A aceleração contemporânea: tempo mundo e espaço mundo". In: Fim de século e globalização. São Paulo: Hucitec/Anpur, 1993.

SARLO, B. Tempo passado - cultura da memória e guinada subjetiva. São Paulo: Companhia das Letras; Belo Horizonte: UFMG, 2007.

SAUSSURE, F. Curso de lingüistica geral. São Paulo: Cultrix, 1970.

SCHEFER, J.-L. L'homme ordinaire du cinema. Paris: Cahiers du Cinema/Gallimard, 1980.

SCHERER, E. A-t-on encore besoin des journalistes? Manifeste pour un "journalisme augmenté". Paris: PUF, 2011.

SCHUDSON, M. Discovering the news. New York: Basic Books, 1978.

. "Creating public knowledge". Media Studies Journal. Media and democracy. Vol. 9,

n. 3. New York: Columbia University, 1995.

SERELLE, M. V. "Metatevê: a mediação como realidade apreensível". Revista Matrizes. Vol. 2 , n. 2 , junho de 2009.

2010.

SFEZ, L. A saúde perfeita. São Paulo: Loyola, 1996.

SHOHAT, E.; STAM, R. Crítica da imagem eurocêntrica. São Paulo: Cosac Naify, 2006.

SILVA, M. D. J. "Um imaginário da redenção: sujeito e história no documentário musical". Doc On-Line. Número 12, agosto de 2012.

SILVA, T. T. (org.). Identidade e diferença. A perspectiva dos estudos culturais. Petrópolis: Vozes, 2000.

SOARES, R. L. Imagens veladas. Aids, imprensa e linguagem. São Paulo: Annablume, 2001. "Margens do jornalismo: linguagem e discurso". Galáxia. Volume 5, 2005.

"Na periferia das bordas: ação e romance nos filmes de Simião Martiniano". In:

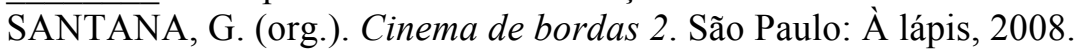
. Margens da comunicação: discurso e mídias. São Paulo: Annablume/Fapesp, 2009.

"Pequeno inventário de narrativas midiáticas: verdade e ficção em discursos audiovisuais". Revista Significação. Volume 34, 2010.

"De convergências e hibridismos: remixagens e pilhagens em filmes de bordas". Revista MATRIZes. Ano 5, $\mathrm{n}^{\mathrm{o}}$ 1, jul.-dez. $2011 \mathrm{a}$.

"Saneamento básico, o filme, ou como fazer um filme de bordas". In:

CARRASCOZA, J. L. A.; ROCHA, R. L. M. (orgs.). Consumo midiático e culturas da convergência. São Paulo: Miró Editorial, 2011 b.

SOARES, R. L.; GOMES, M. R. (orgs.). Profissão Repórter em diálogo. São Paulo: Alameda, 2012.

SOARES, R. L.; FREIRE, M. C. S. "História e narrativas audiovisuais: de fato e de ficção". Revista Comunicação, Mídia e Consumo. Vol. 10, n. 28, 2013. 
SOARES, R. L.; LIMBERTO, A. L. "Tramas do outro nas telas do discurso: circulação audiovisual e consumo cultural". PragMATIZES - Revista Latino-Americana de Estudos em Cultura. Ano 4, n. 6, 2014.

SODRÉ, M. A narrativa do fato. Petrópolis: Vozes, 2009.

SODRÉ, M.; FERRARI, M. H. Técnica de reportagem. Notas sobre a narrativa jornalística. São Paulo: Summus, 1986.

SONTAG, S. Doença como metáfora. Rio de Janeiro: Graal, 1984 (col. Tendências 6). . A Aids e suas metáforas. São Paulo: Companhia das Letras, 1989. Diante da dor dos outros. São Paulo: Companhia das Letras, 2003. Questão de ênfase. São Paulo: Companhia das Letras, 2005.

SOUZA, E. M. Janelas indiscretas. Ensaios de crítica biográfica. Belo Horizonte: UFMG, 2011.

SPIVAK, G. C. Pode o subalterno falar? Belo Horizonte: UFMG, 2010.

STAM, R. "Specificities. From hybridity to the aesthetics of garbage". Social identities. Vol. 3, n. 2, 1997.

"Text and intertext. Introduction". In: STAM, R.; MILLER, T. (eds.). Film and theory. An anthology. Oxford: Blackwell, 2000.

. Introdução à teoria do cinema. Campinas: Papirus, 2003.

STAM, R.; MILLER, T. (eds.). Film and theory. An anthology. Oxford: Blackwell, 2000.

TEIXEIRA, F. E. (org.). Documentário no Brasil. Tradição e transformação. São Paulo: Summus, 2004.

TELLES, S. "Realismo a serviço da subjetividade". O Estado de S. Paulo, Sabático, 10/07/2010.

TELLES, V. S. Pobreza e cidadania. São Paulo: Editora 34, 2001.

TRINDADE, T. N. O documentário chegou à sala de cinema. E agora? O lugar do documentário no mercado cinematográfico brasileiro a partir de seus agentes: da produção à exibição (2000-2009). Campinas: Unicamp, 2011 (dissertação de mestrado).

VENANCIO, R. D. O. Massificação e jornalismo: retórica e linguagem no escopo da comunicação social. São Paulo: ECA-USP, 2010 (dissertação de mestrado).

VERÓN, E. "Lingüística e sociologia: para uma 'lógica natural' dos mundos sociais". In: $A$ produção de sentido. São Paulo: Cultrix, 1980.

VIANA, S. Rituais de sofrimento. São Paulo: Boitempo, 2012.

VICENTE, E. Da Vitrola ao iPod: uma história da indústria fonográfica no Brasil. São Paulo: Alameda, 2014.

VICENTE, E.; SOARES, R. L. "Centro Cultural da Juventude: um olhar sobre a diversidade musical de São Paulo". Música Popular em Revista. Vol. 1, 2012.

. "O folhetim e a canção: a representação do negro e das identidades periféricas na televisão brasileira”. Revista Novos Olhares. São Paulo. Vol. 2, n. 2, 2013.

VIDAL, G. De fato e de ficção. São Paulo: Companhia das Letras, 1987.

VITORELLO, D. M. "A outra cena em 'A vida como ela é"”. IV Encontro Latino-Americano dos Estados Gerais da Psicanálise. Instituto Sedes Sapientiae, 04-06/11/2005. Disponível em: www.estadosgerais.org/encontro/.../Daniel_Migliani_Vitorello.pdf. Acesso em: 20/07/2010.

WAJCMAN, G. L'objet du siècle. Paris: Verdier, 1998 (col. Philia).

WALL, A. "On the edges of words and pictures". Texto apresentado no seminário avançado $L a$ parole comme image. L'image comme parole. ECA/USP, maio de 1998.

WARREN, C. (ed.). Beyond document. Essays on non-fiction film. Hanover: University Press of New England/Wesleyan University Press, 1995.

WATT, I. A ascensão do romance. São Paulo: Companhia das Letras, 1990.

WHITE, H. Trópicos do discurso: ensaios sobre a crítica da cultura. São Paulo: Edusp, 1994.

WILLIS, C.; BOWMAN, S. We media: how audiences are shaping the future of news and information. Media Center, 2008. Disponível em: www.hypergene.net/wemedia/weblog.php.

WINSTON, B. Claiming the real. The documentary film revisited. London: British Film Institute, 1995.

“A maldição do 'jornalístico' na era digital”. In: MOURÃO, M. D.; LABAKI, A. (orgs.). O cinema do real. São Paulo: Cosac Naify, 2005. 
XAVIER, I. O discurso cinematográfico. A opacidade e a transparência. Rio de Janeiro: Paz e Terra, 1984.

. O olhar e a cena - Melodrama, Hollywood, Cinema Novo, Nelson Rodrigues. São Paulo: Cosac Naify, 2003.

. "A alegoria histórica". In: RAMOS, F. P. (org.). Teoria contemporânea do cinema. Volume I. São Paulo: Senac, 2005.

XAVIER, I. (org.). A experiência do cinema: antologia. Rio de Janeiro: Graal, 1983.

YOUNG, I. M. Justice and the politics of difference. New Jersey: Princeton University Press, 1990.

YOUNGBLOOD, G. Expanded cinema. New York: Dutton, 1970.

ZIZEK, S. Looking awry. An introduction to Jacques Lacan through popular culture. Massachusetts: The MIT Press, 1991.

."The truth arises from misrecognition". In: Lacan and the subject of language. New York: Routledge, 1991.

. Bem vindo ao deserto do real! São Paulo: Boitempo, 2003.

. Primeiro como tragédia, depois como farsa. São Paulo: Boitempo, 2011. 